UNIVERSIDADE DE SÃO PAULO

INSTITUTO DE GEOCIÊNCIAS

\title{
ESTUDO DAS MINERALIZAÇÕES AURÍFERAS DO CORPO IV E V DA ESTRUTURA IV DO GREENSTONE BELT DE CRIXÁS (GO)
}

\author{
KLAUS JUERGEN PETERSEN JUNIOR
}

Orientador: Prof. Dr. Caetano Juliani

TESE DE DOUTORAMENTO

COMISSÃO JULGADORA

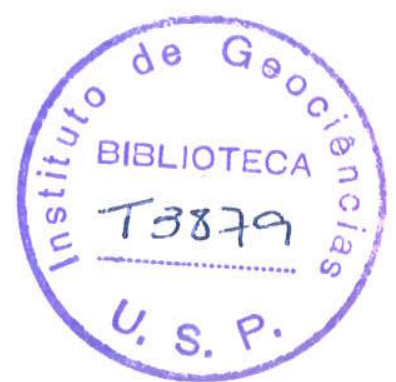

Nome

Presidente: Prof. Dr. Caetano Juliani

Examinadores: Prof. Dr. Edson Farias Mello

Prof ${ }^{\mathrm{a}}$.Dr ${ }^{\mathrm{a}}$.Lydia Maria Lobato

Prof. Dr. Raul Minas Kuyumjian

$\mathrm{Dr}^{\mathrm{a}}$.Rosa Maria da Silveira Bello

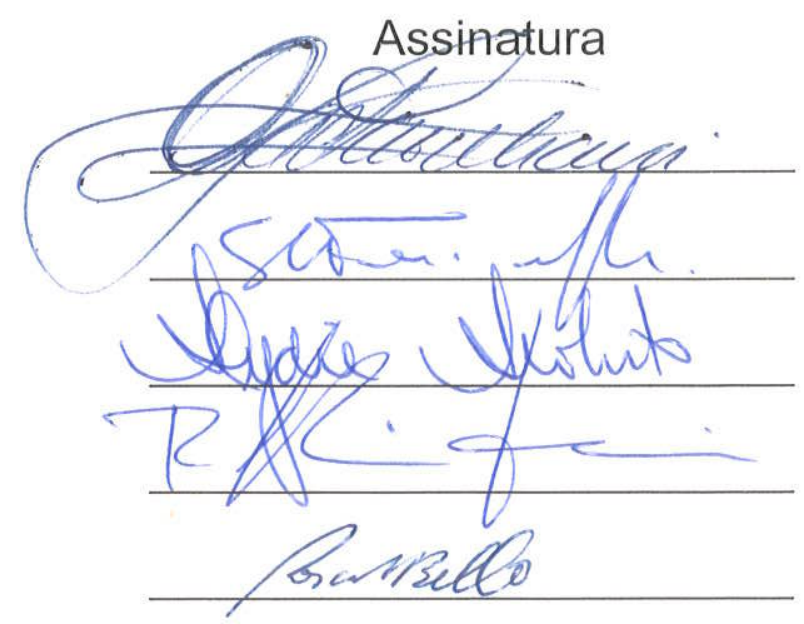

SÃO PAULO

2003 


\section{UNIVERSIDADE DE SÃO PAULO \\ INSTITUTO DE GEOCIENCIAS}

\section{ESTUDO DAS MINERALIZAÇÕES AURÍFERAS DO CORPO IV E V DA ESTRUTURA IV DO GREENSTONE BELT DE CRIXÁS (GO)}

Klaus Juergen Petersen Júnior

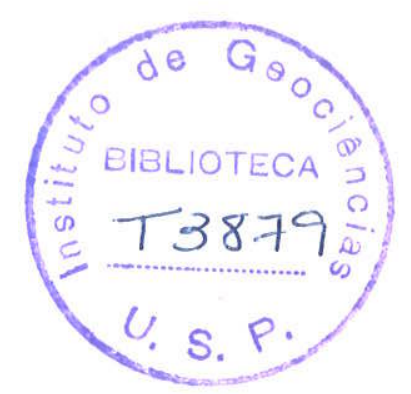

Orientador: Prof. Dr. Caetano Juliani

TESE DE DOUTORAMENTO

Programa de Pós-Graduação em Mineralogia e Petrologia

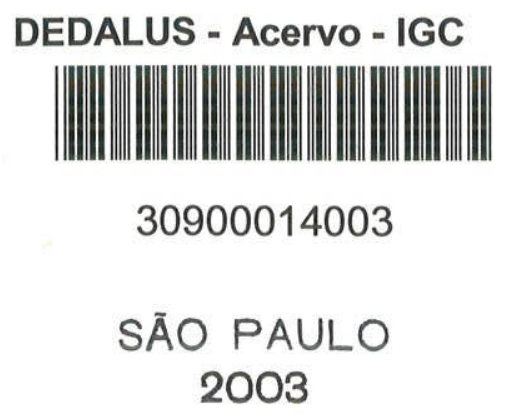


Aos meus pais, Klausão e Elizete. 


\section{AGRADECIMENTOS}

À Erika, Marina e Júlia Yamaguchi Petersen pelo constante apóio e paciência na minha ausência nas diversas etapas deste trabalho.

Ao Prof. Dr. Caetano Juliani pela orientação em todas as etapas da pesquisa, pelas interpretações refinadas de situações geológicas extremamente complicadas e pelo companherismo.

À Mineração Serra Grande que na pessoa do Geólogo Walter Yamaoka deu grande abertura para a concretização deste trabalho, que além do acesso irrestrito a mina e informações, forneceu hospedagem, alimentação e condução nas diversas etapas de campo. Agradeço igualmente aos colegas de trabalho da Mineração Serra Grande que auxiliaram de diversas maneiras nas etapas de campo, entre outros: geólogos Jaimir, Juliano, Márcio, Edvaldo, Edjarbas, Luís Cláudio, Francisco, Waldomiro e ainda ao Paiva, Zé Cláudio, Augusto, Josino e Valdimira.

À FAPESP que tornou este trabalho financeiramente viável (PROCESSO 99/03045-6) e ao relator secreto, que através de críticas bem fundamentadas, auxiliou de sobremaneira no direcionamento deste trabalho.

Aos Professores Jorge Silva Bettencourt, Rainer Allois Schults-Güttler, Valdecir de Assis Janase, Hardy Jost, que contribuiram em diversas etapas para o desenvolvimento da presente tese.

À Dra. Rosa Maria Bello pelas extensas discussões no campo das inclusões fluidas.

Ao Professores Steffen Hagemann e Peter Neumyer, além de outros colegas do Centre for Global Metalogeny da University of Western Australia, pela colaboração e profissionalismo durante a etapa de trabalho no exterior.

Reitero agradecimento a Professores anteriormente mencionados e ainda aos Professores Silvio Vlach, José Noberto Calegari, Gergely A. J. Szabo que contribuiram de diversas formas para os vários estágios de evolução no presente trabalho.

Aos companheiros da Pós-Graduação Rosana Peporini e Éder Luís Santo, Paulo Beljavskis, Gilson Burigo Guimarães, Iede Terezinha Zolinger, Lucelene Martins (Vaudemar), Luiz Gustavo Gallo Vilela (Troglô), Fernando Camargo Feitas (Pobrema), 
Carmen Nunes (Xitah), Flávio Carvalho (flavioms@), Fernando Pellegrini Spinelli, Annabel Pérez Aguilar (Coca), Rafael Hernandes Correa (Apum) e Tathyana Benavides, Gaston, Gustavo Correa de Abreu (Torrinha), Elias Casimiro Nkuanga, Artur Deodato Alves (Metanol), Paulo César Corrêa da Costa, Yuri Garin.

Aos técnicos do Instituto de Geociências que em todas as vezes se mostraram extremamente prestativos: Rosa M. Bello (Inclusões Fluidas), Marcos de Souza Nascimento (Microssonda Eletrônica), Flávio Carvalho (Raio X), Angélica D. M. Morente (Microscopia), Isaac (Microscopia Eletrônica), Paulo (Lab. Preparação de Amostras), Paulo (Lab. de Confecção de Lâminas p/ Microssonda), Sandra e equipe (Química), Cláudio Hopp e equipe (laminação) e outros igualmente importantes.

Aos funcionários do IG-USP que ajudaram diariamente nas etapas do trabalho: Ana Paula Cabonal e Magali P. F. Riso (Secretaria de Pós-Graduação), Sônia G. C. Vieira e Valéria Cristina de S. R. Santos (Secretaria do GMG), Dionísio Tadeu de Azevedo (Secretaria da Pós-Graduação), Maristela P. Severino, Érica Celeste do Nascimento, Brenda Maria Mascarenhas e Maria Aparecida Bezerra (Biblioteca). 
As mineralizações do Corpo IV e V da estrutura IV do Greenstone Belt de Crixás estão encaixadas em metassedimentos carbonosos da Formação Ribeirão das Antas dentro do Grupo Crixás.

As estruturas estudadas revelaram que os corpos com teores econômicos de ouro são núcleos relativamente preservados pelo cisalhamento brasiliano, ou seja apenas a geometria dos corpos de minério é controlada pelos shear zones, segundo um padrão " $\mathrm{S} / \mathrm{C}$ ". Desta maneira propõe-se que a formação dos corpos IV e $\mathrm{V}$ mineralizados em ouro tenham se formado em zonas de cisalhamento paleoproterozóicas, conforme datações realizadas por trabalhos anteriores, e que os mesmos tenham sido reorientados e desmembrados pelas zonas de cisalhamento no ciclo Brasiliano.

As relíquias de estruturas sedimentares da Formação Ribeirão das Antas indicam ambiente deposicional marinho, provavelmente bastante oxigenado, próximo a margens continentais ativas.

Os estudos petrográficos permitiram determinar diversas associações relacionadas à alterações hidrotermais, particularmente das gerações de porfiroblastos metamórficos de granada almandínica, Fe-tschermakita, cloritóide e arsenopirita, que devem representar o pico metamórfico, ao qual se sucedeu a mineralização de sulfetos e ouro.

A química dos minerais do corpo IV revelou grandes semelhanças com os minerais de alteração hidrotermal relacionadas das zonas mineralizadas na Mina III, sugerindo que o conjunto faz parte de um mesmo evento metalogenético. As análises permitiram ainda a caracterização dos tipos de alteração relacionados à mineralização de ouro como propilitização, sericitização, albitização, carbonatização, turmalinização, sulfetização, epidotização, silicificação, dispostos na forma de halos aproximadamente concêntricos. Estes halos são reconhecíveis apenas quando os mesmos não foram obliterados pelo evento neoproterozóico. Também foi possível ainda determinar as condições geotermobarométricas para os pares granada-biotita, que ocorrem no núcleo da alteração hidrotermal, revelando condições de T e P variando de 430 a $580^{\circ} \mathrm{C}$ e 5,7 a $8,3 \mathrm{kbar}$, respectivamente.

As diferentes estruturas tectônicas associam-se a quatro sistemas de veios de quartzo, denominados Q-IV1, Q-IV2, Q-IV3 e Q-IV4. Dentre estes veios. os mais antigos (Q-IV1 e QIV2) são pré-neoproterozóicos. A mineralização principal de ouro e sulfetos, entretanto, 
relaciona-se com o segundo sistema de veios (Q-IV2), mas ocorreu imediatamente após a precipitação de quartzo. Esta afirmação é reforçada pelos resultados microtermométricos de inclusões fluidas em quartzo contido na lineação mineral e de estiramento $\left(\mathrm{L}_{\mathrm{m} / \mathrm{e}}\right)$, que representa o paleo-conduto da mineralização de sulfetos e ouro, com características do fluido e isócoras idênticas às encontradas nas inclusões fluidas do veio de quartzo Q-IV2. Os veios seguintes têm, neste contexto, apenas o papel de remobilização do Au, geralmente precipitado sob a forma livre. A microtermometria de inclusões fluidas revelou variações significativas nas características dos fluidos e das isócoras, permitindo enquadrá-los nos diversos eventos que acometeram as rochas desse pacote. O cruzamento das isócoras relacionadas aos veios de quartzo Q-IV2 e a geotermobarometria mostrou que os mesmos cristalizaram no final do evento D3, imediatamente após a formação dos porfiroblastos metamórficos. Tanto a análise dos dados de microtermometria (faixas mais largas das isócoras extremas, diagrama $\mathrm{ThCO}_{2}$ versus $\mathrm{TfCO}_{2}$, trilhas de inclusões com fortes variações nas relações volumétricas), assim como diversas feições petrográficas indicaram fortes indícios da existência de processos de imiscibilidade e/ou mistura que seriam responsáveis pela precipitação de sulfetos e ouro.

As observações realizadas, particularmente as altas pressões derivadas da geotermobarometria, indicam que a mineralização nos Corpos IV e V é epitermal, podendo chegar a hipotermal, com fortes vínculos metamórficos ocorridos em condições de fácies xisto verde superior à anfibolito inferior.

Para a realização do estudo petrográfico foi elaborado um programa de computação baseado em sofiwares de baixo custo, que permitiram que o banco de dados petrográfico fosse vinculado a um sistema vetorial de posicionamento. Isso resultou em uma melhor organização dos dados para as interpretações e mostrou que não são necessárias ferramentas de informática altamente dispendiosas para esse tipo de processamento. 


\section{ABSTRACT}

The mineralizations of ore bodies $I V$ and $V$ of the structure $I V$ of the Greenstone Belt from Crixás are part of the carbonaceous metassediments of the Ribeirão das Antas Formation in the Crixás group.

The studied structures revealed that the bodies with economic quantities of gold are relatively preserved boudins from the Brasiliano shear event, in other words, the geometry of the ore bodies is controlled mainly by the shear zones, according to a " $S / C^{\prime \prime}$ pattern. In this way it is proposed that the formation of the bodies $I V$ and $V$ mineralized in gold took place in Paleoproterozoic shear zones, according to age determinations accomplished by previous autors, and that these bodies have been only reoriented and dismembered by the shear zones in the Brasiliano cycle.

The relicts of sedimentary structures of the Ribeirão das Antas Formation indicate a marine depositional environment, probably highly oxygenated and close to active continental margins.

The petrographic studies allowed to determine several associations related to hydrothermal alterations, particularly generations of metamorphic porphiroblasts of almandine garnet, $\mathrm{Fe}$ tschermakite, chloritoid and arsenopyrite that should represent the metamorphic peak conditions, to which the sulfide and gold mineralizations are related.

The mineral chemistry of the ore body $I V$ revealed great similarity with the chemistry of the hydrothermal alteration minerals related to the mineralized zones of Mina III, suggesting that the group is part of a same metalogenetic event. The analyses allowed the characterization of the alteration types related to the mineralization of gold as propilization, sericitization, albitization, carbonatization, turmalinization, sulfetization, epidotization and silicification, arranged approximately in the form of concentric haloes. These haloes are only recognizable when the ore bodies were not obliterated by the neoproterozoic event. It was also possible to determine the geothermobarometric conditions for the garnet-biotite pairs, considered as the core of the hydrohtermal alteration and revealing conditions of $T$ and $P$ between 430 to $580^{\circ} \mathrm{C}$ and 5,7 to 8,3 kbar, respectively.

The different tectonic structures may be associated to four quartz veins systems, denominated Q-IVI, Q-IV2, Q-IV3 and Q-IV4. Of these, the oldest (Q-IVI and Q-IV2) are older than the Neoproterozoic. The main mineralization of gold and sulfides, however, links up with the 
second system of veins (Q-IV2), immediately after the precipitation of quartz. This statement is reinforced by microthermometric results in fluid inclusions of quartz related to mineral lineation and stretching $\left(L_{m / e 3}\right)$, that represent the paleo-conduit of the sulfides and gold mineralization, with identical chemical characteristics of the fluid and isochores as in the fluid inclusions of the quartz vein Q-IV2. The following generations of veins have, in this context, only the role of remobilization of Au, generally precipitated as a elemental phase. The microthermometry of fluid inclusions revealed significant variations in the chemical characteristics of the fluids and of the slopes of the isochores, allowing to recognize at last three events that affected these rocks. The crossing of the isochores related to the fluid inclusions of the quartz vein Q-IV2 and the geothermobarometric results showed a crystalization at the end of the D3 event, immediately after the formation of the metamorphic porphiroblasts. The analysis of the microthermometric data (wider gaps of the extreme isochores, diagram Th $\mathrm{CO}_{2}$ versus Tf $\mathrm{CO}_{\mathrm{C}}$, trails of inclusions with strong variations in the volumetric relationships), as well as several petrographic features showed strong indications of the existence of imiscibility and/or mixing processes that would be responsible for the sulfide and gold precipitation.

The experimental observations, particularly the high derived pressures of the geothermobarometry, indicate that the mineralization of the ore bodies $I V$ and $V$ are epithermal to hipothermal, with strong metamorphic links and they formed in conditions of upper greenschist to lower amphibolite facies.

To facilitate the petrographic study, a new program was elaborated based on low cost softwares, that allowed the petrographic database to link to a vectorial system of positioning. This allowed a better organization of the data for the interpretations and it showed that there is no need of expensive software tools for this kind of petrographic data processing. 


\section{CAPÍTULO I}

OBJETIVOS, LOCALIZAÇÃO E MÉTODOS

\begin{tabular}{|c|c|}
\hline \multicolumn{2}{|c|}{ INTRODUÇÃO. } \\
\hline OBJ & 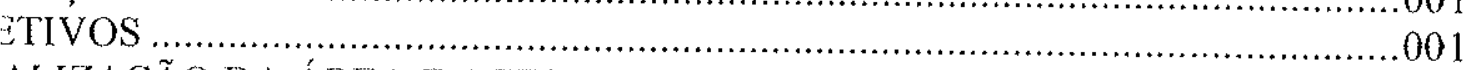 \\
\hline $\mathrm{LOC}$ & 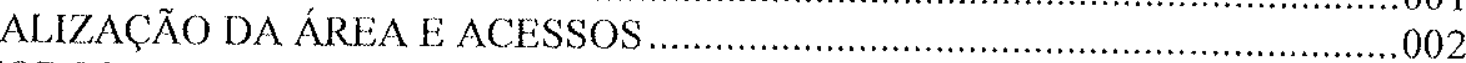 \\
\hline 3 MÉ' & 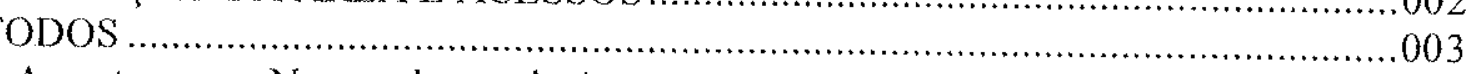 \\
\hline 3.1 & 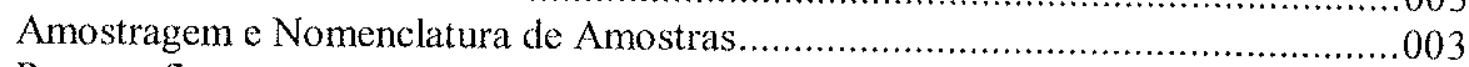 \\
\hline 3.2 & 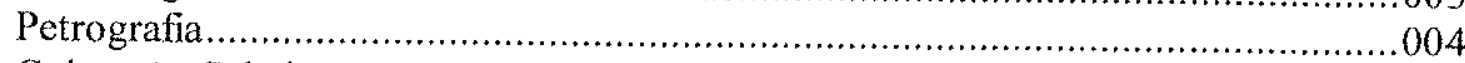 \\
\hline 3.3 & Coloração Seletiva ........................... \\
\hline 3.4 & Cátodo-Luminiscência ........................ \\
\hline 3.5 & 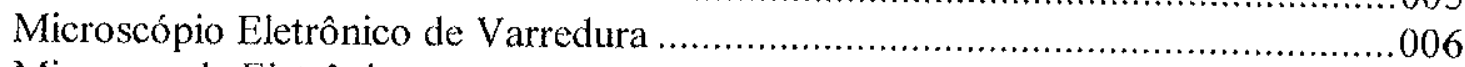 \\
\hline 3.6 & 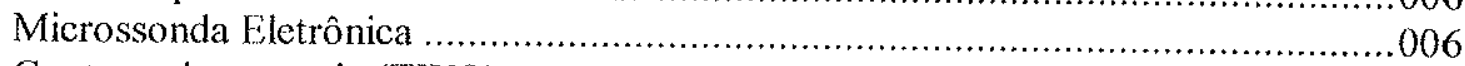 \\
\hline 3.7 & 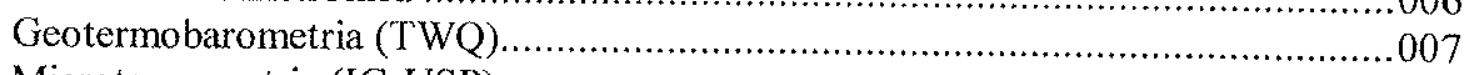 \\
\hline 3.8 & 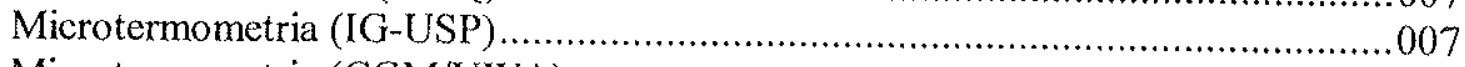 \\
\hline 3.9 & 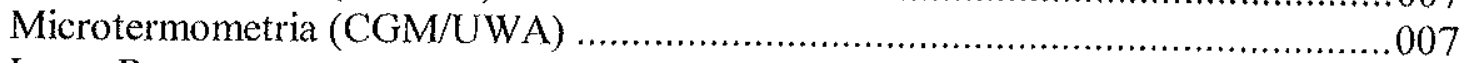 \\
\hline 3.10 & 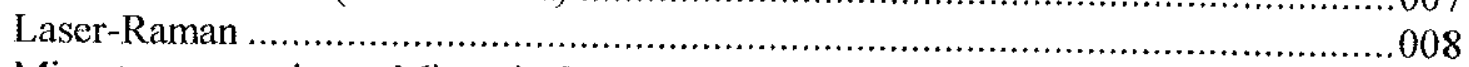 \\
\hline 3.11 & Microtermometria em Minerais Opacos com o Auxilio de Infravermelho.................008 \\
\hline 3.12 & 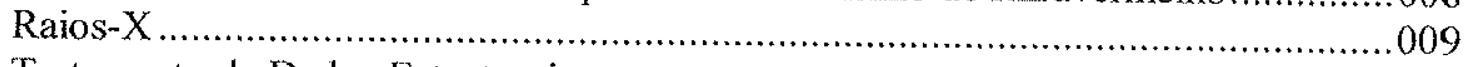 \\
\hline 3.13 & Tratamento de Dados Estruturais......................................... \\
\hline
\end{tabular}

\section{CAPÍTULO II \\ GEOLOGIA REGIONAL E LOCAL}

INTRODUÇÃO

1 HISTÓRICO PROSPECTIVO REGIONAL

2 GEOLOGIA DA REGIÃO DE CRIXÁS

3 ORIGEM EVOLUCÃO DOS CREA

4 O GREDNSTONE BELT DE CRIXAS NT ONE BELTS DE GOIAS........................018

4 O GREENSTONE BELT DE CRIXÁS................................................................. 019

5 DESCRIÇÃO DAS ZONAS DE MINÉRIO CORPO IV E V ………………………..........027

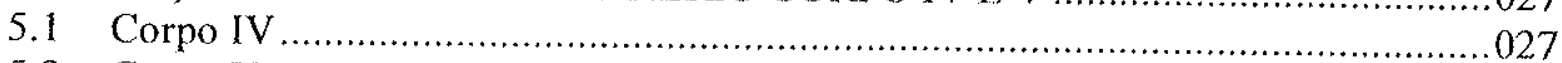

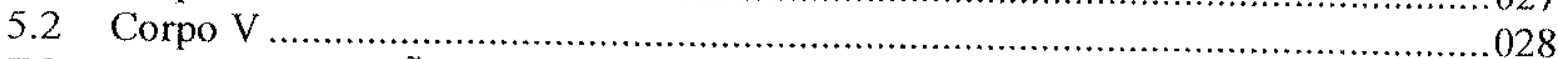

6 ZONA DE ALTERAÇÃO RELACIONADA AOS CORPOS DE MINÉRIO.....................030

7 BRECHAMENTO RELACIONADO AOS CORPOS DE MINÉRIO .................................031

\begin{tabular}{|c|}
\hline $\begin{array}{c}\text { CAPÍTULO III } \\
\text { PETROGRAFIA E BANCO DE DADOS PETROGRÁFICO }\end{array}$ \\
\hline $\begin{array}{ll}\text { INTRODUÇÃO } \\
1 & \text { FÁCIES VULCANOSEDIMENTAR } \\
2 & \text { FÁCIES TERRÍGENA } \\
3 & \text { FÁCIES DE ALTERACCÃO HIDROTERMAL } \\
3.1 & \text { Evento D1 } \\
3.2 & \text { Evento D2 } \\
3.3 & \text { Evento D3 } \\
3.4 & \text { Evento D4 }\end{array}$ \\
\hline
\end{tabular}




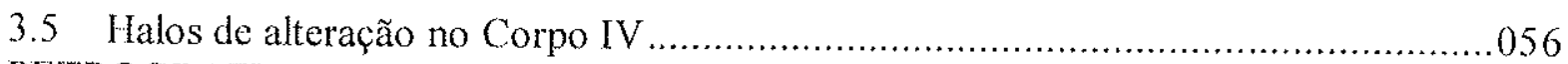

4 PETROGRAFIA DOS MINERAIS OPACOS (SULFETOS E OURO) ...................... 061

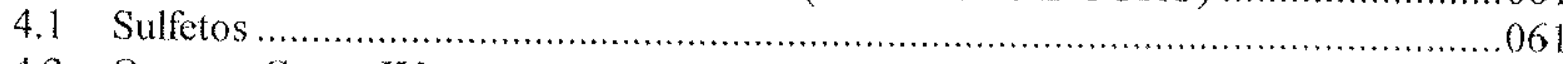

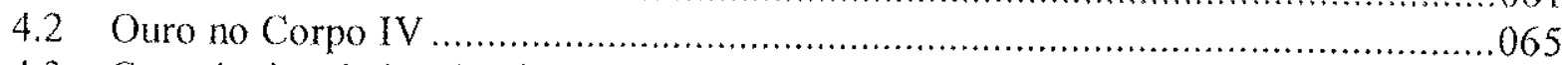

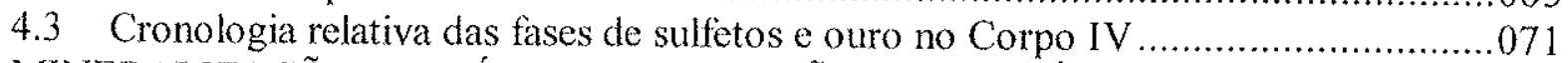

5 MINERALIZAÇÕES AURIFERAS NA REGIÃO DE CRIXÁS …..................................

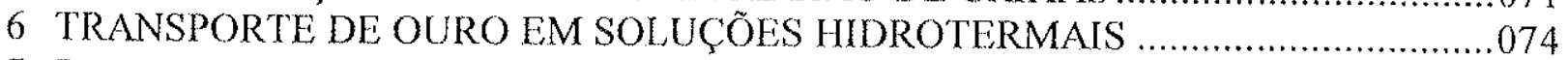

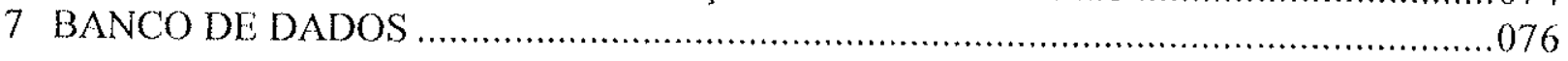

\begin{tabular}{c} 
CAPITULO IV \\
QUIMMICA MINERAL E GETERMOBAROMETRIA \\
\hline
\end{tabular}

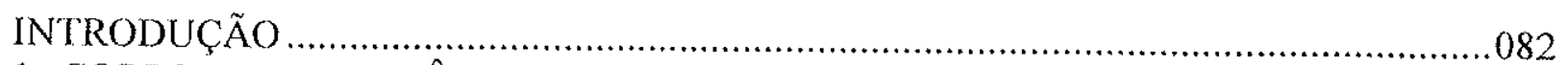

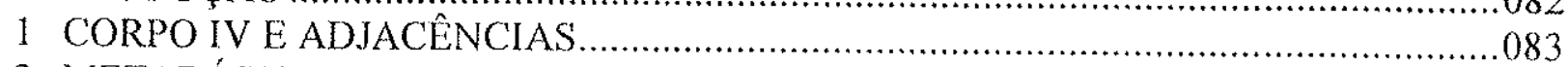

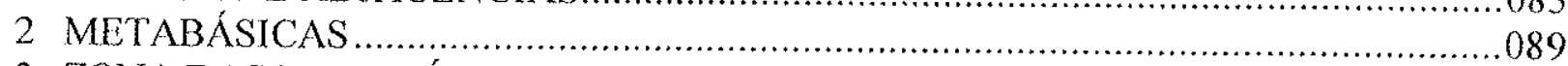

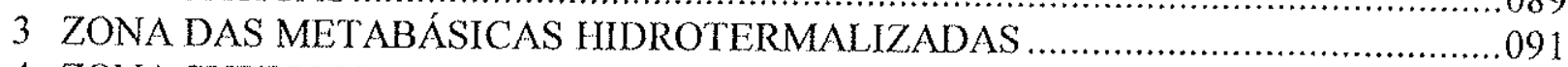

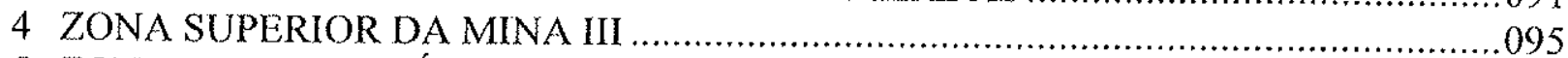

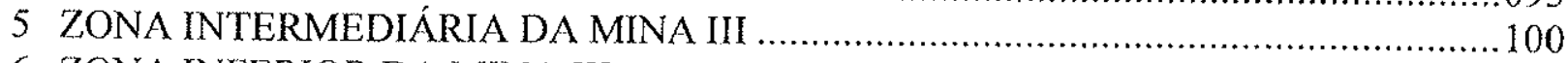

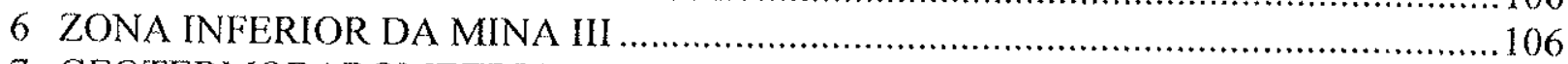

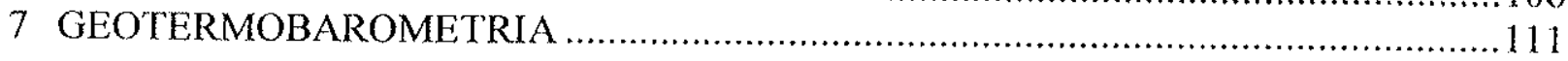

\section{CAPÍTULO V \\ VEIOS DE QUARTZO E INCLUSÕES FLUIDAS}

INTRODUÇÃO

1 PETROGRAFIA DOS VEIOS DE QUARTZO ..................................................118

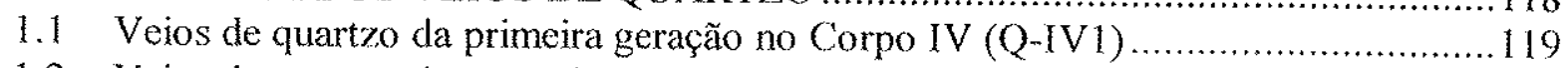

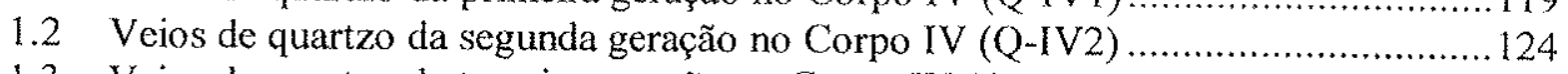

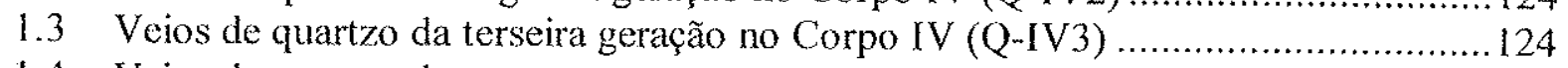

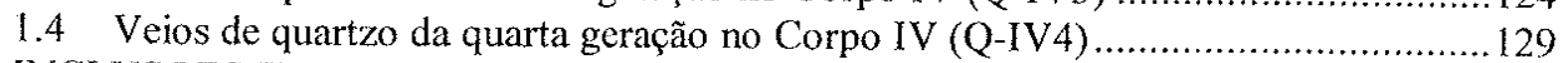

2 INCLUSOES FLUIDAS NOS VEIOS E MINERAIS DO CORPO IV .........................131

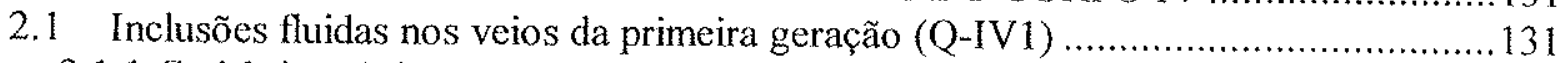

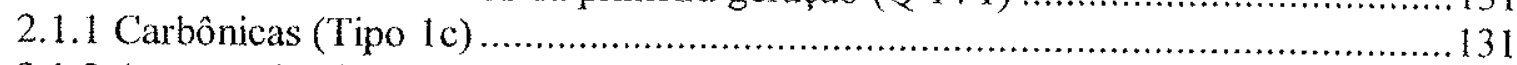

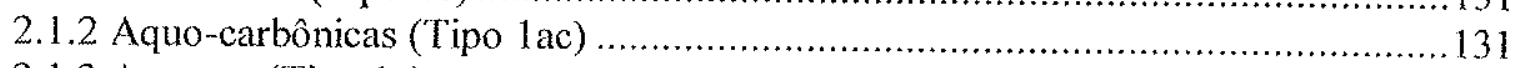

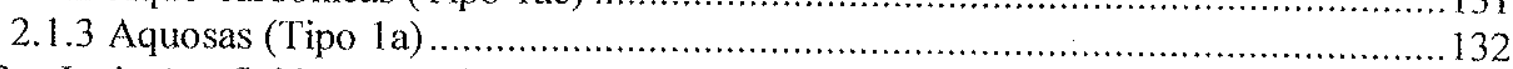

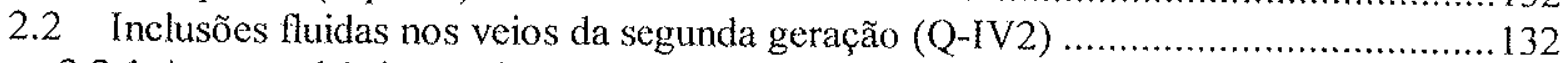

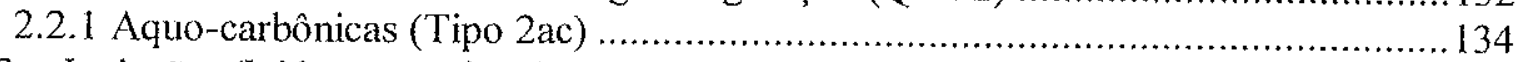

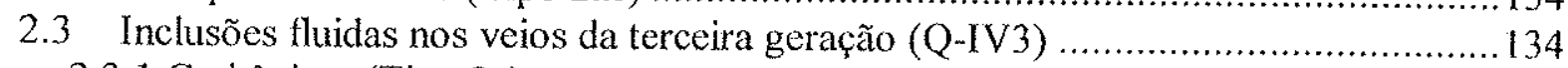

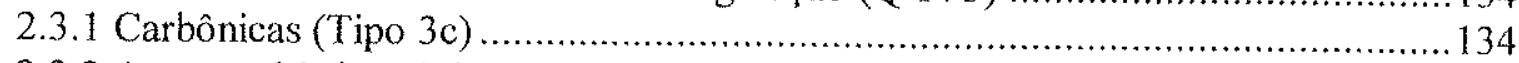

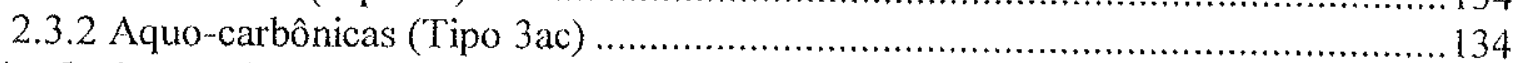

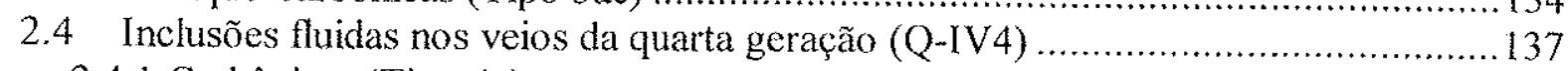

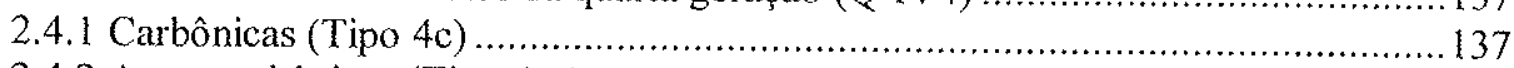

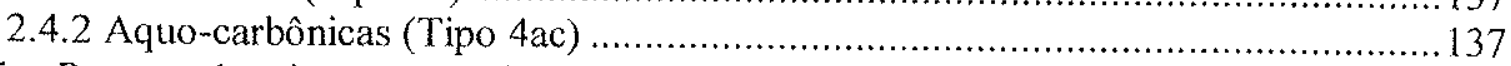

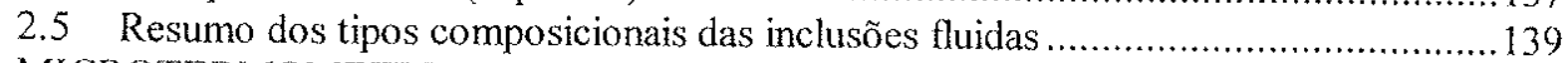

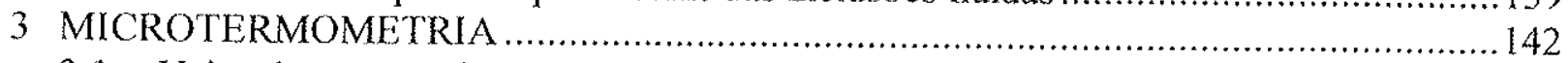

3.1 Veios de quartzo da primeira geração no Corpo IV (Q-IV1) .................................... 143

3.1.1 Inclusões primárias, pseudo-secundárias e secundárias (sistema $\left.\mathrm{CO}_{2}+\mathrm{CH}_{4}\right) \ldots . .144$

3.1.2 Inclusões pseudo-secundárias e secundárias (sistema $\mathrm{H}_{2} \mathrm{O}+\mathrm{CO}_{2}+\mathrm{CH}_{4}+$ sais) .... 146 
3.2 Veios de quartzo da segunda geração no Corpo IV (Q-IV2).

3.2.1 Inclusões primárias, pseudo-secundárias e secundárias (sistema $\mathrm{H}_{2} \mathrm{O}+\mathrm{CO}_{2}+$.

$\mathrm{CH}_{4}+$ sais)

3.3 Veios de quartzo da quarta geração no Corpo IV (Q-IV4)

3.3.1 Inclusões primárias (sistema $\mathrm{CO}_{2}+\mathrm{CH}_{4}$ )

3.3.2 Inclusões primárias, pseudo-secundárias e secundárias (sistema $\mathrm{H}_{2} \mathrm{O}+\mathrm{CO}_{2}+$.

$\mathrm{CH}_{4}+$ sais)

3.4 Quartzo na $\mathrm{L}_{\mathrm{m} / \mathrm{e} 3}$ com pirrotita do Corpo IV

3.5 Diagramas $\mathrm{ThCO}_{2} \times \mathrm{TfCO}_{2}$ para as gerações de veios e $\mathrm{L}_{\mathrm{m} / \mathrm{e} 3}$

3.6 Isócoras.

3.6.1 Veio de quartzo da primeira geração (Q-IV1)

3.6.2 Veio de quartzo da segunda geração (Q-IV2)

3.6.3 Veio de quartzo da quarta geração (Q-IV4).

\section{CONCLUSÕES PARCIAS}

CONLUSÕES PARCIAIS

\section{REFERÊNCIAS BIBLIOGRÁFICAS}

REFERÊNCIAS BIBLIOGRÁFICAS

\section{VITA}

VITA

\section{ANEXOS}

ANEXO I - PERFIL E-W (ENVELOPE NA CONTRA CAPA)

ANEXO II - ANÁLISES DE QUÍMICA MINERAL

ANEXO III - TABELAS MICROTERMOMÉTRICAS

\section{TABELAS}

TABELA I - Tabela de abreviações minerais de Kretz (1983) adotada, com modificações.004 TABELA 2 - Dados geocronológicos (traduzido de Jost \& Fortes, 2001).

TABELA 3 - Estruturas determinadas por Thomson (1991) no greenstone belt de Crixás, caracterizando quatro fases de deformação.

TABELA 4 - Resumo dos eventos definidos por Queiroz (1995).

TABELA 5 - Resumo das principais feições evolutivas do greenstone belt de Crixás. .025

TABELA 6 - Veios de quartzo nas zonas mineralizadas do Corpo IV e V. 
TABELA 7 - Zonas de alteração hidrotermal relacionadas aos Corpos IV e V. .030

TABELA 8 - Correlação das nomenclaturas de rochas utilizadas para a Formação Rio Vermelho e Ribeirão das Antas.

TABELA 9 - Relações de blastese determinadas para as rochas da Fácies Vulcanossedimentar.

TABELA 10 - Relações de blastese determinadas para a Fácies Terrígena, com as alterações e inclusões minerais constatadas ópticamente. A numeração das várias fases minerais se refere ao evento e não ao número de fases encontradas.

.048

TABELA 11 - Relações de blastese determinadas para as assembléias de alteração hidrotermal. A numeração das várias fases minerais se refere ao evento e não ao número de fases encontradas

TABELA 12 - Valores médios, mínimos e máximos de gold fineness para as zonas mineralizadas da Mina III segundo Fortes et al. (2000) em comparação com dados de análises obtidos para o Corpo IV (amostra IV-23-51) neste trabalho. .066

TABELA 13 - Cronologia relativa dos sulfetos e ouro no Corpo IV. O processo recorrente de precipitação da pirrotita com calcopirita e ouro é representado pela repetição das elipses, sem referência direta ao número de ciclos. A espessura das elipses representa aproximadamente a abundância relativa dos minerais.

TABELA 14 - Amostras com fases minerais submetidas a análises com auxílio da microssonda eletrônica de varredura.

TABELA 15 - Tipos composicionais das inclusões fluidas para cada veio no Corpo IV.

TABELA 16 - Relação de amostras submetidas a medições microtermométricas., com as páginas referidas ao $\mathrm{ANEXO} 4$, onde $\mathrm{IF}=$ inclusão fluida, $\mathrm{P}=$ primária, $\mathrm{PS}=$ pseudosecundária e $S=$ secundária.

TABELA 17 - Resultado de análises espectroscópica com o auxílio de Laser-Raman no QIV1.

TABELA 18 - Resultado de análises espectroscópica com o auxílio de Laser-Raman no QIV2.

TABELA 19 - Resultado de análises espectroscópica com o auxílio de Laser-Raman no QIV4.

\section{FIGURAS}

FIGURA 1 - Localização de Crixás (modificado de Yamaoka \& Araújo, 1988) .003

FIGURA 2 - Mapa geológico de Crixás (cedido pela Mineração Serra Grande).

FIGURA 3 - (A) Estereograma sinóptico da foliação $\mathrm{S}_{4}$ (mergulho para $\mathrm{SW}$ ) e $\mathrm{S}_{\mathrm{m} 3}$ (mergulho para NW) com medidas restritas ao Corpo IV e na galeria entre Corpo IV e V. (B) Esterograma sinóptico da foliação $\mathrm{S}_{4}$ (mergulho para $\mathrm{SW}$ ) e $\mathrm{S}_{\mathrm{m} 3}$ (mergulho para $\mathrm{NW}$ ) ao longo da galeria de acesso ao Corpo IV. (C) Estereograma sinóptico da lineação mineral/de estiramento $\left(\mathrm{L}_{\mathrm{m} / \mathrm{e}}\right)$ no Corpo IV e na galeria entre Corpo IV e $\mathrm{V}$, que representa os eixos de boudins e lineação mineral da pirrotita principalmente. (D) Estereograma sinóptico da $\mathrm{L}_{\mathrm{m} / \mathrm{e} 3}$ ao 
longo da galeria de acesso ao Corpo IV, que representa os eixos de boudins e lineação mineral, principalmente da pirrotita.

FIGURA 4 -.- (A) Estereograma sinóptico da superficie " $\mathrm{c}$ " com medidas do Corpo IV e da galeria de acesso ao Corpo IV. (B) Estereograma sinóptico dos eixos de dobras no Corpo IV (vermelho) e ao longo da galeria de acesso ao Corpo IV (preto), coincidentes com $\left(\mathrm{L}_{\mathrm{m} / \mathrm{e} 3}\right)$. (C) Esterograma de contatos tectônicos reconhecidos ao longo da galeria de acesso ao Corpo IV, correlacionáveis à $\mathrm{S}_{4}$ onde, azul = contato dolomita com clorita-xisto, cinza $=$ contato dolomita com xisto carbonoso, verde $=$ contato clorita-xisto com xisto carbonoso. .026

FIGURA 5 - llustração esquemática do mecanismo de brechamento assistido por fluidos em depósitos de veios hidrotermais (A) e a geometria resultante das brechas (B), segundo Jébrak (1997)

FIGURA 6 - Difratograma de um clasto de xisto MCAR na amostra IV-22-11218 mostrando sua composição predominante de fluorapatita $(28,4 \%)$, além de quartzo, carbonatos, pirrotita, flogopita e clinocloro .045

FIGURA 7 - Modelo com as zonas de alteração hidrotermal determinadas no Corpo IV. Ocorrem variações neste modelo em função da intensidade da alteração hidrotermal, do tịpo de rocha encaixante e da proximidade com zonas de cisalhamento neoproterozóicas. .058

FIGURA 8 - Relação Au versus Ag do Corpo IV (amostra IV-22-17905) na borda do veio de quartzo com xisto MCAR ( 5 análises) em comparação com as análises obtidas por Fortes $e t$ al. (2000) da zona de minério inferior na Mina III em veio de quartzo.

.066

FIGURA 9 - Tela de entrada do banco de dados petrográfico em programado em ACCESS 97. 078

FIGURA 10 - Tela de entrada de dados petrográficos fornecidos pela MSG e descrições macroscópicas de amostras colhidas no presente estudo. 079

FIGURA 11 - Tela de entrada de dados petrográficos das descrições de lâminas delgadas de amostras colhidas no presente estudo. .080

FIGURA 12 - Diagramação em 3 dimensões dos testemunhos de sondagem estudados, em vermelho, e a base topográfica da galeria de acesso ao Corpo IV, em azul. A direção real dos testemunhos de sondagem foi obtida com a entrada dos dados de medição com auxílio do Topari fornecidos pela MSG. 080

FIGURA 13 - Recorte de uma das formas de relatório gerado pelo AUTOCAD com dados do banco ACCESS, relacionando diversas informações das amostras analisadas dos testemunhos de sondagem (linha subvertical) e com a superposição da galeria de acesso ao Corpo IV (linha com valores em metros a partir do início da galeria de acesso ao Corpo IV).

FIGURA 14 -- Diagrama de classificação química da biotita nas amostras G-IV-002, IV-22. 16303, IV-22-17695, IV-22-17905 e K59-19435 (39 análises).

FIGURA 15 -.. Diagrama de classificação química da sericita nas amostras G-IV-002, [V-2216303, IV-22-17695, IV-22-17905 e K59-19435 (23 análises).

FIGURA 16 - Diagrama de classificação químical da clorita nas amostras IV-22-16303 e K59-19435 (4 análises). .086

FIGURA 17 - Diagrama de classificação química do feldspato nas amostras G-IV-002, IV22-16303, IV-22-17695 e IV-22-17905 (34 análises).

FIGURA 18 - Diagrama de classificação química da granada na amostra IV-22-16303 (24 análises). 
FIGURA 19 -..-Perfís analíticos para Mg + Mn, Fe e Ca em granada da amostra IV-22-16303. .088

FIGURA 20 --. Diagrama de classificação química do carbonato nas amostras IV-22-16303, IV-22-17695, IV-22-17905 e K59-19435 (24 análises).

FIGURA 21 -- Diagrama de classificação química do anfibólio na amostra IV-22-01914 (20 análises). A seta indica a direção composicional do núcleo para a borda dos cristais.

FIGURA 22 -..- Diagrama de classificação química do feldspato na amostra IV-22-01914 (8 análises). A seta indica a direção composicional do núcleo para a borda dos cristais. .090

FIGURA 23 - Diagrama de classificação química da clorita na amostra IV-22-01914 (3 análises).

FIGURA 24 -- Diagrama de classificação química da biotita na amostra K59-29280, K5934143 e K49-19790 (5 análises).

FIGURA 25 - Diagrama de classificação química da sericita na amostra K59-34143 (3 análises).

FIGURA 26 - Diagrama de classificação química da clorita na amostra K59-29280, K59. 34143 e K49-19790 (16 análises).

FIGURA 27 - Diagrama de classificação química do feldspato na amostra K59-29280, K59 34143 e K49 19790 (18 análises).

FIGURA 28 - Diagrama de classificação química do carbonato nas amostras K59-29280, K59-34143 e K49-19790 (19 análises).

FIGURA 29 - Diagrama de classificação química da sericita e margarita na amostra K4926274 ( 7 análises).

FIGURA 30 - Diagrama de classificação química da clorita na amostra K49-26274 (8 análises).

FIGURA 31 - Diagrama de classificação química da granada metamórfica na amostra K49. 26274 (10 análises). .098

FIGURA 32 - Diagramas do perfil das análises de química mineral em um cristal de granada metamórfica na amostra K49-26274 (10 análises).

FIGURA 33 - Diagrama de classificação química do anfibólio metamórfico na amostra K4926274 (9 análises).

FIGURA 34 - Diagrama de classificação química do carbonato na amostra K49-26274 (8 análises).

FIGURA 35 -.. Diagrama de classificação química da biotita nas amostras K59-38571, K5938578 e K03-23040 (38 análises).

FIGURA 36 - Diagrama de classificação química da sericita nas amostras K59-38571, K5938578 e K03-23040 (22 análises).

FIGURA 37 -..- Diagrama de classificação química da clorita nas amostras K59-38571, K5938578 e K03-22755 (29 análises).

FIGURA 38 - Diagrama de classificação química do feldspato nas amostras K59-38571, K59-38578 e K03-23040 (51 análises).

FIGURA 39 - Diagrama de classificação química do carbonato nas amostras K59-38571, K59-38578, K03-22755 e K03-23040 (36 análises). 
FIGURA 40 -- Diagrama de classificação química da granada nas amostras K59-38571, K5938578 e K03-22755 (89 análises).

FIGURA 41 - Perfís analíticos da granada: à esquerda da amostra K.59-38578 sem mineralização e à direita da amostra K03-22755 com mineralização. Notar que os diagramas da direita abrangem apenas um perfil do núcleo para a borda. .105

FIGURA 42 - - Diagrama de classificação química da biotita nas amostras K49-39614 e K4939664 (27 análises).

FIGURA 43 - Diagrama de classificação química da sericita nas amostras K49-39614 e K49. 39664 (27 análises).

FIGURA 44 - Diagrama de classificação química da clorita nas amostras K49-39614 e K49. 39664 ( 3 análises). 108

FIGURA 45 - Diagrama de classificação química do feldspato nas amostras K49-39614 e K49-39664 (41 análises). As setas indicam variação química do núcleo para borda nas duas amostras.

FIGURA 46 - Diagrama de classificação química do carbonato nas amostras K49-39614 e K49-39664 (12 análises).

FIGURA 47 - Diagrama de classificação química do anfibólio nas amostras K49-39614 e K49-39664 (21 análises).

FIGURA 48 - Diagrama de classificação química da granada nas amostras K49-39614 e K4939664 (20 análises).

FIGURA 49 - Perfís analíticos da granada: à esquerda da amostra K49-39614 sem mineralização e com desenvolvimento em atol e à direita da amostra K49-39614 com maior conteúdo na molécula piropo. Notar que os diagramas abrangem apenas um perfil do núcleo para a borda.

FIGURA 50 -.- Diagramas de equilíbrio de fases para a amostra K59-38571a com análises de núcleos a esquerda e borda a direita.

FIGURA 51 - Diagramas de equilíbrio de fases para a amostra K59-38571b com análises de núcleos à esquerda e borda a direita. 114

FIGURA 52 - Diagramas de equilíbrio de fases para a amostra K49-39664 com análises de núcleos a esquerda e borda a direita.

FIGURA 53 - Diagrama de equilibrio de fases da amostra K49-39664 com análises de núcleos dos minerais.

FIGURA 54 - A parte superior esquerda mostra a imagem geral da amostra CIV-G019-V1 do Q-IV1 em contato com o xisto carbonoso da encaixante dobrado (evento D3). O detalhe na parte superior direita mostra as zonas onde os fluidos com sulfetos afetaram mais o veio de quartzo, gerando regiōes mais leitosas, de cor amarronzada. No recorte ampliado da última imagem pode ser visto como a pirrotita tardia, controlada pela lineação mineral e de estiramento $\left(\mathrm{L}_{\mathrm{m} / \mathrm{s} 3}\right)$, é "injetada" no veio de quartzo. Tanto a partir do veio de pirrotita no quartzo como do contato da encaixante ocorrem zonas permeadas pelos fluidos, gerando zonas de "alta influência" quando há um escurecimento pronunciado do quartzo pelas inclusões fluidas, principalmente pela pirrotita. Abreviações conforme TABELA 1.

FIGURA 55 - Histograma das temperaturas de fusão do $\mathrm{CO}_{2}$ para inclusões do sistema $\mathrm{CO}_{2}+\mathrm{CH}_{4}$ do Q-IV1, onde $\mathrm{P}=$ primária, $\mathrm{PS}=$ pseudo-secundária e $\mathrm{S}=$ secundária. 145 
FIGURA 56 - Diagrama $\mathrm{XCO}_{2}$ versus $\mathrm{XCH}_{4}$ para inclusões do sistema $\mathrm{CO}_{2}+\mathrm{CH}_{4}$ do Q-IV1. 145

FIGURA 57 -. Temperaturas de homogeneização do $\mathrm{CO}_{2}$ nas IF carbônicas do Q-IV1 ...... 146

FIGURA 58 - Temperaturas de fusão do $\mathrm{CO}_{2}$ de IF aquo-carbônicas no Q-IV1. 146

FIGURA 59 - Temperaturas de homogeneização para as IF aquo-carbônicas do Q-IV1 ....147

FIGURA 60 -... Temperaturas do eutético para as IF aquo-carbônicas do Q-IV1. 148

FIGURA 61 -..-As altas salinidades referem-se à amostra 1921, que contêm cristais de saturação de halita, sendo as mesmas calculadas pela dissolução do sal. 148

FIGURA 62 - Temperaturas de homogeneização total para IF do Q-IV1 pseudo-secundárias aquo-carbônicas.

FIGURA 63 - Diagrama temperatura de homogeneização total versus temperatura de dissolução do $\mathrm{NaCl}$ (Amostra 19 21)...

FIGURA 64 - Temperaturas de fusão do $\mathrm{CO}_{2}$ de IF aquo carbônicas no Q-IV2. 151

FIGURA 65 - Diagrama $\mathrm{XCO}_{2}$ versus $\mathrm{XCH}_{4}$ para inclusões do sistema $\mathrm{CO}_{2}+\mathrm{CH}_{4}$ do Q-IV2.

FIGURA 66 - Temperaturas de homogeneização do $\mathrm{CO}_{2}$ nas IF aquo-carbônicas do Q-IV2.

FIGURA 67 - Temperaturas do eutético para as IF aquo-carbônicas do Q-IV1.

FIGURA 68 - Porcentagem em peso de $\mathrm{NaCl}$ equivalente para amostras do Q-IV2, sendo que a amostra primária apresenta um valor estimado de salinidade $(>26 \%)$, uma vez que não foi possível determinar a $\mathrm{Td}_{\mathrm{NaCl}}$.

FIGURA 69 - Temperaturas de homogeneização total para IF do Q-IV2 aquo-carbônicas. 153

FIGURA 70 -.. Temperaturas de fusão do $\mathrm{CO}_{2}$ de IF carbônicas primárias no Q-IV4. 154

FIGURA 71 - Temperaturas de homogeneização do $\mathrm{CO}_{2}$ nas IF carbônicas primárias do QIV4.

FIGURA 72 - Temperaturas de fusão do $\mathrm{CO}_{2}$ de IF aquo-carbônicas no Q-IV4 para quartzo, apatita e siderita. O simbolo " " representa uma faixa de temperaturas sem a presença de medidas.

FIGURA 73 - Diagrama $\mathrm{XCO}_{2}$ versus $\mathrm{XCH}_{4}$ para inclusões do sistema aquo-carbônico do QIV4.

FIGURA 74 -... Temperaturas de homogeneização do $\mathrm{CO}_{2}$ nas IF aquo-carbônicas do Q-IV4.

FIGURA 75 - Temperaturas do eutético para as If aquo carbônicas do Q-IV4.

FIGURA 76 -- Porcentagem em peso de $\mathrm{NaCl}$ equivalente para IF aquo-carbônicas do Q-IV4.

FIGURA 77 - Temperaturas de homogeneização total para IF aquo-carbônicas do Q-IV4. 158 FIGURA 78 - Diagrama $\mathrm{VCO}_{2} \times$ Thtot para IF aquo-carbônicas do Q-IV4, compondo a curva de imiscibilidade.

FIGURA 79 - - Temperaturas de fusão do $\mathrm{CO}_{2}$ de IF aquo-carbônicas no quartzo intimamente associado com a pirrotita da $L_{\mathrm{m} / \mathrm{e} 3}$. 
FIGURA 80 - Diagrama $\mathrm{XCO}_{2}$ versus $\mathrm{XCH}_{4}$ de IF aquo-carbônicas no quartzo intimamente associado com a pirrotita da $\mathrm{L}_{\mathrm{m} / \mathrm{e} 3}$. 160

FIGURA 81 -- Temperaturas de homogeneização do $\mathrm{CO}_{2}$ de $\mathrm{IF}$ aquo-carbônicas no quartzo intimamente associado com a pirrotita da $\mathrm{L}_{\mathrm{m} / \mathrm{e}}$.

FIGURA 82 - Temperaturas do eutético das IF aquo-carbônicas no quartzo intimamente associado com a pirrotita da $\mathrm{L}_{\mathrm{m} / \mathrm{e} 3}$.

FIGURA 83 - Salinidade nas IF aquo-carbônicas no quartzo intimamente associado com a pirrotita da $L m / \mathrm{e}\}$.

FIGURA 84 - Temperaturas de homogeneização total nas IF aquo-carbônicas no quartzo intimamente associado com a pirrotita da $L_{m / \mathrm{e} 3}$.

FIGURA 85 - Diagrama $\mathrm{TfCO}_{2}-\mathrm{ThCO}_{2}$ : (A) Q-IV1 IFP carbônicas, (B) Q-IV1 IFPS carbônicas, (C) Q-IV1 IFS carbônicas, (D) Q-IV1 IFPS aquo-carbônicas. Os números representam associações de IFs relacionados a amostras de cada geração de veios de quartzo. 165

FIGURA 86 - Diagrama TfCO ${ }_{2}$-ThCO $\mathrm{CO}_{2}$ : (A) Q-IV1 IFS aquo-carbônicas, (B) Q-IV2 IFPS aquo-carbônicas, (C) Q-IV2 IFS aquo-carbônicas, (D) Q-IV4 IFP carbônicas. Os números representam associações de IFs relacionados a amostras de cada geração de veios de quartzo. 166

FIGURA 87 - Diagrama $\mathrm{TfCO}_{2}-\mathrm{ThCO}_{2}$ : (A) Q-IV4 IFP aquo-carbônicas em quartzo (12 01A), apatita (26_01AP), quartzo intimamente associado a siderita (73_04Q C/ SID) e siderita (73 05 SID), (B) Q-IV4 IFPS aquo-carbônicas no quartzo (12_01C) e 73 12A) e no quartzo intimamente relacionado a siderita (73 4Q C/ SID), (C) Q-IV4 IFS aquo-carbônicas, (D) IV-22 IFP aquo-carbônicas. Os números representam associações de IFs relacionados a amostras de cada geração de veios de quartzo. 167

FIGURA 88 - Isócoras relativas às densidades extremas, obtidas de inclusões primárias carbônicas do Q-IV1. (Os valores de Th referem-se às temperaturas de homogeneização do $\mathrm{CO}_{2}$ ). 168

FIGURA 89 - Isócoras relativas às densidades extremas, obtidas de inclusões pseudosecundárias carbônicas do Q-IV1. (Th = $=\mathrm{ThCO}_{2}$ ).

FIGURA 90 -... Isócoras relativas às densidades extremas, obtidas de inclusões secundárias carbônicas do Q-IV1. 169

FIGURA 91 - Isócoras relativas às densidades extremas, obtidas de inclusões primárias, pseudo-secundárias e secundárias carbônicas do Q-IV1. 170

FIGURA 92 - Isócoras relativas às densidades extremas, obtidas de inclusões secundárias aquo-carbônicas do Q-IV1. ( $\mathrm{d}=$ densidade total do fluido).

FIGURA 93 - Amostra 1921 apresentando isócoras relativas à inclusões com variações de volumes, alta salinidade $(>30 \%)$, calculado pelo Bakker (2003, programas Bulk e Isoc). $(\mathrm{d}=$ densidade total do fluido).

FIGURA 94 - Isócoras relativas aos termos extremos das inclusões com altas variações em $\mathrm{VCO}_{2}$ /Vtot. $(0,1$ a 0,95$)$ e em salinidade.

FIGURA 95 --. Isócoras relativas às densidades extremas, obtidas da inclusão primária e das pseudo-secundárias aquo-carbônicas do Q-IV2 com os dados de Thtot $\mathrm{e}$ os resultados geotermobarométricos $(\mathrm{d}=$ densidade total do fluido $)$. 
FIGURA 96 - Isócoras relativas às densidades extremas, obtidas de inclusões secundárias aquo-carbônicas do Q-IV2. $(\mathrm{d}=$ densidade total do fluido).

FIGURA 97 - Isócoras relativas às temperaturas de homogeinização do $\mathrm{CO}_{2}$ extremas, obtidas de inclusões primárias carbônicas no quartzo do Q-IV4.

FIGURA 98 -- Isócoras relativas às densidades extremas, obtidas de inclusões primárias aquo-carbônicas no quartzo do Q-IV4 ( $\mathrm{d}=$ - densidade total do fluido).

FIGURA 99 -.- Isócoras relativas às densidades extremas, obtidas de inclusões primárias aquocarbônicas em apatita do Q-IV2 (d =- densidade total do fluido).

FIGURA 100 - Isócoras relativas aos termos extremos das inclusões pseudo-secundárias, com variações em $\mathrm{VCO}_{2} / \mathrm{V}$ tot. $(0,4$ a 0,8$)$, em quartzo do veio Q-IV4 $(\mathrm{d}=$ densidade total do fluido).

FIGURA 101 - Isócoras relativas às densidades extremas, obtidas de inclusões secundárias aquo-carbônicas em quartzo do Q-IV4 ( $\mathrm{d}=$ densidade total do fluido). 176

FIGURA 102 - Isócoras relativas às densidades extremas, obtidas nas inclusões primárias aquo-carbônicas na siderita e nas primárias e pseudo-secundárias aquo-carbônicas em quartzo diretamente relacionado ao carbonato do Q-IV4 $(\mathrm{d}=$ densidade total do fluido $)$.

FIGURA 103 - Isócoras relativas às inclusões fluidas primárias aquo-carbônicas no quartzo da $\left.L_{m / e 3}\right)$, mostrando as condições de $T$ e $P$ mínimas de aprisionamento $(\mathrm{d}=$ densidade total do fluido).

FIGURA 104 - Diagrama P-T onde são apresentadas as áreas de possível formação das gerações de veios de quartzo estudadas, com base nos estudos microtermométricos em inclusões fluidas. As setas indicam trajetórias prováveis da evolução dos fluidos. A área de formação do veio Q-IV2 foi sobreposta com os resultados geotermobarométricos, zona essa onde ocorreu a formação dos porfiroblastos metamórficos, principalmente no núcleo da alteração propilítica.

\section{PRANCHAS DE FOTOGRAFIAS}

PRANCHA 1 - Estrutura brechada nos corpos mineralizados: (A) e (B) Corpo IV; (C) e (D) Corpo V; (E) e (F) Zona Inferior (Mina III).

PRANCHA 2 - (A) - Imagem da amostra K59-34143 da lâmina delgada (5x3cm) submetida aos estudos petrográficos e de análise com auxílio de EDS. Os número representam os círculos nos quais foram realizadas análises. A matriz cinza é sericítico/feldspática, com venulações de cloritito em verde. Em meio a massa sericítico/feldspática ocorrem porfiroblastos de cloritóide, parcialmente decompostos pela cloritização/carbonatização, provavelmente neoproterozóica. (B) Círculo C1 da amostra K59-34143 com cloritóide fraturado. Notar a muscovita fina na matriz (MS1) e muscovita mais grossa (MS3) marcando o reflexo da fratura do porfiroblasto de cloritóide através da matriz. (C) Diagrama da imagem (B) indicando as diversas fases de cristalização dos pares clorita/carbonato sugerindo três pulsos de alteração/preenchimento

PRANCHA 3 - llustração da sequiência de formação e destruição dos "nódulos carbonosos": (A) a evolução da crenulação $\mathrm{S}_{\mathrm{m} 3}$ separou zonas apicais de dobras de material carbonoso; (B) o avanço da intensidade de cisalhamento gerou o "nódulo"; (C) "nódulos" desenvolvidos e já com princípio de deformação; (D), (E) e (F) seqüência de destruição da estrutura de acordo com a intensidade do cisalhamento relacionado ao evento D4. 
PRANCHA 4 - (A) Corte perpendicular a foliação principal mostrando o estiramento de veios de quartzo dobrados e de nódulos carbonosos, segundo a $L_{m / e} 3$ (bloco de amostra com $5 \times 3$ $\mathrm{cm})$, (C) brecha de quartzo com foliação dobrada marcada por material carbonoso $\left(\mathrm{S}_{1}\right)$ em meio a matriz predominantemente sericítica dominado pela foliação $S_{m 3}$ (amostra IV-2218076), (D) brecha com material carbonoso rotacionado, preservando parcialmente a foliação $\left.\mathrm{S}_{1}, \mathbf{E}\right)$ brecha angulosa de quartzo com sombras de pressão, $(\mathbf{F})$ brecha carbonática/carbonosa estirada apresentado bandamento interno $\left(\mathrm{S}_{1}\right),(\mathbf{G})$ clasto carbonático (calcita) com inclusões de ilmenita e plagioclásio (amostra K59-19435).

PRANCHA 5 - (A) Clasto carbonoso analisado com auxílio de raios X (IV-22-16303). (B) Mesma área de (A) com imagem gerada com auxilio da cátodo-luminiscência revela a apatita em verde intenso limitada ao clasto (IV-22-16303).(C) e (D) Ilmenita com deformações provocadas pela crenulação e alterações para rutilo (pseudorutilo?). Ocorre também turmalina associada. (E) ritimito quartzo-carbonático com estruturas primárias bem preservadas. Podese reconhecer claramente a alternância de leitos carbonáticos e quartzo-carbonosos (amostra K59-44950). (F) Epídoto radioativo (ver halo plocróico na biotita a direita) alterado com a proximidade do cisalhamento, gerando microcristalizações. .046

PRANCHA 6 - (A) Dolomito brechado (DOLb) no início de estiramento com associação mineral relacionado às alterações do Evento D2 (Amostra K59-09664).(B) Brechas de QTZFSP-CAB xisto carbonoso sendo estiradas em uma matriz clorítico quartzosa com traços de FSP, TUR, MCAR, EP nas proximidades da zona de cisalhamento (Amostra K59-46249). (C) Brechamento do BT-CHL-SE-PL xisto MCAR (Amostra K59-24100). (D) Albitização do BT-CHL-SE-PL xisto carbonoso à esquerda e seu equivalente não alterado à direita, que apresenta como acessórios ainda PO, TUR, RT. Os nódulos carbonosos são preservados durante a albitização e se apresentam bastante estirados no contato evidenciando proximidade da zona de cisalhamento (Amostra K59-19420). 051

PRANCHA 7 - (A) Zona de desenvolvimento de dobras intrafoliais relacionadas ao evento D3 No topo da amostra ocorre o xisto carbonoso na forma laminada, resultado da evolução da milonitização $\left(\mathrm{S}_{\mathrm{m} 3}\right)$ sobre o xisto carbonoso com brechas. Formam-se então dobras intrafoliais certamente devido a resposta ao esforço em função da competência diferenciada. Tais dobras permitem uma entrada maior de associações de alteração como o cloritito com granada, fina e disseminada neste caso. $O$ veio de quartzo no contato das litologias apresenta pirrotita. Ocorrem ainda veios carbonáticos e biotita. (B) Albitização, cloritização e epidotização provavelmente de um protólito xistoso em virtude das dobras $S_{m 3}$ preservadas. A matriz é basicamente albita com QTZ como traço e até $5 \%$ de epídoto. No canto inferior esquerdo pode ser visto a sobreposição da alteração clorítica com a presença de porfiroblastos euédricos de AMP (Amostra K59-28273). (C) Cloritito contendo veios e porfiroblastos feldspáticos deformados pela milonitização tardia, provavelmente neoproterozóica. .053

PRANCHA 8 - (A) Em meio a dolomita cinza hidrotermal, sem sinais de brechamento, encontra-se uma relíquia do ritmito brechado (ver PRANCHA $5 \mathrm{E}$ ), interpretado como protólito sedimentar, envolto pela alteração dolomítica. Notadamente ocorre uma borda de reação ao redor da reliquia, indicando alteração predominantemente química, relacionada ao Evento D3 (Amostra K59-44950). (B) Brechas de dolomito estirada em meio ao cloritito, com filmes de biotita nas bordas (Amostra K59-32710). (C) Contato do dolomito hidrotermal com relíquias do clorita xisto (CHL2) contendo epídoto, turmalina, biotita e plagioclásio, preservando ainda deformações relacionadas ao Evento D3. O cloritito à esquerda é mais tardio, porém ainda como parte do final do evento D3, que além de porfiroblastos de biotita porta ainda Fe-tschermakita subédrica (Amostra K59-30079). .055 
PRANCHA 9 - (A) Cristal de muscovita de veio que sofreu carbonatização suave nas interfaces da geminação, que pode ser reconhecido na parte inferior da fotogratia (Amostra K59-3857-22).(B) mesma área com alteração carbonática realçada ná imagem gerada pela cátodo-luminiscência (Amostra K59-38571-22). (C) $\mathrm{O}$ mineral que cobre toda a metade esquerda da fotografia é siderita (SID4) do veio de alteração (Amostra K59-38571-22). (D) A mesma área revela na imagem gerada pela cátodo-luminiscência (Amostra K59-38571-22). (E) Turmalina, provavelmente TUR3 zonada hidrotermal do início do evento D3 em contato com siderita (Amostra K49-19790). (F) A imagem gerada com auxílio da cátodoluminiscência revela um núcleo carbonático na turmalina, mas que em função do veio carbonático externo sugere uma alteração posterior, provavelmente SID4, do neoproterozóico (Amostra K49-19790). .059

PRANCHA 10 - (A) Porfiroblasto de cloritóide com inclusões de ilmenita alinhadas segundo o plano $S_{1}$, que por sua vez está dobrado pelo evento D3 (amostra K-59-3414). Porfiroblasto de granada subédrica com inclusões de ilmenita alinhadas segundo o plano $\mathrm{S}_{1}$ igualmente dobrado pelo evento D3 (amostra K-59-36508). (C) Porfiroblasto de granada subédrica parcialmente destruída em virtude da proximidade da zona de cisalhamento neoproterozóica (diâmetro do cristal de granada: 3mm, amostra K49 39614). (D) Porfiroblastos estirados de granada, na parte inferior da imagem, e Fe-tschermakita na parte superior (área da imagem com ca. de $5 \times 3 \mathrm{~mm}$, amostra K49-39664). (E) Porfiroblastos de granada e Fe-tschermakita estirados pelo evento D4 entre as linhas brancas tracejadas, ocorrendo ainda porfiroblastos euédricos dos mesmos fora dessa faixa, nas bordas esquerda e direita da imagem (comprimento da amostra: $12 \mathrm{~cm}$, amostra K59-34000). (F) Porfiroblastos de granada e Fe-tschermakita euédricos na matriz de cloritito, em zonas preservadas do cisalhamento neoproterozóico (comprimento da amostra: $10 \mathrm{~cm}$, amostra K59-34000) .....060

PRANCHA 11 - (A) Arsenopirita no Q-IV1 (amostra 12-01, luz refletida). (B) Arsenopirita com fratura preenchida com calcopirita (Q-IV1, amostra 12-07, luz refletida). (C) Arsenopirita com calcopirita na borda (Q-IV1, amostra 12-07, luz refletida). (D) Arsenopirita subhédrica fraturada em contato com pirrotita mais tardia isenta de fraturas no veio I (Q-IV1, amostra 021, luz refletida). (E) Lineação mineral e de estiramento $3\left(\mathrm{~L}_{\mathrm{m} / \mathrm{c} 3}\right)$ no xisto carbonoso mostra o preenchimento com sulfetos, nesse caso uma borda de arsenopirita com núcleo de pirrotita (Q-IV1, amostra 019, luz refletida). (F) Inclusão euhédrica de arsenopirita na pirrotita (amostra IV-22-17905, luz refletida). Abreviações segundo Tabela 1. .062

PRANCHA 12 - (A) Arsenopirita na borda de um cristal subhédrico de siderita no Q-IV4 (amostra 73 08, luz refletida). (B) Inclusão de arsenopirita na siderita euhédrica com fraturamento induzido pelos falhamentos tardios (Q-IV4, amostra 73_08, luz refletida). (C) Arsenopirita milonitizada com inclusões de esfalerita e pirrotita (Q-IV4, amostra IV-2218076, luz refletida). (D) Pirrotita como sombra de pressão do nódulo de material carbonoso (Q-IV1, amostra 21, luz refletida). (E) Pirrotita fraturada com inclusão de esfalerita e turmalina, e quartzo recristalizado (Amostra IV-22-17905, luz refletida). (F) Vug entre cristais de plagiclásio zonado euédricos preenchido com carbonato e cristais euhédricos de pirrotita (Q-IV4, amostra CIV-G026-V4AU, 100\% luz refletida, 100\% luz transmitida). Abreviações segundo Tabela 1. .064

PRANCHA 13 - (A) Grãos de ouro na encaixante carbonosa do veio de quartzo com $L_{\mathrm{m} / \mathrm{c} 3}$ preservada no xisto (Amostra IV-22-17905, 100\% luz refletida e 30\% luz transmitida). (B) Ouro cristalizado entre grãos de quartzo na zona de influência dos fluidos ligados a pirrotita. O contorno escuro ao redor do grão de ouro é a sombra do próprio mineral na lâmina. (C) Ouro em contato com pirrotita, ambos provenientes da $\mathrm{L}_{\mathrm{m} / \mathrm{c} 3}$ do xisto carbonoso hospedeiro do veio de quartzo, sendo que a partir do grão de Au saem diversas trilhas carbônicas (e aqua?) (Amostra IV-22-17905, 100\% luz refletida e 30\% luz transmitida) (D) O espaço vazio entre 
cristais de plagioclásio ( $v u g$ ) foi preenchido com pirrotita, calcita, calcopirita e ouro (Amostra CIV-G026-V4AU, 100\% luz refletida e 30\% luz transmitida).(E) Imagem gerada com auxílio do microscópio eletrônico de varredura (MEV) com pontos de análise semiquantitativa onde: 7 -. quartzo, 8 - pirrotita, 9 e 10 - ouro (amostra IV-22-17905); (F) Imagem do xisto carbonoso próximo ao veio de quartzo mineralizado onde: 17, 19 - clorita, 18 -oligoclásio, 20, 26 - dolomita ferrosa, 21, 24 - ouro, 23, 25 - pirrotita (amostra IV-23-14820). Abreviações segundo Tabela 1

PRANCHA 14 - (A) Ouro com inclusões de esfalerita (Amostra IV-22-18737, luz refletida). (B) Ouro em contato com esfalerita e com inclusões do mesmo sulfeto (Amostra IV-2218737, luz refletida). (C) Ouro em contato com esfalerita com inclusões do mesmo sulfeto (Amostra IV-22-17905, luz refletida). (D) Ouro em fraturas da esfalerita (Amostra IV-23 14020, luz refletida). (E) Ouro ao redor da esfalerita e ambos inclusos na pirrotita, ouro também na borda da pirrotita (Amostra IV-22-18076, luz refletida). (F) Pirrotita com inclusões de esfalerita e ouro na borda (Amostra IV-22-17905, luz refletida). Abreviações segundo Tabela 1. 069

PRANCHA 15 - (A) Ouro com inclusão de esfalerita e parcialmente incluso na pirrotita (Amostra IV-22-18076, luz refletida). (B) Ouro, arsenopirita e esfalerita parcialmente inclusos na pirrotita, sendo que a arsenopirita subhedrica apresenta fraturamentos em função da $S_{m 3} e$ também contém inclusões de esfalerita (Amostra IV-22-18076, luz refletida). (C) Ouro parcialmente incluso na pirrotita (Amostra IV-22 17905, luz refletida). (D) Ouro parcialmente incluso na pirrotita (Amostra IV-22-18076, luz refletida). (E) Ouro livre com pirrotita no veio de quartzo com carbonato, provavelmente dolomita ferrosa (Amostra IV-23-14877, luz. refletida e transmitida). (F) Ouro no veio de quartzo com pirrotita (Amostra IV-23-14877, luz refletida e transmitida). Abreviações segundo Tabela 1. .070

PRANCHA 16 - (A) Textura do quartzo inequigranular interlobado; o círculo tracejado destaca um cristal subhedral de quartzo (Q-IV1, amostra CIV-G010-V1, campo escuro). (B) Detalhe das formas subhedrais dos cristais de quartzo (Q-IV1, amostra CIV-G010-V1, luz, transmitida). (C) Textura do quartzo inequigranular interlobado e xisto carbonoso dobrado (Q-IV1, amostra CIV-G019-V1, luz transmitida). (D) Turmalinização próxima ao contato do xisto carbonoso com o veio de quartzo (Q-IV1, amostra CIV-G019-V1, luz transmitida). (E) Cristal subhédrico de turmalina "bicolor" em contato com pirrotita anterior, que por sua vez traz uma inclusão de arsenopirita (Q-IV1, amostra CIV-G019-V1, luz transmitida). (F) Finos cristais de turmalina mostrando fraturas com deslocamentos quando posicionados ortogonalmente ao sistema de falhas tardias (evento D4) e cristais paralelos a esse sistema de falha sem fraturas (Q-IV1, amostra CIV G019-V1, luz transmitida). Abreviaçôes conforme TABELA 1 . 122

PRANCHA 17 - (A) Quartzo recristalizado com textura poligonal equigranular e boudins no xisto carbonoso (Q-IV1, amostra CIV-G021-V1, campo escuro). (B) Detalhe da textura equigranular poligonal dentro do boudin. (Q-IV1, amostra CIV-G021-V1, campo escuro). (C) Relíquia do xisto carbonoso no veio de quartzo, o quartzo recristalizado do xisto carbonoso é inteiramente substituído pelo quartzo inequigranular interlobado (Q-IV1, amostra CIV-G021$\mathrm{Vl}$, luz transmitida). (D) Textura inequigranular interlobado com recristalização nas bordas dos grãos devido aos fluidos derivados do xisto carbonoso (Q-IV2, amostra CIV-G027-V2, luz transmitida). (E) Agregado de grãos de quartzo no domínio da veio 3 (Q-IV3, amostra CIV-G014-V3, campo escuro). (F) Estruturas "S/C" no domínio do veio de quartzo 3 , relacionado à $\mathrm{D}_{4}$ (Q-IV3, amostra CIV-G014-V3, luz transmitida). 126

PRANCHA 18 - (A) Grãos de quartzo do domínio da encaixante mostrando quartzo recristalizado com padrão equigranular, poligonal e relativamente menor que o domínio do 
veio (Q-IV3, amostra CIV-G014-V3, luz transmitida). (B) Agregado de grãos de quartzo no domínio do veio (Q-IV3, amostra ClV-G015-V3, luz transmitida). (C) Relíquias da $\mathrm{S}_{\text {; }}$ dobrada com a superposição do cisalhamento posterior à $S_{\mathrm{m} 3}$ milonitica (Q-IV3, amostra CIVG015-V3, luz transmitida). (D) Padrão dos grãos de quartzo no domínio do veio (Q-IV3, amostra CIV-G015-V3, luz transmitida). (E) Agregado de grãos de quartzo no domínio da encaixante com $\mathrm{S}_{\mathrm{m} 3}$ milonítica deslocada pelo sistema ortogonal de fallas strike-slip tardias (Q-IV3, amostra CIV-G015-V3, luz transmitida). (F) Relíquias da $\mathrm{S}_{1}$ dobrada, $\mathrm{S}_{\mathrm{m} 3}$ milonítica e o sistema de falhas tardias com preenchimento de carbonato e pirrotita (Q-IV3, amostra CIV-G015-V3, luz transmitida).

PRANCHA 19 - (A) Veio de quartzo cisalhado/recristalizado (Q-IV4, Amostra CIV-G012V4, luz transmitida). (B) Cristais euhédricos de siderita no veio de quartzo hialino com inclusões fluidas aquo-carbônicas primárias (Q-IV4, Amostra CIV-G073-V4, luz transmitida). 130

PRANCHA 20 - (A) Associação de IFs carbônicas primárias no núcleo do grão de quartzo (Q-IV1, Amostra 19_07). (B) Associação de IFs carbônicas primárias entre relíquias de cristais de quartzo subhédricos (Q-IV1, Amostra 19 10). (C) Um par geminado de cristais de quartzo subhédricos com inclusões primárias em 19_12c e secundárias em 19_12a e 19 12b (Q-IV1, Amostra 19 12). (D) Inclusão fluida aquo-carbônica com dois cristais de saturação sendo halita o cristal cúbico maior e calcita o menor (Q-IV1, Amostra 10_05). (E) Imagem de um cristal subhédrico com um grupo de inclusões carbônicas primárias (1c), vários grupos com inclusões aquo-carbônicas secundárias ( $\left.\operatorname{lac}_{1}\right)$ com até dois cristais de saturação e um grupo de inclusões fluidas aquo-carbônicas tardias $\left(\mathrm{lac}_{2}\right)$ com no máximo um cristal de saturação que corta a trilha do grupo anterior (Q-IV1, Amostra 10 09). (F) Detalhe do canto direito inferior onde a trilha de inclusões aquo-carbônica $1 \mathrm{ac}_{1}$ é cortada pela posterior $1 \mathrm{ac}_{2}$ (Q-IV1, Amostra 10_09). 133

PRANCHA 21 - (A) Cruzamento das duas gerações de inclusões fluidas aquo-carbônicas, onde $\mathrm{lac}_{2}$ mantém a continuidade sobre $1 \mathrm{lac}_{1}$ (Q-IV1, Amostra 10 10). (B) Inclusão fluida aquo-carbônica com dois cristais de saturação (Q-IV1, Amostra 10 10). (C) Grupo de inclusões carbônicas (Q-IV1, Amostra 10_10). (D) Imagem de um grupo de inclusões aquocarbônicas com até dois cristais de saturação (Q IV1, Amostra 21_02). (E) Inclusões fluidas aquo-carbônicas secundárias (Q-IV2, Amostra 27 09). (F) Uma das raras inclusões fluidas aquo-carbônicas primárias com 2 cristais de saturação, provavelmente halita e rutilo (Q-IV2, Amostra 27 10). 135

PRANCHA 22 - (A) Grupo de inclusões carbônicas e aquo-carbônicas com feições que sugerem condições de imiscibilidade e/ou variação de pressão durante o aprisionamento (QIV3, Amostra 14_3). (B) Inclusões aquo-carbônicas predominantes no veio 3 (Veio 3, Amostra 14_10). (C) O mineral no centro aparenta ser de um sulfeto (provável seção ortogonal de uma "injeção" de pirrotita proveniente da $L_{m / e}$ na encaixante) que gerou um halo de inclusões aquo-carbônicas ao seu redor (Q-IV3, Amostra 14_5). (D) Quartzo incluso na arsenopirita com inclusões aquo-carbônicas ricas em metano no contato com o sulfeto e nos planos internos (Q-IV4, Amostra 12 01). (E) Detalhe da fotografia 3-D com inclusões aquo-carbônicas ricas em metano na interface quartzo/arsenopirita (Q-IV4, Amostra 12 1). (F) Trilhas de inclusões aquosas tardias, provavelmente relacionadas aos sistemas de falhas do evento D4 (Q IV4, Amostra 12_07). 136

PRANCHA 23 - (A) Associação pirrotitamapatita-calcita (apatita no centro, incolor), onde ocorre ouro livre, contendo inclusões predominantemente aquo-carbônicas (Q-IV4, Amostra 26 01). (B) Detalhe das inclusões aquo-carbônicas da foto anterior (Q-IV4, Amostra 26 01). (C) Inclusões aquo-carbônicas primárias na siderita (Q-IV4, Amostra 73 05). (D) Trilha de 
inclusões aquo-carbônicas no quartzo (Q-IV4, Amostra 73_09). (E) Raras inclusões carbônicas no veio 4 (Q-IV4, Amostra 73 10). (F) Plano de inclusões fluidas aquo-carbônicas pseudo-secundárias em um cristal subhédrico de quartzo (Q-IV4, Amostra 73_12) …........138

PRANCHA 24 - Trilhas de inclusões fluidas geradas pelas falhas tardias com aspecto "S/C" (Q-IV4, Amostra 73_13). 


\section{CAPÍTULOI \\ OB.JETIVOS, LOCALIZAC ÃO E MÉTODOS}

\section{INTRODUCÃO}

A região de Crixás em Goiás tem sido alvo de diversos estudos desde a década de 70 , década na qual foram caracterizados greenstone belts nesta região, semelhante aos modelos africanos da época. A atividade até então garimpeira foi sendo substituída pela mineração subterrânea mecanizada com a implantação da Mina Serra Grande, logo após a determinação da reserva do Corpo III em meados de 1980.

A contínua sondagem na busca de novos corpos de minério aliado aos avanços na interpretação extremamente complicada do controle estrutural da jazida, resultou no descobrimento dos Corpos IV e V, sendo que o presente trabalho faz um enfoque detalhado do Corpo IV com extensões ao Corpo V.

A sobreposição de eventos paleoproterozóicos a neoproterozóicos e diversos sistemas de alterações hidrotermais com intensidades variadas agindo sobre um pacote de rochas com litologias originais bastante diversas, principalmente das rochas da Formação Ribeirão das Antas, traz grandes complicadores para um estabelecimento preciso do controle da mineralização até os dias de hoje.

O presente trabalho procura contribuir com os numerosos estudos realizados na área por diversos pesquisadores, notadamente da Universidade Federal de Brasília, e propõe um modelo de evolução estrutural para o Corpo IV e Corpo V, ambos relativamente próximos e contidos na Formação Ribeirão das Antas.

\section{OBJETIVOS}

O principal objetivo do presente trabalho é a caracterização metalogenética do Corpo IV e Corpo V, visando uma melhor compreensão dos controles das mineralizações. Para tanto foi dada uma importância especial na comparação petrográfica e litoquímica com as outras zonas de minério próximas (Zona Superior, Intermediária e Inferior da Mina III), visando vincular resultados de pesquisas anteriores com os novos corpos de minério.

Os trabalhos iniciais envolveram o mapeamento de galerias de acesso aos corpos de minério com amostragem e descrições, paralelamente à descrição e amostragem de 
testemunhos de sondagem, considerados essenciais para a compreensão e estabelecimentos de padrões de alteração e zonas de cisalhamento.

Procurou-se, estabelecer a cronologia relativa de eventos que veio a dar forma e/ou a destruir partes da mineralização do Corpo IV. O Corpo $V$ que se situa nas imediações do Corpo IV, possui características semelhantes, o que permite seu enquadramento $\mathrm{em}$ um modelo semelhante.

Coube um destaque especial na interpretação das texturas relacionadas às diversas gerações de veios de quartzo que tem antes, durante e depois das mineralizações um papel fundamental, Ainda, dada à importância dos veios de quartzo, foram estabelecidas características dos fluidos envolvidos por meio da microtermometria de inclusões fluidas.

Visto que, devido a complexidade da mineralização haveria uma grande quantidade de dados a serem processados, de uma maneira que permitisse modificações constantes e sem perda de informação com a evolução da pesquisa, foi elaborado um programa de banco de dados vinculado a um sistema de posicionamento tridimensional. Isso permitiu o manuseio integral dos dados, o que por final auxiliou de sobremaneira na proposta do modelo metalogenético das mineralizações.

\section{LOCALIZACÃO DA ÁREA E ACESSOS}

As zonas mineralizadas denominadas Corpo IV e Corpo $\mathrm{V}$ situammse dentro da área pertencente à Mineração Serra Grande, situada a aproximadamente $5 \mathrm{~km}$ não pavimentados, a sudeste da cidade de Crixás.

Crixás localiza-se a aproximadamente $450 \mathrm{~km}$ a noroeste de Brasilia ou a aproximadamente $400 \mathrm{~km}$ ao norte de Goiânia (FIGURA 1), onde todos os acessos são asfaltados. Conforme a FIGURA 1 pode-se verificar que a rodovia principal de acesso é a BR 153 ou "Belém-Brasilia".

A Cidade de Crixás oferece ainda um campo de pouso para aeronaves bimotor, o que permite um período de viagem de I hora até Brasília. 


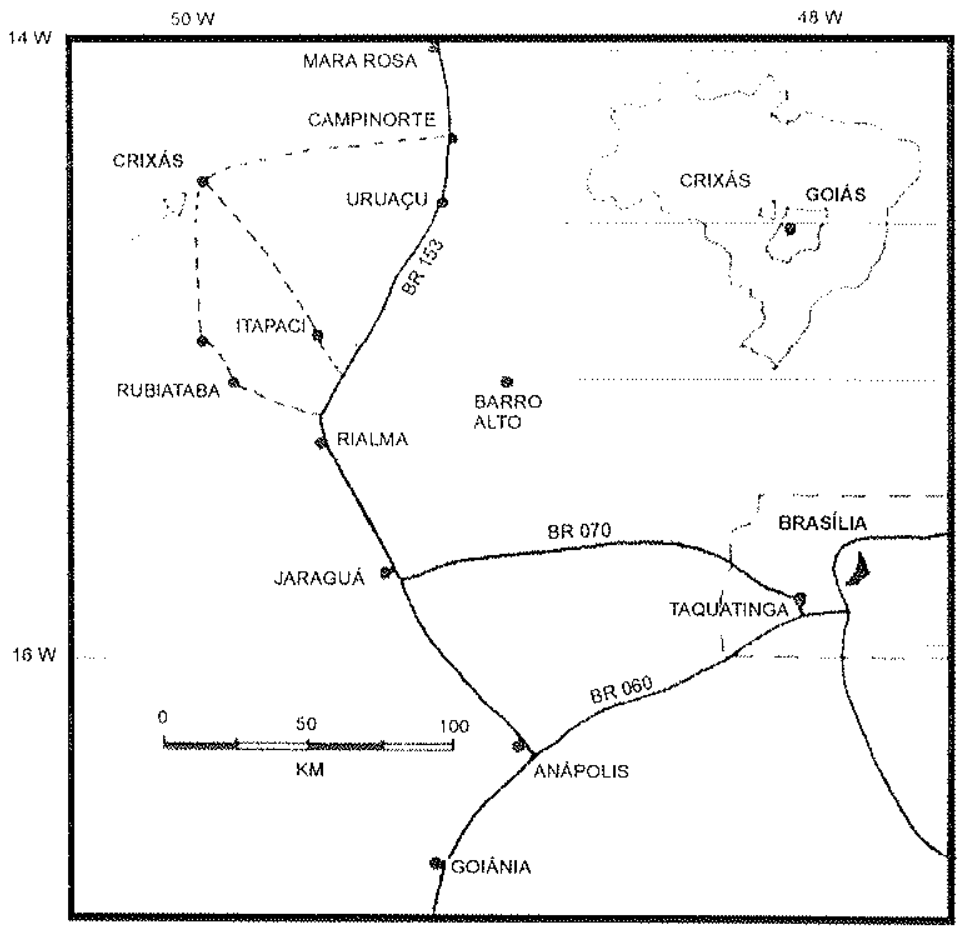

FIGURA 1 - Localização de Crixás (modificado de Yamaoka \& Araújo, 1988).

\section{MÉTODOS}

\subsection{Amostragem e Nomenclatura de Amostras}

Todas as amostras utilizadas no presente estudo foram colhidas nas galerias e dos testemunhos de sondagem. As amostras foram serradas no Laboratório de Tratamento de Amostras do IG-USP conforme as exigências para cada análise.

As amostras dos testemunhos de sondagem, assim como as respectivas lâminas delgadas foram codificadas segundo o nome do furo do testemunho de sondagem seguido de um hífen e a metragem em centímetros. Por exemplo, uma amostra a 161,26 metros, medida do topo da amostra, do início do testemunho de sondagem $(0 \mathrm{~m})$, denominado pela MSG como K59, é codificada como "K59-16126".

Para a abreviação da nomenclatura mineral, foi adotada a proposta de Kretz. (1983) em inglês, com algumas modificações, conforme a TABELA 1 abaixo. 
TABELA 1 - Tabela de abreviações minerais de Kretz (1983) adotada, com modificações.

\begin{tabular}{|c|c|c|c|c|c|}
\hline $\mathrm{ACM}$ & acmita & $\mathrm{EP}$ & epídoto & OPX & ortopiroxênio \\
\hline $\mathrm{ACT}$ & actinolita & FA & faialita & OSMI & ossumilita \\
\hline AEG & aegirina & FAC & ferroactinolita & $\mathbf{P G}$ & paragonita \\
\hline $\mathrm{AK}$ & akermanita & FED & ferroedenita & PRG & pargasita \\
\hline $\mathrm{AB}$ & albita & FS & Ferrosilita & PER & periclásio \\
\hline $\mathrm{ALN}$ & allanita & FTS & ferrotschermakita & PHE & lengita \\
\hline ALM & almandina & FL & fluorita & PHL & llogopita \\
\hline AMP & anfibólio & $\mathrm{FO}$ & forsterita & PGT & pigeonita \\
\hline ANL & analcita & GRT & granada & PL & plagioclásio \\
\hline AND & andalusita & GED & gedrita & PRH & prenhita \\
\hline ANK & ankerita & GLN & glaucotano & PMP & pumpeliíta \\
\hline $\mathrm{ANN}$ & annita & GR & grafita & PY & pirita \\
\hline $\mathrm{AN}$ & anortita & GRS & grossulária & PRP & piropo \\
\hline ATH & antofilita & GRU & grunerita & PRL & pirofilita \\
\hline $\mathrm{AP}$ & apatifa & HD & hedenbergita & $\mathrm{PO}$ & pirrotita \\
\hline $\mathrm{ASP}$ & arsenopirita & HEM & hematita & $Q^{T Z}$ & quartzo \\
\hline BT & biotita & $\mathrm{HC}$ & hercinita & RBK & riebeckita \\
\hline BCR & brucita & $\mathrm{HB} / \mathrm{AC}$ & hornblenda/actinolita & RT & rutilo \\
\hline CAM & Ca-clinoantibólio & ILL & illita & SA & sanidina \\
\hline CPX & Ca-clinopiroxênio & ILM & ilmenita & SPR & Safirina \\
\hline CAL & calcita & JD & jadeíta & SID & siderita \\
\hline $\mathrm{CCP}$ & calcopirita & KLN & caolinita & SRP & serpentina \\
\hline CEN & clinoenstatita & KFS & Feldspato potássico & $\mathrm{SE}$ & sericita \\
\hline CFS & clinoferrosilita & $\mathrm{KY}$ & cianita & SIL & sillimanita \\
\hline CHL & clorita & LMT & laumontita & SPS & espessartita \\
\hline ClD & cloritóide & MCAR & material carbonoso & SP & esfalerita \\
\hline $\mathrm{CHU}$ & clinohumita & MGS & magnesita & SPL & espinélio \\
\hline $\mathrm{CZO}$ & clinozoisita & MAG & magnetita & ST & estaurolita \\
\hline $\mathrm{COE}$ & coesita & $\mathrm{MRG}$ & margarita & STP & estilpnomelano \\
\hline CRD & cordierita & $\mathrm{MC}$ & microclínio & TLC & talco \\
\hline CRN & corindon & MNZ & monazita & TTN & titanita \\
\hline CRO & crossita & MNT & montmorilonita & TUR & turmalina \\
\hline CUM & cummingtonita & MS & muscovita & TR & tremolita \\
\hline DMD & diamante & $\mathbf{N E}$ & nefolina & TS & tschermakita \\
\hline DI & diopsídio & OLG & oligoclásio & USP & ulvoespinélio \\
\hline $\mathrm{DOL}$ & dolomita & $\mathrm{OMP}$ & onfacita & Wo & Wollastonita \\
\hline DOLF & dolomita ferrosa & OAM & ortoantibólio & ZRN & zircào \\
\hline EN & enstatita & OR & ortoclásio & $\mathrm{ZO}$ & zoisita \\
\hline
\end{tabular}

\section{$\underline{3.2 \text { Petrografia }}$}

Foram confeccionadas cerca de 150 lâminas delgadas de rochas. O estudo das seções delgadas foi realizado em microscópios AXIOPLAN, NIKON, OLYMPUS e LEITZ WETZLAR do Laboratório de Petrologia do Departamento de Mineralogia e Petrologia do IG/USP. Nestes equipamentos foram também obtidas as fotomicrografias. 
Foram ainda confeccionadas cerca de 20 seções polidas, que foram estudadas em microscópios NIKON e OLYMPUS do laboratório de inclusões fluidas do Centre for Global Metallogeny da University of Western Australia.

Para o estudo de inclusões fluidas foram confeccionadas cerca de 25 lâminas polidas em ambos os lados. O estudo dessas seções foi realizado no laboratório de inclusões fluidas do Centre for Global Metallogeny da University of Western Australia e no Laboratório de Inclusões Fluidas do IG-USP.

Para a análise com auxílio da microssonda eletrônica foram confeccionadas 18 lâminas delgadas polidas, com recobrimento metálico.

\subsection{Coloracão Seletiva}

Todas as lâminas delgadas foram parcialmente tratadas pelo meio de coloração seletiva segundo o método descrito abaixo:

a) Ataque com $\mathrm{HCl} 1,5 \%$ por 10-15 segundos, seguido de lavagem imediata com água destilada corrente e secagem com pistola de ar quente.

b) Submersão de metade de cada lâmina em solução com $0,2 \mathrm{~g}$ de Alizarina red/100 cc de $\mathrm{HCl} 1,5 \%$ e $2,0 \mathrm{~g}$ de ferrocianeto de potássio/100cc de $\mathrm{HCl} 1,5 \%$, na proporção $3: 2$, respectivamente, por $30-40$ segundos.

c) Submersão das mesmas metades de cada lâmina em recipiente contendo apenas a solução $0,2 \mathrm{~g}$ de alizarina red/100 cc de $\mathrm{HCl} 1,5 \%$, por 10 a 15 segundos. Lavagem imediata em água destilada não corrente e secagem com pistola de ar quente.

d) Colocação das lamínulas para proteção da área tratada.

\subsection{Cátodo-Luminiscência}

O Laboratório de Cátodo-luminiscência do IG-USP dispõe de um equipamento LUMINISCOPE ELM-3K que trabalha em conjunto com a platina Modelo ELM 3.1R. A platina está montada em um Microscópio OLYMPUS BX $40 \mathrm{com}$ uma câmera OLYMPUS PRO SERIES $3 \mathrm{CCD}$, que opera em conjunto com um IBM/PC para geração, edição e armazenamento de imagens. 


\section{$\underline{3.5 \text { Microscópio Eletrônico de Varredura }}$}

Foi utilizado um equipamento MEV LEO 440 I com detector de elétrons secundários retro-espalhados, cátodo-luminiscência e espectrômetro de energia dispersiva de raios X com janela de Si-Li, do Laboratório de Microscopia Eletrônica do IG-USP.

\subsection{Microssonda Eletrônica}

Após conclusão das descrições petrográficas foram escolhidas 18 amostras para a análise química dos minerais em microssonda eletrônica (MSE). Foram analisados minerais representativos dos diversos litotipos, tanto para caracterização e classificação química, como para cálculos geotermobarométricos.

As análises foram realizadas com a microssonda eletrônica JEOL JXA 8600 do Laboratório de Microssonda Eletrônica do IG-USP, com corrente de aceleração do feixe de elétrons de $20 \pm 0,1 \mu \mathrm{A}$, tensão de $15 \mathrm{kV}$ e diâmetro do feixe de $10 \eta \mathrm{m}$ para os feldspatos e de $5 \mu \mathrm{m}$ para os demais minerais.

Os resultados das análises foram processados através dos softwares MICROSOFT EXCEL 2000 e MINPET 2.02, onde foram calculadas proporções catiônicas e elaborados diagramas da variação composicional e de classificação.

As condições para o re-cálculo dos cátions para cada mineral foram:

- Feldspato. Oxigênio e OH $(\mathrm{O}, \mathrm{OH}, \mathrm{F}): 32 ; \mathrm{Al}^{\mathrm{IV}}$ no sítio tetraédrico: 8-Si. Cátions normalizados para o valor $8,0: \mathrm{Si}+\mathrm{Al}$.

- Anfibólio cálcico. Cálculo do Fe $\mathrm{e}^{3+}$ pela média dos processos 15-NK e 13 CNK (Leake et al., 1997).

- Clorita. Oxigênio e OH $(\mathrm{O}, \mathrm{OH}, \mathrm{F})$ : 36; número de grupos $\mathrm{OH}: 16$; $\mathrm{Al}^{\mathrm{IV}}$ no sítio tetraédrico: $8-\mathrm{Si}$. Cátions normalizados para o valor 20: $\mathrm{Si}+\mathrm{Al}^{\mathrm{IV}}+\mathrm{Al}^{\mathrm{IV}}+\mathrm{Ti}+\mathrm{Cr}+\mathrm{Fe}^{2+}+\mathrm{Mn}+\mathrm{Mg}$.

- Muscovita. Oxigênio e $\mathrm{OH}(\mathrm{O}, \mathrm{OH}, \mathrm{F}): 24$; número de grupos $\mathrm{OH}$ : 4; $\mathrm{Al}^{\mathrm{lV}}$ no sítio tetraédrico: 8-Si. Cátions normalizados para o valor 14: $\mathrm{Si}+\mathrm{Al}^{\mathrm{IV}}+\mathrm{Al}^{\mathrm{IV}}+\mathrm{Ti}+\mathrm{Cr}+\mathrm{Fe}^{2+}+\mathrm{Mn}+\mathrm{Mg}$

- Biotita. Oxigênio e $\mathrm{OH}(\mathrm{O}, \mathrm{OH}, \mathrm{F}): 24$; número de grupos $\mathrm{OH}: 2,0 ; \mathrm{Al}^{\mathrm{IV}}$ no sítio tetraédrico: 8-Si. Cátions normalizados para o valor 14: $\mathrm{Si}+\mathrm{Al}^{\mathrm{IV}}+\mathrm{Al}^{\mathrm{IV}}+\mathrm{Ti}+\mathrm{Cr}+\mathrm{Fe}^{2+}+\mathrm{Mn}+\mathrm{Mg}$.

- Granada. Todo o ferro foi assumido como sendo FeO. Normalização com 24 oxigênios e 16 cátions com membros finais segundo Deer et al. (1992). 


\subsection{Geotermobarometria (TWO)}

As interpretações geotermobarométricas foram realizadas com o auxílio do programa de computador TWQ 2.02, que utiliza um banco de dados termodinâmicos internamente consistentes de Berman (1980), para minerais e fluidos das fases $\mathrm{K}-\mathrm{Na}-\mathrm{CASH}$, além de dados para os seguintes minerais:

1. antofilita, talco, rutilo assim como os componentes das seguintes soluções sólidas: olivina (FO, FA), ortopiroxênio (EN, FS, Al-OPX), cordierita (Mg-, Fe-), granada (ALM, PY, GROS, ESPESS), ilmenita (Fe-, GK), e espinélio de Mg-Fe.

2. Propriedades de mixing da Hedenbergita e Clinopiroxênio de Mg-Fe-Al (M1).

3. Propriedades provisionais para Biotita (PHL, ANN, SID, EST).

\subsection{Microtermometria (IG-USP)}

O trabalho de microtermometria foi executado com o auxílio de um microscópio LEITZ WETZLAR, utilizando-se duas platinas CHAIX-MECA tipo MTM 85 (Platina I para resfriamento e Platina II para aquecimento) do Laboratório de Inclusões Fluidas do Departamento de Mineralogia e Petrologia do IG-USP, onde a seção do mineral pode ser resfriada a $-180^{\circ} \mathrm{C}$ e aquecida até $600^{\circ} \mathrm{C}$.

As medições das duas platinas da "SOCIÉTÉ CHAIX-MECA" foram padronizadas para correção da temperatura, uma delas utilizada apenas para resfriamentos (platina I: -180 a $40^{\circ} \mathrm{C}$ ) e outra para aquecimento (platina II: 40 a $550^{\circ} \mathrm{C}$ ).

\subsection{Microtermometria (CGM/UWA)}

As análises microtermométricas foram realizadas com uma platina de aquecimento e resfriamento totalmente automática LINKAM THMSG 600, acoplada a um programador de temperatura TMS 93 do laboratório de inclusões fluidas do Centre for Global Mettalogeny na University of Western Australia. A platina é diariamente calibrada com inclusões sintéticas fornecidas pela SYNFLINK. A bomba de nitrogênio liquido (LNP) do sistema de resfriamento opera diretamente de um recipiente térmico não pressurizado com até 2 litros de nitrogênio líquido. As medições săo coletadas por meio de perfis de temperatura prém estabelecidos que contêm a seqüência de intervalos consecutivos com os gradientes de aquecimento e resfriamento. 


\subsection{Laser-Raman}

Os espectros de Laser Raman foram registrados com o auxilio de um espectrômetro DILOR ${ }^{1}$ SUPERLABRAM equipado com filtro holográfico de ponto, gratings de 600 e 1800 $\mathrm{g} / \mathrm{mm}$ e um detector com CCD refrigerado por $\mathrm{N}_{2}$ líquido com resolução de $2000 \times 400$ pixel. As inclusões são iluminadas com laser de $514,5 \mathrm{~nm}$ gerado por um equipamento de laser de ion-argônio SPECTRA PHYSICS modelo 2017, com intensidade de $5 \mathrm{~mW}$ nas amostras aliado a um periodo de acumulaçăo de 30 segundos. Para a coleta do scattered light e para focar o feixe de laser é utilizado uma objetiva de microscópio OLYMPUS de 100X. O campo do laser focado nas amostras possuí o diâmetro aproximado de $1 \mu$ m. Os valores dos picos săo determinados com um precisão de $\pm 1 \mathrm{~cm}^{-1}$ determinados pelas linhas de emissão de plasma e neônio. Para a análise de $\mathrm{CO}_{2}, \mathrm{O}_{2}, \mathrm{~N}_{2}, \mathrm{H}_{2} \mathrm{~S}$ e $\mathrm{CH}_{4}$ na fase vapor, faz-se a caracterização do espectro de 1000 to $3800 \mathrm{~cm}^{-1}$ utilizando um tempo de integração único de 20 segundos por espectro. O tempo limite de deteç̧ão é dependente da sensitividade instrumental, da pressão parcial de cada gás e da qualidade óptica para cada inclusão fluida. Os limites de deteç̧ão são estimados ao redor de 0,1 mole $\%$ para $\mathrm{CO}_{2}, \mathrm{O}_{2}$ e $\mathrm{N}_{2}$, e 0,03 moles $\%$ para $\mathrm{H}_{2} \mathrm{~S}$ e $\mathrm{CH}_{4}$. Erros nas razões calculadas de gás são geralmente menores que 1 mol \%.

\subsection{Microtermometria em Minerais Opacos com o Auxilio de Infravermelho}

O estudo de propriedades ópticas de minerais com o auxílio do infravermelho não é uma técnica nova, tendo sido utilizada anteriormente a década de 30, mas sua aplicação no estudo de inclusões tluidas teve início apenas em meados de 1980 (Campbell et al., 1984, in: Lindass et al, 2002).

A absorção óptica do cristal ocorre quando o comprimento de onda da luz passando através do cristal corresponde a diferença de energia entre estados de energia ocupados e nãoocupados (eletrônico e vibracional). O excitamento de estados de energia ocupados para estados não-ocupados é acompanhado da absorçăo do comprimento de onda correspondente. Tal processo eletrônico é chamado de transição do espaço de banda (band gap transition). Se, por exemplo, o incremento na absorção com o aumento da energia de fótons for igual ou maior que o espaço de banda, a amostra se apresenta, em essência, opaca. A súbita mudança de absorção com energias próximas do espaço de banda aparece no espectro de absorção como um forte pico, chamado de pico de absorção principal (main absortion edge). No caso da pirita, por exemplo, o pico de absorção principal situa-se a aproximadamente 1,38 $\mu \mathrm{m}$, 
sendo que comprimentos de onda mais curtos que este valor. como da luz visivel $(0.35$ a 0.75 $\mu \mathrm{m})$, possuem energia mais alta que o espaço de banda da pirita, e como resultado, tais comprimentos de onda são inteiramente absorvidos. Comprimentos de onda mais longos que 1,38 $\mu \mathrm{m}$, como do próximo/médio infravermelho, são de energia mais baixa que o espaço de banda da pirita e, em geral, atravessam o cristal sem serem absorvido (Lindass et al., 2002). Mas existem diversos fatores que vem a dificultar a observação com o auxílio de infravermetho como inclusões minerais, intercrescimentos e variações químicas do cristal. Entre elas o conteúdo de arsênio é interpretado como um elemento indesejado para obter observações, mas por outro lado, já foram realizadas observações de inclusões fluidas em arsenopirita (com. verb. Mernaugh, 2002). De qualquer maneira, mesmo que se obtenha condições consideradas ideais de observação, o estudo de inclusões fluidas com o auxílio da câmera infravermelha é bastante difícil, pois a maneira de visualização apresenta uma qualidade que, de longe, não se compara a condições de estudo com luz visivel e, somado a isso, ocorre ainda forte interferência nas imagens em função das variações de temperaturas impostas a amostra durante a microtermometria.

Utilizou-se um microscópio OLIMPUS BX $60 \mathrm{em}$ associação com um programador LINKAM MDS 600. Ao microscópio foi acoplado uma câmera de infravermelho Hamamatsu C2741 que trabalha na faixa de 400 a $2200 \mathrm{~nm}$ e o vidro de quartzo da platina Linkam é substituída por um vidro de C2nSe. É necessário ainda uma objetiva IR-PLAN 50X trabalhando em conjunto com um condensador IR-CONDENSER $20 \mathrm{X}$.

\subsection{Raios X}

A análise utiliza o princípio da difração dos raios $X$, resultado de um processo em que estes raios são dispersos pelos elétrons dos átomos sem mudança de comprimento de onda (dispersão coerente ou de Bragg). Para que ocorra um feixe difratado por dispersão é necessário que algumas condições geométricas satisfaçam a lei de Bragg traduzido na forma de $\mathrm{n} \lambda=2 \mathrm{dhkl} \operatorname{sen} \theta$, onde $\lambda$ é o comprimento de onda da radiação (aproximadamente monocromática), dhkl é à distância interplanar e $\theta$ é o ângulo de Bragg. A difração resultante, que compreende posições e intensidades das linhas de difração, é uma propriedade física fundamental da substância e fornece dados para sua identificação e de sua estrutura atômica (Gomes, 1984). 


\subsection{Tratamento de Dados Estruturais}

Os dados estruturais obtidos nos trabalhos de campo foram processados com o auxílio

do programa de computador GEOorient 9.1. Para tanto utilizou-se da rede equiárea de Schmidt no hemisfério inferior. 


\section{CAPÍTULO II \\ GEOLOGIA REGIONAL E LOCAL}

\section{INTRODUCÃO}

Este Capítulo trata primeiramente do histórico geológico da região de Crixás, da geologia local e de datações realizadas até o momento na área e proximidades. São então apresentadas diversas tabelas, reunindo as diversas hipóteses e descrições macroscópicas detalhadas das zonas mineralizadas do Corpo IV, Corpo V e zonas de alteração hidrotermal, além de dados sobre o desenvolvimento estrutural e metamórfico do Greenstone Belt de Crixás.

\section{HISTÓRICO PROSPECTIVO REGIONAL}

Bartolomeu Bueno da Silva (Anhangüera) descobriu em 1727 um veio aurífero situado no atualmente denominado greenstone belt Serra de Santa Helena, ou de Goiás, que marcou o início da exploração aurifera no estado de Goiás. Após esse fato, seguiram-se 250 anos de exploração não documentada até que Barbosa et al. (1969) produziram o primeiro relato geológico, interpretando os terrenos granito-gnáissicos como Arqueanos e os xistos como Précambrianos, ambos situados na base do Grupo Araxá.

Em meados de 1970 foram estudados alguns propectos em Goiás por parte da Mineração MONITA Lida., através dos Projetos Pilar-Mara Rosa do DNPM/CPRM e Crixás-Goiás da Metais de Goiás S.A. - METAGO. Ribeiro Filho et al. (1978) destacaram dentro do Projeto Pilar-Mara Rosa as diferenças entre rochas vulcanossedimentares de Crixás-Pilar de Goiás e os xistos Araxá, seguido da interpretação de Danni \& Ribeiro (1978), de aquelas rochas supracrustais serem greenstone belts e relacionandomas com terrenos da África do Sul, descritos por Viljoen \& Viljoen (1969) e Anhaeuser (1979). A consagração dos terrenos greenstone veio após a descoberta de rochas ultramáficas com textura spinifex em Crixás por Saboia (1979). Ainda neste período foi realizado o projeto geofísico Brasil-Canadá com levantamentos geofísicos aerotransportados e terrestres (magnetometria, gama-espectrometria) e geoquímica (Carmo, 1978).

O Projeto Crixás merece destaque entre os primeiros trabalhos na região por ter detalhado as mineralizações atualmente exploradas. Esta área foi selecionada em virtude da associação de litotipos que apresentava potencialidades para concentração de metais de base, além de ouro, face à ocorrência de aluviões e eluviões mineralizados ao longo do Rio Vermelho. No final de 1974 as prospeç̧ões aluvionares no Rio Vermelho e tributários conduziram à descoberta das 
mineralizações de arsenopirita, pirrotita e ouro, onde desenvolveram-se as "Minas" I, II, III, IIIExtensão e IV. Sondagens pioneiras interceptaram as mineralizações auríferas, mas devido à dificuldade de determinação da sua continuidade, os trabalhos foram interrompidos para a realização de estudos geofísicos e geoquímicos na tentativa de desvendar a complexidade estrutural da região. Em 1980 as sondagens foram retomadas e a partir de 1983 foram definidas as reservas da Mina III (Yamaoka \& Araújo, 1988).

\section{GEOLOGIA DA REGIÃO DE CRIXÁS}

A geologia da região foi detalhada por diversos trabalhos realizados pela Universidade de Brasília (Kuyumjian, 1981; Danni et al., 1981; Danni et al., 1986; Jost \& Ferreira Filho, 1987; Nilson et al., 1988; Jost et al., 1995), assim como pela METAGO (Teixeira, 1981) com posterior compilação e inclusão de novos dados pelo DNPM, Distrito de Goiânia (Lacerda \& Lima Jr., 1996) e pela CPRM (Montalvão \& Araújo, 1979; Montalvão, 1985, 1986). Neste período foram confeccionadas ainda sínteses bibliográficas sobre a geologia da área por Marini et al. (1984) e Danni (1988).

Os terrenos Arqueanos de Goiás na porção central do Estado representam uma típica associação de complexos granito-gnáissicos e greenstone belts recobrindo cerca de $50.000 \mathrm{~km}^{2}$ do setor meridional do Maciço Mediano de Goiás (Almeida, 1968) ou Maciço de Goiás (Fuck et al., 1993; Fuck, 1994). Os contatos reconhecidamente tectônicos da porção Arqueana são: ao norte e oeste com rochas metavulcânicas, metassedimentares e gnaisses do Neoproterozóico pertencentes ao Arco Magmático de Goiás (Pimentel et al. 1999 in: Jost et al. 1999); a sul e sudeste com uma estreita faixa de rochas supracrustais Paleoproterozóicas da região de Mossâmedes (Pimentel et al., 1996), e a leste e nordeste com rochas metassedimentares Mesoproterozóicas atribuídas ao Grupo Serra da Mesa.

A região de Crixás está inserida no extremo norte dos terrenos Arqueanos de Goiás, onde ocorrem três cinturões de rochas supracrustais arqueanas denominados inicialmente por Danni \& Ribeiro (1978) como Grupo Pilar de Goiás. Os mesmos autores apresentaram ainda um primeiro arcabouço estratigráfico das rochas supracrustais, com rochas ultramáficas serpentinizadas basais, seguidas por vulcânicas básicas predominantes, quartzitos ferruginosos, rochas carbonatadas e quartzitos, metavulcânicas ácidas a básicas, muscovita xistos granatíferos e quartzitos muscovíticos, filitos grafitosos, sericita-clorita xistos, biotita xistos e anfibolitos. 
Estas seqüências foram efetivamente caracterizadas como greenstone belts nas proximidades das cidades de Crixás e Goiás por Saboia (1979). Ao reconhecer texturas spinifex nas rochas ultramáficas de Crixás propos as denominações de Greenstone Belt de Crixás, compreendendo as Faixas de Crixás, Guarinos e Pilar, e Greenstone Belt de Goiás ao sul.

Saboia (1979) também subdividiu as rochas da Faixa Crixás em três unidades maiores, denominadas de: 1) Basal, com rochas vulcânicas ultrabásicas; 2) Média, composta por rochas vulcânicas básicas, e; 3) De Topo, formada essencialmente por rochas sedimentares clásticas e químicas. Estratigrafia semelhante foi também descrita para as faixas de Guarinos e Pilar.

O Grupo Araxá, encontra-se estratigraficamente superposto, discordantemente, aos terrenos granito-greenstone sendo constituído basicamente por mica xistos. O contato tectônico é sugerido pelas mudanças de direções das seqüências observadas, tanto em Crixás (Saboia, 1979), como em Pilar de Goiás e Guarinos (Danni \& Ribeiro, 1978). Em Crixás verifica-se maior deformação no contato entre as duas unidades, onde ocorrem dobras de arrasto e transposição tectônica indicando um possível cavalgamento do Grupo Araxá. Atualmente esta unidade é denominada Seqüência Santa Terezinha, e os greenstone belts como Grupo Crixás (Jost \& Fortes, 2001).

Saboia \& Teixeira (1980) e Teixeira et al. (1981) apresentaram estudos geológicos e petrográficos detalhados de texturas e estruturas das lavas ultramáficas do Greenstone Belt de Crixás, que incluem pillow lavas, pillow brechas, amígdalas, variolas, juntas poliedrais e texturas spinifex, caracterizando completamente os derrames ultrabásicos e as suas estruturas internas. Danni et al. (1980, 1986) verificaram estruturas muito semelhantes a estas no Greenstone Belt de Hidrolina (Grupo Pilar de Goiás), confirmando o caráter vulcânico e komatítico das rochas ultramáficas, e baixo grau de metamorfismo, correspondente à fácies xisto verde. Kuyumjian \& Teixeira (1982) descreveram ainda estruturas orbiculares em lavas ultramáficas de Crixás, e detalharam perfis de variações de texturas e estruturas dos derrames.

Detalhadas descrições estratigráficas dos litotipos de Faixa Crixás foram elaboradas por Saboia et al. (1981) o que propiciou a subdivisão nas seguintes formações, da base para o topo:

a) Córrego Alagadinho: formada predominantemente por metavulcânicas ultramálicas komatíticas com intercalações subordinadas de metachert ferrífero, metassedimentos finos, metatufos aluminosos e corpos intrusivos piroxeníticos e gabróicos;

b) Rio Vermelho: essencialmente composta por metavulcânicas básicas, com corpos menores de grafita xistos, clorita xistos, quartzitos, fuchsita quartzitos, metacherts 
ferríferos ou não e rochas ultrabásicas talcificadas;

c) Ribeirão das Antas: constituída por metassedimentos pelíticos e químicos, representados por grafita-clorita-quartzo xisto, quartzitos grafitosos bandados, cloritóide-clorita-quartzo xisto e níveis descontínuos de mármores dolomíticos, bem como biotita xistos com ou sem hornblenda, metacherts ferríferos, localmente manganesiferos, metacherts, bancos de clorita-talco xisto e anfíbólio xistos. São ainda comuns fuchsita xistos e fuchsita quartzitos.

Ao proporem a revisão estratigráfica do Grupo Pilar de Goiás na Faixa Crixás, Castro \& Magalhães (1984) atribuiram a Danni \& Ribeiro (1978) a extensão da denominação de Grupo Pilar de Goiás às rochas supracrustais do Greenstone Belt de Crixás, e detalharam a litoestratigrafia definida por Saboia et al. (1981), redefinindo seus contatos, litotipos e relações espaciais. Concluíram que as rochas aflorantes na região do Córrego Meia Pataca fazem parte da Formação Córrego Alagadinho, e não da Formação Ribeirão das Antas. Reconheceram ainda contatos gradacionais da Formação Córrego Alagadinho com a Formação Rio Vermelho e, contatos concordantes a gradacionais, desta última com a Formação Ribeirão das Antas. Subdividiram ainda a Formação Ribeirão das Antas, da base para o topo, nas unidades GrafitosaManganesífera, Grafitosa-carbonatada e Grauvaqueana. A unidade Grafitosa-carbonatada apresenta granada-cloritóide-clorita xistos quartzosos com níveis carbonatados e, principalmente na parte sul e central da Faixa, são comuns rochas vulcânicas ácidas e intermediárias e seus derivados vulcanoclásticos. Esta unidade intermediária é a hospedeira das mineralizações de ouro na região.

Como resultado do mapeamento na escala 1:25.000 da região de Hidrolina, Danni et al. (1986) apresentaram uma revisão e reintegração dos dados existentes sobre os terrenos granitogreenstone de Goiás. Estes autores estabeleceram ainda um quadro evolutivo completo com os períodos de vulcanismo e sedimentação, deformação e metamorfismo, além da colocação das massas de rochas ácidas que desmembraram as rochas supracrustais.

A integração dos dados geológicos das sequuências vulcano-sedimentares da região de Goiás, com informações sobre a estratigrafia, quimismo e estruturas dos greenstone belts, foram apresentadas por Danni (1988) e suas modelagens teóricas foram propostas por Kuyumjian (1981), Kuyumjian \& Araújo Filho (1984), Montalvão (1986), Araújo Filho \& Kuyumjian (1991) e Kuyumjian (1993). Os últimos consideraram a hipótese da existência de pontos quentes fixos sob uma crosta fina que teriam gerado as seqüencias vulcanossedimentares. 
Jost \& Oliveira (1991) revisaram a estratigrafia dos greenstone belts Arqueanos da região de Crixás considerando a estratigrafia de cada uma das faixas separadamente e propuseram as denominações de:

a) Grupo Crixás, subdividido nas Formações Córrego Alagadinho, Rio Vermelho e Ribeirão das Antas. Este último com uma Subunidade Inferior com assembléias de metachert carbonoso e filito-manganesífero, uma Média, com predominância de mármore carbonoso fillítico, e uma Superior, formada por metapelitos.

b) Grupo Guarinos, composto pelas Formações Serra do Cotovelo, Serra Azul, São Patricinho, Aimbé e Cabaçal.

c) Grupo Pilar de Goiás, constituído pelas Formações Córrego Fundo, Cedrolina, Boqueirão e Serra do Moinho. Os autores verificaram ainda contatos tectônicos ou bruscos nas Formações Rio Vermelho, e bruscos ou gradacionais nas demais do Grupo Crixás.

Magalhães \& Nilson (1992) definiram o cinturão de cisalhamento de empurrão CórregoGeral-Meia Pataca através de um conjunto de feições de deformação e alterações hidrotermais com mineralizações de ouro associadas. Os mesmos autores propõem ainda subdividir o então Grupo Pilar de Goiás em quatro unidades:

A - metabasalto tolético e anfibolito foliado.

B - clorita xisto, mármore dolomítico e mica-quartzo xisto.

C - granada-sericita-clorita protomilonito (xisto) carbonoso, milonitos-ultramilonitos carbonoso dolomítico sericítico-clorítico (xisto) e quartzoso, e sericita milonito.

D - metagrauvaca.

Nesta subdivisão de unidades, Magalhães \& Nilson (1992) consideram as unidades A e D como protólitos e $\mathrm{B}$ e C como prováveis resultados de processos de deformação e alteração hidrotermal sobre a metabásicas (Formação Rio Vermelho). As paragêneses evidenciam condições de metamorfismo regional e de alteração hidrotermal posterior de fácies xisto-verde e epídoto anfibolito. Baseado nas atitudes das feições estudadas por Magalhães (1991) foram propostos dois domínios estruturais, denominados Córrego Geral (DCG) e Meia Pataca (DMP), interpretados, respectivamente, como rampa frontal e rampa lateral oblíqua, com transporte tectônico de oeste para leste. 
O estudo do quimismo da Unidade Grauvaqueana da Faixa Crixás, ou Unidade D da Formação Ribeirão das Antas, mostrou semelhança com aqueles de arcos magmáticos continentais e nenhuma correlação com as rochas granito-gnáissicas dos blocos Anta e Caiamar, sugerindo que essas rochas não se constituem do embasamento da sequêencia vulcano-sedimentar (Magalkães \& Nilson, 1993).

O quimismo das rochas vulcânicas ultramáficas destas seqüências tem sido sucessivamente estudado, caracterizando-as efetivamente como komatítos (Saboia \& Teixeira, 1980; Saboia et al., 1981; Montalvão et al., 1981; Montalvão et al., 1982; Kuyumjian \& Dardenne, 1983; Kuyumjian \& Dias, 1991a; b). Foram detectadas variações nos padrões de Al e HREE, comparativamente aos greenstones do mundo, provavelmente devido a processos metamórficos ou metassomáticos pouco compreendidos, durante os quais as concentrações de vários elementos tradicionalmente imóveis foram fortemente alteradas (Arndt et al., 1989).

Lacerda (1997) reafirmou as subdivisões supracitadas e relacionou as diversas minas e garimpos de ouro com as formações que as hospedam, destacando que parte da mineralização da Mina III associam-se a Formação Rio Vermelho, vinculada com zonas de falhas de empurrão. Em outros locais, como no Garimpo Neco Machado, vinculam-se a zonas de transcorrência, ou a zonas de charneira de dobras com flancos invertidos, como nos garimpos Tóti e Três Buracos.

Os terrenos vulcano-sedimentares aflorantes entre os municípios de Crixás e Hidrolina formam três faixas alongadas com direção predominante NW-SE, com rochas dobradas em isoclinais apertados, com mergulho para $\mathrm{SW}$, separadas por corpos granito-gnáissicos que Jost et al. (1999) propõem chamar de Complexo Anta, Caiamar, Hidrolina e Bloco Moquém. O Bloco Moquém se distingue dos complexos por apresentar contatos marcados por falhas com planos formando ângulos de mergulho moderados a verticais.

Blum et al. (2000) realizaram levantamentos gravimétricos nas porções centrais e norte de Goiás cobrindo $9000 \mathrm{~km}^{2}$ das associações granito-greenstone. O correlacionamento dos dados gravimétricos obtidos com os resultados do Projeto Brasil-Canada's Geophysical Project (Carmo, 1978) e dos conhecimentos geológicos atualizados resultaram no perfil da estrutura tectônica "em flor" para a Formação Ribeirão das Antas. Os mesmos autores propõem profundidades para os greenstones de Crixás em torno de $1200 \mathrm{~m}$, Guarinos com $1000 \mathrm{~m}$ e Pilar de Goiás com $1550 \mathrm{~m}$.

A compilação de trabalhos anteriores e mapeamentos recentes realizados pela MSG são apresentados no mapa geológico da FIGURA 2. 


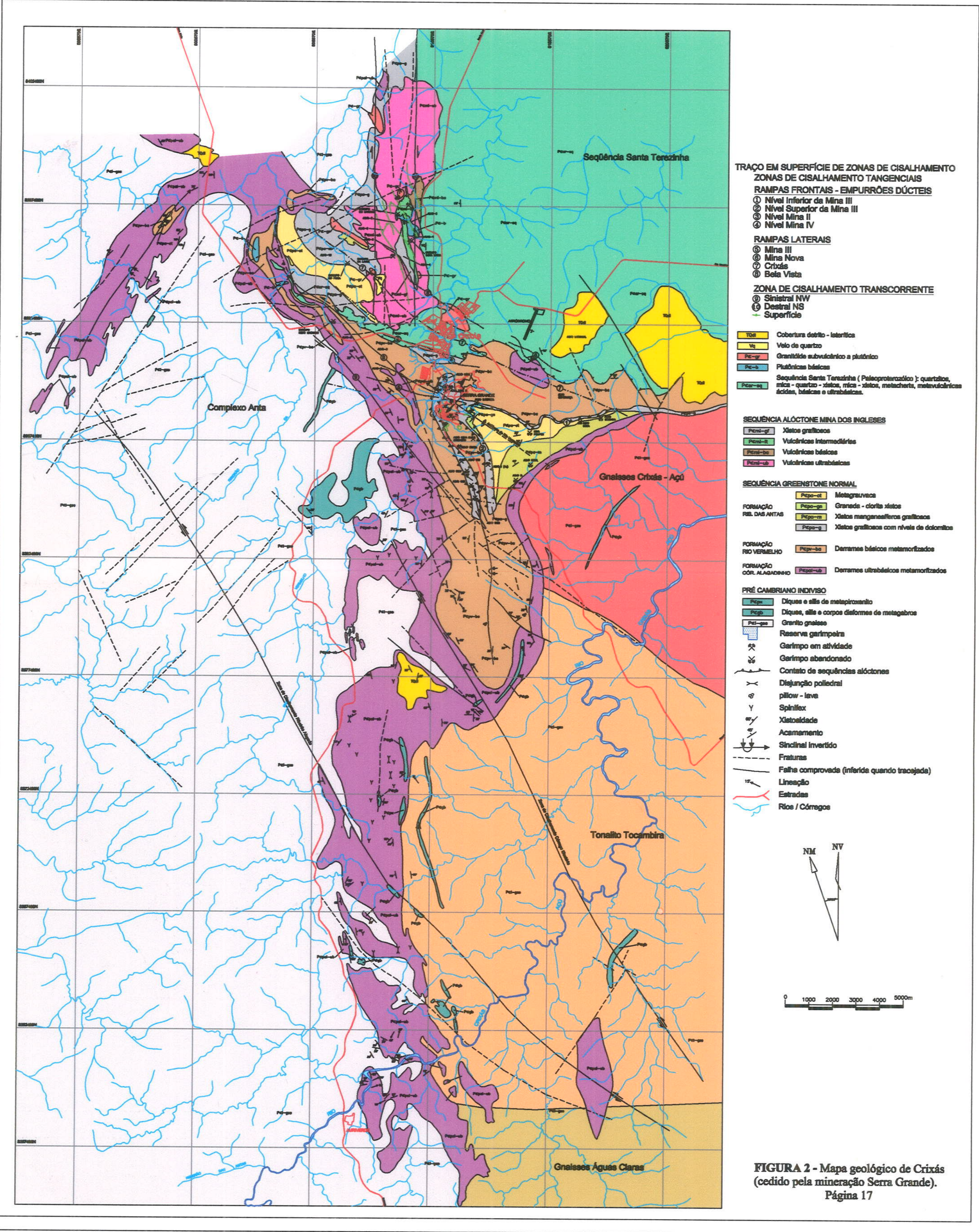




\section{ORIGEM E EVOLUCÃO DOS GREENSTONE BELTS DE GOIÁS}

Segundo Araújo Filho \& Kuyumjian (1991), os greenstone belts de Goiás podem ter se formado intracratônicamente numa mini-placa arqueana delgada, onde dois pontos quentes de idades concomitantes teriam iniciado suas atividades por volta de 2,8-2,7 Ga, quando surgiram as primeiras manifestações conhecidas de formação de rochas verdes no Greenstone de Crixás. Os greenstones setentrionais de Goiás envolvendo Crixás, Pilar de Goiás-Hidrolina e Guarinos, apresentam uma forma grosseiramente triangular em planta, possuindo idades entre 2,8 a 2,5 Ga.

Os pontos-quentes teriam funcionado como uma referência fixa em relação a uma delgada mini-placa arqueana de grande mobilidade, linear e angular, se comparadas às placas pós-jurássicas e, provavelmente, afastadas de 500 a $600 \mathrm{~km}$ uma da outra. O fluxo calórico dos pontos-quentes provocaria um entumecimento original nos greenstones, que serviriam de fonte de sedimentos imaturos. Estes seriam depositados sobre as bordas dos domos gnássicos adjacentes, formando um estágio inicial de proto-aulacógeno e aulacógeno assimétrico. Na sequiencia seriam abertas calhas ou fossas tectônicas incipientes, por onde teriam se instalados condutos onde lavas ultramáficas e máficas fluiriam, formando o empilhamento da seqüência máfica-ultramáfica. Com a progressão da abertura das calhas, o restante da seqüência vulcânica cálcio-alcalina e sedimentar, incompleta e delgada, teria sido instalada (Araújo Filho \& Kuyumjian, 1992).

Uma junção tríplice do tipo RRR, ou análoga, conduziria a formação de um aulacógeno assimétrico na concentração norte dos greenstone belts, onde os braços ativos das calhas estariam formando os greenstones de Crixás, Pilar de Goiás-Hidrolina e Guarinos. Ao sul, por uma assimetria mais acentuada do ponto aulacógeno, uma linearidade maior constituiria o greenstone de Goiás Velho-Faina (Araújo Filho \& Kuyumjian, 1992).

A integração dos resultados analíticos de elementos traço pouco móveis de meta-basaltos das seqüências vulcano-sedimentares proterozóicas levou Kuyumjian \& Dias (1991) a concluirem que estas se formaram em ambientes de subduç̧ão, sugerindo ainda que, a faixa oriental também constitui um arco magmático, da mesma forma que a faixa ocidental (Pimentel \& Fuck, 1987). Segundo Kuyumjian \& Dias (1992), a evolução dos dois arcos magmáticos foi acompanhada e seguida, até o Brasiliano, de processos de acresção envolvendo sistemas de arco e de retro-arco proterozóicos e micro-placas continentais arqueanas, e que tal evolução teria sido responsável pela atual estruturação do maciço. 
Radaelli (1992) interpreta os depósitos de ouro e estanho em Goiás como diretamente relacionados à Tectônica Superimposta Araxá (TSA) do Proterozóico, que teria gerado lascas destacadas do manto superior nas superfícies de décolement mais profundas e cita exemplos como os Complexos de Canabrava, Niquelândia e Barro Alto. Em relação às seqüências metavulcanossedimentares, o mesmo autor considera que a tectônica proterozóica possui características contracionais, o que impossibilitaria que magmas provenientes do manto (básicos e ultrabásicos) pudessem atingir a superfície, e explica a origem das mesmas como sendo Arqueanas. A TSA é definida como um conjunto de deformações rúpteis-dúcteis em planos horizontais restritos, com falhas transcorrentes em rochas do embasamento, além de overthrust faults imbrications entre o Araxá e o embasamento. O evento revelou grau metamórfíco da fácies xisto verde a epídoto-anfibolito em virtude do transporte de massas horizontais das rochas superiores de WNW para ESE (Radaelli 1990, in: Radaelli 1992).

\section{O GREENSTONE BELT DE CRIXÁS}

Existe um consenso geral de que o preenchimento da bacia sedimentar em Crixás se deu em dois estágios, o primeiro com abundante magmatismo tolético, seguido progressivamente pelo segundo, detrítico em ambiente anóxico e que, esta seqüência se apresenta estratigraficamente invertida (Theodoro, 1995). Os xistos carbonosos na metade inferior da seqüência detrítica apresentam intercalações de mármores com relíquias de oólitos e prováveis esteiras algais, indicativas de águas rasas e planícies de maré (Theodoro, 1995; Theodoro \& Jost, 1996). Já na metade superior ocorrem camadas métricas de xisto carbonoso com fragmentos de provável púmice, sugerindo vulcanismo félsico distal contemporâneo (Jost et al., 1996b).

Os estudos geoquímicos permitiram ainda reconhecer "lascas" de rochas metassedimentares Proterozóicas que ocorrem imbricadas ao longo de falhas internamente aos equivalentes arqueanos (Jost et al, 1996a).

Jost et al. (1996b) concluem que a seção metassedimentar em Crixás e Guarinos possue propriedades que não diferem de terrenos arqueanos de outras regiões. Existe um nítido contraste no ambiente deposicional representado pelos xistos carbonosos basais e metaturbiditos distais de topo. A sequiência basal indica uma bacia deposicional rasa que esteve sob regime distensivo, e os metaturbiditos, pela sua natureza e súbito ingresso na bacia, podem sugerir uma fase de soerguimento acelerado. A semelhança geoquímica entre os xistos carbonosos e os metaturbiditos permitem inferir que não houve mudanças na composição da área fonte das duas 
sequiências. Queiroz et al. (1999) propõem que a estrutura dome and keel dos terrenos granitogreenstone evoluíram em resposta aos eventos magmáticos e deformacionais durante o Arqueano. As datações realizadas (SHRIMP, zircão e titanita conforme TABELA 2) definiram dois grupos principais de idades. Complexo Anta, Caiamar e Hidrolina com 2,84 a 2,79 Ga e Bloco Moquém com 2,71 Ga (TABELA 2). Isso sugere que os complexos foram introduzidos numa crosta siálica mais antiga e que o Bloco Moquém representa um magmatismo relativamente juvenil.

Pesquisas enfocando as estruturas tectônicas que afetaram a região de Crixás foram feitas por Kuyumjian (1981) e Kuyumjian \& Araújo Filho (1984), dando continuidade às observações de Saboia (1979), Saboia \& Teixeira (1980) e Saboia et al. (1981). Os resultados indicaram uma sequiência de eventos deformacionais que foram considerados contínuos, exceto para o embasamento, tendo sido iniciados com a formação de dobras isoclinais $\mathrm{D}_{1}$, posteriormente verticalizadas pelas intrusões de rochas ácidas. Essas intrusões teriam gerado as estruturas $\mathrm{D}_{2}$, que por sua vez foram redeformadas juntamente com $D_{1}$, por dobras fechadas com planos axiais de baixo ângulo $\left(\mathrm{D}_{3}\right)$. A estes eventos seguiram-se dobras abertas $\left(\mathrm{D}_{4}\right)$ e dobras de amplitude quilométrica $\left(\mathrm{D}_{5}\right)$.

Thomson (1991) deduziu quatro períodos deformacionais, com metamorfismo da fácies anfibolito superpostos ao evento da fácies de xistos, ao estudar o relacionamento das texturas em inclusões de porfiroblastos metamórficos de granada e plagioclásio, da matriz e das assembléias minerais metamórficas. Esse estudo restringiu-se às rochas imediatamente acima, dentro e abaixo da Zona de Minério Inferior da Mina III, zona essa que apresenta as maiores similaridades com as mineralizações do Corpo IV e V, em função da presença predominante de veios de quartzo no xisto carbonoso, brechamento, e também das relações de Gold Fineness. A autora reconheceu nos trabalhos de campo diversas estruturas tectonicas, compartimentando-as em estruturas regionais, ou fora da área da mina, e dentro da área mineralizada (TABELA 3). Ainda segundo Thomson (1991), existe pouca dúvida que ocorreu um período relacionado a empurrões ou nappismo no Arqueano, mas não havia certeza se esse seria o único evento de importância a afetar as rochas do Greenstone Belt de Crixás. As deformações $\mathrm{D}_{1}$ e $\mathrm{D}_{2}$ foram interpretadas como decorrência de nappismo arqueano, que resultou na inversão estratigráfica observada na região. A estrutura $\mathrm{S}_{3}$ é interpretada como sendo resultado de empurrões pós-arqueanos e essa seria a geradora do metamorfismo da fácies anfibolito verificada no xisto carbonoso, sobreposto ao evento metamórfico da fácies xisto-verde, registrado no clorita-muscovita-granada tepídoto xisto. 
TABELA 2 - Dados geocronológicos (traduzido de Jost \& Fortes, 2001).

a) - Dados de U-Pb SCHRIMP em zircão e titanita em milhões de anos (Queiroz, 1999).

\begin{tabular}{|c|c|c|c|c|c|}
\hline COMPLEXO & ROCHA & MINERAL & IDADE & $\begin{array}{c}\text { IDADE } \\
\text { MAGMÁTICA }\end{array}$ & $\begin{array}{c}\text { IDADE } \\
\text { METAMÓRFICA }\end{array}$ \\
\hline Anta & Tonalito & zircão & $\begin{array}{c}3174 \pm 4 \mathrm{a} \\
2948 \pm 6 \mathrm{Ma} \\
\end{array}$ & $2792 \pm 7 \mathrm{Ma}$ & \\
\hline \multirow[t]{4}{*}{ Caiamar } & $\begin{array}{l}\text { Tonalito } \\
\text { Tocambira }\end{array}$ & zircão & $\begin{array}{c}3073 \pm 6 \mathrm{a} \\
3048 \pm 17 \mathrm{Ma}\end{array}$ & $2842 \pm 6 \mathrm{Ma}$ & \\
\hline & $\begin{array}{c}\text { Crixás-Açu } \\
\text { Gnaisse } \\
\text { Tonalítico }\end{array}$ & zircão & $\begin{array}{c}3051 \pm 5 \mathrm{a} \\
2931 \pm 7 \mathrm{Ma}\end{array}$ & $2772 \pm 3 \mathrm{Ma}$ & \\
\hline & $\begin{array}{c}\text { Crixás-Açu } \\
\text { Gnaisse } \\
\text { Tonalitico } \\
\end{array}$ & titanita & & & $\begin{array}{l}2711 \pm 34 \mathrm{Ma} \\
2011 \pm 15 \mathrm{Ma}\end{array}$ \\
\hline & $\begin{array}{c}\text { Aguas Claras } \\
\text { Gnaisse } \\
\text { Granodiorítico }\end{array}$ & zircão & $\begin{array}{c}3076 \pm 6 \mathrm{a} \\
2976 \pm 22 \mathrm{Ma}\end{array}$ & $2844 \pm 7 \mathrm{Ma}$ & \\
\hline Hidrolina & $\begin{array}{c}\text { Gnaisse } \\
\text { Granodiorítico }\end{array}$ & zircăo & Não & $2875 \pm 5 \mathrm{Ma}$ & \\
\hline \multirow[t]{3}{*}{ Bloco Moquém } & $\begin{array}{c}\text { Gnaisse } \\
\text { Granítico } \\
\end{array}$ & zircão & Não & $2711 \pm 3 \mathrm{Ma}$ & \\
\hline & $\begin{array}{l}\text { Gnaisse } \\
\text { Granítico }\end{array}$ & zircẫo & Não & $2709 \pm 6 \mathrm{Ma}$ & \\
\hline & $\begin{array}{c}\text { Gnaisse } \\
\text { Granodioritico }\end{array}$ & zircão & Não & $2707 \pm 4 \mathrm{Ma}$ & \\
\hline
\end{tabular}

b) - $\mathrm{Sm}-\mathrm{Nd}$, $\mathrm{Pb}-\mathrm{Pb}$, e Rb-Sr de unidades de rocha em milhões de anos.

\begin{tabular}{|c|c|c|c|c|c|}
\hline Unidade & Rocha & Método & Idade/Ma & Razão inicial & Fonte \\
\hline $\begin{array}{c}\text { FormaçãoCórrego } \\
\text { Alagadinho }\end{array}$ & $\begin{array}{c}\text { Meta- } \\
\text { komatíto }\end{array}$ & $\mathrm{Sm} / \mathrm{Nd}$ & $2825 \pm 98$ & & Arndt et al. (1989) \\
& & $\mathrm{Pb} / \mathrm{Pb}$ & $2728 \pm 140$ & - & Arndt et al. (1989) \\
\hline Complexo Caiamar & Tonalito & $\mathrm{Rb} / \mathrm{Sr}$ & $2924 \pm 150$ & 0,7012 & $\begin{array}{c}\text { Montalvão (1985) } \\
\text { Vargas (1992) }\end{array}$ \\
\hline Complexo Anta & Tonalito & $\mathrm{Rb} / \mathrm{Sr}$ & $2929 \pm 105$ & - & Vargas (1992) \\
\hline Complexo Hidrolina & Granodiorito & $\mathrm{Rb} / \mathrm{Sr}$ & $2461 \pm 100$ & 0,707 & Montalvão(1985) \\
\hline
\end{tabular}

c) - Eventos mineralizantes

\begin{tabular}{|c|c|c|c|c|c|}
\hline \multicolumn{2}{|c|}{ Local/Método } & Rocha & Mineral & ldade/Ma & Fonte \\
\hline $\begin{array}{l}\mathrm{M} \\
\mathrm{I} \\
\mathrm{N} \\
\mathrm{A}\end{array}$ & $\mathrm{K}-\mathrm{Ar}$ & $\begin{array}{c}\text { anfibólio xisto } \\
\text { anfibólio xisto com biotita } \\
\text { anfíbólio xisto com clorita } \\
\text { quartzo-clorita-carbonato-sericita-xisto } \\
\text { sericita xisto } \\
\text { sericita xisto } \\
\text { biotita-mármore }\end{array}$ & $\begin{array}{l}\text { Anfibólio } \\
\text { Anfibólio } \\
\text { Biotita } \\
\text { Biotita } \\
\text { Biotita } \\
\text { Muscovita } \\
\text { Paragonita } \\
\text { Cloritóide } \\
\text { Biotita } \\
\end{array}$ & $\begin{array}{l}726 \pm 16 \\
709 \pm 13 \\
506 \pm 7 \\
563 \pm 8 \\
518 \pm 7 \\
478 \pm 7 \\
510 \pm 7 \\
575 \pm 19 \\
561 \pm 8\end{array}$ & $\begin{array}{c}\text { Fortes } \\
(1996) \\
\text { Fortes } e t \text { al. } \\
(1997)\end{array}$ \\
\hline \multirow[t]{2}{*}{$\begin{array}{l}1 \\
1 \\
1\end{array}$} & $\mathrm{Rb}-\mathrm{Sr}$ & $\begin{array}{c}\text { anfibólio xisto com biotita } \\
\text { anfibólio xisto com clorita } \\
\text { quartzo-clorita-carbonato-sericita-xisto } \\
\text { biotita-mármore } \\
\end{array}$ & & $\begin{array}{l}731 \pm 76 \\
647 \pm 27 \\
437 \pm 13 \\
497 \pm 48\end{array}$ & $\begin{array}{c}\text { Fortes } \\
(1996) \\
\text { Fortes et al. } \\
\quad(1997)\end{array}$ \\
\hline & $\mathrm{Ar}-\mathrm{Ar}$ & $\begin{array}{l}\text { anfibólio xisto com biotita } \\
\text { anfíbólio xisto com clorita } \\
\text { sericita xisto } \\
\text { sericita xisto }\end{array}$ & $\begin{array}{l}\text { Anfibólio } \\
\text { Biotita } \\
\text { Muscovita } \\
\text { Paragonita }\end{array}$ & $\begin{array}{l}548 \pm 1 \\
578 \pm 0.5 \\
496 \pm 0.3 \\
504 \pm 1.4 \\
\end{array}$ & $\begin{array}{c}\text { Fortes } \\
(1996) \\
\text { Fortes et al } \\
(1997)\end{array}$ \\
\hline \multicolumn{2}{|c|}{ Cachoeira do Ogó } & minério & Galena & $2025 \pm 40$ & Pulz (1995) \\
\hline
\end{tabular}


Ainda segundo Thomson (1991), os veios de quartzo abundantes que hospedam a Zona de Inferior de minério, seriam evidências dos fluxos em larga escala resultantes do cisalhamento tardio. A autora sugere uma grande semelhança da foliação $S_{1}$ e da lineação mineral com os resultados estruturais obtidos por Hagemann (1989) no Grupo Canastra, relacionado ao Neoproterozóico (Ciclo Brasiliano).

Tabela 3 - Estruturas determinadas por Thomson (1991) no Greenstone Belt de Crixás, caracterizando quatro fases de deformaçăo.

\begin{tabular}{|c|c|c|c|c|}
\hline DOMÍNIOS & FOLIACẼO & LINEAC ÃO & CRENULACĀO & DOBRAS \\
\hline $\begin{array}{l}\text { REGIONAL } \\
\text { (fora da área } \\
\text { mineralizada) }\end{array}$ & $\begin{array}{l}\mathrm{N} 65^{\circ} \mathrm{E} / 20^{\circ} \mathrm{NW} \\
=\mathrm{S}_{3} \\
\mathrm{~N} 25^{\circ} \mathrm{W} / 20^{\circ} \mathrm{SW} \\
=\mathrm{S}_{1}\end{array}$ & $\begin{array}{l}\mathrm{N} 70^{\circ} \mathrm{W} / 15-20^{\circ}, \\
\text { por mineral rinida } \\
\text { sobre o plano de foldiação } \\
\mathrm{N} 65^{\circ} \mathrm{E} / 20^{\circ} \mathrm{NW}\end{array}$ & 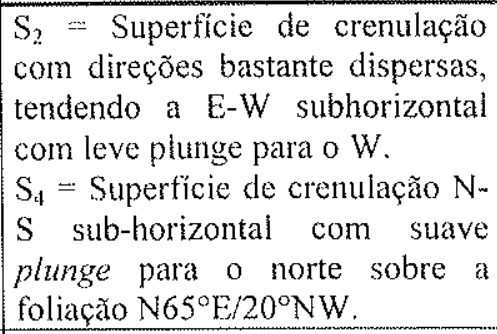 & \\
\hline $\begin{array}{l}\text { LOCAL } \\
\text { (dentro da } \\
\text { área } \\
\text { mineralizada) }\end{array}$ & $\begin{array}{l}\mathrm{N} 65^{\circ} \mathrm{E} / 20^{\circ} \mathrm{NW} \\
=\mathrm{S}_{3}\end{array}$ & $\begin{array}{l}\mathrm{N} 77^{\circ} \mathrm{W} / 12^{\circ} \text { definida por } \\
\text { uma lineação mineral ou } \\
\text { rodding sobre o plano } \\
\mathrm{N} 65^{\circ} \mathrm{E} / 20^{\circ} \mathrm{NW} \text {. Nessa } \\
\text { zona ocorrem rods de } \\
\text { quartzo com até } 10 \mathrm{~m} \text { de } \\
\text { diâmetro, boudinados em } \\
\text { seções longitudionais. }\end{array}$ & & $\begin{array}{l}\mathrm{N} 18^{\circ} \mathrm{W} / 22^{\circ} \\
\mathrm{N} 11^{\circ} \mathrm{E} / 30^{\circ} \\
\text { representam duas } \\
\text { populações de } \\
\text { dobras chevron. } \\
\text { Essas dobram a } \\
\text { foliação assim } \\
\text { como a lineação. }\end{array}$ \\
\hline
\end{tabular}

O Greenstone Belt de Crixás foi anteriormente considerado como synformal keels em função da sua geometria, distribuição espacial das unidades estratigráficas e da interpretação que, os Complexos Granitóides, eram rochas soerguidas do embasamento. As investigações estruturais e estratigráficas em Crixás (Magalhães, 1991 e Queiroz, 1995) mostrararam que as supracrustais não eram sinformes, mas que exibiam a clássica estruturação em domos e quilhas.

Queiroz (1995) identificou três fases de deformação nos seus estudos conforme representados na TABELA 4, a seguir.

Novas investigações estruturais e estratigráficas nos greenstone belts de Crixás (Magalhães, 1991; Queiroz, 1995), Guarinos (Jost \& Ferreira Filho, 1987; Jost et al., 1995) e Pilar de Goiás (Danni et al., 1986) confirmaram que as seqüências supracrustais não são sinformes, mas estruturas mais complexas que resultara de pelo menos 4 eventos deformacionais (D1 a D4). Baseado nessa última premissa, foi elaborado uma tabela que reune os 4 eventos, datações e características relevantes no que tange ao Grupo Crixás, particularmente à Formação Ribeirão das Antas no contexto dos Corpos IV e V (TABELA 5). 
Tabela 4 - Resumo dos eventos definidos por Queiroz (1995).

\begin{tabular}{|c|c|c|c|c|}
\hline Evento & Fase & Período & Descrição da Fase & $\begin{array}{l}\text { Estruturas } \\
\text { relacionadas }\end{array}$ \\
\hline 1 & $D_{n-1}$ & $\begin{array}{l}\text { Arqueano } \\
(?)\end{array}$ & $\begin{array}{l}\text { Estruturação em domos e quilhas em virtude da colocação dos } \\
\text { corpos granito-gnáissicos de composição granodiorítica a } \\
\text { tonalítica. }\end{array}$ & \\
\hline \multirow[t]{2}{*}{2} & $\mathrm{D}_{\mathrm{n}}$ & $\begin{array}{c}\text { Neoprotero- } \\
\text { zóico (?) }\end{array}$ & $\begin{array}{l}\text { Nucleação de dobras } \mathrm{F}_{\mathrm{n}} \text {, foliação } \mathrm{S}_{\mathrm{n}} \text {, lineação mineral e de } \\
\text { estiramento Lm/e e zonas de cisalhamento dúcteis tangenciais } \\
\mathrm{ZC}_{\mathrm{n}} \text {, essas últimas descritas como falhas de empurrão por } \\
\text { Magalhães (1991) no cinturão de cisalhamaneto de empurrão } \\
\text { Córrego Geral-Meia Pataca. Os esforços geradores teriam a } \\
\text { direção NW/SE, com vergência de NW para SW. }\end{array}$ & $\begin{array}{l}F_{n}: \mathrm{N} 71^{\circ} \mathrm{W} / 16^{\circ} \\
\mathrm{S}_{\mathrm{n}}: \\
\mathrm{N} 18^{\circ} \mathrm{E} / 19^{\circ} \mathrm{NW} \\
\mathrm{Lm} / \mathrm{e}_{\mathrm{n}} \mathrm{O} \\
\mathrm{N} 71^{\circ} \mathrm{W} / 16^{\circ}\end{array}$ \\
\hline & $D_{n+1}$ & $\begin{array}{c}\text { Neoprotero- } \\
\text { zóico (?) }\end{array}$ & $\begin{array}{l}\text { Geração de dobras } F_{n+1} \text {, responsáveis pelo dobramento das falhas } \\
\text { de empurrão do cinturão de cisalhamaneto de empurrão Córrego } \\
\text { Geral - Meia Pataca, a foliação } S_{n+1} \text {, a lineação de intersecção } \\
\text { Li }_{n / n+1} \text { e as crenulações Lcr }{ }_{13+1} \text {. A essa fáse é atribuida ainda a } \\
\text { nucleação do Corredor Transpressivo Ribeirão das Antas/Rio } \\
\text { Vermelho com zonas de cisalhamento sinistrógeras. Os esforços } \\
\text { geradores teriam direção } \mathrm{EW} \text {, com vergência de } W \text { para } E \text {. }\end{array}$ & $\begin{array}{l}\mathrm{S}_{\mathrm{n}+1}: \\
\mathrm{N} 09^{\circ} \mathrm{W} / 44^{\circ} \mathrm{SW} \\
\mathrm{Li}_{\mathrm{n} / \mathrm{n}+1}: \\
\mathrm{N} 01^{\circ} \mathrm{W} / 15^{\circ} \\
\mathrm{Lcr}_{\mathrm{n}+\mathrm{l}} \\
\mathrm{N} 01^{\circ} \mathrm{W} / 15^{\circ} \mathrm{e} \\
\mathrm{N} 74^{\circ} \mathrm{W} / 21^{\circ}\end{array}$ \\
\hline
\end{tabular}

Os trabalhos de campo permitiram reunir um modesto número de medidas estruturais, visto que o presente estudo não visa uma análise estrutural detalhada, mas que permite confirmar as conseqüências dos principais eventos. As medidas obtidas dentro dos limites dos Corpos IV e $\mathrm{V}$ revelaram um predomínio do evento Neoproterozóico, $\mathrm{S}_{4}$ com mergulho para SW (FIGURA 3 A e B). Os planos com tendencia para $\mathrm{NE}$ devem representar o evento $\mathrm{D} 3$, com $\mathrm{S}_{\mathrm{m} 3}$, em concordância com os dados de Queiroz (1995). Esta última afirmação é reforçada pelas medições das lineações minerais e estiramento $\left(\mathrm{L}_{\mathrm{m} / \mathrm{e}}\right)$, assim definidas pela autora anteriormente mencionada e que mostram uma forte tendência de se posicionarem sobre a $\mathrm{S}_{\mathrm{m} 3}$ (FIGURA $3 \mathrm{Ce}$ D). Ainda no domínio do Corpo IV foram realizadas medidas das superfícies " $\mathrm{C}$ " das estruturas "S/C" que no esterograma sinóptico mostraram novamente a influência do evento D4 (FIGURA 4 A). Medidas de dobramentos no domínio do Corpo IV demonstram o seu paralelismo com $L_{m / \mathfrak{c} 3}$ (FIGURA $4 \mathrm{~B}$ ), o que sugere uma preservação destas do evento D4. Ao longo da galeria de acesso para o Corpo IV foram realizadas medições de contatos litológicos que demonstraram novamente a imposição tectônica de evento D4 (FIGURA 4 C). Fica assim demonstrado, em acordo com a coleção de medidas realizada por Queiroz (1995), que a região mineralizada do Corpo IV e V foi afetada pelo evento D4 Neoproterozóico, reposiciou os contatos litológicos e destruiu os resquícios de $\mathrm{S}_{\mathrm{m} 3}$ em grande parte. Igualmente pode-se observar que as reliquias da $\mathrm{S}_{\mathrm{m} 3}$ são preservados, assim como a $\mathrm{L}_{\mathrm{m} / \mathrm{e} 3}$, sendo que esta última tem vínculos indiscutíveis como trend da mineralização dos Corpos IV e V. 
TABELA 5 - Resumo das principais feições evolutivas do Greenstone Belt de Crixás.

\begin{tabular}{|c|c|c|c|c|c|c|}
\hline \multicolumn{2}{|c|}{ EVENTO } & IDADE & METAMOR- & EVOLUCÃO ESTRUTURAL & MAGMATISMO & OBSERVAÇŌES \\
\hline $\begin{array}{c}\text { Pré- } \\
\text { DI }\end{array}$ & \multirow{3}{*}{$\begin{array}{l}\mathrm{A} \\
\mathrm{R} \\
\mathrm{Q} \\
\mathrm{U} \\
\mathrm{E} \\
\mathrm{A} \\
\mathrm{N} \\
\mathrm{O}\end{array}$} & $\begin{array}{l}2,825 \mathrm{Ma} \\
\text { Sm-Nd mas } \\
\text { provavel- } \\
\text { mente }>3 \\
\mathrm{Ga}\end{array}$ & & & $\begin{array}{l}\text { Fluxos de lavas komati- } \\
\text { iticas e toleíticas, segui- } \\
\text { das por sedimentação } \\
\text { subaquática. }\end{array}$ & $\begin{array}{l}\text { Estruturas menos deformadas preservam texturas } \\
\text { spinifex, cumuláticas, e brechas de fluxo. As máficas } \\
\text { apresentam pillow, varíolas, vesiculas e orbículos. Os } \\
\text { metassedimentos possuem lentes de chert, } \\
\text { microconglomerados, grauvacas e ritmitos. }\end{array}$ \\
\hline DI & & & $\begin{array}{l}\text { Regional } \\
\text { (fácies xisto } \\
\text { verde). }\end{array}$ & $\begin{array}{l}\text { Desenvolvimento da foliação principal } S_{1} \text { (em geral } \\
\text { paralela a } S_{0} \text { ) com forte transposição e formação de } \\
\text { dobras regionais apertadas e isoclinais (orientação } \\
\text { desconhecida). O evento progrediu para um } \\
\text { empurrão com escamas delgadas e inversão da } \\
\text { seqüencia estratigráfica. }\end{array}$ & & \\
\hline D2 & & $\begin{array}{l}2842 \pm 6 \mathrm{Ma} \\
\text { Caiamar } \\
2792 \pm 7 \mathrm{Ma} \\
\text { Anta } \\
\text { U-Pb }(\mathrm{ZNN}) \\
\text { SHRIMP }\end{array}$ & $\begin{array}{l}\text { De contato } \\
\text { (fácies albita- } \\
\text { epídoto } \\
\text { hornfels) }\end{array}$ & $\begin{array}{l}\text { Soerguimento polifásico dos complexos Anta, Caia- } \\
\text { mar e Hidrolina. Os complexos são delimitados pela } \\
\text { mudança nas trajetórias de } S_{1} \text { das supracrustais e } \\
\text { pelo contato com os granitóides. }\end{array}$ & $\begin{array}{l}\text { Tonalito, granodiorito e } \\
\text { raros granitos em es- } \\
\text { cala quilométrica }\end{array}$ & $\begin{array}{l}\text { Esse evento ocorreu contemporâneamente ou } \\
\text { imediatamente após o primeiro metamorfismo e } \\
\text { transporte tectônico das supracrustais }{ }^{6} \text {. A idade de } \\
\mathrm{D}_{2} \text { em cada greenstone belt depende da idade dos } \\
\text { complexos adjacentes }{ }^{6} \text {, no caso do Greenstone de } \\
\text { Crixás, ca. de } 50 \mathrm{Ma} \text {. }\end{array}$ \\
\hline \multicolumn{2}{|c|}{$\begin{array}{l}\text { D3 } \\
\text { PALEO- } \\
\text { PROTERO- } \\
\text { ZÓICO }\end{array}$} & $\begin{array}{l}2707 \pm 4 \mathrm{Ma} \\
\text { Moquém } \\
2011 \pm 15 \mathrm{Ma} \\
\text { Id. Metam. } \\
\text { Caiamar } \\
\text { U»Pb (ZRN) } \\
\text { SHRIMP5 }\end{array}$ & $\begin{array}{l}\text { Regional. } \\
\text { Fácies } \\
\text { epidoto- } \\
\text { anfibolito? }\end{array}$ & $\begin{array}{l}\text { Reorientação de } \mathrm{S}_{0}, \mathrm{~S}_{1} \text {, desenvolvimento da foliação } \\
\text { milonínica } \mathrm{S}_{\mathrm{m}} \text { e da lineação de estiramento } \mathrm{L}_{\text {mể. }} \text {. } \\
\text { Desenvolvimento de falhas de empurrão, sheat faults } \\
\text { e atividade magmática. Soerguimento do Bloco } \\
\text { Moquém por meio de falhas strike-slip durante a } \\
\text { compressão norte-sul e falhas de empurrão com } \\
\text { vergência para o norte. }\end{array}$ & $\begin{array}{l}\text { Intrusões menores, } \\
\text { provavelmente } \\
\text { graniticas, que sofreram } \\
\text { intenso metassomatis- } \\
\text { mo sódico }{ }^{4} \text {. }\end{array}$ & $\begin{array}{l}\text { Evolução dos dobramento } \mathrm{D}_{1}, \mathrm{D}_{2} \text { e } \mathrm{D}_{3} \text { pode repre- } \\
\text { sentar uma continuidade progressiva de } 2 \text { eventos. } \\
\text { Ocorrem texturas preservadas no Corpo IV como } \\
\text { sericita em microlitons }\left(\mathrm{S}_{1}\right) \text { e matriz com sericita } \\
\text { milonítica }\left(\mathrm{S}_{\mathrm{m} 3}\right) \text {. }\end{array}$ \\
\hline \multicolumn{2}{|c|}{$\begin{array}{l}\text { D4 } \\
\text { NEO- } \\
\text { PROTERO- } \\
\text { ZÓlCO }\end{array}$} & $\begin{array}{l}726 \pm 16 \text { to } \\
478 \pm 7 \mathrm{Ma} \\
\mathrm{K}-\mathrm{Ar}^{3.4}\end{array}$ & Regional & $\begin{array}{l}\text { High-strain corridors transpressivos e redobramento } \\
\text { da dobras } D_{3} \text {. Falhas de empurrão em finas escamas } \\
\text { com vergencia para } E \text { e de dobras apertadas a } \\
\text { isoclinais. }\end{array}$ & & $\begin{array}{l}\text { Relacionado ao ciclo Brasiliano (Neoproterozoico). } \\
\text { Muitas das datações U-Pb SHRHMP em zircões } \\
\text { forneceram idades de até } 590 \mathrm{Ma}^{5} \text {. }\end{array}$ \\
\hline
\end{tabular}

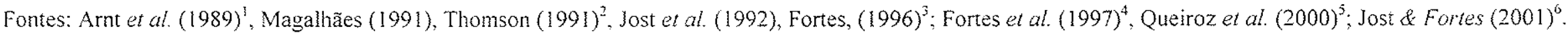



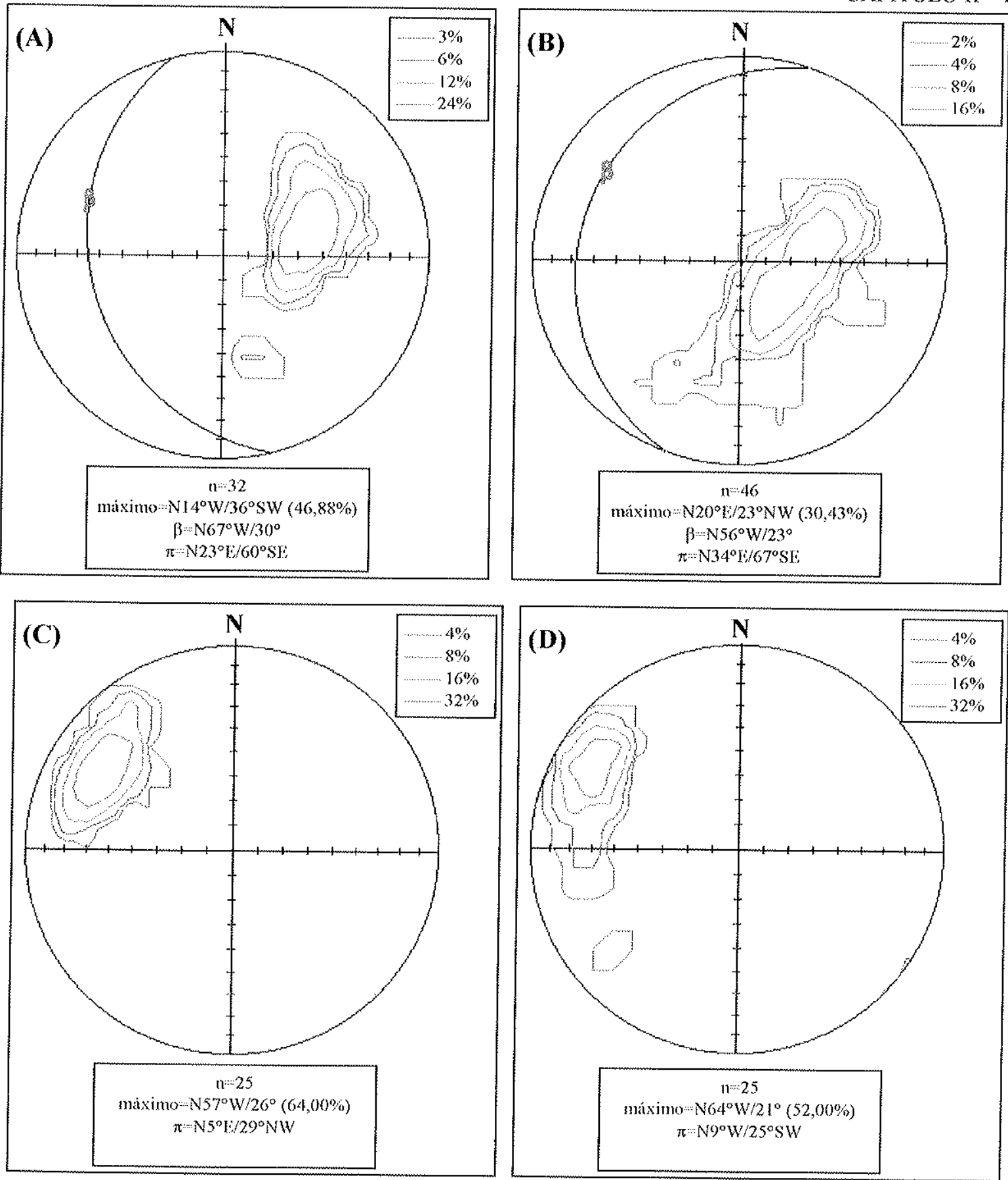

FIGURA 3 - (A) Estereograma sinóptico da foliação $\mathrm{S}_{4}$ (mergulho para $\mathrm{SW}$ ) e $\mathrm{S}_{\mathrm{m} 3}$ (mergulho para $\mathrm{NW}$ ) com medidas restritas ao Corpo IV e na galeria entre Corpo IV e V. (B) Esterograma sinóptico da foliação $S_{4}$ (mergulho para $\mathrm{SW}$ ) e $\mathrm{S}_{\mathrm{m} 3}$ (mergulho para NW) ao longo da galeria de acesso ao Corpo IV. (C) Estereograma sinóptico da lineação mineral/de estiramento $\left(L_{\mathrm{m} / \mathrm{s}}\right)$ no Corpo IV e na galeria entre Corpo IV e $\mathrm{V}$, que representa os eixos de boudins e lineação mineral da pirrotita principalmente. (D) Estercograma sinóptico da $\mathrm{L}_{\mathrm{a} / \mathrm{t} e}$ ao longo da galeria de acesso ao Corpo IV, que representa os eixos de boudins c lineação mineral, principalmente da pirrotita. 

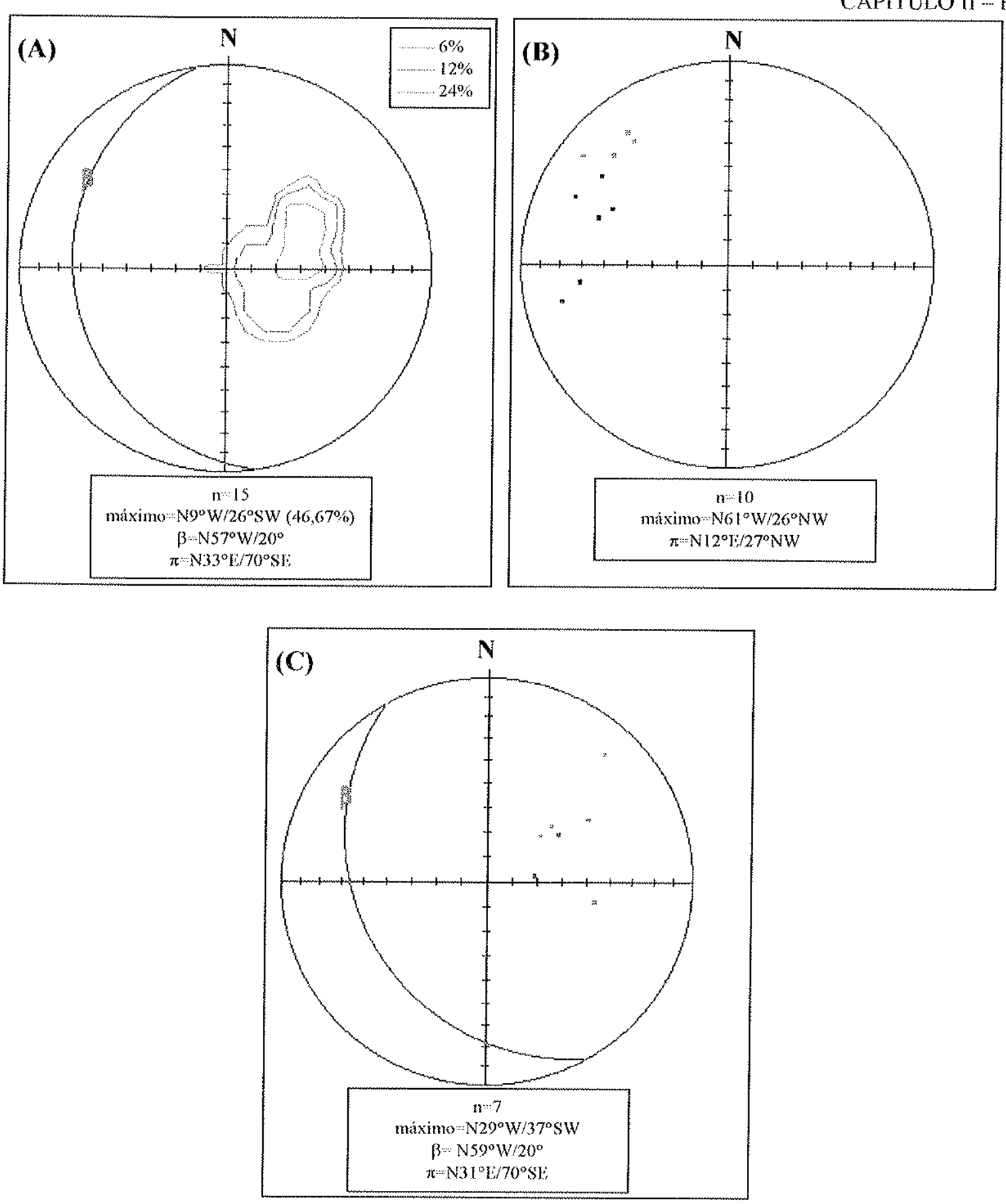

FIGURA 4 - (A) Estereograma sinóptico da superficie "C" com medidas do Corpo IV e da galeria de acesso ao Corpo IV. (B) Estereograma sinóptico dos eixos de dobras no Corpo IV (vermetho) e ao longo da galeria de acesso ao Corpo IV (preto), coincidentes com $\left(\mathrm{L}_{\mathrm{m} / \mathrm{e}, 3}\right)$. (C) Esterograma de contatos tectônicos reconhecidos ao longo da galeria de acesso ao Corpo IV, correlacionáveis à $S_{4}$ onde, azul $=$ contato dolomita com clorita-xisto, cinza $=$ contato dolomita com xisto carbonoso, verde $=$ contato clorita-xisto com xisto carbonoso. 


\section{DESCRICÃO DAS ZONAS DE MINÉRIO CORPO IV E V}

A descrição a seguir sumariza as principais feições determinadas em campo, divididas em Corpo IV, Corpo V e Zona de alteração relacionada aos corpos de minério.

Os eventos de alteração hidrotermal e cisalhamento pré-neoproterozóicos serão considerados doravante como sendo realtivos ao Paleoproterozóico, de acordo com as datações realizadas na área (TABELA 2).

\subsection{Corno IV}

O Corpo IV está encaixado no xisto carbonoso, se apresenta milonitizado e afetado por intensa sericitização pré-cisalhamento neoproterozóica. Lentes delgadas e deformadas de quartzo são relativamente raras e são comuns veios de quartzo pós-cisalhamento, geralmente pouco espessos. Ocorre sulfetização intensa, principalmente com pirrotita e vênulas de carbonato de ferro estirados na foliação. Nas zonas mais preservadas das estruturas "S/C" pôde-se reconhecer em diversos pontos, relíquias da foliação metamórfica $\mathrm{S}_{\mathfrak{l}}, \mathrm{S}_{\mathrm{m} 3}$ crenulada e da lineação mineral $\mathrm{L}_{\mathrm{m} / \mathrm{e} 3}$, paralela ao eixo de crenulação.

O hanging wall do Corpo IV pôde ser reconhecido a aproximadamente $360 \mathrm{~m}$ do corpo $\mathrm{V}$ na galeria de acesso entre o Corpo IV e V, local esse onde predominam xistos carbonosos, com biotita ocorrendo de maneira rítmica, e quartzo com pouco carbonato de ferro em relação as zonas mais distais. Ao se aproximar das zonas mais internas do Corpo IV percebe-se de maneira geral uma intensa alteração sericítica nas encaixantes e forte variação nos mergulhos devido as estruturas " $\mathrm{S} / \mathrm{C}$ ".

Em uma galeria de desenvolvimento do Corpo IV ocorre calcário grafitoso, cinza escuro a preto, e brechas cortadas por diversos veios delgados de quartzo na base, em contato com filito grafitoso. O calcário carbonoso próximo as zonas mais silicificadas adquire tom cinza a acastanhado, onde fica evidente o bandamento sedimentar dobrado. A borda superior desses calcários é silicificada na forma de veios tardios de quartzo hialino a branco, que incluem fragmentos miloníticos e alongados de xistos carbonosos, nos quais se nota forte sericitização.

Porfiroblastos de calcita são comuns em bordas e preenchimento de fraturas. Ocorrem dobras intrafoliais paralelas a foliação milonítica em faixas, que podem representar zonas silicificadas ou de chert em meio ao calcário. O fundo da galeria de desenvolvimento mostra um dobramento em escala métrica com eixo paralelo a lineação de estiramento mineral principal $\left(\mathrm{L}_{m / e}\right.$ : $\mathrm{N} 37^{\circ} \mathrm{W} / 20^{\circ}$ ) e ao plunge dos corpos de minério. O calcário carbonoso apresenta ainda boudins de calcita sugerindo tratarem-se de veios de calcita prévios ao cisalhamento e às dobras intrafoliais. Em meio ao xisto carbonoso ocorre uma faixa com aproximadamente $1,5 \mathrm{~m}$ de espessura de sericita xisto com clorita, contendo porfiroblastos de anfibólio de até $7 \mathrm{~cm}$ de comprimento, e granada mais fina (até $1 \mathrm{~cm}$ de diâmetro). Esses porfiroblastos estão cortados pela foliação milonítica neoproterozóica e apresentam leve rotacionamento, sendo que alguns cristais apresentam-se pouco deformados e orientados segundo a foliação milonítica. 
A foliação principal $S_{1}$ apresenta-se crenulada segundo um eixo paralelo à lineação mineral predominante. Paralelo a foliação $S_{1}$ ocorrem zonas miloníticas $\left(S_{m 3}\right)$ com pouca silicificação em relação aos falhamentos mais tardios e deve que estar relacionado a um evento metamórfico regional, assim como $\mathrm{S}_{1}$.

Nas proximidades do Corpo IV, na galeria de acesso ao Corpo V, pode-se constatar a zona de cisalhamento principal, sendo que os maiores mergulhos situam-se no início do Corpo IV, relativo a galeria, e que devem estar relacionadas as estruturas "S/C".

Os blocos envoltos pela "C" tem os veios de quartzo mais preservados e encaixados na sintética e na antitética. Junto aos veios de quartzo ocorre forte enriquecimento de biotita, silicificação, sericitização, carbonatização (carbonatos de ferro) e sulfetização.

O Corpo IV apresenta diversas gerações de quartzo que foram ordenados segundo a cronologia relativa reconhecida nas paredes da galeria. A TABELA 6 apresenta a cronologia relativa dos veios de quartzo no Corpo IV.

\section{$\underline{5.2 \text { Corpo V }}$}

As rochas do Corpo V estão encaixadas, de maneira semelhante ao Corpo IV, no xisto carbonoso, sendo que o este tem como principal diferença uma estruturação predominantemente de quebra e preenchimento (crak and seal) e apresenta uma quantidade relativamente maior de arsenopirita euhedrica.

A arsenopirita ocorre nos clastos e restitos do xisto grafitoso e restringe-se à foliação milonítica e nas bordas dos veios de Q-V1 e Q-V2 (TABELA 6), onde ocorre crescimento dos maiores cristais, característica semelhante ao halo de alteração reconhecido por Jost \& Fortes (2001) na Mina III. A encaixante com xisto carbonoso apresenta pirrotita foliada segundo $\mathrm{S}_{\mathrm{m} 3}$.

As estruturas de quebra e preenchimento são pré-cisalhamento principal (Pré-Neoproterozóico) no domínio do Corpo $\mathrm{V}$ e se apresentam em bom estado de preservação, sendo que nas imediações externas do corpo de minério ocorrem estruturas relacionadas ao cisalhamento neoproterozóico, indicando um deslocamento para o norte.

Em uma porção mais deformada na borda da estrutura de quebra e preenchimento do Corpo $\mathrm{V}$, ocorre um início de estiramento, cortado por pequenas falhas com preenchimento de carbonato, sugerindo fraturamento nos estágios iniciais da falha e progressão para o cisalhamento principal. Poderiam também ser interpretados como dois eventos deformacionais distintos, mas, de qualquer maneira, o minério correlaciona-se ao cisalhamento. 
TABELA 6 - Veios de quartzo nas zonas mineralizadas do Corpo IV e V.

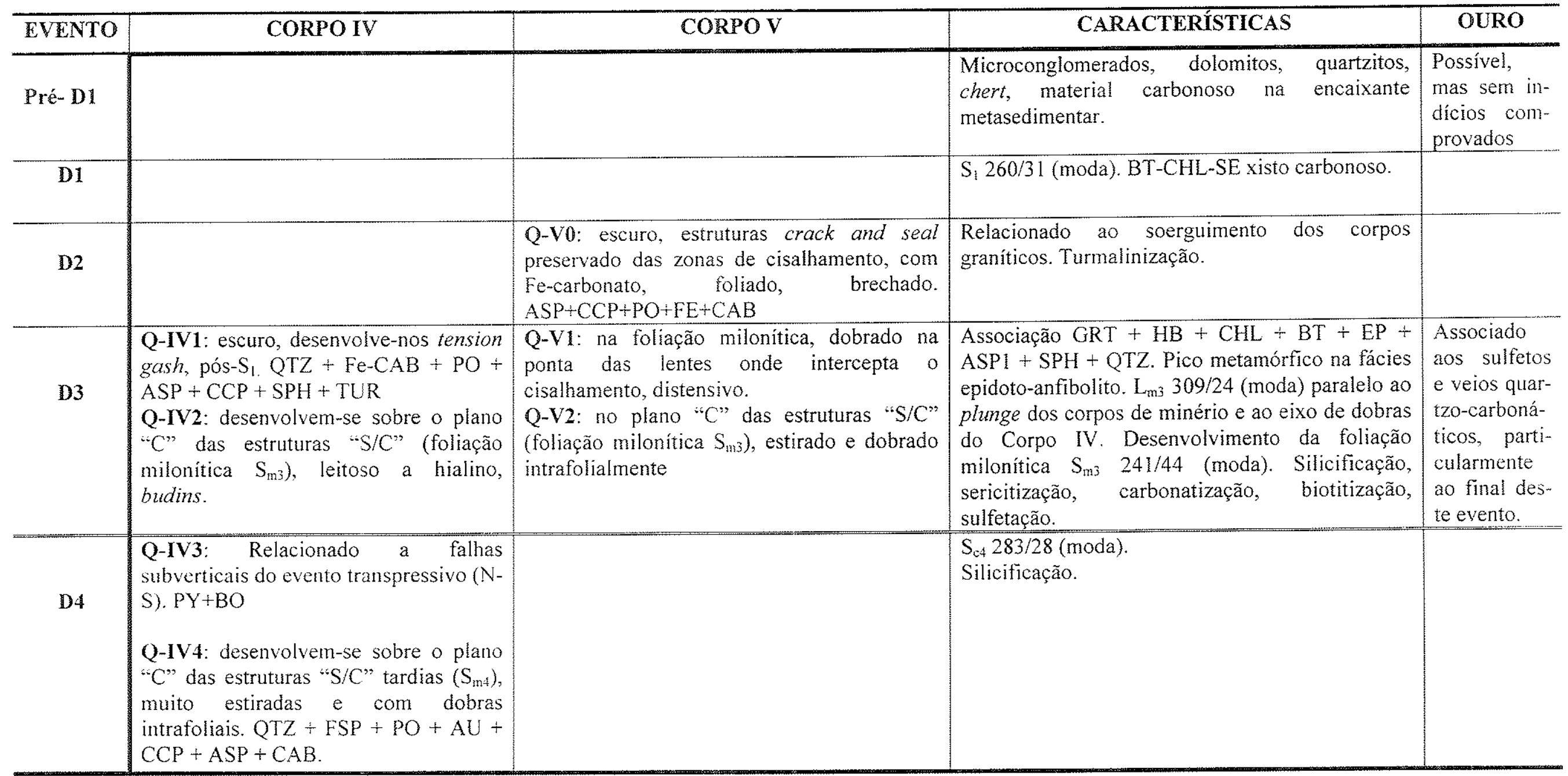

Abreviações: Q-IVI a 4 - veios de quartzo 1 até 4 do Corpo IV, Q-V0 a 2 - veio de quartzo 0 até 2 do Corpo V, Abreviações minerais conforme TABELA 1 
Ocorrem veios de quartzo paralelos a foliação milonítica, deformados com restos de xisto grafitoso e porfiroblastos de arsenopirita. Os veios de quartzo encontrados no Corpo V possuem uma cronologia relativa e características semelhantes aos do Corpo IV, conforme a TABELA 6.

Os Q-V1 e Q-V2 (TABELA 6) ocorrem em zonas pouco deformadas e não foram afetados pelo cisalhamento neoproterozóico. Esses veios mais antigos e cisalhados ao redor do corpo de minério apresentam fe-dolomita fina, sendo muito fraturados e deformados.

\section{ZONA DE ALTERACÃO RELACIONADA AOS CORPOS DE MINÉRIO}

O mapeamento das paredes das galerias permitu o reconhecimento de halos de alteração concêntricos ao redor do minério, bastante semelhantes nos Corpos IV e V, particularmente nas áreas pouco afetadas pelo cisalhamento neoproterozóico. Leitos ou pequenas lentes sericíticas com biotita são comuns nos xistos carbonosos, de maneira semelhante aos que ocorrem no Corpo Superior, e apresentam biotita concentrada nas bordas, sendo cortados pelos veios Q-V2. Afastando-se das lentes, a rocha torna-se mais grafitosa, mais rica em arsenopirita e a sericita aparentemente desaparece.

Uma subdivisão relacionda ao núcleo das alterações encontradas é apresentada na TABELA 7.

TABELA 7 - Zonas de alteração hidrotermal relacionadas aos Corpos IV e V.

\begin{tabular}{|c|c|c|c|}
\hline & PROXIMAL & INTERMEDIARIO & DISTAL \\
\hline CORPOIV & $\begin{array}{l}\text { Xisto carbonoso, veios de } \\
\text { quartzo com granada, } \\
\text { anfibólio, biotita, sericita, } \\
\text { pirrotita, arsenopirita, } \\
\text { calcopirita (predominância } \\
\text { da pirrotita) }\end{array}$ & $\begin{array}{l}\text { Biotita + sericita } \\
\text { Lentes de sericita no xisto } \\
\text { carbonoso }\end{array}$ & $\begin{array}{l}\text { Xisto carbonoso } \\
\text { Carbonato de ferro } \\
\text { (siderita?) }\end{array}$ \\
\hline CORPO V & $\begin{array}{l}\text { Xisto carbonoso, veios de } \\
\text { quartzo com granada, } \\
\text { anfibólio, biotita, sericita, } \\
\text { pirrotita, arsenopirita, } \\
\text { calcopirita (predominância } \\
\text { da arsenopirita) }\end{array}$ & $\begin{array}{l}\text { Biotita }+ \text { sericita } \\
\text { Lentes de sericita no xisto } \\
\text { carbonoso }\end{array}$ & $\begin{array}{l}\text { Xisto carbonoso } \\
\text { Carbonato de ferro } \\
\text { (siderita?) }\end{array}$ \\
\hline
\end{tabular}

\section{BRECHAMENTO RELACIONADO AOS CORPOS DE MINÉRIO}

Visto que a presença de brechamento está estritamente relacionada com a entrada de fluidos hidrotermais e que ambos os processos estão vinculados aos processos mineralizantes, 
é feito aqui uma caracterização dos tipos possíveis de sistemas de brechamento que afetam os corpos de minério.

Brechas são mais comumente encontradas nas partes superiores da crosta terrestre, saturadas de fluidos, onde a deformação rúptil é dominante. As brechas hidrotermais constituem uma subclasse da familia das brechas, na qual as rochas brechadas interagem com soluções hidrotermais, típicamente ricas em água (Jébrak, 1997).

Os estudos petrográficos tem mostrado que os sistemas de brechamento nos corpos mineralizados do Greenstone Belt de Crixás, principalmente nos Corpos IV e V e Zona Inferior, conforme PRANCHA 1, estão intimamente relacionados à alterações hidrotermais ao longo de condutos, resultando em diversos tipos e intensidades de alteração. Outra feição importante foi o reconhecimento da forma recorrente da atuação dos fluidos, que pôde ser reconhecida, por exemplo, em porfiroblastos de cloritóide. A PRANCHA 2 mostra um porfiroblasto de cloritóide com preenchimento da fratura caracterizado pela precipitação repetitiva de clorita e calcita. Essas características limitam a classificação de processos na área estudada a dois tipos, de acordo com os critérios de Jébrak (1997):

a) Brechamento assistido por fluidos (fraturamento hidráulico): é relacionado a um incremento da pressão do fluido dentro dos veios. O aumento da pressão do fluido pode ter várias origens, entre elas, a diminuição da permeabilidade da falha pelo movimento desta ou pela deposição de minerais, ou pela efervecência ou boiling, como resultado de reações químicas. O stress se manifesta na forma de pulsos de maneira uniforme e é um brechamento comum em depósitos minerais.

b) Brechamento assistido por fluidos (fraturamento crítico): é relacionado a destruição do equilibrio entre a pressão do fluido e o stress regional dentro do veio. A pressão do fluido diminui em resposta a uma súbita abertura de espaços geradas por movimentos rápidos ou pela intersecção de veios diferentes, o que vem a explicar porque as intersecções de veios são associadas com zonas de brechamento intenso. O stress se manifesta na forma de pulsos de maneira uniforme, sendo esse tipo de brechamento comumente encontrado em depósitos do tipo lode.

Esses dois tipos de brechamento podem ser vistos no esquema da FIGURA 5, sendo que os mesmos ocorrem, geralmente, em intima associação, porque ambos dependem de variações na pressão dos fluidos. Ambos os tipos de brechamento assistidos por fluidos geram texturas de fragmentação in situ, como brechas em mosaico, num padrão de "quebra-cabeça" 
sem rotação significativa dos fragmentos. Uma leve rotação dos fragmentos foi observada no Corpo $\mathrm{V}$, como resultado do brechamento crítico, porque os fragmentos sofrem um colapso imediatamente após a fragmentação. Isso indica que ocorreu um brechamento crítico extenso e que o processo de dilatação foi um processos contínuo com larga disponibilidade de espaços abertos (Jébrak, 1997).

Outra característica do brechamento assistido por fluidos é o fato dos fragmentos serem angulares e do brechamento seguir tipicamente planos de descontinuidade préexistentes (Jébrak, 1997), como é o caso das brechas de xisto carbonoso rompidas preferencialmente nos planos de foliação nos Corpos IV, $\mathrm{V}$ e da Zona Inferior.
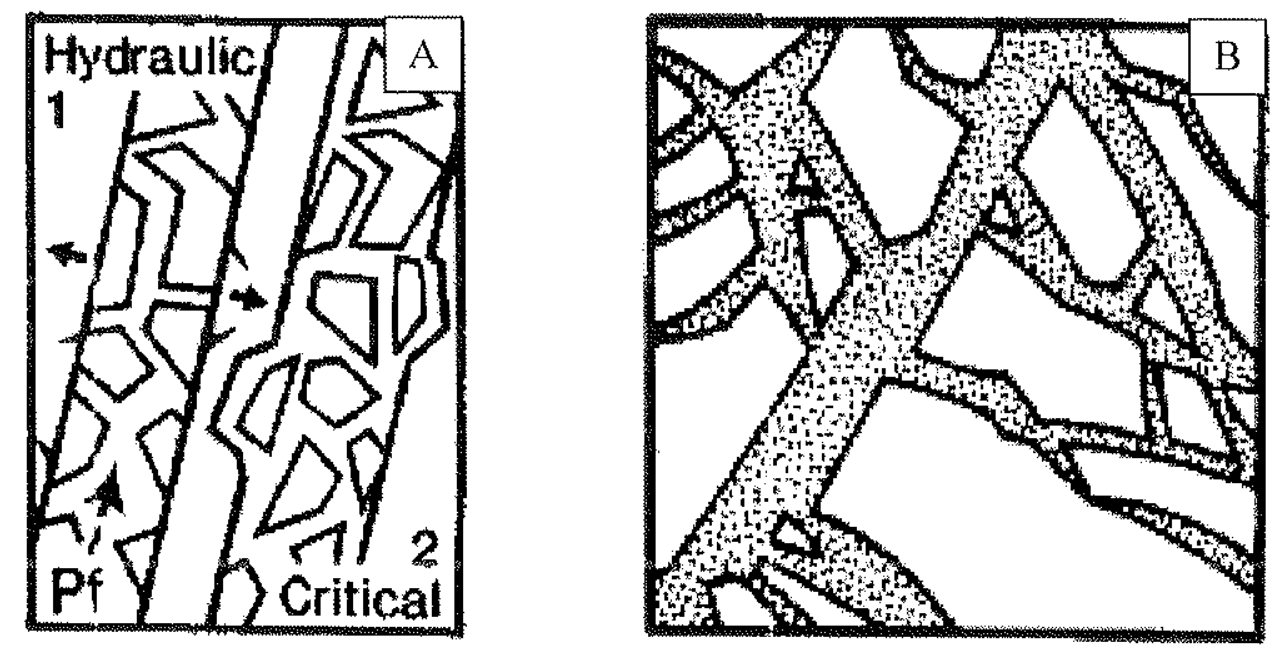

FIGURA 5 - llustração esquemática do mecanismo de brechamento assistido por fluidos em depósitos de veios hidrotermais (A) e a geometria resultante das brechas (B), segundo Jébrak (1997). 

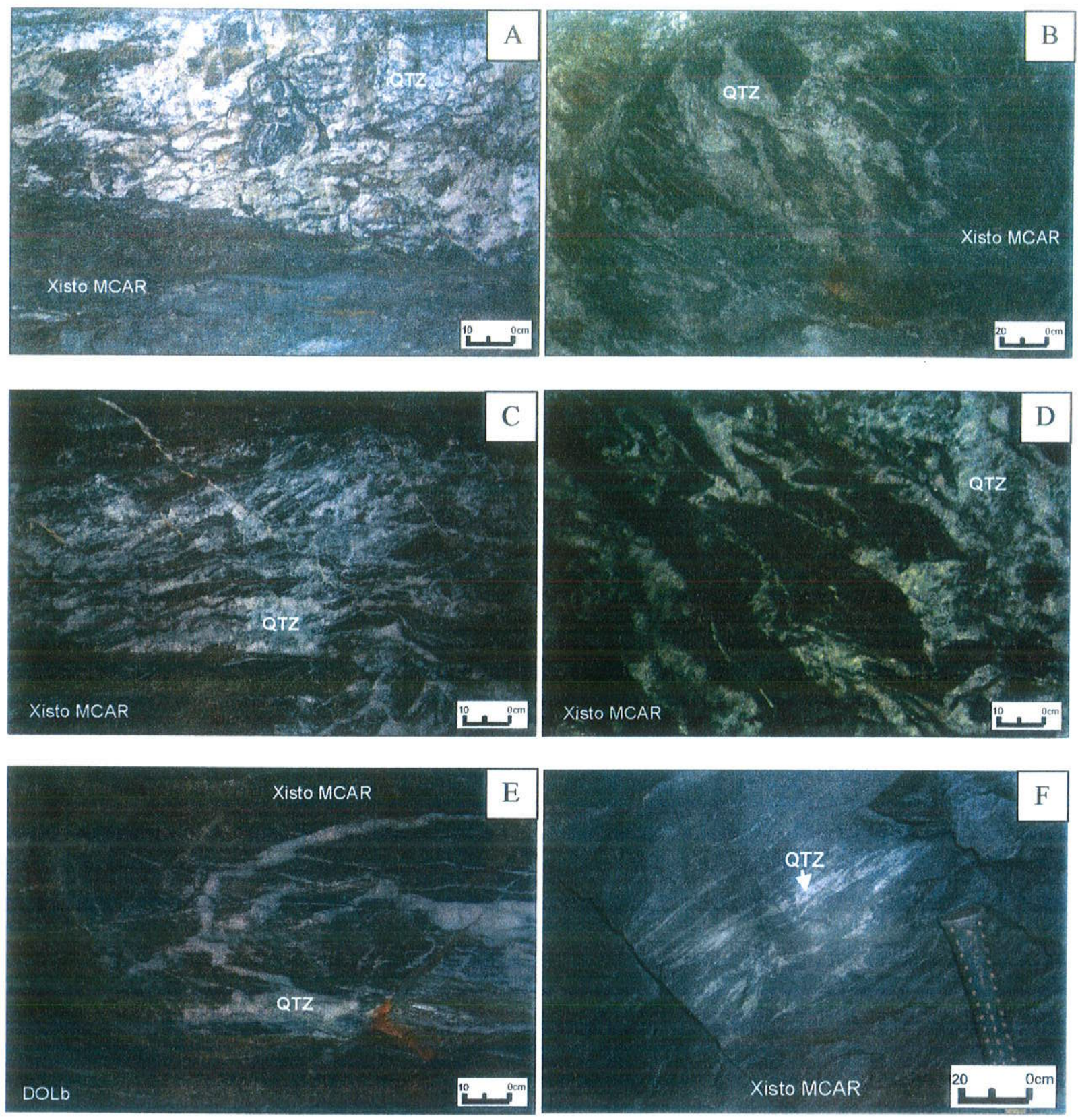

PRANCHA 1 - Estrutura brechada nos corpos mineralizados: (A) e (B) Corpo IV; (C) e (D) Corpo V; (E) e (F) Zona Inferior (Mina III). 

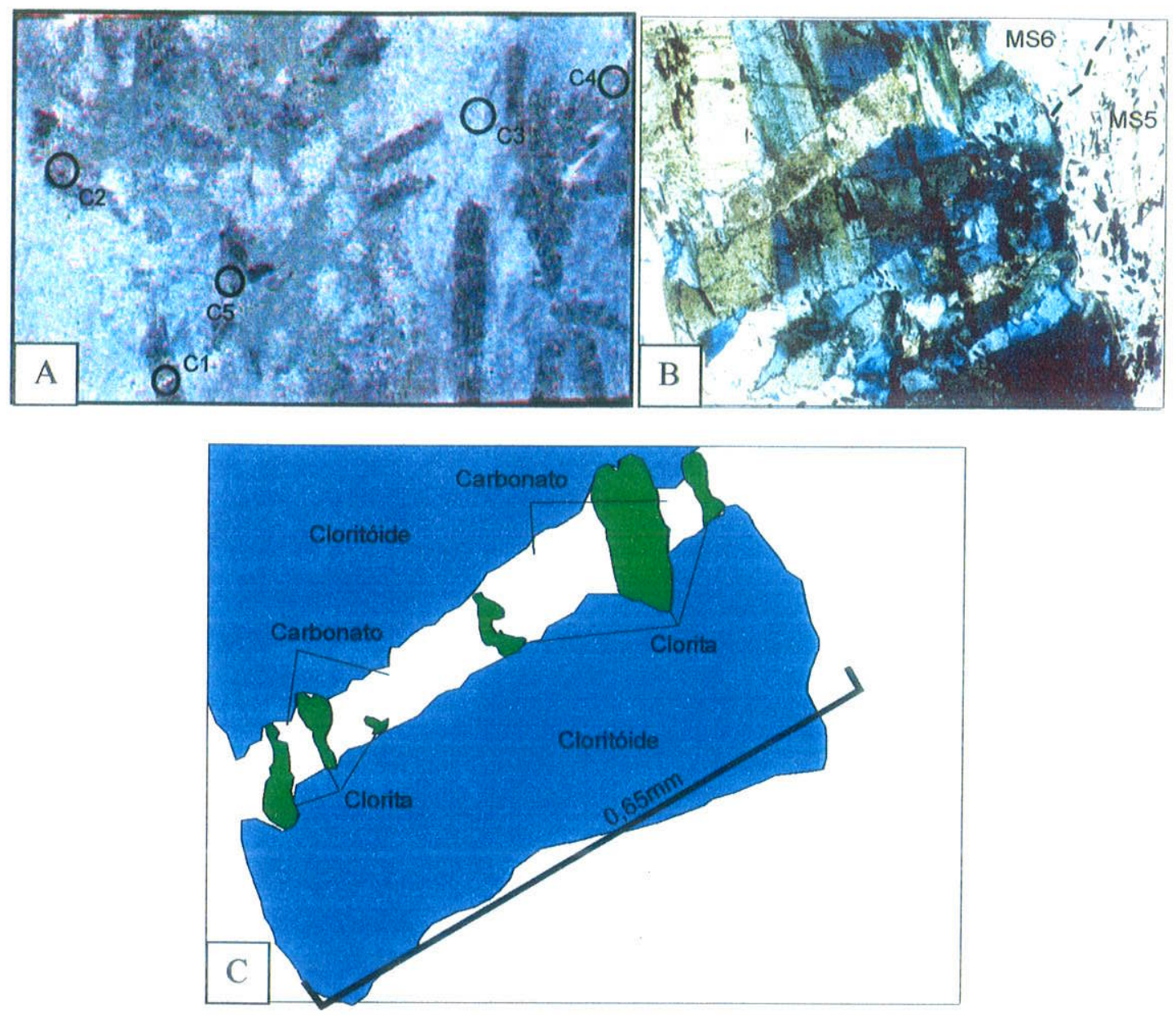

PRANCHA 2 - (A) - Imagem da amostra K59-34143 da lâmina delgada (5x3cm) submetida aos estudos petrográficos e de análise com auxílio de EDS. Os número representam os círculos nos quais foram realizadas análises. A matriz cinza é sericítico-feldspática, com venulações de cloritito em verde. Em meio a massa sericítico/feldspática ocorrem porfiroblastos de cloritóide, parcialmente decompostos pela cloritização/carbonatização, provavelmente neoproterozóica. (B) Círculo C1 da amostra K59-34143 com cloritóide fraturado. Notar a muscovita fina na matriz (MS1) e muscovita mais grossa (MS3) marcando o reflexo da fratura do porfiroblasto de cloritóide através da matriz. (C) Diagrama da imagem (B) indicando as diversas fases de cristalização dos pares clorita-carbonato sugerindo três pulsos de alteração/preenchimento. 


\section{CAPÍTULO III \\ PETROGRAFIA E BANCO DE DADOS PETROGRÁFICO}

\section{INTRODUCÃO}

Os diversos trabalhos geológicos efetuados na área da Mina III por vários autores utilizaram termos distintos na descrição das mesmas unidades ou litotipos, dificultando muitas vezes o resgate dos dados obtidos no decorrer dos últimos 20 anos. Por este motivo é inicialmente apresentada uma proposta de correlação dos termos utilizados nos principais estudos petrográficos e das nomenclaturas de rochas adotadas pela Mineração Serra Grande conforme a TABELA 8.

TABELA 8 - Correlação das nomenclaturas de rochas utilizadas para a Formação Rio Vermelho e Ribeirão das Antas.

\begin{tabular}{|c|c|c|c|}
\hline Nomenclatura MSG & THOMSON (1986) & THEODORO (1995) & FOR'PS (1996) \\
\hline \multicolumn{4}{|l|}{ Solo } \\
\hline \multicolumn{4}{|l|}{ Saprólito, atmarejo marrom, verde. vermelko grafitoso) } \\
\hline \multirow[t]{2}{*}{ Antibolito lino, médio e grosso } & & \multirow{3}{*}{$\begin{array}{l}\text { Fácies } \\
\text { Vulcanossedimenta: }\end{array}$} & Talco xisto \\
\hline & & & Metabasalto \\
\hline Clorita-anfibólio xisto & Anfibolito foliado & & Anfibólio xisto \\
\hline \multicolumn{2}{|l|}{ Dolomito } & \multirow[t]{6}{*}{ Fácies Carbonática } & \\
\hline Dolomito biotítico, dolomito brechado com grafita & $\begin{array}{l}\text { Clorita-plagioclasio- } \\
\text { geartzo-dolomita xisto }\end{array}$ & & \\
\hline \multicolumn{2}{|l|}{ Dolomito grafitoso } & & \\
\hline $\begin{array}{l}\text { Dolomito impuro, com disseminação de biotita e/ou } \\
\text { dorita. cheaixante da zoma mineralizada }\end{array}$ & $\begin{array}{l}\text { Dolomitanclorita* } \\
\text { biotita-quartzo xisto }\end{array}$ & & \\
\hline \multirow[t]{2}{*}{$\begin{array}{l}\text { Carbonatomclorita xisto. Transiçäo entre o dolomito } \\
\text { impuro e o clorila-xisto (CVX) }\end{array}$} & $\begin{array}{l}\text { Dolomito venuladio e } \\
\text { clorita-biotita-guartzo } \\
\text { xisto }\end{array}$ & & $\begin{array}{l}\text { Quartzo-clorita- } \\
\text { carbonato-sericita } \\
\text { xistos }\end{array}$ \\
\hline & $\begin{array}{l}\text { Dolomito maciço com } \\
\text { zonas ricas em clorita } \\
\text { e sericita }\end{array}$ & & $\begin{array}{l}\text { Sericita-carbonates } \\
\text { xistos }\end{array}$ \\
\hline Clorita-xisto verde, granadito e granada-clorita xisto & $\begin{array}{l}\text { Clorita-sericita- } \\
\text { granada xisto bandado }\end{array}$ & \multirow[t]{6}{*}{$\begin{array}{l}\text { Facies } \\
\text { Vulcanossedimentar }\end{array}$} & $\begin{array}{l}\text { Clorida-granada xisto } \\
\text { c granaditos }\end{array}$ \\
\hline Clorita xisto & Sericita-clorita xisto & & Sericita-clorita xisto \\
\hline $\begin{array}{l}\text { Sericita xisto e sericita-cttartzo xisto da capa da zona } \\
\text { mineralizada }\end{array}$ & & & $\begin{array}{l}\text { Quartzo-ciorita- } \\
\text { sericita-granada xisto }\end{array}$ \\
\hline $\begin{array}{l}\text { Clorita-granadat-magnetita-anfibolio xistoe } \\
\text { mathetita matciça }\end{array}$ & Clorita-magnetita xisto & & $\begin{array}{l}\text { Pirrotita-magnetita* } \\
\text { biotita xisto }\end{array}$ \\
\hline \multicolumn{2}{|l|}{ Sulfeto maciço } & & Sulfeto Macico \\
\hline \multicolumn{2}{|l|}{ Veio de quartzo e metachert } & & $\begin{array}{l}\text { Veios die quartzo } \\
\text { mineralizados }\end{array}$ \\
\hline Grafita xisto fino & Pelito gratitoso & \multirow[t]{2}{*}{ Facies Carbonosa } & Xistos Carbonosos \\
\hline $\begin{array}{l}\text { Cratita xisto e/ veios de quartzo, gratita xisto superior a } \\
\text { zona de veios de quartzo e metacherl gratitoso }\end{array}$ & $\begin{array}{l}\text { Brecha pelitica } \\
\text { gratitosa cimentadta } \\
\text { por quartzo (zona } \\
\text { mineralizada inferior) }\end{array}$ & & \\
\hline Metagrauvaca & $\begin{array}{l}\text { Quartzo-biotita- } \\
\text { plagiochásio xisto } \\
\text { bandado }\end{array}$ & Tácies Terrigena & Xistos feldispaticos \\
\hline
\end{tabular}

As sobreposições de alterações hidrotermais e falhas trazem grandes dificuldades para o reconhecimento, separação e interpretação das unidades e dos eventos que acometeram 
principalmente as rochas da Formação Ribeirăo das Antas. As diferenças de competencia existentes nos contatos litológicos são um dos controles fundamentais para o desenvolvimento das zonas de cisalhamento e/ou reativação de zonas de cisalhamento mais antigas. Os fluidos de alteração utilizam-se da permeabilidade nas rochas impostas pelo brechamento, dobramento e das zonas de cisalhamento.

A inversão estratigráfica reconhecida por autores anteriores (Theodoro, 1995; Jost et. al., 2000) pode ser reconfirmada na interpretação da descrição dos testemunhos de sondagem. No detalhamento das unidades pertencentes à área em estudo será considerado o posicionamento estratigráfico atual, ou seja, os metassedimentos da Formação Ribeirão das Antas na base e as metabásicas da Formação Rio Vermelho no topo.

Com base nos estudos petrográficos dos testemunhos de sondagem IV -22, IV-23, IV29, K-03, K-06, K-44, K-49, K-59 e mapeamento geológico das galerias de acesso, foi possível a subdivisão de três unidades litotípicas. Esta subdivisão utiliza a nomenclatura proposta por Theodoro (1995) com modificações, que refere-se à composição do protólito metamorfisado e às zonas de alteração hidrotermal, o que simplifica o agrupamento das unidades, dada a grande complexidade litológica.

Os sulfetos representam uma parte fundamental na associação com a mineralização de ouro dos Corpos IV e V e, sendo assim, foi feita uma cuidadosa descrição aos mesmos. Outra meta importante no estudo dos opacos foi a tentativa de se estabelecer uma correlação temporal relativa entre as diversas espécies de sulfetos e com o ouro. Os estudos foram realizados em seções polidas e nas amostras de veios polidos em ambos os lados (flinks), visando também uma melhor fundamentação petrográfica para o estudo das inclusões fluidas.

Após a descrição das unidades litotípicas segue uma descrição do banco de dados construído especialmente para atender as necessidades do projeto, no processamento e posicionamento do grande número de informações petrológicas.

\section{FÁCIES VULCANOSSEDIMENTAR}

As rochas da fácies vulcanossedimentar na área estudada são representadas por metabasaltos toleíticos, apresentando-se freqüentemente como anfibolitos a anfibólio-xistos, com cores verde clara a verde escura, em função do conteúdo de anfibólio, granulações que vão do muito fino ao grosso e texturas grano- a nematoblástica. Ocorrem diversas estruturas reliqueas de estruturas ígneas, como amígdalas, pillow lavas, materiais interpillows, tufos, 
brechas (pillow breccias) e derrames maciços. As principais características destas rochas são a presença constante de hornblenda/actinolita.

A composição principal dos anfibolitos é de anfibólio com núcleo de actinolita e bordas de hornblenda (70-80\%, ver Capítulo IV - Química Mineral), cristais grandes de oligoclásio recristalizado (15\%) e acessórios como zircão e óxidos de ferro.

$O$ anfibolito ainda sofre alterações posteriores que afetam principalmente zonas menos impermeáveis como de falhas, inter-brechas, inter-pillows e tufos, onde ocorre silicificação, epidotização, sulfetização, cloritização, biotitização e carbonatização. A grande diferença de competencia entre os derrames maciços e pillows com os depósitos de tufos torna estes últimos altamente suceptíveis a direcionar as zonas de cisalhamento, resultado dos esforços a que todo o pacote foi submetido.

Dentro das zonas mais permeáveis e alteradas hidrotermalmente ocorrem titanita e epídoto, por vezes relacionados a estruturas "S/C". O carbonato de ferro de cor azul na coloração seletiva substitui o anfibólio, sendo que quartzo $(15-20 \%)$, calcita $(<10 \%)$ e clorita (picnoclorita) (5-20\%) compõem as fases de alteração hidrotermal mais tardias. Na lâmina IV-22-01687 foram encontrados cristais de turmalina que devem estar relacionados aos eventos de alteração. A dolomita como mineral de alteração se apresenta muitas vezes na forma de pseudomorfos da hornblenda/actinolita, principalmente nas zonas de fraturas, o que pode ser indicativo de altas pressões de $\mathrm{CO}_{2}$ relacionadas ao evento que fraturam os porfiroblastos. A clorita e epídoto são singenéticos e a biotita é cloritizada (CHL3) e epidotizada (EP3). O plagioclásio possui inclusões de epídoto (EP1), titanita e clorita. Existe uma relação de blastese entre a dolomita, biotita, sulfetos e clorita com a foliação, provavelmente $\mathrm{S}_{\mathrm{m} 3}$. A pirrotita ocorre envolta por epídoto microcristalino. Em zonas mais intensamente alteradas são encontrados porfiroblastos euédricos de anfibólio tardios (amostra IV-22-01687), que podem ser correlacionados às zonas ricas em porfiroblastos de ferrotschermakita, nos metassedimentos da Formação Ribeirão das Antas, que está relacionado ao evento de alteração hidrotermal associado ao evento D3.

Os estudos petrográficos permitiram elaborar uma tabela de relações de blastese que foram associados aos eventos que ocorreram nos litotipos do Grupo Crixás apresentado na TABELA 9. 
TABELA 9 - Relações de blastese determinadas para as rochas da Fácies Vulcanossedimentar.

\begin{tabular}{|c|c|c|c|c|c|}
\hline \multicolumn{6}{|c|}{ FACIES VULCANOSSEDIMENTAR } \\
\hline & \multicolumn{3}{|c|}{ ARQUEANO } & \multirow{2}{*}{$\begin{array}{c}\text { PALEOPROTERO- } \\
\text { ZÓICO } \\
\text { D3 }\left(\mathrm{S}_{\mathrm{m}}\right) \\
\end{array}$} & \multirow{2}{*}{$\begin{array}{c}\text { NEOPROTERO- } \\
\text { ZÓICO } \\
D 4\left(S_{4}\right)\end{array}$} \\
\hline & $\mathrm{S}_{0}$ & $D 1\left(S_{1}\right)$ & $\overline{D 2}$ & & \\
\hline \multicolumn{6}{|l|}{$\begin{array}{l}\text { Hornblenda/actin } \\
\text { olita }\end{array}$} \\
\hline \multicolumn{6}{|l|}{ Oligoclásio } \\
\hline \multicolumn{6}{|l|}{ Zircão } \\
\hline \multirow{2}{*}{\multicolumn{6}{|c|}{$\begin{array}{l}\text { Óxido de ferro } \\
\text { Dolomita }\end{array}$}} \\
\hline & & & & & \\
\hline \multicolumn{6}{|l|}{$\begin{array}{l}\text { Dolomita } \\
\text { Fe-tschermakita }\end{array}$} \\
\hline \multicolumn{6}{|l|}{ Quartzo } \\
\hline \multicolumn{6}{|l|}{ Epídoto } \\
\hline \multicolumn{6}{|l|}{ Titanita } \\
\hline \multirow{2}{*}{\multicolumn{6}{|c|}{$\begin{array}{l}\text { Turmalina } \\
\text { Clorita }\end{array}$}} \\
\hline & & & & & \\
\hline \multicolumn{6}{|l|}{ Calcita } \\
\hline \multicolumn{6}{|l|}{ Biotita } \\
\hline \multirow{2}{*}{\multicolumn{6}{|c|}{$\begin{array}{l}\text { Pirrotita } \\
\text { Quartzo }\end{array}$}} \\
\hline & & & & & $\longrightarrow$ \\
\hline & $\begin{array}{l}\text { Derrames } \\
\text { submari- } \\
\text { nos }\end{array}$ & $\begin{array}{l}\text { Desenvolve } \\
\text { em zonas } \\
\text { de menor } \\
\text { competên- } \\
\text { cia }\end{array}$ & & $\begin{array}{l}\text { Fácies epídoto- } \\
\text { anfibolito. Alterações } \\
\text { em locais de maior } \\
\text { permeabilidade ( } p \text {. } \\
\text { ex.: tufos, materiais } \\
\text { inter-pillows ) }\end{array}$ & $\begin{array}{l}\text { Falhas tardias } \\
\text { reativam } \\
\text { falhas } \\
\text { anteriores }\end{array}$ \\
\hline Convenção: & $\begin{array}{l}\text { Min } \\
\text { Min }\end{array}$ & direita altera & & & \\
\hline
\end{tabular}

A base desta unidade com a Unidade Terrígena é tectônica, e a sua espessura total é estimada em 300 a 500 m (Jost \& Fortes, 2001). O contato no topo com os meta-komatiítos da Formação Córrego Alagadinho, que não foi constatada nos trabalhos de mapeamento, é considerado abrupto pelos autores anteriormente mencionados.

Foram reconhecidos episódios vulcanogênicos, caracterizando ciclos com pequenas variações e com escala métrica variável, que se repetem várias vezes ao longo do pacote de metabásicas. Esta seqüência se apresenta invertida nos testemunhos de sondagem, podendo ser dividida por meio de suas estruturas e litotipos em três episódios vulcanogênicos correlatos, que se repetem várias vezes dentro da unidade vulcanossedimentar. Da base para o topo foi observada a seguinte ordem:

a) Derrames maciços: metabasitos maciços a pouco foliados, verde claro com granulações muito fina a grossa. Freqüentemente apresentam venulações preenchidas com calcita branca, condicionadas por fraturas, com bordas cloritizadas.

b) Pillow lava: pillows com mais de $20 \mathrm{~cm}$ de altura, às vezes com amígdalas em suas bordas, com leitos de tufos carbonatizados e geralmente foliados. 
c) Tufos: coloração verde clara a branca, apresentam granulação média, laminados e/ou foliados.

\section{FÁCIES TERRÍGENA}

A fácies terrígena constitui camadas de xistos deformados, com intercalações de rochas dolomíticas e metabásicas, freqüentemente cortadas por zonas de cisalhamento e zonas com forte alteração hidrotermal sobrepostas. Esta unidade litológica é particularmente importante por hospedar quase todos os corpos mineralizados da Mina III, além dos Corpos IV e V.

As rochas desta unidade tem sido usualmente denominada de metagrauvacas, no sentido de Krynine (in: Friedman \& Sanders, 1978), onde a graywacke é considerado como: "arenito composto por partículas de quartzo anguloso, chert e fragmentos abundantes de rochas metamórficas, com pouco ou nenhum cimento e feldspato, contendo mais que $12-17 \%$ de micas e clorita, tanto na matriz argilosa como nos fragmentos de rocha". Este termo tem gerado confusão nas descrição de terrenos metamorfisados, vulcanossedimentares ou não, devido ao seu vínculo genético com a teoria dos geossinclinais e, assim sendo, Friedman \& Sanders (1978) não recomendam a sua utilização. Esses autores sugerem que estas rochas sejam denominadas de arenitos líticos argilosos. Suguio (1998) propõe ainda a tradução para o português do termo wacke como "vaque". Neste trabalho será adotada a nomenclatura metawacke, em acordo com Ronde et al. (1992).

Será adotado ainda o termo carbonoso ao invés de grafitoso, em acordo com Fortes (1996) que definiu valores isotópicos $\left(\delta \mathrm{C}_{\text {org }}\right)$ de $-15,11$ a $-17,99 \%$ para a matéria carbonosa, indicando uma grafitização apenas incipiente e, ainda, classificando-os como sendo de origem orgânica.

Existem duas terminologias para descrever a matéria carbonosa precambriana: querogênio e betume. Querogênio se refere a matéria orgânica insolúvel, em partículas macromoleculares, dispersa em sedimentos consolidados, os quais estiveram virtualmente imóveis desde sua deposição. Acredita-se que o querogênio precambriano deve ter sido similar aos querogênios tipo I, derivado de algas lacustrinas, e tipo II de fitoplâncton marinho. Betume se refere a substâncias orgânicas macromoleculares, as quais são móveis na forma de fluidos viscosos (em geral óleo ou gás), ou que passaram a uma fase imóvel, solidificado por processos de polimerização. O depósito mineral de Witwatersrand também apresenta material 
carbonoso na forma de leitos e nódulos (Spangenberg \& Frimmel. 2001), de forma semelhante à encontrada na Formação Ribeirão da Antas.

Rasmussen et al. (1999) demonstraram que o movimento de hidrocarbonetos que atravessam arenitos podem formar nódulos ao redor de minerais pesados e radioativos detríticos (p. ex. monazita e torita). Sua teoria se baseia no fato que a radiação ionizante provoca ligações cruzadas e polimerização das moléculas de hidrocarbonetos. Durante tal processo, as ligações $\mathrm{C}-\mathrm{H}$ e $\mathrm{C}$-S são quebradas preferencialmente às $\mathrm{C}-\mathrm{C}$, o que resulta na liberação de H e S para o fluido circundante. Se houver uma salmoura rica em metais em migração simultânea ou posterior nestas rochas, é possível que o enxôfre reaja com os metais formando sulfetos disseminados dentro do betume ou na forma de uma fina camada de sulfetos ao redor deste, mantendo seu núcleo radioativo. Este é o caso encontrado em Eastern Goldfields no oeste Australiano e na bacia de Witwatersrand na África do Sul. Os nódulos encontrados na Formação Ribeirão das Antas não apresentavam camadas de sulfetos, traços de radioatividade, segundo testes feitos com contador Geiger, e não foram encontrados minerais pesados radioativos nos metassedimentos desta formação.

Os "nódulos carbonosos" encontrados nos metassedimentos da Formação Ribeirão das Antas, constituídos por material carbonoso e carbonato em proporções diversas (PRANCHA 3), foram primeiramente interpretados como de origem sedimentar. Os estudos petrográficos, entretanto, indicam que a maioria destes nódulos são provenientes de leitos mais ricos em matéria carbonosa que foram transpostos pela $S_{1}$ e, na região apical das dobras associadas ao evento regional de crenulação, foram truncados, isolados e rotacionados pela transposição plano-axial $\mathrm{S}_{\mathrm{m} 3}$ (PRANCHA $4 \mathrm{G}$ ). Com a superposição da foliação geradas pela zona de cisalhamento houve rotação e a recristalização dos clastos, o que provocou uma aglutinação da matéria carbonosa em pequenos elipsóides posicionados perpendicularmente ao esforço, conforme pode ser observado na PRANCHA 3 A, B e C. Em seções perpendiculares ao esforço os fragmentos mostram-se com seções circulares conforme PRANCHA 4 A. Com o aumento da intensidade do cisalhamento estas estruturas são ainda mais estiradas, surgem sombras de pressão e com a continuidade da deformação, os nódulos são destruídos (PRANCHA 3 D, E e F, ver também a TABELA 10).

Esta evolução sugere que outros materiais considerados como clastos, como os carbonatos, agregados de quartzo com ou sem micas, xisto carbonoso e material pelítico, podem ser, pelo menos em parte, originados por brechamentos pré- ou $\sin -\mathrm{S}_{\mathrm{m} 3}$ (PRANCHA 4 C, D, E e F), feições essas bastante comuns nas zonas mineralizadas (ver Capítulo II, 
Brechamento relacionado aos corpos de minério).

A litologia é composta predominantemente por metawacke feldspáticos de cor cinza a negra, carbonosos e com freqüentes clastos líticos diversos, chegando a constituir leitos de metawackes líticos. Esta unidade inclui freqüentes camadas, bandas e lâminas de filito carbonoso, derivadas de folhelhos, geralmente em contato gradacional, onde são mais poupados das deformações regionais associadas aos eventos de cisalhamento. Não raramente ocorrem leitos ricos em clastos variando de grânulos a seixos com até $5 \mathrm{~cm}$ de comprimento, constituindo metarenitos feldspáticos ou líticos argilosos conglomeráticos. Freqüentemente possuem clastos de carbonatos, que podem predominar sobre os demais nas proximidades dos corpos de rochas carbonáticas.

A matriz do metawacke é composta, em essência, por plagioclásio (10 a 40\%), quartzo $(\sim 5 \%)$, biotita ( 3 a $15 \%$ ), clorita (10 a $20 \%$ ), material carbonoso (1 a $20 \%)$, muscovita $(0$ a $30 \%$ ), carbonatos ( 0 a $20 \%$ ), além de acessórios como ilmenita, turmalina, epídoto, rutilo, titanita, apatita, pirrotita, arsenopirita, calcopirita e pirita.

Localmente a rocha encontra-se bem preservada de deformações tardias e nestes partes pode-se verificar clastos angulosos a pouco arredondados, com granulação submilimétrica a decimétrica. Estes últimos são formados predominantemente por quartzo monomilerálico ou como agregados de feldspatos, carbonatos com inclusões de material carbonoso e/ou óxidos de Ti/Fe e fragmentos líticos carbonáticos, de filitos carbonosos, de quartzitos ou metachert e, mais raramente, de agregados de quartzo e feldspato (PRANCHA 4 B). Em função da proximidade das zonas de cisalhamento tardias, que também coincidem com as áreas de influência da alteração hidrotermal, ocorrem deformações suaves a destrutivas como estiramento dos clastos/brechas e dos "nódulos carbonosos". 

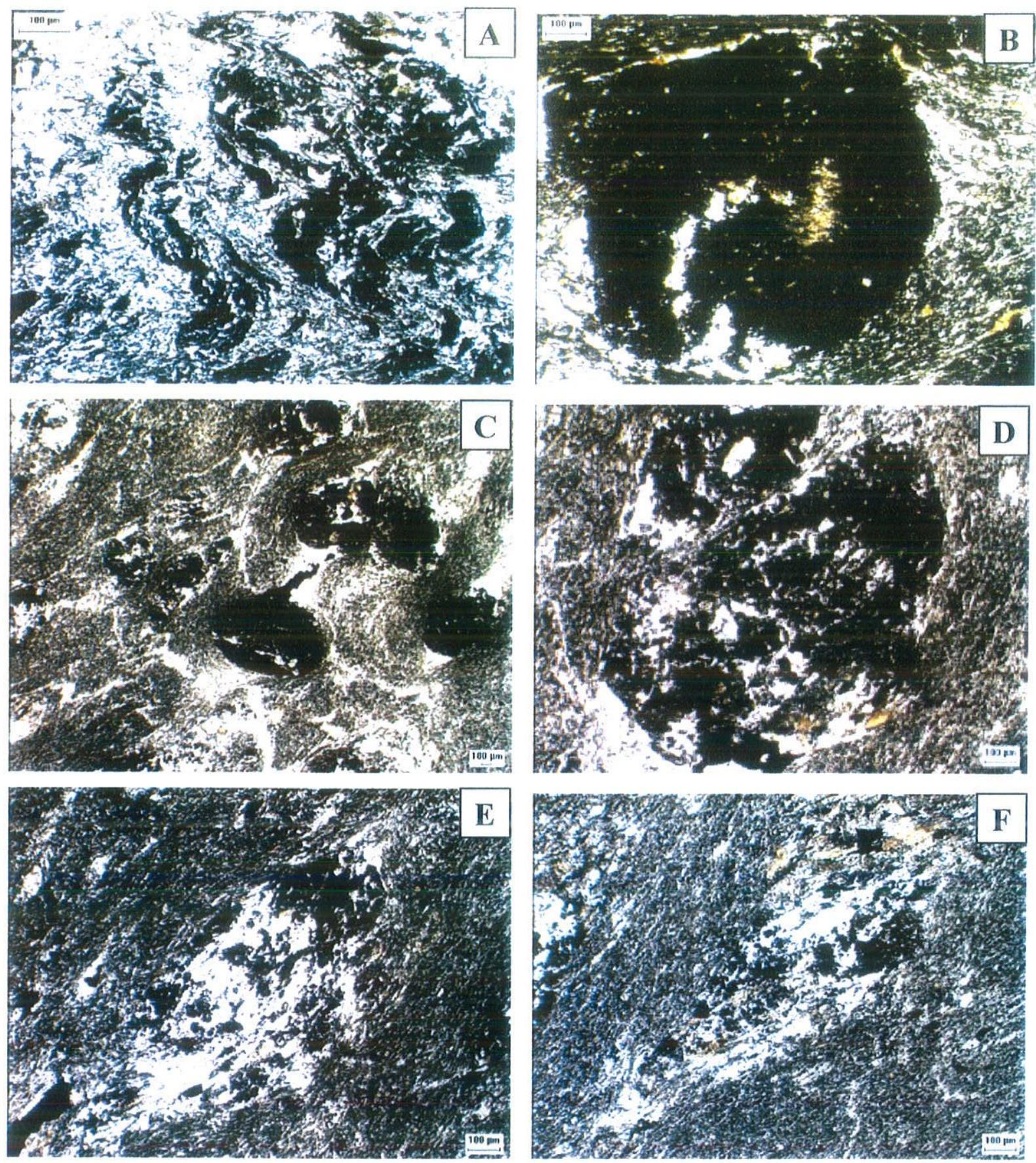

PRANCHA 3 - Ilustração da seqüência de formação e destruição dos "nódulos carbonosos": (A) a evolução da crenulação $\mathrm{S}_{\mathrm{m} 3}$ separou zonas apicais de dobras de material carbonoso; (B) o avanço da intensidade de cisalhamento gerou o "nódulo"; (C) "nódulos" desenvolvidos e já com princípio de deformação; (D), (E) e (F) seqüência de destruição da estrutura de acordo com a intensidade do cisalhamento relacionado ao evento D4. 

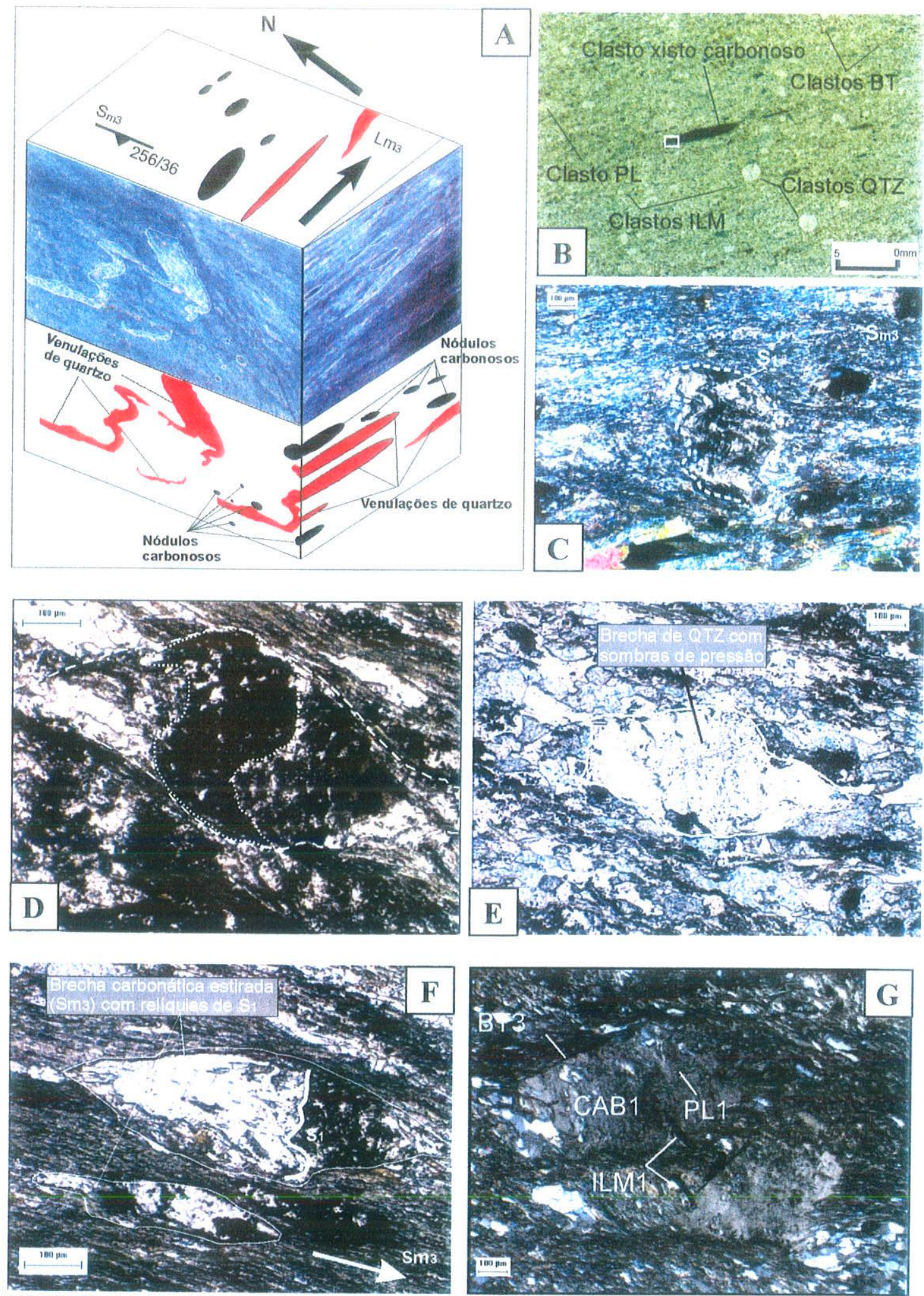

PRANCHA 4 - (A) Corte perpendicular a foliação principal mostrando o estiramento de veios de quartzo dobrados e de nódulos carbonosos, segundo a $\mathrm{L}_{\mathrm{m} / \mathrm{e} 3}$ (bloco de amostra com $5 \times 3 \mathrm{~cm}$ ), (C) brecha de quartzo com foliação dobrada marcada por material carbonoso $\left(\mathrm{S}_{1}\right)$ em meio a matriz predominantemente sericítica dominado pela foliação $\mathrm{S}_{\mathrm{m} 3}$ (amostra IV-22-18076), (D) brecha com material carbonoso rotacionado, preservando parcialmente a foliação $S_{1},(\mathbb{E})$ brecha angulosa de quartzo com sombras de pressão, (F) brecha carbonática/carbonosa estirada apresentado bandamento interno $\left(\mathrm{S}_{1}\right),(\mathbf{G})$ clasto carbonático (calcita) com inclusões de ilmenita e plagioclásio (amostra K5919435) 
O contato inferior dos xisto carbonosos com as metabásicas é abrupto marcado pela zona de cisalhamento, que no Perfil E-W (ANEXO 1) pode ser reconhecida na superficie pelo sistema superimposto de drenagem do Rio Vermelho. A parte superior da Unidade Terrígena apresenta ritmitos e/ou dolomitos primários e os bitotita-clorita xistos, mas está geralmente mascarada pela intensa dolomitização (Jost \& Fortes, 2001).

Foram encontradas várias relíquias das rochas originais nos testemunhos de sondagem tectonizadas, às vezes com suave alteração hidrotermal, como por exemplo ritmitos quartzocarbonático-carbonoso (PRANCHA $5 \mathrm{E}$ ), arenitos e microconglomerados. No testemunho de sondagem F-462 foi identificado uma zona de microconglomerados com seixos de até $0,6 \mathrm{~cm}$, predominantemente de quartzo, arredondados, que gradam para meta-arenito a meta-siltito com grânulos dispersos, com estruturas típicas de correntes de turbidez, indicando ambiente deposicional próximo a margens continentais ativas, corroborando a afirmação de Jost \& Fortes (2001).

Foi detectada uma alta concentração (até $\sim 28,4 \%$ ) de fluorapatita, em uma análise de clasto carbonoso da Unidade Terrígena na metawacke (FIGURA 6, PRANCHA 5 A e B, amostra IV-22-11218). A presença de apatita nas concentrações acima mencionadas traz informações complementares sobre o ambiente deposicional, principalmente da zona mineralizada. Sobre a precipitação do fosfato, Froelich et al. (1982), propõem que partículas de oxi-hidróxido de ferro, formadas hidrotermalmente pela reação entre fluidos ricos em ferro e água do mar oxigenada, podem co-precipitar fosfato. Adicionalmente a crosta oceânica e seus sedimentos em regiões de flancos de arcos também atuam como sítios removedores de fosfato da água marinha (Wheat et al., 1996). A retirada de fosfato pelos óxidos de Fe está relacionada com o nível de oxigênio da atmosfera e hidrosfera (Shen et al., 2000). Os mesmos autores citam ainda um exemplo de fosfogênese no periodo final do Proterozóico em um oceano bastante oxigenado, permitindo a retirada de fosfato pelo "bombeamento" de $\mathrm{Fe}$ hidrotermal e pela proliferação da atividade microbiológica.

A análise da FIGURA 6 revela ainda que o clasto rico em fluorapatita apresenta calcita e flogopita, provavelmente primários, em concordância com análises da química mineral (ver Capítulo da química mineral), sendo que a clorita e dolomita foram gerados durante os eventos de alteração hidrotermal.

Foi ainda ópticamente constatada a alteração da ilmenita, provavelmente para pseudorutilo (PRANCHA 5, C e D), sendo que este tipo de alteração é muito comum em 
depósitos de minerais pesados com ilmenita detrítica (Wort \& Jones, 1980). O rutilo parece associar-se predominantemente com as zonas hidrotermais mineralizadas em ouro, de modo semelhante os descrito por De Ronde et al. (1992) em mineralizações de ouro no Greenstone Belt de Barberton. Houston (1988, in: de Ronde et al., 1992) também relata aumento de concentração de $\mathrm{TiO}_{2}$, principalmente sob a forma de rutilo em rochas cisalhadas mineralizadas em ouro da mina de Barbrook, também em Barberton.

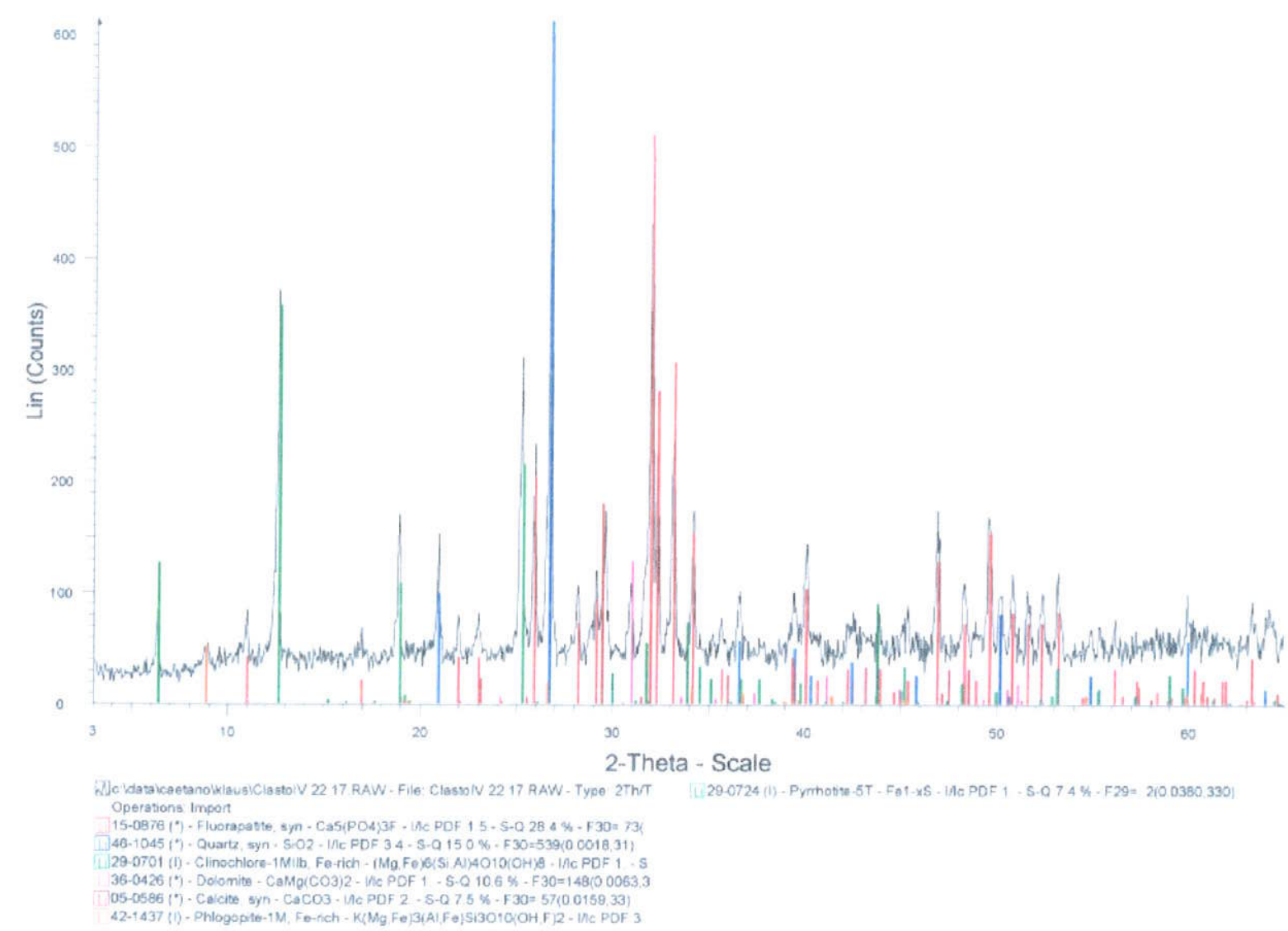

FIGURA 6 - Difratograma de um clasto de xisto MCAR na amostra IV-22-11218 mostrando sua composição predominante de fluorapatita $(28,4 \%)$, além de quartzo, carbonatos, pirrotita, flogopita e clinocloro.

A TABELA 10 apresenta as relações de blastese na Fácies Terrígena reconhecidos ópticamente nos estudos petrográficos. 

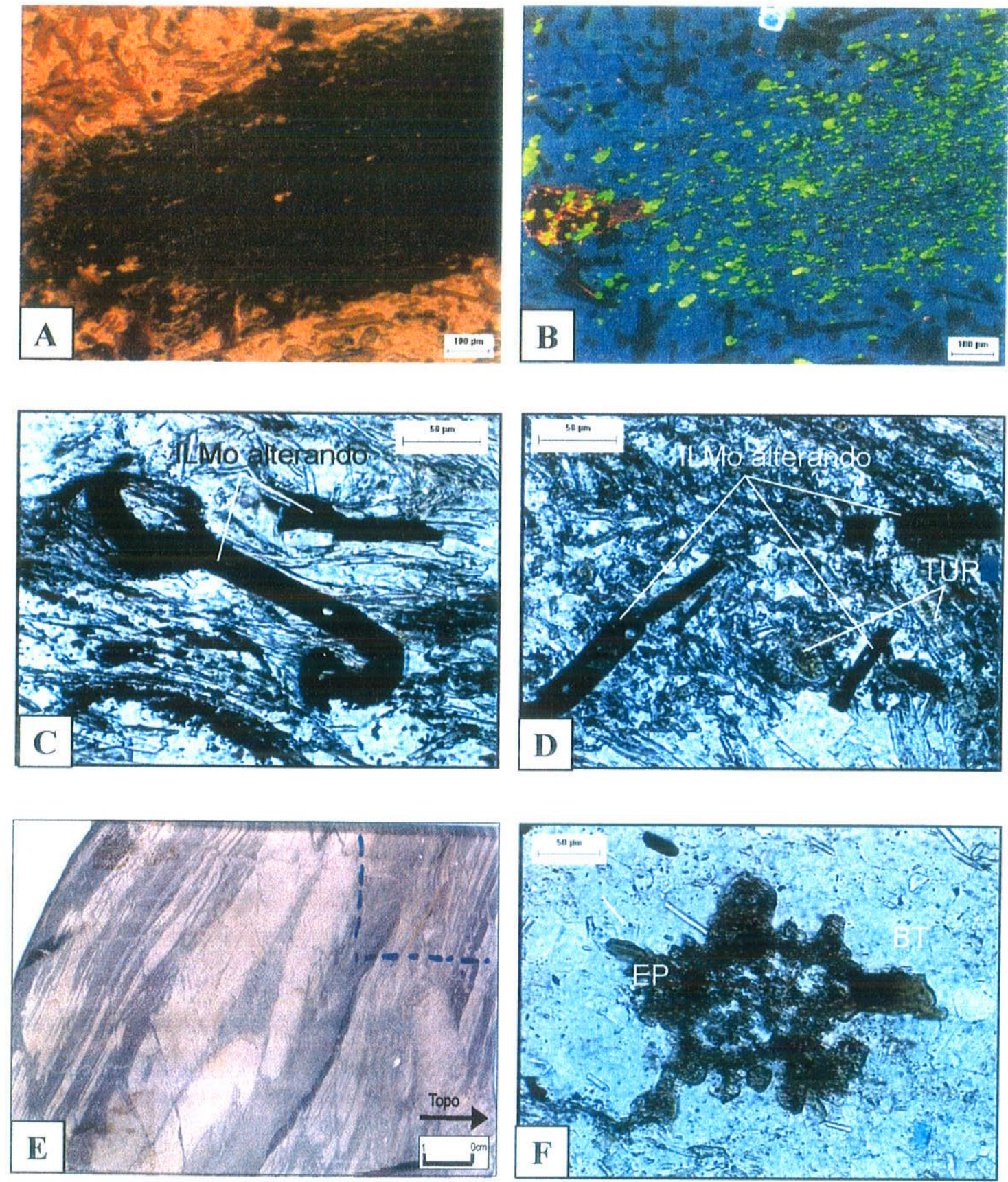

PRANCHA 5 - (A) Clasto carbonoso analisado com auxílio de raios X (IV-22-16303). (B) Mesma área de (A) com imagem gerada com auxílio da cátodo-luminiscência revela a apatita em verde intenso limitada ao clasto (IV-22-16303).(C) e (D) Ilmenita com deformações provocadas pela crenulação e alterações para rutilo (pseudorutilo?). Ocorre também turmalina associada. (E) ritimito quartzocarbonático com estruturas primárias bem preservadas. Pode-se reconhecer claramente a alternância de leitos carbonáticos e quartzo-carbonosos (amostra K59-44950). (F) Epídoto radioativo (ver halo plocróico na biotita a direita) alterado com a proximidade do cisalhamento, gerando microcristalizações. 
Nas zonas de alteração da ilmenita, o epídoto é também alterado, restando apenas contornos microcristalinos em agregados muito finos de minerais, ou apenas como pseudomorfos (PRANCHA $5 \mathrm{~F}$ ), indicando, provavelmente, mudanças na composição do fluido hidrotermal essencialmente aquoso para fluidos com $\mathrm{CO}_{2}$, que instabilizam o epídoto (Kerrick, 1974). Outra característica marcante é o aporte de $\mathrm{K}^{+}$no sistema, dando início a pelo menos duas gerações de biotita e uma de sericita (D3), seguida de uma redução de temperatura e da atividade do potássio no evento D4, resultando em intensa cloritização tardia.

Os clastos já arredondados e estirados de carbonato primário sofrem alterações para clorita e biotita, restando seus contornos marcados pela biotita milonítica. Clastos de xisto carbonoso tem turmalina e ilmenita, este último substituído por rutilo. A turmalina ocorre ainda no xisto carbonos, nos "nódulos" carbonosos e em veios de quartzo (Q-IV1), apresentando às vezes cristais rompidos pela crenulação $S_{\mathrm{m} 3}$.

A presença de rochas carbonáticas sedimentares intercaladas na fácies terrígena é bastante limitada, o que dentro das dimensões deste estudo, não permitiu um tratamento individualizado (por exemplo, uma fácies carbonática primária). A ocorrência dos carbonatos com características primárias será tratada dentro do contexto da fácies terrígena e os grandes corpos de dolomito, resultado da alteração das rochas metassedimentares, foi incluida na Fácies de alteração hidrotermal, discutida a seguir.

Nas proximidades das zonas mineralizadas há grandes dificuldades nas interpretações da origem das rochas carbonáticas, devido à deformação intensa e ao hidrotermalismo com carbonatização associada. Entretanto, alguns corpos com tamanhos limitados de dolomito, intercalados na fácies terrígena, foram considerados sedimentares em função dos contatos gradacionais com o metawacke, estruturas laminadas carbonosas (PRANCHA 5 E), pela presença de leitos micáceos e de clastos silicáticos, observada fora das zonas de deformação e/ou alteração mais intensa. Próximo aos contatos com a metawacke ocorre freqüentemente texturas sugestivas de que parte do material carbonoso e da calcita sejam de origem sedimentar. Muitas vezes a recristalização da rocha oblitera ainda mais estas texturas, que são reconhecíveis apenas pelos contornos deixados pelo material carbonoso. 
TABELA 10 - Relações de blastese determinadas para a Fácies Terrígena, com as alterações e inclusões minerais constatadas ópticamente. A numeração das várias fases minerais se refere ao evento e não ao número de fases encontradas.

\begin{tabular}{|c|c|c|c|c|c|}
\hline \multicolumn{6}{|c|}{ FACIES TERRIGENA } \\
\hline \multirow{3}{*}{$\begin{array}{c}\text { Fase Mineral } \\
\text { Material } \\
\text { Carbonoso }\end{array}$} & \multicolumn{3}{|c|}{ ARQUEANO } & $\begin{array}{l}\text { PALEOPROTERO- } \\
\text { ZOOICO }\end{array}$ & $\begin{array}{l}\text { NEOPROTERO- } \\
\text { ZÓICO }\end{array}$ \\
\hline & \multirow{2}{*}{$\begin{array}{c}S_{0} \\
\downarrow \downarrow \downarrow \\
\end{array}$} & \multirow[t]{2}{*}{$D 1\left(s_{1}\right)$} & \multirow[t]{2}{*}{$D 2$} & $D 3\left(S_{m 3} / L_{m / e 3}\right)$ & $D 4\left(S_{4}\right)$ \\
\hline & & & & & .' \\
\hline \multicolumn{6}{|l|}{ Zircão } \\
\hline \multirow{2}{*}{\multicolumn{6}{|c|}{$\begin{array}{l}\text { Óxido de ferro } \\
\text { Quartzo }\end{array}$}} \\
\hline & & 4 & $<$ & & $\longrightarrow$ \\
\hline \multicolumn{6}{|l|}{ Muscovita } \\
\hline \multicolumn{6}{|l|}{ Oligoclásio } \\
\hline \multicolumn{6}{|l|}{$\begin{array}{l}\text { Albita } \\
\text { Clorita }\end{array}$} \\
\hline \multicolumn{6}{|l|}{$\begin{array}{l}\text { Clorita } \\
\text { Biotita }\end{array}$} \\
\hline \multicolumn{6}{|l|}{ Epídoto } \\
\hline \multicolumn{6}{|l|}{ Calcita } \\
\hline \multicolumn{6}{|l|}{ Dolomita } \\
\hline \multicolumn{6}{|l|}{ IImenita } \\
\hline \multicolumn{6}{|l|}{ Rutilo } \\
\hline \multirow{2}{*}{\multicolumn{6}{|c|}{$\begin{array}{l}\text { Turmalina } \\
\text { Titanita }\end{array}$}} \\
\hline \multicolumn{4}{|l|}{$\begin{array}{l}\text { Titanita } \\
\text { Granada }\end{array}$} & & \\
\hline \multirow{2}{*}{\multicolumn{6}{|c|}{ Fe-tschermakita }} \\
\hline & & & \multicolumn{3}{|c|}{ Cloritóide } \\
\hline \multicolumn{6}{|l|}{ Arsenopirita } \\
\hline \multicolumn{6}{|l|}{ Pirrotita } \\
\hline \multicolumn{6}{|l|}{ Calcopirita } \\
\hline \multicolumn{6}{|l|}{ Ouro } \\
\hline \multirow{2}{*}{\multicolumn{6}{|c|}{ Flúorapatita }} \\
\hline & & & & & \\
\hline \multirow{2}{*}{ BRECHAMENTO } & & & EDE & & \\
\hline & $\begin{array}{l}\text { Deposi- } \\
\text { ção sub- } \\
\text { aquática, } \\
\text { provável- } \\
\text { mente } \\
\text { próxima a } \\
\text { margens } \\
\text { continen- } \\
\text { tais } \\
\text { ativas. }\end{array}$ & $\begin{array}{l}\text { Aproximada- } \\
\text { mente para- } \\
\text { lela a } \mathrm{S}_{0} \text {. }\end{array}$ & & $\begin{array}{l}\text { Fácies epídoto-anfibolito, } \\
\text { principais alteraçōes e } \\
\text { geração de porfiroblastos } \\
\text { (GRT, AMP, CLD, ASP). } \\
\text { Precipitação de Au durante } \\
\text { a sulfetização. }\end{array}$ & $\begin{array}{l}\text { Falhas tardias } \\
\text { reativam fa- } \\
\text { Ihas anteriores } \\
\text { Milonitização } \\
\text { das diversas } \\
\text { associações } \\
\text { de alterações } \\
\text { minerais. }\end{array}$ \\
\hline Convenção: & $\begin{array}{cc}--- & \text { Mine } \\
& \text { Mine }\end{array}$ & $\begin{array}{l}\text { al da direita altera } \\
\text { al da direita inclusc }\end{array}$ & $\begin{array}{l}\text { ra miner } \\
\text { o minera }\end{array}$ & $\begin{array}{l}\text { uerda. } \\
\text { erda. }\end{array}$ & \\
\hline
\end{tabular}

Nos dolomitos, são comuns porções brechadas, interpretadas por Theodoro (1995) como provavelmente originadas por sobrecarga, colapso ou solapamento durante a diagênese. Esse processo, provavelmente de maneira semelhante à amostra da PRANCHA 5 E, parece ser raro na Formação Ribeirão das Antas. Foram reconhecidos de maneira mais geral, 
brechamentos generalizados, tanto nas rochas carbonáticas como nos xistos, provavelmente em função da colocação dos Complexos Anta e Caiamar e do desenvolvimento dos diversos sistemas de falhas.

De acordo com estas estruturas e texturas, os dolomitos foram subdivididos em dolomito clástico e dolomito brechado, ambos com conteúdos variáveis em material carbonoso.

O dolomito clástico apresenta dolomita levemente ferrosa (30 a 40\%), clorita (10 a $30 \%$ ), feldspato (15\%), quartzo (10\%), biotita (10 a $40 \%$ ), turmalina (5 a $15 \%$ ) além de acessórios como rutilo, epídoto e sulfetos. Devido a granulação fina, o feldspato não pode ser identificado opticamente, mas parece constituir plagioclásio. A dolomita apresenta cor azul clara na coloração seletiva, distinguindo-se da dolomita hidrotermal, que apresenta cor azul forte.

$\mathrm{O}$ dolomito brechado apresenta carbonatos $(65 \%)$, quartzo (10\%), clorita $(10 \%)$, biotita $(10 \%)$ e turmalina, muscovita, rutilo, plágioclásio, material carbonoso e epídoto como acessórios, sendo que os últimos em conjunto chegam a perfazer mais de $5 \%$ do volume da rocha. A dolomita levemente ferrosa nestas rochas é substituída por dolomita ferrosa, sugerindo que estas brechas, pelo menos em parte não são diagenéticas, e sim hidrotermais. A dolomita ferrosa foi reconhecida como parte das alterações hidrotermais desenvolvidas durante o evento D3. Ocorre ainda carbonato fino na interface entre os fragmentos e a matriz, geralmente orientadas pelo cisalhamento, identificado como calcita levemente ferrosa.

\section{FÁCIES DE ALTERACÃO HIDROTERMAL}

Com base nos estudos petrográficos, foram caracterizadas diversas fácies de alteração hidrotermal, que puderam ser enquadrados nos diversos eventos que deram origem aos Corpos mineralizados IV e V e adjacências. Sistemas minerais relacionados ao metamorfismo estão geralmente relacionados a eventos metamórficos progressivos, comuns em depósitos de ouro encaixados em turbiditos e de lodo arqueano (Pirajno, 1992).

Entre as diversas fácies de alteração destaca-se a ocorrida no evento D3, paleoproterozóico, relacionado com a foliação milonítica $\mathrm{S}_{\mathrm{m} 3}$. A esta última é também atribuída a mineralização dos Corpos IV e V. 
As alterações são relacionadas a seguir, separadas por evento, as fases minerais características podem ser vistas nas TABELAS 10 e 11 . Por último é apresentado um diagrama com os halos de alteração hidrotermal reconhecidos no Corpo IV.

\section{$\underline{3.1 \text { Evento D1 }}$}

As alterações relacionadas ao primeiro evento são raras em virtude de terem sido sobrepostas a pelo menos dois eventos miloníticos e alterações hidrotermais posteriores, reduzindo as chances da preservação.

Foram reconhecidos uma sericitização (MS1) provavelmente associada a uma epidotização (EP1) na Formação Ribeirão das Antas e a anfibolitização, provavelmente dos piroxênios originais, dos metabasaltos na Formação Rio Vermelho.

Não foi reconhecido qualquer relação destas alterações com a mineralização dos Corpos IV e V.

\subsection{Evento D2}

Neste evento há um aumento do número de alterações, provavelmente devido ao aumento da permeabilidade das rochas devido ao brechamento (PRANCHA $6 \mathrm{~A}, \mathrm{~B}, \mathrm{C}$ e D) e pelo soerguimento polifásico dos complexos granito-gnáissicos. Estes complexos trouxeram provavelmente consigo elevações de temperatura e fluidos, com destaque para os mais potássicos.

As alterações definidas foram: potassificação (BT2), cloritização (CHL2), dolomitização (DOL2) e com menor intensidade e mais localizados, turmalinização associada com a formação de rutilo, este último parcialmente como resultado da alteração da ilmenita (PRANCHA 6 B e D).

Esses eventos de alteração também não são reconhecidos como diretamente relacionados à mineralização do Corpo IV e V, a não ser pelo relacionamento estrutural do brechamento, considerado uma das características presentes nos corpos de minério. 

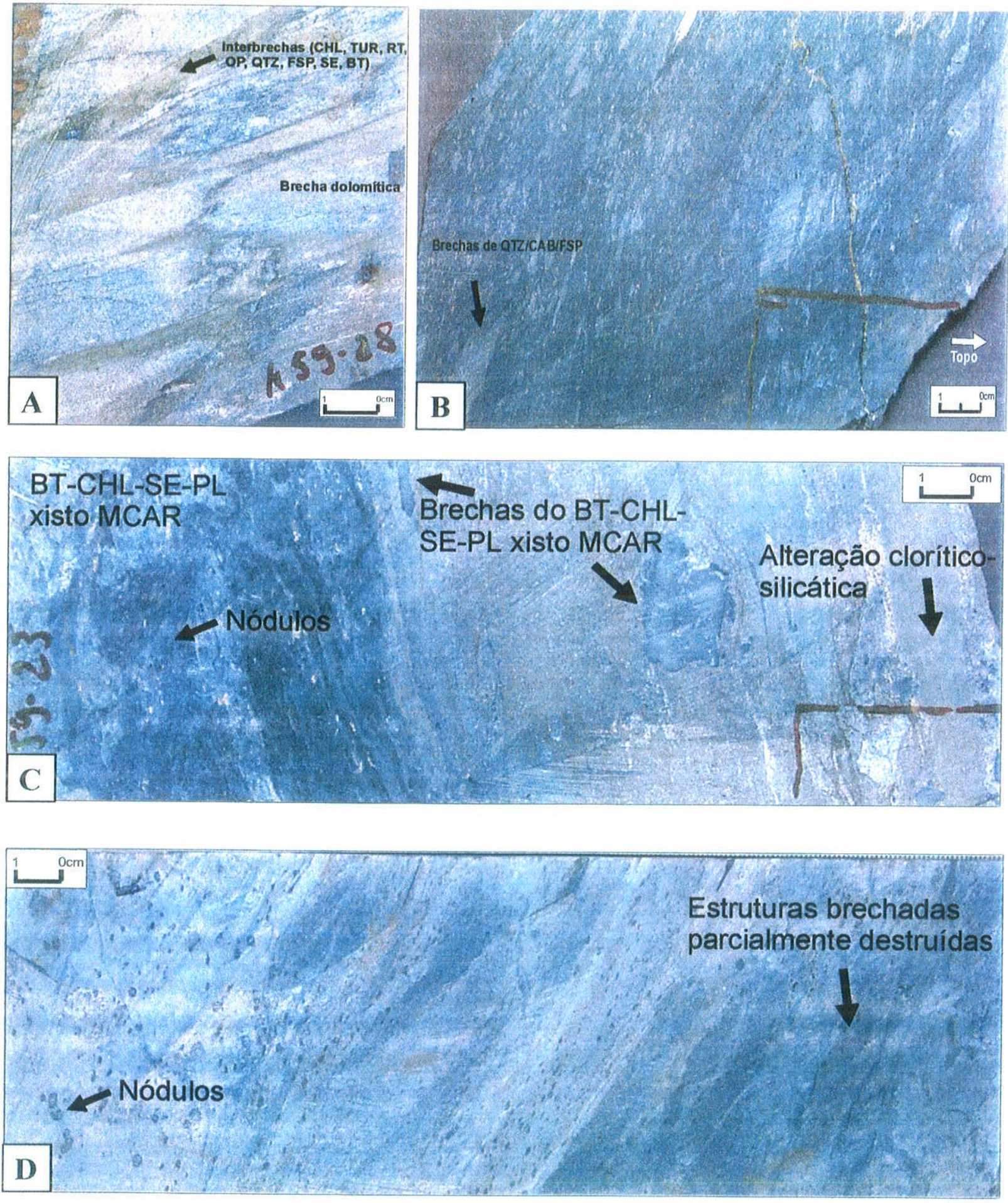

PRANCHA 6 - (A) Dolomito brechado (DOLb) no início de estiramento com associação mineral relacionado às alterações do Evento D2 (Amostra K59-09664).(B) Brechas de QTZ-FSP-CAB xisto carbonoso sendo estiradas em uma matriz clorítico-quartzosa com traços de FSP, TUR, MCAR, EP nas proximidades da zona de cisalhamento (Amostra K59-46249). (C) Brechamento do BT-CHL-SEPL xisto MCAR (Amostra K59-24100). (D) Albitização do BT-CHL-SE-PL xisto carbonoso à esquerda e seu equivalente não alterado à direita, que apresenta como acessórios ainda PO, TUR, RT. Os nódulos carbonosos são preservados durante a albitização e se apresentam bastante estirados no contato evidenciando proximidade da zona de cisalhamento (Amostra K59-19420). 


\subsection{Evento $D 3$}

Este evento sem dúvida engloba o conjunto de alterações hidrotermais mais importante no que tange a mineralização do Corpo IV e V, e possivelmente das outras mineralizações da Mina III.

Pôde-se caracterizar também uma assembléia de minerais de alteração que sugere a atuação de uma intensa alteração propilítica (Pirajno, 1992), nas zonas das mineralizações (ver TABELA 10 e 11). As alterações associadas são:

- albitização: fase importante na alteração propilítica que resulta provavelmente da concentração de sódio liberado de plagiclásios (provavelmente OLG1), tendo sido ópticamente constatada ainda albitização da muscovita (MS1), o que deve contribuir ainda mais com relação ao conteúdo de Na. A albitização como um tipo separado de alteração exigiria uma introdução metassomática de sódio no processo, o que não foi confirmado neste evento. O plagiclásio resultante da alteração atinge composições da albita pura próximo ao minério e de oligoclásio em porções mais afastadas (PRANCHA $6 \mathrm{D}$ - ver ainda Capítulo 4, Química Mineral).

- cloritização: a clorita de alteração (CHL3) também assume um papel de destaque neste evento (PRANCHA $7 \mathrm{~A}, \mathrm{~B}$ e C, PRANCHA $8 \mathrm{~B}$ e C) e as análises de química mineral demonstraram tratar-se basicamente de picnoclorita com raras exceções no campo da ripidolita e pseudoturingita. A variação química pode refletir diferentes distâncias zonais de corpos de minério sulfetado, fato que não pôde ser comprovado neste estudo. A clorita como uma das fases dominantes revela uma larga adição de magnésio e/ou ferro ao sistema, o que pode ser comprovado pelas outras assembléias minerais ricas nesses elementos (p. ex. dolomita ferrosa, almandina e ferro-tschermakita). Entre as associações comumente encontradas com a cloritização, foram determinadas pirrotita, arsenopirita (ASP3), calcopirita, esfalerita e pirita (PRANCHA 6 D), sendo que cabe destaque para os porfiroblastos metamórficos granada almandínica, ferro-tschermakita, cloritóide e mais raramente, biotita e albita. Os porfiroblastos são detalhados abaixo, após a descrição das alterações. 

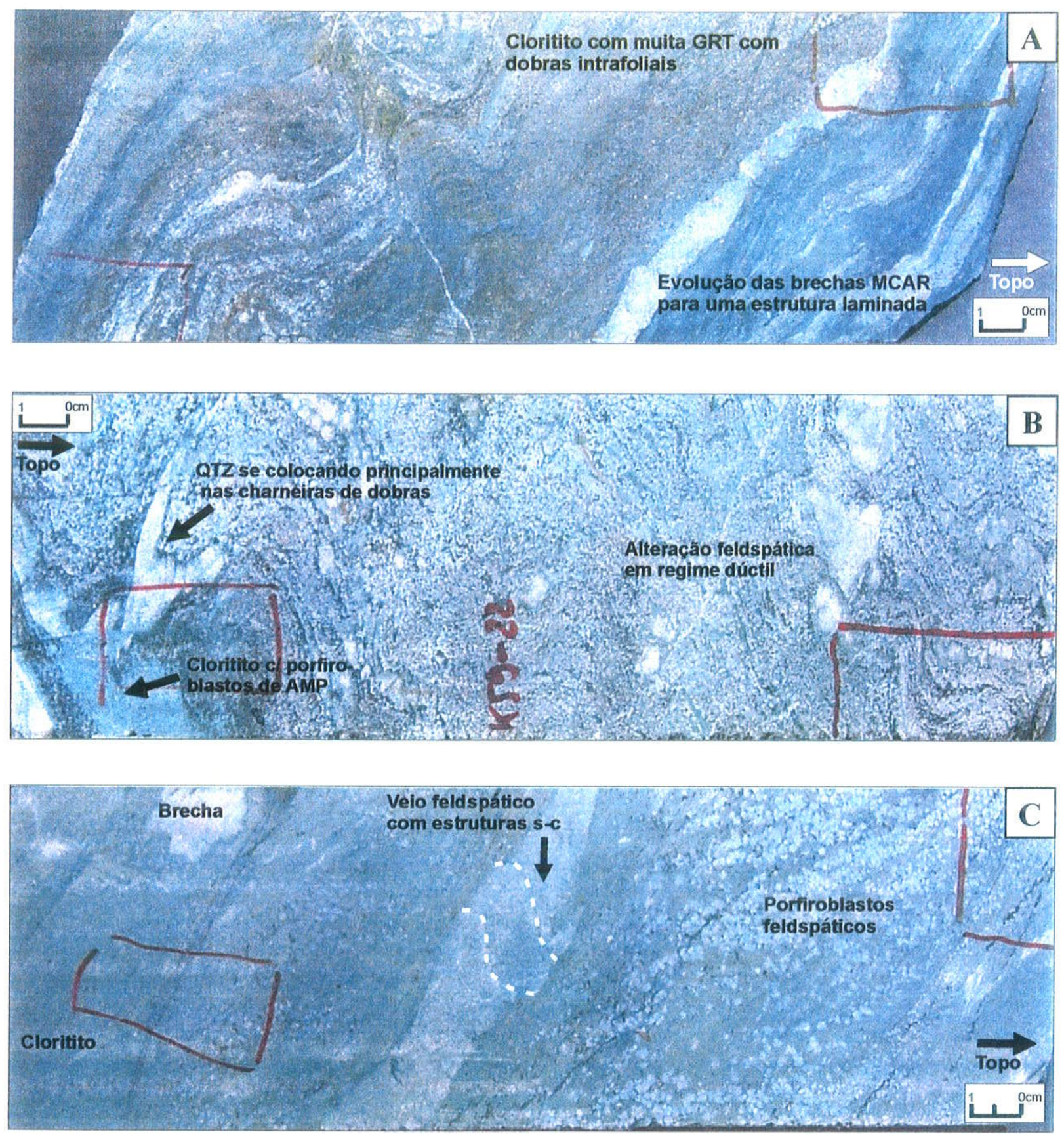

PRANCHA 7 - (A) Zona de desenvolvimento de dobras intrafoliais relacionadas ao evento D3 No topo da amostra ocorre o xisto carbonoso na forma laminada, resultado da evolução da milonitização $\left(\mathrm{S}_{\mathrm{m} 3}\right)$ sobre o xisto carbonoso com brechas. Formam-se então dobras intrafoliais certamente devido a resposta ao esforço em função da competência diferenciada. Tais dobras permitem uma entrada maior de associações de alteração como o cloritito com granada, fina e disseminada neste caso. O veio de quartzo no contato das litologias apresenta pirrotita. Ocorrem ainda veios carbonáticos e biotita. (B) Albitização, cloritização e epidotização provavelmente de um protólito xistoso em virtude das dobras $\mathrm{S}_{\mathrm{m} 3}$ preservadas. A matriz é basicamente albita com QTZ como traço e até 5\% de epídoto. No canto inferior esquerdo pode ser visto a sobreposição da alteração clorítica com a presença de porfiroblastos euédricos de AMP (Amostra K59-28273). (C) Cloritito contendo veios e porfiroblastos feldspáticos deformados pela milonitização tardia, provavelmente neoproterozóica. 
- carbonatização: as assembléias de carbonatos de alteração exigem principalmente magnésio, ferro, cálcio e manganês, sendo que a dolomitização de calcário envolve normalmente extenso metassomatismo magnesiano. A carbonatização de rochas silicáticas envolve predominantemente metassomatismo aniônico com a introdução de $\mathrm{CO}_{3}{ }^{2-}$, como por exemplo a substituição carbonática multifásica de silicatos em assembléias ricas em clorita ou sericita associadas a veios de quartzo com ouro em terrenos metamórficos. A dolomitização é um dos eventos hidrotermais dominantes nas proximidades dos corpos mineralizados e apresenta variações composicionais entre a dolomita e anquerita, sendo tratada doravante como dolomita ferrosa (PRANCHA 8 A, B e C). Essa variação poderia, assim como nas cloritas, revelar auréolas com relação à proximidade do corpo de minério, confirmada no Corpo IV na forma de um largo halo de carbonato de ferro ao redor da mineralização. Outra feição que determina dolomitos como resultado da alteração carbonática, quando não ocorrem relíquias preservados do protólito (PRANCHA $8 \mathrm{~A}$ ), são aqueles dolomitos cinza nos quais se encontram acessórios como feldspato, material carbonoso, turmalina e rutilo, associação característica da fácies terrígena com minerais de alteração. A PRANCHA $8 \mathrm{C}$ ilustra uma porção dolomítica com tais caracterísicas, onde ainda pode ser visto um veio de alteração tardio com quartzo, clorita, carbonato e biotita. Os dolomitos hidrotermais sofrem pelo menos dois tipos de alteração: uma predominantemente albítica e outra, aparentemente posterior a última, com cloritização e silicificação.

- epidotização: geração EP3 relacionado ao final do evento D3 onde os cristais de epídoto apresentam algumas vezes sombras de pressão de pirrotita (PRANCHA 7 B). Ocorre ainda um freqüente zonamento no epídoto, que deve representar o desenvolvimento do EP3 sobre núcleos de EP1, caracterizado por zonamento: a) interno, com muitas inclusões de opacos, biotita, muscovita, feldspato, e b) externo com cristalização quase isenta de inclusões, apenas poucos opacos. 

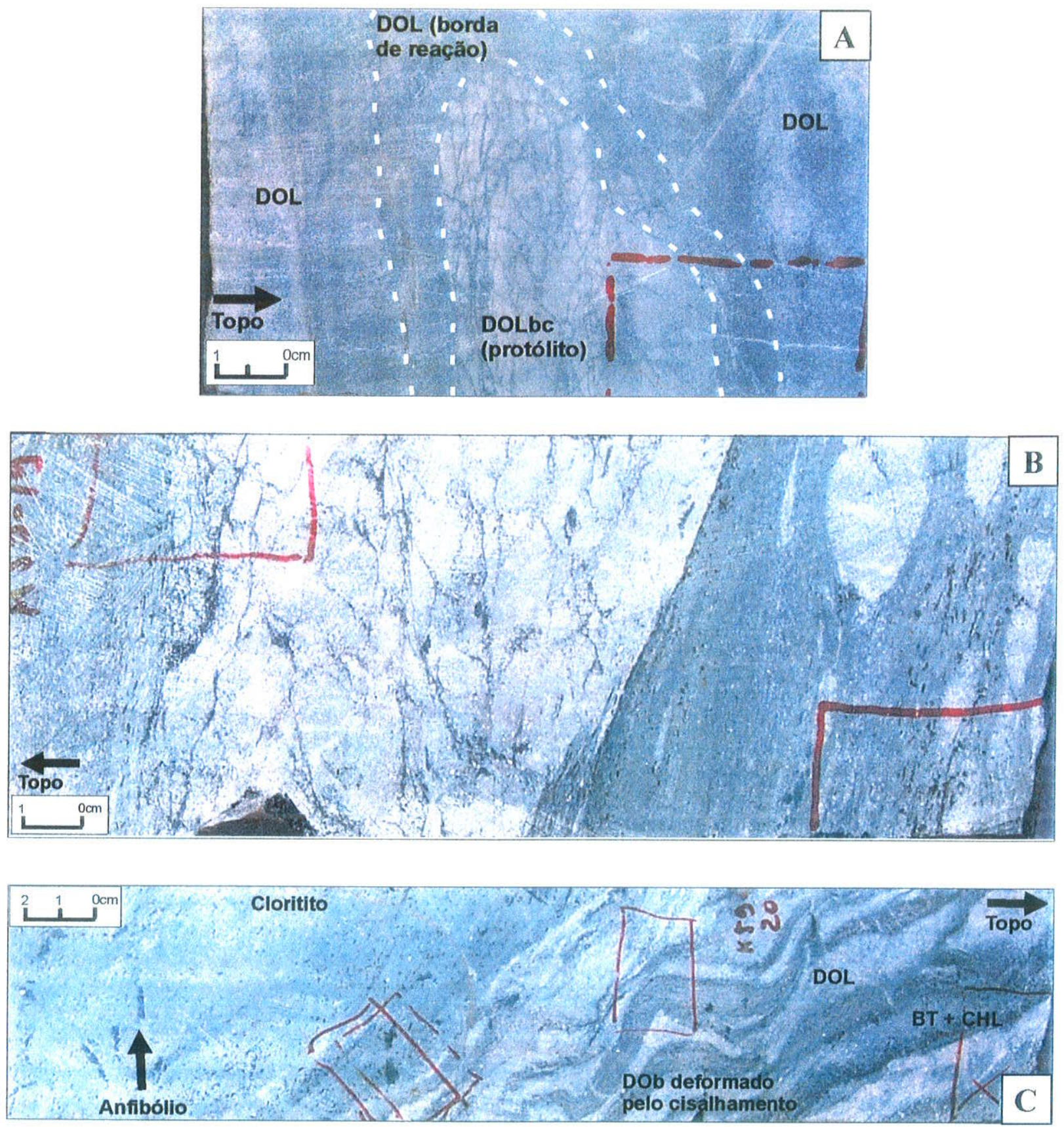

PRANCHA 8 - (A) Em meio a dolomita cinza hidrotermal, sem sinais de brechamento, encontra-se uma relíquia do ritmito brechado (ver PRANCHA $5 \mathrm{E}$ ), interpretado como protólito sedimentar, envolto pela alteração dolomítica. Notadamente ocorre uma borda de reação ao redor da relíquia, indicando alteração predominantemente química, relacionada ao Evento D3 (Amostra K59-44950). (B) Brechas de dolomito estirada em meio ao cloritito, com filmes de biotita nas bordas (Amostra K59-32710). (C) Contato do dolomito hidrotermal com relíquias do clorita xisto (CHL2) contendo epídoto, turmalina, biotita e plagioclásio, preservando ainda deformações relacionadas ao Evento D3. $\mathrm{O}$ cloritito à esquerda é mais tardio, porém ainda como parte do final do evento D3, que além de porfiroblastos de biotita porta ainda Fe-tschermakita subédrica (Amostra K59-30079). 


\subsection{Evento D4}

O evento revela alterações hidrotermais limitadas a veios quartzo-carbonáticos e uma cloritização tardia (CHL4) que, nos limites dos Corpos IV e V não apresentaram conexões com a mineralização de ouro.

Os carbonatos desse evento de alteração revelaram composições de calcita a siderita, esta última característica desse evento, ocorrendo basicamente como mineral de veio e comumente na forma de cristais euédricos. A análise com auxílio da cátodo-luminiscência indica alteração para siderita, conforme pode ser visto na PRANCHA 9, de A a F.

A TABELA 11 relaciona os eventos de alteração determinados para cada evento do Greenstone Belt de Crixás.

TABELA 11 - Relações de blastese determinadas para as assembléias de alteração hidrotermal. A numeração das várias fases minerais se refere ao evento e não ao número de fases encontradas.

\begin{tabular}{|c|c|c|c|c|c|}
\hline \multicolumn{6}{|c|}{ FACIES DE ALTERACGAO HIDROTERMAL } \\
\hline & \multicolumn{3}{|c|}{ ARQUEANO } & $\begin{array}{c}\text { PALEOPROTERO- } \\
\text { ZÓICO }\end{array}$ & $\begin{array}{l}\text { NEOPROTERO- } \\
\text { ZÓICO }\end{array}$ \\
\hline Fase Mineral & $S_{0}$ & $D 1\left(S_{1}\right)$ & D2 & $D 3\left(S_{m 3} / L_{m / e}\right)$ & $D 4\left(S_{4}\right)$ \\
\hline \multicolumn{6}{|l|}{ Quartzo } \\
\hline Muscovita & MS1 & & & MS3 & \\
\hline \multicolumn{6}{|l|}{ Oligoclásio } \\
\hline \multicolumn{6}{|l|}{ Albita } \\
\hline \multicolumn{6}{|l|}{ Clorita } \\
\hline \multicolumn{6}{|l|}{ Biotita } \\
\hline \multicolumn{6}{|l|}{ Epídoto } \\
\hline \multicolumn{6}{|l|}{ Calcita } \\
\hline Dolomita & & & & DOL3 & \\
\hline \multicolumn{6}{|l|}{ IImenita } \\
\hline \multicolumn{6}{|l|}{ Rutilo } \\
\hline \multicolumn{6}{|l|}{ Turmalina } \\
\hline \multicolumn{6}{|l|}{ Titanita } \\
\hline \multicolumn{6}{|l|}{ Granada } \\
\hline \multicolumn{6}{|l|}{ Fe-tschermakita } \\
\hline \multicolumn{6}{|l|}{ Cloritóide } \\
\hline \multicolumn{6}{|l|}{ Arsenopirita } \\
\hline \multicolumn{6}{|l|}{ Pirrotita } \\
\hline \multicolumn{6}{|l|}{ Calcopirita } \\
\hline \multicolumn{6}{|l|}{ Ouro } \\
\hline Siderita & & & $\begin{array}{l}\text { Cloritização, } \\
\text { potassificação, } \\
\text { dolomitização, } \\
\text { turmalinização } \\
\text { e alteração da } \\
\text { ilmenita para } \\
\text { rutilo. }\end{array}$ & Alteração & $\begin{array}{l}\text { Carbonatiza- } \\
\text { ção associada } \\
\text { com silicifi- } \\
\text { cação e } \\
\text { cloritização. }\end{array}$ \\
\hline
\end{tabular}




\subsection{Halos de alteração no Corno IV}

A construção do modelo dos halos de alteração relacionados ao Corpo IV, mostrou-se bastante dificil devido às deformações presentes neste evento (D3) e a sobreposição do evento neoproterozóico.

A ocorrência de zonas com porfiroblastos metamórficos relacionados a cloritização do final do evento D3 são uma marca comum em todas as mineralizações da Mina III (Corpo superior, intermediário e inferior e do Corpo IV e V), com granada almandínica, Fetschermakita e cloritóide (ver capítulo de .química mineral).

O Corpo IV e $\mathrm{V}$, assim como todas as zonas mineralizadas da Mina III apresentam núcleos de de alteração com clorititos e porfiroblastos de granada \pm Fe-tschermakita \pm cloritóide, sendo que cloritóide não foi constatado no Corpo IV. Esta zona deve representar o núcleo da alteração propilítica que se manifestou no final do Evento D3 porque a mesma ocorre tanto acima como abaixo das zonas mineralizadas em geral, invariavelmente preservadas do Evento D4.

A granda almandínica ocorre na forma de duas variedades: uma mais abundante que não foi constatada em associação com ouro ou sulfetos e outra, relativamente mais magnesiana, que ocorre em íntima associação com ouro e sulfetos, como no caso do Corpo IV e Zona Inferior da Mina III (ver capítulo IV sobre química mineral). Os porfiroblastos de granada se apresentam euédricos a subédricos freqüentemente com inclusões de ilmenita que marcam a $\mathrm{S}_{1}$ dobrada durande o evento D3 (PRANCHA 10, B e F). Esses planos de inclusões podem, em certos casos, sugerir erradamente o rotacionamento do cristal de granada durante o seu crescimento. Da mesma maneira os porfiroblastos de cloritóide pré a singenéticos da granada apresentam as mesmas feições quanto a planos de inclusões (PRANCHA $10 \mathrm{~A}$ ). Outra informação importante fornecida pelas gerações de porfiroblastos é quando os mesmos foram afetados pelo cisalhamento do evento neoproterozóico, verificado na forma do estiramento e destruição desses porfiroblastos (PRANCHA 10, C, D e E).

Foi confirmado petrográficamente as características singenéticas da albita na forma de seu membro final, dolomita ferrosa e arsenopirita, relacionados a zona de minério.

Ocorrendo a presença de nódulos carbonosos, estes indicam proximidade da zona de cisalhamento Neoproterozóico quando achatado/estirados, marcando as estruturas que cortam e delimitam zonas de minério, enquanto seu equivalente arredondado indica preservação do evento tardio e, eventual existência de zonas propicias para existência de minério. 
A FIGURA 7 apresenta uma diagramação do modelo de halos de alteração hidrotermal relacionado ao Corpo IV com suas associações minerais.

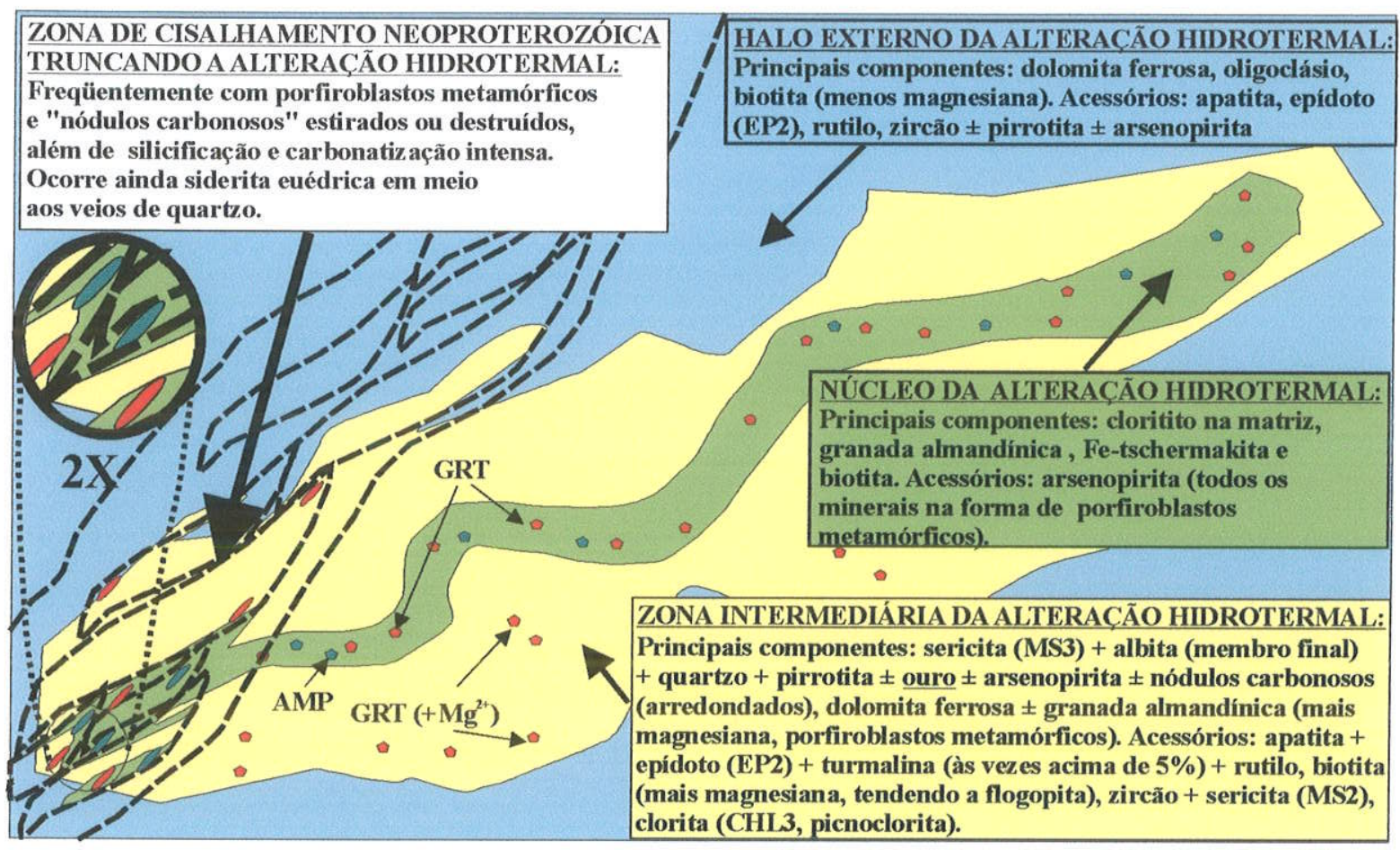

FIGURA 7 - Modelo com as zonas de alteração hidrotermal determinadas no Corpo IV. Ocorrem variações neste modelo em função da intensidade da alteração hidrotermal, do tipo de rocha encaixante e da proximidade com zonas de cisalhamento neoproterozóicas, esta última representada na parte esquerda da figura. 

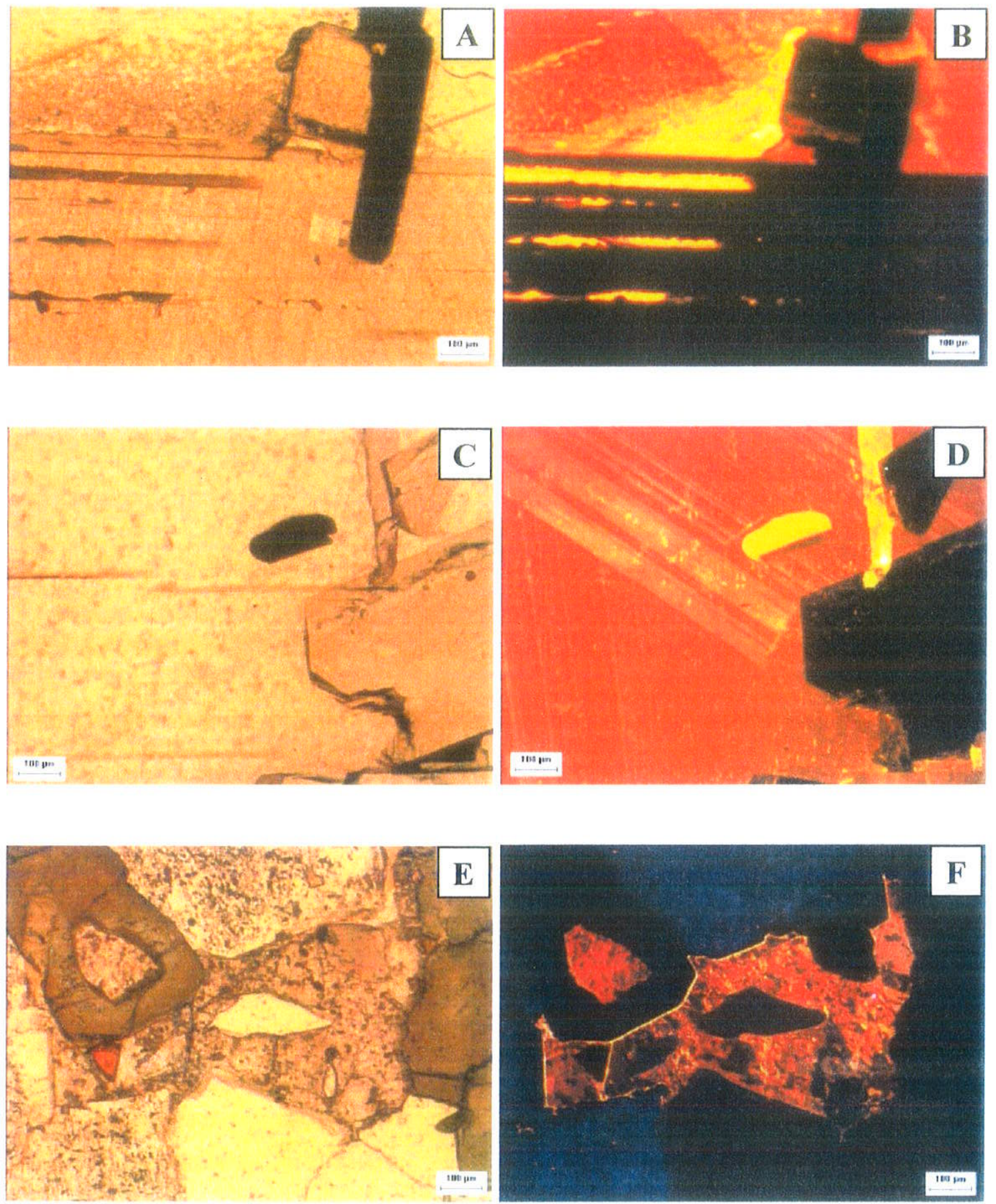

PRANCHA 9 - (A) Cristal de muscovita de veio que sofreu carbonatização suave nas interfaces da geminação, que pode ser reconhecido na parte inferior da fotografia (Amostra K59-38571-22).(B) mesma área com alteração carbonática realçada na imagem gerada pela cátodo-luminiscência (Amostra K59-38571-22). (C) O mineral que cobre toda a metade esquerda da fotografia é siderita (SID4) do veio de alteração (Amostra K59-38571-22). (D) A mesma área revela na imagem gerada pela cátodo-luminiscência (Amostra K59-38571-22). (E) Turmalina, provavelmente TUR3 zonada hidrotermal do início do evento D3 em contato com siderita (Amostra K49-19790). (F) A imagem gerada com auxílio da cátodo-luminiscência revela um núcleo carbonático na turmalina, mas que em função do veio carbonático externo sugere uma alteração posterior, provavelmente SID4, do neoproterozóico (Amostra K49-19790). 

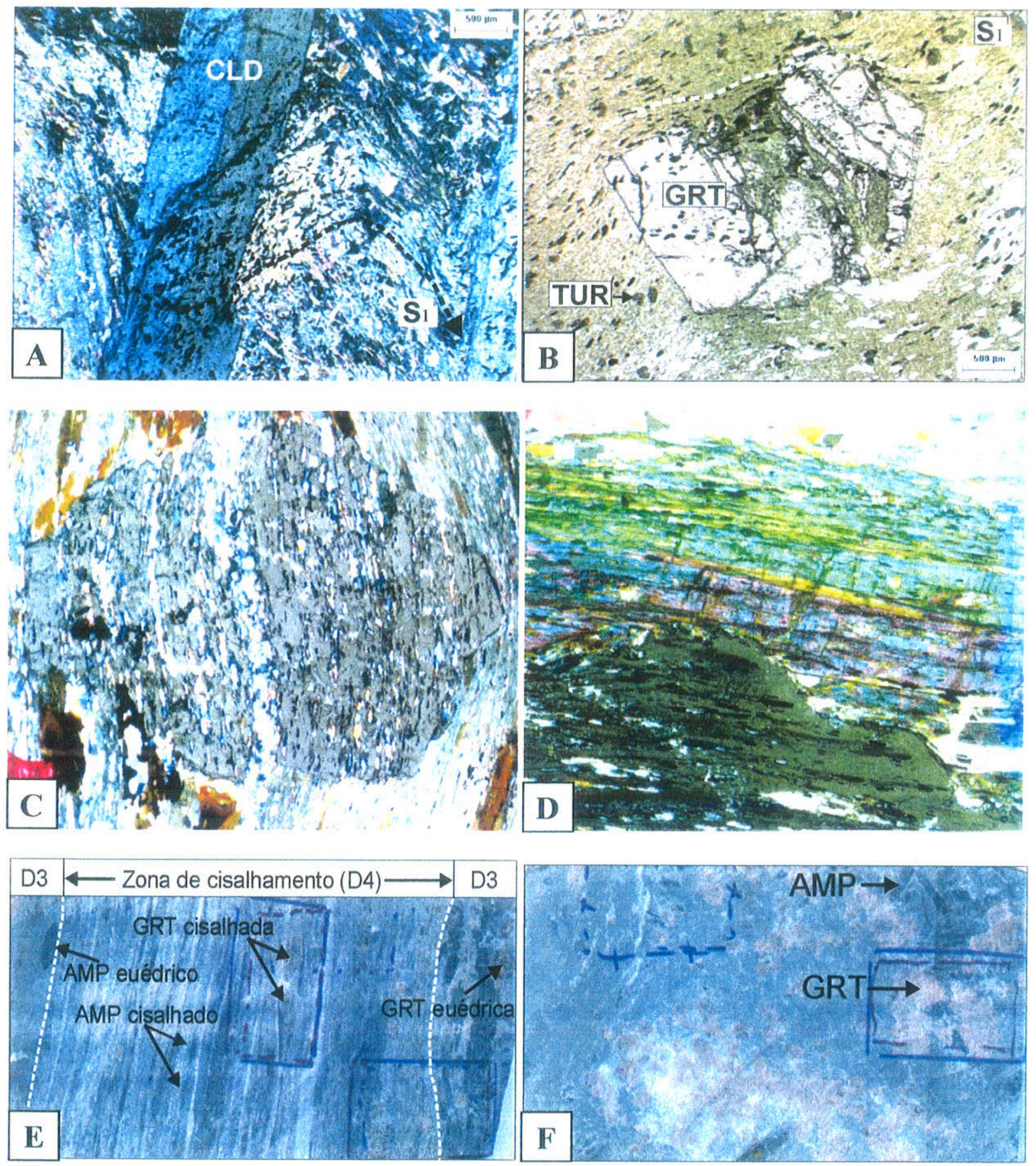

PRANCHA 10 - (A) Porfiroblasto de cloritóide com inclusões de ilmenita alinhadas segundo o plano $\mathrm{S}_{1}$, que por sua vez está dobrado pelo evento D3 (amostra K-59-3414). (B) Porfiroblasto de granada subédrica com inclusões de ilmenita alinhadas segundo o plano $\mathrm{S}_{1}$ igualmente dobrado pelo evento D3 (amostra K-59-36508). (C) Porfiroblasto de granada subédrica parcialmente destruída em virtude da proximidade da zona de cisalhamento neoproterozóica (diâmetro do cristal de granada: 3mm, amostra K49 39614). (D) Porfiroblastos estirados de granada, na parte inferior da imagem, e Fe-tschermakita na parte superior (área da imagem com ca. de 5 × 3 mm, amostra K49-39664). (E) Porfiroblastos de granada e Fe-tschermakita estirados pelo evento D4 entre as linhas brancas tracejadas, ocorrendo ainda porfiroblastos euédricos dos mesmos fora dessa faixa, nas bordas esquerda e direita da imagem (comprimento da amostra: $12 \mathrm{~cm}$, amostra K59-34000). (F) Porfiroblastos de granada e Fe-tschermakita euédricos na matriz de cloritito, em zonas preservadas do cisalhamento neoproterozóico (comprimento da amostra: 10 cm, amostra K59-34000). 


\section{PETROGRAFIA DOS MINERAIS OPACOS (SULFETOS E OURO)}

Os minerais opacos relacionados ou não a mineralização de ouro são detalhados petrograficamente, ainda conforme a TABELA 10, apresentada anteriormente. Por problemas de amostragem não foi possível determinar associações com ouro no Corpo V. A sua proximidade e semelhança com o Corpo IV, entretanto, permitem inferir associações correlacionáveis para ambos os corpos de minério.

\subsection{Sulfetos}

Os Corpos IV e V apresentam basicamente uma mesma associação de sulfetos que são: esfalerita, arsenopirita, pirrotita e calcopirita, sendo que no Corpo IV prevalece a pirrotita e no Corpo $\mathrm{V}$ há uma quantidade relativamente maior de arsenopirita, geralmente na forma de porfiroblastos euhédricos.

A esfalerita que ocorre disseminada nas encaixantes dos xistos carbonosos é normalmente anédrica, e de granulação fina (abaixo de $1 \mathrm{~mm}$ ). A mesma nunca foi encontrada nos veios de quartzo, indicando uma cristalização anterior aos veios.

A arsenopirita se apresenta normalmente euhédrica na primeira geração (ASP2) e irregular na segunda (ASP3), sendo normalmente restrita a fraturas (PRANCHA 11 A) e a lineação mineral e de estiramento $L_{m / e 3}$ (PRANCHA 11 E). Outra característica da arsenopirita da primeira geração nas lâminas estudadas é fato da mesma se apresentar freqüentemente fraturada, provavelmente pela $S_{m 3}$ (PRANCHA 11 D). A PRANCHA $11 \mathrm{~F}$ apresenta um cristal de arsenopirita euhédrico (ASP2) incluso na pirrotita. A calcopirita aparece freqüentemente preenchendo fraturas ou na borda dos cristais de arsenopirita $\mathrm{e}$

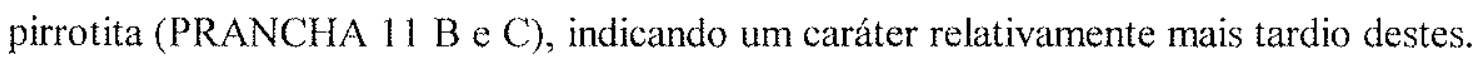

A siderita é característica do evento D4, freqüentemente euhédrica, e apresenta arsenopirita como inclusão, indicando seu caráter tardio em relação arsenopirita, como na amostra 73_08. Tanto os cristais de siderita como a arsenopirita são cortados por fraturas, provavelmente relacionadas aos falhamentos tardios (PRANCHA $12 \mathrm{~A}$ e B). Outro fator que permite o reconhecimento da arsenopirita como sendo anterior ao cisalhamento, são os cristais arredondados pela milonitização relacionado ao evento D4, como pode ser verificado na PRANCHA 12 C. Ainda nessa figura pode-se notar uma fase anterior da pirrotita, próximo da esfalerita, indicando o caráter recorrente de cristalização, particularmente da pirrotita. 

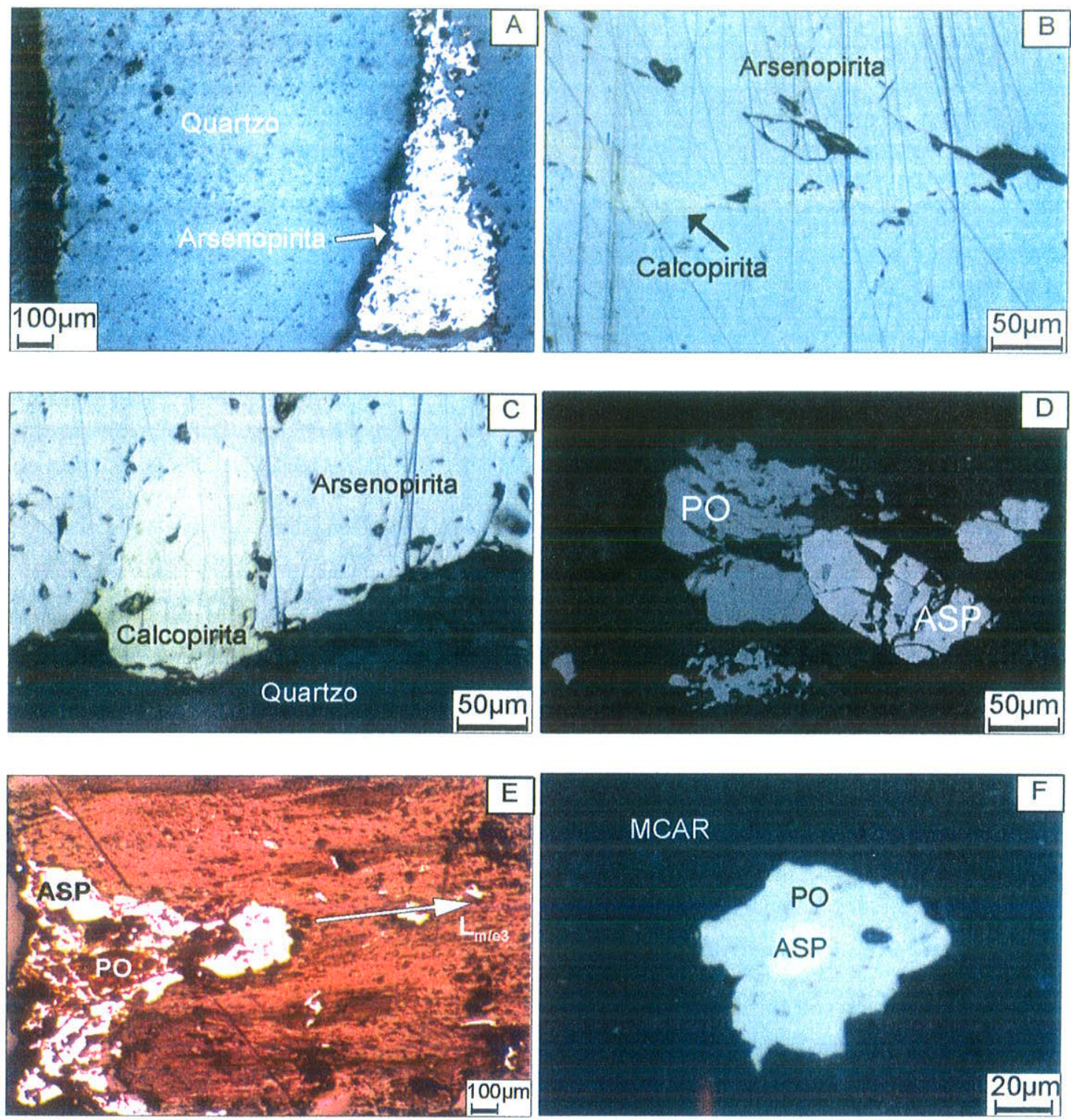

PRANCHA 11 - (A) Arsenopirita no Q-IV1 (amostra 12-01, luz refletida). (B) Arsenopirita com fratura preenchida com calcopirita (Q-IV1, amostra 12-07, luz refletida). (C) Arsenopirita com calcopirita na borda (Q-IV1, amostra 12-07, luz refletida). (D) Arsenopirita subhédrica fraturada em contato com pirrotita mais tardia isenta de fraturas no veio 1 (Q-IV1, amostra 021, luz refletida). (E) Lineação mineral e de estiramento $3\left(\mathrm{~L}_{\mathrm{m} / \mathrm{3}}\right)$ no xisto carbonoso mostra o preenchimento com sulfetos, nesse caso uma borda de arsenopirita com núcleo de pirrotita (Q-IV1, amostra 019, luz refletida). (F) Inclusão euhédrica de arsenopirita na pirrotita (amostra IV-22-17905, luz refletida). Abreviações segundo TABELA 1. 
O sulfeto mais tardio do evento D3, ao qual associa-se a mineralização de ouro no Corpo IV, é a pirrotita, que ocorre principalmente em fraturas e nos veios de quartzo. A pirrotita possui um forte controle estrutural relacionado à $\mathrm{L}_{\mathrm{m} / \mathrm{e} 3}$ (PRANCHA $11 \mathrm{E}$ ). A PRANCHA $11 \mathrm{E}$ mostra a pirrotita fraturada no veio de quartzo recristalizado com inclusões de turmalina (TUR3) e esfalerita reforçando o caráter tardio desse sulfeto, mas sendo précisalhamento principal (Evento D4).

As análises de grãos de sulfeto com auxilio da microscopia eletrônica de varredura aliada ao programa SEMquant, para determinação semiquantitativa da porcentagem atômica de elementos, revelaram uma razão de enxofre e ferro com média de 56,5:43,5, respectivamente (Amostra IV-23-14820), tendo sido detectado até 0,3\% de cobre em um dos pontos analisados.

Em uma das amostras dos veios de quartzo ocorrem bordas de plagioclásio na forma de cristais euhédricos zonados desenvolvidos nas paredes de cavidades (vugs). A PRANCHA $12 \mathrm{~F}$ mostra um corte nessa zona onde os espaços vazios entre os cristais de plagioclásio são preenchidos por uma matriz carbonática com porfiroblastos euhédricos de pirrotita. $\mathrm{O}$ fato da superficie dos cristais de feldspato se apresentarem bastante preservados pode indicar: a) um $\mathrm{pH}$ em condições próximas do neutro do fluido com pirrotita e b) que os fluidos com sulfetos devem ter precipitado a pirrotita devido ao súbito alívio de pressão quando da entrada nos espaços vazios (vugs). Esse processo representa um dos mecanismos tardios da precipitação do ouro pela desestabilização das espécies dominantes no transporte de ouro como AuHS(aq) e $\mathrm{Au}(\mathrm{HS})^{2-}$ (Cooke \& Simmons, 2000), particularmente do último que prevalece em condições de $\mathrm{pH}$ próximo do neutro. A microtermometria de inclusões fluidas reforça essa hipótese (ver Capítulo V adiante). 

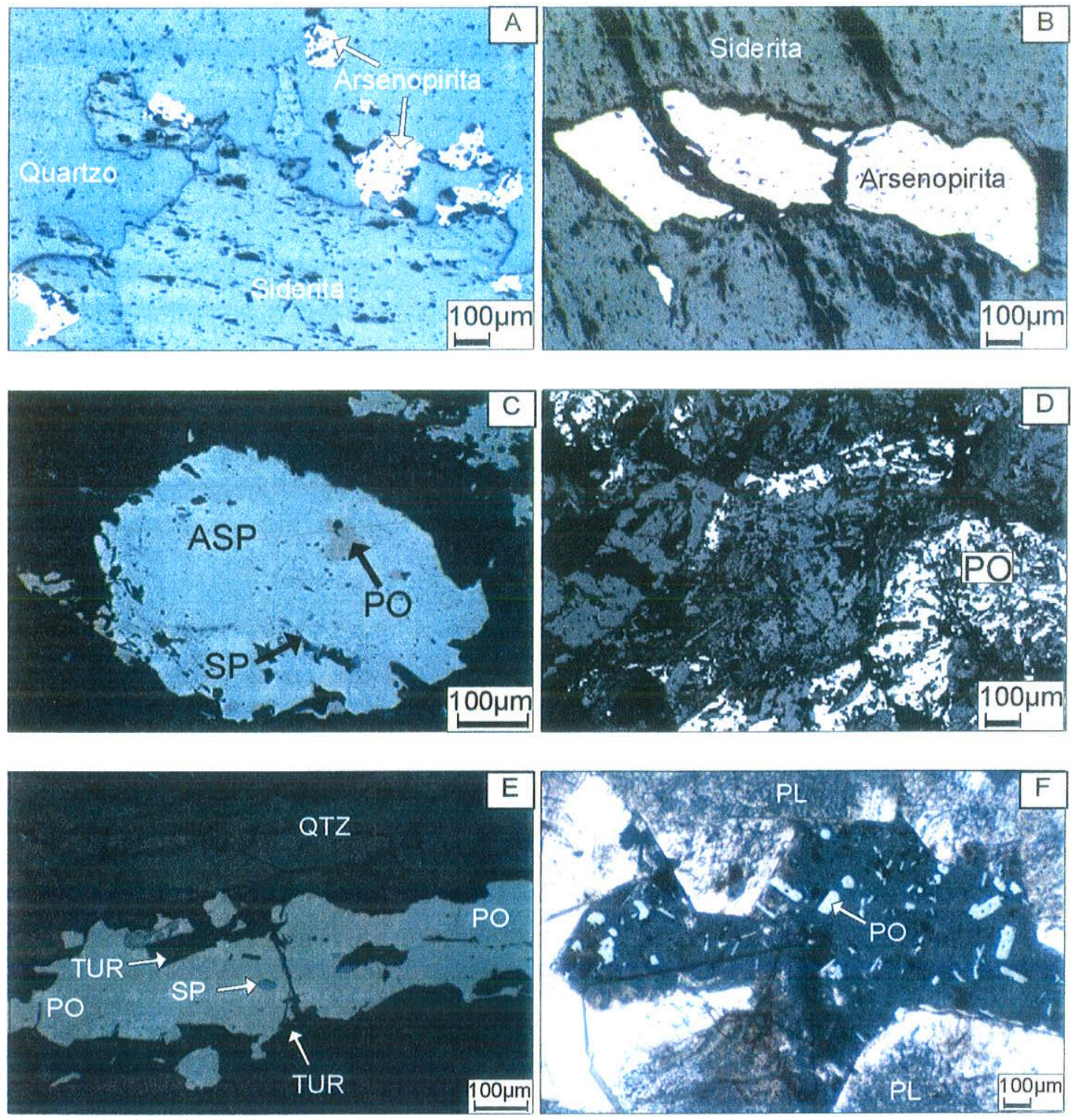

PRANCHA 12 - (A) Arsenopirita na borda de um cristal subhédrico de siderita no Q-IV4 (amostra 73 08, luz refletida). (B) Inclusão de arsenopirita na siderita euhédrica com fraturamento induzido pelos falhamentos tardios (Q-IV4, amostra 73_08, luz refletida). (C) Arsenopirita milonitizada com inclusões de esfalerita e pirrotita (Q-IV4, amostra IV-22-18076, luz refletida). (D) Pirrotita como sombra de pressão do nódulo de material carbonoso (Q-IV1, amostra 21, luz refletida). (E) Pirrotita fraturada com inclusão de esfalerita e turmalina, e quartzo recristalizado (Amostra IV-22-17905, luz refletida). (F) Vug entre cristais de plagioclásio zonado euédricos preenchido com carbonato e cristais euhédricos de pirrotita (Q-IV4, amostra CIV-G026-V4AU, 100\% luz refletida, 100\% luz transmitida). Abreviações segundo TABELA 1. 


\subsection{Ouro no Corpo IV}

O ouro no Corpo IV ocorre com granulação variável desde submicroscópica até pepitas centimétricas, sendo que, em quase todas as amostras estudadas, o mesmo está ligado a veios distensivos de quartzo ou na matriz do xisto carbonos relacionado à $L_{m / e}$. Uma exceção é a precipitação de ouro tardio em fraturas no plagioclásio nas bordas do Q-IV4, com associação predominantemente pirrotita/calcita/apatita, que sugere remobilização de um veio anterior pelo evento D4, devido à presença de associações incomuns relativos ao evento neoproterozóico, como pirrotita e plagioclásio, e a ausência de quartzo (PRANCHA 13 D).

As análises de grãos de ouro por microscopia eletrônica de varredura, revelaram uma associação freqüente de ouro e prata (amostras IV-22-17905 e IV-23-14820) com 7,1 a 9\% (média de 8\% em cinco análises) de prata. Em pontos da amostra IV-22-17905 foram encontrados teores mais altos de cobre nos grãos de ouro com 8,5 a $15 \%$ (média de $6,8 \%$ em três análises), sendo que nesses também ocorre prata com média de $8 \%$.

A razão $\mathrm{Au} / \mathrm{Ag}$ nos grãos de ouro apresenta variação intimamente associada aos minerais hospedeiros ou aos quais o metal está associado. Isso sugere que razões $\mathrm{Au} / \mathrm{Ag}$ iniciais em rochas-fonte e mecanismos de deposição, como reações do fluido com as rochas encaixantes, fluidos de alta salinidade e imiscibilidade de líquidos tenham grande importância nas variações observadas (Coelho, 1999).

Fortes et al. (2000) fizeram uma discussão baseada em análises com auxilio da microssonda em grãos de Au visando obter a relação de gold fineness definida por Fischer (1945) conforme $(\mathrm{Au} / \mathrm{Au}+\mathrm{Ag}) \times 1000$, com $\mathrm{Au}$ e $\mathrm{Ag}$ em porcentagem em peso. Os valores obtidos para análises nas três Minas variam entre 866 e 980 (média de 942) que são compatíveis com valores de mineralizações de Au tipicamente arqueanas que, segundo Morrison et al. (1991), são de 940,780 e 1000, respectivamente para média, mínimo e máximo.

A aplicação do gold fineness para a mineralização do Corpo IV visou encontrar relações com os corpos mineralizados da Mina III, utilizando-se os resultados obtidos por meio de microscopia eletrônica de varredura (amostra IV-22-17905, PRANCHA 13 E), de maneira semelhante aos dados analíticos obtidos por Fortes et al. (2000). Os valores obtidos nessa interpretação para o Corpo IV revelaram valores relativamente mais baixos em relação aos dos demais corpos mineralizados da Mina III (TABELA 12), sendo que o diagrama de relação $\mathrm{Au}$ (porcentagem atômica) versus $\mathrm{Ag}$ (porcentagem atômica) do Corpo IV mostrou 
grande semelhança com o diagrama referente à zona inferior da Mina III conforme a FIGURA 8.

TABELA 12 - Valores médios, mínimos e máximos de gold fineness para as zonas mineralizadas da Mina III segundo Fortes et $a l$. (2000) em comparação com dados de análises obtidos para o Corpo IV (amostra IV-23-51) neste trabalho.

\begin{tabular}{|c|c|c|c|c|c|}
\hline & $\begin{array}{l}\text { Koma Superior } \\
\text { (sulfeto maciço) }\end{array}$ & $\begin{array}{l}\text { Zona Inferior } \\
\text { (veio de getart\%o) }\end{array}$ & $\begin{array}{l}\text { Zona Inferior } \\
\text { (xisto catbonoso) }\end{array}$ & $\begin{array}{l}\text { Zona da Granada } \\
\text { (quartzo-clorita } \\
\text { metscovita-granada xisto) }\end{array}$ & $\begin{array}{l}\text { Corpo IV (veio de quartzo, } \\
\text { borda conn xisto MCAR) }\end{array}$ \\
\hline Média & 947 & 949 & 942 & 938 & 915 \\
\hline mínimo & 925 & 929 & 866 & 923 & 909 \\
\hline máximo & 980 & 962 & 961 & 955 & 928 \\
\hline
\end{tabular}

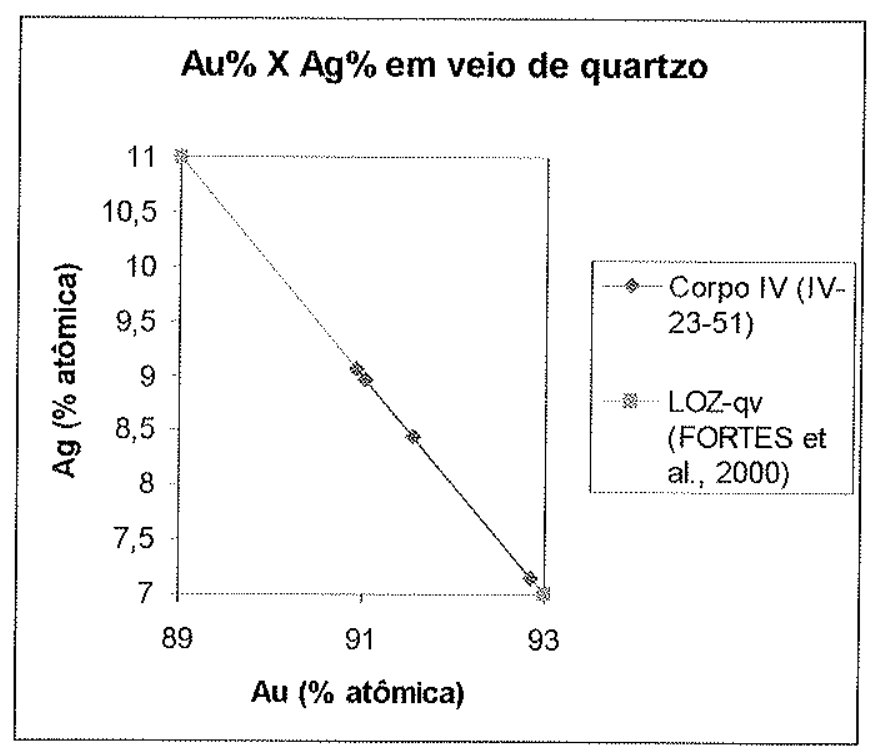

FIGURA 8 -- Relação Au versus Ag do Corpo IV (amostra IV-22-17905) na borda do veio de quartzo com xisto MCAR (5 análises) em comparação com as análises obtidas por Fortes et al. (2000) da zona de minério inferior na Mina III em veio de quartzo.

No depósito do Corpo IV não foram encontradas evidências da ocorrência de ouro associado a arsenopirita, como definidos por Fortes (1996) na Mina III. Todas as amostras estudadas mostraram uma forte relação de ouro com a pirrotita (PRANCHA 13 B, C, D, E e F).

A pirrotita, como discutida anteriormente, mostra forte controle estrutural relacionado à $L_{m / 3}$ e essa canalização dos fluidos nessa estrutura deve representar o principal conduto de transporte do ouro e sulfetos no corpo IV (PRANCHA $13 \mathrm{~A}$ ). Não foram constatadas evidências do transporte de ouro e/ou sulfetos pelos veios de quartzo, sendo que todos os sulfetos assim como o ouro associado tem fortes vínculos com a encaixante do xisto carbonoso. Esse fato sugere que os veios de quartzo mineralizados atuaram como zonas de descompressão de fluidos e/ou de mistura, o que deve ter causado a desestabilização dos fluidos transportando sulfetos e ouro tanto nos veios como na encaixante carbonosa. 

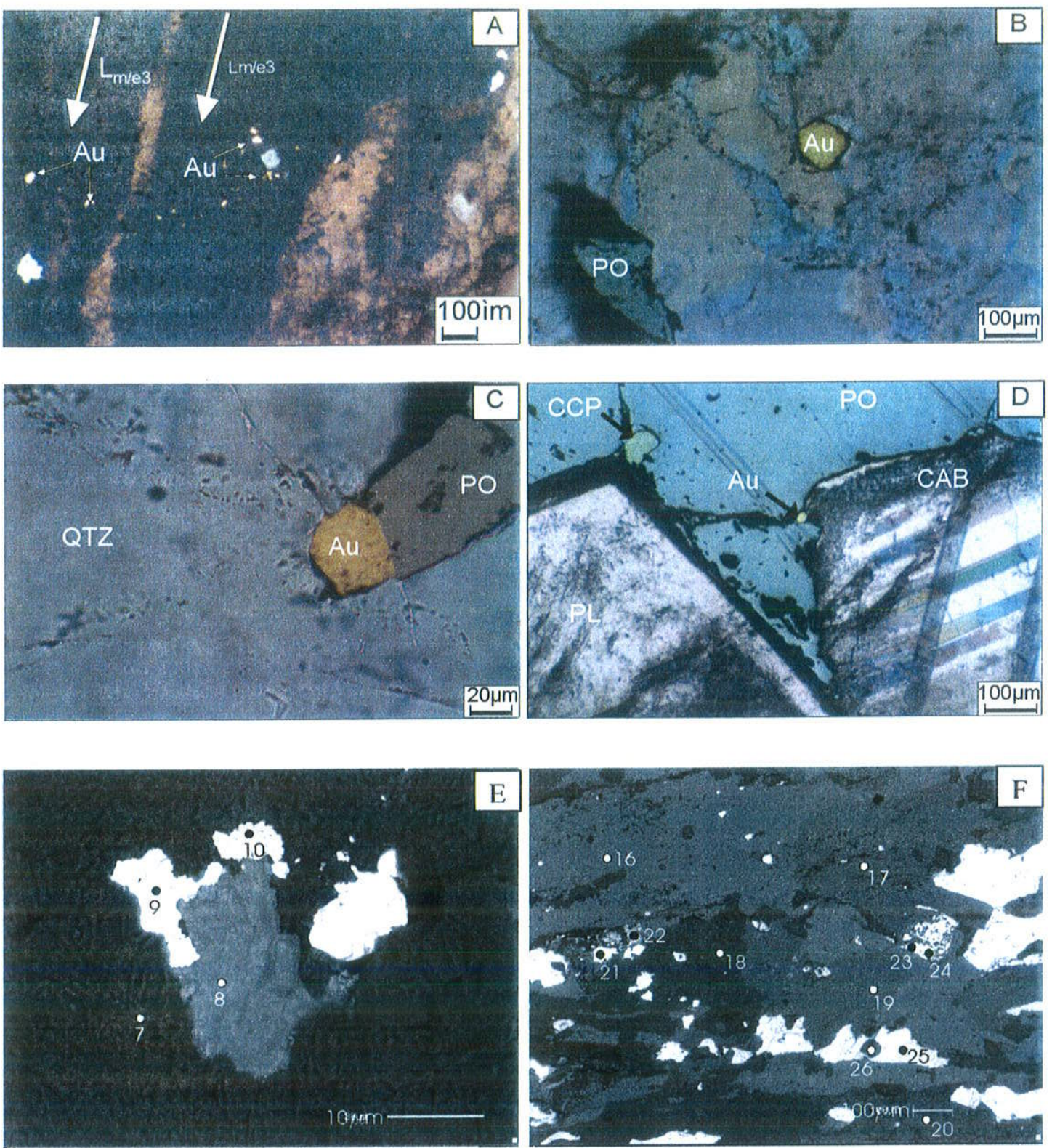

PRANCHA 13 - (A) Grãos de ouro na encaixante carbonosa do veio de quartzo com $\mathrm{L}_{\mathrm{m} / \mathrm{e} 3}$ preservada no xisto (Amostra IV-22-17905, 100\% luz refletida e 30\% luz transmitida). (B) Ouro cristalizado entre grãos de quartzo na zona de influência dos fluidos ligados a pirrotita. O contorno escuro ao redor do grão de ouro é a sombra do próprio mineral na lâmina. (C) Ouro em contato com pirrotita, ambos provenientes da $\mathrm{L}_{\mathrm{m} / \mathrm{e} 3}$ do xisto carbonoso hospedeiro do veio de quartzo, sendo que a partir do grão de Au saem diversas trilhas carbônicas (e aqua-carbônicas?) (Amostra IV-22-17905, 100\% luz refletida e $30 \%$ luz transmitida) (D) O espaço vazio entre cristais de plagioclásio (vug) foi preenchido com pirrotita, calcita, calcopirita e ouro (Amostra CIV-G026-V4AU, $100 \%$ luz refletida e $30 \%$ luz transmitida).(E) Imagem gerada com auxílio do microscópio eletrônico de varredura (MEV) com pontos de análise semiquantitativa onde: 7 - quartzo, 8 - pirrotita, 9 e 10 - ouro (amostra IV-2217905); (F) Imagem do xisto carbonoso próximo ao veio de quartzo mineralizado onde: 17, 19 clorita, 18 -oligoclásio, 20, 26 - dolomita ferrosa, 21, 24 - ouro, 23, 25 - pirrotita (amostra IV-2314820). Abreviações segundo TABELA 1. 
O ouro no Corpo IV deve ter sido precipitado próximo aos estágios finais da pirrotita, provaveimente durante diversos pulsos mineralizantes relacionados ao final do evento D3. Grãos maiores de ouro apresentam inclusões de esfalerita que ocorre de maneira disseminada no xisto carbonoso, reforçando o caráter relativamente primário do sulfeto, sem demonstrar maiores afinidades deste em relação ao ouro e a pirrotita (PRANCHA 14 A, B, C). Algumas vezes foi observada a presença de ouro em fraturas da esfalerita como mostra a PRANCHA 14 D. A PRANCHA 14 E, F e PRANCHA 15 A, B mostra a cronologia relativa entre o ouro, esfalerita e pirrotita, onde a pirrotita envolve a esfalerita e parcialmente o ouro. A arsenopirita também não apresentou relacionamento direto com ouro, pelo menos a arsenopirita da primeira geração fraturada (ASP2), como mostra a PRANCHA 15 B onde um cristal euhédrico fraturado de arsenopirita está em contato com pirrotita e ouro, esses últimos mais tardios, ocorrendo ainda esfalerita inclusa tanto na pirrotita como na arsenopirita.

A associação pirrotita e ouro no veio de quartzo podem ser vistas na PRANCHA 15 E, F onde o ouro ocorre sob a forma livre no quartzo e associado a pirrotita. Carbonato está presente entre a encaixante do xisto carbonoso e o quartzo de veio, conforme a PRANCHA 15 $\mathrm{E}$, o que indica uma fase de veios mais tardios. 

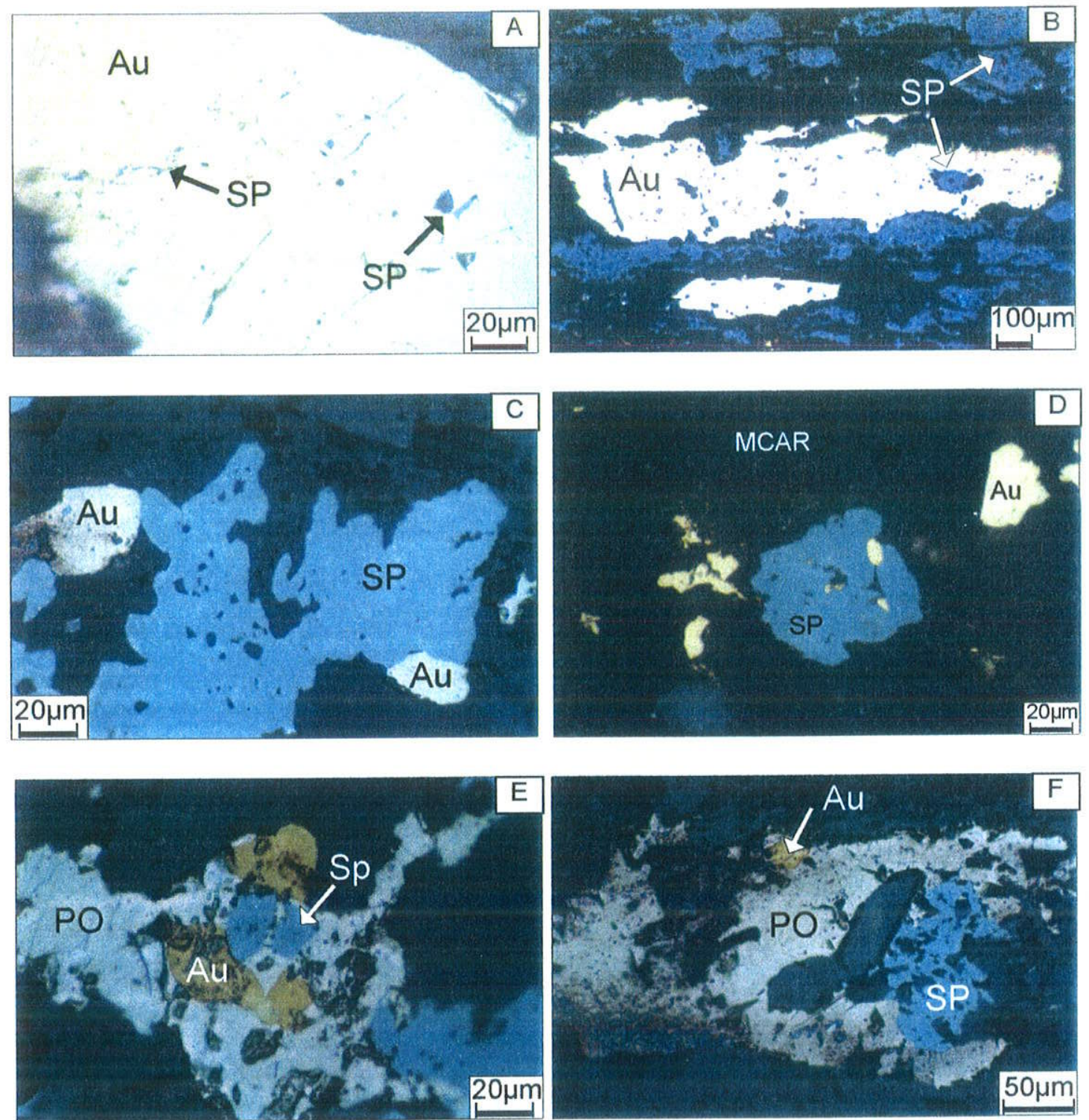

PRANCHA 14 - (A) Ouro com inclusões de esfalerita (Amostra IV-22-18737, luz refletida). (B) Ouro em contato com esfalerita e com inclusões do mesmo sulfeto (Amostra IV-22-18737, luz refletida). (C) Ouro em contato com esfalerita com inclusões do mesmo sulfeto (Amostra IV-2217905, luz refletida). (D) Ouro em fraturas da esfalerita (Amostra IV-23-14020, luz refletida). (E) Ouro ao redor da esfalerita e ambos inclusos na pirrotita, ouro também na borda da pirrotita (Amostra IV-22-18076, luz refletida). (F) Pirrotita com inclusões de esfalerita e ouro na borda (Amostra IV-2217905, luz refletida). Abreviações segundo TABELA 1. 

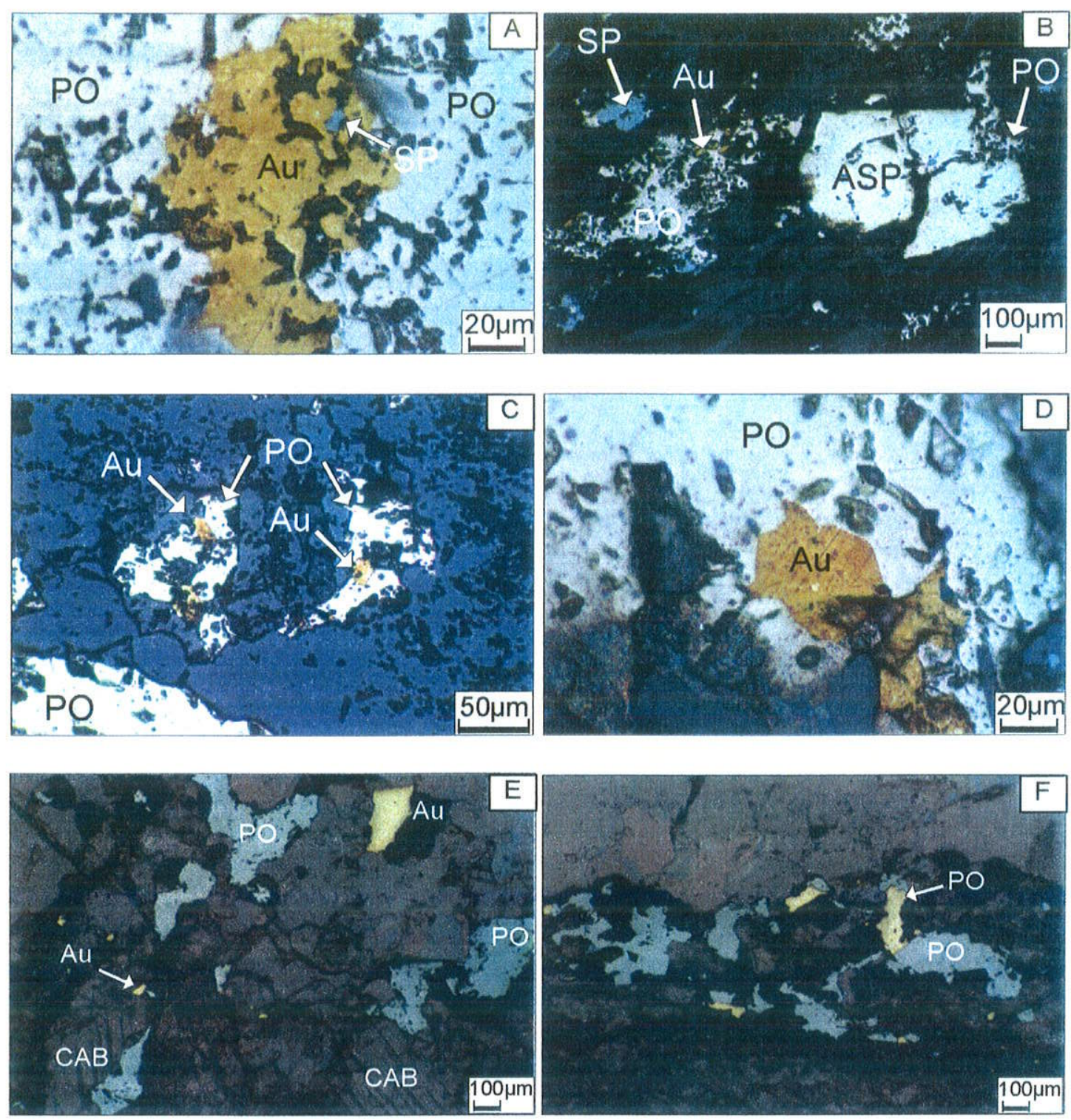

PRANCHA 15 - (A) Ouro com inclusão de esfalerita e parcialmente incluso na pirrotita (Amostra IV22-18076, luz refletida). (B) Ouro, arsenopirita e esfalerita parcialmente inclusos na pirrotita, sendo que a arsenopirita subhédrica apresenta fraturamentos em função da $\mathrm{S}_{\mathrm{m} 3}$ e também contém inclusões de esfalerita (Amostra IV-22-18076, luz refletida). (C) Ouro parcialmente incluso na pirrotita (Amostra IV-22-17905, luz refletida). (D) Ouro parcialmente incluso na pirrotita (Amostra IV-2218076, luz refletida). (E) Ouro livre com pirrotita no veio de quartzo com carbonato, provavelmente dolomita ferrosa (Amostra IV-23-14877, luz refletida e transmitida). (F) Ouro no veio de quartzo com pirrotita (Amostra IV-23-14877, luz refletida e transmitida). Abreviações segundo TABELA 1. 


\subsection{Cronologia relativa das fases de sulfetos e do ouro no Corpo IV}

A análise petrográfica permitiu estabelecer uma cronologia para os sulfetos, ouro e minerais associados confome a TABELA 13, abaixo.

A precipitação da pirrotita nos veios de quartzo está aparentemente relacionada a imiscibilidade e/ou mistura de fluidos constatada ópticamente nas associações de inclusões fluidas relacionadas (ver Capítulo V, estudo das inclusões fluidas).

TABELA 13 - Cronologia relativa dos sulfetos e ouro no Corpo IV. O processo recorrente de precipitação da pirrotita com calcopirita e ouro é representado pela repetição das elipses, sem referência direta ao número de ciclos. A espessura das elipses representa aproximadamente a abundância relativa dos minerais. As linhas tracejadas indicam inclusões minerais nos minerais relativamente mais tardios, da esquerda para a direita, respectivamente.

\begin{tabular}{|c|c|c|c|c|c|}
\hline \multicolumn{6}{|c|}{ SULFETOS, OURO E MINERAIS RELACIONADOS NO CORPOIV } \\
\hline & \multicolumn{3}{|c|}{ ARQUEANO } & $\begin{array}{l}\text { PALEOPROTERO- } \\
\text { ZÓICO }\end{array}$ & $\begin{array}{l}\text { NEOPROTERO- } \\
\text { ZÓICO }\end{array}$ \\
\hline Fase Mineral & $S_{0}$ & $D 1\left(s_{1}\right)$ & D2 & $D 3\left(S_{m 3} / L_{m / 63}\right)$ & $D 4\left(S_{4}\right)$ \\
\hline \multirow{2}{*}{\multicolumn{6}{|c|}{$\begin{array}{l}\text { Quartzo } \\
\text { Albita }\end{array}$}} \\
\hline & & & & & \\
\hline Dolomita & & & \multicolumn{2}{|c|}{ DOL3 $\square$} & \\
\hline \multicolumn{6}{|l|}{ Turmalina } \\
\hline \multicolumn{6}{|l|}{ Arsenopirita } \\
\hline \multicolumn{6}{|l|}{ Pirrotita } \\
\hline \multicolumn{6}{|l|}{ Calcopirita } \\
\hline \multicolumn{6}{|l|}{ Ouro } \\
\hline Siderita & & & & & 0 \\
\hline \multicolumn{6}{|l|}{ Esfalerita } \\
\hline Calcopirita & & $\begin{array}{c}\text { Esfalerita } \\
\text { ocorre } \\
\text { inclusa nos } \\
\text { outros } \\
\text { sulfetos. }\end{array}$ & $\begin{array}{l}\text { Primeira } \\
\text { geração de } \\
\text { arsenopirita, } \\
\text { euédrica, } \\
\text { fraturada. }\end{array}$ & $\begin{array}{l}\text { Evento relacionado a } \\
\text { mineralização de ouro e } \\
\text { sulfetos }\end{array}$ & \\
\hline
\end{tabular}

\section{MINERALIZAÕES AURÍFERAS NA REGIÃO DE CRIXÁS}

As primeiras descrições detalhadas das mineralizações auríferas da Mina III são devidas a Yamaoka \& Araújo (1986), quando destacaram a ocorrência de três tipos de minérios, quais sejam: 1) de sulfeto maçico com arsenopirita, pirrotita e magnetita em abundância, além de pirita e calcopirita subordinados, com ganga de sericita, cloritóide e granada; 2) minério com cloritóide e granada \pm arsenopirita \pm pirrotita \pm magnetita; 3) sericítico, composto por xistos sericíticos finos com arsenopirita e pirrotita disseminados em pequenas quantidades. $\mathrm{O}$ minério nessas três formas de ocorrência varia em dimensão, teor, reserva, localização e rocha hospedeira, de modo geral, considerados como gerados durante o desenvolvimento de uma falha de empurrão. 
Kuyumjian \& Dardenne (1983) sugerem uma origem hidrotermal exalativa e posterior segregação metamórfica em zonas axiais de dobras isoclinais para o depósito da Mina III. Já Thomson $(1986 ; 1990)$ considera o depósito como hidrotermal desenvolvido ao longo da falha de empurrão e relacionada ao ciclo Brasiliano, enquanto Yamaoka \& Araújo (1988) classificam o depósito como sendo do tipo stratabound e estratiforme singenético de origem exalativa. Bettencourt et al. (1990) associa o depósito da Mina III a zonas de cisalhamento de baixo ângulo, confinados em nível estratigráfico preferencial, ou seja, imediatamente acima do contato entre metabásicas e metassedimentos, sugerindo uma natureza estratiforme.

As mineralizações de ouro encontram-se confinadas a faixas mais intensamente deformadas, notadamente em planos de empurrão e estruturas derivadas, em encaixantes como sericita milonitos e milonito-ultramilonitos carbonosos. Os corpos mineralizados encontram-se orientados ou dobrados segundo, ou próximo, à direção da lineação de estiramento $L_{n+2}$. Esta lineação associada à foliação milonítica $S_{n+2}$ caracteriza a fase $D_{n+2}$ definida como deformação de cisalhamento simples dúctil-frágil (Magalhães, 1991; 1992). O ouro ocorre associado a sulfoarseniatos, sulfetos e óxidos (arsenopirita, pirrotita, calcopirita e ilmenita), sendo considerada como uma mineralização epigenética, relacionada a fase de deformação $\mathrm{D}_{\mathrm{n}+2}$ citada e a um possível evento posterior de alteração hidrotermal (Magalhães \& Lobo, 1986; Magalhães, 1991).

O ouro ocorre incluso ou preenchendo microfraturas na arsenopirita, incluso no quartzo da ganga, no contato entre sulfetos ou entre sulfetos e minerais de ganga, incluso em ilmenita, preenchendo microfraturas em porfiroblastos de granada, incluso ou preenchendo microfraturas de quartzo em veios. Esta grande variedade de ocorrência indica diversos estágios de precipitação do ouro (Fortes \& Jost, 1996).

Kuyumiian \& Costa (1999) em seu estudo na Seqüência Mina Inglesa, situada a noroeste da Mina III, considerada hospedada em uma unidade de topo do Greenstone Belt de Crixás (Kuyumjian, 1981), realça a importância das anomalias de potássio e sódio relacionadas a granitogênese tardias e de volumes relativamente menores em Crixás. Os dados fornecidos por Pires (1995) por meio da análise de dados gama-espectométricos, particularmente para o canal do potássio, possibilitou evidenciar diversas anomalias correlacionáveis diversas vezes com intrusões granitóides, zonas de alteração hidrotermal e ocorrências auríferas ao longo de zonas de cisalhamento NS (Kuyumjian \& Costa, 1999). A principal diferença da mineralização na Seqüência Mina Inglesa das mineralizações da Mina 
III e Mina Nova são a ausência nestas últimas de intrusivas granitóides/gabróicas e de galena. Os autores sugerem que o fluido hidrotermal responsável pela mineralização na Mina Inglesa percolou os granitóides, promovendo carbonatização e lixiviamento do chumbo. A conclusão sobre a mineralização segundo Kuyumjian \& Costa (1999) é de que a Seqüência Mina Inglesa e intrusivas associadas sofreram tectonismo, provavelmente neoproterozóico, que como resultado gerou segregação metamórfica de fluidos, reconcentração de sulfetos e ouro de origem hidrotermal, sem descartar sua possível origem vulcano-exalativa, ao longo da zona de cisalhamento direcional dextrógira NS.

Os corpos de minério são controlados estruturalmente pela intersecção de lineações paralelas ao eixo de dobras semi-recumbentes, assimétricas e apertadas, formadas por cisalhamento dúctil simples progressivo, quase puro. A gênese do depósito foi considerada como produto de mobilização metamórfica-hidrotermal aliada a concentração, ou remobilização e reconcentração, sem descartar a existência de pré-concentrações singenéticas (Fortes \& Jost, 1996).

Jost \& Fortes (2001) classificam as mineralizações de ouro na Mina III, correlacionáveis em parte ao Corpo IV e V, em dois tipos:

- Sulfetos maciços: foi determinada próxima a interface entre metabasaltos e uma fácies de formação ferrífera óxido-silicática (Formação Rio Vermelho) e xistos carbonosos e mármores maciços (Formação Ribeirão das Antas). Sulfetos e carbonatos substituem magnetita e silicatos da formação ferrifera bandada indicando atividade hidrotermal epigenética pós-metamórfica, em contraste com a alteração sin-vulcânica rica em alumínio e ferro.

- Veios de quartzo: ocorrem inseridos nos xistos carbonosos cisalhados da Formação Ribeirão das Antas. Como alterações hidrotermais foram reconhecidos carbonatizações discretas e sulfetização. O ouro ocorre tanto como inclusões no quartzo, carbonato ou minerais de sulfeto, como também no material carbonoso.

Os autores reconhecem ainda um terceiro tipo de mineralização restrito ao depósito da Mina Nova, denominado de minério disseminado, nos xistos carbonosos cisalhados da Formação Ribeirão das Antas. 


\section{TRANSPORTE DE OURO EM SOLUCÕES HIDROTERMAIS}

Os complexos aquosos bi-sulfetados e cloretados eram até pouco tempo os tipos considerados mais apropriados para promover o transporte de ouro em soluções hidrotermais, em virtude da disponibilidade de ligands de $\mathrm{S}$ e $\mathrm{Cl}$ reduzido na maioria dos fluidos mineralizantes e, da estabilidade termodinâmica elevada destes complexos (Seward, 1991, in Mikucki, 1998). Atualmente existe um consenso que três complexos de bi-sulfetos; $\mathrm{Au}(\mathrm{HS})^{0}$, $\mathrm{HAu}(\mathrm{HS})_{2}{ }^{0}$ e $\mathrm{Au}(\mathrm{HS})_{2}{ }^{-}$são potencialmente importantes no transporte de ouro em soluções hidrotermais (Seward, 1973; Shenberger \& Barnes, 1989; Hayashi \& Ohmoto, 1991, in Mikucki, 1998). Neste contexto, os complexos de ouro-cloreto são geralmente considerados de pouca importância em condições típicas da fácies sub-anfibolito.

Estudos recentes procuram extrapolar os dados existentes para condições de temperatura mais alta, resultando em discrepâncias com dados de solubilidades medidas. Experimentos recentes confirmaram, entretanto, a dominância de $\mathrm{AuCl}_{2}{ }^{-}$como cloreto que transporta ouro sob condições hidrotermais em condições altas de P-T (Mikucki, 1998).

Os cálculos de Mikucki (1998), indicaram que os formadores de complexos de ouro predominantes são:

- $\mathrm{Au}(\mathrm{HS})^{0}$ em temperaturas limitadas até $300^{\circ} \mathrm{C}$, temperatura e pH relativamente baixo dos fluidos.

- $\mathrm{Au}(\mathrm{HS})_{2}{ }^{-}$seria o principal bi-sulfeto atuando com conteúdos moderados a altos de $\mathrm{H}_{2} \mathrm{~S}$ ( $m$ f2s) e a altas temperaturas.

- $\mathrm{AuCl}_{2}{ }^{\prime}$ apenas em altas temperaturas, podendo superar $\mathrm{Au}(\mathrm{HS})_{2}{ }^{-}$como principal complexo transportador de Au.

Os estudos de solubilidade de ouro transportado como $\mathrm{Au}(\mathrm{HS})_{2}{ }^{-}$confirmaram valores de 1-100ppb em baixa temperatura e 10-10000 ppb em fluidos mineralizantes de alta temperatura, mesmo desprezando-se a contribuição de $\mathrm{AuCl}_{2}{ }^{-}$em sistemas de alta temperatura. A solubilidade do ouro em altas temperaturas traz várias conseqüências importantes. Primeiramente as solubilidades excedem amplamente as concentrações mínimas requeridas para formar um fluido efetivamente mineralizado em ouro $(\sim 5 \mathrm{ppb} \mathrm{Au}$, Heinrich et al., 1989) tornando desnecessária a explicação através de complexos de ouro exóticos (p. ex. complexos de ouro de tioarseniato). E, mais importante, os cálculos feitos por Mikucki (1998) dão suporte a especulações anteriores de que a maioria dos fluidos mineralizantes arqueanos foram provavelmente, insaturados em ouro em suas regiões de origem (conforme Phillips \& 
Powell 1993). Esses fatores permitem a canalização de fluidos mineralizados em ouro que, em função da modesta subsaturação, não permitem a sua precipitação em niveis crustais mais profundos, próximo à fonte, o que faz com que os fluidos se mantêm efetivamente mineralizados em toda a extensão crustal, onde os depósitos de ouro arqueano se formaram. Deve ser levado em consideração ainda que esses fatores podem ser responsáveis pela produção relativamente baixa de ouro em terrenos da fácies anfibolito em relação aqueles depósitos relacionados à fácies xisto verde (conforme Ridley et al., 1996), ou seja, uma subsaturação a temperaturas mais elevadas levaria a processos menos eficientes na deposição mineral (Mikucki 1998).

O ouro associado a arsenopirita e/ou pirita com arsênio é encontrado em vários depósitos meso- a epitermais, ou seja, com temperaturas abaixo de $300^{\circ} \mathrm{C}$. Nestes depósitos o ouro precipita-se após a formação da arsenopirita, nas bordas e fraturas da mesma. Este processo se daria através da redissolução da arsenopirita, produzindo localmente "armadilhas redutoras" para o ouro. Esta reação de dissolução pode ser exemplificada através da fórmula estequiométrica sob condições de $\mathrm{HCl} 0,01$ molar a $350^{\circ} \mathrm{C}$ (Pokrovski et al., 2002):

$$
\mathrm{FeAs}_{0,97} \mathrm{~S}_{\mathrm{l}, 07}+3 \mathrm{H}_{2} \mathrm{O}+\mathrm{H}^{+}+2 \mathrm{Cl}^{\prime \prime}=\mathrm{FeCl}_{2}{ }^{\circ}(\mathrm{aq})+0,97 \mathrm{AS}(\mathrm{OH})_{3}{ }^{\circ}(\mathrm{aq})+1,07 \mathrm{H}_{2} \mathrm{~S}^{\circ}(\mathrm{aq})+
$$
$1,48 \mathrm{H}_{2}^{\circ}(\mathrm{aq})$

A precipitação do ouro por meio da criação de condições altamente redutoras em relação ao fluido global pela dissolução da arsenopirita pode representar um mecanismo eficiente na extração de Au das soluções hidrotermais (Pokrovski et al., 2002).

A presença de fluidos aquo-carbônicos com salinidades muito altas coexistindo com fluidos aquo-carbônicos com salinidade média também podem ser indicativos de imiscibilidade (Fortes \& Giuliani, 1995, in: Fortes et al., 2000). Isto também pode influenciar o transporte de ouro na forma de complexos de hidrosulfetos e/ou cloretos e na sua deposição por meio de variações no $\mathrm{pH}, \mathrm{Eh}, \mathrm{aCl}, \mathrm{aS}$ e $\mathrm{fO}_{2}$ da solução, resultando na variação das razões $\mathrm{Au} / \mathrm{Ag}$. Estas razões têm ainda nítidas relações para cada zona mineralizada com os minerais hospedeiros e associações minerais, sugerindo que as seqüências paragenéticas, onde os sulfetos tendem a ser tardios, também têm influência na razão $\mathrm{Au} / \mathrm{Ag}$. 


\section{BANCO DE DADOS}

O projeto da presente tese previu o tratamento de um grande número de informações, particularmente em relação a dados de descrição petrográfica e posicionamento espacial dos mesmos. Para que houvesse um tratamento rápido e sem perda de informação, optou-se pelo armazenamento dos dados em um banco de dados, sendo que para tanto, foi necessário elaborar um programa com características específicas.

Dada a importância que essa ferramenta representou no manuseio dos dados petrográficos, é apresentada uma descrição sucinta dos motivos que levaram a elaboração de um programa e a maneira que foi realizada.

O mercado de software oferece diversos programas de gerenciamento de dados voltados para o setor mineral, os quais oferecem recursos necessários para um manuseio eficiente de dados petrográficos com posicionamento espacial (por exemplo: VULCAN ${ }^{\circledR}$, DATAMINE $^{\circledR}$, GENCOM $^{\circledR}$, entre outros). Esses programas em geral são direcionados para questões gerenciais de minas, de alto custo, exigem treinamento específico e um equipamento de computação sofisticado, em geral uma estação de trabalho. Isso desestimulou a utilização de tais programas para a aplicação bastante específica exigida no desenvolvimento do presente estudo.

Por outro lado, a aquisição de um número relativamente grande de dados tornou imprescindivel o uso de uma ferramenta que tornasse possivel a atualização e manuseio constante destes dados, sem risco de perda de informação. Aliado a essa versatilidade seria ainda necessário à amarração espacial dos dados selecionados sobre uma projeção tridimensional em escala dos posicionamentos de testemunhos e das galerias mapeadas. Outro fator importante seria o uso de programas de computador relativamente acessíveis, que pudessem utilizar microcomputadores padrão e até mesmo portáteis, sem exigir muito investimento financeiro e de tempo no treinamento.

Após uma análise dos softwares disponiveis no IG-USP, optou-se pelo uso do MICROSOFT ACCESS $97^{\text {(2) }}$ para construção do banco de dados do projeto, o qual é definido como um sistema de gerenciamento de dados relacionável e que trabalha sob a plataforma WINDOWS $^{9} 95$ e 98 . Este gerenciador de banco de dados ofereceu uma grande flexibilidade no manuseio dos dados preenchendo as necessidades do projeto.

Na parte gráfica foi utilizado o programa AUTOCAD 2000 precisão nas modelagens tridimensionais e, nesta versão em particular, oferece uma 
conectividade mais eficiente com bancos de dados externos, visando relacionar os dados com objetos espacialmente. O mesmo programa permite também a execução de rotinas de filtragem dos dados proveniente do banco.

Para que o AUTOCAD 2000 acesse as informações de um banco de dados externo são necessários dois procedimentos (Burchard \& Pitzer,2000):

a) É necessário utilizar o $O D B C$ Data Source Administrator que é fornecido pelo sistema operacional WINDOWS, que é uma interface de programação permitindo ao AUTOCAD acessar o banco de dados, no caso do ACCESS 97. Importante notar que o AUTOCAD 2000 não consegue acessar bancos de dados em versões posteriores ao ACCESS 97. O MICROSOFT ACCESS 97 fornece drivers diretos de banco de dados que podem evitar a configuração de um arquivo de origem de dados $O D B C$, podendo-se acessar os seus arquivos diretamente de um arquivo de configuração $O L E D B$. Na configuração do banco de dados do presente trabalho ocorreram situações em que o driver fornecido pela MICROSOFT não permitia uma conexão com o arquivo de configuração $O L E D B$, por motivos desconhecidos.

b) Deve-se configurar um arquivo. UDL através da caixa de diálogo Data Link Properties do AUTOCAD que vai apontar para a tabela do banco de dados ACCESS 97.

c) Cria-se um arquivo de configuração de $O L E D B$ que conterá as informações que o AUTOCAD utiliza para acessar dados em arquivos de banco de dados. $O$ arquivo de configuração é onde se adicionam as informações que identificam o nome do arquivo da origem de dados de $O D B C$. Esse arquivo é criado através do comando Tools/dbConnect Manager onde se cria um Data Source Name. Logo após a confirmação, acessa-se o guia Provider onde se seleciona Microsoft OLE DB Provider for ODBC Drivers. No guia Connection seleciona-se o botão de opção Use Data Source Name onde se busca o nome de origem de dados (data source name - DSN). Se necessário adota-se uma senha no Step 2 e no Step 3 escolhe-se o catálogo da lista. Após esses procedimentos faz-se o teste (botão Test Connection) para se assegurar que o AUTOCAD estabeleceu corretamente a conexão com o banco de dados.

O Gerenciador de Banco de Dados criado (FIGURA 9) permite a correlação ampla ou detalhada de toda a gama de descrições, particularmente das descrições minerais, tendo sofrido inúmeras adaptações no decorrer dos trabalhos de pesquisa. 
Através desse banco é possível, por exemplo, correlacionar o conteúdo em porcentagem de determinado mineral nos pontos ou áreas de interesse, seleção de litotipos ou determinados minerais em um perfil, sondagem ou em toda área, seleção dos pontos com análises petrográficas, químicas, recuperação de amostras a partir da especificação de, por exemplo, teores.

Para o total aproveitamento do potencial no manuseio destes dados, é necessário o amarramento dos posicionamentos individuais, relativo e absoluto, das descrições, em uma concepção tridimensional, que é desempenhado pelo programa de desenho vetorial AUTOCAD. Esta estrutura organizacional pode gerar perfis com elementos de interesse, em qualquer posição desejada, culminando com perfil E-W da área de pesquisa (ANEXO 1).

Para facilitar o relacionamento dos nomes de minerais foi necessário a adoção de formas abreviadas, utilizando-se para tal, a forma modificada da tabela proposta por Kretz (1983), com abreviações em inglês e nomes por extenso em português (ver TABELA 1).

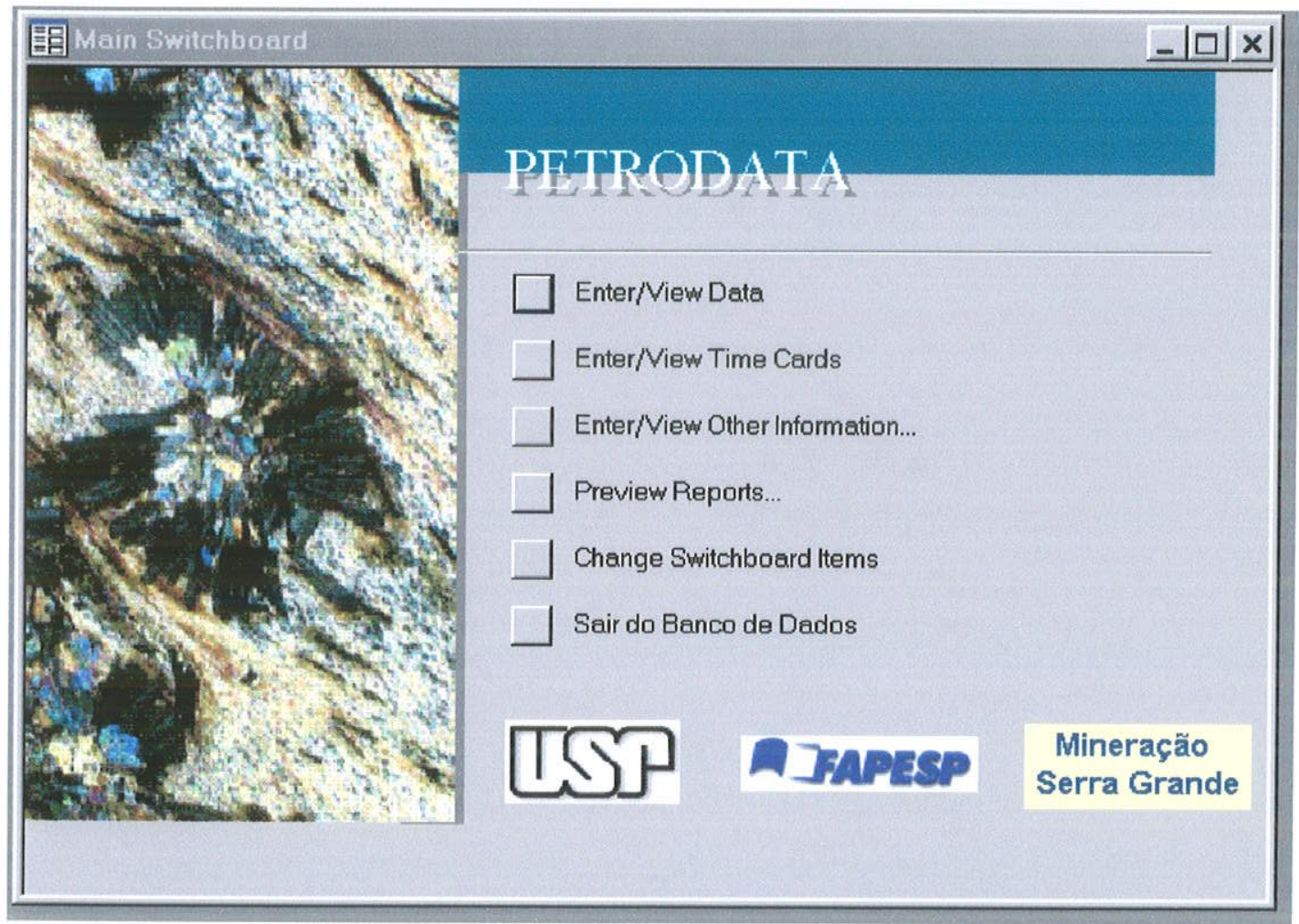

FIGURA 9 - Tela de entrada do banco de dados petrográfico elaborado em ACCESS 97.

O atual nível de desenvolvimento do banco de dados em ACCESS 97 no trabalho de pesquisa, já permite um processamento constante das descrições petrográficas, de acordo com a evolução dos conhecimentos. A FIGURA 10 apresenta a página de entrada de dados acumulados pela MSG e descrições macroscópicas realizadas no presente trabalho. Ao se 
acessar a pasta PETRO no canto inferior da FIGURA 10, é aberta uma tela para a inserção dos dados petrográficos do estudo de lâminas delgadas (FIGURA 11). Nesta etapa foi também elaborada a estrutura para plotagem do mapa em três dimensões em AUTOCAD 2000 (FIGURA 12), com o posicionamento e desvios dos testemunhos de sondagem estudados, além da posterior inserção dos dados do banco, que culminou com a proposta do modelo da área estudada (ANEXO 1, perfil E-W). A FIGURA 13 mostra um recorte de uma das formas de mapas gerados pelo AUTOCAD com dados do banco ACCESS. Até o final do presente estudo, o banco de dados se mostrou funcional e deverá continuar evoluindo para formas com mais recursos e velocidade de fornecimento de interpretações equacionadas.

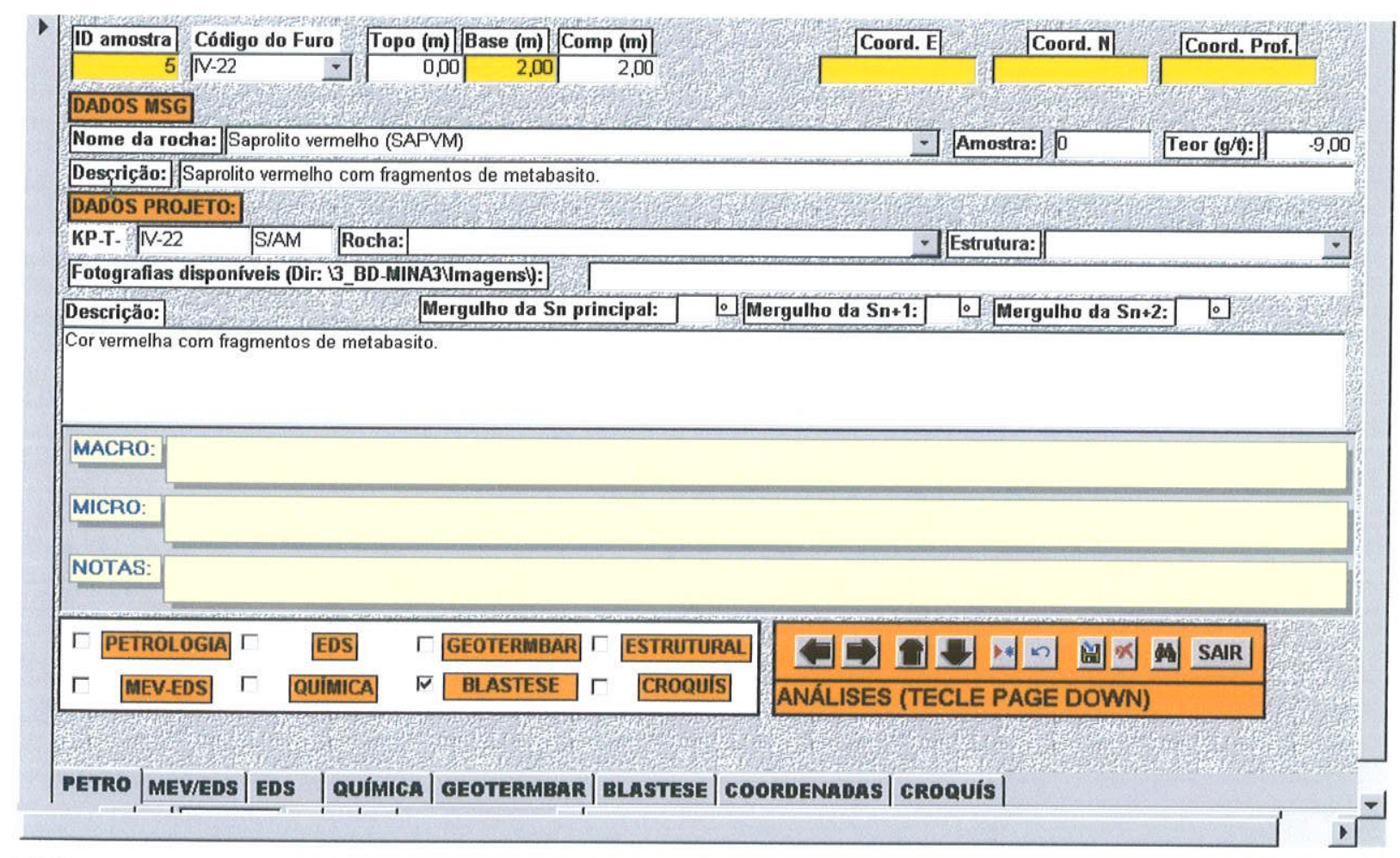

FIGURA 10 - Tela de entrada de dados petrográficos fornecidos pela MSG e descrições macroscópicas de amostras colhidas no presente estudo. 


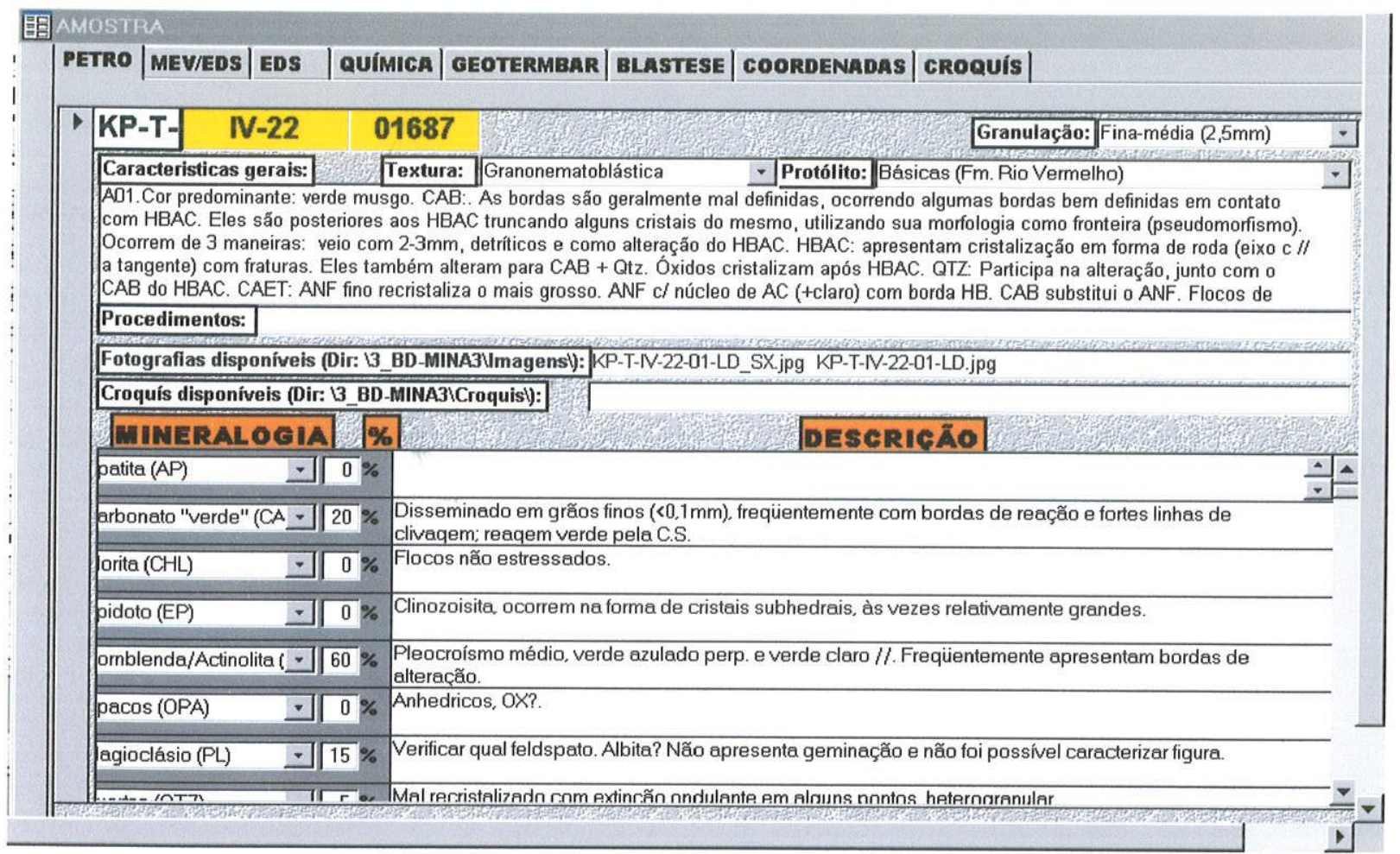

FIGURA 11 - Tela de entrada de dados petrográficos das descrições de lâminas delgadas de amostras colhidas no presente estudo.

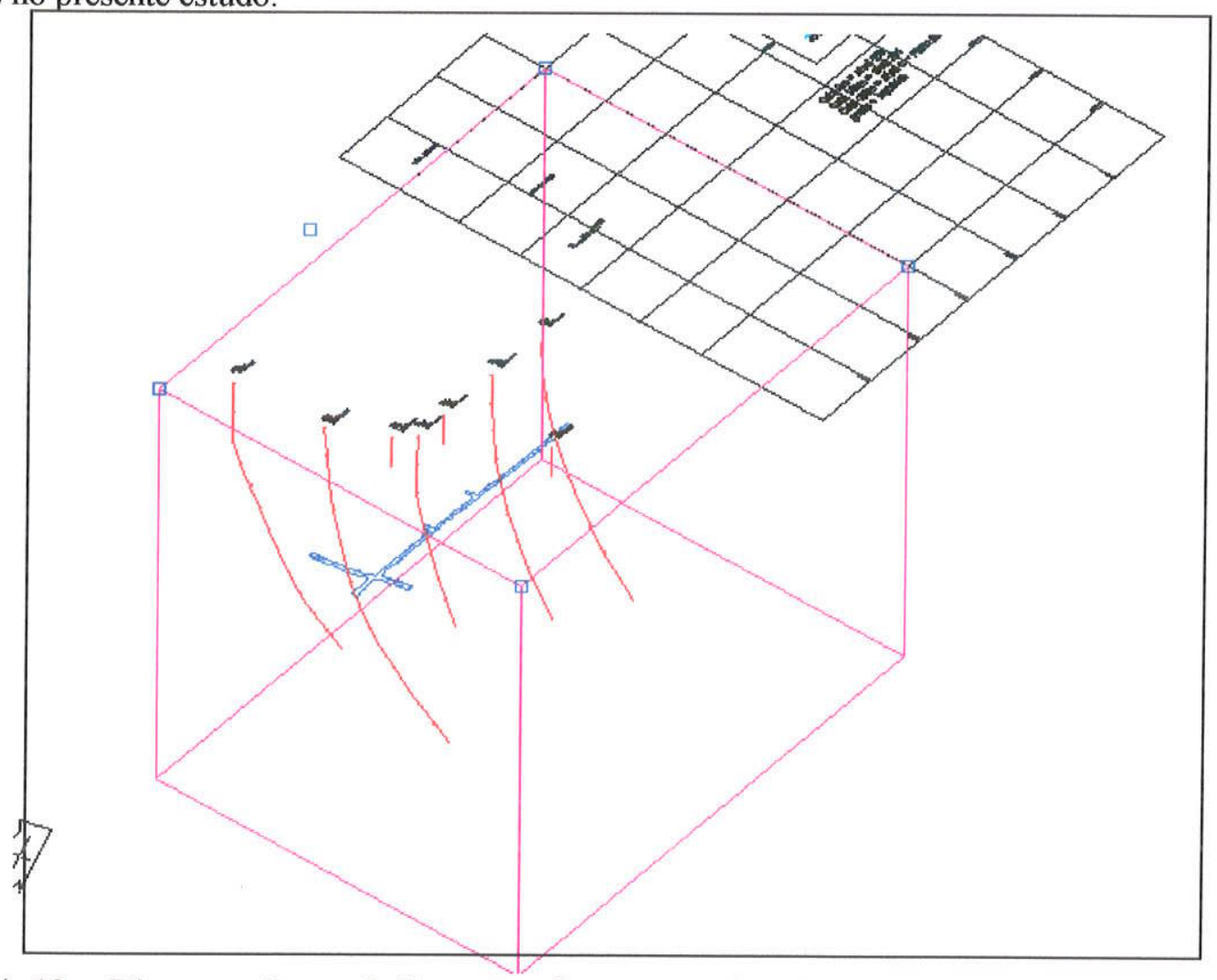

FIGURA 12 - Diagramação em 3 dimensões dos testemunhos de sondagem estudados, em vermelho, e a base topográfica da galeria de acesso ao Corpo IV, em azul. A direção real dos testemunhos de sondagem foi obtida com a entrada dos dados de medição com auxílio do Topari fornecidos pela MSG. 


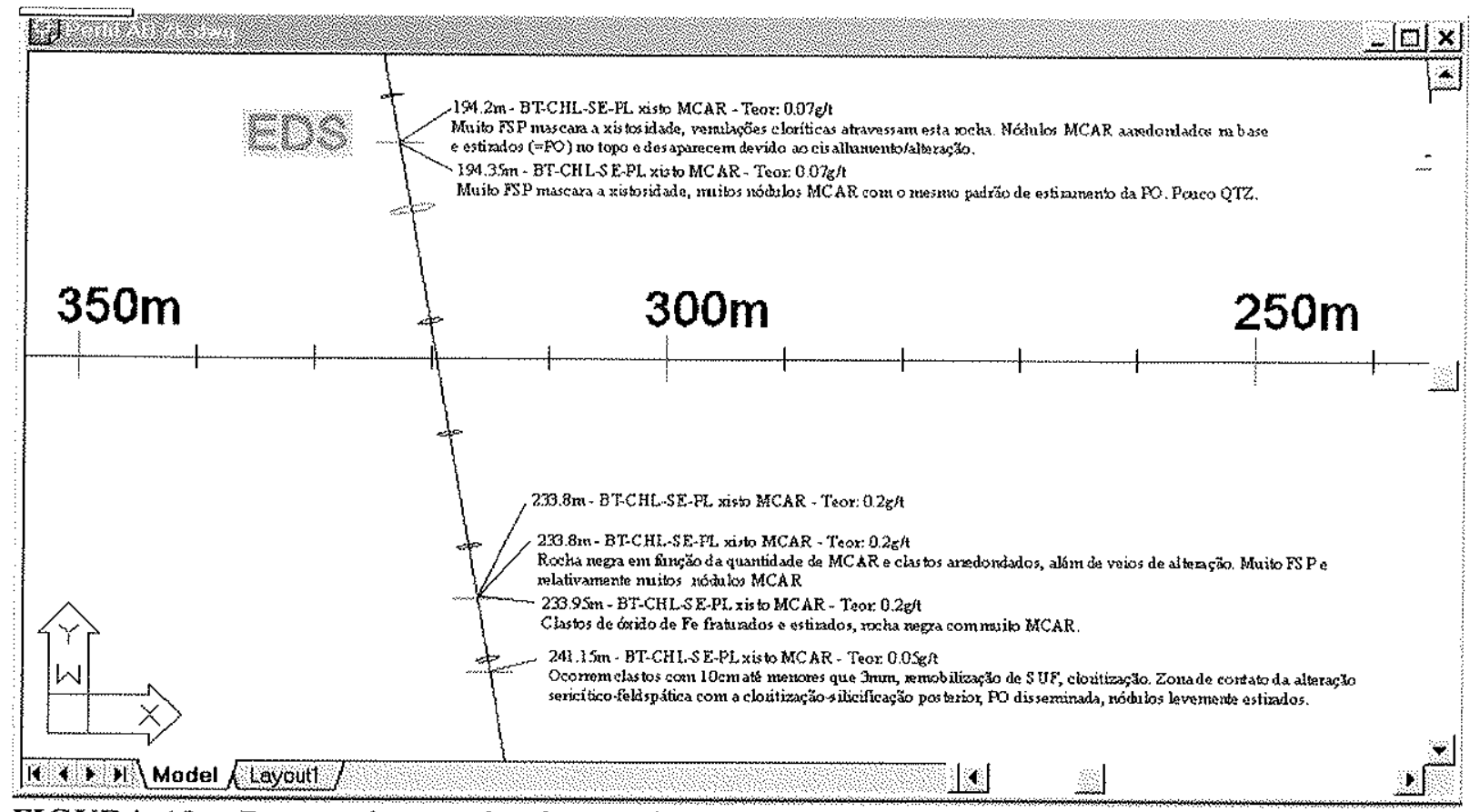

FIGURA 13 - Recorte de uma das formas de relatório gerado pelo AUTOCAD com dados do banco ACCESS, relacionando diversas informações das amostras analisadas dos testemunhos de sondagem (linha subvertical), e com a superposição da galeria de acesso ao Corpo IV (linha com valores em metros a partir do início da galeria de acesso ao Corpo IV). 


\section{CAPÍTULO IV}

\section{QUÍMICA MINERAL E GEOTERMOBAROMETRIA}

\section{INTRODUCÃO}

Foram selecionadas amostras representativas de fases minerais do Corpo IV, mineralizados ou não, e ainda das zonas interpretadas como núcleos de alteração hidrotermal dos diversos corpos de minério da Mina III (zona superior, intermediária e inferior), conforme TABELA 14 abaixo e ANEXO 2 com tabelas de resultados analíticos. Visto que as alterações são semelhantes nos diversos corpos de minério, tentou-se estabelecer um padrão comparativo entre as mesmas, na busca de uma classificação mais refinada do Corpo IV.

TABELA 14 - Amostras com fases minerais submetidas a análises com auxílio da microssonda eletrônica de varredura.

\begin{tabular}{|c|c|c|}
\hline AMOSTRA & NOME DA ROCHA & CARACTERISTICAS \\
\hline \multicolumn{3}{|c|}{ CORPO IV (zonas mineralizadas e adjacências) } \\
\hline G-IV-002a & Biotita-sericita xisto carbonoso & $\begin{array}{l}\text { Metawacke, próxima do Corpo IV, cisalhado, carbonoso. } \\
\text { Acessórios: TUR, PO, ASP, AP }\end{array}$ \\
\hline IV-22-17695 & Biotita-sericita xisto carbonoso & $\begin{array}{l}\text { Metawacke, } \mathrm{Au}>20,00 \mathrm{~g} / \mathrm{t}, \mathrm{clastos} \text { deformados } \mathrm{c} \\
\text { sombras de pressão. TUR, GRT, PO, ASP, EP, AP }\end{array}$ \\
\hline IV-22-16303 & Clorita-biotita xisto carbonoso & $\begin{array}{l}\text { Metawacke, Au<0,01 g/t, clastos estirados. Acessórios: } \\
\text { GRT, SE, TUR, ASP }\end{array}$ \\
\hline IV-22-17905 & $\begin{array}{l}\text { Clorita-flogopita-sericita xisto } \\
\text { carbonoso }\end{array}$ & $\begin{array}{l}\text { Metcrwacke, } \mathrm{Au}>3,00 \mathrm{~g} / \mathrm{t} \text {, contato com veio de quartzo. } \\
\text { Acessórios: TUR, ASP, PO }\end{array}$ \\
\hline K59-19435 & $\begin{array}{l}\text { Clorita-biotita-sericita } \\
\text { carbonoso }\end{array}$ & Metawacke, $\mathrm{Au}=0,07 \mathrm{~g} / \mathrm{t}$, Acessórios: TUR, EP, PO. \\
\hline \multicolumn{3}{|c|}{ Anfibolito (Fm. Rio Vermelho) e prováveis metabásicas alteradas da Fm. Ribeirão das Antas } \\
\hline IV-01914 & Anfibolito fino & Metabásica da Formação Rio Vermelho \\
\hline $\mathrm{K} 59 m 29280$ & $\begin{array}{l}\text { Oligoclásio-dolomita-clorita } \\
\text { xisto }\end{array}$ & Metabásica alterada na Formação Ribeirão das Antas \\
\hline K.59-34143 & $\begin{array}{l}\text { Clorita-turmalina-oligoclásio- } \\
\text { cloritóide-sericita xisto }\end{array}$ & Metabásica alterada na Formação Ribeirão das Antas \\
\hline K49m19790 & $\begin{array}{l}\begin{array}{l}\text { Biotita-dolomita-oligoclásio } \\
\text { xisto }\end{array} \\
\end{array}$ & Metabásica alterada na Formação Ribeirão das Antas \\
\hline \multicolumn{3}{|c|}{ Zonas mineralizada Superior da Mina III (Perfil E-W) } \\
\hline $\mathrm{K} 49-26274$ & $\begin{array}{l}\text { Cloritito o/ porfiroblastos de } \\
\text { CLD, AMP e GRT }\end{array}$ & Lapa do minério sem análise de Au. \\
\hline \multicolumn{3}{|c|}{ Zonas mineralizada Intermediária da Mina III (Perfil E-W) } \\
\hline K59-38571 & Cloritito c/ porfirobl. de GRT & S/ mineralização \\
\hline K59-38587 & Cloritito c/ porfirobl. de GRT & S/ mineralização \\
\hline K03-22755 & Cloritito c/ porfirobl. de GRT & Mineralizado \\
\hline K03-23040 & Biotita-xisto carbonoso & Mineralizado \\
\hline \multicolumn{3}{|c|}{ Zonas mineralizada Inferior da Mina III (Perfil $E-W)$} \\
\hline K49-39614 & $\begin{array}{l}\text { Biotita-sericita-plagioclásio } \\
\text { xisto c/ porfirobl. de GRT e } \\
\text { AMP }\end{array}$ & Zona da GRT/AMP não mineralizada. \\
\hline K49-39664 & $\begin{array}{l}\text { Biotita-sericita-plagioclásio } \\
\text { xisto c/ porfirobl. de GRT e } \\
\text { AMP }\end{array}$ & Zona da GRT/AMP não mineralizada. \\
\hline
\end{tabular}


Alguns litotipos amostrados indicaram tratar-se de metabásicas alteradas em meio aos metasedimentos da Formação Ribeirão das Antas, devido a feições como estruturas pillow e interpillow. Para efetuar comparações foram realizadas análises destas associações encontradas nos metassedimentos e, ainda, de uma amostra de metabásica da Formação Rio Vermelho.

Por problemas de amostragem, não foi possível realizar análises do Corpo $\mathrm{V}$, sendo que pela proximidade e semelhanças estruturais e litológicas, o mesmo poderá ser inicialmente enquadrado em uma caracterização semelhante à proposta para o Corpo IV.

Considera-se aqui o termo mineralizado como sendo a presença de ouro ou sulfeto em qualquer quantidade, no limite de detecção da análise química realizada pela MSG, diferente do termo utilizado na mina onde o mesmo representa o teor mínimo para viabilidade de lavra. Novamente os índices relativos às fases minerais representam o evento gerador (D1 a D4) que pode ser visualizado na TABELA 10 do Capítulo III.

\section{CORPO IV E ADJACENCIAS}

Foram amostrados pontos do Corpo IV, tanto nas galerias (G-IV-002) como dos testemunhos de sondagem (IV-22-16303, IV-22-17695 e IV-22-17905), mineralizadas ou não, visando a caracterização das fases e associações minerais. Para efeitos comparativos foram realizadas análises em uma amostra de clorita-biotita-sericita xisto carbonoso (K59-19435), não mineralizada, em uma posição estratigráficamente diferente do Corpo IV, mas com características petrográficas bastante semelhantes.

A amostra G-IV-002 do Corpo IV foi colhida durante os trabalhos de mapeamento como uma amostra representativa do xisto carbonoso com veios quartzo-carbonáticos e sua descrição segue abaixo:

- Amostra G-IV-002 (Biotita-sericita xisto carbonoso): é caracterizada pela sua cor negra em função do conteúdo em material carbonoso, estrutura xistosa bastante deformada, com clastos muito estirados e venulações quartzosas. Esta rocha possui ainda turmalina e rutilo, este último provavelmente como resultado da alteração da ilmenita (ver Capítulo 3). Ocorre pequena quantidade de carbonato associado ao quartzo de veio dobrado, mas não na matriz sericítica. Essta amostra não possui análise química em relação ao Au. 
A partir do testemunho de sondagem IV -22 foram colhidas três amostras do xisto carbonoso nas imediações do Corpo IV onde:

- Amostra IV-22-16303 (Clorita-biotita xisto carbonoso): região não mineralizada, pouco menos de $10 \mathrm{~m}$ acima do Corpo IV, onde a biotita está levemente cloritizada. Como alterações foram reconhecidas albitização, silicificação, sulfetação, carbonatização e cloritizaçao, sendo a última a mais fraca em relação às demais. Nódulos carbonosos se apresentam achatados (evento D4). Como acessórios ocorrem apatita zonada, sericita (MS1, inclusa no quartzo da matriz), epídoto, granada (porfiroblasto metamórfico), rutilo, titanita, zircão e arsenopirita.

- Amostra IV-22-17695 (Biotita-sericita xisto carbonoso): faixa com mineralização incipiente a pouco menos de $5 \mathrm{~m}$ do Corpo IV. Foram reconhecidas as seguintes alterações hidrotermais: predominância da sericitização (MS3) superposto a albitização, silicificação, carbonatização, turmalinização e sulfetação. Ocorre um conteúdo maior de pirrotita em relação à amostra IV-22-16303 e uma ausência de clorita relativamente às outras amostras. Como acessórios ocorrem apatita, epídoto, granada (porfiroblasto metamórfico), rutilo, titanita, zircão, arsenopirita e pirrotita.

- Amostra IV-22-17905 (Clorita-flogopita sericita xisto carbonoso): amostra mineralizada do Corpo IV com ouro livre. A sulfetação se destaca com até 5\% de pirrotita e arsenopirita associada a sericitização (MS3), silicificação (na forma de veios de quartzo colocados na $\mathrm{S} 1$ crenulada pelo evento D3, além das $\mathrm{L}_{\mathrm{m} / \mathrm{e} 3}$ ). Foram observados ainda a albitização, turmalinização e cloritização, nódulos carbonosos arredondados (poupados do evento D4) e a ausência da granada. Como acessórios tem-se: zircão, turmalina, apatita, sericita (MS1).

A amostra escolhida do testemunho de sondagem K59 por sua semelhança petrográfica com o xisto carbonoso mineralizado do Corpo IV, apresenta as seguintes características:

- Amostra K59-19435 (Clorita-biotila-sericita xisto): indicação incipiente de mineralização de ouro. Pode representar a borda da alteração sericítica, onde ainda se reconhece a albitização, cloritização, turmalinização. Nódulos carbonosos se apresentam arredondados e não foi observado granada. Ocorre destruição pelo evento D3 do epídoto assim como a deformação do plagioclásio. Os acessórios são: zircão, turmalina, apatita, epídoto, dolomita e rutilo. 
Foram realizadas diversas análises nessas amostras visando caracterizar as diversas fases minerais envolvidas nas alterações que se relacionam ou não a mineralização de ouro.

As análises da biotita em todas as amostras anteriormente mencionadas foram reunidas na FIGURA 12. Pode-se notar que a biotita da amostra IV-22-16303 (BT4) deve representar possivelmente as zonas de influência mais próximas do cisalhamento imposto pelo evento neoproterozóico, e estas apresentam uma composição mais definida no campo de classificação da biotita (FIGURA 14). Todas as outras amostras apresentam uma composição intermediária entre a flogopita e a biotita, sendo que ocorrem fortes indícios de que a biotita relativamente mais magnesiana, chegando à composição da flogopita, está relacionada ao evento mineralizante no D3. Essa observação reforça o fato que ao final deste evento ocorreu um forte metassomatismo ferro-magnesiano relacionado a mineralização de ouro e sulfetos.

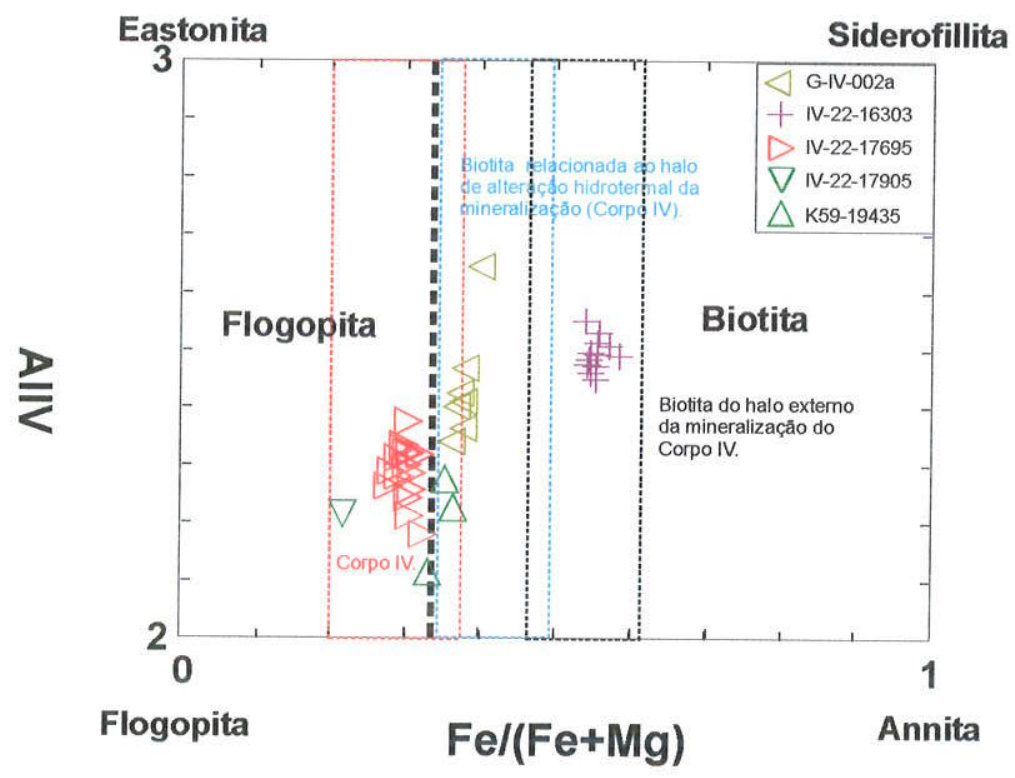

FIGURA 14 - Diagrama de classificação química da biotita nas amostras G-IV-002, IV-22-16303, IV-22-17695, IV-22-17905 e K59-19435 (39 análises).

A sericitização (MS3) é reconhecidamente um componente da alteração relacionada a mineralização, sendo a mesma rara a inexistente fora dos halos hidrotermais mineralizados ou dentro das zonas intensamente cisalhadas pelo tardio evento D4 (FIGURA 15). Na amostra GIV-002a, a sericita é o componente principal da matriz com freqüente ocorrência de micrólitons revelando a foliação anterior $\left(\mathrm{S}_{1}\right)$. Sua composição química varia entre os cristais dos micrólitons, na qual há enriquecimento em $\mathrm{Mg}^{2+} \mathrm{e} \mathrm{Fe}^{2+}$ em direção às bordas e uma leve tendência de empobrecimento em sílica. Essa entrada de fluidos ferro-magnesianos no sistema está aparentemente vinculada ao evento D3 e conseqüentemente a mineralização de ouro e sulfetos no Corpo IV, fato comprovado pelas medições microtermométricas nas inclusões fluidas (ver Capítulo V, medidas das temperaturas do eutético). 

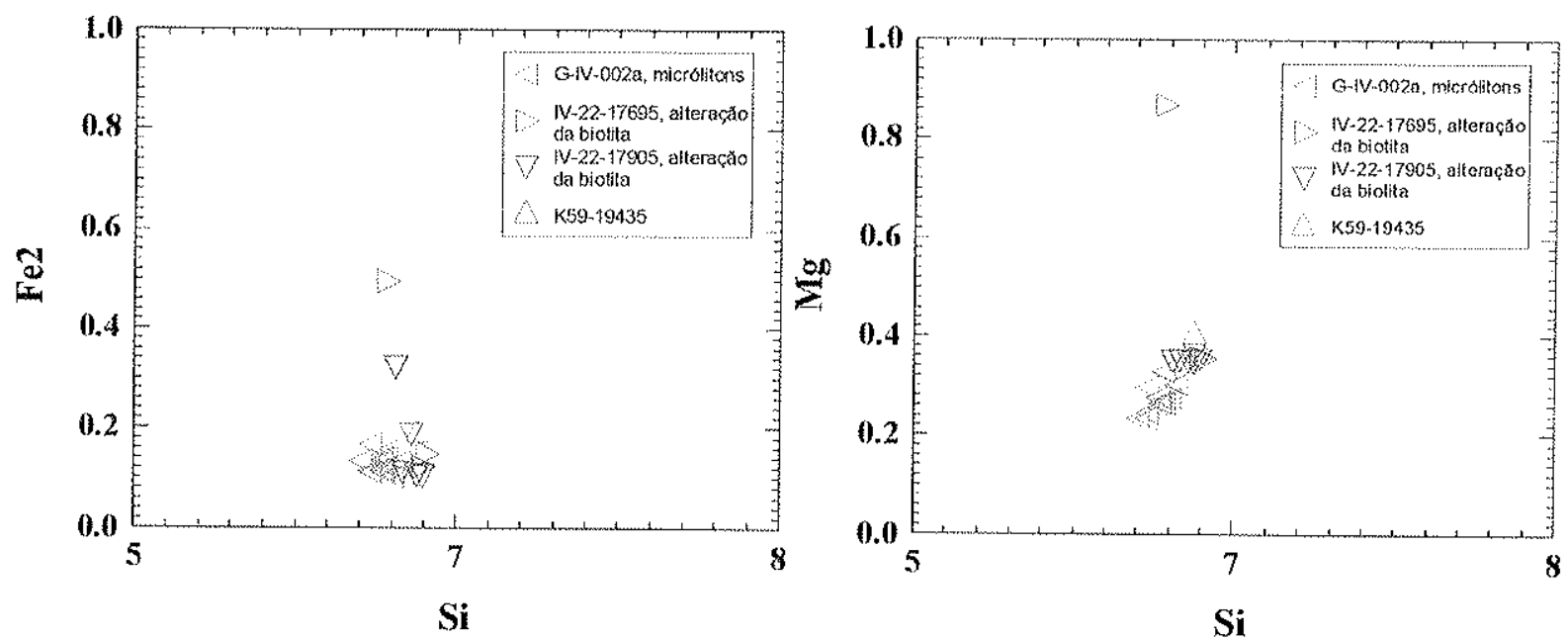

FIGURA 15 - Diagrama de classificação química da sericita nas amostras G-IV-002, IV-22-16303, IV-22-17695, IV-22-17905 e K59-19435 (23 análises).

A análise da clorita (CHL3 ou CHL4) apresenta problemas devido à alteração hidrotermal tardia que afeta os cristais. As poucas análises de qualidade indicam que a clorita hidrotermal tem composição de picnoclorita, com variações para ripidiolita (FIGURA 16). Essas análises foram feitas em um mineral do mesmo domínio estrutural e com as mesmas características ópticas, havendo, desta forma, necessidade de mais análises para avaliar se esta variação no quimismo esta relacionada a variações no fluido hidrotermal, ou se trata apenas de um problema analítico. A petrografia indica pouco ou nenhum relacionamento direto com a mineralização, mas a presença intensa de clorita pode indicar alterações posteriores que eventualmente tenham obliterado zonas mineralizadas.

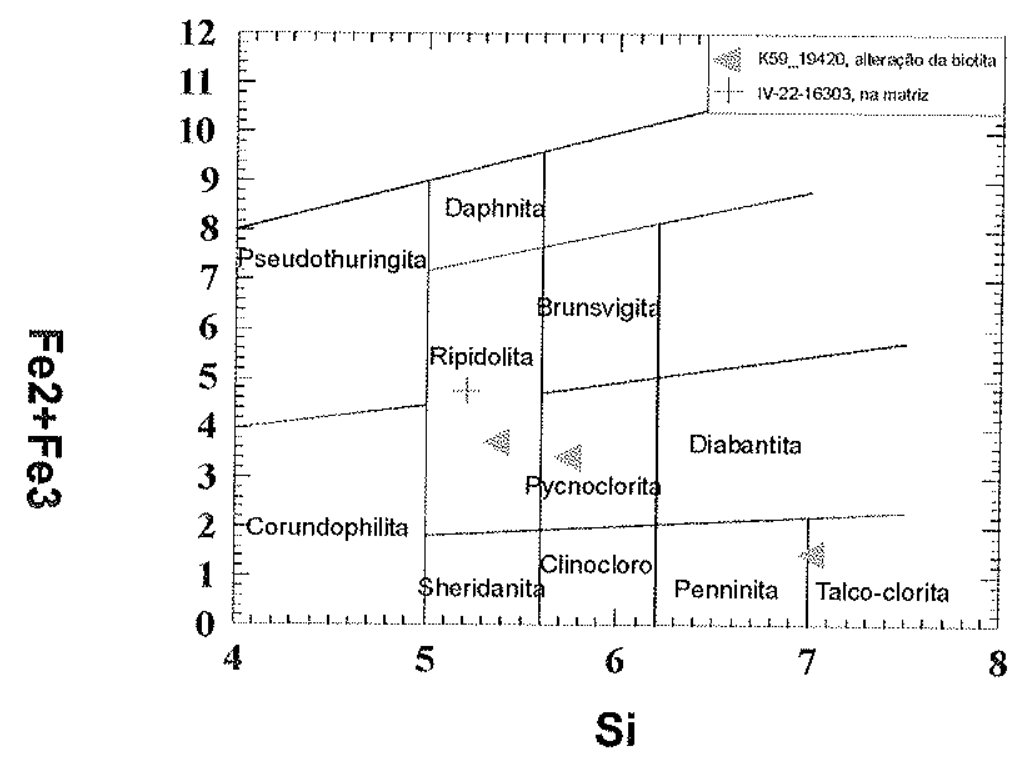

FIGURA 16 - Diagrama de classificação quúmica da clorita nas amostras IV-22-16303 e K59-19435 (4 análises). 
As análises dos feldspatos nas amostras G-IV-002, IV-22-16303, IV-22-17695 e IV22-17905 revelaram diferenças entre as fases mais proximais e distais da zona mineralizada conforme mostra a FIGURA 17. As zonas mais externas em relação a mineralização apresentam oligoclásio alterando para plagioclásio mais sódico, enquanto que dentro da zona mineralizada ocorre a albita praticamente pura.

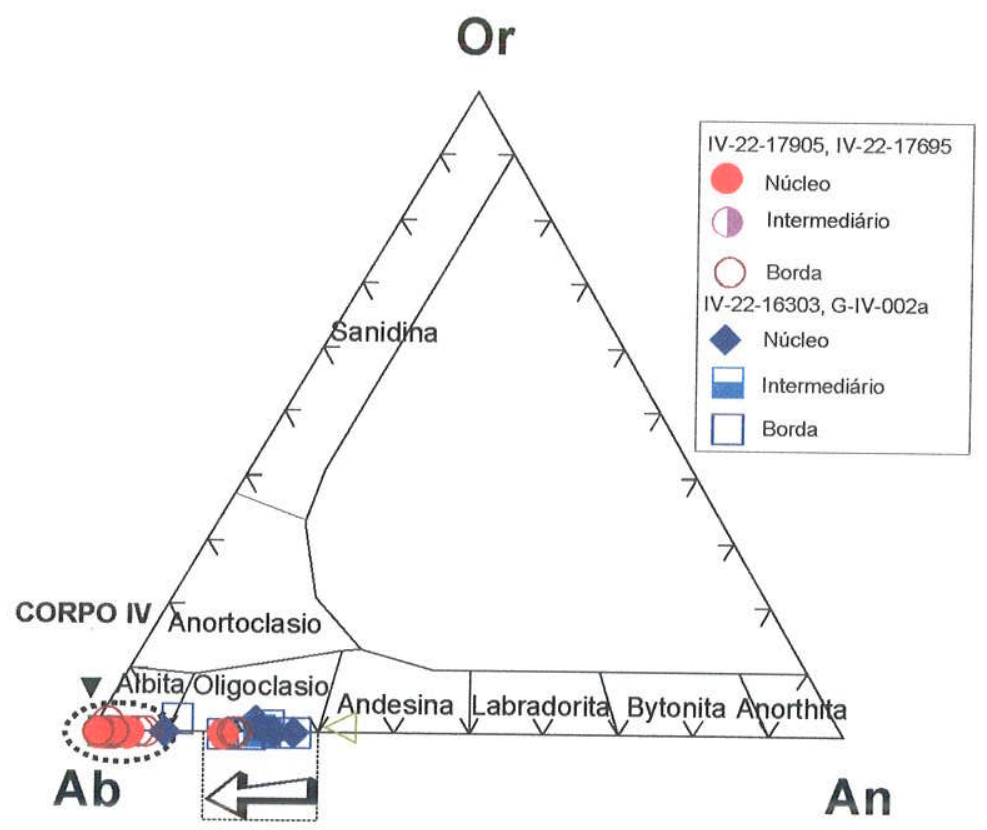

FIGURA 17 - Diagrama de classificação química do feldspato nas amostras G-IV-002, IV-22-16303, IV-22-17695 e IV-22-17905 (34 análises).

Foram realizadas análises em granada da amostra IV-22-16303 (FIGURA 18), permitindo a sua classificação como almandínica, e, revelando uma composição mais magnesiana em relação a granada nas demais zonas não mineralizadas com granada da Mina III (ver adiante).

Os perfís analíticos realizados em uma granada da amostra IV-22-16303 (FIGURA 19) mostram uma tendência de enriquecimento de ferro em detrimento ao cálcio do núcleo para as bordas do cristal. 


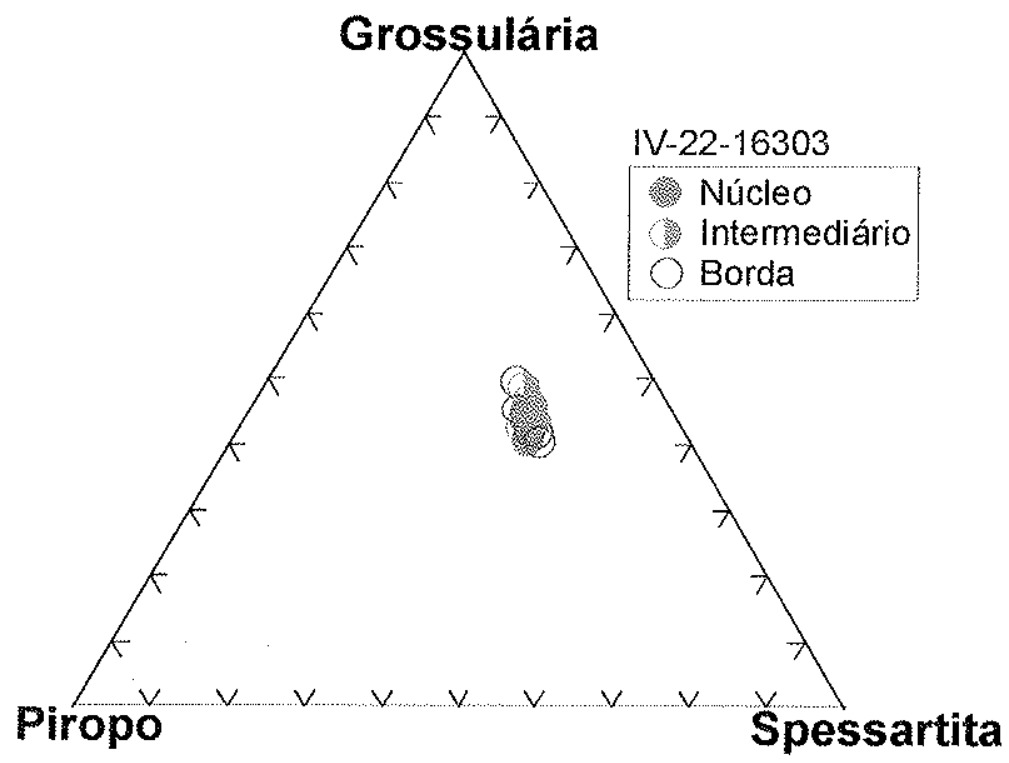

FIGURA 18 - Diagrama de classificação química da granada na amostra IV-22-16303 (24 análises).
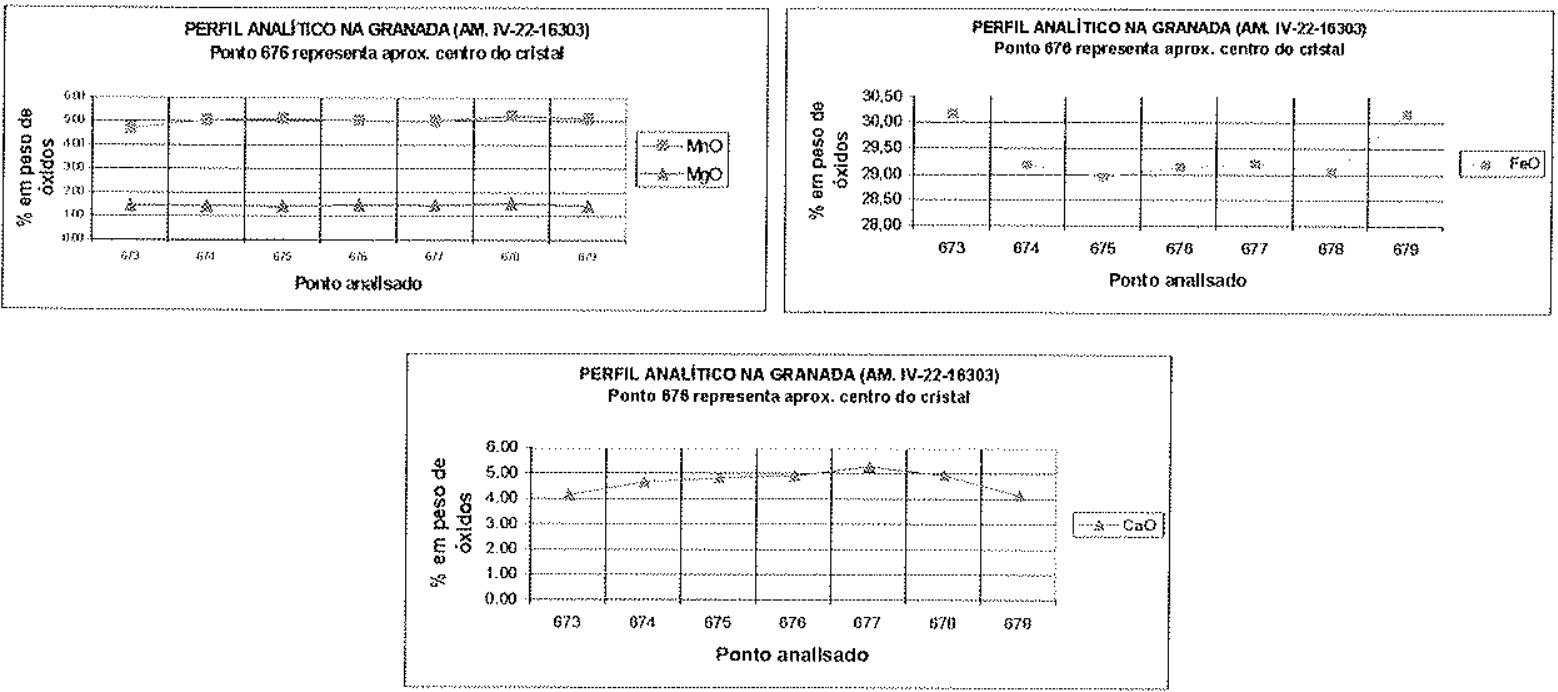

FIGURA 19 - Perfis analíticos para $\mathrm{Mg}+\mathrm{Mn}, \mathrm{Fe}$ e Ca em granada da amostra IV-22-16303

A análise de carbonatos nas amostras IV-22-16303, IV-22-17695, IV-22-17905 e K59-19435 (FIGURA 20) mostrou que os mesmos apresentam composição intermediária entre a dolomita e a anquerita, tratada doravante como dolomita ferrosa. Nas fases mineralizadas a dolomita ferrosa ocorre inclusa no plagioclásio e parcialmente inclusa na pirrotita. A calcita levemente ferrosa ocorre na amostra K59-19435 associados a clastos. Em alguns pontos da amostra os clastos já arredondados e estirados de calcita primária sofrem alterações, gerando clorita e biotita, restando seus contornos marcados pela biotita milonítica (BT3). As análises em geral não revelaram a presença de rodocrosita e, sendo assim, não foi necessária a apresentação do diagrama de classificação com essa fase carbonática. 


\section{Calcita}

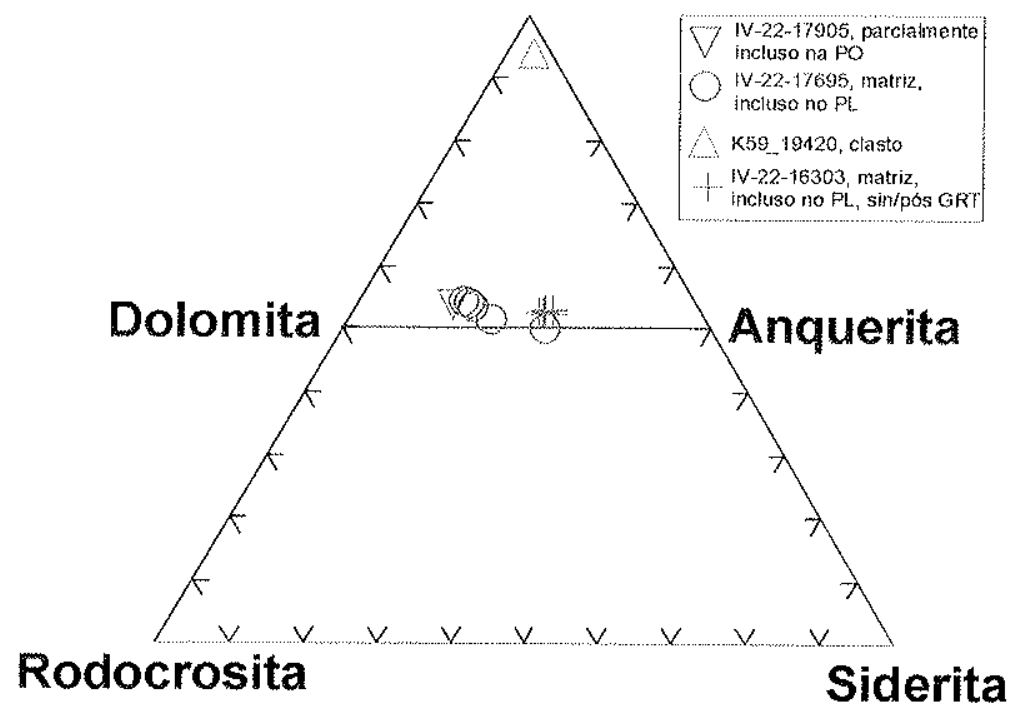

FIGURA 20 - Diagrama de classificação química do carbonato nas amostras IV-22-16303, IV-2217695, IV-22-17905 e K59-19435 (24 análises).

\section{METABÁSICAS}

Foram realizadas análises nas fases minerais de anfibolito da Formação Rio Vermelho para a caracterização da associação mineral, visando confrontá-la com análises de rochas metabásicas alteradas encontradas dentro da Formação Ribeirão das Antas.

A amostra IV-01914 (anfibolito fino) apresenta uma geração porfiroblástica de anfibólios, as vêzes orientados radialmente, imersos em uma matriz de anfibólios finos e plagioclásio. Como acessórios ocorrem epídoto, opacos não identificados, rutilo e titanita. Um veio tardio quartzo-feldspático tardio corta a amostra, possivelmente como resultado das mesmas alterações hidrotermais reconhecidas nos metasedimentos da Formação Ribeirão das Antas.

O anfibólio da metabásica pertencente à Formação Rio Vermelho revelou uma composição de hornblenda magnesiana/actinolita (FIGURA 21), relativamente ao núcleo e borda, sendo que esta associação é considerada uma relíquia da alteração dos piroxênios originais.

As análises dos porfiroblastos euédricos de anfibólio de alteração, relacionados ao final do evento D3, apresentam uma composição nitidamente diferenciada, caracterizada com Fe-tschermakita (ver adiante). Esta última geração de anfibólio foi reconhecida em quase todas as zonas mineralizadas (Mina III e Corpo IV) e se associa intimamente com os porfiroblastos euédricos de granada, cloritóide e arsenopirita (ASP3). 


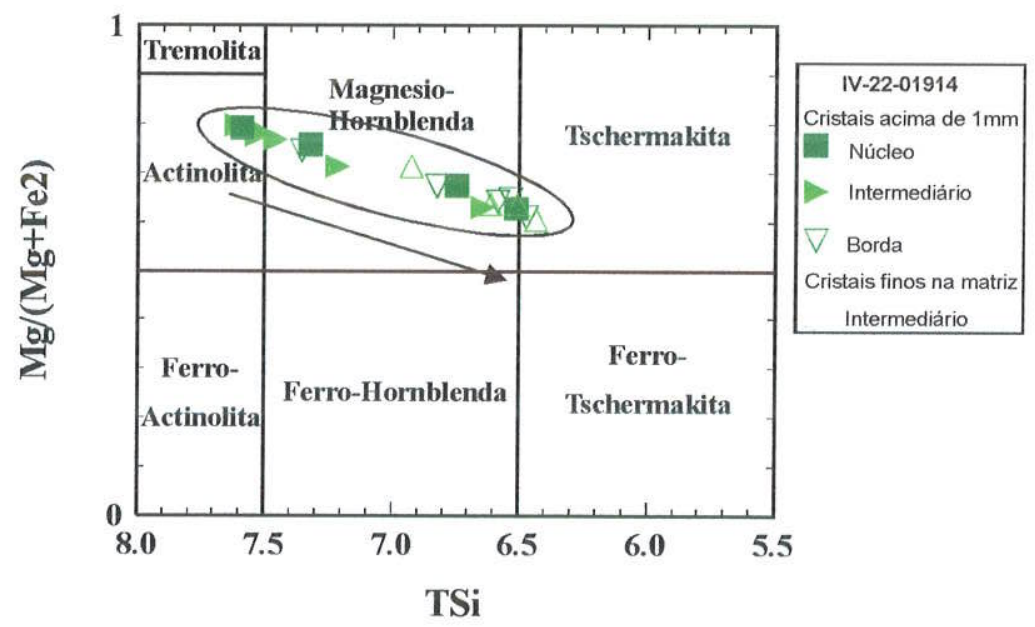

FIGURA 21 - Diagrama de classificação química do anfibólio na amostra IV-22-01914 (20 análises). A seta indica a direção composicional do núcleo para a borda dos cristais.

A análise dos feldspatos revelou uma tendência bastante semelhante da alteração hidrotermal as outras zonas mineralizadas da Mina III, caracterizada no halo interno da mineralização do Corpo IV, onde o oligoclásio torna-se mais sódico (FIGURA 22). O veio quartzo-feldspático tardio que corta a amostra IV-01914 também indica tal tendência. Isso sugere novamente uma semelhança dos sistemas de alteração que acometeram tanto o Corpo IV como as metabásicas e, se esse for o caso, mostra que a alteração feldspática permite a preservação de relíquias ígneas nas rochas metabásicas.

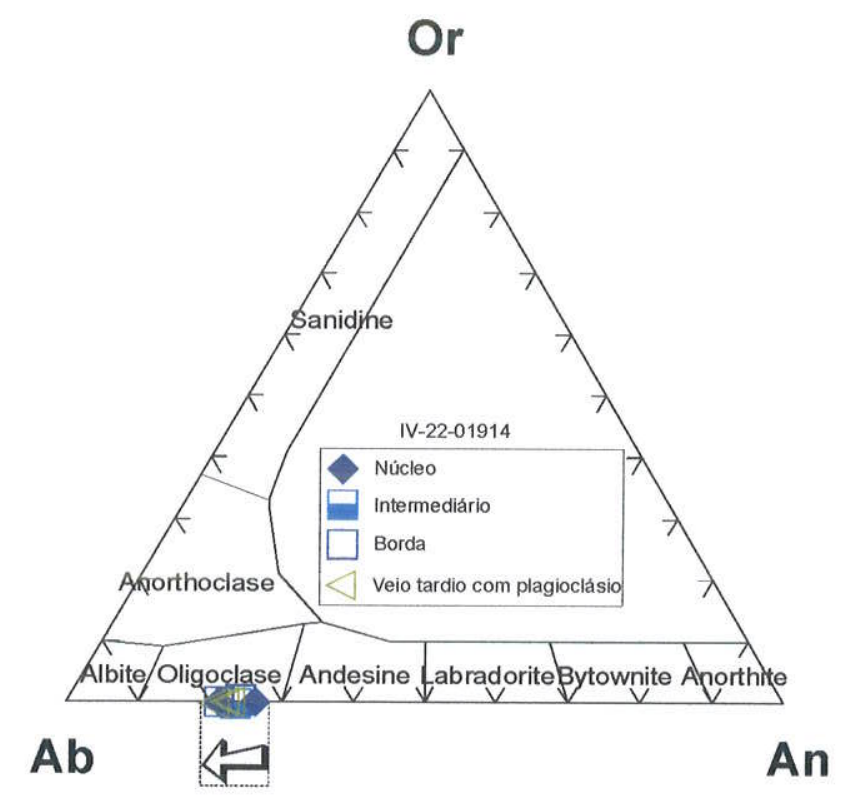

FIGURA 22 - Diagrama de classificação química do feldspato na amostra IV-22-01914 (8 análises). A seta indica a direção composicional do núcleo para a borda dos cristais. 
De maneira semelhante ao oligoclásio, a clorita encontrada nos veios quartzofeldspáticos tardios revela também uma composição semelhante à encontrada nos halos externos do Corpo IV (picnoclorita, FIGURA 23).

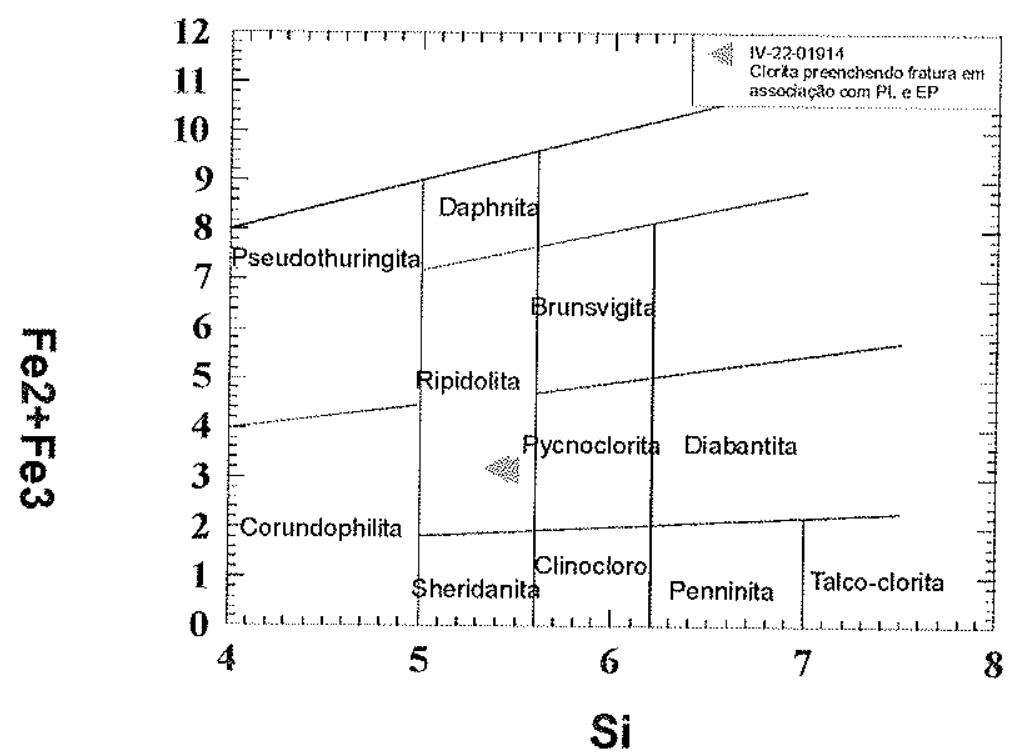

FIGURA 23 - Diagrama de classificação química da clorita na amostra IV-22-01914 (3 análises).

\section{ZONA DAS METABÁSICAS HIDROTERMALIZADAS}

Os estudos de testemunhos de sondagem que são apresentados na forma do perfil E-W (ANEXO 1) permitiram o reconhecimento de um corpo com dimensões consideráveis, e com características de rocha metabásicas, intercalado nos metassedimentos da Formação Ribeirão das Antas.

Foram analisadas 3 amostras com e sem mineralização de ouro, desta zona para se determinar as fases minerais e associações relacionadas com essas zona. As amostras analisadas foram:

- Amostra K59-29280 (Oligoclásio-dolomita-clorita xisto): a rocha apresenta silicificação, dolomitização e cloritização, esta última principalmente como resultado da alteração da biotita. Ocorrem porfiroblastos pós-tectônicos de magnetita em associação com veios carbonáticos (dolomita). Os acessórios são magnetita (porfiroblastos metamórficos), ilmenita e epídoto. Sem mineralização

- Amostra K59-34143 (Clorita-turmalina-oligoclásio-cloritóide-sericita xisto): ocorrem duas gerações de sericita sendo que a última é resultado da sericitização de vários 
minerais, em particular do oligoclásio. Ocorre mineralização a $10 \mathrm{~m}$ abaixo desta amostra. Outra alteração presente é a turmalinização que representa até $10 \%$ dos minerais na lâmina delgada estudada. Essa zona ainda apresenta porfiroblastos de Fe-tschermakita e cloritóide. Foram identificados apenas sulfetos como acessórios.

- Amostra K49-19790 (Biotita-dolomita-oligoclásio xisto): zona com forte albitização, mineralizada, além de vênulas tardias quartzo-carbonáticas. Como acessório ocorre arsenopirita euédrica com calcopirita nas bordas, além de leves sombras de pressão de biotita e carbonato. A sombra de pressão nos porfiroblastos se deve provavelmente a atuação do evento neoproterozóico.

As análises da biotita nas amostras K59-29280, K59-34143 e K49-19790 revelaram uma composição bem próxima do limite da flogopita, indicando a proximidade da mineralização, confirmada com exceção da amostra K59-29280 (FIGURA 24).

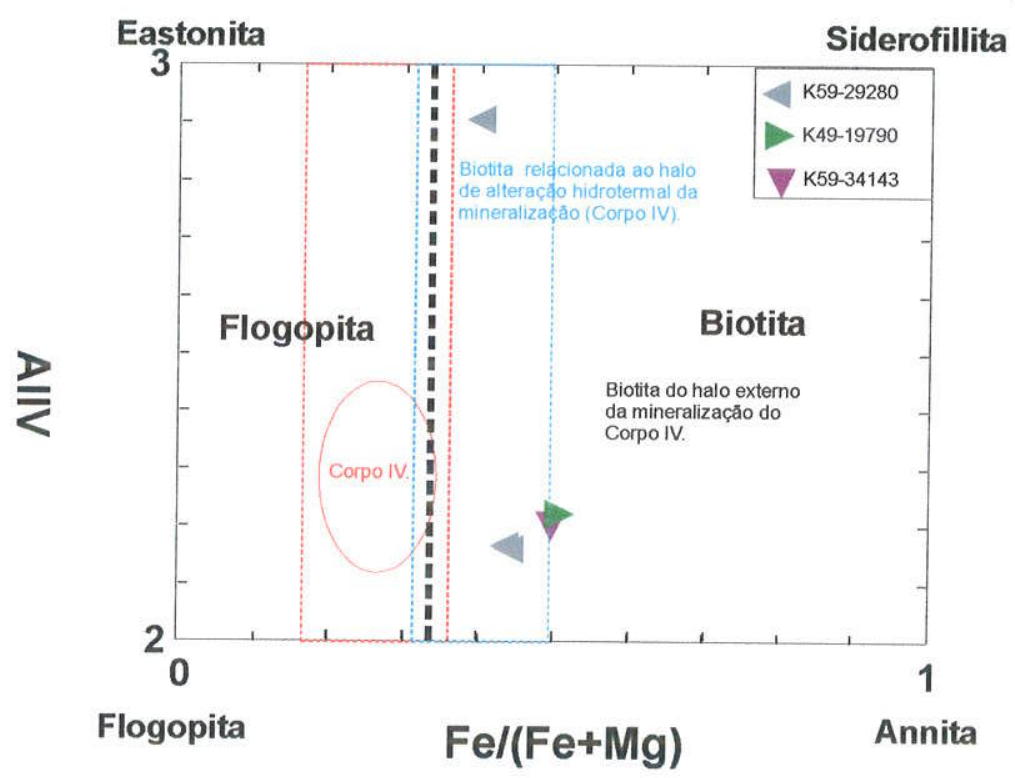

FIGURA 24 - Diagrama de classificação química da biotita na amostra K59-29280, K59-34143 e K49-19790 (5 análises).

A sericita pôde ser analisada na amostra K59-34143, cuja composição é muito semelhante à da MS3, relacionada ao evento D3 (FIGURA 25). Essa geração de sericita preenche parcialmente fraturas no cloritóide. 

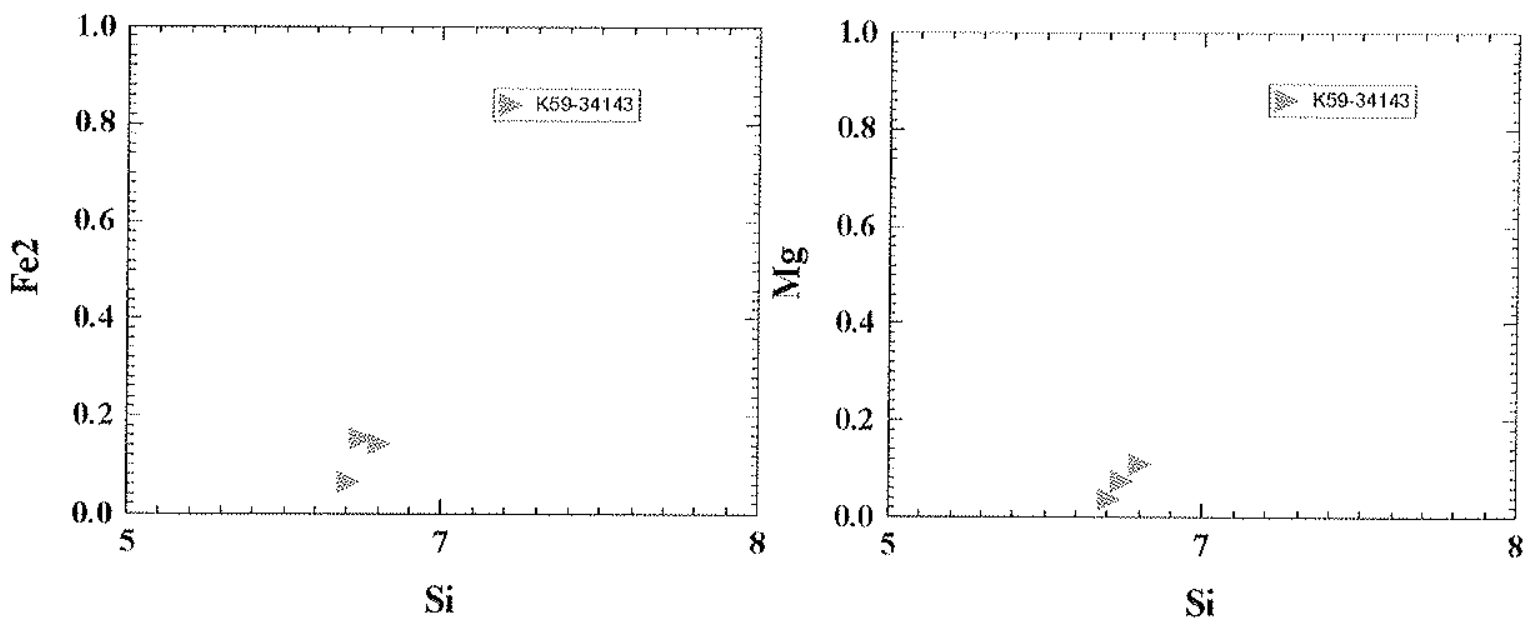

FIGURA 25 - Diagrama de classificação química da sericita na amostra K59-34143 (3 análises).

A clorita analisada nas três amostras mostrou uma variação composicional (FIGURA 26), provavelmente devido ao tipo de protólito alterado. A alteração da Fe-tschermakita gera picnoclorita, enquanto que a alteração da biotita na amostra K49-19790 gera diabanita. As características dos cristais alterados da clorita analisada pode ter causado problemas analíticos, sendo que os dados obtidos devem ser interpretados com reservas. Ocorre ainda clorita na matriz, entre os porfiroblastos metamórficos de cloritóide, que apresentam uma cor de interferência azul intensa e distinta dos demais tipos de clorita.

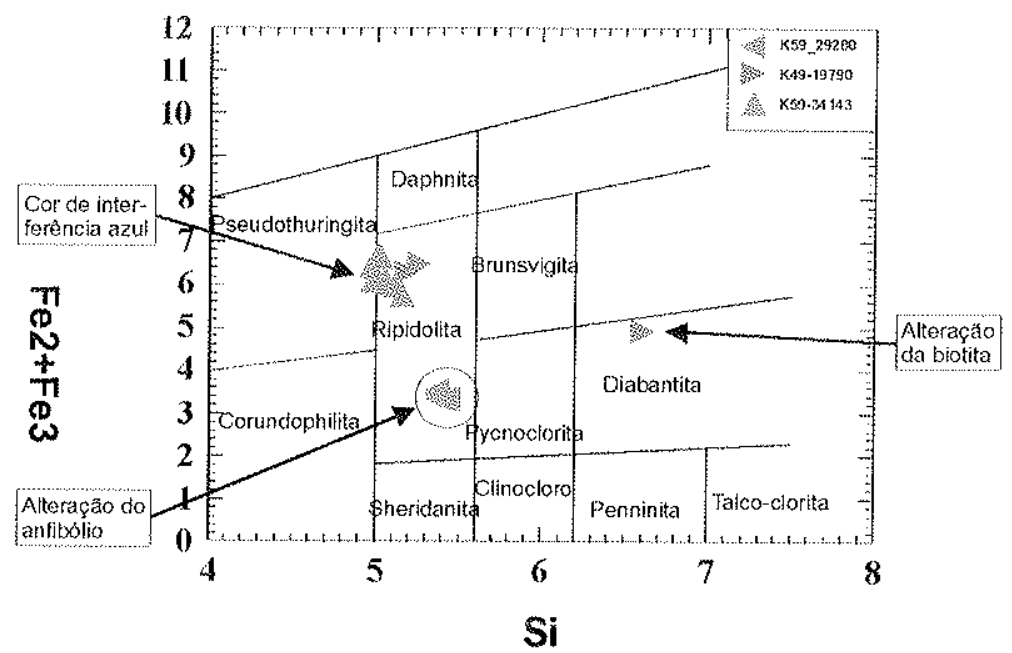

FIGURA 26 - Diagrama de classificação química da clorita na amostra K59-29280, K59-34143 e K49-19790 (16 análises).

Os feldspatos nas três amostras revelaram composições muito semelhantes às proximidades do Corpo IV, com destaque para a amostra K49-19790 (FIGURA 27). A 
amostra K59-34143 apresenta oligoclásio com inclusões de ilmenita e blastese singenética à granada. O oligoclásio na amostra K59-29280 ocorre na matriz. Na amostra K49-19970 ocorre albita na forma pura em concordância com a mineralização desta amostra, como resultado extremo da albitização, preenchendo fraturas, às vezes com formas euédricas e sendo interpretado como singenético à turmalina e à arsenopirita.
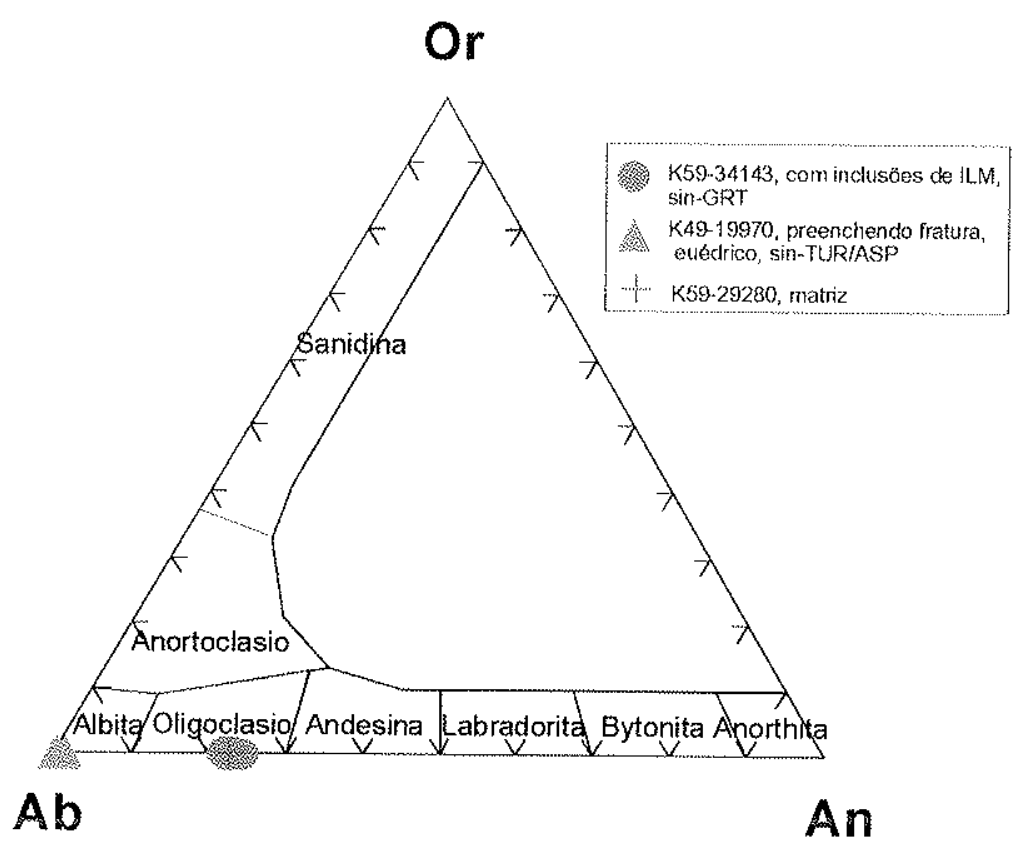

FIGURA 27 - Diagrama de classificação química do feldspato na amostra K59-29280, K59-34143 e K49-19790 (18 análises).

As análises dos carbonatos revelaram novamente uma variação entre as composições de calcita e de dolomita ferrosa (FIGURA 28), sendo caracterizado sua fase singenética com a arsenopirita, provavelmente ASP3. A calcita ocorre como uma fase tardia, pós-fraturas do cloritóide, provavelmente relacionada ao evento D4.

As análises nas diversas fases minerais não confirmaram indícios de variação química que pudesse caracterizar essa zona como sendo alterações de um protólito metabásico, com exceção, talvez, da presença de magnetita e cloritóide e da ausência de granada. 


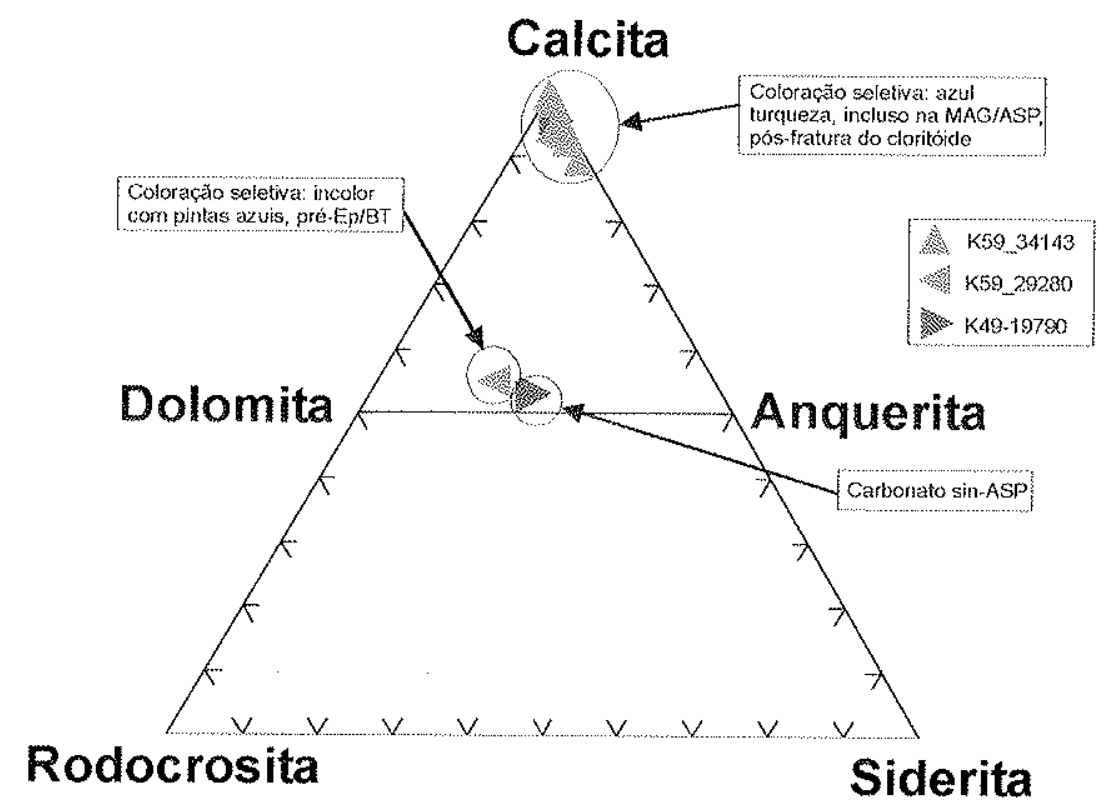

FIGURA 28 - Diagrama de classificação química do carbonato nas amostras K59-29280, K59-34143 e K49-19790 (19 análises).

\section{ZONA SUPERIOR DA MINA III}

Durante os estudos dos testemunhos de sondagem foi coletada uma amostra nas proximidades da zona superior, descrita a seguir:

- Amostra K49-26274 (Cloritito com porfiroblastos de cloritóide, anfibólio e granada): zona da lapa do minério da zona superior, sendo que $20 \mathrm{~m}$ acima no testemunho de sondagem tem início as anomalias de Au (a amostra estudada não tem análise), onde ocorre uma massa de cloritito com porfiroblastos metamórficos sin- a pós-tectônicos (evento D3), centimétricos, de granada, Fe-tschermakita e cloritóide. Como acessórios ocorrem carbonato e biotita e como minerais de alteração hidrotermal, clorita (alteração do anfibólio, cloritóide e granada) e sericita (alteração do cloritóide). Ocorrem ainda delgados veios quartzo-carbonáticos tardios.

A sericita encontrada na amostra é resultado da alteração de fases minerais como a clorita (CH2), cloritóide e biotita (BT2) como evidência da sericitização do evento D3, que associada aos outros processos de alteração caracteriza a alteração propilítica (ver Capítulo

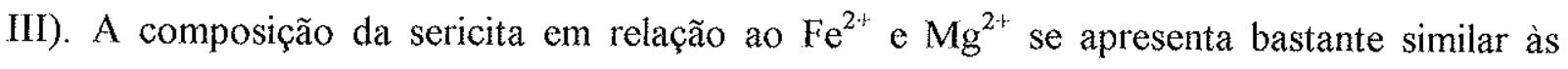
outras zonas de alteração (FIGURA 29), reforçando a hipótese anteriormente mencionada. Esta amostra revelou ainda a presença de margarita, inclusa parcial- ou totalmente no cloritóide e representa uma das alterações desse mineral. 

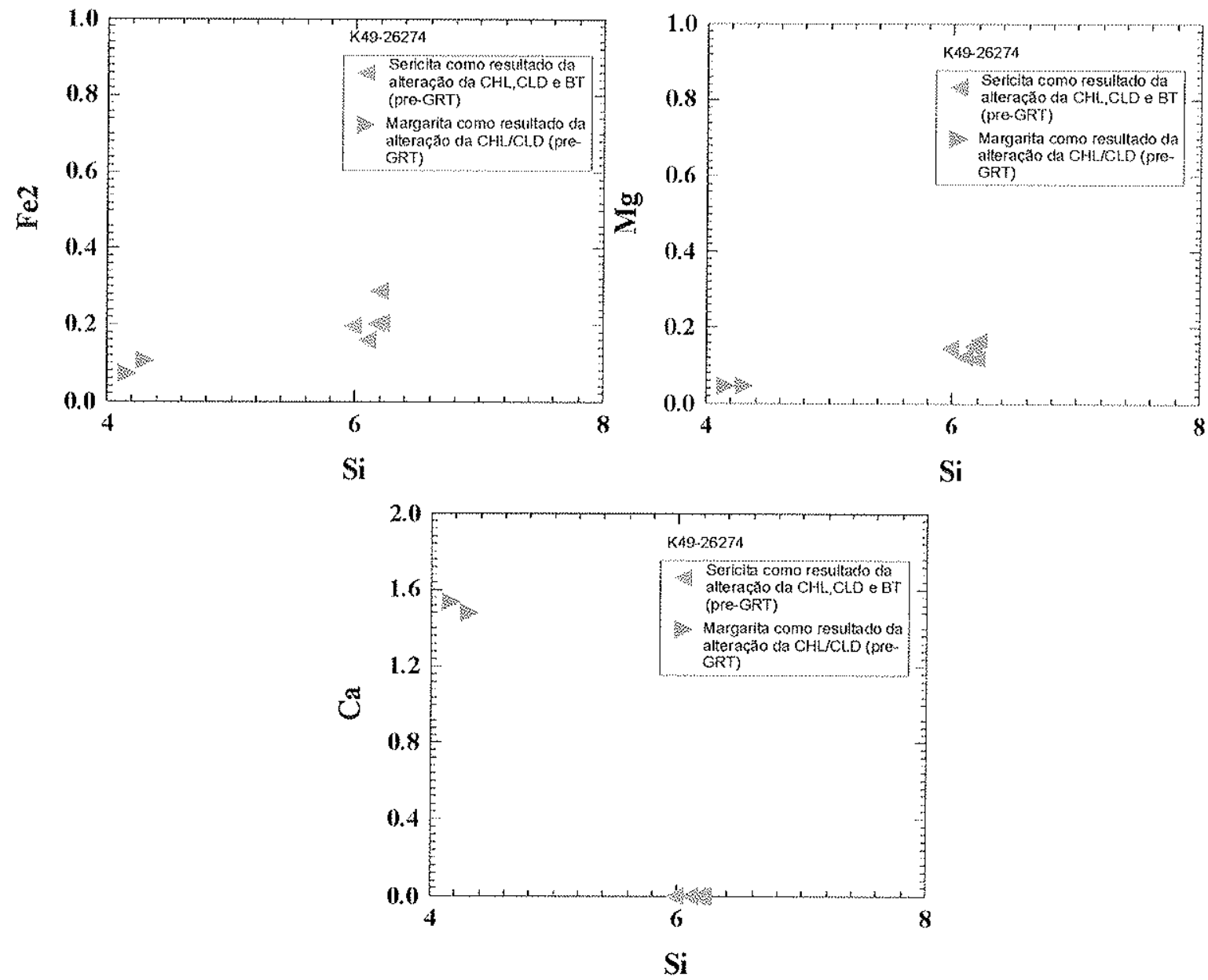

FIGURA 29 - Diagrama de classificação química da sericita e margarita na amostra K49-26274 (7 análises).

Foram realizadas análises em alguns cristais de clorita (FIGURA 30) que são resultado de alteração da sericita e granada, devendo assim tratar-se da CHL4 tardia (neoproterozóica). A sua composição é de ripidolita, em contrapartida à clorita do evento D3, que é picnoclorita. Essa observação é reforçada pelas características da mudança composicional na sericita e granada, com um enriquecimento quase contínuo em ferro. 


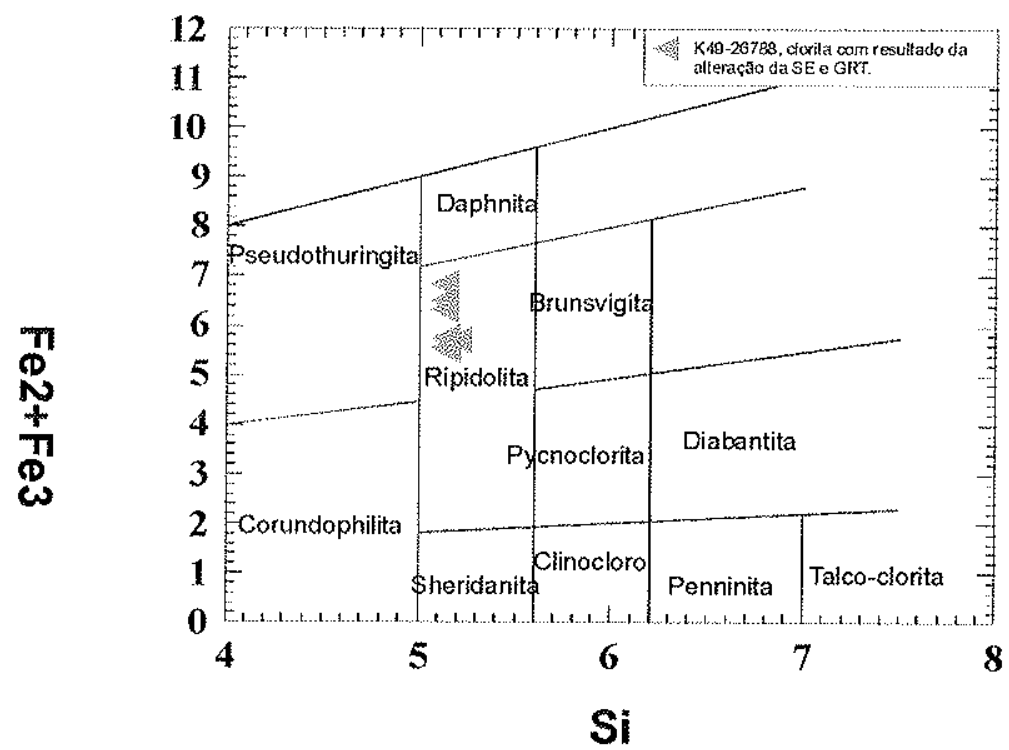

FIGURA 30 - Diagrama de classificação química da clorita na amostra K49-26274 (8 análises).

A granada se apresenta sob a forma de porfiroblastos metamórficos, singenéticos ao anfibólio e cloritóide (com pequenas diferenças de contemporaneidade), sendo que foram realizados perfis analíticos em diversos cristais na tentativa de revelar modificações composicionais durante o seu desenvolvimento. Trata-se basicamente de almandina com variações nos membros piropo, grossulária e espessartita conforme mostra a FIGURA 31. Na FIGURA 31 pode-se reconhecer basicamente duas fases evolutivas distintas (ver seta): uma inicial de enriquecimento em Ca com perda de Mn e logo após uma fase com enriquecimento em $\mathrm{Mg}$ e Fe. Essa última fase caracteriza uma das evidências para a alteração propilitica associada à mineralização de ouro e sulfetos, durante o final do evento D3.

O detalhamento do perfil analítico dessa granada mostra (FIGURA 32) relações dos teores de $\mathrm{Ca}-\mathrm{Mg}-\mathrm{Fe}-\mathrm{Mn}$ que indicam que a cristalização do núcleo da granada ocorreu em temperaturas relativamente baixas, mas a pressões relativamente mais altas, ao qual segue-se uma parte intermediária com aumento contínuo da temperatura e queda da pressão. Após esta fase houve ainda aumento da temperatura e da pressão, até os reequilíbrios finais nas bordas, com fortes quedas na temperatura e na pressão. Este complexo padrão terá de ser melhor estudado, mas mostra correlações com o comportamento do zonamento químico observado parcialmente no plagioclásio, podendo ainda estar associado à evolução de forma recorrente na fase final do evento D3. 


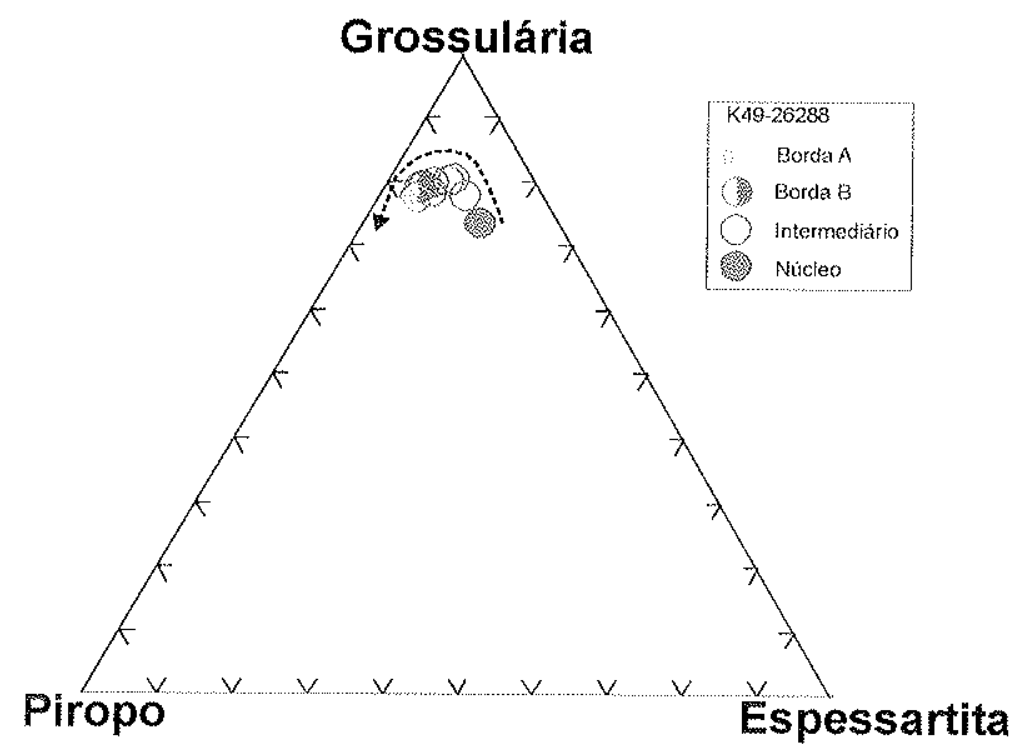

FIGURA 31 - Diagrama de classificação química da granada metamórfica na amostra K49-26274 (10 análises).
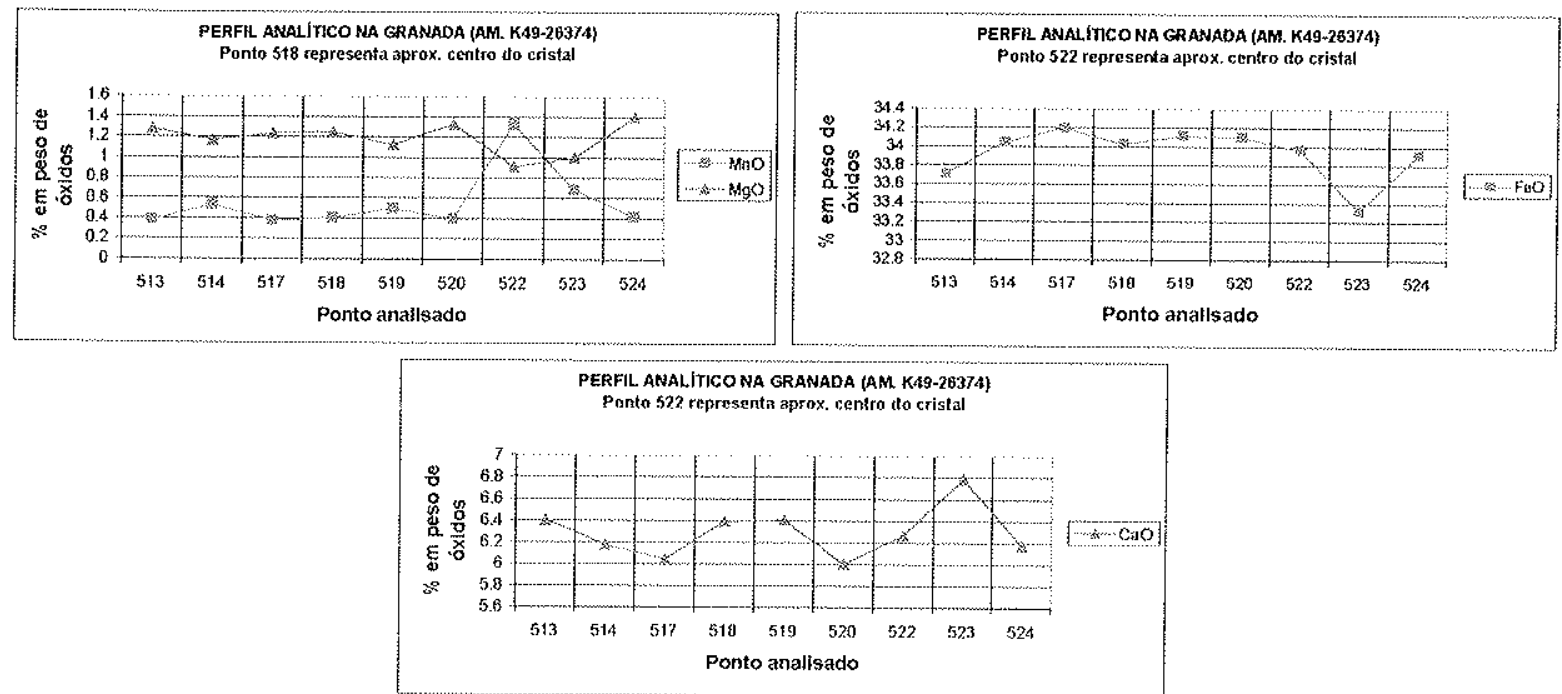

FIGURA 32 - Diagramas do perfil das análises de química mineral em um cristal de granada metamórfica na amostra K49-26274 (10 análises).

As análises do anfibólio confirmam a diferença composicional em relação à hornblenda/actinolita encontradas nas metabásicas da Formação Rio Vermelho. O anfibólio dessa zona é Femtschermakita (FIGURA 33) na forma de porfiroblastos metamórficos relacionados ao final do evento D3, possivelmente paleoproterozóico, sem evidências consideráveis de mudança composicional nas análises de núcleo e borda dos cristais. 


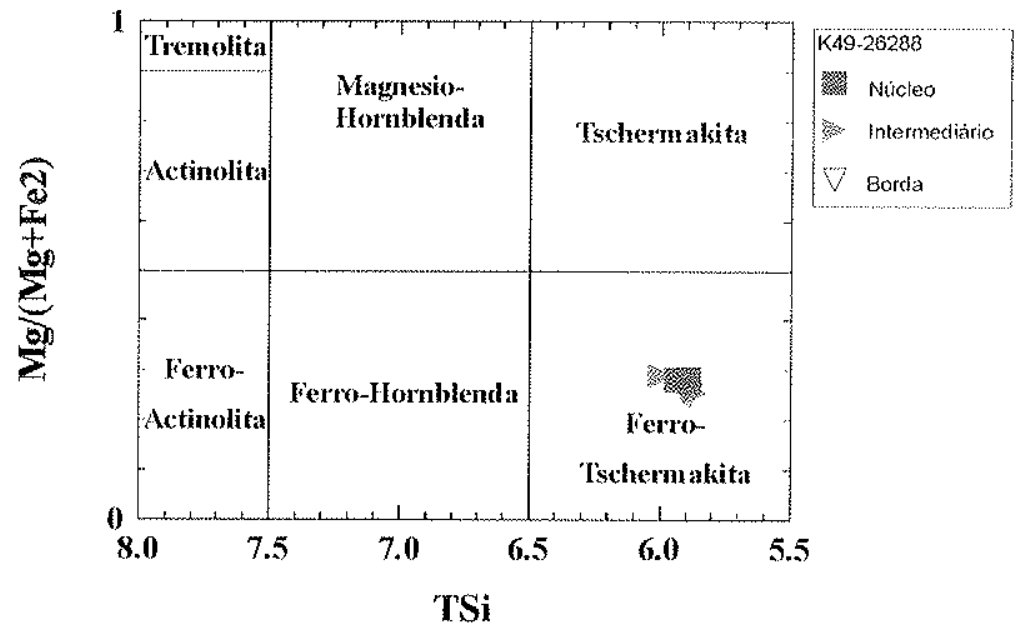

FIGURA 33 - Diagrama de classificação química do anfibólio metamórfico na amostra K49-26274 (9 análises)

Os carbonatos da amostra K49-26378 ocorrem apenas como inclusões nos porfiroblastos metamórficos da granada e anfibólio (com exceção dos veios quartzocarbonáticos tardios), não tendo sido encontrado na matriz. A análise dessas inclusões minerais revelou composição da calcita, que pode representar fases primárias preservadas do carbonato (FIGURA 34)

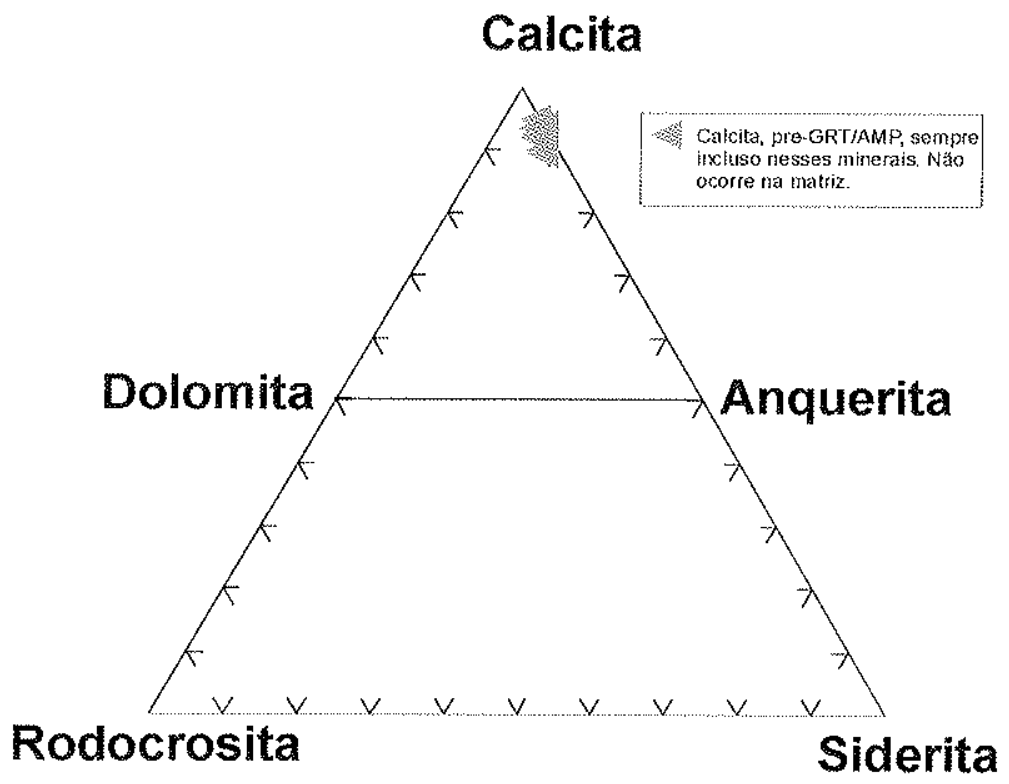

FIGURA 34 - Diagrama de classificação química do carbonato na amostra K49-26274 (8 análises). 


\section{ZONA INTERMEDIÁRIA DA MINA III}

As amostras a seguir representam a Zona Intermediária da Mina III, onde a mineralização também apresenta a associação granada, Fe-tschermakita e as alterações, que em conjunto caracterizam o evento propilítico.

As amostras possuem as seguintes características petrográficas:

- Amostra K59-38571 (Cloritito com porfiroblastos de granada): basicamente na porção superior de uma faixa de cloritito com porfiroblastos metamórficos de granada sem mineralização de Au ou sulfetos, situa-se na capa de uma anomalia de Au e sulfetos (não atinge teor de corte nessa região). Ocorrem veios quartzo-carbonáticos onde se reconhecem cristais euédricos de quartzo, indicando crescimento em condições de alívio, provavelmente devido a um evento (D2?) que gerou brechamento nessa porção. O carbonato substitui pseudomorficamente a granada e o plagioclásio, e a sericita ocorre como duas gerações: uma que se apresenta dobrada, pré- D3, e outra que sericitiza a clorita (CHL2), provavelmente do final do evento D3. Como acessórios ocorrem biotita, quase sempre intensamente cloritizada, apatita e rutilo.

- Amostra K59-38587 (Cloritito com porfiroblastos de granada): bastante semelhante a Amostra K59-38571, mas agora em uma posição no limite inferior da faixa do cloritito com granada em relação à amostra K59-38571. Não ocorrem mineralização de ouro e sulfetos. Um veio tardio (evento D4) corta a amostra com quartzo, calcita e cristais euédricos de siderita, esta última típica do evento D4 (ver Capítulo V sobre estudo dos veios de quartzo). Biotita ocorre de maneira disseminada, sendo que a clorita se apresenta na forma de várias gerações (CHL2, CHL3 e CHL4), alterando diversas fases minerais. Essa zona ainda sofreu albitização. Sericita, epídoto e apatita foram observados como acessórios.

- Amostra K03-22755 (Cloritito com porfiroblastos de granada): Esta amostra representa praticamente a lapa da zona intermediária mineralizada, com Au visível e sulfetos (pirrotita até $5 \%$ e arsenopirita em menor quantidade). Basicamente clorita na matriz, com sulfetos e carbonatos. Ocorrem também nódulos carbonosos arredondados e porfiroblastos de granada sin-sulfetos. A biotita destaca-se entre os acessórios estando quase totalmente cloritizada. Ausência de plagioclásio.

- Amostra K03-23040 (Biotita xisto carbonoso): Ainda na zona intermediária mineralizada, representando a capa do minério com Au visível e sulfetos (com até $10 \%$ de arsenopirita e 
3\% de pirrotita). Apresenta bastante carbonato, sulfetização e albitização. Até $10 \%$ de material carbonoso.

Foi analisada a biotita das amostras K59-38571, K59-38578 e K03-23040, sendo que as duas primeiras apresentaram fases bem caracterizadas no campo da biotita (FIGURA 35), semelhante a biotita que ocorre no halo mais externo e não mineralizado do Corpo IV (relativamente menos magnesianas). A biotita da amostra mineralizada K03-23040 destaca-se pelo seu conteúdo relativamente maior em magnésio, comprovando a hipótese da variação composicional relativamente à distância da mineralização, onde as zonas hidrotermais mais próximas à mineralização contêm minerais de composição mais magnesiana.

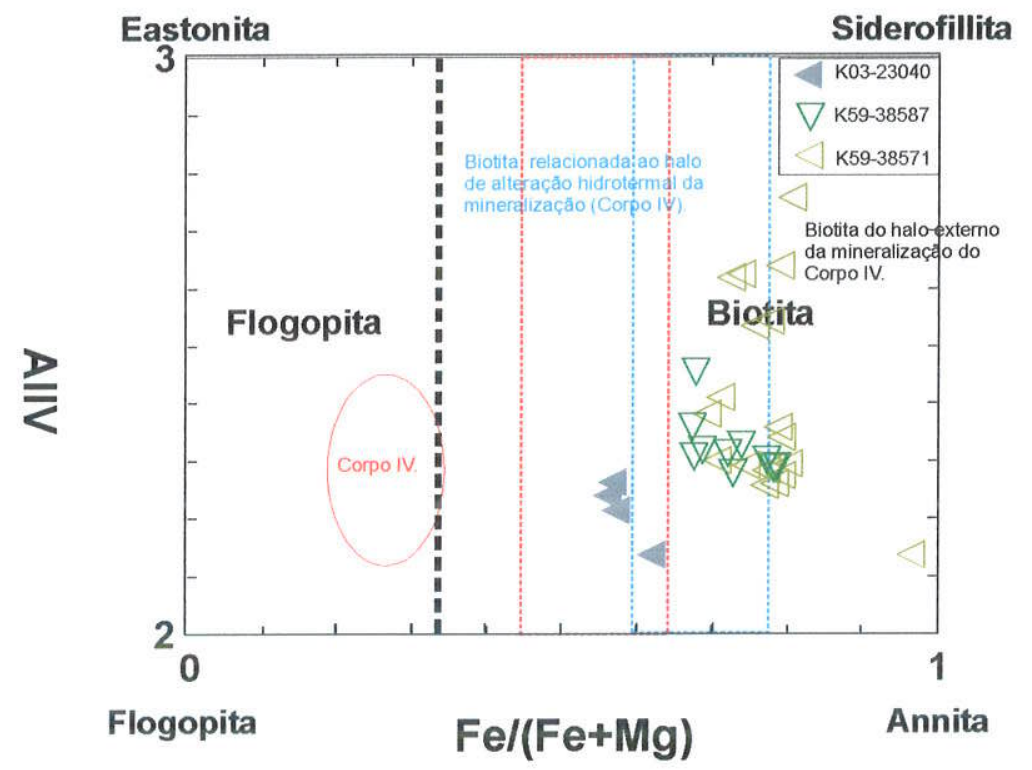

FIGURA 35 - Diagrama de classificação química da biotita nas amostras K59-38571, K59-38578 e K03-23040 (38 análises).

A sericita apresentou pouca variação composicional nas amostras K59-38571, K5938578 e K03-23040 mantendo ainda grande semelhança composicional com a sericita do Corpo IV. Fica evidente, entretanto, a relação inversa do conteúdo em ferro e magnésio onde as amostras não mineralizadas K59-38571 e K59-38578 são mais ricas em $\mathrm{Fe}^{2+}$ ao contrário da sericita na amostra fortemente mineralizada K03-23040, que tem variação positiva para $\mathrm{Mg}^{2+}$ (FIGURA 36). 

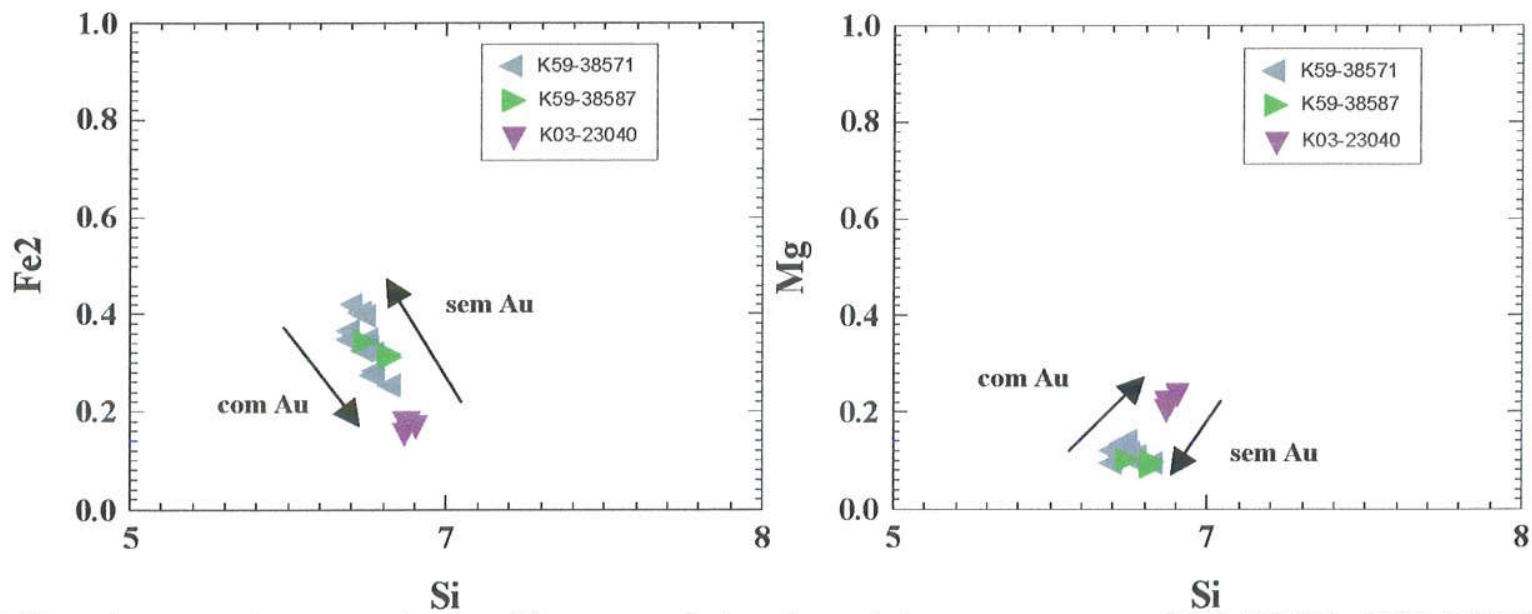

FIGURA 36 - Diagrama de classificação química da sericita nas amostras K59-38571, K59-38578 e K03-23040 (22 análises).

A análise da clorita revelou de maneira geral uma composição da ripidolita (FIGURA 37), semelhante a amostra K49-26274 (zona superior não mineralizada quanto a sulfetos e $\mathrm{Au}$, e relacionada ao evento neoproterozóico) e a amostra IV-22-16303 (halo externo da mineralização do Corpo IV, também sem mineralização). Ocorrem exceções em campos de classificação próximos, mas sem representação interpretativa até o momento, podendo até tratar-se de problemas analíticos gerados pelo estado alterado dos cristais de clorita.

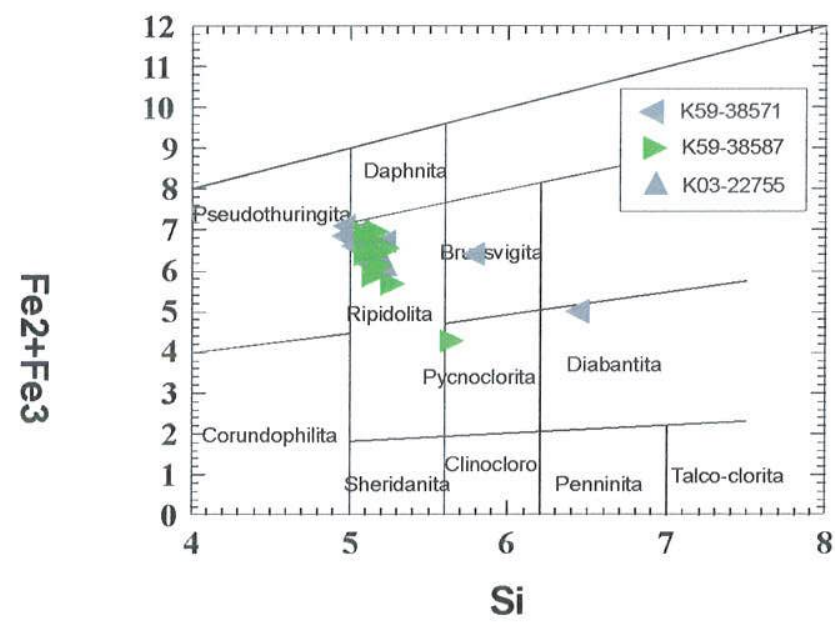

FIGURA 37 - Diagrama de classificação química da clorita nas amostras K59-38571, K59-38578 e K03-22755 (29 análises).

O feldspato mostrou a mesma tendência das zonas albitizadas com uma evolução do oligoclásio em direção a albita pura, como mostra a FIGURA 38, com a classificação do plagioclásio das amostras K59-38571, K59-38578 e K03-23040. Nota-se que na amostra 
mineralizada K03-23040, não é atingido o campo da albita pura, o que pode evidenciar instabilidade dessa próxima do núcleo da alteração (cloritito com granada).

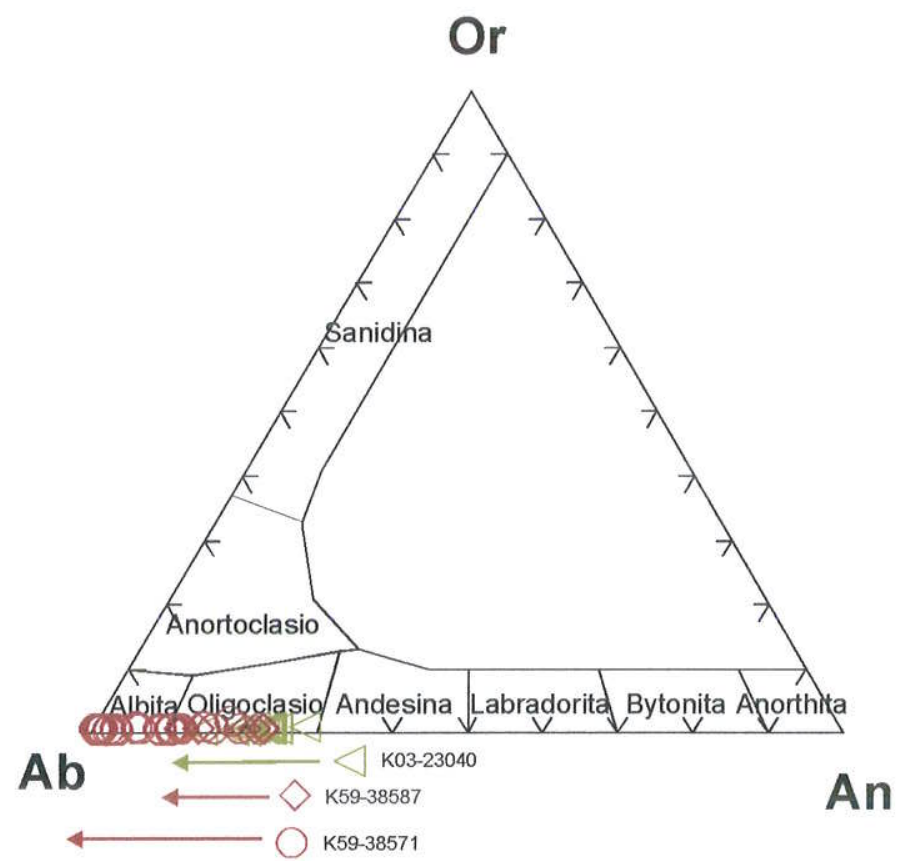

FIGURA 38 - Diagrama de classificação química do feldspato nas amostras K59-38571, K59-38578 e K03-23040 (51 análises).

Os carbonatos ocorrem nas diversas formas já constatadas nas análise de outras zonas (FIGURA 39). A calcita foi reconhecida como sendo resultado de alterações tardias da granada, preenchimento de fraturas ou como parte da matriz, por vêzes, com feições de clastos primários. Cabe aqui destacar que o carbonato da zona efetivamente mineralizada apresenta a mesma composição de dolomita ferrosa de outras zonas mineralizadas (e.g. Corpo IV). A anquerita na forma do membro final é o resultado de alterações da granada e epídoto, gerando às vezes pseudomorfos desses minerais. A siderita é uma fase carbonática característica do evento neoproterozóico e se apresenta normalmente na forma de cristais euédricos, em meio aos veios de quartzo de geração análoga. 


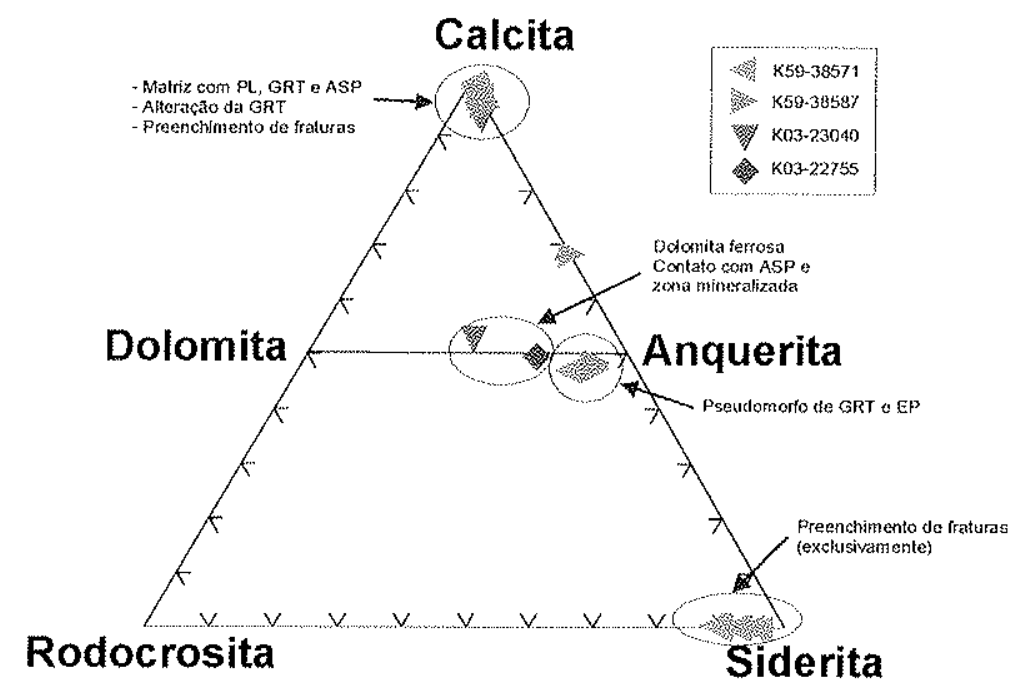

FIGURA 39 - Diagrama de classificação química do carbonato nas amostras K59-38571, K59-38578, K03-22755 e K03-23040 (36 análises).

Foram realizados diversos perfís analíticos na granada almandínica das amostras K5938571, K59-38587 (ambas não mineralizadas) e K03-22755 (mineralizada) (FIGURA 40). De maneira semelhante a toda granada analisada, é mantida uma evolução que inicia com relativamente mais moléculas de espessartita/piropo, evoluindo para aumento do teor de grossulária e por fim de piropo/espessartita. Essa evolução caracteriza a entrada de fluidos carbonáticos, relacionados às fases de dolomitização no início do evento D3 e logo após o forte metassomatismo ferromagnesiano que, ao fim do evento D3 estaria relacionado à mineralização de ouro e sulfetos. O perfil analítico da amostra K03-22755 mineralizada comparado ao perfil da amostra K59-38587 não mineralizada (FIGURA 41) revela a maior diferença no conteúdo em magnésio, que, na granada associada à mineralização possui pelo menos três vezes mais da molécula de piropo. A comparação da variação composicional e dos valores em porcentagem de óxidos com as granadas do Corpo IV, revela grandes semelhanças. 


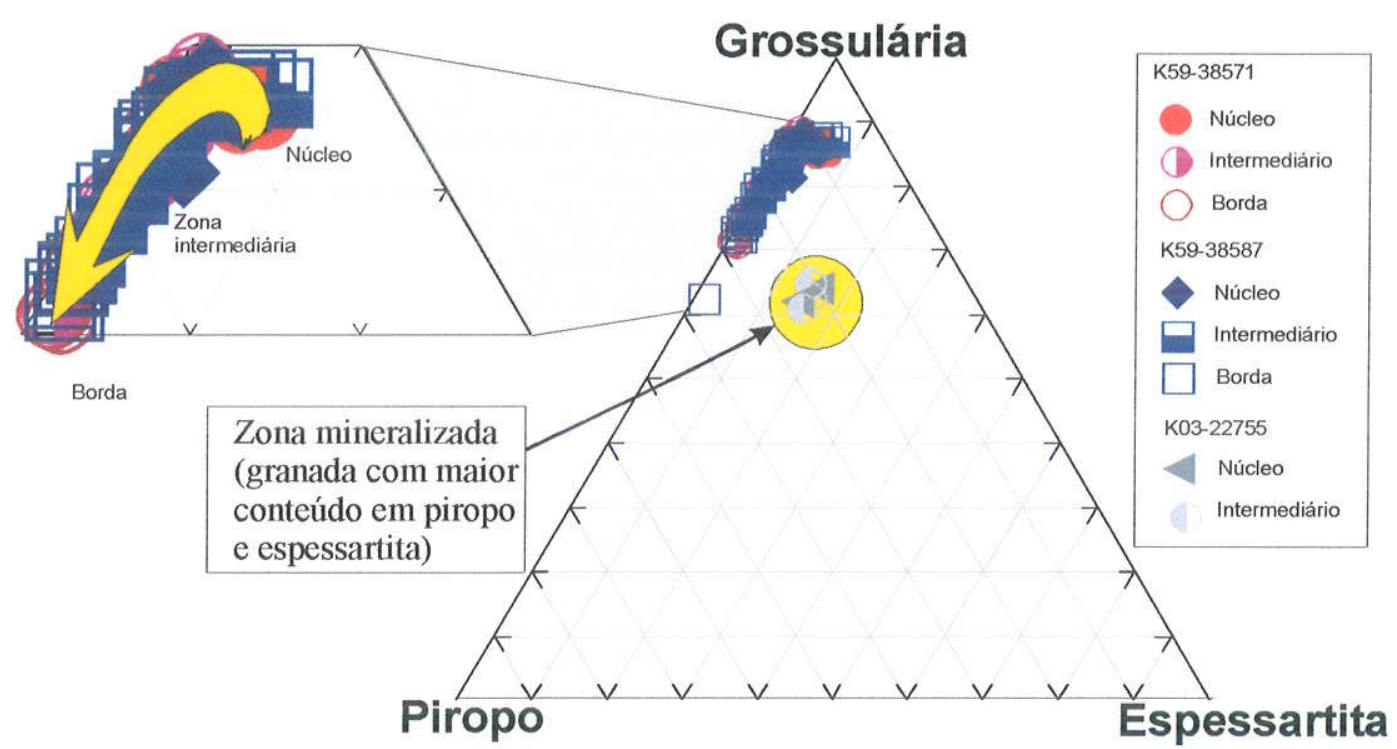

FIGURA 40 - Diagrama de classificação química da granada nas amostras K59-38571, K59-38578 e K03-22755 (89 análises).
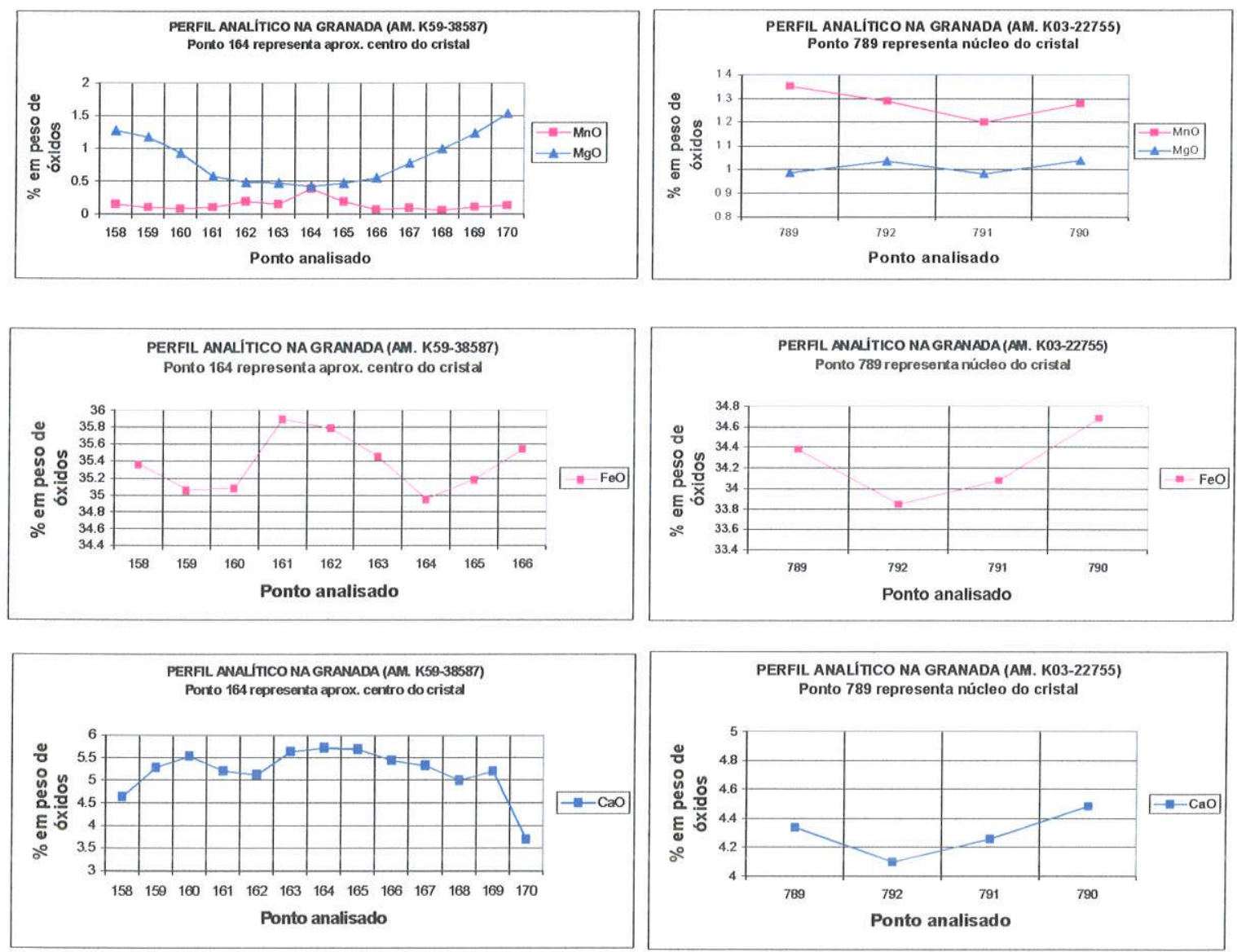

FIGURA 41 - Perfís analíticos da granada: à esquerda da amostra K59-38578 sem mineralização e à direita da amostra K03-22755 com mineralização. Notar que os diagramas da direita abrangem apenas um perfil do núcleo para a borda. 


\section{ZONA INFERIOR DA MINA III}

A zona inferior da Mina III é considerada petrograficamente a mais semelhante ao Corpo IV, pelo seu forte vínculo com veios de quartzo em meio ao xisto carbonoso, e freqüentes texturas brechadas. A análise do gold fineness também indica similaridades dessas mineralizações (ver capítulo de petrografia).

Foram analisadas as fases minerais de duas amostra próximas com as seguintes características:

- Amostra K49-39614 (Biotita-sericita-plagioclásio xisto com porfiroblastos de granada e anfibólio): Ocorrem zonas de cloritito permeados com porfiroblastos centimétricos de granada e anfibólio, numa região da amostra menos afetada pelo cisalhamento relacionado ao evento D4. A zona da granada/anfibólio não mineralizada representa a capa do minério da zona inferior. Ocorrem duas gerações de biotita. Porfiroblastos de anfibólio apresentam inclusões de granada (granada pré- a sin-anfibólio).

- Amostra K49-39664 (Biotita-sericita-plagioclásio xisto com porfiroblastos de granada e anfibólio): Ocorrem zonas de cloritito permeados com porfiroblastos centimétricos de granada e anfibólio, parcialmente destruídos em alguns pontos pelo cisalhamento relacionado ao evento D4. A zona da granada e anfibólio não mineralizada representa a capa do minério da zona inferior.

As análises da biotita nas duas amostras, mesmo as sericitizadas foram classificadas dentro do campo da biotita e devem representar, da mesma maneira que na biotita do Corpo IV, o halo próximo da mineralização (FIGURA 42). A petrografia revelou que a biotita nessas amostras é prémgranada e anfibólio (BT2), sofrendo a sericitização imposta pelo evento D3. Ocorre ainda uma geração de biotita pós-tectônica. 


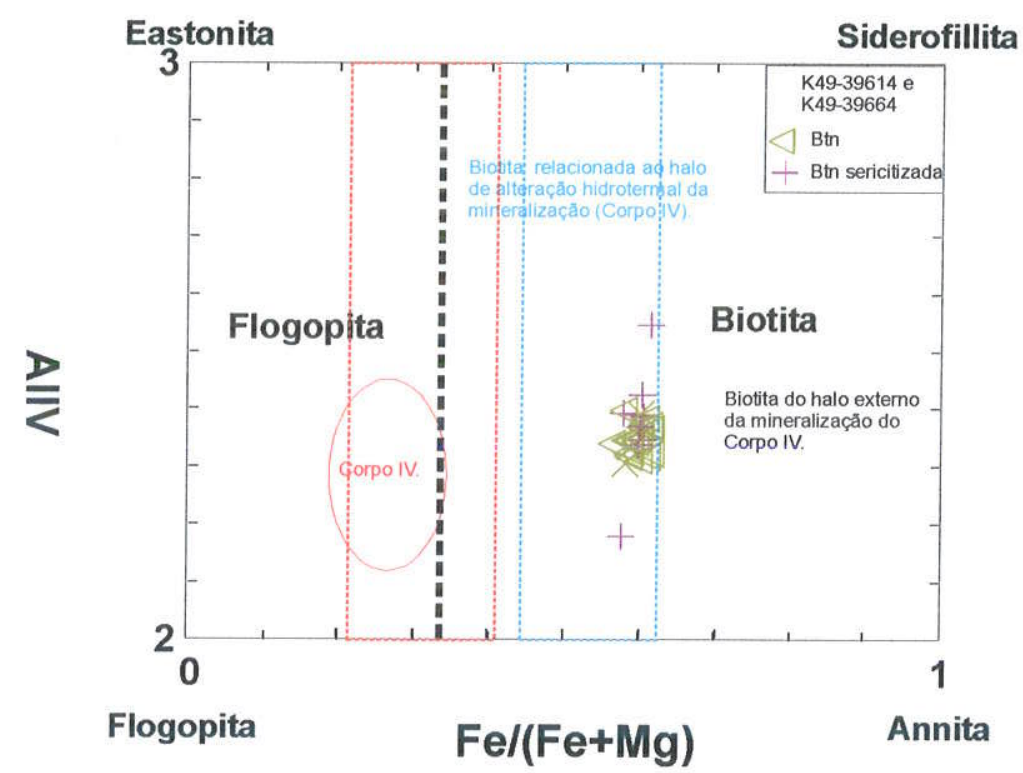

FIGURA 40 - Diagrama de classificação química da biotita nas amostras K49-39614 e K49-39664 (27 análises).

A sericita ocorre sob duas formas: inclusa no anfibólio com uma composição relativamente menos ferro-magnesiana, e como alteração da biotita (BT2), indicando aumento

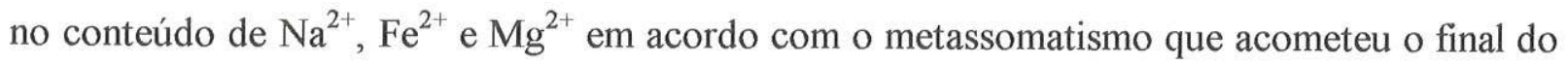
evento D3 (FIGURA 43). Pode-se destacar a sericita da amostra K59-39614, que ocorre inclusa no anfibólio, por apresentar uma relação maior para $\mathrm{Mg} / \mathrm{Fe}$.
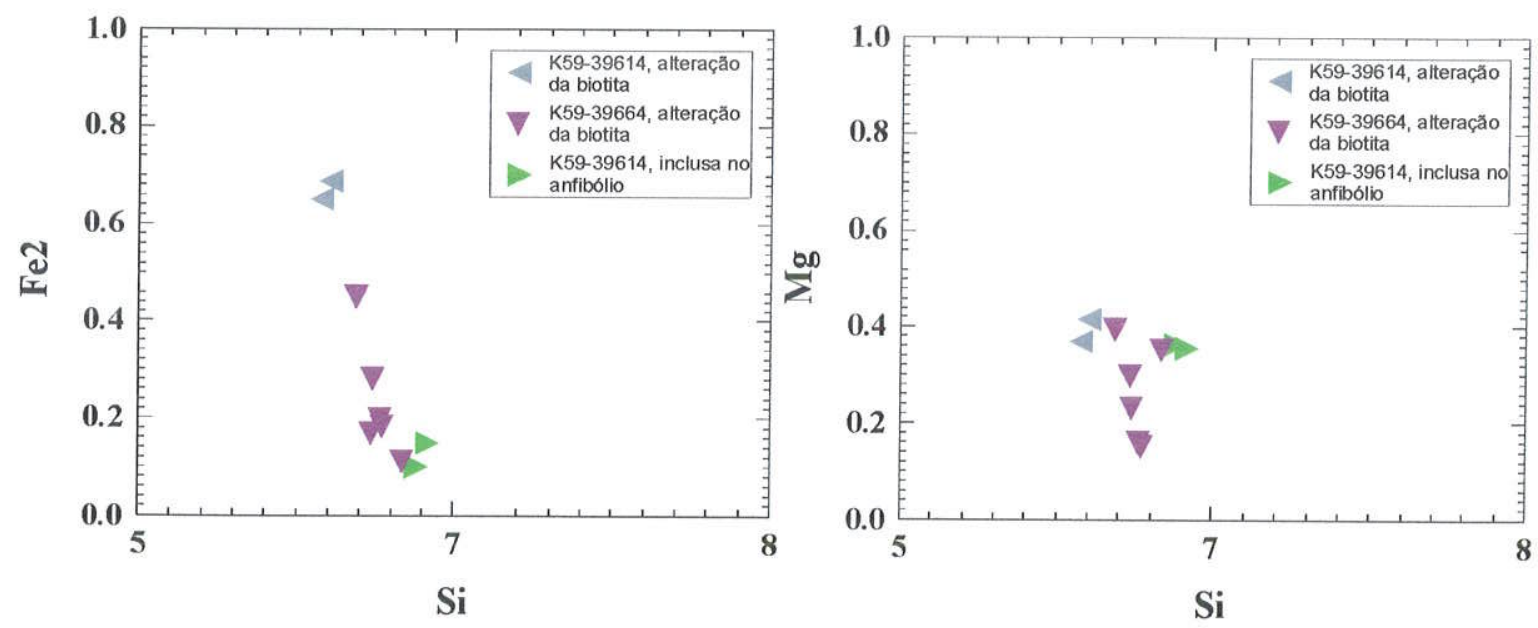

FIGURA 43 - Diagrama de classificação química da sericita nas amostras K49-39614 e K49-39664 (27 análises).

A clorita analisada revelou ser o resultado da alteração da biotita e do anfibólio e pode ser caracterizada como sendo picnoclorita (FIGURA 44). 


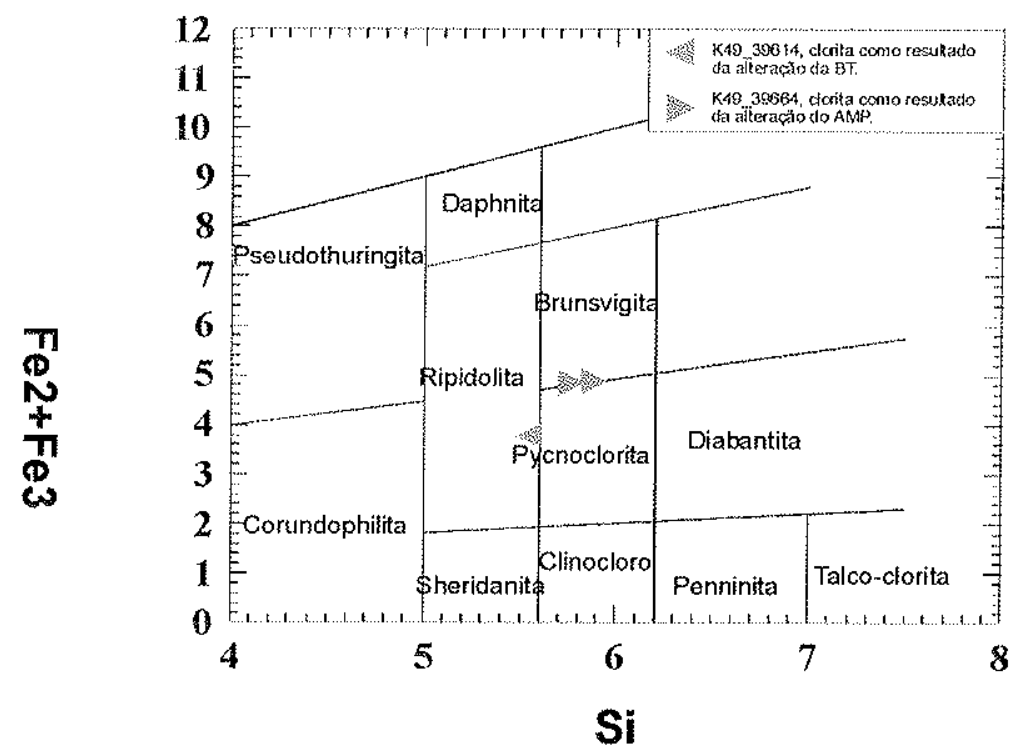

FIGURA 44 - Diagrama de classificação química da clorita nas amostras K49-39614 e K49-39664 (3 análises).

As análises dos feldspatos nas amostras K49-39614 e K49-39664 foram reunidas no diagrama classificatório da FIGURA 45 e apresentam o mesmo sentido evolutivo das demais zonas com plagioclásio. Essas amostras são diferenciáveis por apresentarem plagioclásio mais cálcico (iniciando com a labradorita) que todas as outras amostras analisadas.

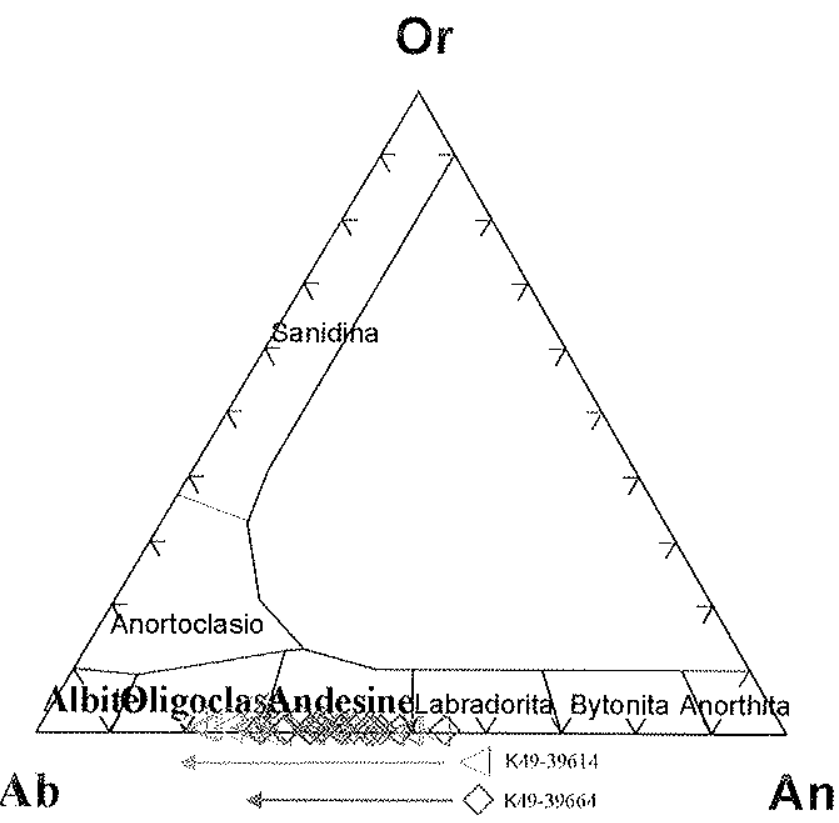

FIGURA 45 - Diagrama de classificação química do feldspato nas amostras K49-39614 e K49-39664 (41 análises). As setas indicam variação química do núcleo para borda nas duas amostras.

A análise dos carbonatos revela a presença de calcita (FIGURA 46) como resultado da alteração da granada/anfibólio, sendo que a alteração apresenta padrões claros do cisalhamento neoproterozóico que afetou essa zona, destruindo parcialmente a alteração 
gerada pelo evento D3. A deformação, chegando a destruição, dos porfiroblastos de anfibólio e granada foi também observada nos trabalhos de mapeamento das galeria do Corpo IV, marcando a proximidade dos limites do mesmo, no truncamento neoproterozóico dos corpos de minério.

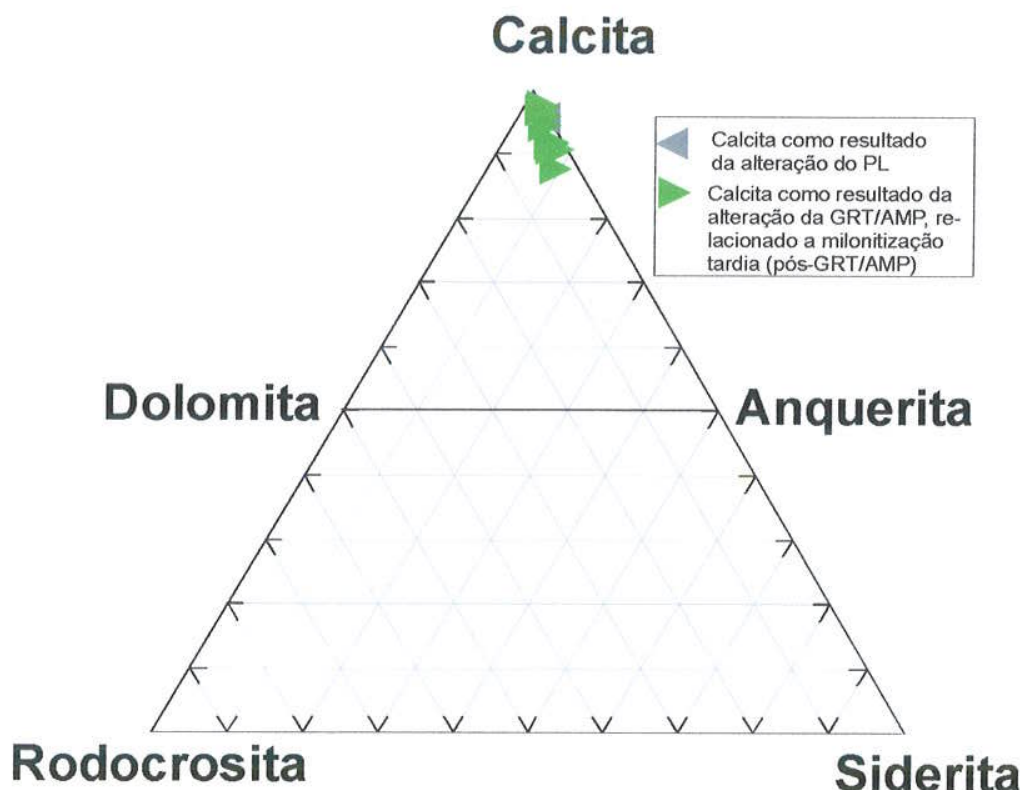

FIGURA 46 - Diagrama de classificação química do carbonato nas amostras K49-39614 e K4939664 (12 análises).

Os porfiroblastos de anfibólio metamórfico apresentam composição da Fetschermakita, da mesma forma que nas outras zonas mineralizadas, sem variações maiores nos perfis composicionais, conforme a FIGURA 47.

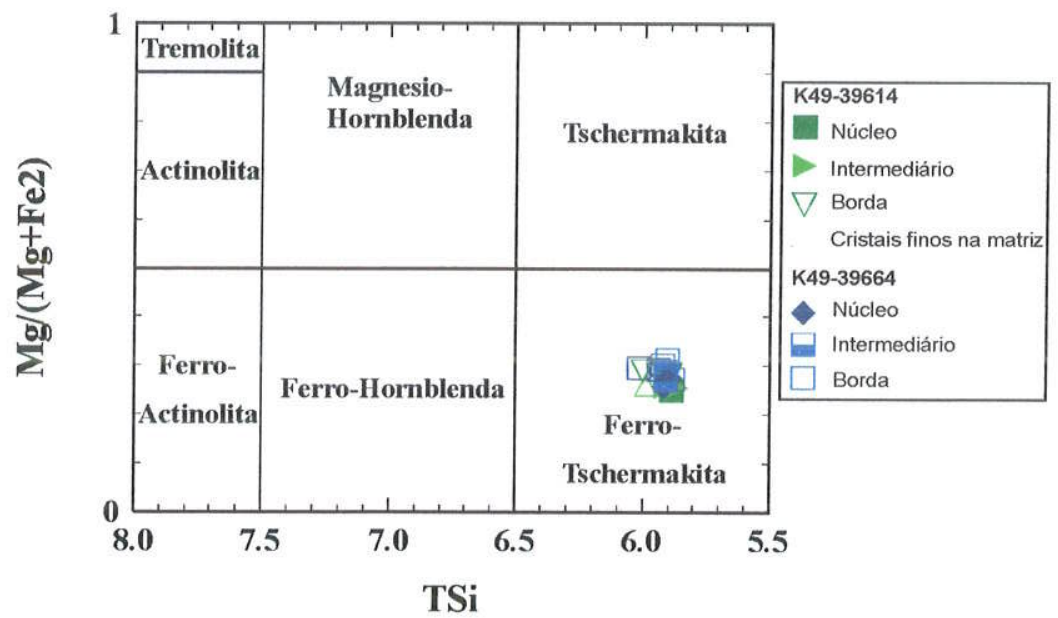

FIGURA 47 - Diagrama de classificação química do anfibólio nas amostras K49-39614 e K49-39664 (21 análises). 
A granada apresenta a mesma composição almandínica das demais amostras, sendo que nessas amostras ocorre apenas o segundo estágio de seu padrão evolutivo (FIGURA 48), ou seja, enriquecimento na molécula piropo. Isso ainda pode explicar o padrão de cristalização em atol dessas granadas, observado apenas nesse local, indicando apenas a segunda fase evolutiva do padrão geral (falta a fase de enriquecimento na molécula grossulária). Em contrapartida ocorre a granada almandínica mais rica em magnésio, a algumas dezenas de metros abaixo zona mineralizada inferior da Mina III. Esta se distingue do padrão geral, sendo indicativa da proximidade da zona mais alterada em relação ao $\mathrm{Mg}^{2+} \mathrm{e}$, conseqüentemente, uma zona mais propícia para mineralização.

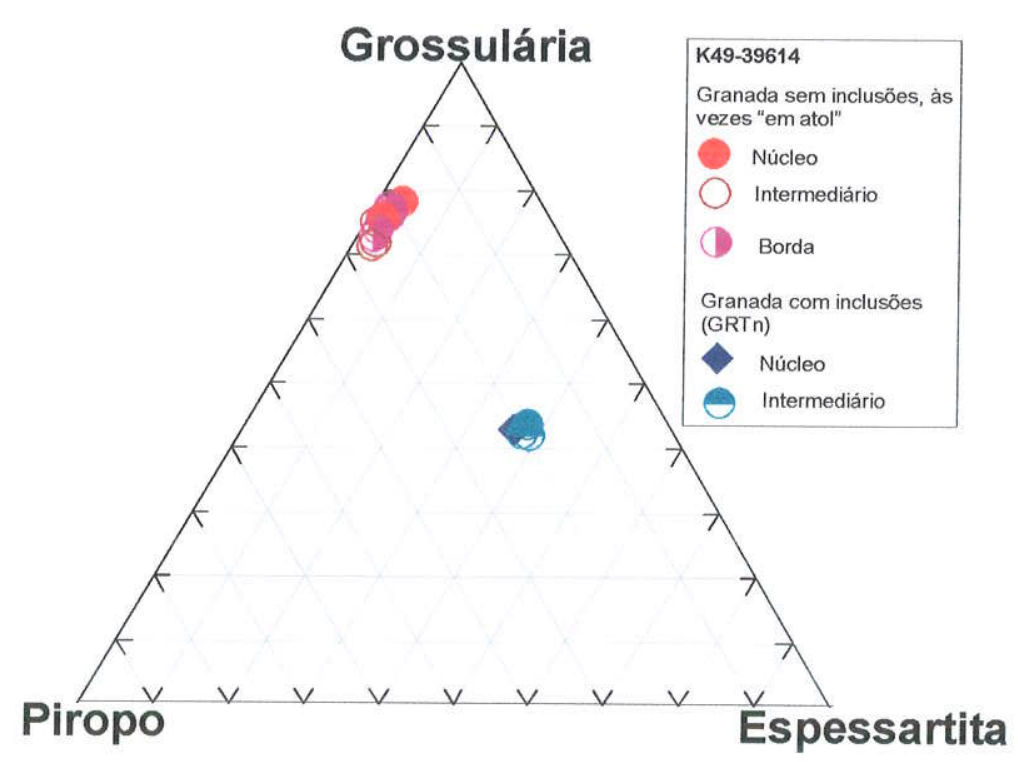

FIGURA 48 - Diagrama de classificação química da granada nas amostras K49-39614 e K49-39664 (20 análises).

Os perfis analíticos realizados nas duas granadas da FIGURA 48 revelaram a mesma evolução composicional do núcleo para a borda dos cristais (FIGURA 49), além da variedade de granada almandínica, com maior conteúdo em piropo que deve indicar proximidade da mineralização. 

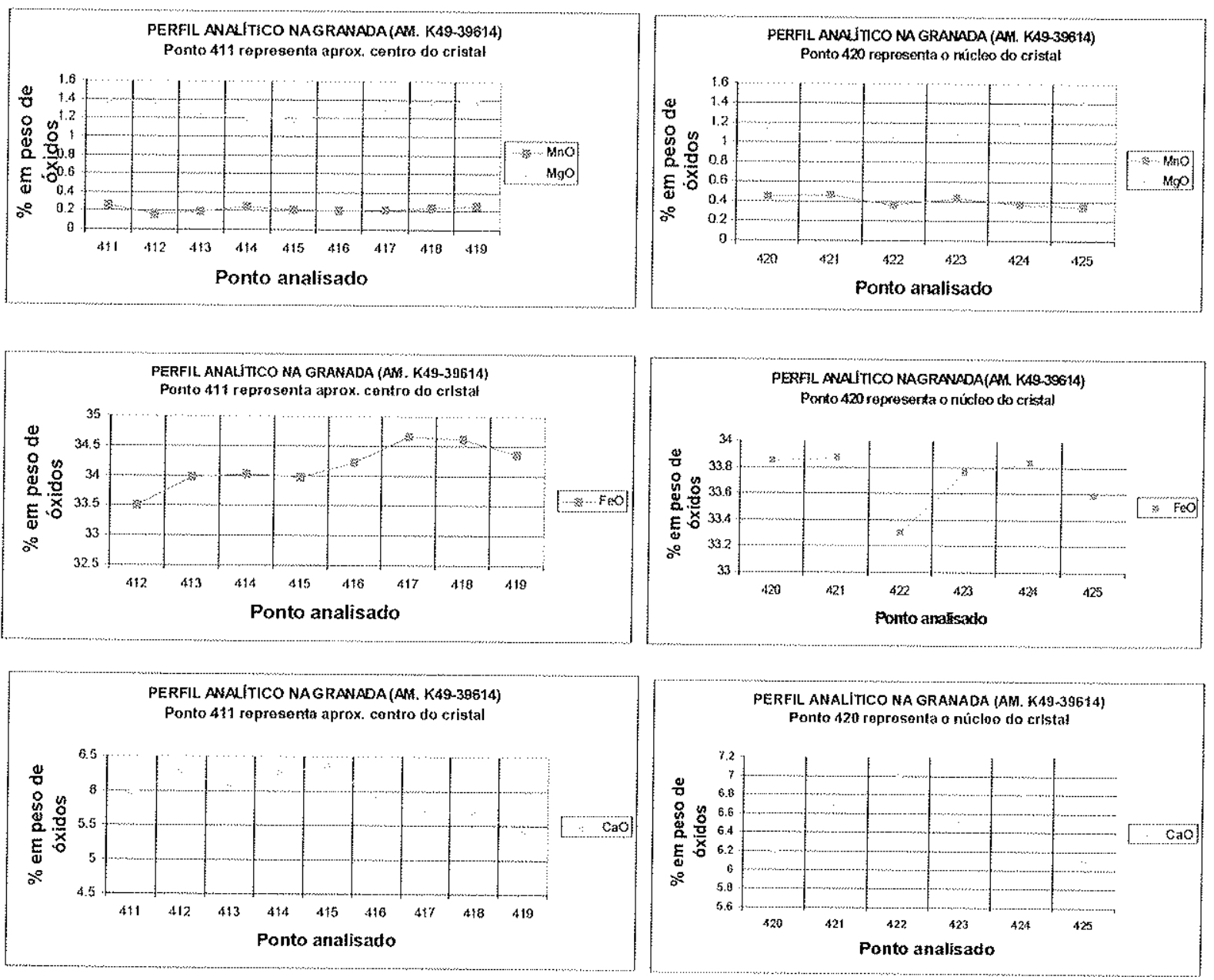

FIGURA 49 - Perfís analíticos da granada: à esquerda da amostra K49-396/4 sem mineralização e com desenvolvimento em atol e à direita da amostra K49-39614 com maior conteúdo na molécula piropo. Notar que os diagramas abrangem apenas um perfil do núcleo para a borda.

\section{GEOTERMOBAROMETRIA}

Foram realizados estudos termobarométricos utilizando-se a paragênese granadaanfibólio-biotitamplagioclásio-sericita. Os resultados obtidos mostram-se muito interessantes para definição do modelo genético da mineralização, notadamente quanto ao nível crustal do desenvolvimento da zona de cisalhamento e das temperaturas dos fluidos hidrotermais.

Duas amostras foram avaliadas, uma representada por um metassedimento com granada, plagioclásio, quartzo, biotita, muscovita, opacos, carbonatos e clorita na matriz, cortada por veios hidrotermais com micas, plagioclásio e carbonato.

Uma outra amostra corresponde a um milonito com cristalização de hornblenda e granada pós-cisalhamento pré-neoproterozóico, com plagioclásio, biotita, quartzo, carbonatos, clorita e muscovita menos freqüente. 
Os minerais utilizados nos cálculos são de cristalização associada à zona de cisalhamento, com possiveis núcleos remanescentes do metamorfismo regional. Todos se situam nas proximidades das zonas mineralizadas, razão pela qual as temperaturas obtidas devem corresponder ao evento hidrotermal associado a mineralização de ouro.

Nestes cálculos foi utilizada a termobarometria com o banco de dados termodinâmicos internamente consistentes de Berman (1988), através do software TWQ (Berman, 1992). Devido à presença de carbonatos todos os cálculos foram efetuados com fração molar de $\mathrm{H}_{2} \mathrm{O}: \mathrm{CO}_{2}$ de $0,8: 0,2$. Os equilíbrios das reações analisadas mostram-se muito susceptíveis à variação da fração molar de $\mathrm{CO}_{2}$, razão pela qual haverá necessidade de melhor estimativas desta atividade nos estudos futuros. Pode-se notar também que será necessário adequar o modelo de atividade do end-member flogopita nos cálculos, devido às composições muito ricas em ferro dos minerais.

Para os cálculos geotermobarométricos foram utilizadas as composições do núcleo e da borda dos seguintes minerais em paragênese: granada, biotita, muscovita e plagioclásio.

Os resultados da amostra K59-38571 podem ser observados nas FIGURAS 50 e 51, calculadas através das seguintes reações químicas:

1): $\alpha \mathrm{QTZ}+2 \mathrm{CAL}+\mathrm{AN}=\mathrm{GRT}+2 \mathrm{CO}_{2}$

2): $\mathrm{ALM}+2 \mathrm{CAL}+\mathrm{MS}+\alpha \mathrm{QTZ}=2 \mathrm{AN}+\mathrm{ANN}+2 \mathrm{CO}_{2}$

3): $\mathrm{PHL}+\mathrm{ALM}=\mathrm{ANN}+\mathrm{PY}$

4): $\mathrm{MS}+\mathrm{GRT}+\mathrm{ALM}=\mathrm{ANN}+3 \mathrm{AN}$

5): $3 a \mathrm{QTZ}+\mathrm{MS}+6 \mathrm{CAL}+\mathrm{ALM}=\mathrm{ANN}+2 \mathrm{GRT}+6 \mathrm{CO}_{2}$

6): $\alpha \mathrm{QTZ}+\mathrm{PY}+\mathrm{MS}+2 \mathrm{CAL}=2 \mathrm{AN}+\mathrm{PHL}+2 \mathrm{CO}_{2}$

7): $\mathrm{PY}+\mathrm{MS}+\mathrm{GRT}=3 \mathrm{AN}+\mathrm{PHL}$

8): $3 \alpha \mathrm{QTZ}+\mathrm{PY}+\mathrm{MS}+6 \mathrm{CAL}=2 \mathrm{GRT}+\mathrm{PHL}+6 \mathrm{CO}_{2}$

Na amostra K59-38571 (FIGURA 50), as análises com as composições dos núcleos dos minerais mostraram-se razoavelmente equilibradas ao redor de $545-550^{\circ} \mathrm{C}$, a $7,1-7,8$ kbar. Nota-se também que o equilibrio biotita/granada situa-se em aproximadamente $500^{\circ} \mathrm{C}$ e 6,8 kbar, condição esta que pode ser atribuídas à maior facilidade de difusão iônica intracristalina na biotita, relativamente aos minerais desidratados e com clivagem menos proeminente, com conseqüência do resfriamento do sistema. As composições das bordas mostram-se, ao contrário do esperado, ainda mais desequilibradas que as dos núcleos, com condições situadas entre $540-550^{\circ} \mathrm{C}$ e $6,6-7,8$ e $450^{\circ} \mathrm{C}$ e 5,9 kbar para a biotita-granada, mostrando pequena redução das condições P-T. 

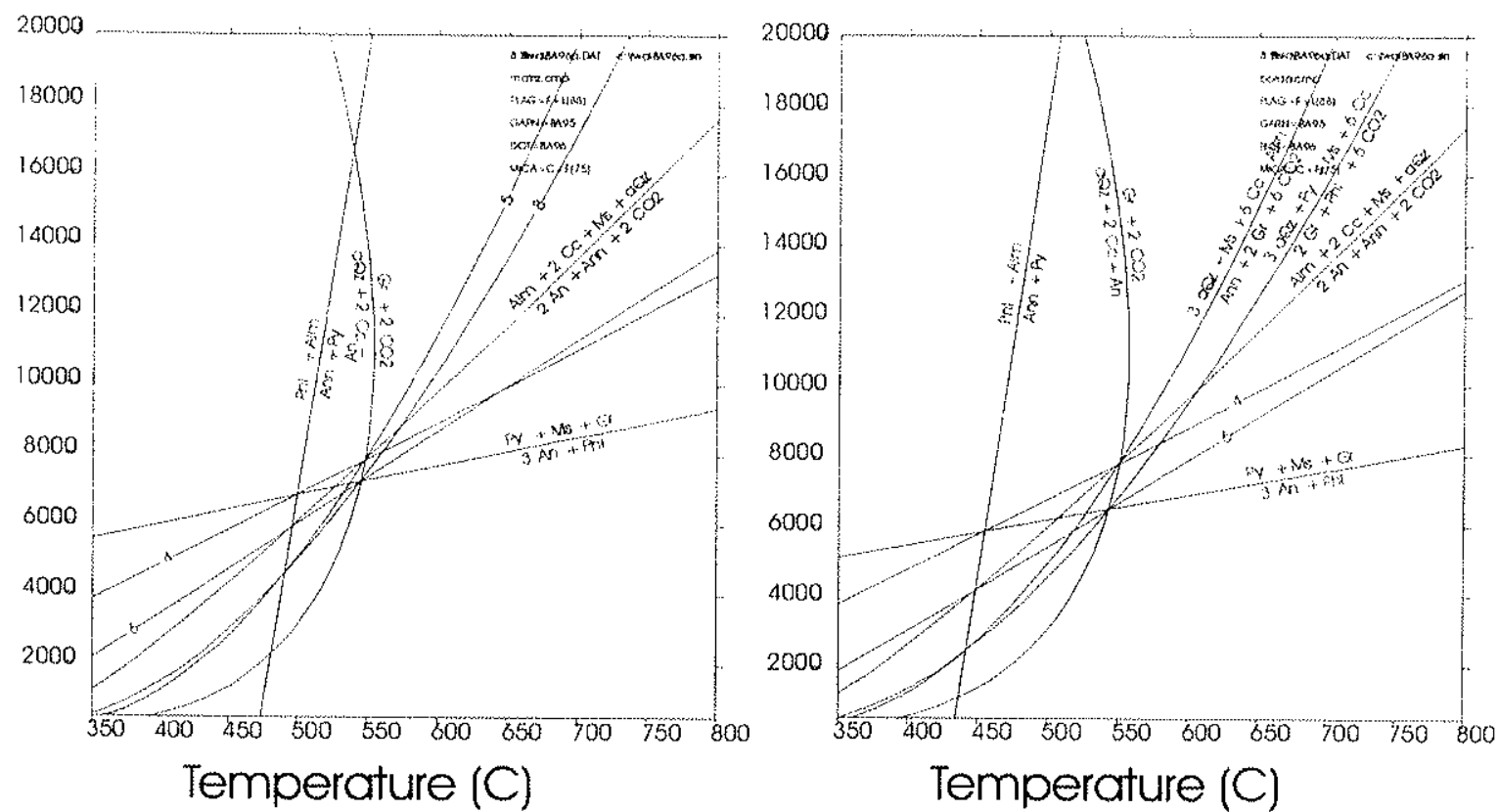

FIGURA 50 - Diagramas de equilibrio de fases para a amostra K59-38571 a com análises de núcleos a esquerda e borda a direita.

Um outro conjunto de minerais da mesma amostra K59-38571 (FIGURA 51) revelaram uma faixa de variação que vai de $580^{\circ} \mathrm{C} / 10,8 \mathrm{kbar}$ até $585^{\circ} \mathrm{C} / 12,2 \mathrm{kbar}$ e com um ponto de desequilibrio da biotita/granada em $750^{\circ} \mathrm{C} / 14,8 \mathrm{kbar}$. As análises na borda forneceram am uma faixa de variação que vai de $570^{\circ} \mathrm{C} / 10,5 \mathrm{kbar}$ até $570^{\circ} \mathrm{C} / 11,4 \mathrm{kbar}$ e com um ponto de desequilibrio da biotita/granada em $655^{\circ} \mathrm{C} / 12,6 \mathrm{kbar}$.

Excetuando o equilibrio granada-biotita da amostra anterior, os resultados são compatíveis com temperaturas da fácies xisto verde, em seu limite superior, ou início da fácies anfibolito, o que está em acordo com as observações petrográficas, com cloritóide estável nos metassedimentos hidrotermalizados. Entretanto, as pressões resultantes são, de modo geral, bastante altas, o que é incompatível com uma evolução tectônica em crosta com grau geotérmico típico de zonas de subducção e evolução barrowiana, e mais coerente com zonas metamórficas de alta pressão. Entretanto, as temperaturas estão, face à proximidade dos minerais com os veios, relacionadas ao evento hidrotermal, o que sugere, que a zona de cisalhamento instalou-se em niveis crustais profundos, em rochas relativamente frias. Em sendo correto este pressuposto, os terrenos greenstone deveriam ser parte de crátons estáveis e frios, quando das mineralizações auríferas, que seriam então mesotermais a hipotermais e, possivelmente, relacionadas a fluidos predominantemente metamórficos gerados em níveis crustais inferiores. 

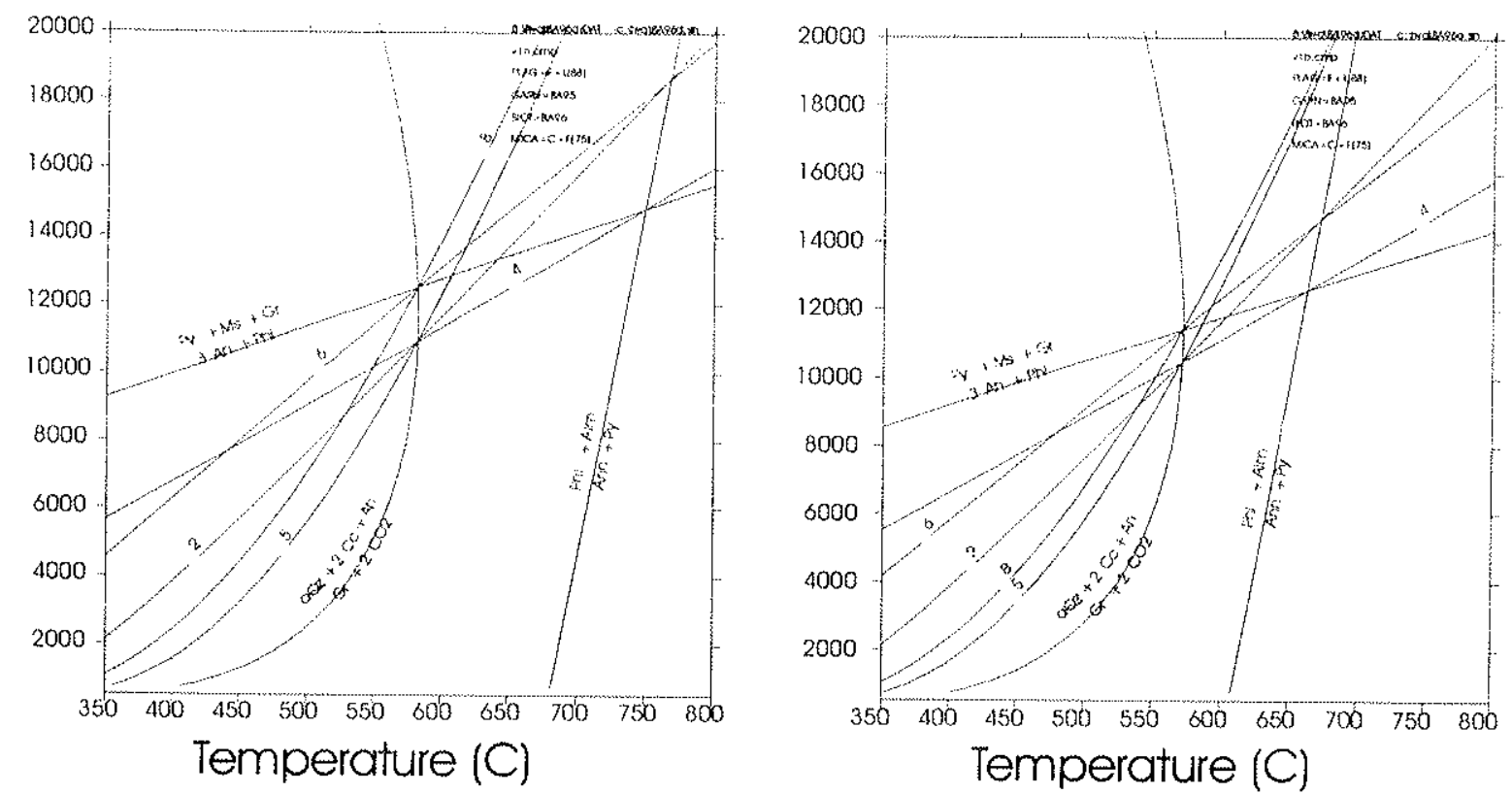

FIGURA 51 - Diagramas de equilibrio de fases para a amostra K59-38571b com análises de núcleos à esquerda e borda a direita.

Entretanto, não pode ser descartada a hipótese destes resultados serem consequiência de desequilíbrios químicos causados pelos fluidos hidrotermais em minerais de eventos anteriores parcialmente recristalizados.

Devido às pressões altas obtidas nestes metassedimentos, foram feitos alguns cálculos com o anfibólio, granada, plagioclásio e biotita da amostra K49-39664, objetivando analisar as condições P-T em outro sistema químico. Nestes cálculos foram utilizadas as seguintes reações de equilibrio:

1): $36 \mathrm{Ab}+68 \mathrm{ALM}+64 \mathrm{GRT}+15 \mathrm{PARG}+48 \mathrm{WO}=51 \mathrm{Fe}-\mathrm{PA}+12 \mathrm{TR}+96 \mathrm{AN}$

2): $3 \mathrm{PARG}+4 \mathrm{ALM}=4 \mathrm{PY}+3 \mathrm{Fe}-\mathrm{PA}$

3): $5 \mathrm{PHL}+16 \mathrm{GRT}+17 \mathrm{ALM}+9 \mathrm{AB}+12 \mathrm{WO}=5 \mathrm{ANN}+24 \mathrm{AN}+3 \mathrm{TR}+9 \mathrm{FePa}$

4): $17 \mathrm{PHL}+16 \mathrm{GRT}+17 \mathrm{ALM}+9 \mathrm{AB}+12 \mathrm{WO}=17 \mathrm{ANN}+24 \mathrm{AN}+3 \mathrm{TR}+9 \mathrm{Parg}$

5): $5 \mathrm{PY}+16 \mathrm{GRT}+12 \mathrm{ALM}+9 \mathrm{AB}+12 \mathrm{WO}=24 \mathrm{AN}+3 \mathrm{TR}+9 \mathrm{Fe}-\mathrm{PA}$

6): $17 \mathrm{PY}+16 \mathrm{GRT}+9 \mathrm{Ab}+12 \mathrm{WO}=24 \mathrm{AN}+3 \mathrm{TR}+9 \mathrm{PARG}$

7): $9 \mathrm{AB}+17 \mathrm{ALM}+16 \mathrm{GRT}+12 \mathrm{WO}=9 \mathrm{Fe}-\mathrm{PA}+3 \mathrm{Fe}-\mathrm{TR}+24 \mathrm{AN}$

8): $36 \mathrm{TR}+80 \mathrm{GRT}+85 \mathrm{ALM}+45 \mathrm{AB}+60 \mathrm{WO}=120 \mathrm{AN}+51 \mathrm{Fe}-\mathrm{TR}+45 \mathrm{PARG}$

9): $\mathrm{PHL}+\mathrm{ALM}=\mathrm{ANN}+\mathrm{PY}$

10): $5 \mathrm{ALM}+3 \mathrm{TR}=3 \mathrm{Fe}-\mathrm{TR}+5 \mathrm{PY}$

11): $\mathrm{PY}+16 \mathrm{GRT}+12 \mathrm{ANN}+9 \mathrm{AB}+12 \mathrm{WO}=24 \mathrm{AN}+12 \mathrm{PHL}+3 \mathrm{TR}+9 \mathrm{Fe}-\mathrm{PA}$

12): $\mathrm{PHL}+16 \mathrm{GRT}+17 \mathrm{ALM}+9 \mathrm{Ab}+12 \mathrm{WO}=12 \mathrm{ANN}+24 \mathrm{AN}+3 \mathrm{Fe}-\mathrm{TR}+9 \mathrm{PARG}$

13): $36 \mathrm{FeTr}+85 \mathrm{PY}+80 \mathrm{GRT}+45 \mathrm{AB}+60 \mathrm{WO}=120 \mathrm{AN}+51 \mathrm{TR}+45 \mathrm{Fe}-\mathrm{PA}$

14): $12 \mathrm{PY}+16 \mathrm{GRT}+5 \mathrm{ALM}+9 \mathrm{AB}+12 \mathrm{WO}=24 \mathrm{AN}+3 \mathrm{Fe}-\mathrm{TR}+9 \mathrm{PARG}$

15): $15 \mathrm{Fe}-\mathrm{PA}+68 \mathrm{PY}+64 \mathrm{GRT}+36 \mathrm{AB}+48 \mathrm{WO}=96 \mathrm{AN}+12 \mathrm{Fe}-\mathrm{TR}+51 \mathrm{PARG}$

16): $17 \mathrm{PY}+16 \mathrm{GRT}+17 \mathrm{ANN}+9 \mathrm{AB}+12 \mathrm{WO}=24 \mathrm{AN}+17 \mathrm{PHL}+3 \mathrm{Fe}-\mathrm{TR}+9 \mathrm{Fe}-\mathrm{PA}$

17): $17 \mathrm{PY}+16 \mathrm{GRT}+5 \mathrm{ANN}+9 \mathrm{AB}+12 \mathrm{WO}=24 \mathrm{AN}+5 \mathrm{PHL}+3 \mathrm{Fe}-\mathrm{TR}+9 \mathrm{PARG}$ 
Apesar de muito desequilibrados (FIGURA 52), os resultados das composições dos núcleos revelaram uma faixa de variação que vai de $470^{\circ} / 7,4 \mathrm{kbar}$ até $545^{\circ} \mathrm{C} / 7,8 \mathrm{kbar}$ e as de bordas $550^{\circ} \mathrm{C} / 7,5 \mathrm{kbar}$ até $605^{\circ} \mathrm{C} / 8 \mathrm{kbar}$, que indicam as condições P-T semelhantes aos da amostra anterior, o que sugere fortemente que a secção da zona de cisalhamento e a mineralização hoje exposta em superficie foram geradas em profundidade.
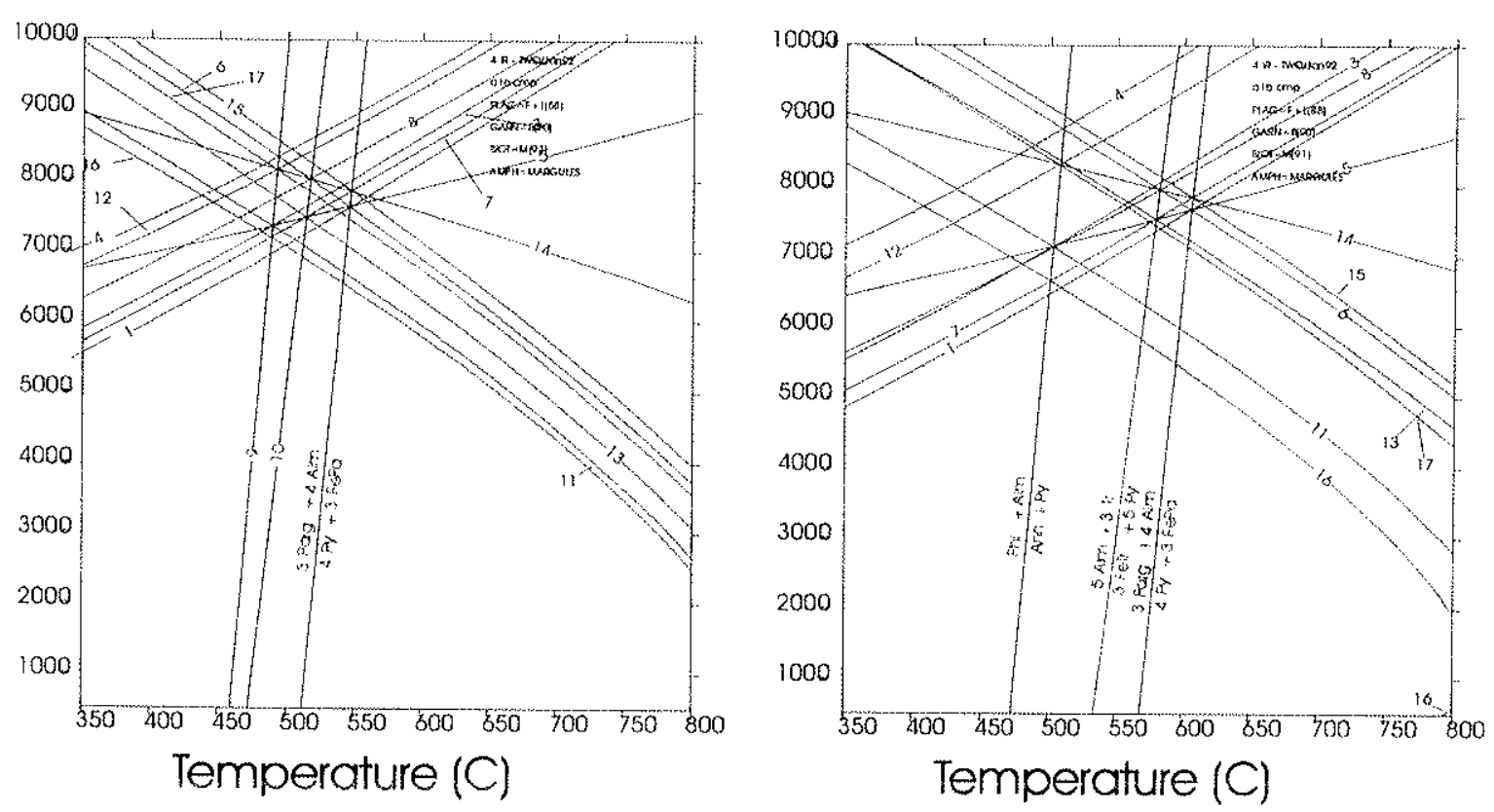

FIGURA 52 - Diagramas de equilíbrio de fases para a amostra K49-39664 com análises de núcleos a esquerda e borda a direita.

A amostra K49-39664 pertence à zona de intensa alteração hidrotermal dos clorititos com granada nos metassedimentos próximo à Zona Inferior da Mina III, e é o único ponto amostrado que apresenta os porfiroblastos estirados e fraturados pelo cisalhamento neoproterozóico, gerando ainda oma foliação no cloritito (protólito hidrotermal). A rocha é um cloritito com biotita e muscovita na matriz e porfiroblastos de plagioclásio, almandina e Fe-tschermakita.

Foram gerados diversos diagramas P-T, utilizando-se a mesma fração molar de H2O:CO2 de 0,8:0,2, com a associação granada, biotita, muscovita e plagioclásio, dos quais foram selecionados os dois apresentados na FIGURA 53, utilizando as seguintes reações químicas:

1): $6 \mathrm{Fe}-\mathrm{TS}+\mathrm{ANN}=7 \mathrm{ALM}+4 \mathrm{GRT}+\mathrm{MS}+3 \alpha \mathrm{QTZ}+6 \mathrm{~W}$

2): $7 \mathrm{ALM}+5 \mathrm{GRT}+\mathrm{PHL}+6 \mathrm{CO} 2+6 \mathrm{WO}=6 \mathrm{Fe}-\mathrm{TS}+3 \mathrm{DOL}+\mathrm{ANN}$

3): $6 \mathrm{ALM}+5 \mathrm{GRT}+\mathrm{PY}+6 \mathrm{CO}_{2}+6 \mathrm{WO}=6 \mathrm{Fe}-\mathrm{TS}+3 \mathrm{DOL}$ 
4): $3 \mathrm{DOL}+\mathrm{MS}+3 \alpha \mathrm{QTZ}=\mathrm{PHL}+\mathrm{GRT}+6 \mathrm{CO}_{2}$

5): $7 \mathrm{ALM}+12 \mathrm{DOL}+5 \mathrm{MS}+15 \alpha \mathrm{QTZ}+6 \mathrm{WO}=6 \mathrm{Fe}-\mathrm{TS}+4 \mathrm{PHL}+\mathrm{ANN}+24 \mathrm{CO}_{2}$

6): $3 \alpha Q T Z+\mathrm{MS}+3 \mathrm{DOL}+\mathrm{ALM}=\mathrm{ANN}+\mathrm{GRT}+\mathrm{PY}+6 \mathrm{CO}_{2}$

7): $21 \mathrm{DOL}+6 \mathrm{MS}+18 \alpha \mathrm{QTZ}+6 \mathrm{Fe}-\mathrm{TS}=7 \mathrm{PY}+11 \mathrm{GRT}+6 \mathrm{ANN}+6 \mathrm{WO}+42 \mathrm{CO}_{2}$

8): $11 \mathrm{ALM}+12 \mathrm{DOL}+5 \mathrm{MS}+15 \alpha \mathrm{QTZ}+6 \mathrm{WO}=6 \mathrm{Fe}-\mathrm{TS}+4 \mathrm{PY}+5 \mathrm{ANN}+24 \mathrm{CO}_{2}$

9): PHL + ALM = ANN + PY

10): $7 \mathrm{PY}+5 \mathrm{GRT}+6 \mathrm{ANN}+6 \mathrm{WO}+6 \mathrm{CO}_{2}=3 \mathrm{DOL}+6 \mathrm{PHL}+6 \mathrm{Fe}-\mathrm{TS}$

11): $3 \alpha \mathrm{QTZ}+7 \mathrm{PY}+\mathrm{MS}+4 \mathrm{GRT}+6 \mathrm{ANN}+6 \mathrm{WO}=7 \mathrm{PHL}+6 \mathrm{Fe}-\mathrm{TS}$

12): $3 \alpha \mathrm{QTZ}+\mathrm{PY}+\mathrm{MS}+4 \mathrm{GRT}+6 \mathrm{ALM}+6 \mathrm{WO}=\mathrm{PHL}+6 \mathrm{Fe}-\mathrm{TS}$

13): $00 \alpha \mathrm{QTZ}+7 \mathrm{PY}+5 \mathrm{MS}+12 \mathrm{DOL}+6 \mathrm{ANN}+6 \mathrm{WO}=11 \mathrm{PHL}+6 \mathrm{Fe}-\mathrm{TS}+24 \mathrm{CO}_{2}$

14): $15 \alpha \mathrm{QTZ}+\mathrm{PY}+5 \mathrm{MS}+12 \mathrm{DOL}+6 \mathrm{ALM}+6 \mathrm{WO}=5 \mathrm{PHL}+6 \mathrm{Fe}-\mathrm{TS}+24 \mathrm{CO}_{2}$

A amostra F49-39664 apresenta uma faixa de equilíbrio razoável do núcleo com 510$560^{\circ} \mathrm{C}$ a $9,4-11,2$ kbar. As bordas mostram-se mais equilibradas com $525-570^{\circ} \mathrm{C}$ a $7,8-8,8$ kbar.

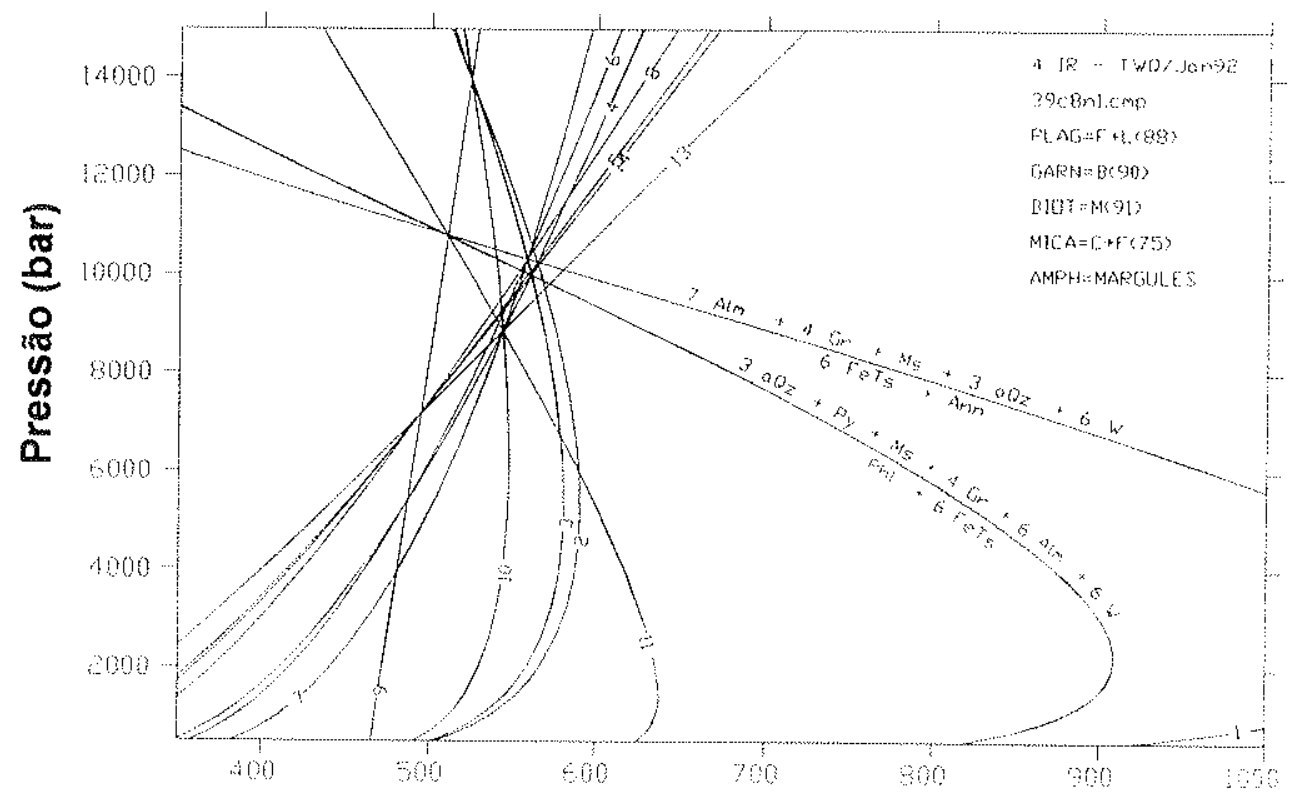

Temperatura $\left({ }^{\circ} \mathrm{C}\right)$

FIGURA 53 - Diagrama de equilíbrio de fases da amostra K49-39664 com análises de núcleos dos minerais. 


\section{CAPÍTULO V \\ VEIOS DE QUARTZO E INCLUSÕES FLUIDAS}

\section{INTRODUCÃO}

O corpo de minério Corpo IV esta inteiramente encaixado no xisto carbonoso da Formação Rio Vermelho e apresenta diversos sistemas de veios de quartzo (ver TABELA 6 do Capítulo II). A análise microtermométrica nos veios do corpo de minério foi realizada visando uma melhor compreensão dos processos físico-químicos envolvidos, particularmente nos eventos anteriores ao Brasiliano, considerando que o mapeamento das galerias revelou que as zonas mineralizadas são relíquias preservadas dos últimos eventos tectônicos.

O estudo microtermométrico realizado por Fortes (1996) selecionou amostras das zonas de minério na Mina III e Mina Nova. Esse enfoque das amostras coletadas para análise traz dificuldades ao se tentar realizar comparações, porque o presente estudo analisou gerações de veios de quartzo cronologicamente diferenciadas no Corpo IV, relacionados a mineralização ou não, através do mapeamento nas galerias da mina.

Entre os objetivos dos estudos das inclusões fluidas nos veios de quartzo do Corpo IV podem ser citados:

- a caracterização da a evolução P-V-T-X dos veios e/ou dos fluidos hidrotermais mineralizantes ou não.

- a identificação da relação entre a evolução dos fluidos e da deposição dos sulfetos, particularmente daqueles associados com ouro.

Cabe aqui reafirmar que o significado deste estudo depende da suposição de que o volume e composição das inclusões fluidas examinadas permaneceram constantes (condição isoplética e isocórica) desde o seu aprisionamento (Roedder, 1984; Diamond, 1990; Goldstein \& Reynolds, 1994). As bases para a validade destas condições são dadas no capítulo sobre petrografia dos veios de quartzo.

Goldstein \& Reynolds (1994) mencionaram ainda a importante condição para se obter dados microtermométricos consistentes: "A única maneira possível para se interpretar dados microtermométricos de inclusões fluidas é quando se processam conjuntamente os dados de várias inclusões dentro de uma mesma assembléia de inclusões fluidas (Fluid Inclusion Association - FIA), ou seja, num grupo de inclusões petrograticamente associado, passível de uma descriminação". 
A seguir são relacionados os diversos grupos de inclusões fluidas reconhecidos em cada veio de quartzo estudado, com os critérios de cronologia relativa da TABELA 6 do Capítulo II.

\section{PETROGRAFIA DOS VEIOS DE QUARTZO}

Para uma correta interpretação das medições microtermométricas é necessário uma petrografia detalhada dos veios amostrados, visando reconhecer evidências de que não houve processos de deformação e/ou recristalização tardias. Esses processos podem destruir ou modificar as inclusões fluidas, descaracterizando o pré-requisito de que a inclusão fluida represente um sistema isoplético e isocórico desde o seu aprisionamento (Goldstein, 1986).

Todas as amostras de veios de quartzo neste trabalho foram submetidas a uma cuidadosa investigação petrográfica para determinar se houve algum processo de modificação posterior das inclusões fluidas e, se houve, qual poderia ter sido sua influência na análise microtermométrica.

Passchier \& Trouw (1996) determinaram várias evidências para o reconhecimento petrográfico da recristalização dinâmica e estática, sendo esses os dois processos de recristalização mais importantes. Essas evidências podem ser reconhecidas com algumas limitações nos veios de quartzo e outros minerais, conforme explicado abaixo.

A recristalização dinâmica pode ocorrer de maneira parcial ou completa, de acordo com sua intensidade, revelando as seguintes texturas características:

- Recristalização parcial, onde os grãos apresentam um padrão bimodal, com agregados de pequenos grãos com tamanhos uniformes entre grãos maiores com extinção ondulante. Os grãos maiores podem apresentar sub-grãos com o mesmo tamanho dos grãos menores.

- Recristalização completa onde ocorre ausência de evidências de deformação interna, uma orientação preferencial e um tamanho relativamente uniforme dos grãos.

Já a recristalização estática se manifesta principalmente através da redução da área de borda (grain boundary area reduction), impondo aos cristais contatos retos ou suavemente curvos.

A seguir é apresentada a descrição petrográfica das amostras, até então estudadas, polidas de ambos os lados (flink's) e que foram submetidas à análise microtermométrica (sub- 
capítulo de microtermometria a seguir). A classificação em Q-IV1 a Q-IV4 representa uma cronologia relativa dos veios (TABELA 6 do Capítulo II), determinada nos trabalhos de mapeamento das galerias, sendo que a numeração adotada não possui vínculo direto com as 4 fases de deformação (Jost, 2001) estabelecidas na geologia regional.

\subsection{Veios de quartzo da primeira geracão no Corpo IV (Q-IVI)}

\subsubsection{Amostra CIV-G010-V1}

Granulação: 0,14 to $2 \mathrm{~mm}$

Forma dos grãos: anhedrais com poucos cristais subhedrais.

Tipo dos agregados de grãos: inequigranulares interlobados (PRANCHA $16 \mathrm{~A}$ )

O Q-IV1 desenvolveu-se durante uma fase distensiva (tension gash veins) nos xistos carbonosos (PRANCHA $16 \mathrm{C})$.

O xisto carbonoso encaixante apresenta pirrotita, arsenopirita e calcopirita associados à lineação mineral e de estiramento $\left(\mathrm{L}_{\mathrm{m} / \mathrm{e} 3}\right)$. Essa lineação é paralela à direção de crenulação, sugerindo um forte controle estrutural na precipitação e recristalização dos sulfetos acima. A esfalerita ocorre de maneira disseminada no xisto carbonoso. A pirrotita, com alguma calcopirita nas bordas, apresenta-se freqüentemente como uma fase tardia entre os sulfetos sendo controlada pela $L_{m}$ ez. Esses sulfetos invadem os veios de quartzo de maneira dendrítica, quando o veio de quartzo seciona a $\mathrm{L}_{\mathrm{m} / \mathrm{e} 3}$ no xisto carbonoso, feição essa bastante preservada nas amostras estudadas (FIGURA 54), sugerindo uma recorrência dos processos hidrotermais.

Os grãos de quartzo apresentam pouca ou nenhuma extinção ondulante, às vezes com sub-grãos e contatos irregulares. Alguns poucos cristais subhedrais prismáticos ocorrem com suas pontas voltadas para o centro do veio, com padrão sintético de crescimento, corroborando com a interpretação obtida nos trabalhos de mapeamento e com o padrão predominantemente distensivo do veio (PRANCHA 16 A e B).

Um número relativamente pequeno de grãos apresenta grupos de inclusões isoladas no centro indicando uma suave recristalização das bordas.

A ausência de contatos retos e junções tríplices com 120 graus, indicam que a amostra do veio de quartzo pode ser considerada como bem preservada, com algumas modificações locais, principalmente na borda de alguns grãos. 


\subsubsection{Amostra CIV-G019-Vl}

Granulação: 0,1 to $1,4 \mathrm{~mm}$

Forma dos grãos: anhedrais com poucos cristais subhedrais.

Tipo dos agregados de grãos: inequigranulares interłobados (PRANCHA 16 C)

A rocha hospedeira do veio de quartzo é o xisto carbonoso e neste ocorrem arsenopirita, pirrotita e calcopirita orientados segundo a lineação mineral e de estiramento $\left(\mathrm{L}_{\mathrm{m} / \mathrm{e} 3}\right)$. Esfalerita disseminada ocorre subordinadamente no xisto. A FIGURA 54 mostra a relação entre $L_{m / 23}$, os sulfetos e as áreas do veio de quartzo mais ou menos afetadas pela interação dos fluidos mineralizantes com a encaixante. As áreas mais afetadas do veio de quartzo destacam-se pela coloração marrom mais intensa do quartzo, coloração essa que apresenta diferenças devido a relações de tipos de inclusões fluidas e sólidas (ver a discussão posterior sobre tipos de inclusões fluidas).

No contato entre o xisto carbonoso e os veios de quartzo ocorrem, às vezes, cristais aciculares de turmalina que invadem o veio de quartzo. Esses cristais, que cortam diversos grãos de quartzo, apresentam-se bem preservados, mas localmente estão fraturados, apesar de possuirem tamanhos maiores que $1 \mathrm{~mm}$ de comprimento e $10 \mu \mathrm{m}$ de espessura. Algumas das fraturas na turmalina apresentam deslocamentos (PRANCHA $16 \mathrm{~F}$ ), particularmente quando os cristais se posicionam ortogonalmente ao sistema de falhas tardias (evento D4). Por outro lado, os cristais que se posicionam paralelamente a esse evento estão totalmente preservados. A turmalina ocorre envolvida ou inclusa em todos os minerais do veio (pré-/sin-pirrotita, conforme pode ser visto na PRANCHA $16 \mathrm{E}$ ), e é claramente pós-dobramento do xisto carbonoso. Isso demonstra que a turmalina foi o primeiro mineral a precipitar durante o episódio de abertura do veio e ainda que, o veio de quartzo não sofreu modificações fortes após a cristalização da turmalina.

Alguns grãos de quartzo apresentam extinção ondulante fraca, bordas irregulares com sub-grãos e recristalização suave.

\subsubsection{Amostra CIV-G021-V1}

A amostra apresenta dois domínios distintos relacionados ao quartzo:

a) Domínio do veio de quartzo 
Granulação: 0,4 to $2,0 \mathrm{~mm}$

Forma dos grãos: anhedrais, com poucos cristais subhedrais.

Tipo dos agregados de grãos: inequigranulares interlobados a poligonais

$O$ veio de quartzo apresenta algumas relíquias do xisto carbonoso encaixante, refletindo o processo de abertura que também permitiu a entrada de fluidos mais tardios (PRANCHA $17 \mathrm{C}$ ). O quartzo original nas relíquias está quase todo substituído pelo seu equivalente recristalizado, apresentando grãos inequigranulares característicos do veio.

Ocorrem duas assembléias distintas de inclusões fluidas no veio: uma aquo-carbônica com cristais de saturação (halita e possivelmente carbonato) e uma carbônica.

O veio apresenta granulação variada com formas irregulares, poucas vêzes poligonais ou com junções tríplices, o que indica processos de recristalização locais.

\section{b) Quartzo no domínio da encaixante}

Granulação: 0,2 to $0,8 \mathrm{~mm}$

Forma dos grãos: cristais subhedrais a euhédricos.

Tipo dos agregados de grãos: equigranulares poligonais (PRANCHA 17 A e B)

O quartzo no domínio da encaixante carbonosa foi recristalizado e está associado a dobras apertadas e boudins. Pirrotita é fase dominante entre os sulfetos controlados pela $L_{m / e}$, com inclusões muito pequenas de calcopirita sendo claramente pós-milonitização (evento D3). A esfalerita ocorre disseminada no xisto e, junto com a arsenopirita, como inclusão na pirrotita. A arsenopirita apresenta freqüentemente fraturas induzidas pela milonitização, o que reforça a existência de uma fase prévia deste sulfeto, provavelmente anterior ao dobramento e milonitização do xisto carbonoso (ASP2).

O quartzo mostra texturas de recristalização e grãos aproximadamente equidimensionais, em geral menores que os grãos do veio (PRANCHA 17 A e B). Essas feições sugerem, juntamente com as dobras apertadas e boudins, que a recristalização foi promovida durante ou imediatamente após a primeira fase de milonítização do xisto. $\mathrm{O}$ quartzo recristalizado apresenta poucas inclusões fluidas, sempre muito pequenas $(<5 \mu \mathrm{m})$ e sem cristais de saturação, comuns nos veios. Inclusões arredondadas, com fases cristalinas constituidas por minerais opacos e transparentes, são interpretados como melt inclusions. 

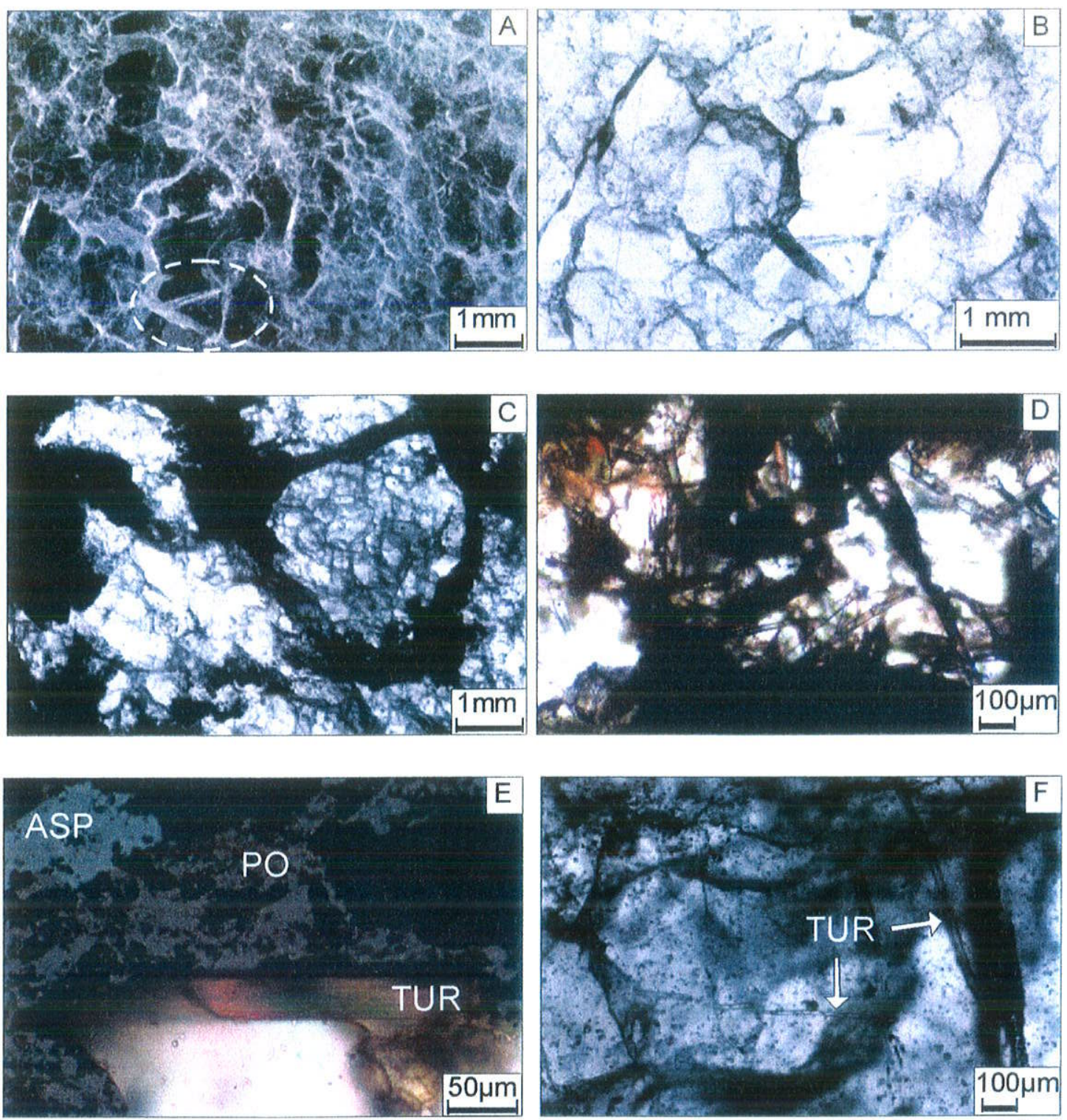

PRANCHA 16 - (A) Textura do quartzo inequigranular interlobado; o círculo tracejado destaca um cristal subhedral de quartzo (Q-IV1, amostra CIV-G010-V1, campo escuro). (B) Detalhe das formas subhedrais dos cristais de quartzo (Q-IV1, amostra CIV-G010-V1, luz transmitida). (C) Textura do quartzo inequigranular interlobado e xisto carbonoso dobrado (Q-IV1, amostra CIV-G019-V1, luz transmitida). (D) Turmalinização próxima ao contato do xisto carbonoso com o veio de quartzo (QIV1, amostra CIV-G019-V1, luz transmitida). (E) Cristal subédrico de turmalina "bicolor" em contato com pirrotita anterior, que por sua vez traz uma inclusão de arsenopirita (Q-IV1, amostra CIV-G019V1, luz transmitida). (F) Finos cristais de turmalina mostrando fraturas com deslocamentos quando posicionados ortogonalmente ao sistema de falhas tardias (evento D4) e cristais paralelos a esse sistema de falha sem fraturas (Q-IV1, amostra CIV-G019-V1, luz transmitida). Abreviações conforme TABELA 1. 


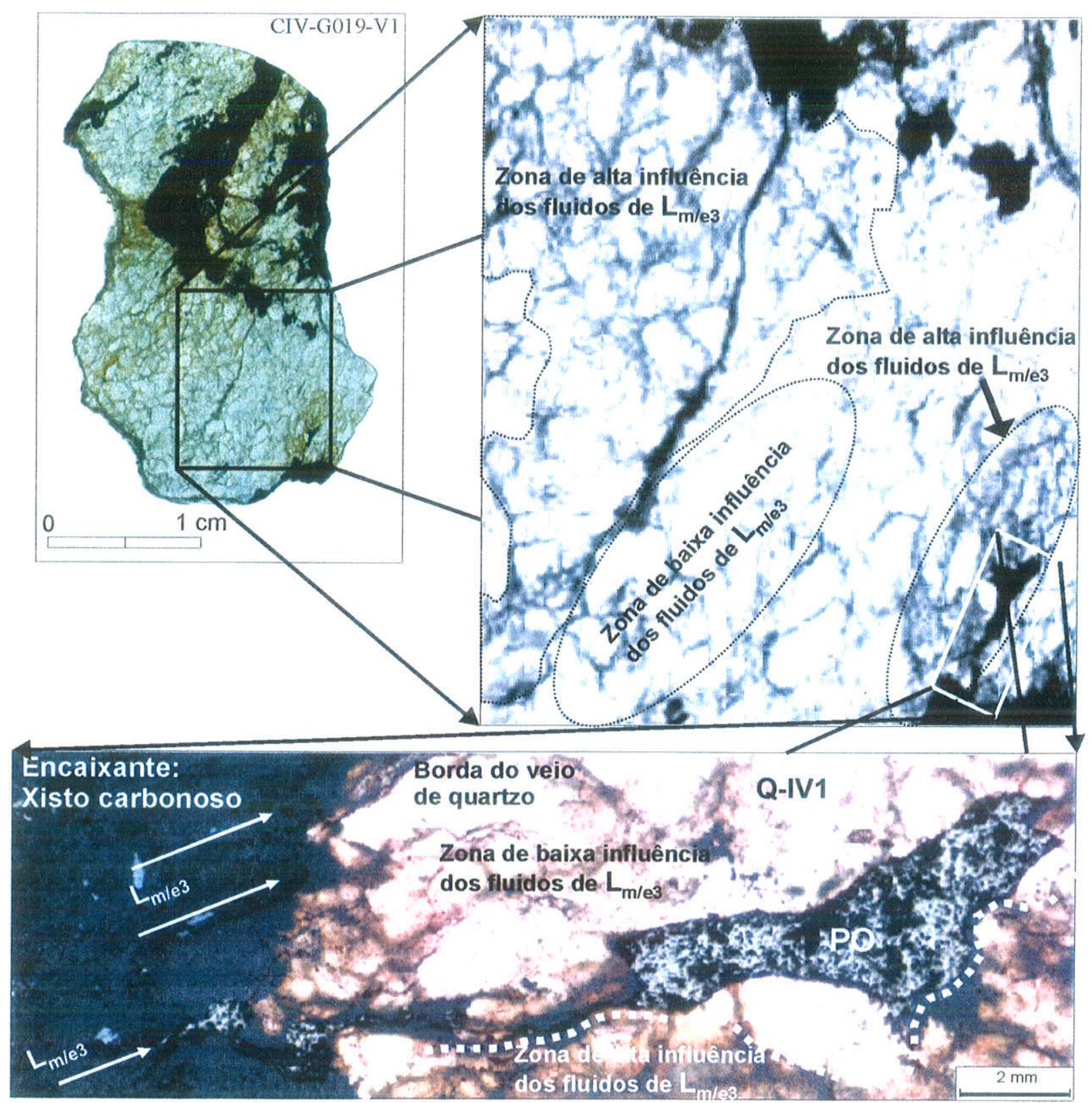

FIGURA 54 - A parte superior esquerda mostra a imagem geral da amostra CIV-G019-V1 do Q-IV1 em contato com o xisto carbonoso dobrado da encaixante (evento D3). O detalhe na parte superior direita mostra as zonas onde os fluidos com sulfetos afetaram mais o veio de quartzo, gerando regiões mais leitosas, de cor amarronzada. No recorte ampliado da última imagem pode ser visto como a pirrotita tardia, controlada pela lineação mineral e de estiramento $\left(\mathrm{L}_{\mathrm{m} / \mathrm{e} 3}\right)$, é "injetada" no veio de quartzo. Tanto a partir do veio de pirrotita no quartzo como do contato da encaixante ocorrem zonas

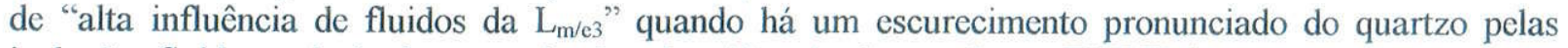
inclusões fluidas, principalmente pela pirrotita. Abreviações conforme TABELA 1. 
A ausência de inclusões fluidas com cristais de saturação no domínio da encaixante sugere que o fluido mais salino veio através de aberturas mais largas (> que $1 \mathrm{~cm}$ ) após a milonitização e dobramento, ao final do evento D3.

\subsection{Veio de quartzo da segunda geracão no Corpo IV (O-IV2)}

\subsubsection{Amostra CIV-G027-V1}

Granulação: 0,4 to $2,5 \mathrm{~mm}$

Forma dos grãos: anhedrais

Tipo dos agregados de grãos: inequigranulares interlobados (PRANCHA 17 C)

Os núcleos dos grãos de quartzo não apresentam sinais de recristalização. Os grãos apresentam formas irregulares com contornos curvos, ocorrendo recristalização nas bordas, bordas essas, realçadas pelos fluidos provenientes das encaixantes de xisto carbonoso. Em certas zonas do quartzo ocorre maior influência dos fluidos derivados do xisto carbonoso, evidenciado pela coloração marrom mais intensa, dando um aspecto túrbido ao quartzo. Uma das fraturas é preenchida com arsenopirita não fraturada com pequenas inclusões de calcopirita nas bordas. Essa arsenopirita deve ser pós-milonítica (ASP3) ou simplesmente ter sido poupada pelo fraturamento, verificado em alguns cristais de arsenopirita.

\subsection{Veio da terceira geracão no Corno IV (Q-IV3)}

\subsubsection{Amostra CIV-G014-V3}

A amostra apresenta dois domínios distintos relacionados ao quartzo:

a) Domínio do veio de quartzo

Granulação: 0,4 to $2,5 \mathrm{~mm}$

Forma dos grãos: anhedrais

Tipo dos agregados de grãos: inequigranulares interlobados (PRANCHA $17 \mathrm{E}$ )

O veio apresenta uma grande variação na granulação, sendo basicamente constituído por grãos com núcleos preservados, contendo grupos de inclusões, além de bordas irregulares parcialmente recristalizadas. Ocorre um sistema de fraturas ortogonais à $S_{1}$ e à $S_{m 3}$ provavelmente relacionadas ao evento mais tardio $\left(\mathrm{D}_{4}\right)$ e que aparentemente não causa 
modificações dos grupos de inclusões nas proximidades. Na amostra analisada, esses eventos tardios de deformação são reconhecíveis apenas em relíquias do xisto carbonoso destacados dentro do veio e na encaixante. No domínio do veio, esse sistema de fraturas apresenta finas linhas definidas por inclusões fluidas, muito pequenas $(<3 \mu \mathrm{m})$, provavelmente aquosas, em uma disposição semelhante à "S/C", cortando os grãos mais antigos de quartzo (PRANCHA $17 \mathrm{~F})$.

\section{b) Quartzo no domínio da encaixante}

Granulação: 0,2 to $0,8 \mathrm{~mm}$

Forma dos grãos: subhedrais

Tipo dos agregados de grãos: equigranulares poligonais a interlobados (PRANCHA $18 \mathrm{~A}$ )

Os grãos de quartzo no xisto carbonoso encaixante são menores que os grãos no domínio do veio, com pequenas variações em suas dimensões. As bordas dos grãos apresentam linhas geralmente retas, com junções tríplices de 120 graus.

Esse domínio mostra finas linhas de material carbonoso que são interpretadas como $\mathrm{S}_{1}$ dobradas, cortadas pelo evento milonítico posterior $S_{m 3}$, o qual reposiciona o material carbonoso em um padrão semelhante a "S/C". A amostra toda é cortada pelas últimas fases deformacionais, provavelmente relacionadas à $\mathrm{D}_{4}$, em geral ortogonais a $\mathrm{S}_{4}$.

\subsubsection{Amostra CIV-G015-V3}

A amostra apresenta dois domínios distintos relacionados ao quartzo:

a) Domínio do veio de quartzo

Granulação: 0,1 to $1,6 \mathrm{~mm}$

Forma dos grãos: anhedrais

Tipo dos agregados de grãos: inequigranulares interlobados (PRANCHA 18 B, C e D). 

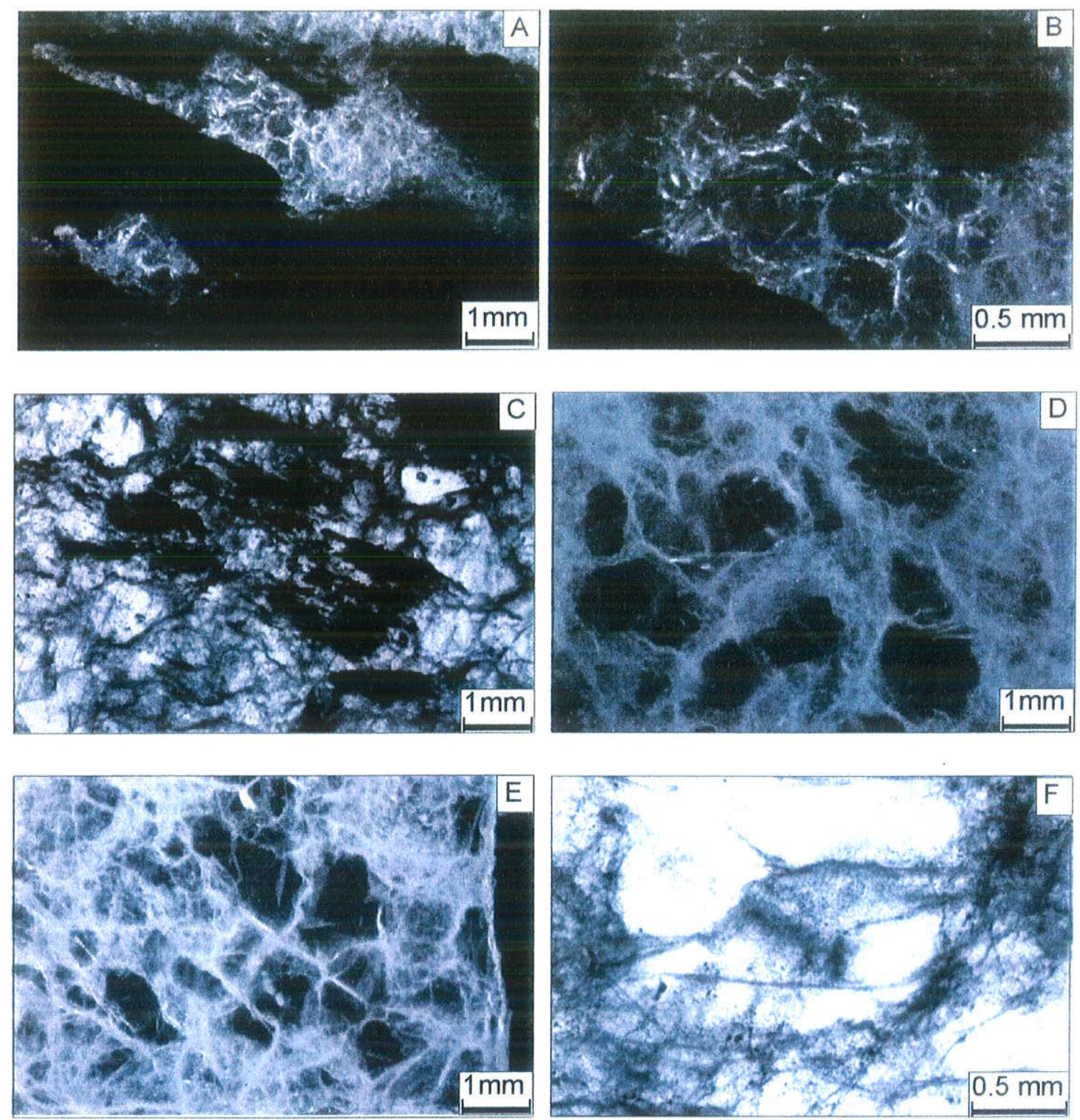

PRANCHA 17 - (A) Quartzo recristalizado com textura poligonal equigranular e boudins no xisto carbonoso (Q-IV1, amostra CIV-G021-V1, campo escuro). (B) Detalhe da textura equigranular poligonal dentro do boudin. (Q-IV1, amostra CIV-G021-V1, campo escuro). (C) Relíquia do xisto carbonoso no veio de quartzo; o quartzo recristalizado do xisto carbonoso é inteiramente substituído pelo quartzo inequigranular interlobado (Q-IV1, amostra CIV-G021-V1, luz transmitida). (D) Textura inequigranular interlobada com recristalização nas bordas dos grãos devido aos fluidos derivados do xisto carbonoso (Q-IV2, amostra CIV-G027-V2, luz transmitida). (E) Agregado de grãos de quartzo no domínio da veio 3 (Q-IV3, amostra CIV-G014-V3, campo escuro). (F) Estruturas "S/C" no domínio do veio de quartzo 3 , relacionado à $\mathrm{D}_{4}$ (Q-IV3, amostra CIV-G014-V3, luz transmitida). 
O veio de quartzo desta amostra possui características idênticas ao da amostra CIVG014.V3. Os grãos de quartzo apresentam grande variação no tamanho e bordas irregulares com relíquias do xisto carbonoso dobrado e cisalhado (pré-D4). Essas reliquias são interpretadas como a evidência principal de que o veio de quartzo é posterior ao sistema de dobras e ao cisalhamento que afetou o xisto carbonoso da encaixante. Ocorre ainda um sistema de fraturas ortogonais às foliações no xisto carbonoso e às paredes do veio o qual deve estar relacionado às zonas de cisalhamento tardias (PRANCHA $18 \mathrm{C}$ e D). Essas fraturas são preenchidas com carbonato e pirrotita, sendo o carbonato característico dos sistemas de falhas tardias.

\section{b) Quartzo no domínio da encaixante}

Granulação: 0,1 to $0,6 \mathrm{~mm}$

Forma dos grãos: subhedrais

Tipo dos agregados de grãos: equigranulares poligonais a interlobados.

Os grãos de quartzo na encaixante de xisto carbonoso são em geral equigranulares com tamanhos menores que os cristais do veio, indicando que a recristalização está relacionada à fase milonitica, provavelmente D3. Essa observação também sugere que a recristalização no xisto carbonoso teve lugar antes da abertura e preenchimento do veio de quartzo principal. A zona de cisalhamento destruiu parcialmente os leitos carbonosos da $\mathrm{S}_{\mathbf{1}}$ dobrada e, tanto a zona de cisalhamento como a $S_{1}$ dobrada são cortados por falhas tardias (PRANCHA 18 E e F).

Movimentos tardios de strike-slip são evidenciados por deslocamentos nas estruturas $\mathrm{S}_{1}$ e $\mathrm{S}_{\mathrm{m} 3}$ e são interpretados como sendo parte dos sistemas de falhas relacionados ao cisalhamento tardio (PRANCHA $18 \mathrm{E}$ e F). A ocorrência de preenchimento das fraturas com carbonato reforça essa afirmação. 

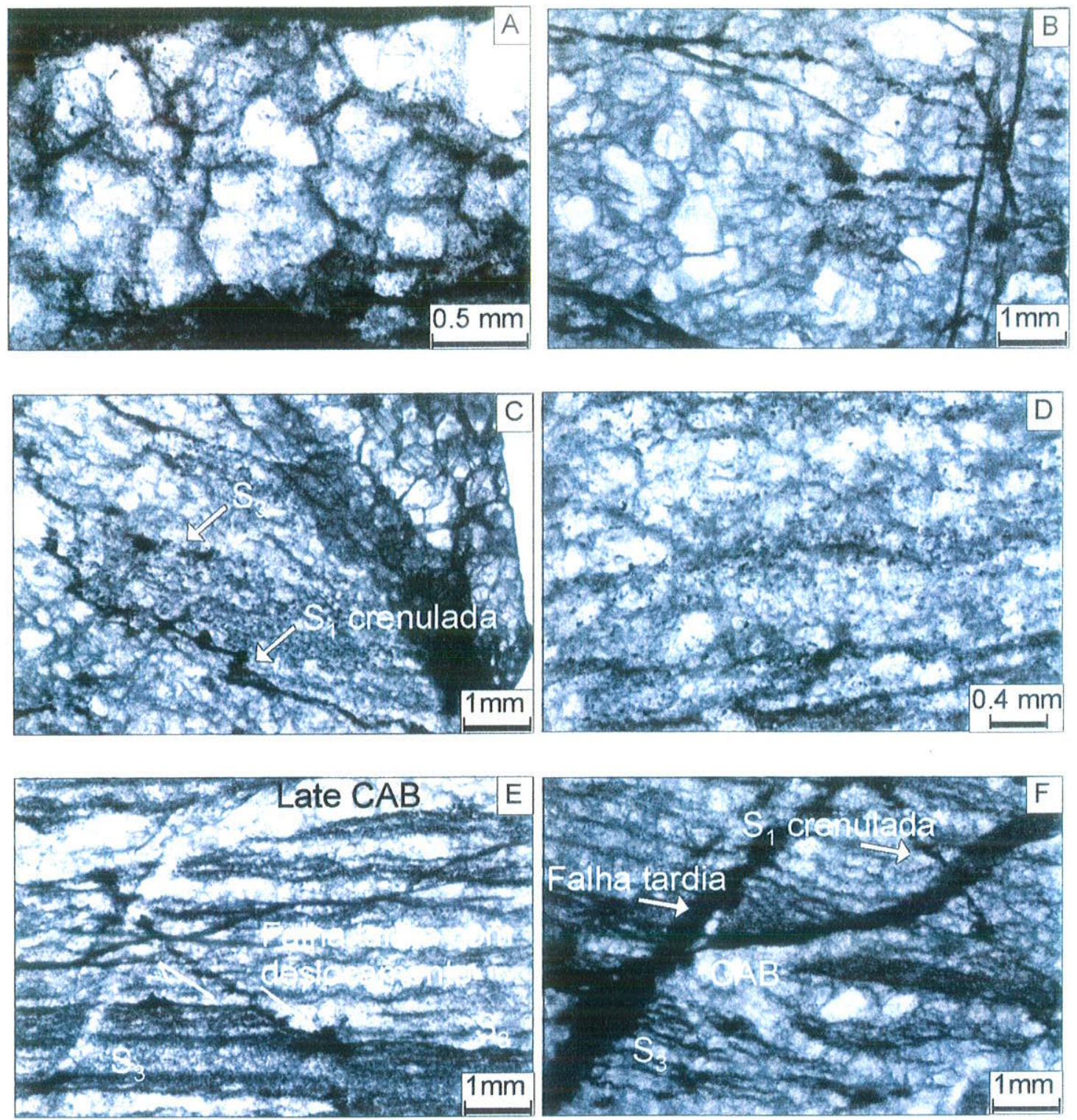

PRANCHA 18 - (A) Grãos de quartzo do domínio da encaixante mostrando quartzo recristalizado com padrão equigranular, poligonal e relativamente menor que o domínio do veio (Q-IV3, amostra CIV-G014-V3, luz transmitida). (B) Agregado de grãos de quartzo no domínio do veio (Q-IV3, amostra CIV-G015-V3, luz transmitida). (C) Relíquias da $S_{1}$ dobrada com a superposição do cisalhamento posterior à $\mathrm{S}_{3}$ milonítica (Q-IV3, amostra CIV-G015-V3, luz transmitida). (D) Padrão dos grãos de quartzo no domínio do veio (Q-IV3, amostra CIV-G015-V3, luz transmitida). (E) Agregado de grãos de quartzo no domínio da encaixante com $\mathrm{S}_{3}$ milonítica deslocada pelo sistema ortogonal de falhas strike-slip tardias (Q-IV3, amostra CIV-G015-V3, luz transmitida). (F) Relíquias da $\mathrm{S}_{1}$ dobrada, $\mathrm{S}_{3}$ milonítica e o sistema de falhas tardias com preenchimento de carbonato e pirrotita (Q-IV3, amostra CIV-G015-V3, luz transmitida). 


\subsection{Veio da quarta geracão no Corpo IV (Q-IV4)}

\subsubsection{Amostra CIV-G012-V4}

A amostra apresenta dois domínios distintos relacionados ao quartzo:

a) Domínio do veio de quartzo hialino

Veio de quartzo muito translúcido com algumas fraturas. Não há sinais de recristalização nesse domínio.

b) Domínio do veio de quartzo cisalhado

Granulação: 0,2 to $1,0 \mathrm{~mm}$

Forma dos grãos: anhedrais

Tipo dos agregados de grãos: equigranulares poligonais a interlobados.

O domínio do veio de quartzo cisalhado na amostra localiza-se próximo aos sulfetos e mostra sinais de recristalização associados com zonas de quartzo mais escuras devido ao número relativamente grande de inclusões fluidas (zonas de alta influência dos fluidos derivados da encaixante). A arsenopirita ocorre com pequenas inclusões de calcopirita nas bordas.

\subsubsection{Amostra CIV-G026-V4}

Granulação: 0,2 to $1,0 \mathrm{~mm}$

Forma dos grãos: anhedrais

Tipo dos agregados de grãos: equigranulares poligonais a interlobados (PRANCHA $19 \mathrm{~A}$ ).

Granulação: até $20,0 \mathrm{~mm}$ no carbonato e feldspato

Forma dos grãos: anhedrais a subhedrais

Tipo dos agregados de grãos: o quartzo no meio do veio é maciço e leitoso. O carbonato e feldspato mostram contornos retos e corroídos

Esse veio tardio de quartzo, com $10 \mathrm{~cm}$ de espessura, está hospedado no xisto carbonoso dobrado, sendo que suas bordas apresentam pirrotita, calcopirita, ouro livre, apatita, carbonato e feldspato (sem quartzo). Essa borda, com aproximadamente $5 \mathrm{~cm}$ de espessura e constituída por cristais subédricos menores que $2 \mathrm{~cm}$, fornece indícios, através de 
associações petrográficas com os minerais anteriormente mencionados, de que o veio tenha se formado num evento anterior (provavelmente D3) e tenha sido reativado pelo evento neoproterozóico, com a neoformação de quartzo no núcleo do veio. O quartzo que ocorre no núcleo do veio é leitoso e não apresenta sinais de recristalização. As fraturas estão limitadas às bordas deste veio (pré-D4) e são preenchidas com sulfetos e ouro. As paredes das fraturas apresentam contatos corroídos, provavelmente devido à entrada de fluidos com a mineralização.

A amostra abrange a borda do veio, que tem associado carbonato, apatita, feldspato, sulfetos e ouro. O ouro ocorre nessa amostra como um grão de aproximadamente $1 \times 0,3 \times$ $1,5, \mathrm{~cm}$ intimamente associado com a pirrotita.

\subsubsection{Amostra CIV-G073-V4 (4SI)}

O quartzo é de maneira geral hialino e maciço com poucas fraturas. Essa amostra do veio é caracterizada pela ocorrência de cristais euhédricos de siderita $(3-5 \mathrm{~mm}$, PRANCHA $19 \mathrm{~B}$ ), mas foram encontrados cristais com até $5 \mathrm{~cm}$. Sulfetos ocorrem nas fraturas do quartzo e como inclusões nas bordas dos cristais euhédricos de siderita. O sulfeto dominante é a pirrotita, sendo que a Arsenopirita (ASP2) também ocorre, com fraturas pré-pirrotita.
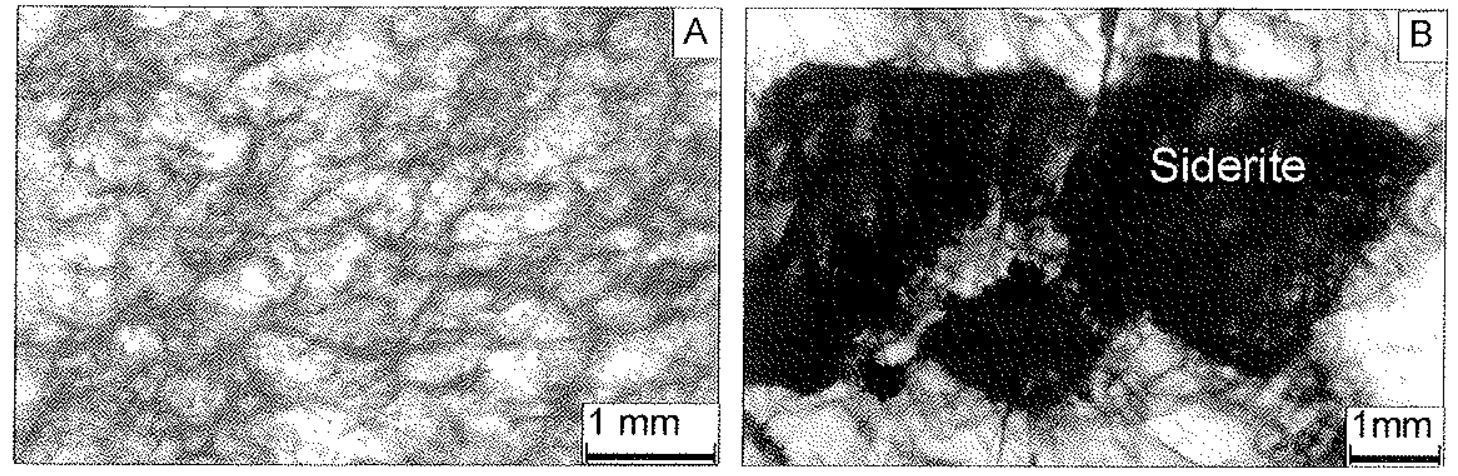

PRANCHA 19 - (A) Veio de quartzo cisalhado/recristalizado (Q-IV4, Amostra CIV-G012-V4, luz transmitida). (B) Cristais euhédricos de siderita no veio de quartzo hialino com inclusões fluidas aquocarbônicas primárias (Q-IV4, Amostra CIV-G073-V4, luz transmitida). 


\section{INCLUSÕES FLUIDAS NOS VEIOS E MINERAIS DO CORPO IV}

Os grupos de inclusões fluidos (IF) estudados foram selecionados cuidadosamente através de critérios de classificação onde, inicialmente são separadas associações de interesse, relacionadas a feições texturais e/ou a proximidades de fases minerais de interesse para o estudo. Estas são separadas em inclusões contidas em grãos individualizados (contendo principalmente as IF primárias e pseudo-secundárias) e em fraturas e/ou zonas de inter-grãos (IF secundárias), sempre no quartzo, salvo descrição específica em contrário. Esstas são então classificadas em carbônicas (c), aquo-carbônicas (aq-c) e aquosas (aq), que por sua vez contêm as subdivisões genéticas: primárias, pseudosecundárias e secundárias de acordo com Roedder (1984).

Foi ainda possível a obtenção de medidas a partir de minerais como apatita (com íntima relação com pirrotita e ouro) e siderita, sendo que ambas apresentaram inclusões fluidas primárias aquo-carbônicas.

As classificações definidas nas amostras dos veios de quartzo do Corpo IV são apresentadas a seguir, divididas inicialmente pela geração do veio de quartzo à qual se relacionam e subdivididos em sistemas químicos.

\subsection{Inclusões fluidas no veio da primeira geracão (Q-IV1)}

O veio de quartzo 1 apresenta a maior diversidade de inclusões fluidas, com inclusões carbônicas, aquo-carbônicas e aquosas. Para maior clareza, os tipos composicionais serão abordados separadamente. O Q-IV1 é representado pelas amostras CIV-G010-V1, CIV-G019V1 e CIV-G021-V1.

Alguns grupos de inclusões carbônicas são de difícil classificação, por causa da possibilidade da existência de detgados filmes de $\mathrm{H}_{2} \mathrm{O}$, podendo ser, na realidade, aquocarbônicas.

\subsubsection{Carbônicas (Tino 1c)}

As inclusões carbônicas no Q-IV1 são interpretadas como sendo primárias, ocorrendo em trilhas isoladas no núcleo dos grãos (PRANCHA $20 \mathrm{~A}$, PRANCHA $21 \mathrm{C}$ ) ou de cristais subédricos (PRANCHA $20 \mathrm{C}$ e E). A PRANCHA $20 \mathrm{~B}$ apresenta um plano de inclusões que se desenvolveu provavelmente entre 2 cristais subédricos de quartzo. 
De maneira geral as inclusões formadas em fraturas inter-grãos de quartzo são interpretadas como sendo secundárias, mas não diferem muito nas suas qualidades físicas das formadas no interior do quartzo.

\subsubsection{Aquo-carbônicas (Tipo 1ac)}

Algumas regiões do Q-IV1 apresentam associações de inclusões aquo-carbônicas pseudo-secundárias em planos, nas quais pode-se reconhecer relações $\mathrm{VCO}_{2} / \mathrm{V}$ tot com 0,3 a 0,5 ou mais (amostras 19_5, 19_21). Essas mesmas feições foram também encontradas em IF aquo-carbônicas secundárias no quartzo. Esses grupos possuem um dos critérios indicativos de imiscibilidade, conforme discussão de Ramboz et al. (1982).

A maior parte das inclusões aquo-carbônicas secundárias contêm, freqüentemente, de um a três cristais de saturação (PRANCHA 20 D, PRANCHA 21 B e D). Foi ainda reconhecida uma geração tardia de inclusões $\left(\operatorname{lac}_{2}\right)$, de ocorrência mais rara, que corta a primeira geração (PRANCHA 20 E e detalhe F, PRANCHA 21 A).

O cristal de saturação mais freqüente é a halita, ocorrendo ainda, calcita, determinada ópticamente e com o auxílio da espectrometria Laser-Raman.

\subsubsection{Aquosas (Tipo 1a)}

Existe um número relativamente menor de inclusões aquosas que aparentemente ocorrem associadas com as inclusões carbônicas. As inclusões tipo la apresentam normalmente um a dois cristais de saturação, sendo um deles a halita.

\subsection{Inclusões fluidas no veio da segunda geracão (Q-IV2)}

A amostra do Q-IV2 apresenta como principal característica, em relação ao Q-IV1, a ausência de inclusões carbônicas e aquosas. A petrografia revelou apenas inclusões fluidas aquo-carbônicas no quartzo, sem cristais de saturação. Um único caso de inclusão fluida primária, que ocorre isolada, revelou a existência de um cristal de saturação de halita, ao lado de outro mineral, provavelmente, rutilo (PRANCHA $21 \mathrm{~F}$ ), determinado pela espectrometria Laser-Raman (o cristal acicular negro, foi destruído pelo feixe de laser - amostra CIV-G027V2). 

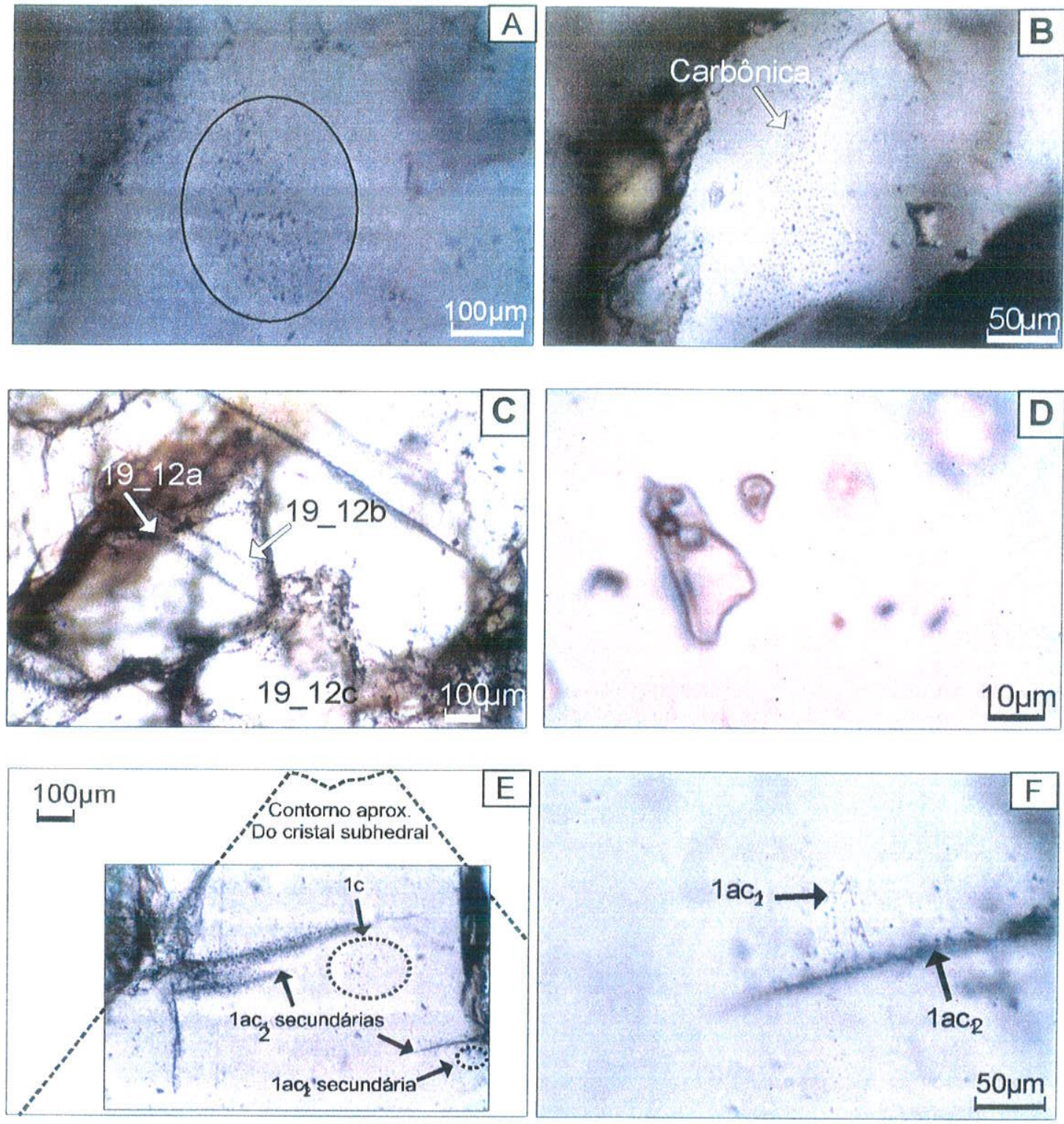

PRANCHA 20 - (A) Associação de IFs carbônicas primárias no núcleo do grão de quartzo (Q-IV1, Amostra 19_07). (B) Associação de IFs carbônicas primárias entre relíquias de cristais de quartzo subédricos (Q-IV1, Amostra 19_10). (C) Um par geminado de cristais de quartzo subédricos com inclusões primárias em 19_12c e secundárias em 19_12a e 19_12b (Q-IV1, Amostra 19 12). (D) Inclusão fluida aquo-carbônica com dois cristais englobados, sendo halita o cristal cúbico maior e calcita o menor (Q-IV1, Amostra 10_05). (E) Imagem de um cristal subédrico com um grupo de inclusões carbônicas primárias (1c), vários grupos com inclusões aquo-carbônicas secundárias (lac $\left.{ }_{1}\right)$ com até dois cristais de saturação e um grupo de inclusões fluidas aquo-carbônicas tardias $\left(1 \mathrm{lac}_{2}\right)$, com no máximo um cristal de saturação, que corta a trilha do grupo anterior (Q-IV1, Amostra 10 09). (F) Detalhe do canto direito inferior onde a trilha de inclusões aquo-carbônica lac $\mathrm{ac}_{1}$ é cortada pela posterior $1 \mathrm{ac}_{2}$ (Q-IV1, Amostra 10_09). 


\subsubsection{Aquo-carbonicas (Tipo 2ac)}

De maneira geral as relações volumétricas entre as fases carbônicas e aquosas das inclusões aquo-carbônicas são bastante semelhantes nos três grupos genéticos, primárias: pseudosecundárias e secundárias (PRANCHA 21 E).

Destaca-se apenas a inclusão primária 27_10 com cristais de saturação (PRANCHA $21 \mathrm{~F}$ ), único caso na amostra estudada.

Da mesma maneira que na amostra do veio 1 ocorrem pelo menos duas gerações de trilhas com inclusões aquo-carbônicas, sendo a primeira geralmente menor (IF menores que 3 $\mu \mathrm{m})$ que a segunda (IF menores que $15 \mu \mathrm{m}$ ).

\subsection{Inclusões fluidas no veio da terceira geracão (Q-IV3)}

O Q-IV3 se caracteriza por apresentar diversas regiões com inclusões carbônicas e aquo-carbônicas em uma mesma trilha, com forte variação nas relações $\mathrm{VCO}_{2} / \mathrm{V}$ tot, particularmente nos veios relacionados aos sulfetos, sugerindo processos de imiscibilidade (Ramboz et al., 1982).

Ocorrem ainda diversas falhas tardias que formam finos cordões de inclusões fluidas com uma ou duas fases, que raramente, ultrapassam $3 \mu \mathrm{m}$. Essas falhas são características dos eventos tardios que afetaram a encaixante e os veios, provavelmente pelo evento D4.

O Q-IV3 é representado pelas amostras CIV-G014-V3 e CIV-G015-V3 .

\subsubsection{Carbônicas (Tipo 3c)}

As inclusões carbônicas parecem estar intimamente ligadas aos veios com sulfetos, ocorrendo basicamente em fraturas e associadas a trilhas de inclusôes aquo-carbônicas, com feições de imiscibilidade (PRANCHA $22 \mathrm{~A}$ ).

\subsubsection{Aquo-carbônicas (Tipo 3ac)}

As inclusões aquo-carbônicas predominam no Q-IV3, sendo em geral secundárias, relacionadas a fraturas inter-grãos. Elas freqüentemente apresentam cristais de saturação e quase sempre são constituídas por $\mathrm{H}_{2} \mathrm{O}+\mathrm{CO}_{21}+\mathrm{CO}_{2 \mathrm{~g}}+$ sólido.

Em alguns pontos ocorre uma segunda geração de inclusões aquo-carbônicas, evidenciada pelo truncamento de trilhas da geração anterior. 

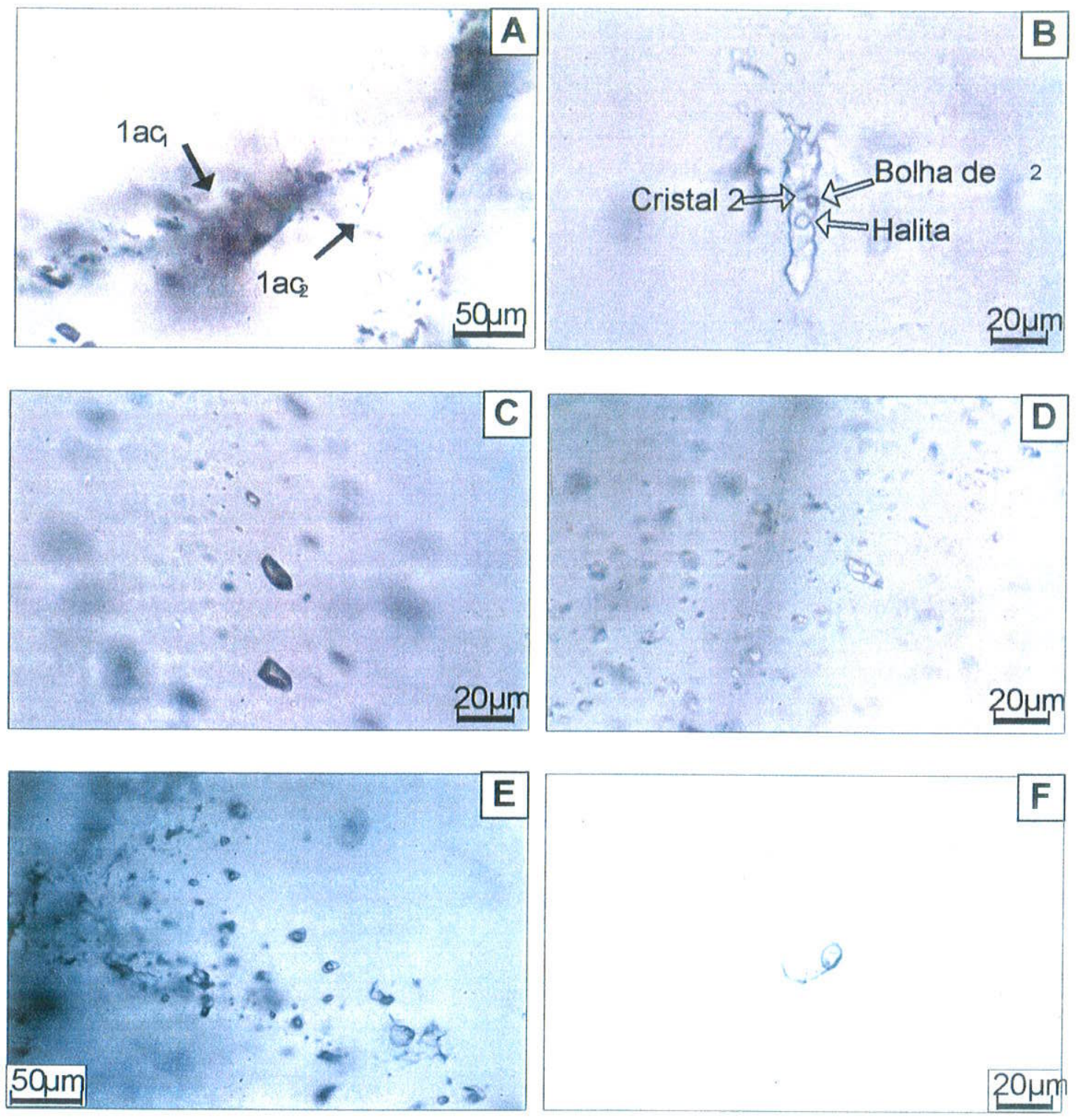

PRANCHA 21 - (A) Cruzamento das duas gerações de inclusões fluidas aquo-carbônicas, onde $1 \mathrm{lac}_{2}$ mantém a continuidade sobre $1 \mathrm{lac}_{1}$ (Q-IV1, Amostra 10_10). (B) Inclusão fluida aquo-carbônica com duas fases cristalinas (Q-IV1, Amostra 10_10). (C) Grupo de inclusões carbônicas (Q-IV1, Amostra 10_10). (D) Imagem de um grupo de inclusões aquo-carbônicas com até dois cristais de saturação (QIV1, Amostra 21_02). (E) Inclusões fluidas aquo-carbônicas secundárias (Q-IV2, Amostra 27 09). (F) Uma das raras inclusões fluidas aquo-carbônicas primárias com fases cristalinas, provavelmente halita e rutilo (Q-IV2, Amostra 27 10). 

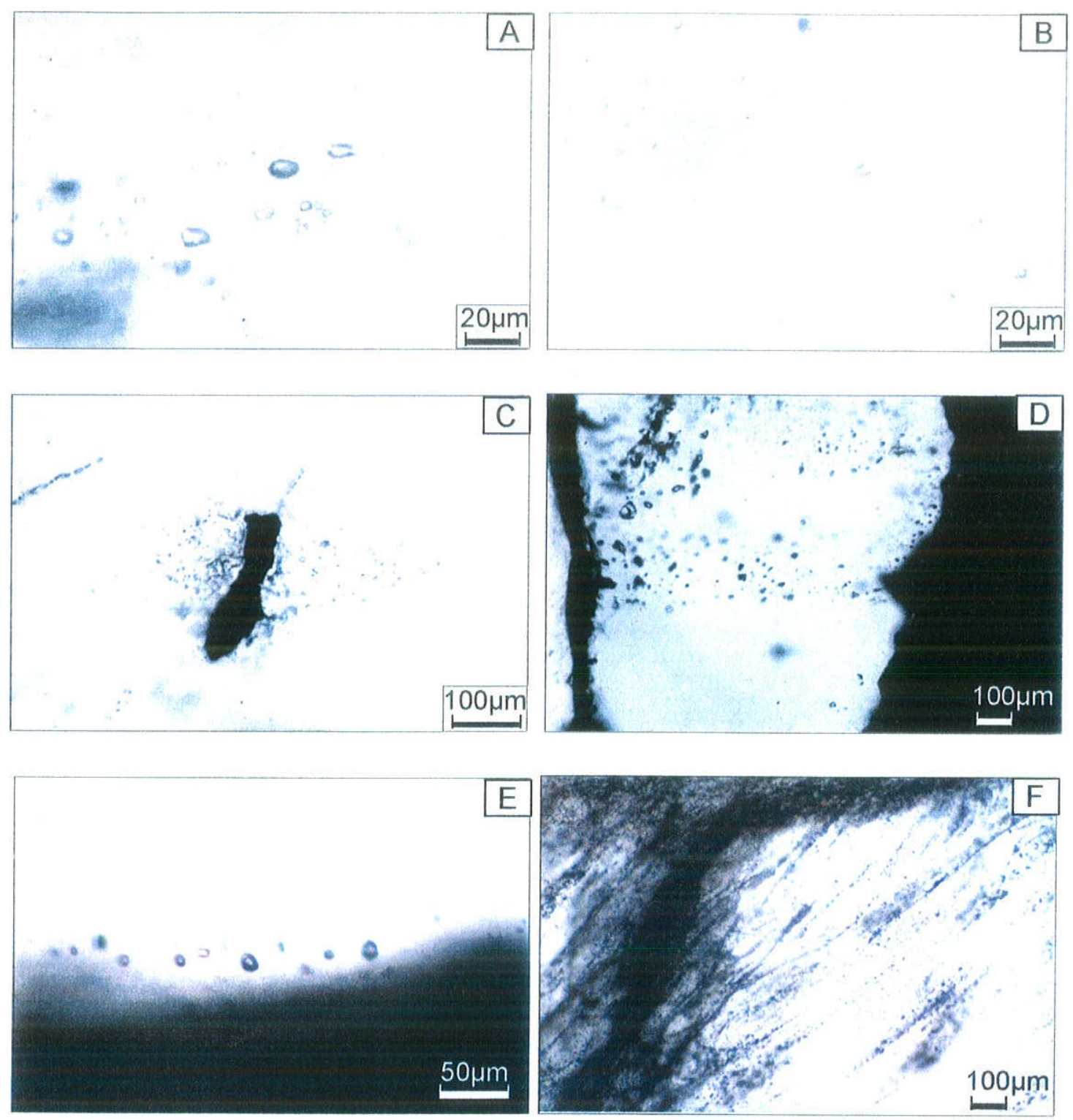

PRANCHA 22 - (A) Grupo de inclusões carbônicas e aquo-carbônicas com feições que sugerem condições de imiscibilidade e/ou variação de pressão durante o aprisionamento; discussão no texto (QIV3, Amostra 14_3). (B) Inclusões predominantemente aquo-carbônicas (Q-IV3, Amostra 14_10). (C) O mineral no centro aparenta ser de um sulfeto (provável seção ortogonal de uma "injeção" de pirrotita proveniente da $\mathrm{L}_{\mathrm{m} / \mathrm{e} 3}$ da encaixante) que gerou um halo de inclusões aquo-carbônicas ao seu redor (Q-IV3, Amostra 14_5). (D) Quartzo incluso na arsenopirita com inclusões aquo-carbônicas ricas em metano no contato com o sulfeto e nos planos internos (Q-IV4, Amostra 12_01). (E) Detalhe da fotografia 3-D com inclusões aquo-carbônicas ricas em metano na interface quartzo/arsenopirita (Q-IV4, Amostra 12_1). (F) Trilhas de inclusões aquosas tardias, provavelmente relacionadas aos sistemas de falhas do evento D4 (Q-IV4, Amostra 12_07). 


\subsection{Inclusões fluidas no veio da quarta geracão (Q-IV4)}

O Q-IV4 caracteriza-se por apresentar uma granulação mais grossa, por vezes maciça, hialina e com diversos sistemas de fraturas provavelmente induzidos por falhamentos tardios. Essas fathas geram linhas finas em padrões semelhantes às estruturas " $\mathrm{S} / \mathrm{C}$ " e que portam inclusões fluidas monofásicas bastante finas e de dificil medição.

Os cristais de siderita euédrico freqüentes nestes veios possuem inclusões fluidas aquo-carbônicas primárias que, através de medições microtermométricas, puderam ser confrontadas com as inclusões no quartzo próximo ao carbonato, visando confirmar a inexistência de eventuais modificações nas inclusões fluidas do veio (ver microtermometria adiante).

O Q-IV4 é representado pelas amostras CIV-G012-V4, CIV-G026-V4AU e CIVG073-V4SI.

\subsubsection{Carbônicas (Tipo 4c)}

Inclusões carbônicas primárias são raras no Q-IV4 e exigem muita atenção na sua classificação pelo fato de freqüentemente ocorrerem "filmes" muito finos de $\mathrm{H}_{2} \mathrm{O}$ nas suas bordas. Foram determinadas inclusões carbônicas apenas na amostra CIV-G073-V4SI (PRANCHA $23 \mathrm{E}$ ).

\subsubsection{Aquo-carbônicas (Tipo 4ac)}

As inclusões aquo-carbônicas são dominantes nas três amostras a estudadas, mas no Q-IV4, raramente apresentam cristais de saturação (PRANCHA 23 D).

Próximos aos contatos do quartzo com a arsenopirita e pirrotita ocorrem grupos de inclusões aquo-carbônicas primárias com uma baixa proporção volumétrica de $\mathrm{H}_{2} \mathrm{O}(<10 \%)$ e com tonalidade escura o que dificulta interpretação das fases. Esse grupo representa, provavelmente, a melhor amostra dos fluidos relacionados a mineralização (PRANCHA 22 B).

A amostra apresenta predominantemente inclusões aquo-carbônicas com proporções $\mathrm{H}_{2} \mathrm{O}: \mathrm{CO}_{2}$ altos, tendo sido evidenciado, em vários pontos, seu caráter tardio em relação às inclusões aquo-carbônicas com baixos valores de $\mathrm{H}_{2} \mathrm{O}: \mathrm{CO}_{2}$.

As inclusões com proporções $\mathrm{H}_{2} \mathrm{O}: \mathrm{CO}_{2}$ altas também ocorrem nos cristais de siderita euhédricos (Amostra CIV-G073-V4SI), sugerindo que as IF's no veio sofreram pouca ou nenhuma modificação (PRANCHA $23 \mathrm{C}$ ). 

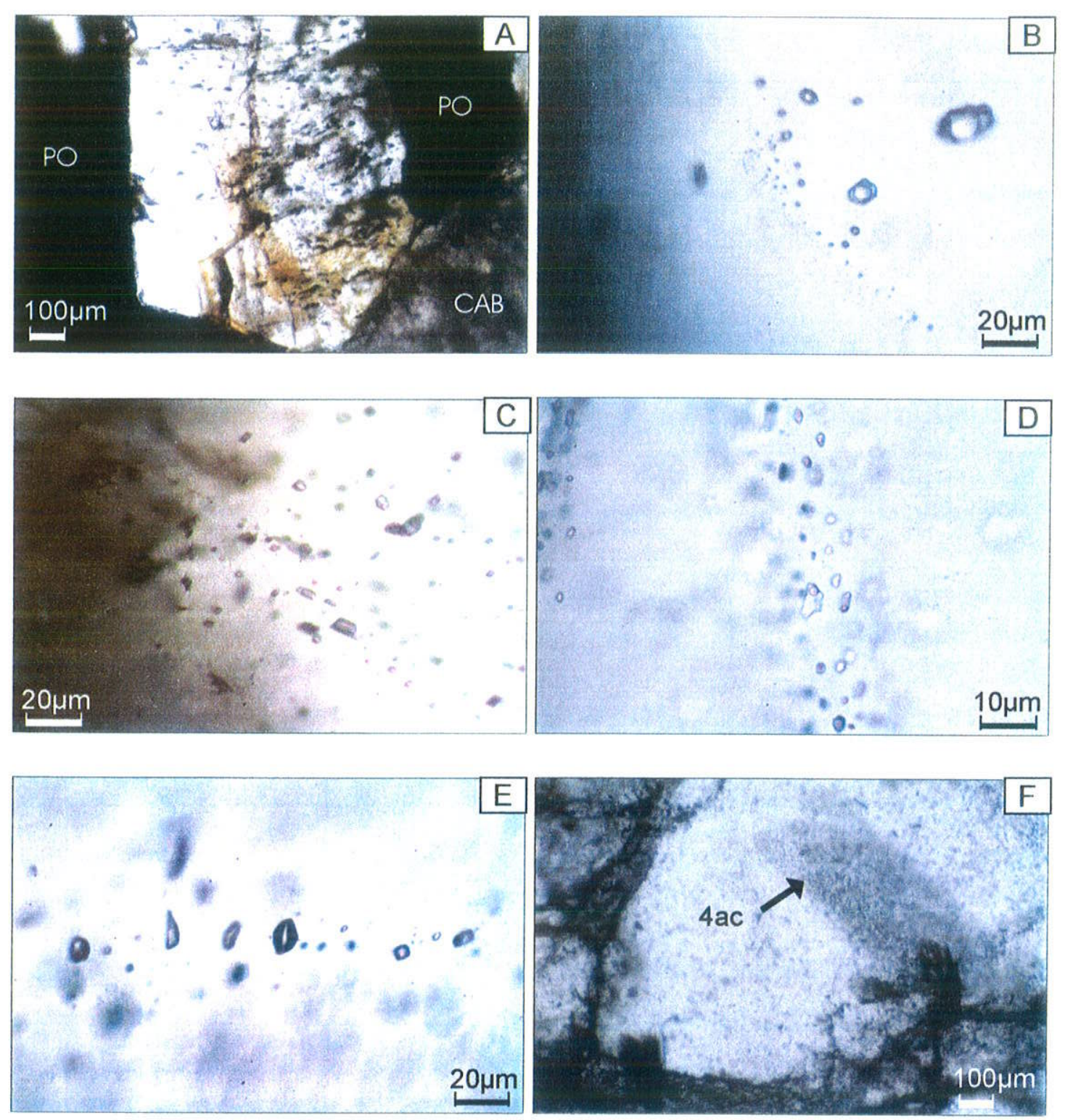

PRANCHA 23 - (A) Associação pirrotita-apatita-calcita (apatita no centro, incolor), onde ocorre ouro livre, contendo inclusões predominantemente aquo-carbônicas (Q-IV4, Amostra 26_01). (B) Detalhe das inclusões aquo-carbônicas da foto anterior (Q-IV4, Amostra 26_01). (C) Inclusões aquocarbônicas primárias na siderita (Q-IV4, Amostra 73_05). (D) Trilha de inclusões aquo-carbônicas no quartzo (Q-IV4, Amostra 73_09). (E) Raras inclusões carbônicas no veio da quarta geração (Q-IV4, Amostra 73_10). (F) Plano de inclusões fluidas aquo-carbônicas pseudo-secundárias em um cristal subédrico de quartzo (Q-IV4, Amostra $73 \_12$ ). 
Foram encontradas inclusões pseudo-secundárias com cristais de saturação apenas em um ponto da amostra CIV-G073-V4SI onde o plano de inclusões está situado em um cristal subédrico de quartzo, de maneira muito semelhante aos cristais subédricos freqüentes do QIV1, devendo tratar-se de outra geração (PRANCHA 23 F).

A PRANCHA 24 apresenta trilhas de inclusões fluidas muito pequenas, provavelmente monofásicas aquosas que seguem um padrão " $\mathrm{S} / \mathrm{C}$ ".

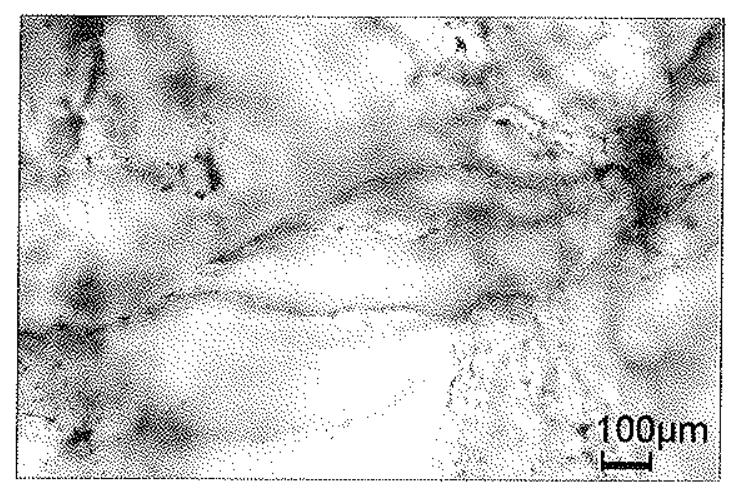

PRANCHA 24 -..Trithas de inclusões fluidas geradas pelas falhas tardias com aspecto "S/C" (Q-IV4, Amostra 73 13).

\subsection{Resumo dos tipos composicionais das inclusões fluidas}

As dimensões das inclusões fluidas variam de submicroscópicas até $50 \mu \mathrm{m}$ sem demonstrar padrões definidos. Os resultados microtermométricos não apresentaram variações em função dos tamanhos, podendo-se, portanto, presumir que durante a formação das inclusões não houve uma influência diferencial sobre a composição local e a densidade dos fluidos no veio, por meio de qualquer efeito físico-químico dependente de área superficial (Diamond, 1990). Essa afirmação pode ser reforçada, em relação à última geração de veios de quartzo estudada, pela análise microtermométrica com resultados coerentes em outras fases minerais distintas, como nas IFs primárias da siderita euédrica e do quartzo circundante, relacionados ao Q-IV4.

A TABELA 15 estabelece os tipos composicionais encontrados nas amostras dos diversos veios de quartzo.

Os cristais de quartzo do Q-IV1 destacam-se pela grande quantidade de inclusões aquo-carbônicas com minerais de saturação. Essas inclusões apesar de serem em geral secundárias, indicam a influência de fluidos relativamente mais salinos que os dos veios posteriores. Além dessas inclusões, o Q-IV1 se caracteriza pelas inclusões carbônicas 
CAPÍTULO V - Página 140

primárias, particularmente em cristais de quartzo subédricos e pelas evidências de imiscibilidade e/ou variações de pressão (a serem discutidas no capítulo de microtermometria), relacionadas aos veios com sulfetos.

Ocorrem muitos veios de sulfetos (com ou sem ouro) e carbonato que invadem o QIV1, provenientes do xisto carbonoso, particularmente dos pontos onde a $L_{m / e}$ é seccionada pelo veio de quartzo ("injeções" de pirrotita no veio a partir da encaixante carbonosa) sugerindo um sistema recorrente do movimento de fluidos no sistema hidrotermal. Geralmente, a partir de um veio principal com sulfetos e carbonatos, normalmente reconhecido pela sua espessura maior e quantidade de minerais precipitados, derivam uma infinidade de veios menores, criando uma malha dendrítica formada predominantemente por inclusões minerais (geralmente pirrotita) e inclusões fluidas carbônicas e aquo-carbônicas. Essa quantidade localizada de inclusões fornece uma aparência túrbida com coloração amarronzada ao quartzo nestes locais (zonas de alta influência de fluidos derivados da encaixante no veio de quartzo). Nestas zonas são freqüentemente encontradas evidências de imiscibilidade, com grupos de inclusões fluidas numa mesma trilha com grande variação de relações volumétricas entre as fases, associações de inclusões carbônicas com aquocarbônicas, estas últimas com ou sem cristais de saturação.

A amostra do Q-IV2 revelou apenas grupos de inclusões aquo-carbônicas primárias, praticamente isentas de cristais de saturação. A ausência de uma diversidade maior de grupos de inclusões pode estar associada ao fato que a amostra analisada não possui contato com o xisto carbonoso e sulfetos, mineralizados ou não.

O Q-IV3 apresenta inclusões predominantemente aquo-carbônicas, de maneira semelhante ao Q-IV1, incluindo cristais de saturação com dimensões relativamente menores. Novamente o grupo de aquo-carbônicas ocorre em pelo menos duas gerações. Neste veio ocorrem fraturas relacionadas à falhas tardias raramente evidenciadas nos Q-IV1 e Q-IV2. Esse fato deve estar relacionado aos cuidados tomados na coleta das amostras da primeira geração, ao se evitar a influências de eventos posteriores. Essas fraturas tardias contém inclusões muito finas $(<3 \mu \mathrm{m})$ monofásicas, provavelmente aquosas, que não oferecerem condições ópticas para análise microtermométrica.

As inclusões encontradas no Q-IV4 se assemelham às do Q-IV1 com exceção de ocorrerem aquo-carbônicas primárias e um número relativamente menor de cristais de saturação. Na amostra CIV-G073-V4SI foi encontrado um único cristal de quartzo subédrico, com grupos de inclusões aquo-carbônicas primárias contendo cristais de saturação. O Q-IV4 
apresenta também zonas com evidências de imiscibilidade (a serem discutidas no capítulo de microtermometria), além do sistema de fraturas com diminutas inclusões fluidas monofásicas, provavelmente aquosas, relacionadas aos sistemas de falhas tardios.

TABELA 15 - Tipos composicionais das inclusões fluidas para cada veio no Corpo IV.

\begin{tabular}{|c|c|c|c|c|}
\hline \multicolumn{5}{|c|}{ GRUPOS DE INCLUSÕES FLUIDAS NOS VEIOS DE QUARTZO DO CORPO IV } \\
\hline & Q-IVI & $Q-1 V 2$ & $Q-1 V 3$ & Q-IV4 \\
\hline Primária & $c^{I}$ & $a c_{2}$ & $\begin{array}{c}c_{3} \\
a c_{3}\end{array}$ & $\begin{array}{c}c_{. t} \\
a c_{4}\end{array}$ \\
\hline $\begin{array}{l}\text { Pseudo-se- } \\
\text { cundária }\end{array}$ & $\begin{array}{c}c_{l} \\
a c_{1}\end{array}$ & $a c_{2}$ & $a c_{3}$ & $a c$ \\
\hline Secundária & $\begin{array}{c}c_{1}+a_{1} \\
c_{1}+a c_{1}^{*} \\
a c_{2}\end{array}$ & $a c_{2}$ & $\begin{array}{c}c+a c_{3} \\
a c_{3} \\
x_{1}\end{array}$ & $\begin{array}{c}c_{4}+a c_{4}^{*} \\
x_{4}\end{array}$ \\
\hline \multirow[t]{2}{*}{ Observações } & $\begin{array}{c}-a c_{1} \text { sempre com } \\
\text { cristal de } \\
\text { saturação } \\
* \text { zonas } \\
\text { prováveis de } \\
\text { imiscibilidade }\end{array}$ & $\begin{array}{l}\text {-ac sem cristais de } \\
\text { saturação (apenas } \\
\text { uma exceção na } a c_{2} \\
\text { primária). IFs com } \\
\text { prováveis fluidos } \\
\text { hidrotermais } \\
\text { responsável pelo } \\
\text { transporte de ouro } \\
\text { e sulfetos. }\end{array}$ & $\begin{array}{l}\text { - freqüentemente } \\
\text { com um pequeno } \\
\text { cristal de saturação } \\
\text { (em relação ao Q- } \\
\text { IV1) } \\
\text { - } x \text { representa IF } \\
\text { monofásica } \\
\text { relacionada às } \\
\text { falhas tardias (D4) }\end{array}$ & $\begin{array}{c}\text {-ac sempre com } \\
\text { cristal de saturação } \\
\text { - ocorrem zonas de } \\
\text { imiscibilidade } \\
\text { - } x \text { representa If } \\
\text { monofásica } \\
\text { relacionada às } \\
\text { falhas tardias (D4). }\end{array}$ \\
\hline & Abreviaçố & arbônica, ac- aquo- & rbônica, $a-$ aquosa, & F - inclusão fluida \\
\hline
\end{tabular}

As inclusões fluidas primárias nos contatos dos sulfetos com quartzo são em geral carbônicas a aquo-carbônicas, com $\mathrm{VCO}_{2} / \mathrm{V}$ tot maiores que 0,9 , de cor escura e normalmente na forma de cristais negativos. A cor escura e a pouca quantidade de água dificuitam muitas vezes a classificação correta e a microtermometria. A microtermometria a ser discutida posteriormente revela também um aumento na quantidade de $\mathrm{CH}_{4}$ nesses grupos de inclusões, confirmado pela espectrometria Laser-Raman.

Na amostra CIV-G073-V4SI ocorrem cristais euhédricos de siderita com inclusões aquo-carbônicas primárias que podem ser confrontadas com as inclusões do mesmo tipo no quartzo para constatar modificações eventuais devido a eventos posteriores. É importante lembrar que a siderita possui inclusões de arsenopirita pré- a sin-genéticas podendo-se relacionar esse carbonato a uma das últimas fases mineralizantes. 


\section{MICROTERMOMETRIA}

Nos trabalhos de mapeamento do Corpo IV foram amostradas 4 gerações cronologicamente ordenadas de veios de quartzo (Q-IV1, Q-IV2, Q-IV3 e Q-IV4), com as quais foi realizado um trabalho microtermométrico. As amostras analisadas são relacionadas na TABELA 16, onde o primeiro número revela o número da amostra e o segundo a área da amostra onde as medições de inclusões fluidas (IF) foram realizadas. Os dados microtermométricos obtidos e os resultados calculados a partir dos mesmos encontram-se nas tabelas do ANEXO 3. A seleção das IFs foi realizada com base na associação mais representativa de cada grupo de inclusões fluidas relacionada a cada geração de veios de quartzo.

Foi possível ainda realizar medições em inclusões fluidas em quartzo, que ocorre junto à pirrotita, na $\mathrm{L}_{\mathrm{m} / \mathrm{e} 3}$ do xisto carbonoso do Corpo IV, a qual deve ter servido como condutor principal dos fluidos mineralizantes.

Inclusões fluidas aquosas contento $\mathrm{CO}_{2}$ e sais são muito comuns em uma ampla variedade de ambientes geológicos. Como a solubilidade do $\mathrm{CO}_{2}$ na água cresce sob elevadas temperaturas e pressões (Takenouchi \& Kennedy, 1965), o $\mathrm{CO}_{2}$ é geralmente o componente principal de inclusões fluidas formadas em rochas metamórficas de médio a alto grau, em "stocks" intrusivos e em sistemas hidrotermais mineralizados (Roedder, 1984).

Entre as lâminas dos veios de quartzo foram selecionadas inclusões fluidas representativas dos diversos grupos identificados, às quais foram submetidas à análise espectroscópica com o auxílio de Laser-Raman.

Foram realizadas diversas tentativas de visualização de inclusões fluidas em sulfetos relacionados a mineralização, utilizando-se uma câmera de infravermelho do laboratório da Australian Geological Survey Organization (AGSO). Para tanto foram selecionadas 6 amostras de pirrotita, com e sem ouro, do Corpo IV, além de 4 amostras com pirrotita e arsenopirita, sem ouro, do Corpo V. Todos os testes realizados nas amostras de sulfetos do Corpo IV e V não apresentaram qualquer sinal de transparência ao infravermelho, inviabilizando a microtermometria de opacos nas amostras. 
TABELA 16 - Relação de amostras submetidas a medições microtermométricas., com as páginas referidas ao $\mathrm{ANEXO} 3$, onde $\mathrm{IF}=$ inclusão fluida, $\mathrm{P}=$ primária, $\mathrm{PS}=$ pseudo-secundária e $\mathrm{S}=$ secundária.

\begin{tabular}{|c|c|c|}
\hline \multicolumn{3}{|c|}{ AM. Área CARACTERISTICAS } \\
\hline \multicolumn{3}{|c|}{ Q-IV1-Veios de quartzo da primeira geraçấo relativa, ANEXO 3-Página 1 a 5} \\
\hline 192 & & Carbônicas, primárias (IFP), encaixante xisto carbonoso \\
\hline 1911 & & Carbônicas, primárias (IFP), encaixante xisto carbonoso \\
\hline 1912 & & Carbônicas, primárias (IFP), encaixante xisto carbonoso \\
\hline 197 & & Carbônicas, primárias (IFP), encaixante xisto carbonoso \\
\hline $197 \mathrm{a}$ & & Carbônicas, primárias (IFP), encaixante xisto carbonoso \\
\hline $1912 \mathrm{e}$ & & Carbônicas, pseudo-secundárias (IFPS), encaixante xisto carbonoso \\
\hline 1913 & & Carbônicas, pseudo-secundárias (IFPS), encaixante xisto carbonoso \\
\hline $19 \quad 19$ & & Carbônicas, pseudo-secundárias (IFPS), encaixante xisto carbonoso \\
\hline $1912 \mathrm{f}$ & & Carbônicas, secundárias (IFS), encaixante xisto carbonoso \\
\hline 1914 & & Carbônicas, secundárias (IFS), encaixante xisto carbonoso \\
\hline 1920 & & Carbônicas, secundárias (IFS), encaixante xisto carbonoso \\
\hline 194 & & Carbônicas, secundárias (IFS), encaixante xisto carbonoso \\
\hline 1919 & & Aquo-carbônicas, pseudo-secundárias (IFPS), encaixante xisto carbonoso \\
\hline 1921 & & Aquo-carbônicas, pseudo-secundárias (IFPS), encaixante xisto carbonoso \\
\hline $1912 \mathrm{a}$ & & Aquo-carbônicas, secundárias (IFS), encaixante xisto carbonoso \\
\hline $1917 \mathrm{a}$ & & Aquo-carbônicas, secundárias (IFS), encaixante xisto carbonoso \\
\hline 1920 & & Aquo-carbônicas, secundárias (IFS), encaixante xisto carbonoso \\
\hline \multicolumn{3}{|c|}{ Q-IV2 - Veios de quartzo da segunda geração relativa, ANEXO 3 - Página 5 a 6} \\
\hline $27 \quad 10$ & Aqu & do-carbônicas, primárias (IFP), encaixante xisto carbonoso \\
\hline 276 & $\mathrm{Aqu}$ & 1o-carbônicas, pseudo-secundárias (IFPS), encaixante xisto carbonoso \\
\hline $27 \quad 6 a$ & Aqu & lo-carbônicas, pseudo-secundárias (IFPS), encaixante xisto carbonoso \\
\hline $276 \mathrm{c}$ & Aqu & Io-carbônicas, secundárias (IFS), encaixante xisto carbonoso \\
\hline \multicolumn{3}{|c|}{ Q-IV4 - Veios de quartzo da quarta geração relativa, $A N E X O 3$-Página 6 a 8} \\
\hline 731 & Car & bônicas, primárias (IFP), encaixante xisto carbonoso \\
\hline 73.4 & Aqu & do-carbônicas, primárias (IFP), encaixante xisto carbonoso \\
\hline 735 & Aqu & Uo-carbônicas, primárias (IFP), siderita \\
\hline 121 & Aqu & uo-carbônicas, primárias (IFP), encaixante xisto carbonoso \\
\hline 261 & Aqu & uo-carbônicas, primárias (IFP), encaixante xisto carbonoso \\
\hline 734 & Aqu & uo-carbônicas, pseudo-secundárias (IFPS), encaixante xisto carbonoso \\
\hline $7312 a$ & Aqu & to-carbônicas, pseudo-secundárias (IFPS), encaixante xisto carbonoso \\
\hline $12 \mathrm{lc}$ & Aql & uo-carbônicas, pseudo-secundárias (IFPS), encaixante xisto carbonoso \\
\hline $123 a$ & $\mathrm{Aqu}$ & uo-carbônicas, secundárias (IFS), encaixante xisto carbonoso \\
\hline 129 & $\mathrm{Aql}$ & uo-carbônicas, secundárias (IFS), encaixante xisto carbonoso \\
\hline \multicolumn{3}{|c|}{ Quartzo da $L_{m / e 3}$} \\
\hline IV22 & & icas, primárias (IFP), encaixante xisto carbonoso, $L_{\mathrm{m} / \mathrm{e} 3}$ \\
\hline
\end{tabular}

Os resultados analíticos da microtermometria são discutidos a seguir, separados pelas gerações de quartzo determinadas e subdivididos pelos sistemas termodinâmicos e classificação das inclusões fluidas (primárias, pseudo-secundárias e secundárias). 


\subsection{Veio de quartzo da primeira geracão do Corpo IV (Q-IV1)}

As inclusões primárias presentes em cristais de quartzo deste veio são, em essência, carbônicas monofásicas, mas podem conter quantidades subordinadas de outros voláteis. Nas IFs pseudo-secundárias e secundárias, por outro lado, além das carbônicas, foram observadas as compostas por $\mathrm{H}_{2} \mathrm{O}+\mathrm{CO}_{2}+\mathrm{CH}_{4}+$ sais dissolvidos, bifásicas ou trifásicas.

A análise com auxílio de espectroscopia Laser-Raman (TABELA 17) revelou um teor relativamente alto de metano nas inclusões da amostra 19 14, sendo que nesta, as inclusões estão em trilhas compartilhadas com cristais de pirrotita derivados do xisto carbonoso.

$\mathrm{Na}$ área 19 12a e 19_12b foram encontradas inclusões secundárias com até duas fases sólidas, dispostas em trilhas cortando cristais subédricos de quartzo no veio. A espectrometria de Laser-Raman (análise 074, 074c e 080) permitiu a análise de tais cristais revelando que os maiores, com formas cúbicas são halita, e os menores, calcita.

Foram ainda encontradas diversas inclusões no veio de quartzo com feições sugestivas de constituírem melt inclusions, sendo formadas apenas por minerais, sem sinais de fase líquida ou gasosa. A análise com auxílio da espectroscopia de Laser-Raman (19_12c em $\mathrm{R} 411 \mathrm{a}, \mathrm{R} 411 \mathrm{~b}$ e $\mathrm{R} 411 \mathrm{c}$ ) revelou que os minerais que constituem o preenchimento de tais inclusões são dolomita, silicato (provavelmente muscovita ou clorita) e grafita. Outra feição freqüente nessas inclusões são rosetas de grafita, desenvolvidas nas bordas.

TABELA 17 - Resultado de análises espectroscópica com o auxílio de Laser-Raman no Q-IV1.

\begin{tabular}{|c|c|c|c|c|}
\hline Amostra_área & No. da IF & $\mathrm{CO}_{2}(\mathrm{~mol} \%)$ & $\mathrm{N}_{2}(\mathrm{~mol} \%)$ & $\mathrm{CH}_{4}\left(\mathrm{~mol}^{\circ}\right)$ \\
\hline 192 & 003 & 100 & 0 & 0 \\
\hline 194 & 142 & 98,3 & 0,7 & 1,0 \\
\hline $1912 b$ & 80 & 99,5 & 0,3 & 0,2 \\
\hline $1912 \mathrm{f}$ & 83 & 100 & 0 & 0 \\
\hline 1913 & 110 & 99,6 & 0 & 0,4 \\
\hline 1914 & 127 & 95,0 & 0,0 & 5,0 \\
\hline 1914 & 125 & 92,3 & 5,7 & 2,0 \\
\hline $19 \quad 19$ & 151 & 100 & 0 & 0 \\
\hline 1920 & 156 & 100 & 0 & 0 \\
\hline 1921 & P329 & 100 & 0 & 0 \\
\hline 1921 & 181 & 100 & 0 & 0 \\
\hline
\end{tabular}

\subsubsection{Inclusões primárias, pseudo-secundárias e secundárias (sistema $\mathrm{CO}_{2}+\mathrm{CH}_{4}$ )}

As temperaturas de fusão do $\mathrm{CO}_{2}\left(\mathrm{Tf}_{\mathrm{CO} 2}\right)$ variam de $-58,8$ a $-56,6^{\circ} \mathrm{C}$, apresentando, na maioria dos casos, valores inferiores a $-56,6^{\circ} \mathrm{C}$, referente ao ponto triplo do $\mathrm{CO}_{2}$ puro, o que é 
indicativo da existência de outros componentes voláteis associados. Dados de espectroscopia Laser-Raman revelaram a presença do $\mathrm{CH}_{4}$, tanto nas inclusões primárias, como nas pseudosecundárias e secundárias. Observa-se, no entanto, pelas figuras (FIGURAS 55 e 56) um aumento relativo no teor desse componente em direção às inclusões secundárias.

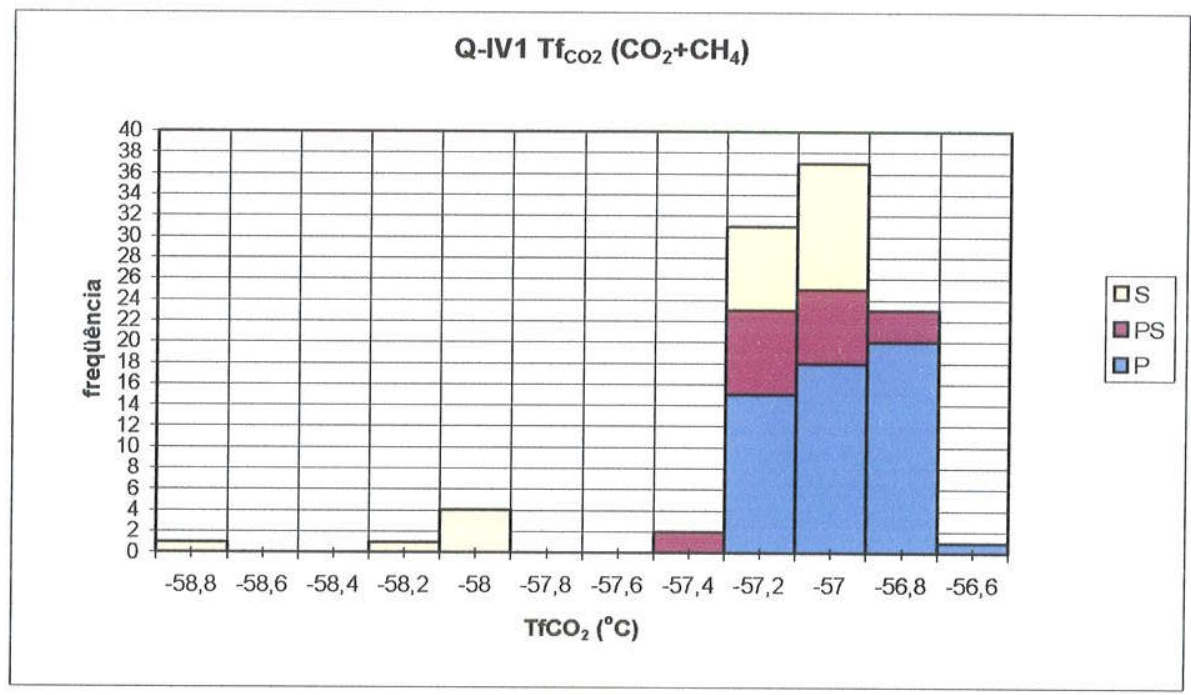

FIGURA 55 - Histograma das temperaturas de fusão do $\mathrm{CO}_{2}$ para inclusões do sistema $\mathrm{CO}_{2}+\mathrm{CH}_{4}$ do $\mathrm{Q}-\mathrm{IV} 1$, onde $\mathrm{P}=$ primária, $\mathrm{PS}=$ pseudo-secundária e $\mathrm{S}=$ secundária.

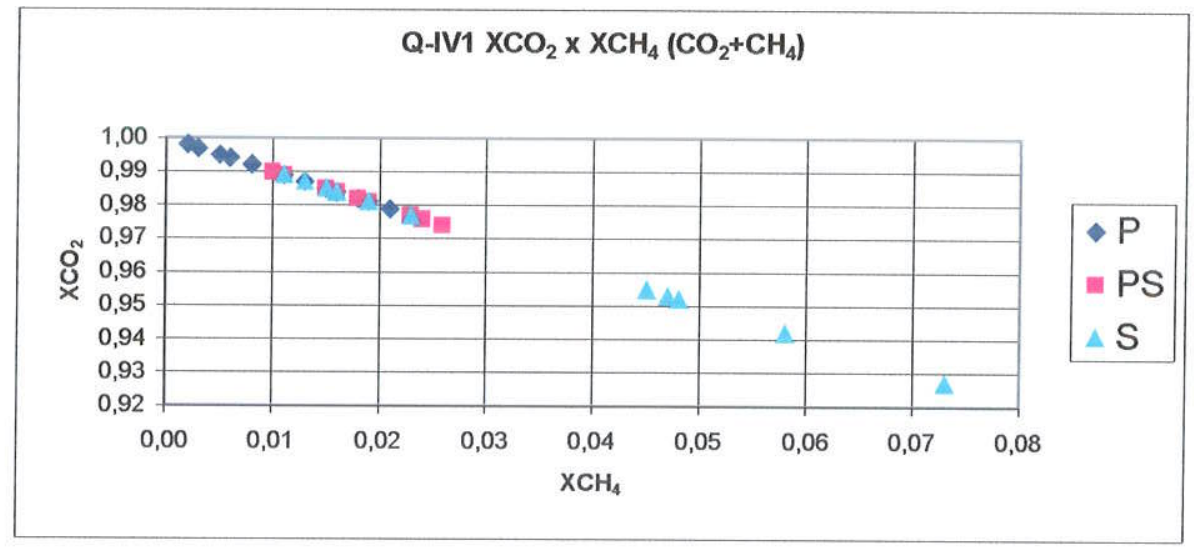

FIGURA 56 - Diagrama $\mathrm{XCO}_{2}$ versus $\mathrm{XCH}_{4}$ para inclusões do sistema $\mathrm{CO}_{2}+\mathrm{CH}_{4}$ do Q-IV1.

A homogeneização do $\mathrm{CO}_{2}$, sempre para o estado líquido, ocorreu a temperaturas variando de $-5,5 \mathrm{a}+8,2^{\circ} \mathrm{C}$ nas inclusões primárias, indicando uma faixa de densidades de $\mathrm{CO}_{2}$ $\left(\mathrm{dCO}_{2}\right)$ situada entre 0,948 e $0,854 \mathrm{~g} / \mathrm{cm}^{3}$. Observa-se pelo diagrama (FIGURA 57) que nas inclusões pseudo-secundárias, as temperaturas de homogeneização do $\mathrm{CO}_{2}\left(\mathrm{ThCO}_{2}\right)$ atingem, em alguns casos, valores mais baixos, até $-11,5^{\circ} \mathrm{C}$, indicativos de maiores densidades. A faixa de variação de $\mathrm{dCO}_{2}$ para essas inclusões é de 0,969 a $0,892 \mathrm{~g} / \mathrm{cm}^{3}$. Nas inclusões 
secundárias, por outro lado, a faixa de variação de $\mathrm{ThCO}_{2}$ é bem mais ampla, atingindo valores até $21,5^{\circ} \mathrm{C}$, indicativos de $\mathrm{dCO}_{2}$ bem inferiores em relação às anteriores. $\mathrm{As} \mathrm{dCO}_{2}$ variam, neste caso, de 0,906 a $0,746 \mathrm{~g} / \mathrm{cm}^{3}$. Deve ser ressaltado que os maiores valores de $\mathrm{ThCO}_{2}$ são relativos a inclusões secundárias pertencentes a uma trilha distinta, mostrando a existência de mais de uma etapa de desenvolvimento e cicatrização de fraturas.

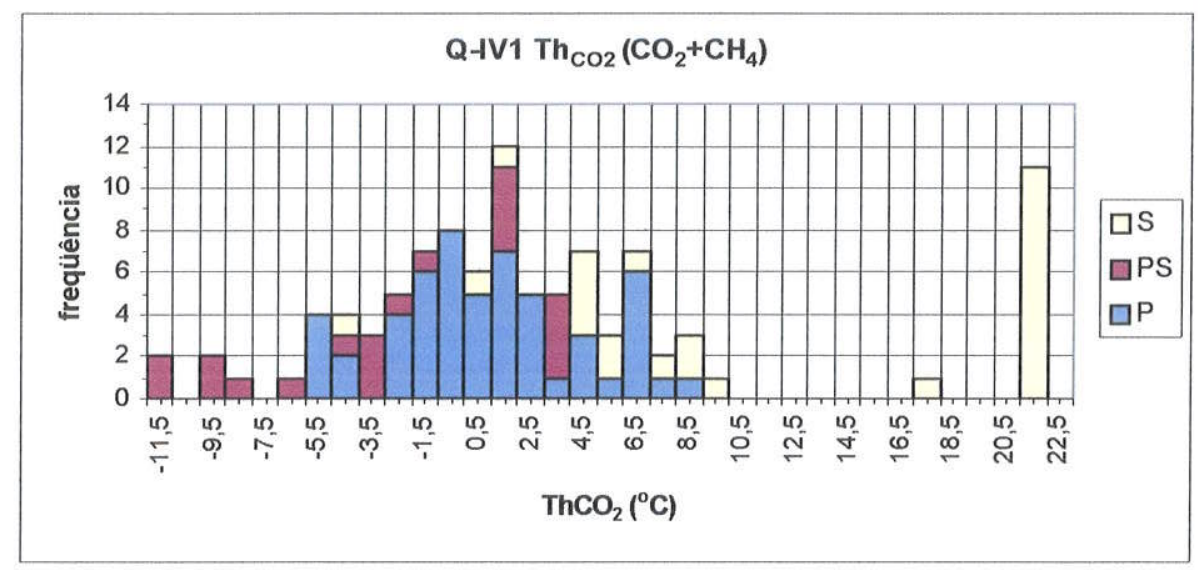

FIGURA 57 - Temperaturas de homogeneização do $\mathrm{CO}_{2}$ nas IF carbônicas do Q-IV1.

\subsubsection{Inclusões pseudo-secundárias e secundárias (sistema $\mathrm{H}_{2} \mathrm{O}+\mathrm{CO}_{2}+\mathrm{CH}_{4}+$ sais)}

Inicialmente deve ser enfatizado que esse sistema ocorre apenas nas inclusões pseudosecundárias e secundárias do Q-IV1, estando sempre ausente nas primárias. Trata-se de inclusões bifásicas a trifásicas à temperatura ambiente, em certos casos com variações nas razões $\mathrm{VCO}_{2} / \mathrm{V}_{\text {tot }}$ (volume de $\mathrm{CO}_{2} /$ volume total da IF).

A FIGURA 58 mostra que nas inclusões PS e $\mathrm{S}$ aquo-carbônicas, as $\mathrm{TfCO}_{2}$ apresentam menor rebaixamento do ponto triplo do $\mathrm{CO}_{2}$ puro em relação às carbônicas deste veio, indicando menores quantidades de outros voláteis associados. Também neste caso foi identificado o $\mathrm{CH}_{4}$ por espectroscopia Laser-Raman. (TABELA 17). 


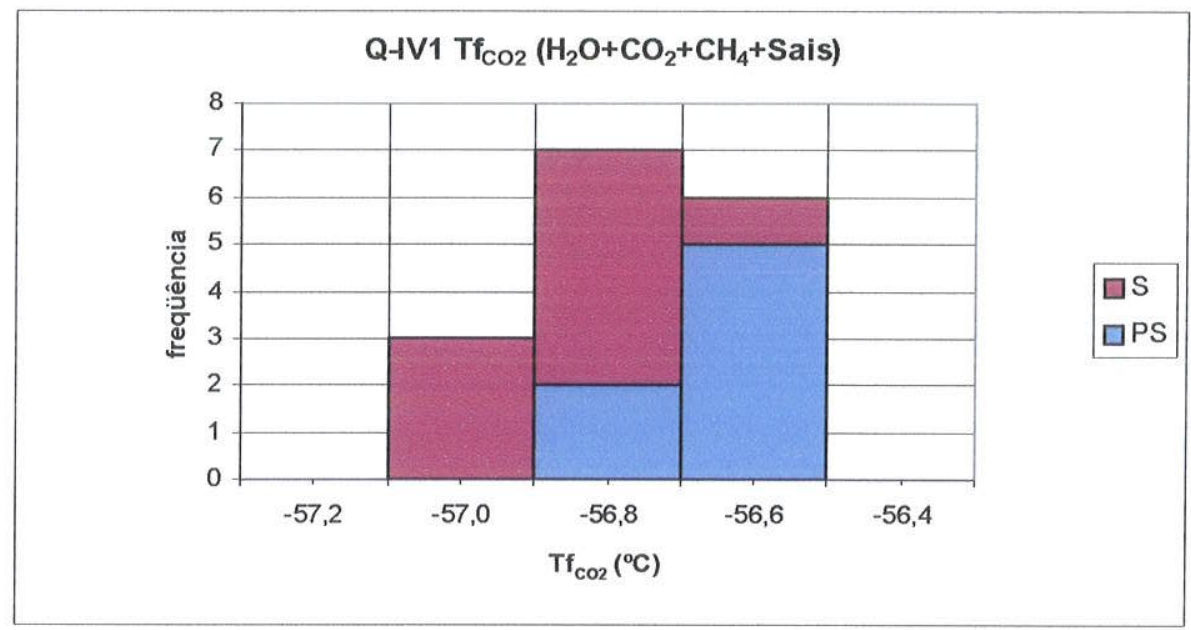

FIGURA 58 - Temperaturas de fusão do $\mathrm{CO}_{2}$ de IF aquo-carbônicas no Q-IV1.

As $\mathrm{ThCO}_{2}$ apresentam valores de 30,9 a $-1,00^{\circ} \mathrm{C}$ nas inclusões pseudo-secundárias (FIGURA 59), tendo sido observada uma faixa de variação menor $\left(25,2\right.$ a $\left.-0,9{ }^{\circ} \mathrm{C}\right)$ nas secundárias, indicando os seguintes intervalos de $\mathrm{dCO}_{2}$ : inclusões pseudo-secundárias de 0,906 a $0,952 \mathrm{~g} / \mathrm{cm}^{3}$ e inclusões secundárias de 0,953 a $1,092 \mathrm{~g} / \mathrm{cm}^{3}$. Tais variações de $\mathrm{ThCO}_{2}$ são discutidas adiante.

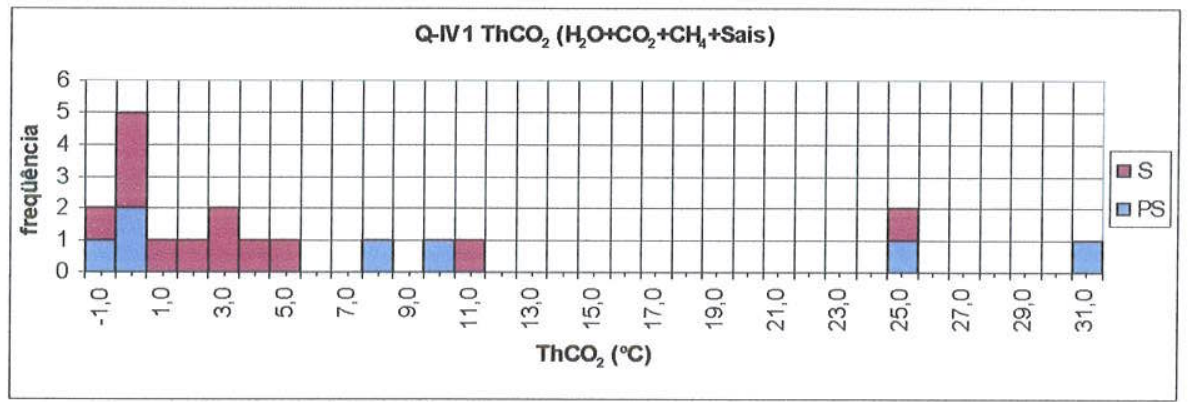

FIGURA 59 - Temperaturas de homogeneização para as IF aquo-carbônicas do Q-IV1.

As temperaturas do ponto eutético das soluções aquosas (Te, FIGURA 60) são indicativas dos sistemas $\mathrm{H}_{2} \mathrm{O}+\mathrm{NaCl}$, (Te mínimo até $-28^{\circ} \mathrm{C}$, Davis et al., 1990), embora a grande maioria dos dados apresente valores inferiores, sugerindo a presença de íons bivalentes como $\mathrm{Fe}^{2+}, \mathrm{Mg}^{2+}$ e $\mathrm{Ca}^{2+}$ de acordo com os dados disponíveis na literatura relacionados a seguir:

- sistema $\mathrm{MgCl}_{2}+\mathrm{NaCl}+\mathrm{H}_{2} \mathrm{O}, \mathrm{Te}=-35^{\circ} \mathrm{C}$ (Crawford, 1981; Davis et al., 1990).

- sistema $\mathrm{MgCl}_{2}+\mathrm{H}_{2} \mathrm{O}, \mathrm{Te}=-33,6^{\circ} \mathrm{C}$ (Borisenko, 1978; Davis et al., 1990).

- sistema $\mathrm{FeCl}_{2}+\mathrm{NaCl}+\mathrm{H}_{2} \mathrm{O}, \mathrm{Te}=-37^{\circ} \mathrm{C}$ (Borisenko, 1978).

- sistema $\mathrm{CaCl}_{2}+\mathrm{H}_{2} \mathrm{O}, \mathrm{Te}=-49,8^{\circ} \mathrm{C}$ (Borisenko, 1978; Crawford, 1981).

- sistema $\mathrm{CaCl}_{2}+\mathrm{NaCl}+\mathrm{H}_{2} \mathrm{O}, \mathrm{Te}=-52,0^{\circ} \mathrm{C}$ (Crawford, 1981; Oakes et al., 1990). 
Valores de $\mathrm{Te}$ abaixo de $-40^{\circ} \mathrm{C}$ já são atribuídos à presença de cálcio no sistema aquoso (Roedder 1984).

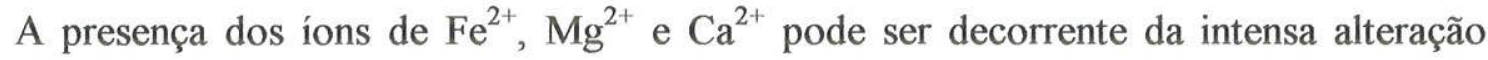
propilítica, já discutida no capítulo de petrografia, associada a mineralização do Corpo IV.

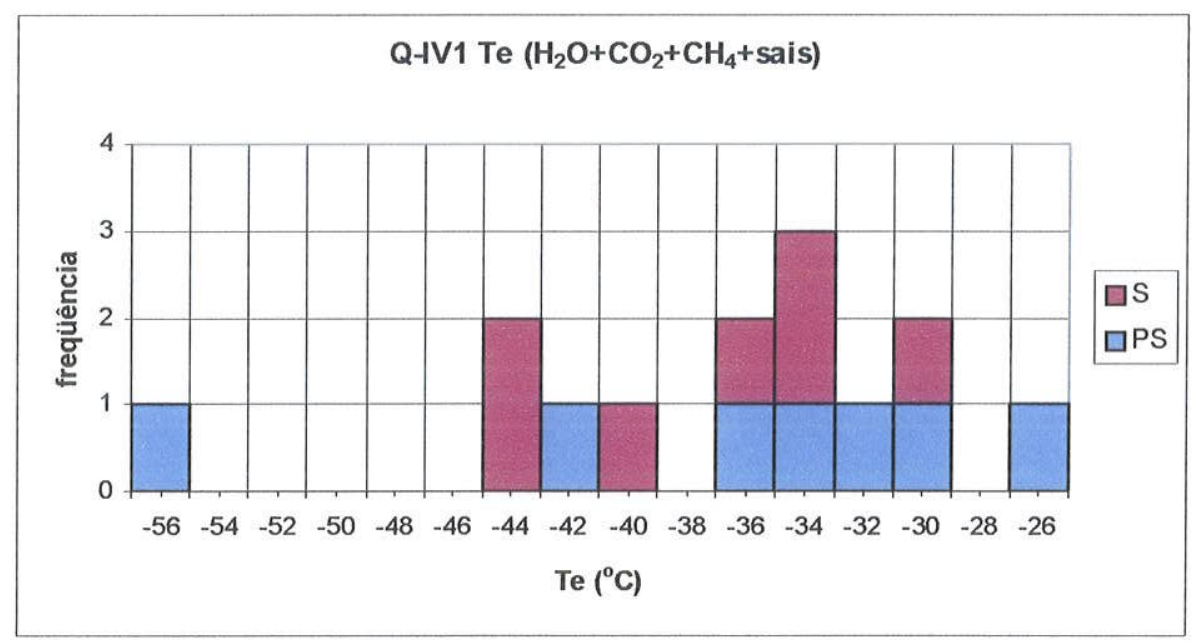

FIGURA 60 - Temperaturas do eutético para as IF aquo-carbônicas do Q-IV1.

As salinidades das soluções aquosas foram obtidas a partir das temperaturas de fusão dos clatratos ou, quando estavam presentes cristais de saturação, pelas temperaturas de dissolução dos mesmos. Os resultados obtidos encontram-se representados na FIGURA 61, que mostra valores normalmente intermediários para as inclusões secundárias. As inclusões pseudo-secundárias, por sua vez, contêm, em essência, soluções aquosas extremamente salinas, embora salinidades intermediárias também sejam observadas. Essas inclusões apresentam também variações nas razões $\mathrm{VCO}_{2} / \mathrm{V}_{\text {tot }}$ sugerindo, numa primeira aproximação, processos de imiscibilidade. No entanto, observa-se que nas inclusões mais ricas $\mathrm{em}^{\mathrm{H}_{2} \mathrm{O} \text { as }}$ salinidades são inferiores, o que segundo Ramboz et al. (1982), não condiz com as condições de imiscibilidade, podendo representar mais propriamente processos de mistura. Um refinamento dessa hipótese poderia ser obtido a partir de um diagrama relacionando as $\mathrm{Th}_{\text {tot }}$ com as salinidades, o que não foi possível, devido à pequena quantidade de dados de homogeneização referentes às regiões onde ocorre esse comportamento. 


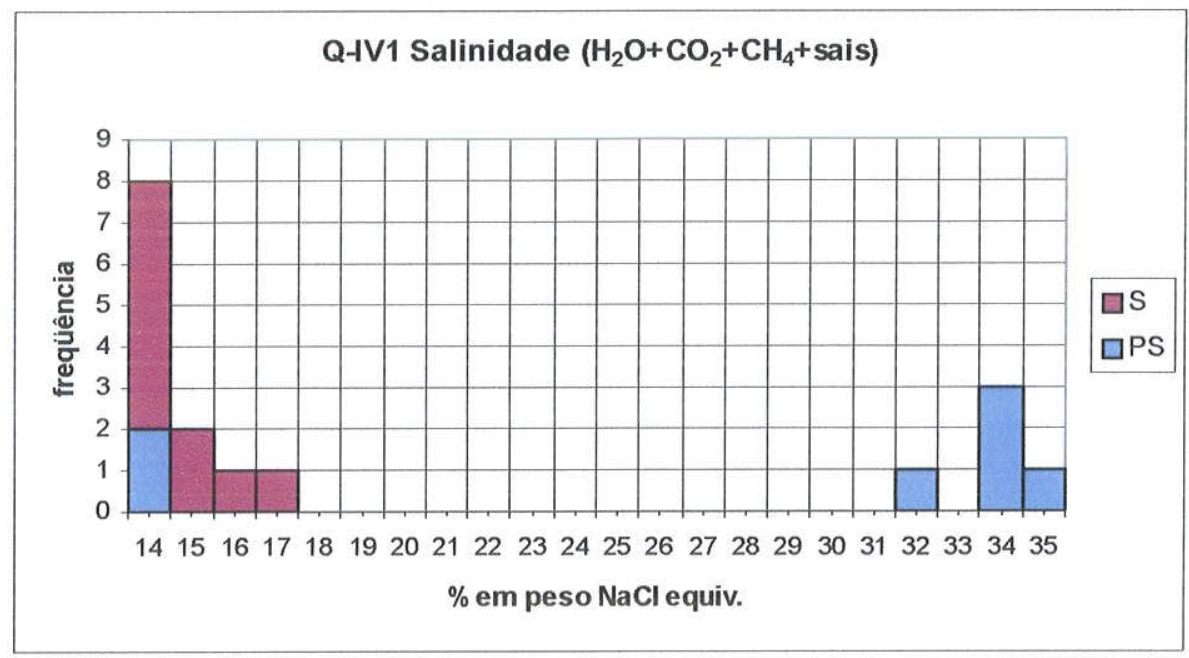

FIGURA 61 - As altas salinidades referem-se à amostra 19_21, que contêm cristais de saturação de halita, sendo as mesmas calculadas pela dissolução do sal.

As temperaturas de homogeneização total $\left(\mathrm{Th}_{\mathrm{tot}}\right)$ foram obtidas apenas para certas regiões onde ocorrem as inclusões fluidas pseudo-secundárias de alta salinidade discutidas anteriormente, cuja imiscibilidade não foi completamente caracterizada, tendo sido observada uma variação de 240 a $280^{\circ} \mathrm{C}$ (FIGURA 62).

A presença de imiscibilidade deste veio foi, no entanto, bem caracterizada em inclusões pseudo-secundárias de outra região do mesmo, nas quais ocorrem variações volumétricas $\mathrm{VCO}_{2} / \mathrm{V}_{\text {tot }}$ de 0,1 a 0,95 . Foi constatado neste caso, que as inclusões mais ricas em água são também as mais salinas, o que está bastante coerente com as premissas indicativas de imiscibilidade discutidas em Ramboz et al. (1982). Para essas inclusões, embora não tenha sido possível determinar por microtermometria as $\mathrm{Th}_{\text {tot., }}$ uma temperatura de aprisionamento de $325^{\circ} \mathrm{C}$ foi obtida, de modo aproximado, por meio do cruzamento de isócoras relativas aos termos extremos (FIGURA 95, adiante).

Essas diferenças de temperatura parecem indicar a existência de mais de uma etapa de aprisionamento das inclusões pseudo-secundárias nos veios da primeira geração, sugerindo a existência de flutuações de pressão relacionadas a um evento hidrotermal recorrente, já anteriormente constatado pelos estudos petrográficos. Além disso, os resultados parecem indicar que, nos estágios finais de cristalização desses veios, os processos de imiscibilidade e/ou mistura, representados pelas inclusões com menores $\mathrm{Th}_{\text {tot. }}\left(240-280^{\circ} \mathrm{C}\right)$, ocorreram em fluidos mais evoluídos de maiores salinidades (FIGURA 61), aprisionados em menores temperaturas. 


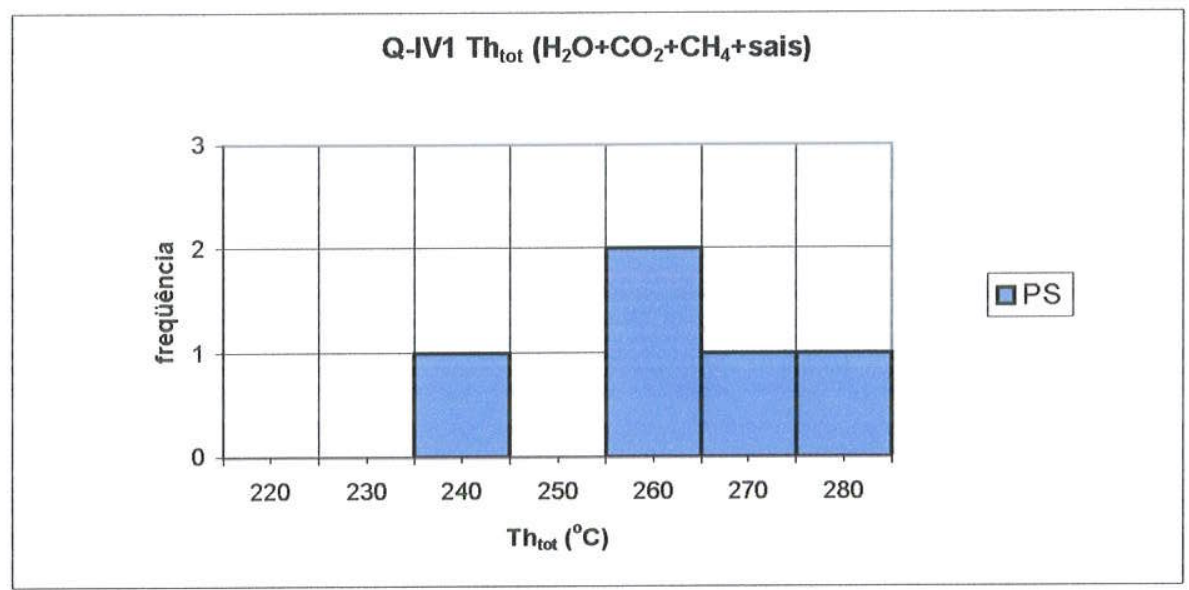

FIGURA 62 - Temperaturas de homogeneização total para IF do Q-IV1 pseudo-secundárias aquocarbônicas.

No caso dessas inclusões salinas, a FIGURA 63 mostra que as temperaturas de homogeneização relativas às fases fluidas são sempre maiores que as temperaturas de dissolução dos sólidos, indicando que os cristais foram formados após o aprisionamento como resultado do resfriamento natural do mineral hospedeiro, conforme discussão de Ramboz et al. (1982).

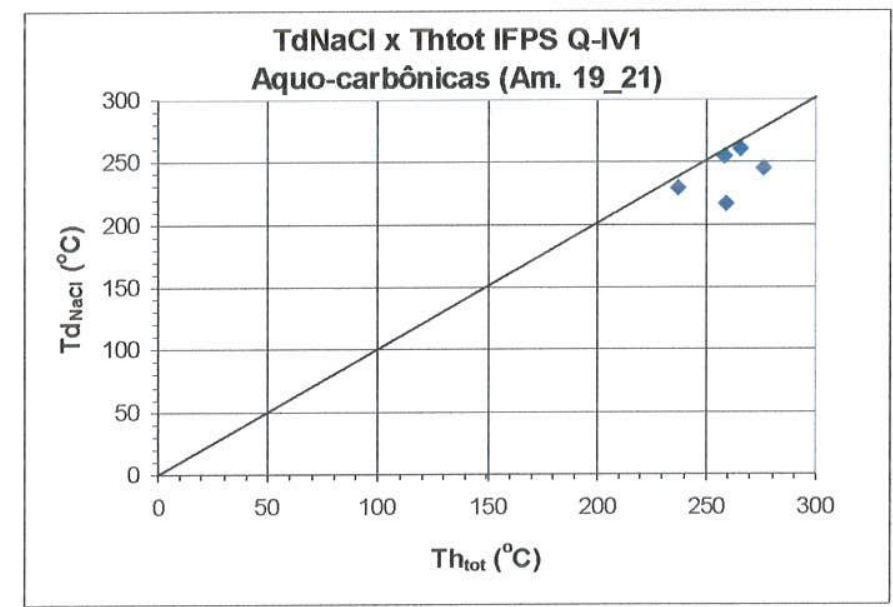

FIGURA 63 - Diagrama temperatura de homogeneização total versus temperatura de dissolução do $\mathrm{NaCl}$ (Amostra 19_21).

\subsection{Veio de quartzo da segunda geracão do Corpo IV (Q-IV2)}

No quartzo deste veio foram observadas, em essência, inclusões aquo-carbônicas pseudo-secundárias e secundárias, localmente com variações consideráveis nas razões $\mathrm{VCO}_{2} / \mathrm{V}_{\text {tot }}$. Foi observada apenas uma inclusão primária isolada, contendo um cristal de saturação de halita e um cristal acicular negro, provavelmente de grafita. 
Uma IF pseudo-secundária contida no quartzo revelou, através da análise com auxílio de espectroscopia de Laser-Raman, um conteúdo relativamente alto de metano, o que pode ser, provavelmente, relacionado a um fluido proveniente do xisto carbonoso Q-IV2 (TABELA $18)$.

TABELA 18 - Resultado de análises espectroscópica com o auxílio de Laser-Raman no Q-IV2.

\begin{tabular}{|l|l|l|l|l|}
\hline Amostra_área & Nr. da IF & $\mathbf{C O}_{\mathbf{2}}(\mathbf{m o l} \%)$ & $\mathbf{N}_{\mathbf{2}}(\mathbf{m o l} \%)$ & $\mathbf{C H}_{\mathbf{4}}(\mathbf{m o l} \%)$ \\
\hline $27 \_6 a$ & R412 & 96,3 & 0,0 & 3,7 \\
\hline
\end{tabular}

\subsubsection{Inclusões primárias, pseudo-secundárias e secundárias (sistema $\mathrm{H}_{2} \mathrm{O}+\mathrm{CO}_{2}+$}

\section{$\underline{\mathrm{CH}}_{4}+$ sais)}

As $\mathrm{TfCO}_{2}$ apresentam valores inferiores aos do ponto triplo do $\mathrm{CO}_{2}$ puro (FIGURA 64), revelando a presença de outros voláteis associados, que não puderam ser detectados com o auxílio da espectroscopia Laser-Raman.

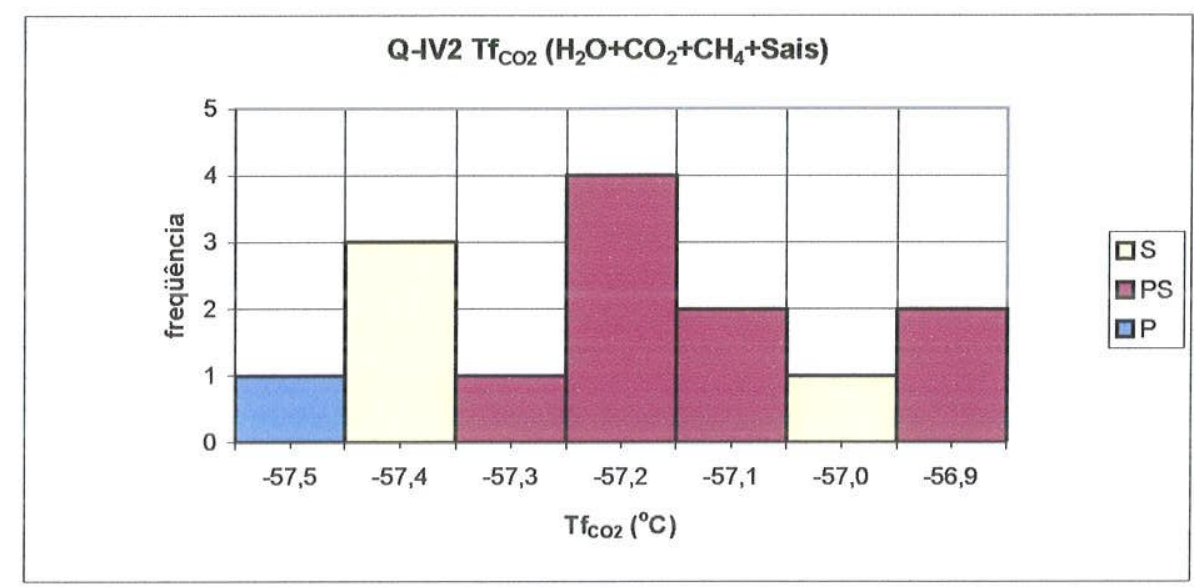

FIGURA 64 - Temperaturas de fusão do $\mathrm{CO}_{2}$ de IF aquo-carbônicas no Q-IV2.

O diagrama abaixo (FIGURA 65) mostra uma tendência de acréscimo das frações molares de $\mathrm{CH}_{4}$ nas inclusões secundárias, de modo semelhante ao observado no Q-IV1.

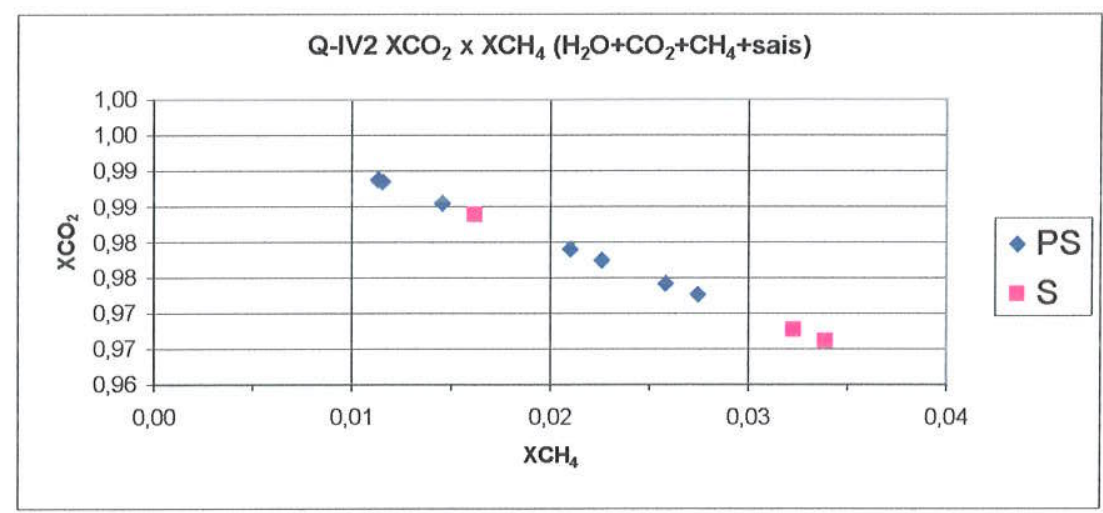

FIGURA 65 - Diagrama $\mathrm{XCO}_{2}$ versus $\mathrm{XCH}_{4}$ para inclusões do sistema $\mathrm{CO}_{2}+\mathrm{CH}_{4}$ do Q-IV2. 
CAPÍTULO V - Página 152

A homogeneização do $\mathrm{CO}_{2}$, para o estado líquido, variou de 14,0 a $25,3^{\circ} \mathrm{C}$ nas inclusões pseudo-secundárias e de 13,6 a $22,1^{\circ} \mathrm{C}$ nas secundárias (FIGURA 66), indicando $\mathrm{dCO}_{2}$ situadas entre 1,03 e $1,01 \mathrm{~g} / \mathrm{cm}^{3}$ e entre 0,99 e $1,04 \mathrm{~g} / \mathrm{cm}^{3}$, respectivamente.

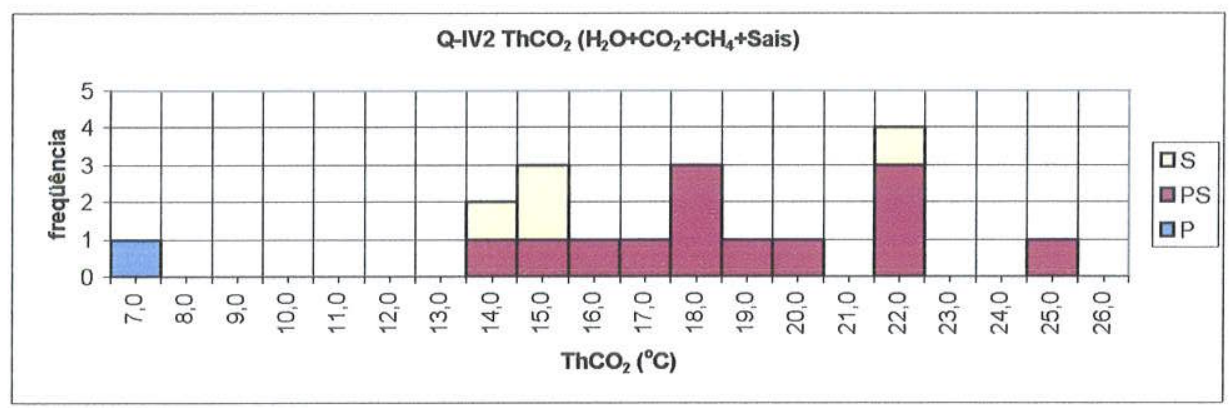

FIGURA 66 - Temperaturas de homogeneização do $\mathrm{CO}_{2}$ nas IF aquo-carbônicas do Q-IV2.

As Te das soluções aquosas variam de -42 a $-36^{\circ} \mathrm{C}$, indicando os mesmos sistemas presentes no quartzo do Q-IV1 (FIGURA 67).

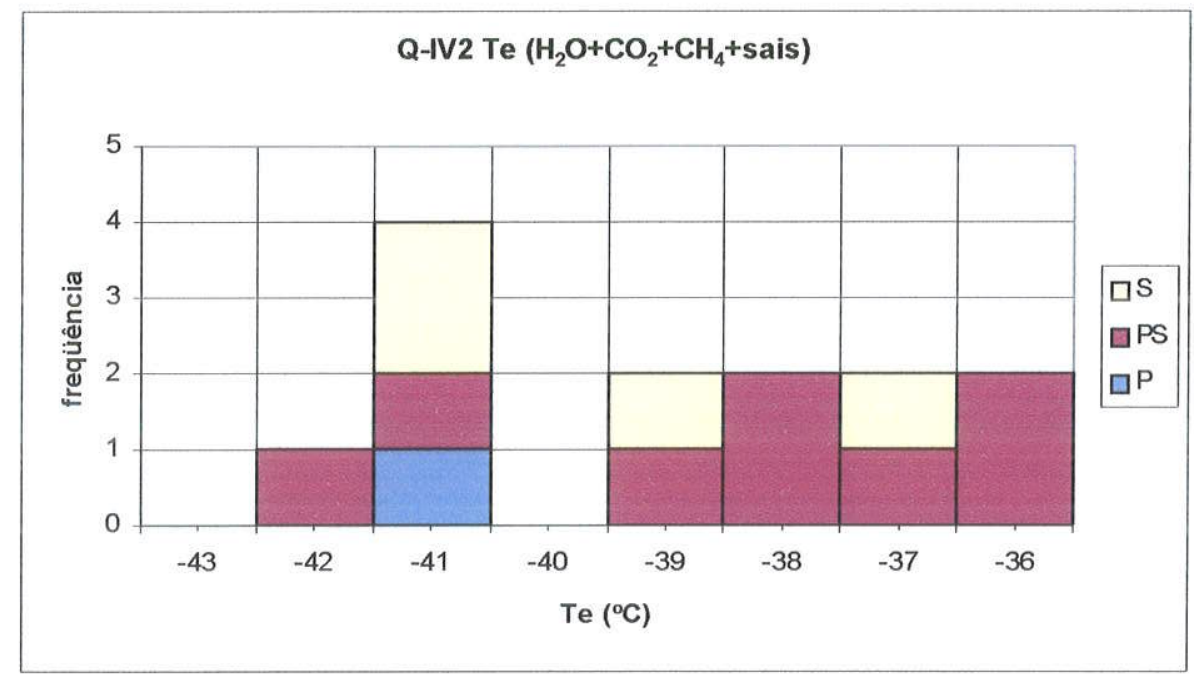

FIGURA 67 - Temperaturas do eutético para as IF aquo-carbônicas do Q-IV1.

As salinidades das soluções aquosas das inclusões pseudo-secundárias e secundárias (FIGURA 68), obtidas a partir das temperaturas de fusão dos clatratos, situaram-se na faixa de 8 a $11 \%$ em peso do $\mathrm{NaCl}$ equivalente. Esses valores são inferiores aos das inclusões aquocarbônicas pseudo-secundárias e secundárias do Q-IV1. Na única inclusão primária observada, com cristal de saturação de halita, a salinidade foi estimada como sendo superior a $26 \%$ em peso do $\mathrm{NaCl}$ equiv., uma vez que não foi possível a observação da $\mathrm{Td}_{\mathrm{NaCl}}$. 


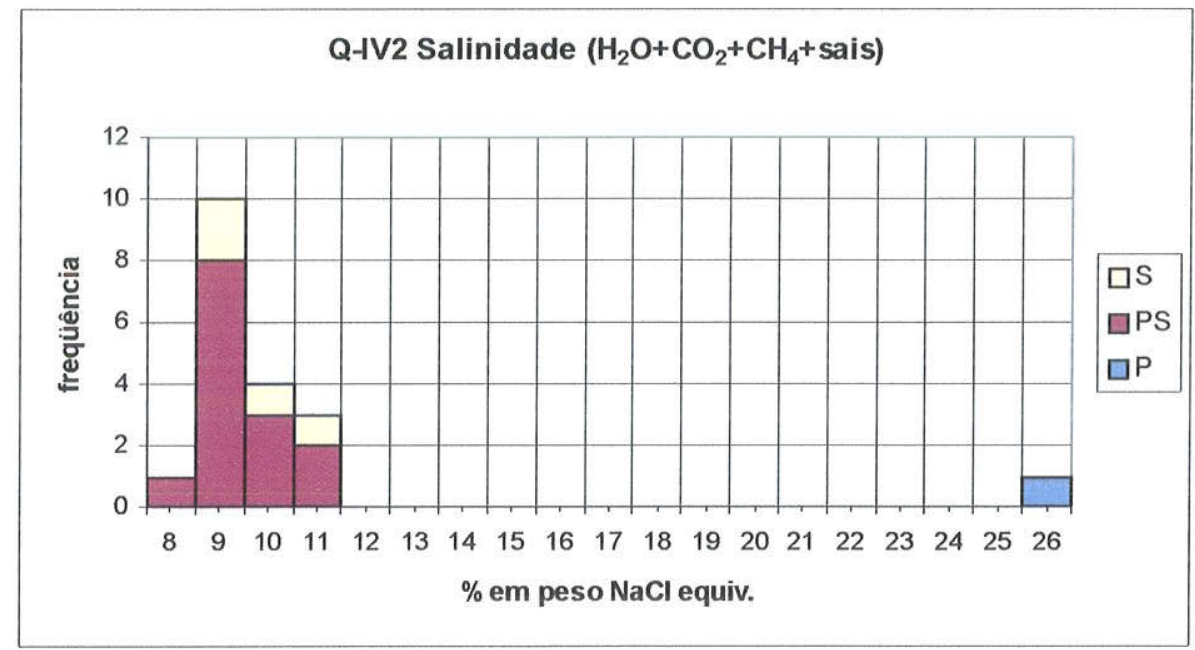

FIGURA 68 - Porcentagem em peso de $\mathrm{NaCl}$ equivalente para amostras do Q-IV2, sendo que a amostra primária apresenta um valor estimado de salinidade $(>26 \%)$, uma vez que não foi possível determinar a $\mathrm{Td}_{\mathrm{NaCl}}$.

As $\mathrm{Th}_{\mathrm{tot}}$ situaram-se num intervalo relativamente amplo (FIGURA 69), variando de 310 a $410^{\circ} \mathrm{C}$, no caso das inclusões pseudo-secundárias, apresentando valores bem inferiores nas secundárias $\left(230\right.$ a $\left.240^{\circ} \mathrm{C}\right)$. Isso eventualmente pode indicar a influência do evento Neoproterozóico nas inclusões secundárias.

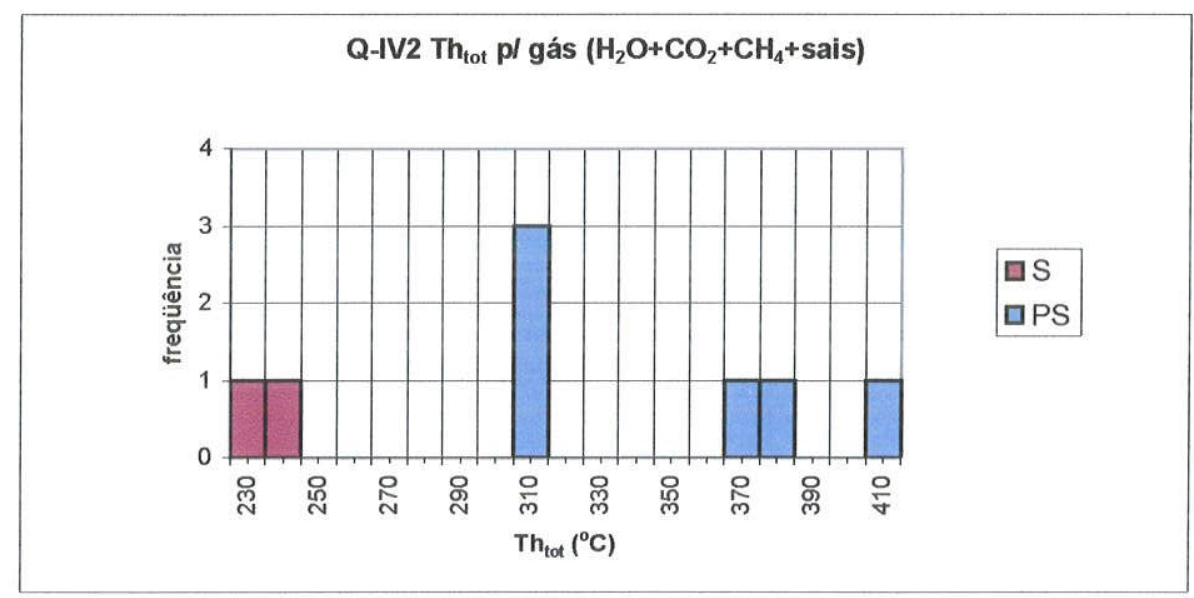

FIGURA 69 - Temperaturas de homogeneização total para IF do Q-IV2 aquo-carbônicas.

\subsection{Veio de quartzo da quarta geracão do Corpo IV (Q-IV4)}

Neste veio foram medidas inclusões fluidas em quartzo (primárias, pseudo-secundárias e secundárias), apatita (primárias) e siderita (primárias). De modo geral, as inclusões primárias são carbônicas (quartzo) e aquo-carbônicas (quartzo, apatita e siderita), enquanto que as pseudo-secundárias e secundárias no quartzo são constituídas, em essência, por fluidos aquo-carbônicos. 
A análise com o auxílio da espectroscopia de Laser-Raman (TABELA 19) em IFP no quartzo, localizado muito próximo ao contato com a arsenopirita, revelou conteúdos bastante elevados de $\mathrm{CH}_{4}$, indicando um possível enriquecimento em metano no fluido residual que levou à cristalização da arsenopirita, uma vez que tais porcentagens de $\mathrm{CH}_{4}$ não foram encontradas nas IFs intimamente relacionadas ao xisto carbonoso.

Foram ainda analisadas as inclusões primárias contidas na siderita euédrica (SID4) no Q-IV4 e, visando comparações, também as pseudo-secundárias e secundárias do quartzo circundante ao carbonato. Os resultados microtermométricos, comentados abaixo, são bastante semelhantes nestes dois minerais. Observa-se, no entanto, que ocorre uma diferença no conteúdo de $\mathrm{CH}_{4}$ nas inclusões do quartzo, sugerindo novamente um enriquecimento desta molécula nos fluidos residuais próximos a cristalização, neste caso, da siderita, em relação àqueles presentes durante a formação do quartzo não associado a esse mineral.

TABELA 19 - Resultado de análises espectroscópica com o auxílio de Laser-Raman no Q-IV4.

\begin{tabular}{|c|c|c|c|c|c|}
\hline Amostra área & Nr. da IF & $\mathrm{CO}_{2}(\mathrm{~mol} \%)$ & $\mathrm{N}_{2}(\mathrm{~mol} \%)$ & $\mathrm{CH}_{4}\left(\mathrm{~mol}^{\circ} \%\right)$ & Características \\
\hline 1201 & $\mathrm{R} 400$ & 70,1 & & 29,9 & Próx. ao contato c/ASP \\
\hline 1201 & $\mathrm{R} 401$ & 76,3 & & 23,7 & 4 \\
\hline 1201 & R402 & 85,9 & & 14,1 & $"$ \\
\hline 1201 & $\mathrm{R} 403$ & 97,0 & & 3,0 & $"$ \\
\hline 1201 & 171 & 96,3 & & 3,7 & $"$ \\
\hline 1201 & 176 & 96,6 & & 3,4 & $"$ \\
\hline 1201 & 178 & 96,9 & & 3,1 & 6 \\
\hline 129 & 207 & 97,1 & 1,6 & 1,3 & Próx. ao contato $\mathrm{c} / \mathrm{ASP}$ \\
\hline $73 \quad 12$ & P346 & 99,5 & & 0,5 & C/ cristal de halita \\
\hline $73 \quad 12$ & P348 & 98,7 & & 1,3 & "9 \\
\hline 734 & 239 & 97,5 & 0,0 & 2,5 & $\begin{array}{l}\text { QTZ relacionado a SID } \\
\text { IFPS }\end{array}$ \\
\hline 734 & 243 & 95,5 & 0,0 & 4,5 & $\begin{array}{c}\text { QTZ relacionado a SID } \\
\text { IFP }\end{array}$ \\
\hline 735 & 234 & 99,5 & 0,0 & 0,5 & SID \\
\hline 735 & 238 & 99,6 & 0,0 & 0,4 & SID \\
\hline
\end{tabular}

\subsubsection{Inclusões primárias (sistema $\mathrm{CO}_{2}+\mathrm{CH}_{4}$ )}

As $\mathrm{TfCO}_{2}$ das inclusões primárias essencialmente carbônicas presentes no quartzo (FIGURA 70) apresentaram valores pouco variáveis, entre - 57,6 e $-57,7$. O rebaixamento desses valores em relação ao ponto triplo do $\mathrm{CO}_{2}$ puro é indicativo da presença de voláteis associados, tendo sido determinado o $\mathrm{CH}_{4}$ por espectroscopia laser Raman (TABELA 19). 


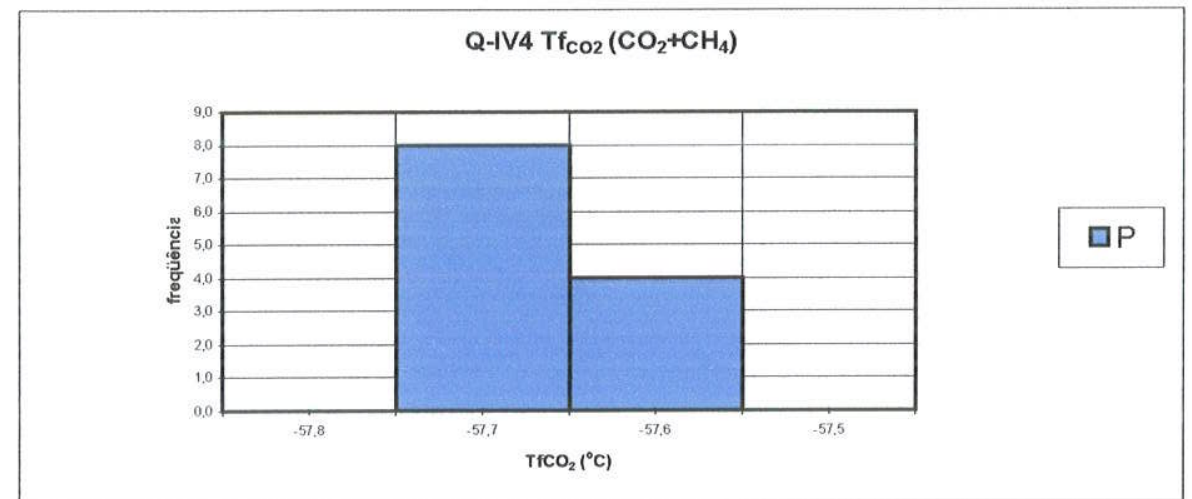

FIGURA 70 - Temperaturas de fusão do $\mathrm{CO}_{2}$ de IF carbônicas primárias no Q-IV4.

As $\mathrm{ThCO}_{2}$ dessas inclusões (FIGURA 71) apresentaram uma pequena faixa de variação, situada entre 21,9 e $23,7^{\circ} \mathrm{C}$, indicando $\mathrm{dCO}_{2}$ situada entre 0,631 e $0,682 \mathrm{~g} / \mathrm{cm}^{3}$.

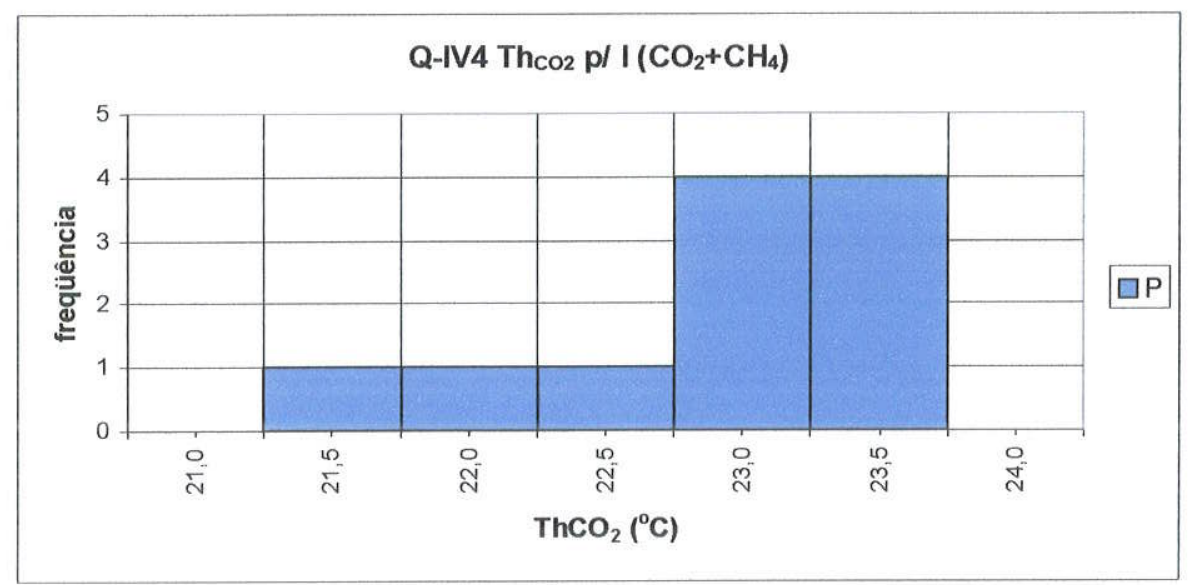

FIGURA 71 - Temperaturas de homogeneização do $\mathrm{CO}_{2}$ nas IF carbônicas primárias do Q-IV4.

\subsubsection{Inclusões primárias, pseudo-secundárias e secundárias (sistema $\mathrm{H}_{2} \mathrm{O}+\mathrm{CO}_{2}+\mathrm{CH}_{4}$ + sais)}

As $\mathrm{Tf}_{\mathrm{CO} 2}$ também neste caso são indicativas de outros voláteis associados à fase

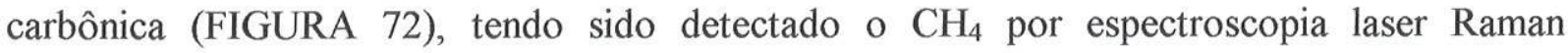
(TABELA 19). O rebaixamento em relação à temperatura crítica do $\mathrm{CO}_{2}$ puro é mais pronunciado no contato com arsenopirita. A siderita e o quartzo circundante associado revelam uma semelhança nas $\mathrm{Tf}_{\mathrm{CO} 2}$. 


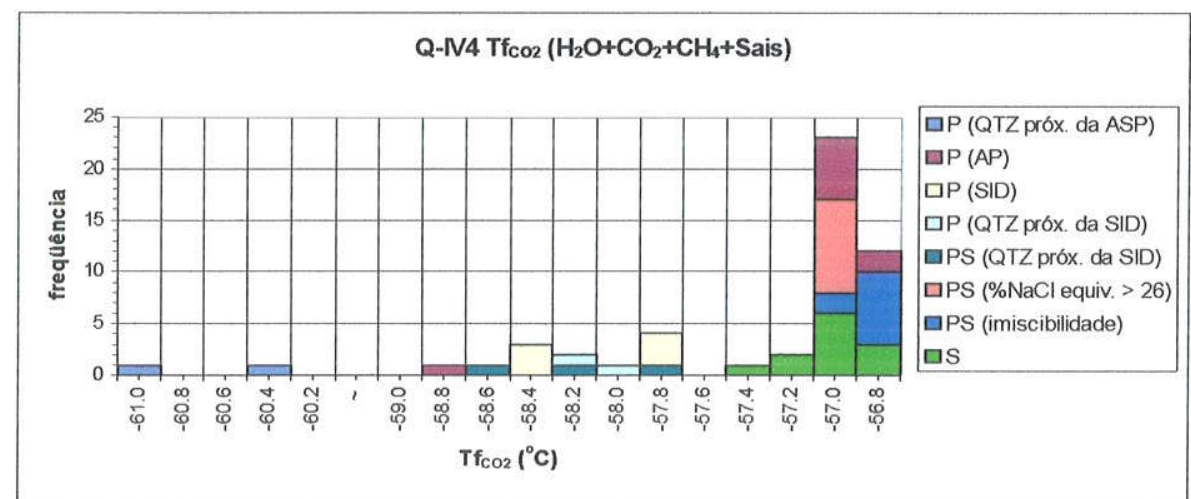

FIGURA 72 - Temperaturas de fusão do $\mathrm{CO}_{2}$ de IF aquo-carbônicas no Q-IV4 para quartzo, apatita e siderita. $\mathrm{O}$ símbolo “ $\sim$ " representa uma faixa de temperaturas sem a presença de medidas.

$\mathrm{O}$ diagrama $\mathrm{XCO}_{2} \times \mathrm{XCH}_{4}$ (FIGURA 73) forneceu indicações de empobrecimento do $\mathrm{CH}_{4}$, de maneira inversa à tendência observada no Q-IV1 e Q-IV2. Esse fato caracteriza um comportamento diferenciado na evolução dos fluidos do evento paleoproterozóico para o neoproterozóico. Nessa figura foram omitidos dois valores de $\mathrm{XCH}_{4}$ de IFs primárias muito próximos da arsenopirita, porque seus valores anormalmente altos $\left(0,16 \%\right.$ de $\left.\mathrm{XCH}_{4}\right)$ impedem a visualização da disposição dos outros dados.

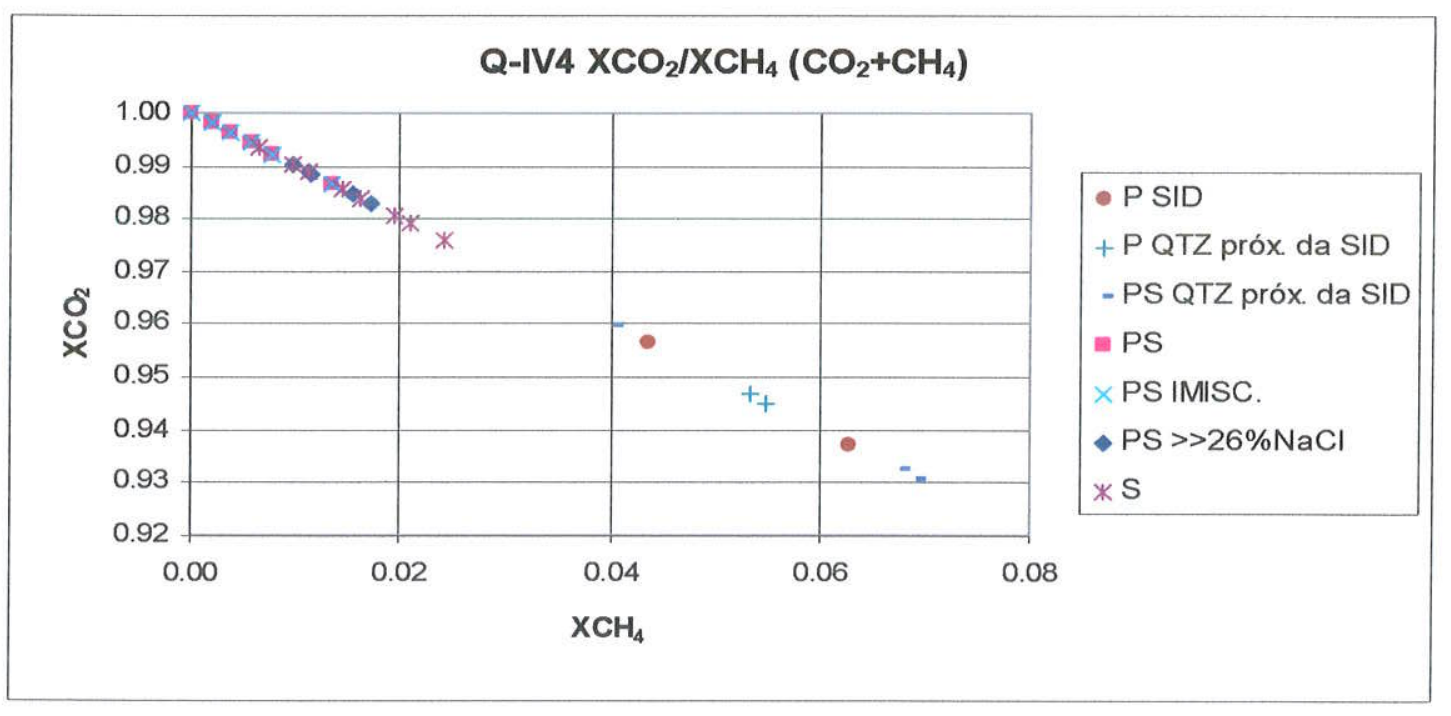

FIGURA 73 - Diagrama $\mathrm{XCO}_{2}$ versus $\mathrm{XCH}_{4}$ para inclusões do sistema aquo-carbônico no Q-IV4.

As $\mathrm{ThCO}_{2}$ apresentam as seguintes variações (conforme FIGURA 74):

quartzo: $\mathrm{ThCO}_{2}$ de 10,1 a $11,2^{\circ} \mathrm{C}$ nas inclusões primárias $\left(\mathrm{dCO}_{2}\right.$ de 0,698 a $\left.0,735 \mathrm{~g} / \mathrm{cm}^{3}\right)$. Nas inclusões pseudo-secundárias foram obtidos dois intervalos de variação em amostras distintas, o primeiro de 18,0 a $28,9\left(\mathrm{dCO}_{2}=0,847\right.$ a $\left.0,944 \mathrm{~g} / \mathrm{cm}^{3}\right)$ e o segundo de 27,3 a $28,8\left(\mathrm{dCO}_{2}=\right.$ $0,500$ a 0,609$)$. Nas secundárias, $\mathrm{ThCO}_{2}$ varia de 6,8 a $11,9^{\circ} \mathrm{C}\left(\mathrm{dCO}_{2}\right.$ de 0,931 a 0,930$)$; 
apatita: $\mathrm{ThCO}_{2}$ de 18,6 a $29,3^{\circ} \mathrm{C}\left(\mathrm{dCO}_{2}=0,873\right.$ a 0,741$)$, nas inclusões primárias;

siderita: $\mathrm{ThCO}_{2}$ de 12,1 a $13,0^{\circ} \mathrm{C}\left(\mathrm{dCO}_{2}=0,889\right.$ a 0,888$)$, nas inclusões primárias.

quartzo situado ao redor da siderita: $\mathrm{ThCO}_{2}$ ao redor de $16^{\circ} \mathrm{C}\left(\mathrm{dCO}_{2} \cong 0,89 \mathrm{~g} / \mathrm{cm}^{3}\right)$ nas inclusões primárias; $\mathrm{ThCO}_{2}$ de 14,2 a $15,4^{\circ} \mathrm{C}\left(\mathrm{dCO}_{2}\right.$ de 0,868 a $\left.0,857 \mathrm{~g} / \mathrm{cm}^{3}\right)$ nas pseudosecundárias.

Deve ser ressaltado que na amostra de quartzo com inclusões de maiores $\mathrm{ThCO}_{2}$, estas também apresentam $\mathrm{VCO}_{2} /$ Vtot. bastante variáveis $(0,4$ a 0,8$)$ sugestivas de processos de imiscibilidade ou mistura de fluidos.

Em todos os outros casos as inclusões não apresentam variações nas relações volumétricas entre as fases.

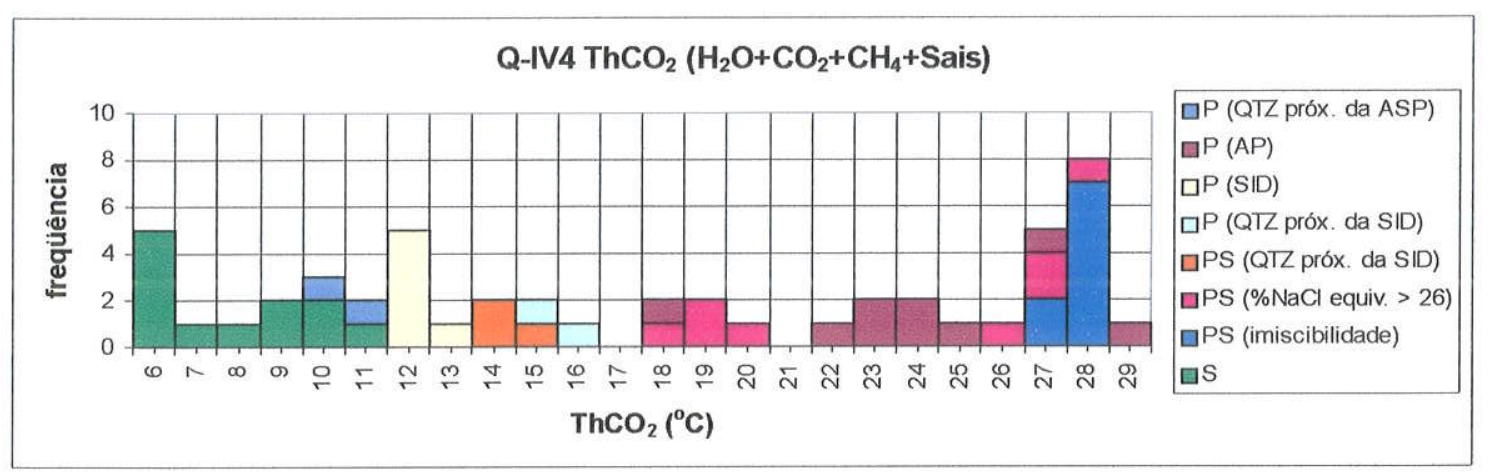

FIGURA 74 - Temperaturas de homogeneização do $\mathrm{CO}_{2}$ nas IF aquo-carbônicas do Q-IV4.

As Te são indicativas dos mesmos sistemas anteriores, embora, em alguns casos, a presença de cálcio seja bem marcada pelos mais baixos valores, como nas inclusões encontradas próximas da arsenopirita (FIGURA 75).

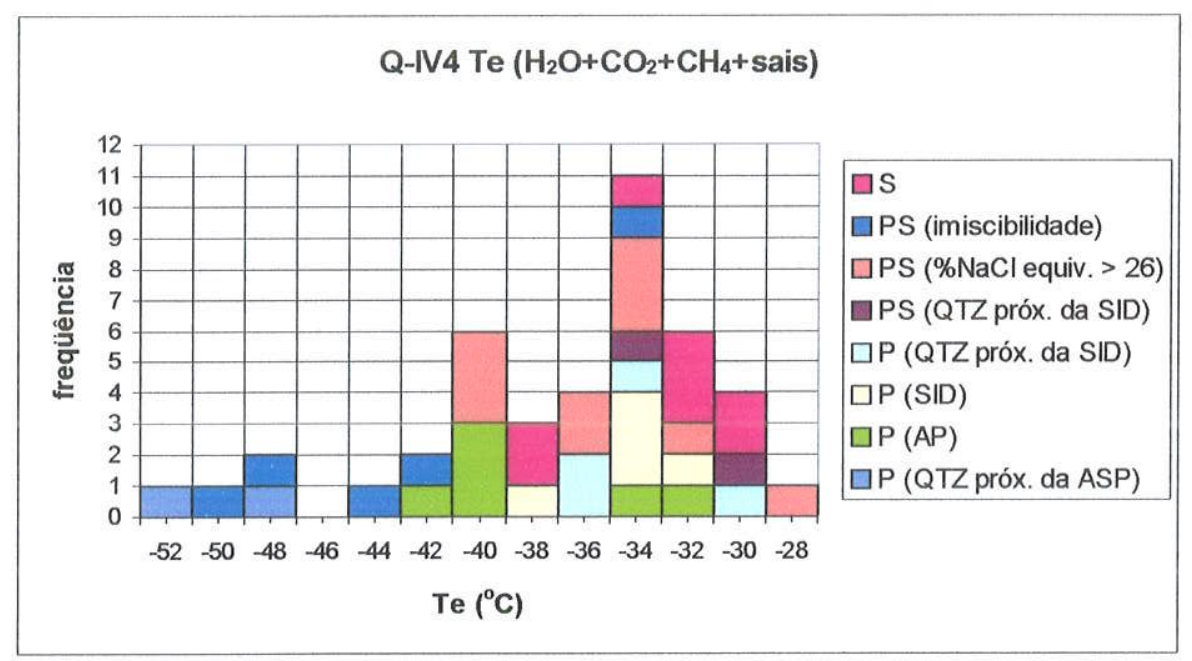

FIGURA 75 - Temperaturas do eutético para as IF aquo-carbônicas do Q-IV4. 
As variações de salinidade são, de modo geral de 0 a $7 \%$ em peso do $\mathrm{NaCl}$ equiv., (FIGURA 76). Um grupo de valores mais elevados de salinidades ( $>26 \%$ em peso do $\mathrm{NaCl}$ equiv.) refere-se a inclusões pseudo-secundárias no quartzo com cristais de saturação, nas quais não existem evidências de processos de imiscibilidade $\left(\mathrm{VCO}_{2} / \mathrm{V}\right.$ tot. constantes). As inclusões pseudo-secundárias da outra amostra com fortes feições de imiscibilidade, apresentam uma faixa muito estreita de variação de salinidades $(0,0$ a $2,31 \%$ em peso de $\mathrm{NaCl}$ equiv.), não condizentes com processos de misturas de fluidos, sugerindo, neste caso, o aprisionamento a partir de fluidos imiscíveis.

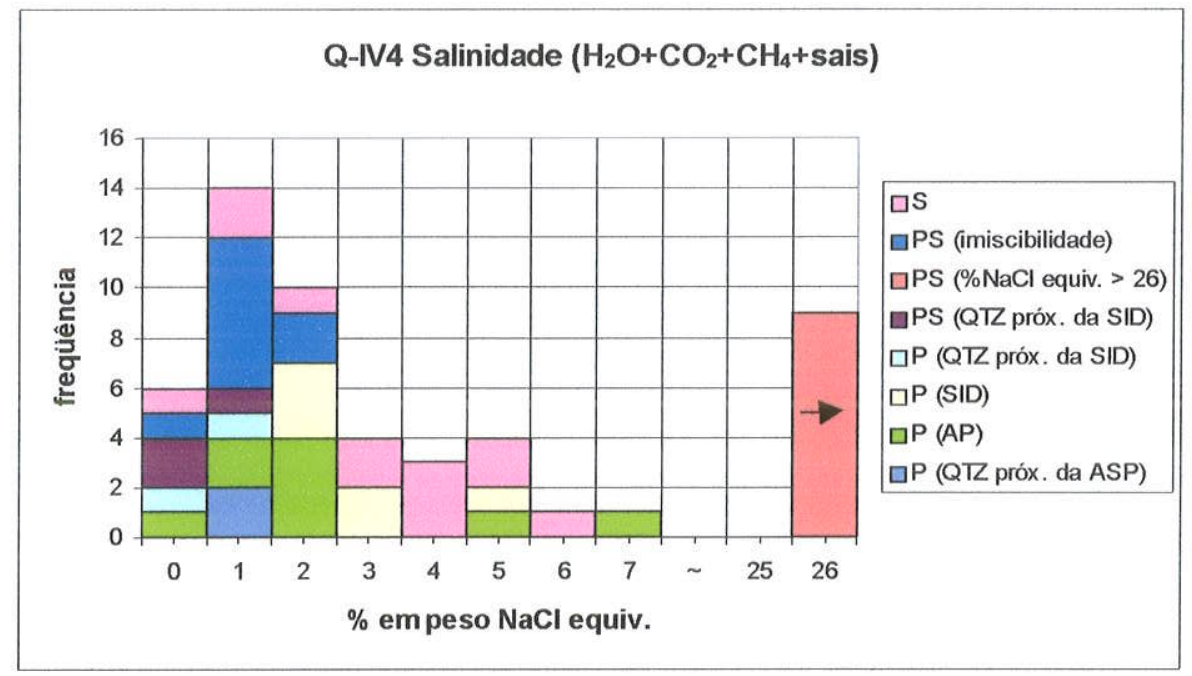

FIGURA 76 - Porcentagem em peso de $\mathrm{NaCl}$ equivalente para IF aquo-carbônicas do Q-IV4.

Nas inclusões pseudo-secundárias com $\mathrm{VCO}_{2} / \mathrm{V}_{\text {tot. }}$ variáveis, discutidas anteriormente, as homogeneizações totais ocorrem ora pela expansão da fase aquosa, ora da carbônica, o que constitui uma das premissas de Ramboz et al. (1982) para caracterizar o aprisionamento a partir de sistemas imiscíveis. Observa-se ainda que os valores de Th tot $_{\text {(FIGURA 77) são }}$ muito variáveis (160,9 a 370,5), também sugerindo fluidos originais imiscíveis, o que ainda é indicado pelo diagrama $\mathrm{Th}_{\text {tot }} \mathrm{x} \mathrm{VCO}_{2}$ (FIGURA 78), onde a distribuição de pontos assemelhase a uma curva de imiscibilidade. Desse modo, pode-se inferir um aprisionamento a partir de fluidos originalmente imiscíveis em temperaturas ao redor de 150 a $200^{\circ} \mathrm{C}$.

Observa-se, ainda, no diagrama abaixo (FIGURA 77) que as $\mathrm{Th}_{\mathrm{tot}}$ de inclusões primárias na borda do contato do quartzo com arsenopirita, situam-se ao redor de $370^{\circ} \mathrm{C}$.Esse fato associado ao diferenciado conteúdo $\mathrm{em}^{\mathrm{CH}_{4}}$ pode indicar que esse mineral não tenha sido precipitado nessa geração de veios, mas numa anterior, como sugerido pelas observações petrográficas. 


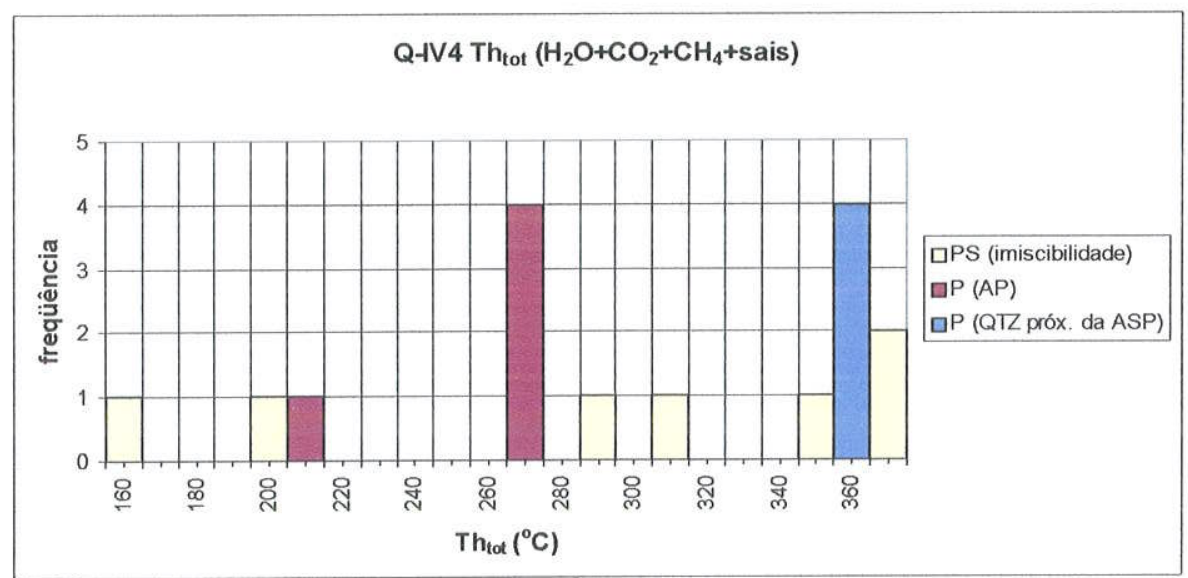

FIGURA 77 - Temperaturas de homogeneização total para IF aquo-carbônicas do Q-IV4.

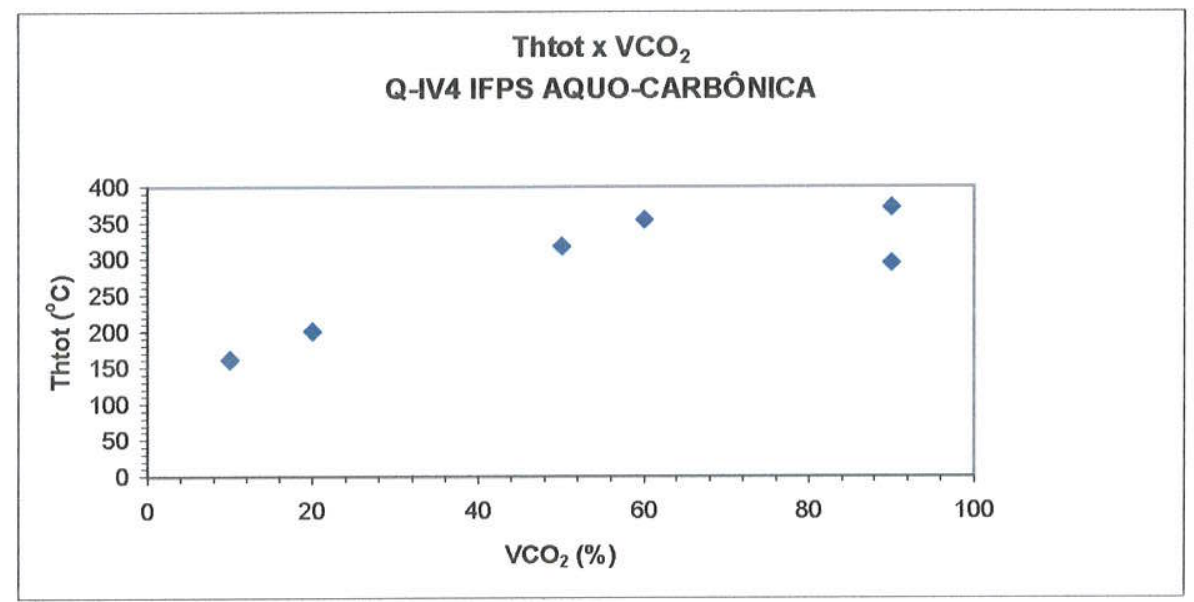

FIGURA 78 - Diagrama $\mathrm{VCO}_{2} \times$ Thtot para IF aquo-carbônicas do Q-IV4, compondo a curva de imiscibilidade.

\subsection{Quartzo na $\mathrm{L}_{\mathrm{m} / \mathrm{e}}$ com pirrotita do Corpo IV}

Esta amostra representa uma seção perpendicular às lineações minerais e de estiramento pertencentes ao evento D3 $\left(\mathrm{L}_{\mathrm{m} / \mathrm{e} 3}\right)$ no xisto carbonoso do Corpo IV. As zonas apicais das crenulações geradas por este evento permitiram o fluxo de fluidos de forma recorrente, registrado pela precipitação de pirrotita, quartzo, calcopirita e ouro. A petrografia demonstrou que estas zonas de alteração hidrotermal, concentradas em regiões preferenciais de percolação de fluidos nos xistos carbonosos, foram cortadas pelos veios de quartzo e que nestes locais de seccionamento ocorre precipitação de pirrotita e ouro no quartzo, particularmente nos veios do Q-IV1. Através de uma busca exaustiva nas seções do xisto carbonoso com as $\mathrm{L}_{\mathrm{m} / \mathrm{e} 3}$, foram localizados alguns grupos de inclusões aquo-carbônicas primárias no quartzo, tendo sido possível a obtenção de um limitado número de medidas microtermométricas. O provável vínculo destas inclusões com a mineralização do Corpo IV 
torna-as particularmente importantes para realizar comparações com as inclusões dos veios, em especial do Q-IV1.

As medições do $\mathrm{Tf}_{\mathrm{CO} 2}$ apresentam pouca variação (FIGURA 79), mas dão indicações de uma composição contendo outros gases além do $\mathrm{CO}_{2}$ pelo rebaixamento em relação ao ponto triplo do $\mathrm{CO}_{2}$ puro $\left(\mathrm{Tf}_{\mathrm{CO} 2} \mathrm{com}\right.$ aproximadamente $\left.-58,0^{\circ} \mathrm{C}\right)$.

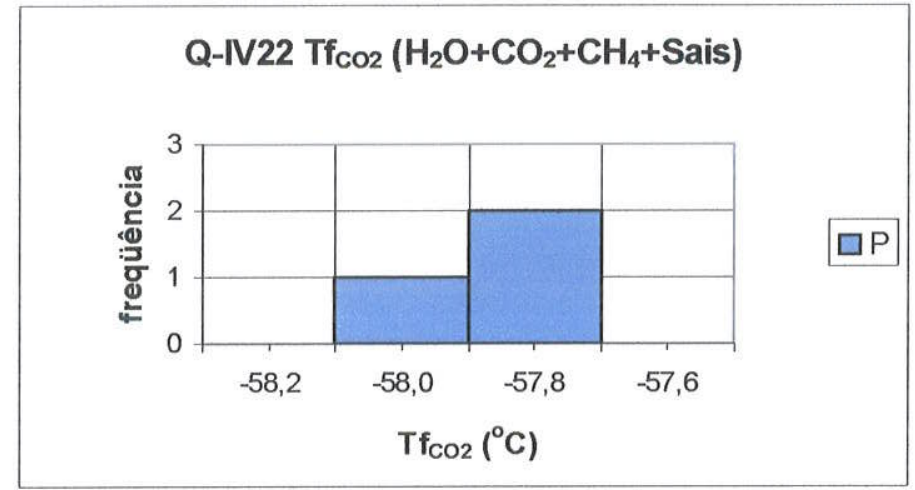

FIGURA 79 - Temperaturas de fusão do $\mathrm{CO}_{2}$ de IF aquo-carbônicas no quartzo intimamente associado com a pirrotita da $\mathrm{L}_{\mathrm{m} / \mathrm{e} 3}$.

$\mathrm{O}$ diagrama $\mathrm{XCH}_{4} \times \mathrm{XCO}_{2}$ na FIGURA 80 mostra uma tendência de inclusões primárias com $\mathrm{XCO}_{2}$ entre 0,04 e 0,06 , o que apesar das limitações impostas pelo número de análises, pode ser comparado aos grupos de IF secundárias de Q-IV1 e Q-IV2. Cabe aqui relembrar que as "injeções" de pirrotita constatadas nos veios de quartzo Q-IV1 são relativamente tardias em relação à maioria do quartzo contido nos veios (ver petrografia dos veios de quartzo no início deste capítulo).

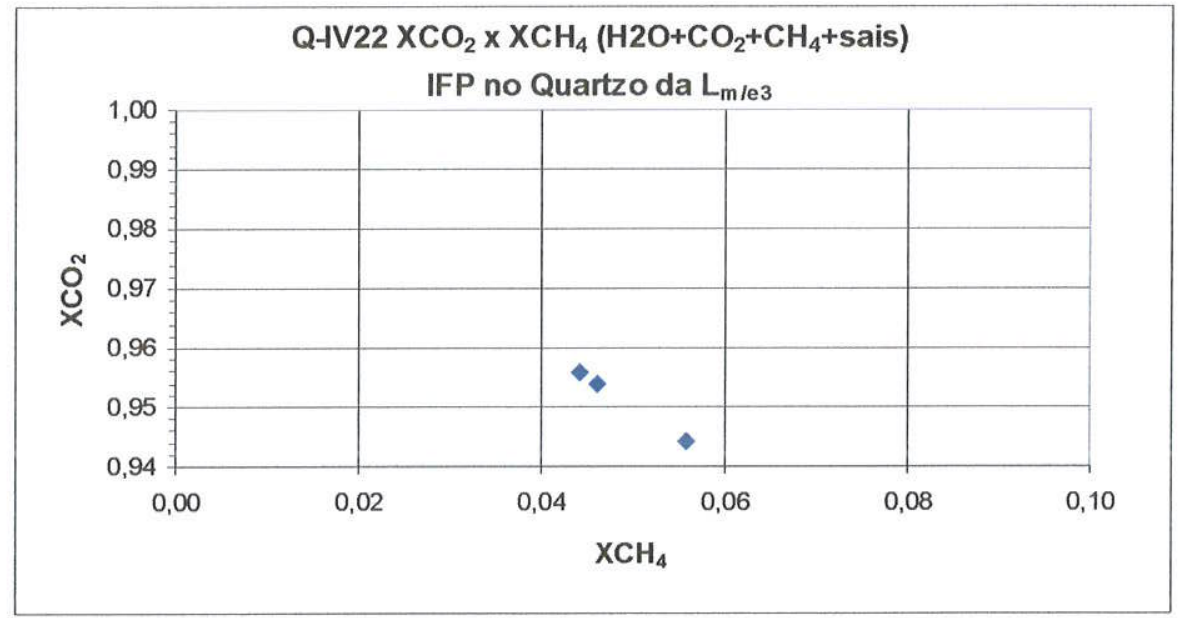

FIGURA 80 - Diagrama $\mathrm{XCO}_{2}$ versus $\mathrm{XCH}_{4}$ de IF aquo-carbônicas no quartzo intimamente associado com a pirrotita da $\mathrm{L}_{\mathrm{m} / \mathrm{e} 3}$. 
A $\mathrm{ThCO}_{2}$ apresenta uma variação pequena com valores entre 22 e $24^{\circ} \mathrm{C}$ conforme a FIGURA 81. Esta faixa mostra uma melhor correlação com as $\mathrm{ThCO}_{2}$ das IFPS e IFS do QIV2 em relação aos outros grupos de inclusões nos diversos veios.

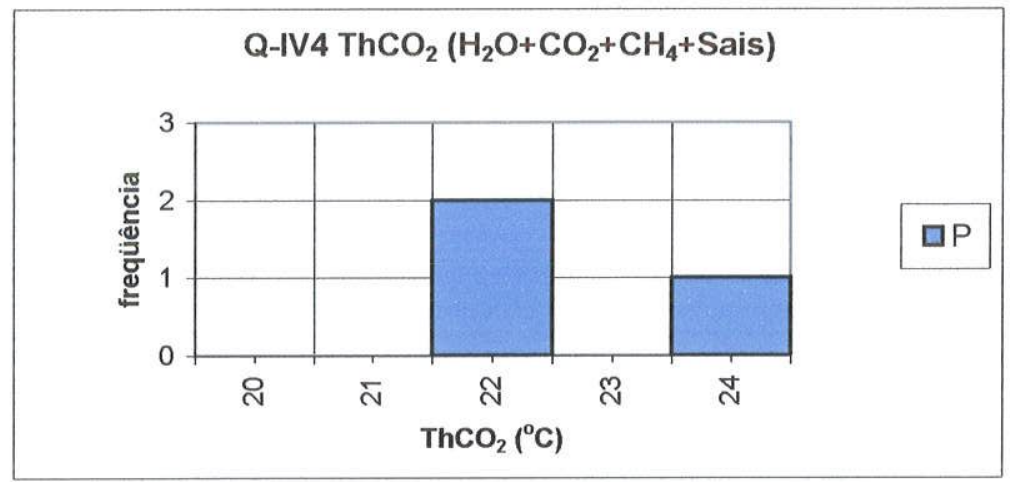

FIGURA 81 - Temperaturas de homogeneização do $\mathrm{CO}_{2}$ de IF aquo-carbônicas no quartzo intimamente associado com a pirrotita da $\mathrm{L}_{\mathrm{m} / \mathrm{e} 3}$.

As temperaturas do eutético obtidas (FIGURA 82) revelam uma sugestão de composição semelhante aos contidos nos diversos veios de quartzo, podendo-se dizer que, neste caso, não são atingidas temperaturas menores que $-40^{\circ} \mathrm{C}$, ao contrário das medidas obtidas no Q-IV4.

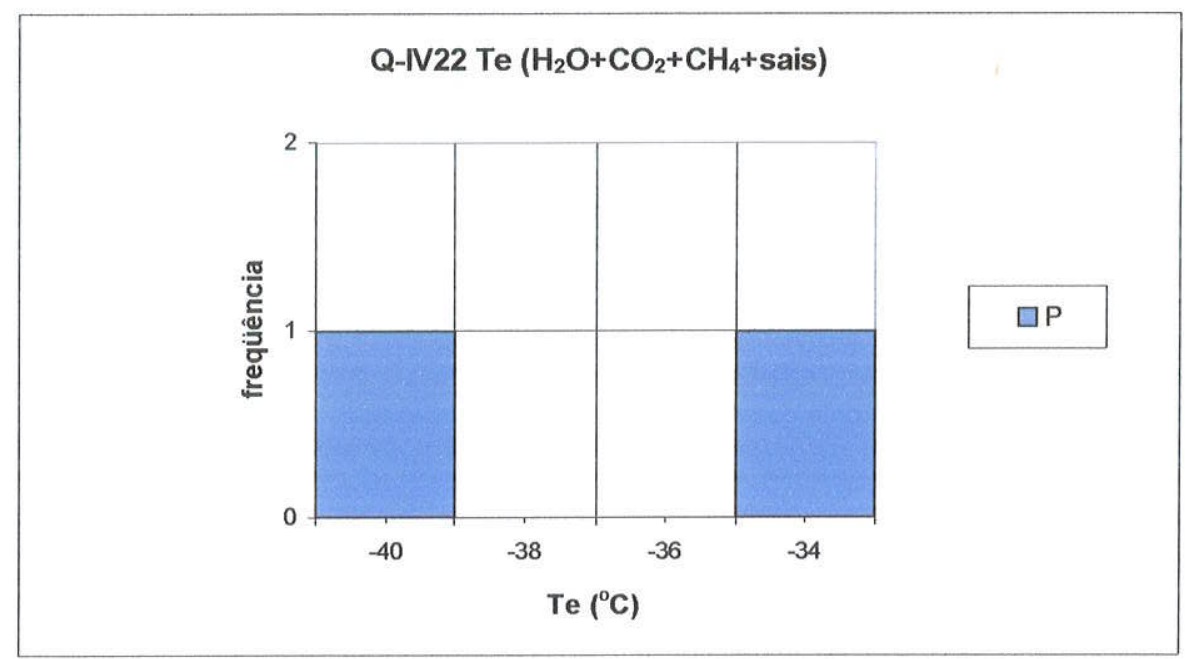

FIGURA 82 - Temperaturas do eutético das IF aquo-carbônicas no quartzo intimamente associado com a pirrotita da $\mathrm{L}_{\mathrm{m} / \mathrm{e} 3}$.

A salinidade varia de 3 a $4 \%$ em peso de $\mathrm{NaCl}$ equivalente (FIGURA 83) que em relação aos grupos de inclusões dos veios de quartzo, se assemelha aos valores obtidos no QIV4 e ao Q-IV2. 


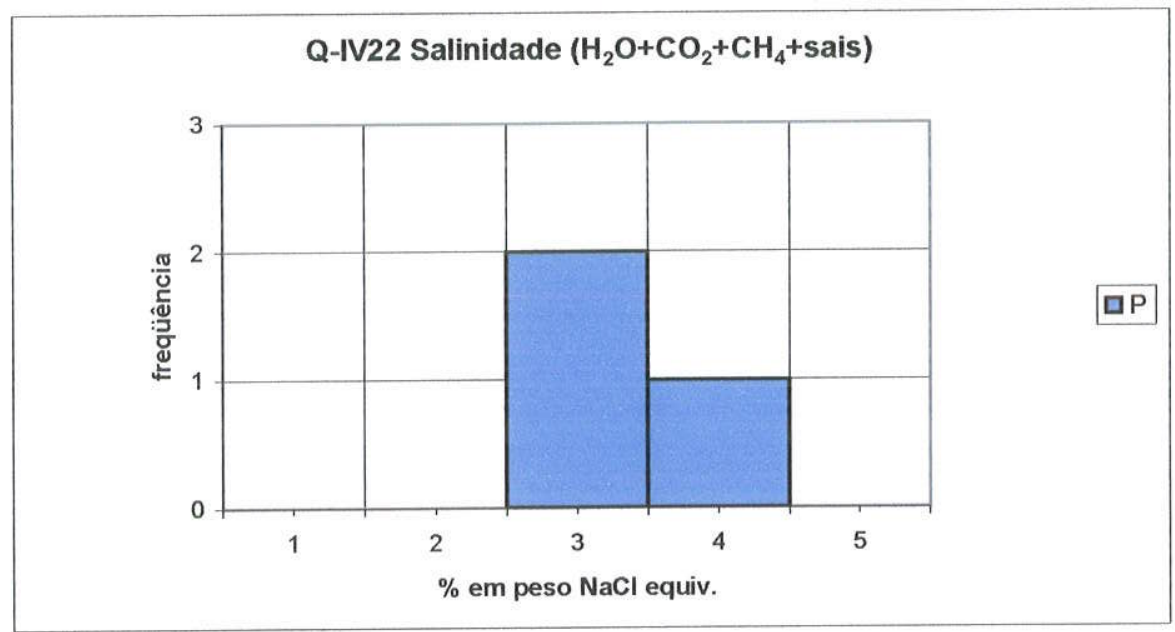

FIGURA 83 - Salinidade nas IF aquo-carbônicas no quartzo intimamente associado com a pirrotita da $\mathrm{L}_{\mathrm{m} / \mathrm{e} 3}$.

Os valores de temperaturas de homogeneização total variam de 299,2 a $305,9^{\circ} \mathrm{C}$ conforme apresentado na FIGURA 84.

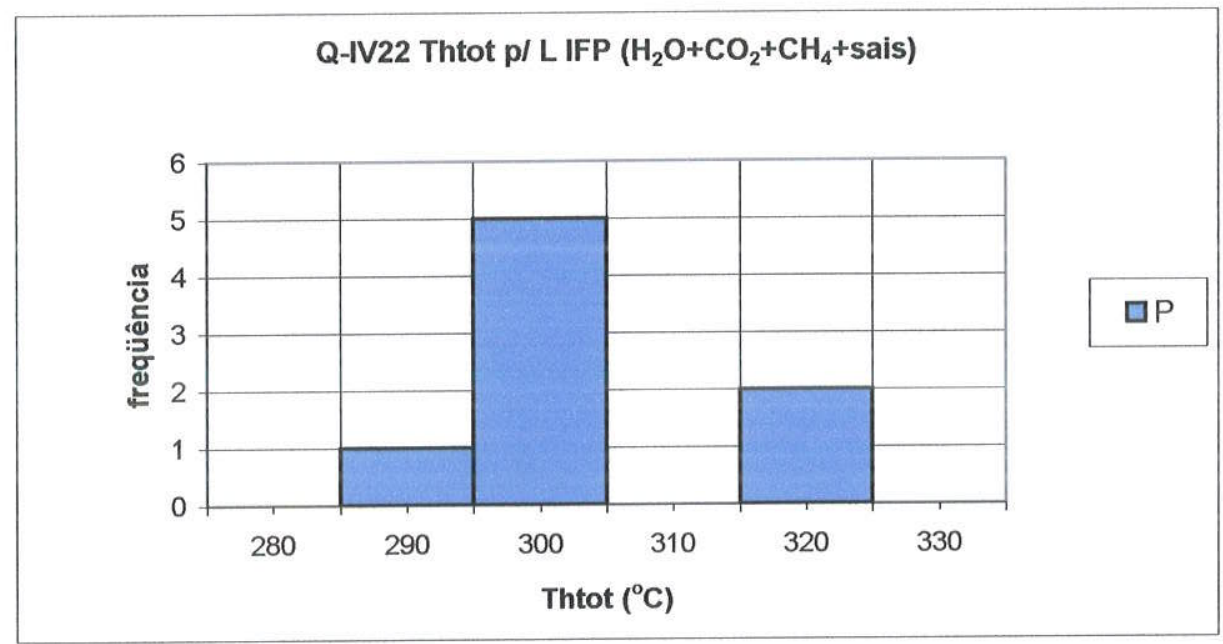

FIGURA 84 - Temperaturas de homogeneização total nas IF aquo-carbônicas no quartzo intimamente associado com a pirrotita da $\mathrm{L}_{\mathrm{m} / \mathrm{e} 3}$. 


\subsection{DIAGRAMAS ThCO 2 TCCO 2 PARA AS GERACÕES DE VEIOS L L W/E}

Em muitas associações de IFs foram observadas variações nas $\mathrm{ThCO}_{2}$, tendo sido sugerido, algumas vezes que são decorrentes de flutuações de pressão. Os diagramas abaixo confirmam a existência desses processos em algumas etapas de aprisionamento. Essas observações permitem inferir um modelo tipo faultwalve (Sibson et al., 1988) ou cyclic veindevelopment (Robert et al., 1995) para a geração dos veios de quartzo.

O diagrama $\mathrm{TfCO}_{2}-\mathrm{ThCO}_{2}$ (FIGURA $85 \mathrm{~A}$ ) para as inclusões carbônicas primárias do Q-IV1 mostra, de modo geral, uma grande variação de $\mathrm{ThCO}_{2}$, para faixas relativamente estreitas de $\mathrm{TfCO}_{2}$, o que de acordo com discussões de Dugdale \& Hagemann (2001) é indicativo de flutuações de pressão. No caso particular da amostra 11, observa-se que as variações nas temperaturas de homogeneização do $\mathrm{CO}_{2}$ também estão refletindo mudanças composicionais, uma vez que maiores quantidades de $\mathrm{CH}_{4}$ associado ao $\mathrm{CO}_{2}$, implicam num decréscimo nas temperaturas de fusão e homogeneização da fase gasosa.

Por outro lado, no caso das inclusões pseudo-secundárias e secundárias do mesmo veio, as variações em $\mathrm{ThCO}_{2}$ parecem estar principalmente relacionadas aos processo de flutuação de pressão, uma vez que ocorrem diferenças acentuadas nas $\mathrm{ThCO}_{2}$ para valores relativamente constantes de $\mathrm{TfCO}_{2}$ (FIGURA $85 \mathrm{~B} \mathrm{e} \mathrm{C}$ ).

Nas inclusões pseudo-secundárias e secundárias aquo-carbônicas, a flutuação de pressão é bastante evidenciada, pois, praticamente para uma mesma $\mathrm{TfCO}_{2}$, ocorre uma variação de $\mathrm{ThCO}_{2}$ de 0 a $30^{\circ} \mathrm{C}$, no primeiro, caso e de -1 a $11^{\circ} \mathrm{C}$, no segundo (FIGURA $85 \mathrm{D}$ e FIGURA 86 A). No caso das inclusões pseudo-secundárias, as evidências já existentes de aprisionamento a partir de fluidos imisciveis, são reforçadas pelos processos de flutuação de pressão.

A amostra 6 b mostra que nas inclusões secundárias e pseudo-secundárias do Q-IV2, as variações de $\mathrm{ThCO}_{2}$ podem ser decorrentes de variações nas quantidades de $\mathrm{CH}_{4}$. No entanto, de modo geral prevalecem as evidências de flutuações de pressão, embora não tão proeminentes como no Q-IV1 (FIGURA 86 B e C).

Evidências de flutuações de pressão também foram observadas nos diagramas referentes às inclusões carbônicas e aquo-carbônicas do Q-IV4 (FIGURA 86 D, e 87 A, B e C). A apatita, intimamente associada com ouro e pirrotita, possui inclusões aquo-carbônicas primárias com evidências muito marcantes desses processos de flutuação de pressão. Já nos cristais de siderita euhédricos presentes no Q-IV4, os dados referentes às inclusões primárias 
não mostram qualquer influência das variações de pressão. Isso pode ser indicativo do desenvolvimento tardio ou de uma zona mais preservada em relação ao cisalhamento do Neoproterozóico. Os dados relativos ao quartzo intimamente associado a siderita, no veio, apresentam o mesmo comportamento, o que, aliado à semelhança dos resultados microtermométricos das inclusões primárias desses minerais, pode sugerir a ausência de qualquer modificação posterior nas mesmas (FIGURA 87 A). Essas características também podem ser observadas nas inclusões pseudo-secundárias presentes no mesmo quartzo (FIGURA 87 B).

A presença na mesma amostra de inclusões pseudo-secundárias em quartzo, umas com feições indicativas de imiscibilidade e outras de aprisionamento a partir de fluidos homogêneos, refletem processos cíclicos das flutuações de pressão indicadas pela (FIGURA $87 \mathrm{~B})$, e que sua formação ocorreu em épocas relativamente distintas.

$\mathrm{O}$ diagrama $\mathrm{TfCO}_{2}-\mathrm{ThCO}_{2}(\mathrm{FIGURA} 87 \mathrm{C}$ ), relativo às inclusões secundárias do veio Q-IV4, mostra uma menor variação de $\mathrm{ThCO}_{2}$ em relação aos anteriores e também que, em alguns casos, essa variação está condicionada às quantidades de $\mathrm{CH}_{4}$. Isso pode sugerir uma mudança no regime de pressões, possivelmente representando o final do processo cíclico de pulsos.

Ainda foi construído um diagrama $\mathrm{TfCO}_{2}-\mathrm{ThCO}_{2}$ para as inclusões medidas da $\mathrm{L}_{\mathrm{m} / \mathrm{e}}$ (FIGURA 87 D). O número restrito de resultados, associado à dificuldade de visualização durante a microtermometria, impõe algumas limitações para a interpretação do diagrama que sugere variações de pressão e/ou variações químicas. 

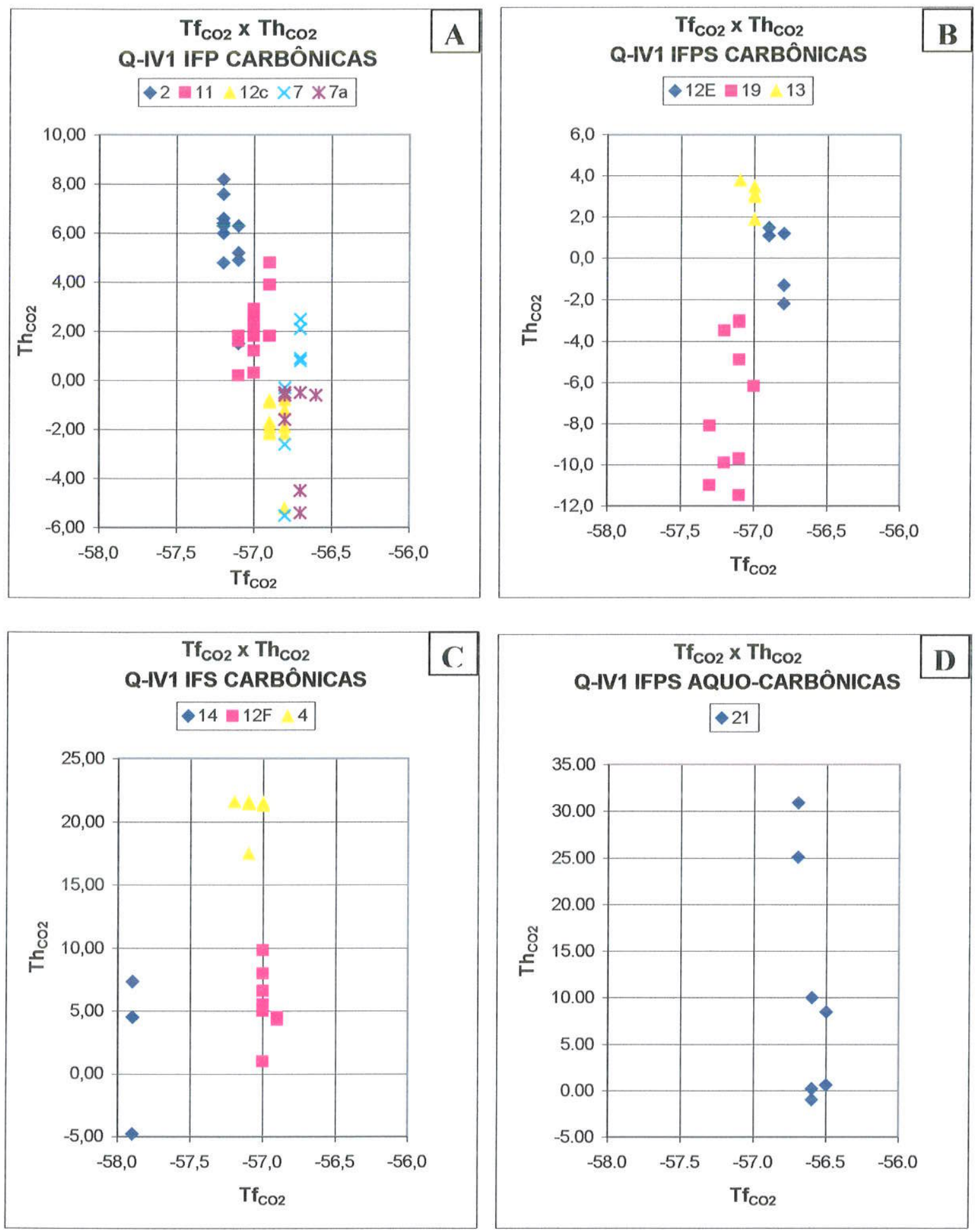

FIGURA 85 - Diagrama $\mathrm{TfCO}_{2}$-ThCO ${ }_{2}$ : (A) Q-IV1 IFP carbônicas, (B) Q-IV1 IFPS carbônicas, (C) Q-IV1 IFS carbônicas, (D) Q-IV1 IFPS aquo-carbônicas. Os números representam associações de IFs relacionados a amostras de cada geração de veios de quartzo. 

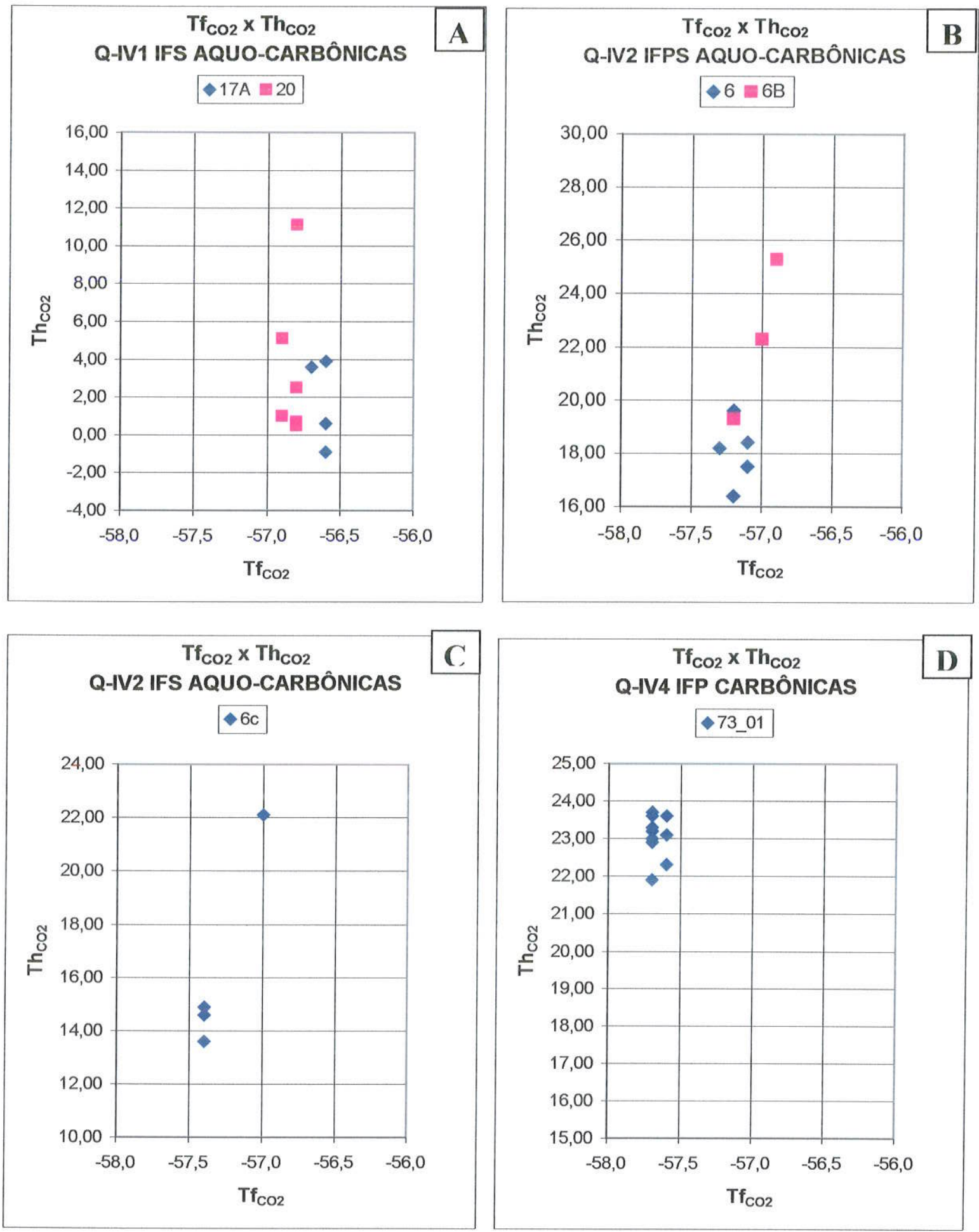

FIGURA 86 - Diagrama $\mathrm{TfCO}_{2}-\mathrm{ThCO}_{2}$ : (A) Q-IV1 IFS aquo-carbônicas, (B) Q-IV2 IFPS aquocarbônicas, (C) Q-IV2 IFS aquo-carbônicas, (D) Q-IV4 IFP carbônicas. Os números representam associações de IFs relacionados a amostras de cada geração de veios de quartzo. 

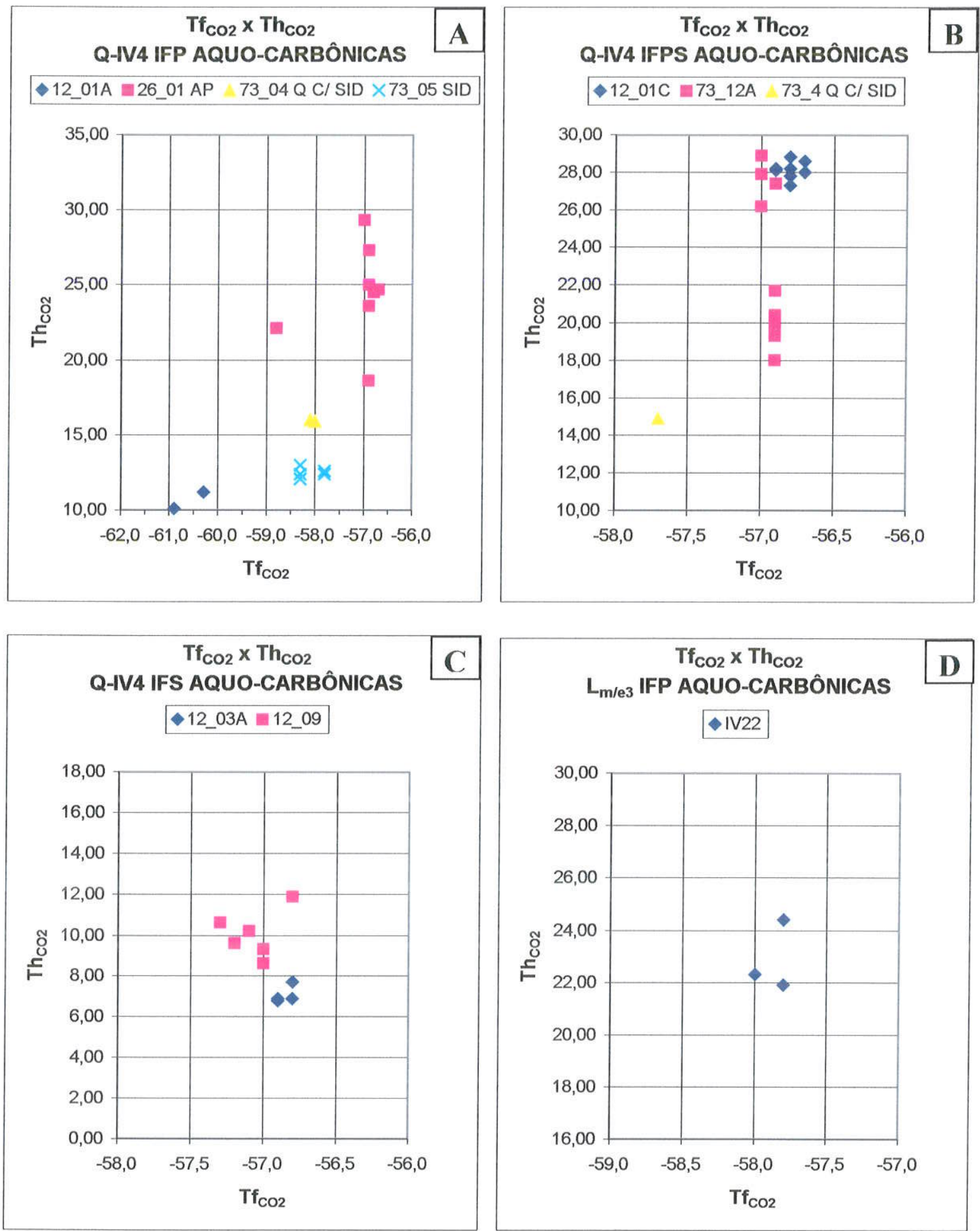

FIGURA 87 - Diagrama $\mathrm{TfCO}_{2}$-ThCO ${ }_{2}$ : (A) Q-IV4 IFP aquo-carbônicas em quartzo (12_01A), apatita (26_01AP), quartzo intimamente associado a siderita (73_04Q C/ SID) e siderita (73_05 SID), (B) Q-IV4 IFPS aquo-carbônicas no quartzo (12_01C) e $\overline{73}$ _12A) e no quartzo intimamente relacionado a siderita (73_4Q C/ SID), (C) Q-IV4 IFS aquo-carbônicas, (D) IV-22 IFP aquocarbônicas. Os números representam associações de IFs relacionados a amostras de cada geração de veios de quartzo. 


\subsection{ISÓCORAS}

A partir dos dados microtermométricos foram obtidas as composições dos fluidos em termos das frações molares dos componentes, bem como as densidades totais que permitiram a construção das isócoras de interesse. Para tanto foi utilizado o programa FLINCOR (Brown, 1989), McFLINCOR (Brown \& Hagemann, 1995) e os programas desenvolvidos por Bakker $(1997,2003)$.

As Flutuações de pressão já sugeridas pelos dos diagramas $\mathrm{TfCO}_{2} \sim \mathrm{ThCO}_{2}$ das FIGURAS 85,86 e 87, referentes a inclusões fluidas aprisionadas ora a partir de sistemas originalmente homogêneos, ora imiscíveis, são ainda indicadas pelas faixas de variação das densidades totais do fluido (FIGURAS 88 a 93, 95, 96, 99 e 102), representadas pelas isócoras (e.g. Dugdale \& Hagemann, 2001). De modo geral, as isócoras mostram variações de pressão, às vezes bem significativas, sugerindo, mais uma vez, processos de flutuações de pressão dos fluidos durante o desenvolvimento dos veios.

São apresentadas a seguir diagramas de isócoras que foram selecionadas como sendo representativas de cada geração de veios de quartzo, em ordem semelhante às discussões anteriores.

\subsubsection{Veio de quartzo da primeira geracão (OMIV1)}

As isócoras para os sistemas carbônico e aquo-carbônico em quartzo do Q-IV1 apresentam faixas de variação de pressão bastante semelhantes, sendo, no entanto, mais amplas nas inclusões secundárias (FIGURAS 88 a 92).

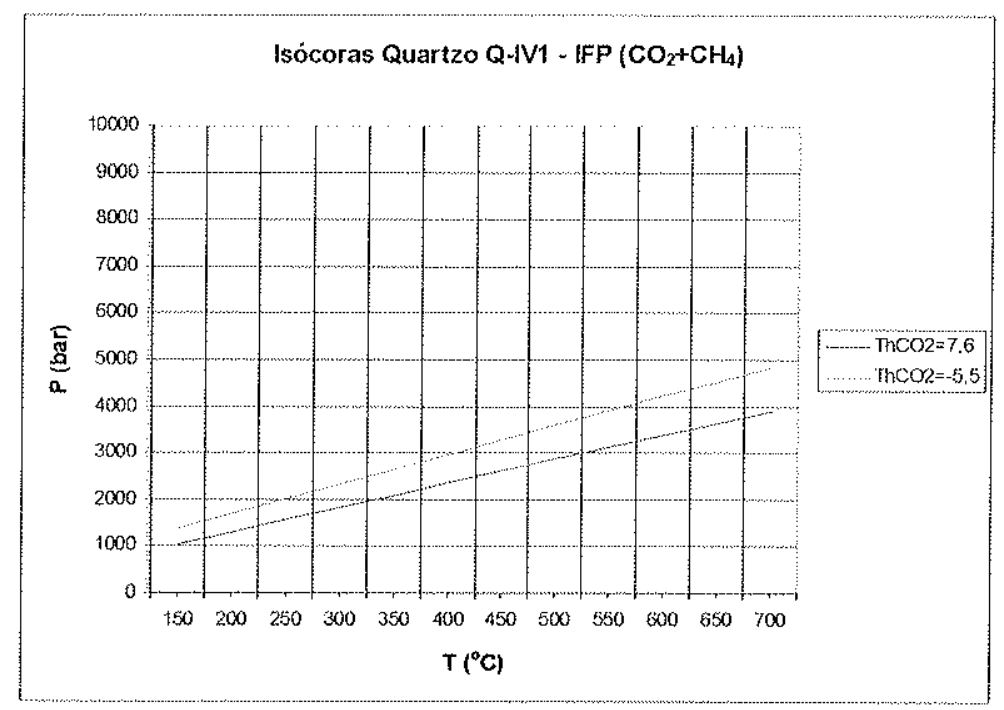

FIGURA 88 - Isócoras relativas às densidades extremas, obtidas de inclusões primárias carbônicas do Q-IV1. (Os valores de Th referem-se às temperaturas de homogeneização do $\mathrm{CO}_{2}$ ). 


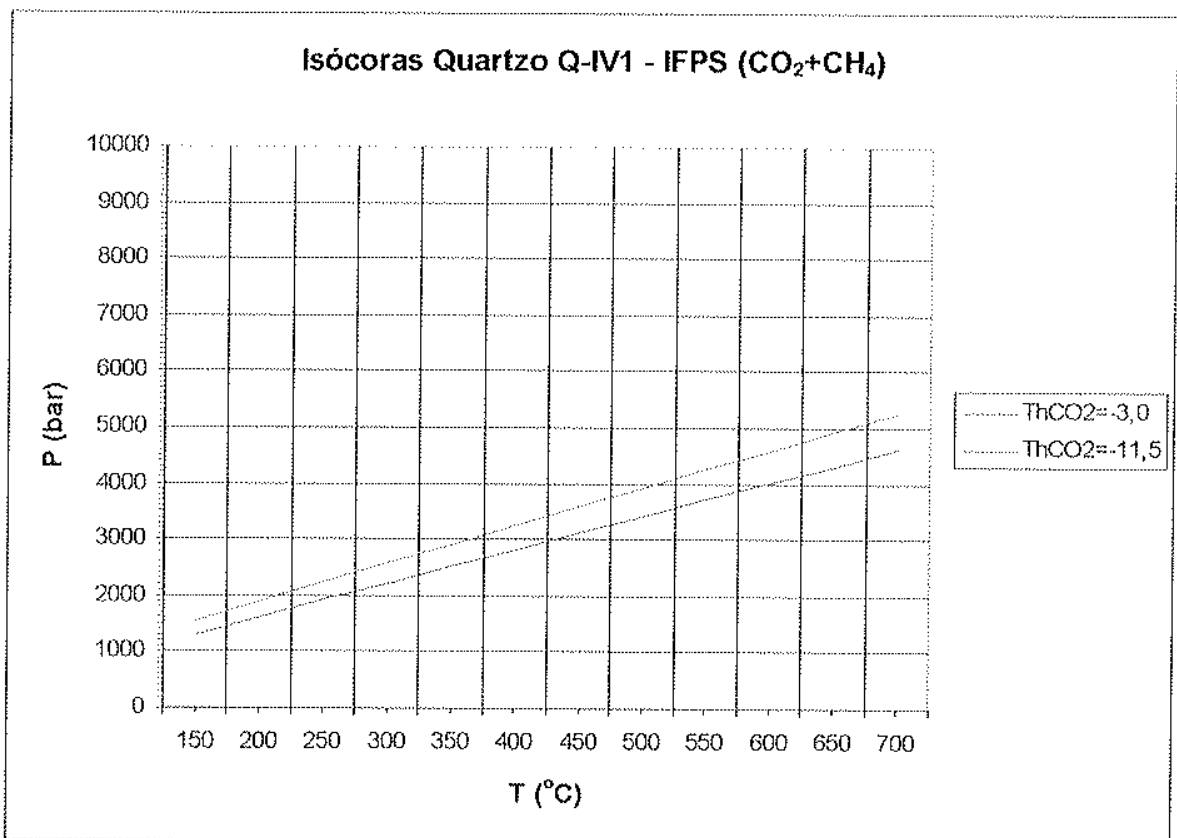

FIGURA 89 - Isócoras relativas às densidades extremas, obtidas de inclusões pseudo-secundárias carbônicas do Q-IVI. $\left(\mathrm{Th}=\mathrm{ThCO}_{2}\right)$.

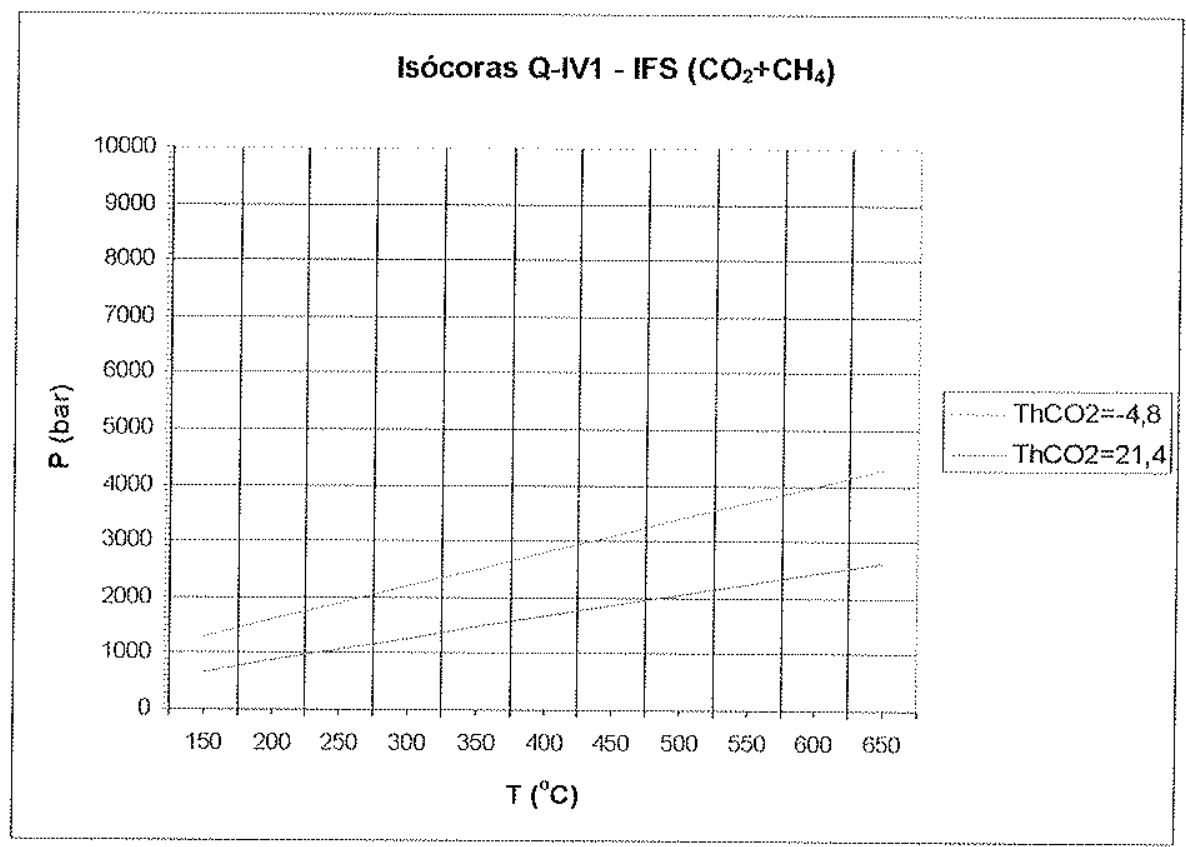

FIGURA 90 - Isócoras relativas às densidades extremas, obtidas de inclusões secundárias carbônicas do Q-IV1.

Representando-se as três gerações de inclusões carbônicas num mesmo diagrama (FIGURA 91), observa-se que, embora já ocorram variações de pressão durante os processos de formação das inclusões primárias, essas flutuações são bem mais acentuadas durante as etapas distintas de aprisionamento das secundárias, conforme já observado nos diagramas $\mathrm{TfCO}_{2}-\mathrm{ThCO}_{2}($ FIGURAS $85 \mathrm{~A}, \mathrm{~B}$ e C) 


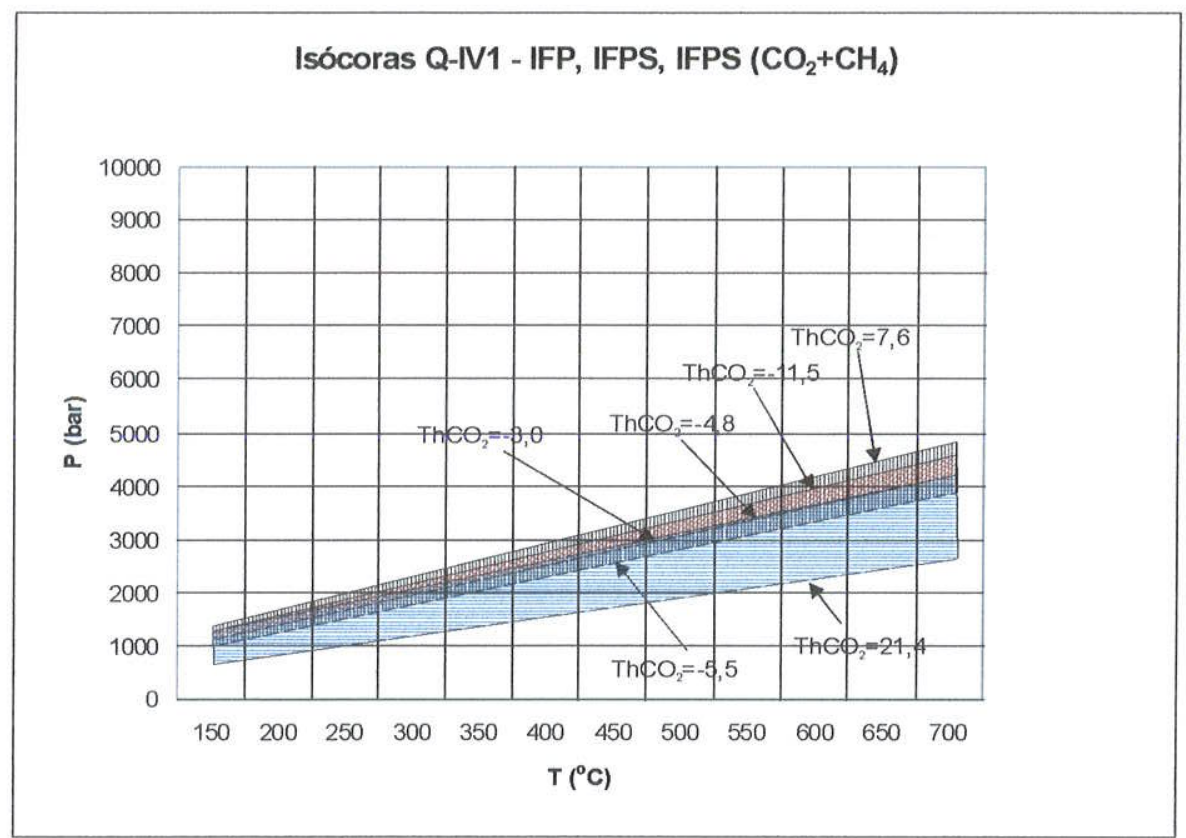

FIGURA 91 - Isócoras relativas às densidades extremas, obtidas de inclusões primárias, pseudosecundárias e secundárias carbônicas do Q-IV1.

Uma ampla faixa de variação de pressões também é observada no caso das inclusões aquo-carbônicas secundárias em quartzo (FIGURA 92), conforme já havia sido sugerido pelo diagrama $\mathrm{TfCO}_{2}$ versus $\mathrm{ThCO}_{2}$ discutido anteriormente (FIGURA $86 \mathrm{~A}$ ).

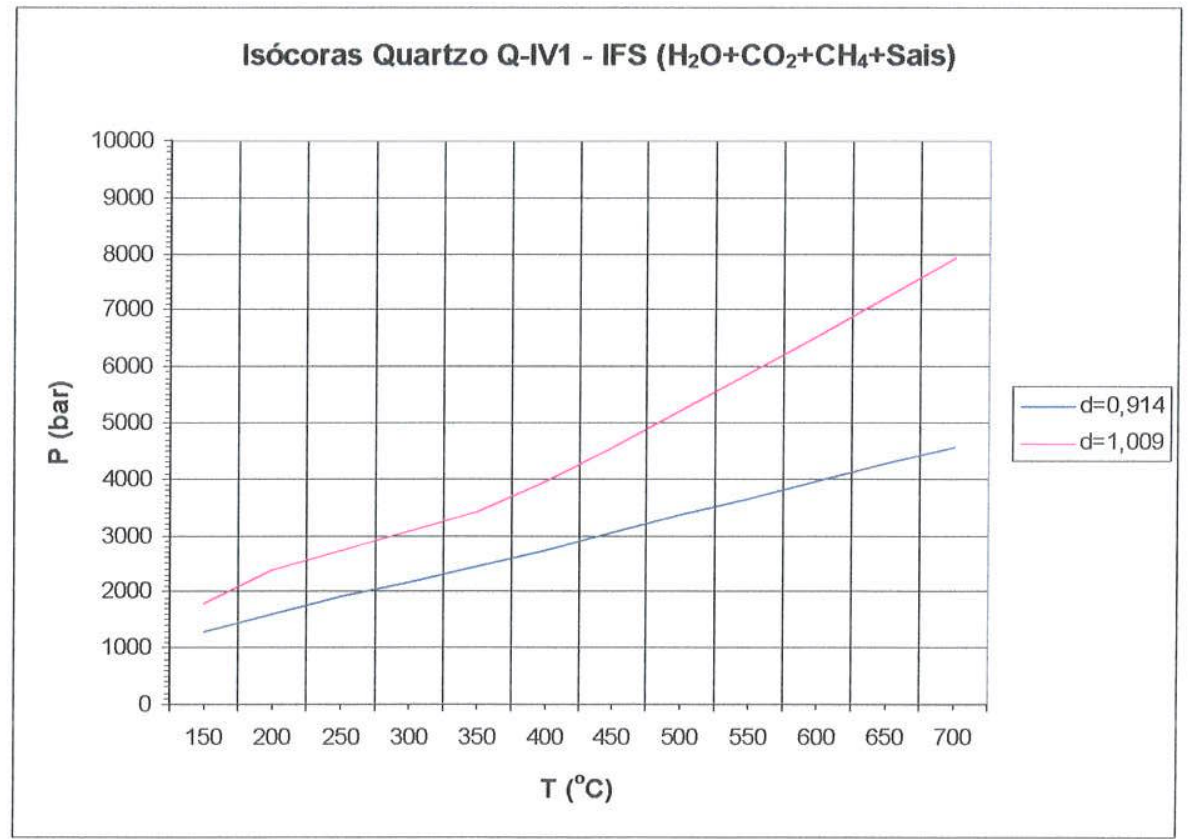

FIGURA 92 - Isócoras relativas às densidades extremas, obtidas de inclusões secundárias aquocarbônicas do Q-IV1. ( $\mathrm{d}=$ densidade total do fluido). 
Em certos cristais de quartzo desse veio, onde ocorrem inclusões aquo-carbônicas pseudo-secundárias com altas salinidades $(>30 \%$ do $\mathrm{NaCl}$ equiv.), variáveis proporções volumétricas de $\mathrm{CO}_{2}$ e características sugestivas de aprisionamento a partir de sistemas originais imiscíveis e/ou de misturas de fluidos, foram construídas as isócoras representadas na FIGURAS 93.

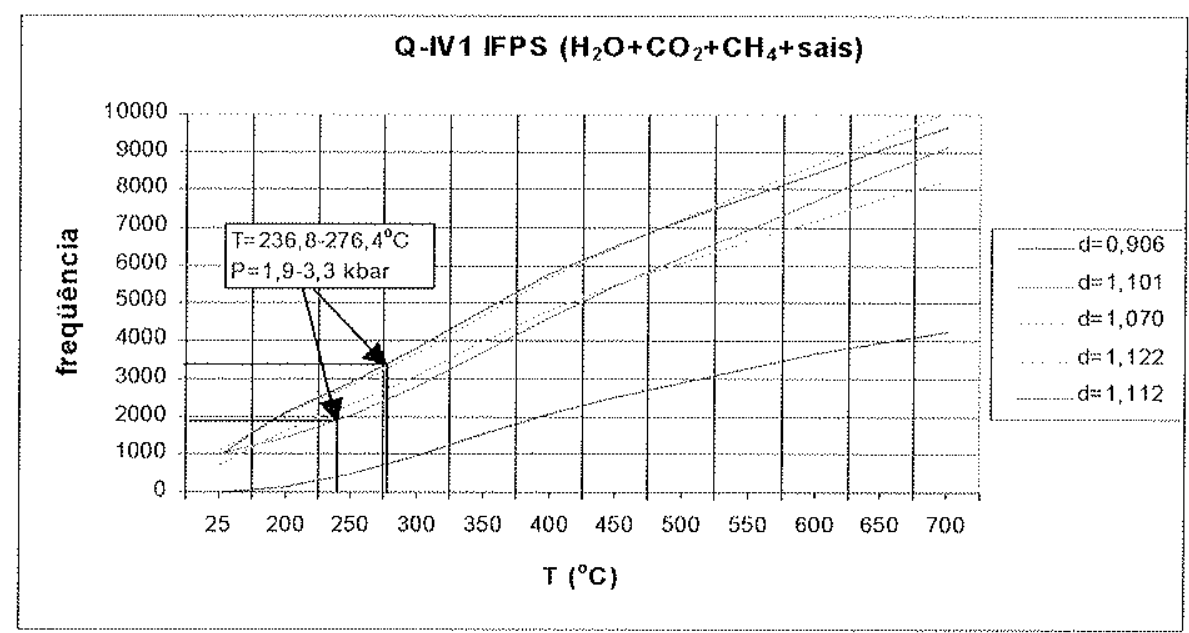

FIGURA 93 - Amostra 19_21 apresentando isócoras relativas à inclusões com variações de volumes, alta salinidade $(>30 \%)$, calculado pelo Bakker (2003, programas Bulk e Isoc). $(\mathrm{d}=$ densidade total do fluido).

Como discute Ramboz et al. (1982) e Roedder (1984), dados microtermométricos obtidos a partir de fluidos que sofreram processos de imiscibilidade e/ou mistura não permitem a determinação exata de suas densidades e, conseqüentemente, das pressões de aprisionamento. No entanto, como as variações de $\mathrm{VCO}_{2} / \mathrm{V}_{\mathrm{IF}}$ ocorrem num intervalo estreito (30 a 50\%), as isócoras apresentadas na FIGURA 93, com exceção da IF (161), podem constituir ao menos uma aproximação das densidades do fluido. Desse modo, dados aproximados de pressões, situadas entre 2,2 e 3,3 kbar, podem ser deduzidos considerando-se a faixa de variação das $\mathrm{Th}_{\text {tot }}$ mínimas de 236,8 a $276,4^{\circ} \mathrm{C}$, que também são as mais representativas das temperaturas de aprisionamento.

Em outras regiões da amostra foram também observadas associações de inclusões aquo-carbônicas pseudo-secundárias com variações extremas em $\mathrm{VCO}_{2} / \mathrm{Vtot}$ ( $(0,1$ a 0,95$)$ e em salinidades (as extremamente aquosas sendo mais salinas), que, segundo os critérios de Ramboz et al. (1982), caracterizam processos de imiscibilidade. Para essas inclusões foi possível utilizar o método do cruzamento das isócoras relativas aos termos extremos da imiscibilidade (FIGURA 94). Embora com certas limitações, esse método permite, de modo 
aproximado, a determinação das condições de temperaturas e pressões de aprisionamento, tendo sido obtidos valores de $325^{\circ} \mathrm{C}$ e $2,1 \mathrm{kbar}$, respectivamente.

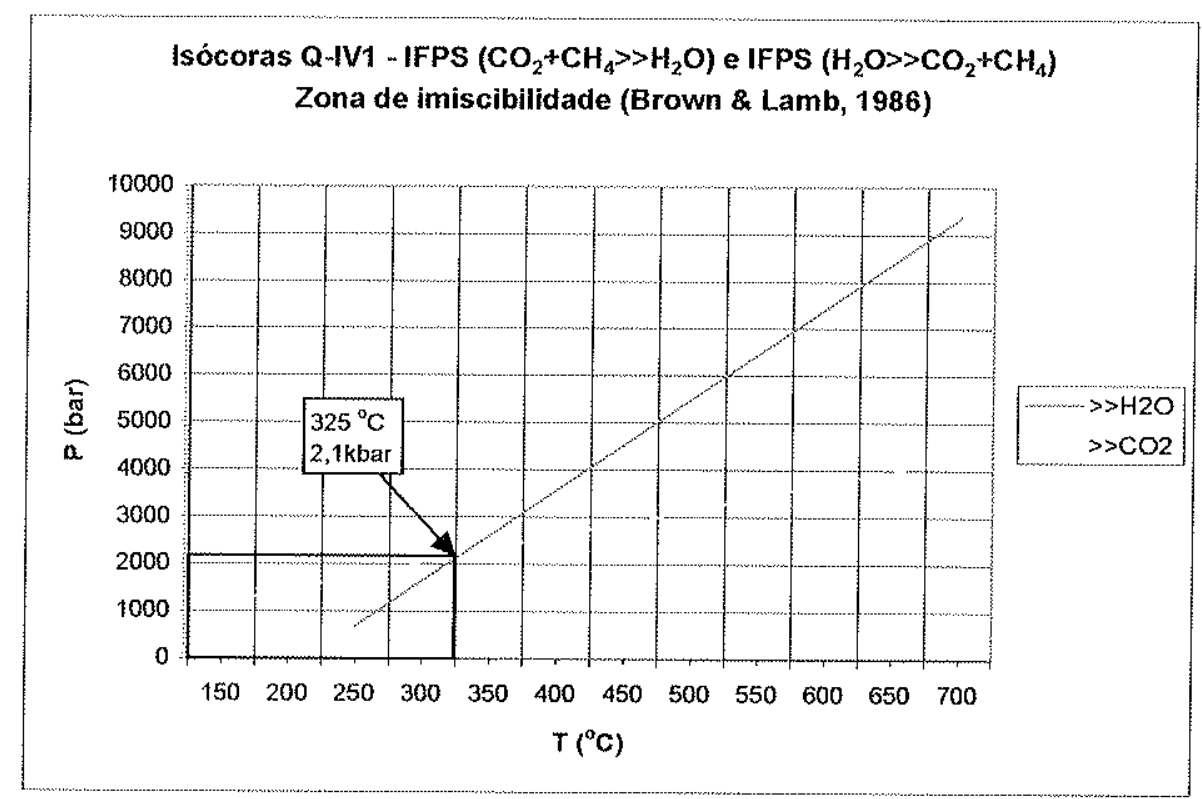

FIGURA 94 - Isócoras relativas aos termos extremos das inclusões com altas variações em $\mathrm{VCO}_{2} /$ Vtot. $(0,1$ a 0,95$)$ e em salinidade.

\subsubsection{Veio de quartzo da segunda geracão (Q-IV2)}

Os diagramas isocóricos relativos às inclusões primárias, pseudo-secundárias e secundárias aquo-carbônicas do veio Q-IV2 refletem, do mesmo modo, que os processos de flutuações de pressão foram relativamente acentuados (FIGURAS 95 E 96), principalmente no caso das inclusões dispostas em trilhas posteriores à formação dos minerais. Também é observado que, neste caso, as isócoras apresentam inclinações superiores àquelas do Q-IV1, refletindo em maiores pressões envolvidas durante o aprisionamento das inclusões.

Relacionando-se os resultados obtidos por meio da geotermobarometria (Capítulo IV) com as isócoras da FIGURA 95, observa-se um cruzamento nos valores de $\mathrm{T}$ e $\mathrm{P}$ variando de 428 a $580^{\circ} \mathrm{C}$ e 5,7 a $8,3 \mathrm{kbar}$, respectivamente, bem representativos das condições de aprisionamento das inclusões primárias e pseudo-secundárias e, portanto, próximos aos da formação do mineral. 


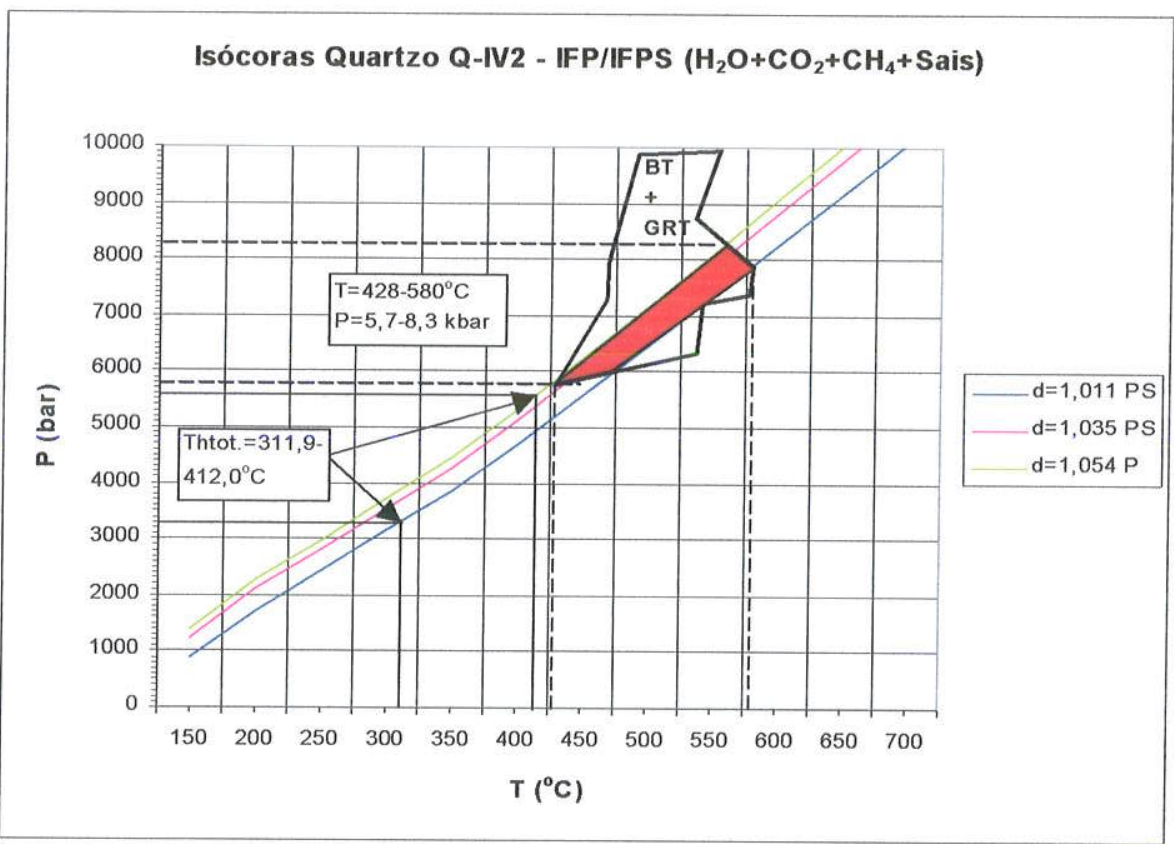

FIGURA 95 - Isócoras relativas às densidades extremas, obtidas da inclusão primária e das pseudosecundárias aquo-carbônicas do Q-IV2 com os dados de $\mathrm{Th}_{\text {tot }}$ e os resultados geotermobarométricos. (d $=$ densidade total do fluido).

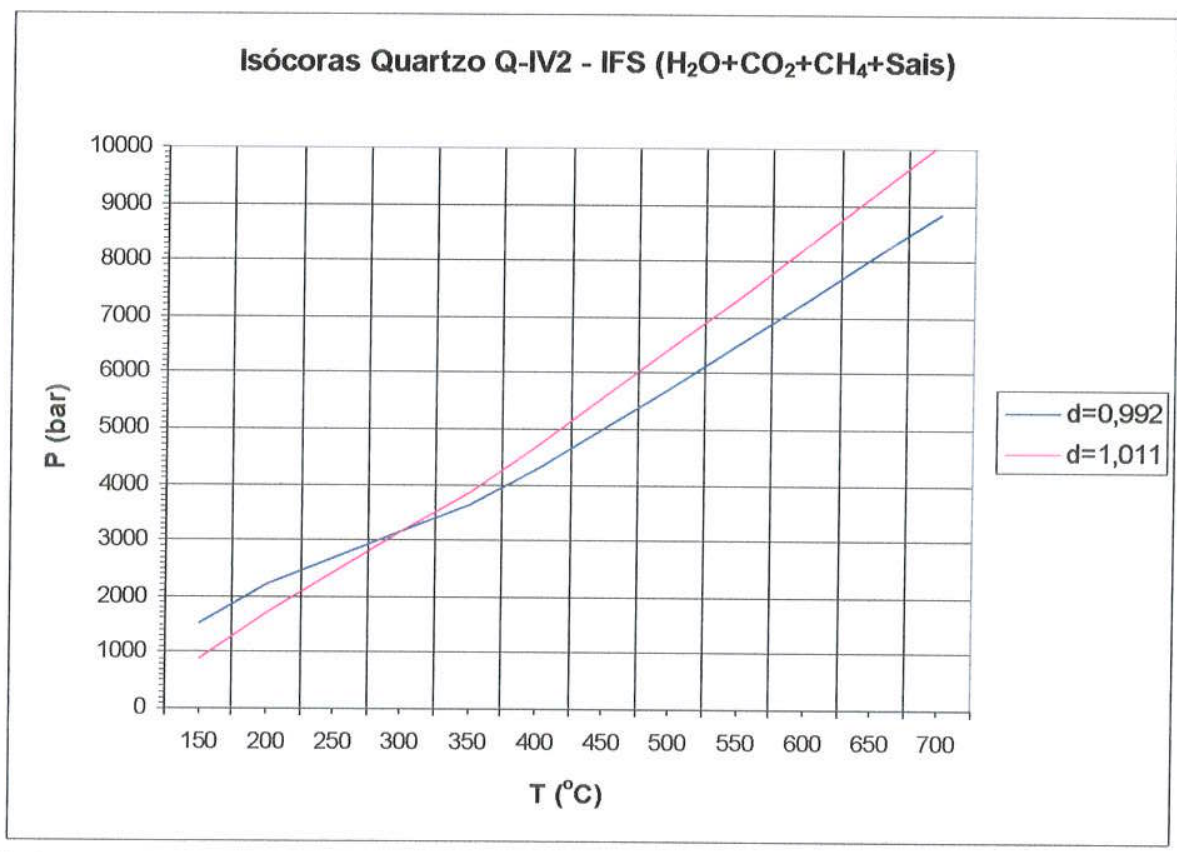

FIGURA 96 - Isócoras relativas às densidades extremas, obtidas de inclusões secundárias aquocarbônicas do Q-IV2. ( $\mathrm{d}=$ densidade total do fluido).

\section{$\underline{\text { 3.6.3 Veio de quartzo da quarta geracão (O-IV4) }}$}

No veio Q-IV4 existem poucas evidências de flutuações de pressão durante o aprisionamento de inclusões fluidas primárias carbônicas e aquo-carbônicas em quartzo (FIGURAS 86 D, 87 A, 97 e 98). Entretanto, faixas de variação de pressão bem acentuadas são observadas nas inclusões primárias aquo-carbônicas presentes em cristais de apatita 
CAPítullo V -- Página 174

(FIGURA 87 A e 99) que ocorrem marginalmente ao quartzo do veio Q-IV4, sugerindo que sua formação não pertence a essa geração de veios, em conformidade com as observações petrográficas. A apatita ocorre intimamente relacionada ao ouro, pirrotita e plagioclásio, encontrando-se nas bordas do veio Q IV 4, tendo sido cristalizada antes da colocação desse veio.

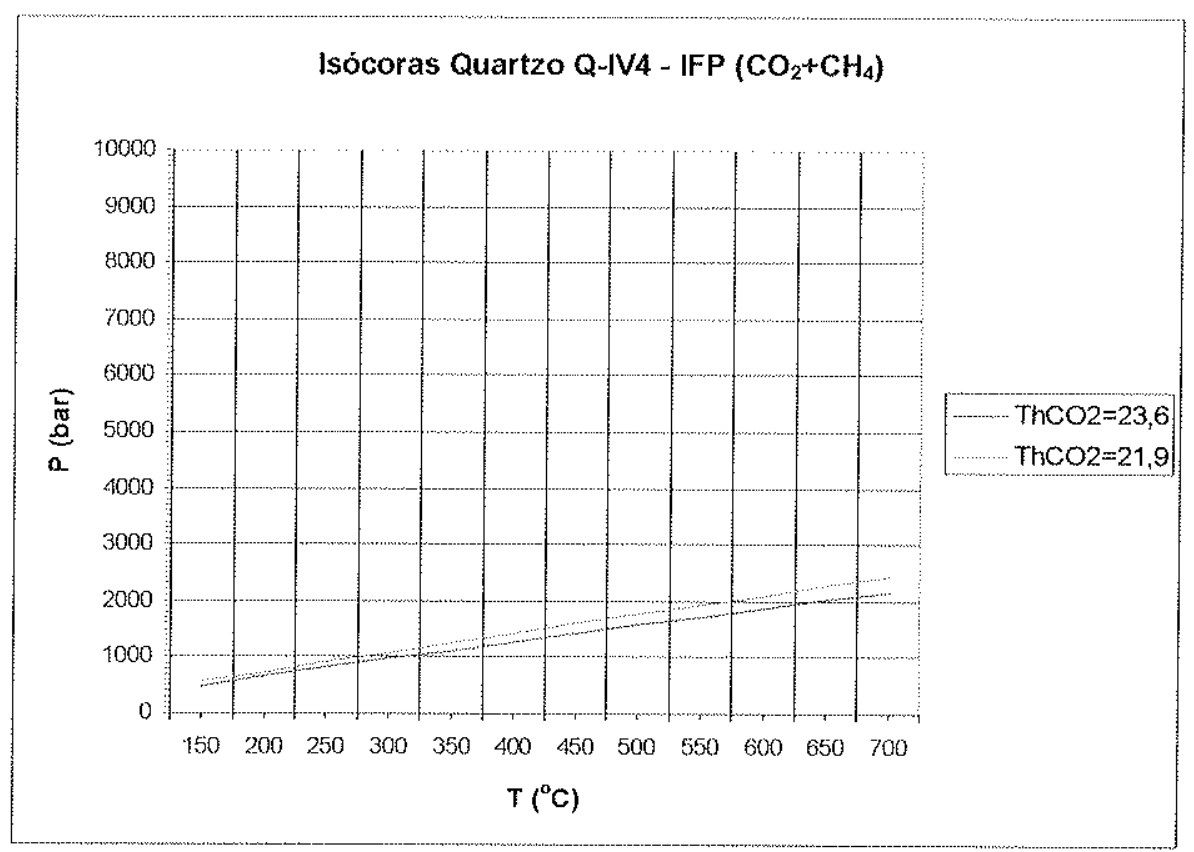

FIGURA 97 - Isócoras relativas às temperaturas de homogeneização do $\mathrm{CO}_{2}$ extremas, obtidas de inclusões primárias carbônicas no quartzo do Q-IV4.

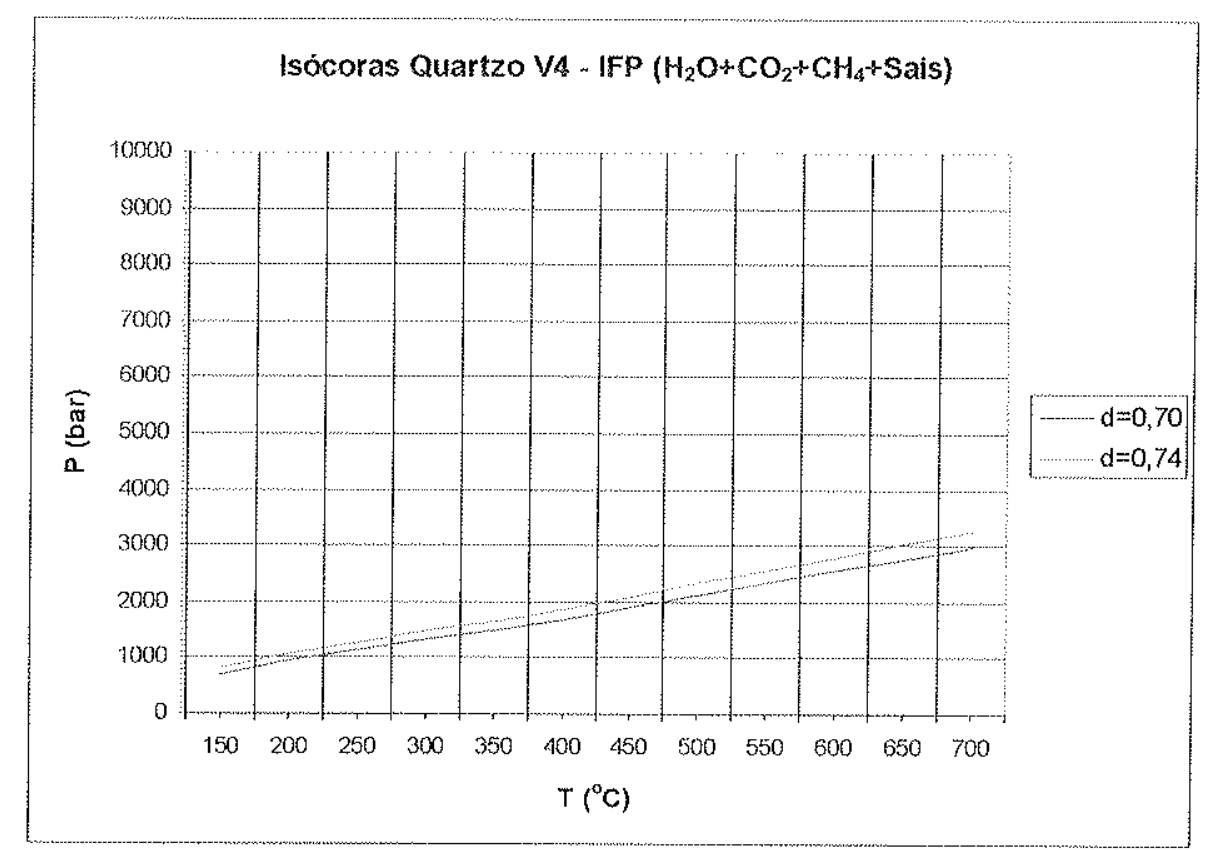

FIGURA 98 - Isócoras relativas às densidades extremas, obtidas de inclusões primárias aquocarbônicas no quartzo do Q-IV4 ( $\mathrm{d}=$ densidade total do fluido). 
CAPÍTULO V-Página 175

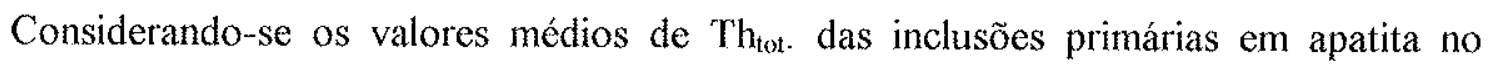
diagrama isocórico da FIGURA 99, observamse que as condições mínimas de formação desse mineral são representadas por temperaturas ao redor de $275^{\circ} \mathrm{C}$ e pressões variando de 1,19 a 2,31 kbar. Essas condições foram também obtidas a partir de inclusões pseudo-secundárias em quartzo do Q-IV1, formadas a partir de fluidos originalmente imiscíveis, conforme já discutido anteriormente (FIGURAS 93 e 94). A faixa relativamente larga de variação de densidades, somado à pressões em geral mais altas que as encontradas nas isócoras do Q-IV4, reforça as afirmações de que a apatita tenha sido formada antes da quarta geração dos veios.

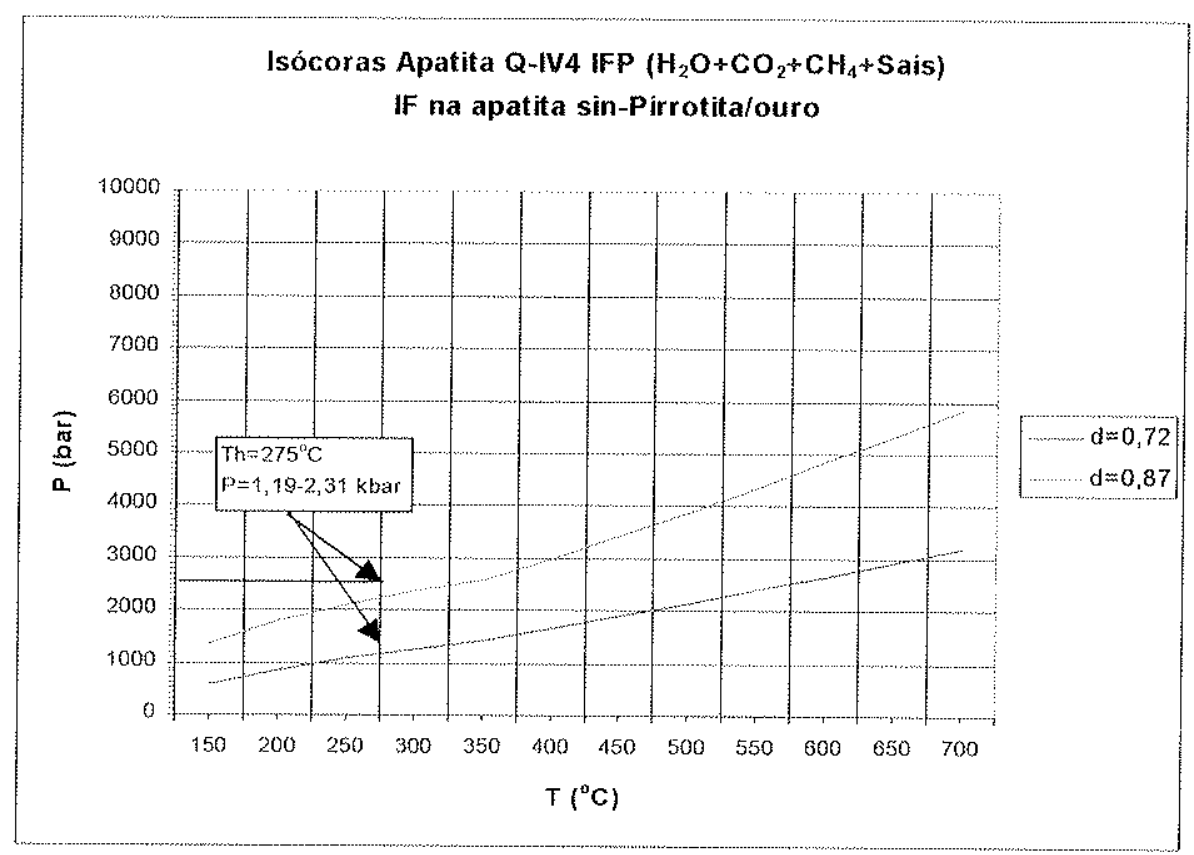

FIGURA 99 - Isócoras relativas às densidades extremas, obtidas de inclusões primárias aquocarbônicas em apatita do Q-IV2 (d =- densidade total do fluido).

Já para as inclusões pseudo-secundárias em quartzo do veio Q-IV4, com características de imiscibilidade de fluidos anterior ao aprisionamento, foi utilizado o método do cruzamento das isócoras relativas aos termos extremos $\left(\mathrm{VCO}_{2} / \mathrm{Vtot}\right.$. de 0,4 a 0,8$)$, de modo semelhante ao aplicado nas inclusões pseudo-secundárias do Q-IV1, tendo sido obtidas temperaturas e pressões de aprisionamento ao redor de $225^{\circ} \mathrm{C}$ e $0,45 \mathrm{kbar}$ (FIGURA 100). Esses valores indicam as condições diferenciadas do evento Neoproterozóico, sugerindo novamente que a apatita não pertence a essa geração de veios, tendo sido cristalizada anteriormente, em condições de maiores pressões e temperaturas. 


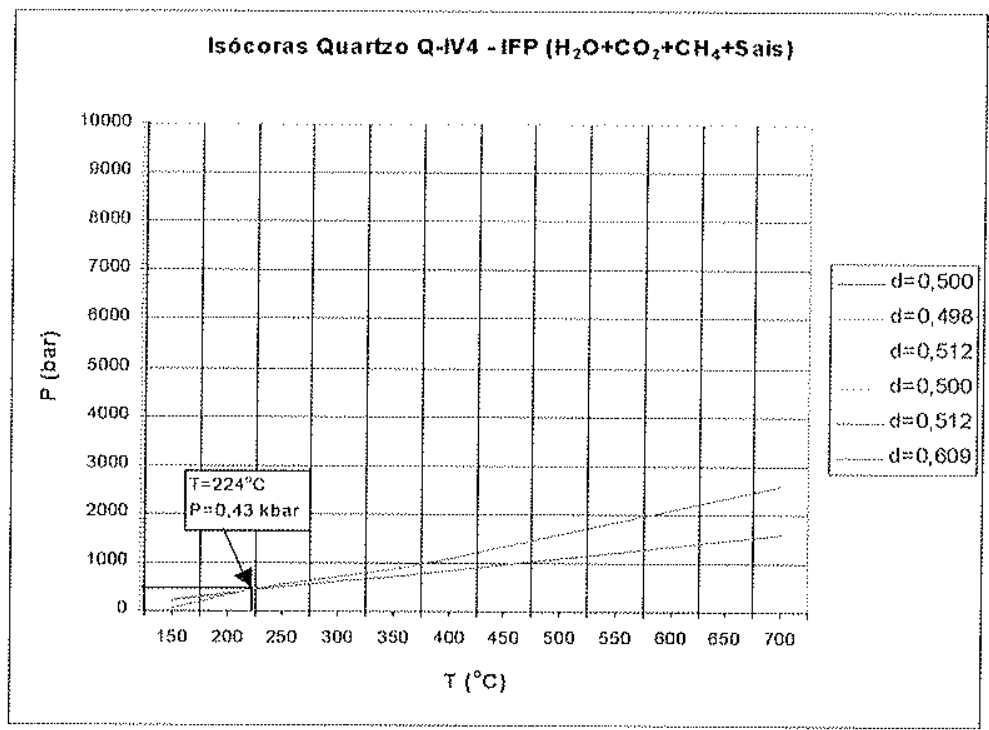

FIGURA 100 - Isócoras relativas aos termos extremos das inclusões pseudo-secundárias, com

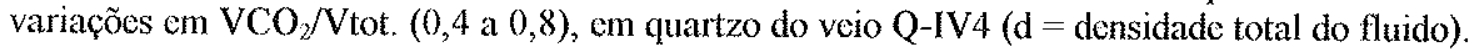

No caso das inclusões fluidas secundárias no quartzo do veio Q-IV4, embora não tenham sido obtidas as $\mathrm{Th}_{\mathrm{tot}}$, que poderiam permitir a determinação das condições mínimas de aprisionamento, observa-se no diagrama (FIGURA 101) uma maior inclinação das isócoras, o que é indicativo do envolvimento de maiores pressões, provavelmente relacionadas ao cisalhamento do Neoproterozóico. O número reduzido de medidas que foram obtidas neste caso, pode não representar as faixas de variação total das densidades e, portanto das pressões atuantes durante o aprisionamento dessas inclusões, sendo este um resultado apenas aproximado.

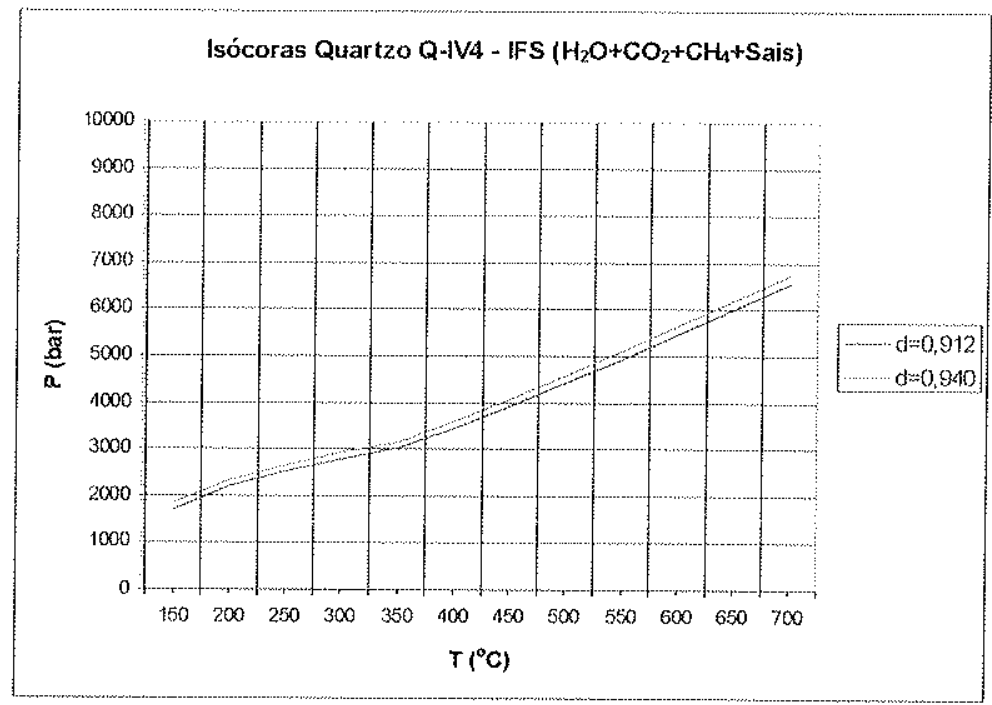

FIGURA 101 - Isócoras relativas às densidades extremas, obtidas de inclusões secundárias aquocarbônicas em quartzo do Q-IV4 ( $\mathrm{d}=$ densidade total do fluido). 
A análise microtermométrica em inclusões primátias de um cristal euédrico de siderita no veio de quartzo Q-IV4 e naquelas presentes no quartzo intimamente relacionado ao carbonato revelou uma grande similaridade nos dados. Assim podemse inferir que essas inclusões não sofreram modificações posteriores ao aprisionamento, as quais causariam diferenças significativas no resultados microtermométricos, ao atuarem sobre dois minerais distintos. Esse fato contribui para a premissa assumida no estudo de inclusões fluidas em que o volume e composição das inclusões fluidas examinadas permaneceram constantes (condição isoplética e isocórica) desde o seu aprisionamento (Roedder, 1984; Diamond, 1990; Goldstein \& Reynolds, 1994).

As isócoras relativas às inclusões primárias na siderita (FIGURA 102), mineral de veio característico do evento Neoproterozóico, não indicam as flutuações de pressão semelhantes às obtidas no Q-IV1 e Q-IV2. O mesmo ocorre em relação às inclusões primárias em quartzo relacionado à siderita, quando são consideradas temperaturas até $350^{\circ} \mathrm{C}$, que representam o limite superior dos maiores valores obtidos em inclusões fluidas de todas as gerações de veios. Assim, no Neoproterozóico não ocorrem as condições favoráveis à precipitação do ouro relacionadas às flutuações de pressão. Essas mesmas condições são observadas nas inclusões fluidas secundárias em quartzo não diretamente relacionado à siderita do Q-1V4 (FIGURA 101), mostrando o caráter mais tardio de cristalização do carbonato neste veio.

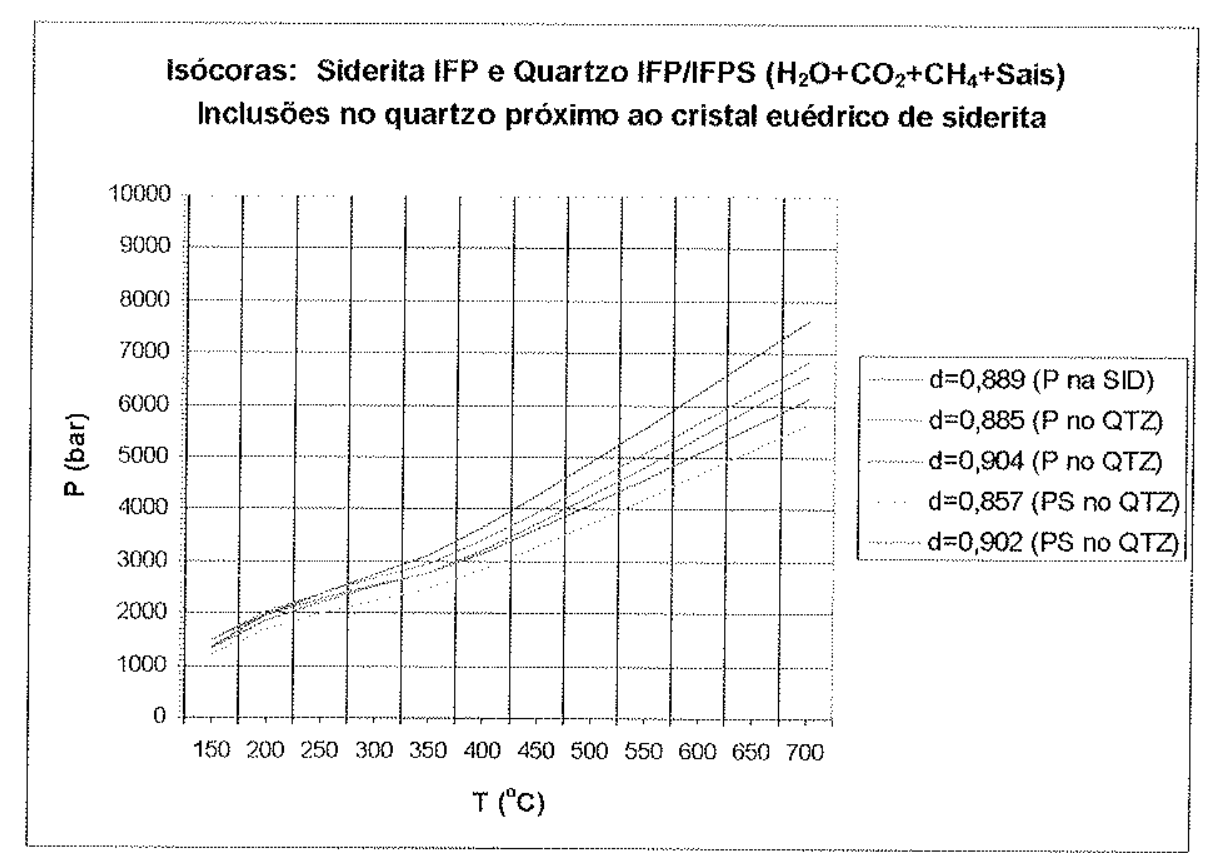

FIGURA 102 - Isócoras relativas às densidades extremas, obtidas nas inclusões primárias aquocarbônicas na siderita e nas primárias e pseudo-secundárias aquo-carbônicas em quartzo diretamente relacionado ao carbonato do Q-IV4 ( $\mathrm{d}=$ densidade total do fluido). 


\subsubsection{Quartzo na $\mathrm{L}_{\mathrm{m} / \mathrm{e} 3}$}

Embora o diagrama (FIGURA 103) não mostre a presença de flutuações de pressão devido à pequena quantidade de medidas, a isócora média obtida para as inclusões fluidas primárias em quartzo da $L_{m / 3}$ no xisto carbonoso assemelha-se àquelas referentes às inclusões pseudo-secundárias e secundárias em quartzo do Q-IV2.

O veio Q-IV2 foi desenvolvido durante a evolução do cisalhamento quando é criado um ambiente propício a flutuações de pressão e percolação de fluidos através da encaixante carbonosa, com liberação de sulfetos e, provavelmente, ouro. Os registros dessas soluções estão também impressos nas inclusões pseudo-secundárias aprisionadas no quartzo do Q-IV2, podendo ser responsáveis pelas precipitações de sulfetos e ouro induzidas pelos processos de imiscibilidade e/ou misturas de fluidos.

As feições descritas anteriormente podem ser claramente observadas nas regiões onde as $\mathrm{L}_{\mathrm{m} / \mathrm{s} 3}$ interceptam o veio Q-IV1, nas quais está presente a pirrotita $\mathrm{e}$, mais raramente, o ouro e onde os processos de imiscibilidade e/ou mistura estão bem representados. A recorrência desses processo, com desenvolvimento de novas fraturas no próprio Q-IV2, pode ser indicada pela similaridade entre as inclusões pseudo-secundárias e secundárias observadas em cristais desse veio (FIGURAS 95 e 96).

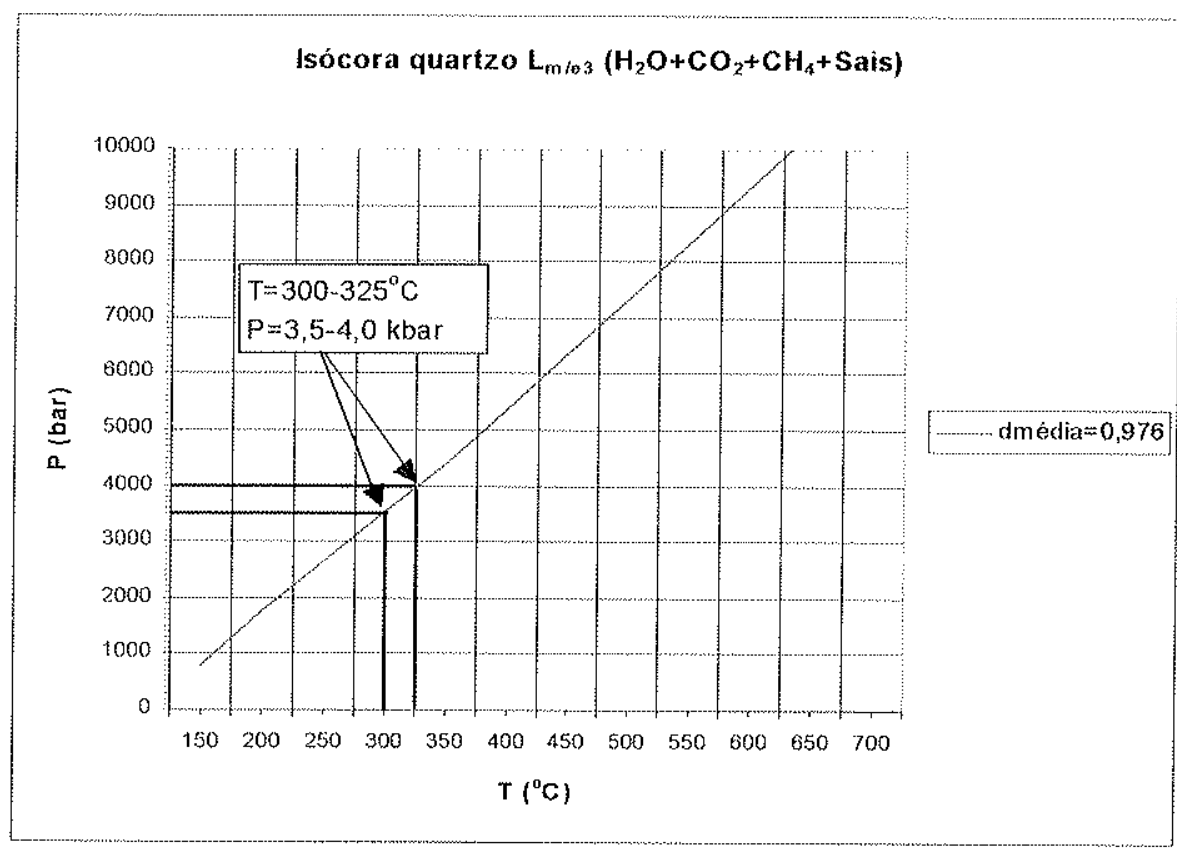

FIGURA 103 - Isócoras relativas às inclusões fluidas primárias aquo-carbônicas no quartzo da $\mathrm{L}_{\mathrm{n} / \mathrm{e} 3}$ ), mostrando as condições de T c P minimas de aprisionamento $(\mathrm{d}=$ densidade total do fluido $)$. 


\section{CONCLUSÕES PARCIAS}

\section{INTRODUCÃO}

As correlações sobre as idades das mineralizações de ouro nos Corpos IV e V, feitas no presente trabalho, baseiam-se na existência de quatro eventos deformacionais no Greenstone Belt de Crixás (Jost \& Fortes, 2001), sendo que as feições pré-neoproterozóicas observadas, foram relacionadas ao período Paleoproterozóico (evento D3), conforme apresentado na TABELA 5.

Entre as ferramentas empregadas no desenvolvimento da pesquisa, cabe destaque para a elaboração do programa do banco de dados vinculado a um sistema de posicionamento tridimensional. Este revelou-se como uma ferramenta prática e indispensável na evolução dos trabalhos de pesquisa, mostrando ainda que, o gerenciamento de dados, seja na pesquisa ou em mineradoras de pequeno porte, não exige necessariamente sistemas altamente sofisticados e dispendiosos.

A utilização do método de coloração seletiva dos carbonatos foi amplamente utilizada, ajudando na separação e interpretação das várias gerações e fases carbonáticas envolvidas, sejam elas primárias ou como resultado de alterações hidrotermais.

\section{FORMACÃO RUBEIRÃO DAS ANTAS}

Observações realizadas nos testemunhos de sondagem, revelaram zonas de microconglomerados com seixos de até $0,6 \mathrm{~cm}$, predominantemente de quartzo, arredondados, que gradam para metarenito a metassiltito com grânulos dispersos, com estruturas típicas de correntes de turbidez, indicando ambiente deposicional proximal. Isso sugere que sedimentação da Formação Ribeirão das Antas deve ter ocorrido próximo a margens continentais ativas, corroborando com as deduções de Jost \& Fortes (2001).

A presença de rochas carbonáticas sedimentares intercaladas na Formação Ribeirão das Antas é bastante limitada, o que, dentro das dimensões deste estudo, não permitiu um tratamento individualizado, como, por exemplo, a separação de uma fácies carbonática primária.

Foi constatada a presença de teores altos de fluorapatita, chegando a $28 \%$ em conteúdo no xisto carbonoso, reforçando as características de ambiente marinho de deposição da 
Formação Ribeirão das Antas, possivelmente com muito oxigênio na água e em regiões de flancos de arcos.

\section{CORPOSIVEV}

Os trabalhos de campo permitiram identificar diversas estruturas tectônicas préneoproterozóicas preservadas nos corpos IV e $\mathrm{V}$ e em outras zonas mineralizadas ou não da Mina III. Com isso foi possivel reconhecer que o Corpo IV e o Corpo V constituem blocos preservados pelo cisalhamento tardio nos xistos carbonosos da Formação Ribeirão das Antas e, dessa maneira, a mineralização é controlada por shear zones e a geometria dos corpos de minério segue um padrão "S/C". Assim, interpreta-se que os corpos mineralizados formaramse, provavelmente, no Paleoproterozóico, tendo sido reorientados e desmembrados pelas zonas de cisalhamento no ciclo Brasiliano.

Fica evidente que os corpos mineralizados são controlados pelo cisalhamento neoproterozóico, mas não foram formados depósitos de ouro nesse evento. Assim, o evento neoproterozóico apenas reorienta e trunca os corpos mineralizados gerados durante o evento de cisalhamento anterior. Isso também se confirma pela análise da distribuição de ouro nos canais de amostragem nas paredes das galerias, onde os teores mais altos de minério não se associam com os veios de quartzo relacionados ao evento D4.

No Corpo V foram observados abundantes sistemas de quebra e preenchimento, relativamente mais freqüentes que os observados no Corpo IV, quando preservados do evento D4, e que devem ter desempenhado um importante papel como conduto de fluidos mineralizantes, em provável sincronia com o desenvolvimento do Corpo IV.

O Corpo IV foi estudado em maior detalhe, devido ao desenvolvimento mais avançado de sua lavra na época dos mapeamentos, mas que, em função da proximidade e similaridade da encaixante, podem ser feitas extensões das interpretações ao Corpo $\mathrm{V}$.

As características principais do Corpo IV são relacionadas abaixo:

- tratam-se de blocos relativamente preservados pelo evento neoproterozóico;

- foi reconhecido um sistema de alteração propilitica, bem como de albitização, sericitização, turmalinização, sulfetização e epidotização, relacionado à mineralização e ao evento D3, provavelmente paleoproterozóicos;

- as associações minerais características do minério no xisto carbonoso são: sericita, albita, dravita, ilmenita alterando para rutilo, biotita relativamente mais magnesiana chegando à 
composição flogopita, dolomita ferrosa, pirrotita, arsenopirita, calcopirita, esfalerita, apatita e quartzo.

- ocorre uma relação constante entre os porfiroblastos metamórficos, como os de granada almandínica, Fe-tschermakita, cloritóide, arsenopirita, plagioclásio e biotita e as rochas cloríticas, que representam as zonas de alteração hidrotermal mais intensas. Isso se repete em todas as mineralizações na Mina III;

- quando ocorre granada no xisto carbonoso em rochas próximas à mineralização, no halo dominado pela sericita (halo intermediário), esta se distingue da granada do núcleo das zonas de alteração hidrotermal, por ser relativamente mais magnesiana;

- na zona mineralizada, a albita é muito pura, apresentando composições próximas à do membro final, e o carbonato é a ferro-dolomita;

- ocorrem veios de quartzo da primeira e segunda geração (Q-IV1 e Q-IV2), dobrados, mas ainda preservando suas estruturas hidrotermais primárias e as tectônicas préneoproterozóico e, não se verificou em nenhum momento transporte de ouro ou sulfetos pelos veios de quartzo, mas apenas precipitações destes minerais nas proximidades da interface do xisto carbonoso com o veio de quartzo. Esse fato sugere que os veios de quartzo, quando mineralizados, atuaram como zonas de descompressão e/ou de mistura, o que deve ter causado a desestabilização dos fluidos transportando sulfetos e ouro, principalmente nas proximidades da interface da encaixante carbonosa com os veios;

- "nódulos carbonosos", quando presentes, apresentam-se menos estirados;

- vários fatores indicam semelhança do Corpo IV e V com a Zona Inferior da Mina III como: o gold fineness, a encaixante de xisto carbonoso e as estruturas brechadas;

- o ouro no Corpo IV deve ter sido precipitado próximo aos estágios finais da pirrotita, provavelmente durante diversos pulsos mineralizantes, relacionados ao final do evento D3.

O presente estudo não visou uma interpretação estrutural detalhada mas, os dados obtidos nos Corpo IV e V demonstraram, em acordo com a coleção de medidas realizada por Queiroz (1995), que as regiões mineralizadas foram afetadas pelo evento D4, neoproterozóico, que reposicionou os contatos litológicos e destruiu os resquícios de $S_{\mathrm{m} 3}$ e $\mathrm{L}_{\mathrm{m} / \mathrm{e} 3}$, paleoproterozóicos. $\mathrm{A} \mathrm{L}_{\mathrm{m} / \mathrm{e} 3}$ foi preservada em vários locais, da mesma maneira, sendo que esta tem vínculos indiscutíveis com o trend da mineralização dos Corpos IV e V. 
O Corpo IV apresenta dobramentos em escala métrica com eixos paralelos a lineação de estiramento mineral principal $\left(\mathrm{L}_{\mathrm{m} / \mathrm{e} 3}: \mathrm{N} 37^{\circ} \mathrm{W} / 20^{\circ}\right)$ e ao plunge dos corpos de minério, indicando a migração de fluidos mineralizantes para zonas de charneira de dobras, relacionadas, provavelmente, ao evento D3, constatado também em escala microscópica.

Esta manifestação tectônica é também refletida na geração dos "nódulos carbonosos", formados em zonas apicais de dobras durante o evento D3, sendo os mesmos destruídos, quando afetados pelo evento neoproterozóico. Tais feições também indicam as variações na preservação das rochas pelos eventos deformacionais relacionados ao ciclo Brasiliano. A presença de nódulos carbonosos ocorre em outros depósitos arqueanos, como o Witwatersrand na África do Sul, mas no caso da Formação Ribeirão das Antas, não se verificou relacionamento da formação desses com minerais radioativos.

\section{ALTERACÕES HIDROTERMAIS}

Os halos concêntricos da alteração hidrotermal observados em várias escalas nas paredes das galerias são igualmente pré-brasilianas, pois são deformados e truncados pelo cisalhamento brasiliano. A sulfetação intensa no Corpo IV, por exemplo, não se limita às relíquias preservada pelas zonas de cisalhamento.

Foram constatadas alterações hidrotermais como: sericitização, potassificação, cloritização, dolomitização, turmalinização, epidotização, silicificação e sulfetização. Estas são o resultado de vários processos com intensidades diferenciadas, mas, em conjunto, predomina a alteração propilítica nos condutos hidrotermais, envelopada por zonas de alteração carbonática e parcialmente substituida por alteração sericítica. Essas zonas concêntricas de alterações podem ser reconhecidas em zonas preservadas do evento Brasiliano, conforme esquematizado na FIGURA 7. Halos de alteração bastante semelhantes foram constatados na mina de ouro de Atud, na parte central do Eastern Desert no Egíto, caracterizados como sendo pós-metamorfismo regional. Este local apresenta veios de quartzo com ouro preenchendo fraturas em rochas dioríticas e ao longo de seus contatos com metagabros (Harraz, 1999).

Observou-se que a alteração da ilmenita, provavelmente para pseudorutilo, parece associar-se com as zonas hidrotermais mineralizadas em ouro, de modo semelhante os descrito por De Ronde et al. (1992) em mineralizações de ouro no Greenstone Belt de Barberton. 
A alteração do epídoto deixa apenas contornos microcristalinos em agregados muito finos de minerais, ou apenas como pseudomorfos, indicando, provavelmente, mudanças na composição do fluido hidrotermal essencialmente aquoso para fluidos com $\mathrm{CO}_{2}$, que instabilizam o epídoto (Kerrick, 1974). Outra característica marcante é o aporte de $\mathrm{K}^{+}$no sistema, dando início a pelo menos duas gerações de biotita e uma de sericita (D3), seguida de uma redução de temperatura e da atividade do potássio no evento $\mathrm{D} 4$, resultando em intensa sericitização tardia.

A alteração que afetou as metabásicas da Formação Rio Vermelho se assemelha com a verificada na Formação Ribeirão das Antas, preservando texturas ígneas. $O$ anfibólio nas metabásicas possui uma composição que varia entre a hornblenda e a actinolita (núcleo e borda respectivamente), diferentemente do anfibólio porfiroblástico relacionado à alteração hidrotermal do evento D3, que foi caracterizado como Fe-tschermakita em todas as zonas mineralizadas, incluindo as da Mina III.

A dolomita associada com a alteração hidrotermal dos corpos de metabasalto da Formação Rio Vermelho é semelhante à encontrada nos xistos carbonosos da Formação Ribeirão das Antas, se apresenta muitas vezes na forma de pseudomorfos da hornblenda/actinolita, principalmente nas zonas de fraturas, o que pode ser indicativo de altas pressões de $\mathrm{CO}_{2}$, relacionado ao evento que fratura os porfiroblastos.

A turmalina magnesiana ou a dravita, observada freqüentemente nas proximidades das mineralizações, são normalmente encontradas nas associações metamórficas ou metassomáticas. Em geral a turmalina encontrada em rochas metamórficas representam a recristalização de grãos detríticos presentes no sedimento original, podendo indicar relação com ambientes evaporíticos ou proximidade com centros submarinos de fumarolas. Em rochas básicas elas são normalmente encontradas, associadas com axinita e datolita (Deer, 1992). Essas últimas não foram constatadas nas zonas de mineralização do Corpo IV e V, reforçando o caráter metassedimentar da encaixante, sendo que o boro deve ser sido introduzido metassomaticamente. Turmalina marrom magnesiana ocorre como importante mineral de ganga em vários tipos de depósitos minerais do tipo stratabound, e sua abundância sugere a presença de boro como parte integral do sistema hidrotermal. 


\section{CARACTERÍSTICAS DA MINERALIZACÃO}

As mineralizações do Corpo IV e V da estrutura IV do Greenstone Belt de Crixás apresentam uma grande semelhança com a mineralização da mina Lily em Barbetown na África dos Sul. Essa mineralização epigenética apresenta diferenças apenas na ocorrência de grunerita, ao invés de Fe-tschermakita, ouro relacionado à arsenopirita e não à pirrotita e pressões de formação mais baixas (<3 kbar) para a mineralização (Williams, 1997)

O Corpo IV, ao contrário do Corpo $\mathrm{V}$, permitiu a coleta de várias amostras com ouro livre, fato esse que mostrou a estreita associação do metal com a pirrotita. Os estudos de minerais opacos permitiram reconhecer ainda o caráter tardio da pirrotita em relação a esfalerita e arsenopirita. O ouro possui uma relação síncrona a tardia em relação à precipitação da pirrotita, e, como foi constatado nos trabalhos de campo, a sulfetação que atinge o Corpo IV é pré-cisalhamento brasiliano.

Outro fato muito evidente na relação da pirrotita com o xisto carbonoso da encaixante, é o forte controle estrutural do mesmo, ligado principalmente a lineação mineral e de estiramento $\left(L_{m / e}\right)$. A arsenopirita, provavelmente na sua forma mais tardia, também foi encontrada associada com essa estrutura.

A abertura de espaços, dando lugar a entrada do quartzo na forma de tension gashs, tem fortes vinculações com o evento milonítico paleoproterozóico. Após a entrada do quartzo nesses espaços, ocorreu a entrada de sulfetos provenientes da encaixante carbonosa no veio, particularmente da pirrotita com ou sem ouro, gerando zonas escuras no quartzo, como resultado da grande quantidade de inclusões fluidas e minerais trazidas no fluido. Em várias amostras foi possível observar-se que os sulfetos se concentraram justamente na interface encaixante carbonosa, no truncamento da estrutura $L_{m 3}$ pelas paredes do veio de quartzo.

Foi ainda observado que as superficies de cristais de feldspato com terminações euédricas desenvolvidos em espaços abertos, não foram atacadas pelo fluidos mais tardios, que se cristalizaram na forma de uma matriz carbonática com porfiroblastos euédricos de pirrotita. Este fato pode indicar que: a) o pH situava-se em condições próximas do neutro no fluido com sulfeto e, b) que os fluidos com sulfeto devem ter precipitado a pirrotita devido ao súbito alívio de pressão, quando da entrada nos espaços vazios (vugs), limitado nesse caso pelos feldspatos. Esse processo representa um dos mecanismos tardios da precipitação do ouro pela desestabilização das espécies dominantes no transporte de ouro como AuHS(aq) e 
$\mathrm{Au}(\mathrm{HS})^{2-}$ (Cooke \& Simmons, 2000), particularmente do último em que prevalecem condições de pH próximo do neutro.

Os resultados geotermobarométricos indicaram, para o par granada-biotita do núcleo das alterações hidrotermais, que as temperaturas são compatíveis com as da fácies xisto verde, em seu limite superior ou início da fácies anfibolito. Isso está em acordo com as observações petrográficas, com cloritóide estável nos metassedimentos hidrotermalizados. Entretanto, as pressões obtidas são, de modo geral, bastante altas, o que é incompatível com uma evolução tectônica em baixas profundidades da crosta com grau geotérmico típico de zonas de subducção e evolução barrowiana, e mais coerente com zonas metamórficas de alta pressão. As temperaturas sugerem, face à proximidade dos minerais com os veios relacionados ao evento hidrotermal, que a zona de cisalhamento instalou-se em níveis crustais profundos e em rochas relativamente frias. Em sendo correto este pressuposto, os terrenos greenstone deveriam ser parte de crátons estáveis e frios, quando das mineralizações auríferas, que seriam então mesotermais a hipotermais e, possivelmente, relacionadas a fluidos predominantemente metamórficos gerados em níveis crustais inferiores.

O estudo de inclusões fluidas nas gerações de veios de quartzo estudados permitiram reconhecer diferenças nas isócoras que refletem o evento pré-neoproterozóico, Q-IV1 e QIV2, do quartzo da última geração de veios estudada, Q-IV4, que mostrou pressões e temperaturas de homogeneização total relativamente mais baixas. Entre os dois veios de quartzo paleoproterozóicos estudados, o Q-IV2 forneceu uma isócora compatível com as condições determinadas pela geotermobarometria, indicando que esse veio teria se formado simultaneamente à atuação hidrotermal propilítica, e conseqüentemente do ouro e sulfetos, nos valores de $\mathrm{T}$ e $\mathrm{P}$ variando de 428 a $580^{\circ} \mathrm{C}$ e 5,7 a $8,3 \mathrm{kbar}$, respectivamente.

Diversos grupos de inclusões fluidas forneceram fortes indícios de imiscibilidade e/ou mistura (faixas mais largas das isócoras extremas, diagrama $\mathrm{ThCO}_{2}$ versus $\mathrm{TfCO}_{2}$ ), que atuaram com maior intensidade nos veios pré-neoproterozóicos, reforçando a hipótese do motivo da desestabilização do ouro e sulfetos dos fluidos mineralizantes.

Foi possivel ainda realizar o estudo microtermométrico em inclusões no quartzo na $\mathrm{L}_{\mathrm{m} / \mathrm{s} 3}$, internamente ao xisto carbonoso e intimamente relacionado a pirrotita. As isócoras resultantes mostraram grande semelhança com as obtidas do Q-IV2, relacionando-se assim a mineralização dos sulfetos e ouro ao período imediatamente após a formação desses veios. 
Os fluidos nas três gerações estudadas dos veios e do quartzo apresentaram propriedades contrastantes sendo que os veios Q-IV1 apresentam fluidos aquo-carbônicos com frações molares de $\mathrm{CO}_{2}$ sempre acima de 0,2, associado a salinidades baixas, com exceção de inclusões em zonas de imiscibilidade ou mistura. Os veios Q-IV2 mostraram uma grande pureza em água $\left(\mathrm{XH}_{2} \mathrm{O}\right.$ acima de 0,89$)$ e a mais baixa salinidade entre as inclusões dos diversos veios, com uma correlação quase idêntica ao fluido das inclusões contidas no quartzo da $\mathrm{L}_{\mathrm{m} / \mathrm{e} 3}$. Estes fluidos tem características semelhantes às encontradas na mineralização epigenética de ouro da mina Shamva no Zimbábue. Neste local foram definidos fluidos metamórficos relacionados à mineralização, com $\mathrm{XH}_{2} \mathrm{O}$ variando entre 0,85 e 0,90 e temperaturas de 500 a $530^{\circ} \mathrm{C}$ (Jelsma et al., 1996). O veio Q-IV4, por sua vez apresenta fluidos nas inclusões com frações molares de $\mathrm{CO}_{2}$ maiores que Q-IV2, de maneira semelhante aos fluidos de Q-IV1, mas com $\mathrm{XCO}_{2}<0,63$. Isso relaciona a mineralização de sulfetos e ouro a um sistema com fluidos relativamente mais aquosos e de baixa salinidade, em acordo com os fluidos relacionados a outras mineralizações em greenstone arqueanas.

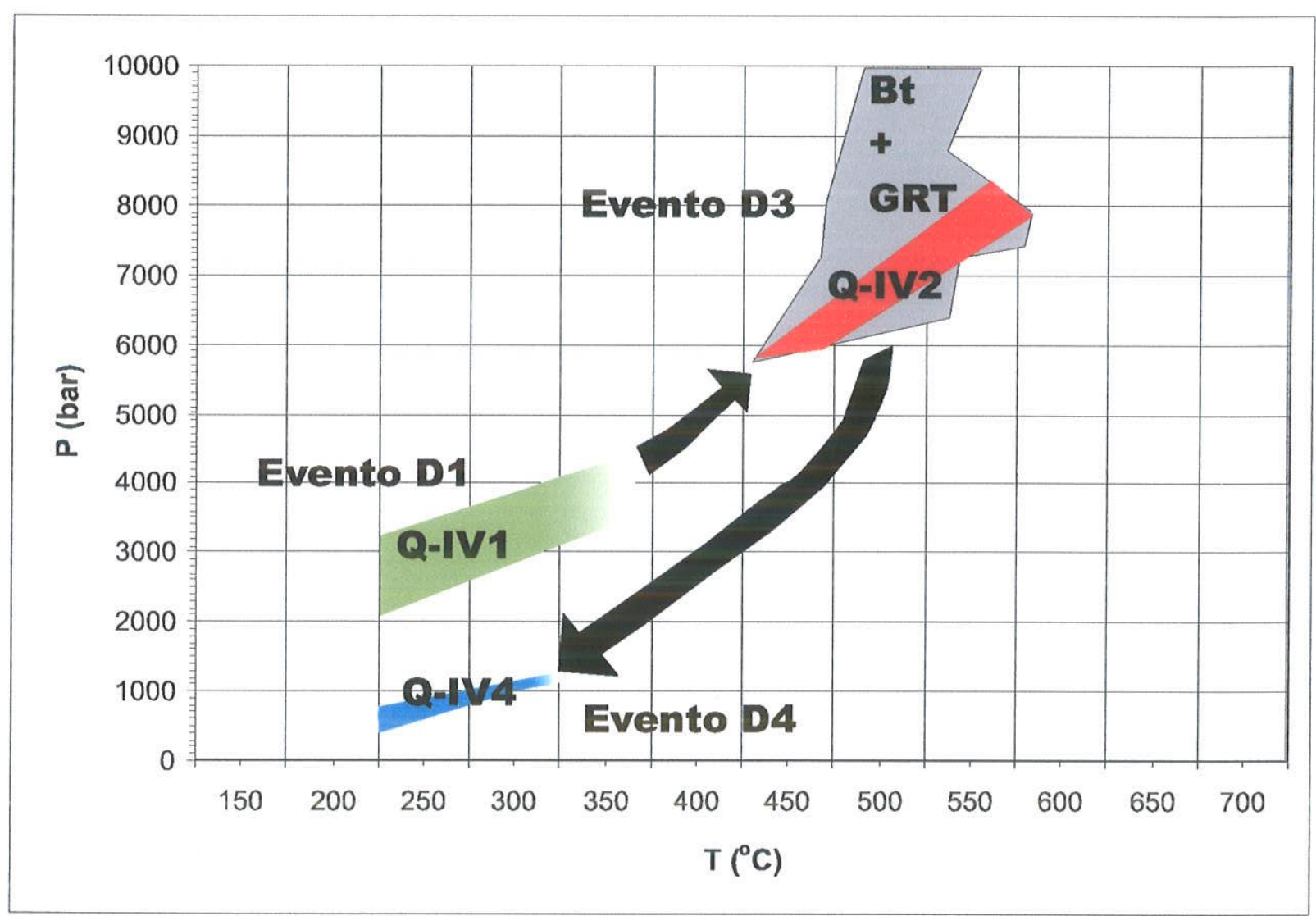

FIGURA 104 - Diagrama P-T onde são apresentadas as áreas de possível formação das gerações de veios de quartzo estudadas, com base nos estudos microtermométricos em inclusões fluidas. As setas indicam trajetórias prováveis da evolução dos fluidos. A área de formação do veio Q-IV2 foi sobreposta com os resultados geotermobarométricos, zona essa onde ocorreu a formação dos porfiroblastos metamórficos, principalmente no núcleo da alteração propilítica. 


\section{REFERẾNCIAS BIBLIOGRÁFICAS}

ALMEIDA, F.F.M. (1968) Evolução tectônica do centro-oeste brasileiro. Academia Brasileira de Ciências, Anais, 40:280-296.

ANHAEUSSER, C.R. (1979) The Barberton Mountain Land, South Africa -- a guide to understanding of the geology of western Australia. Geol. Soc. Australia, Special Publication, 3:103-119

ARANOVICH, L.Y.; BERMAN, R.G. (1990) Optimized standard state and mixing properties of minerals: II. Comparisons, predictions, and applications. Contributions to Mineralogy \& Petrology (in press).

ARAÚJO FILHO, J.O de; KUYUMJAN, R.M. (1991) Implicações dos pontos-quentes (hot-spots) na formação dos greenstone belts de Goiás. In: SIMPÓSIO DE GEOLOGIA DO CENTRO-OESTE, 3, Cuiabá, 1991. Anais...SBG, Núcleo Centro-Oeste/Brasília, 185-195.

ARAÚJJO FIL.HO, J.O de; KUYUMJIAN, R.M. (1992) Uma hipótese alternativa para a origem e evolução dos terrenos arqueanos e das sequiências vulcano-sedimentares paleo-proterozóicas de Goiás. In: CONGRESSO BRASIleiro DE GEOLOGIA, 37, São Paulo, 1992. Boletim de Resumos Expandidos, Sessões Temáticas...SBG, 2:168-169.

ARNDT, N. T.; TEIXEIRA, N. A.; WHITE, W.M. (1989) Bizarre geochemistry of komatiites from the Crixás Greenstone Belt, Brazil. Contributions to Mineralogy and Petrology, 101(2):187-197.

BAKKER, R.J. (1997) Clatrates: computer programs to calculate fluid inclusion v-x properties using clathrate melting temperatures. Computers \& Geosciences, 23(1):1-18.

BAKKER, R.J. (2003) Package FLUIDS 1. Computer programs for analysis of fluid inclusion data and for modelling bulk fluid properties. Chemical Geology, 194:2-23.

BARBOSA, O.; BAPTISTA, M.B.; DYER, R.C.; BRAUN, O.P.G.; COTTA, J.C. (1969) Geologia e Inventário dos Recursos Minerais da Região Central do Estado de Goiás - Projeto Brasília. DNPM, Série Geologia, nº 18 , Seção Geologia Básica, N 13, Brasilia. DF, 1981.

BERBERT, C.O.; MELLO, J.C.R. (1970) Notas sobre a ocorrência de ouro na região de Crixás (Goiás). In: CONGRESSO BRASILEIRO DE GEOLOGIA, 27., Aracaju, 1973. Anais... Aracaju, SBG. p.167-179.

BERMAN, R.G. (1980) Internally-consistent thermodynamic data for stoichiometric minerals in the system $\mathrm{Na}_{2} \mathrm{O}-$ $\mathrm{K}_{2} \mathrm{O}-\mathrm{CaO}-\mathrm{MgO}-\mathrm{FeO}-\mathrm{Fe}_{2} \mathrm{O}_{3}-\mathrm{Al}_{2} \mathrm{O}_{3}-\mathrm{SiO}_{2}-\mathrm{TiO}_{2}-\mathrm{H}_{2} \mathrm{O}-\mathrm{CO}_{2}$. Journal of Petrology, 29:445-522.

BERMAN, R.G. (1990) Mixing properties of Ca-Mg-Fe-Mn garnets. The American Mineralogist, 75:328-344.

BERMAN, R.G. (1990) Thermobarometry using multiequilibrium calculations: a new technique with petrologic applications. Canadian Mineralogist, 29:833 855.

BERMAN, R.G.; ARANOVICH, L.Y. (1990) Optimized standard state and mixing properties of minerals: I. Model calibration for olivine, orthopyroxene, cordiertie, garnet, and ilmenite in the system $\mathrm{FeO}-\mathrm{MgO}-\mathrm{CaO}-\mathrm{Al}_{2} \mathrm{O}_{3}-\mathrm{TiO}_{2}-$ $\mathrm{SiO}_{2}$. Contributions to Mineralogy \& Petrology (in press).

BERMAN, R.G.; ARANOVICH, L.Y.; PATTISON, D.R.M. (1990) Reanalysis of the garnet - clinopyroxene Fe-Mg exchange thermometer. II. Thermodynamic analysis. Contributions to Mineralogy \& Petrology, 119:30-42

BETTENCOURT, J.S.; COSTA, A.R.; SOUZA, L.H.; MATOS, T.T. (1991) Controls of gold mineralization in the Córrego Geral Sector, north central section of the Crixás greenstone belt: a preliminary report - In: SYMPOSIUM BRAZLL GOLD 91, Belo Horizonte, 1991, Proceedings, Rotterdam, Balkema, p.699-703.

BLUM, M. de L.B; PIRES, A.C.B.; MORAES, R.A.V. de (2000) Gravity inversion on the Granite-Greenstone Belt Areas: Crixás, Guarinos e Pilar de Goiás, Brazil. Revista Brasileira de Geociências, 30(3):547-550.

BLUM, M.L.B.; MORAES, R.A.V.; PIRES, A.C.B. (1999) Modelagem e inversão de dados gravimétricos em terrenos granitóide-greenstone belt: Crixás, Guarinos e Pilar de Goiás. In: SIMPÓSIO DE GEOLOGIA DO CENTRO-OESTE, VII, e SIMPÓSIO DE GEOLOGIA DE MINAS GERAIS, X, Boletim de Resumos...SBG, p. I15[D4].

BODNAR, R.J.; VITYK, M.O. (1994) Interpretation of microthermometric data for $\mathrm{H}_{2} \mathrm{O}-\mathrm{NaCl}$ inclusions. In: De Vivo, B.; Frezzotti, M.L. (Eds.), Fluid Inclusions in Minerals: Methods and Applications. Virginia Polytechnic Institute Press, p.117-130. 
BORISENKO, A.S. (1978) Study of the salt composition of solutions of gas-liquid inclusions in minerals by the cryometric method. Sov. Geol. Geophys, 18:11-19.

BOYLE, R.W. (1980) Gold, History and Genesis of Deposits. New York, Van Nostrand Reinhold, $676 \mathrm{p}$.

BROWN, P.E. (1989) FLINCOR: A microcomputer program for the reduction and investigation of fluid inclusion data. American Mineralogist, 74:1390-1393.

BROWN, P.E; HAGEMANN, S.T. (1995) MacFlinCor and its application to fluids in Archean lode-gold deposits. Geochimica et Cosmochimica Acta, 59(19):3943-3952.

BURCHARD, B; PIZER, D. (2000) Desvendando o AutoCAD 2000. Docware Traduções Técnicas, Rio de Janeiro, Ed. Campus, $971 \mathrm{p}$.

CARMO, S.D. (1978) Programação e execução do Projeto Geofísico Brasil-Canadá. In: GONGRESSO BRASILEIRO DE GEOLOGIA, 30, 1978, Anais... SBG, 5:2233-2247

CASTRO, J.H.G. de; MAGALHÃES, L.F. (1984) Revisão estratigráfica do Grupo Pilar de Goiás na Faixa Crixás. In: CONGRESSO BRASILEIRO DE GEOLOGIA, 33, Rio de Janeiro, 1984. Anais...SBG, 6:2563-2576.

CASTRO, J.H.G.; MAGALHÃES, L.F; BORGES, O.C. (1980) Ouro na Faixa Crixás: sistemática de prospeç̧ão e pesquisa. In: SIMPÓSIO SOBRE MINERALIZAÇÕES AURÍfERAS NO ESTADO DA BAHIA, 1. Salvador, 1983. Anais..., Salvador, SBG. p. 47-55.

COELHO R.F. (1999) Caracterizaçăo mineralógica de minério das Jazidas Auriferas Mina III e Mina Nova, Greenstone Belt de Crixás (GO). Brasília, Dissertação de Mestrado, Universidade Federal de Brasília, 125p.

CONDIE, K.C. (1981) Developments in Precambrian Geology 3: Archean Greenstone Belts. Elsevier, Amsterdam, $434 \mathrm{p}$.

COOKE, D.R.; SIMMONS, S.T. (2000) Characteristics and Genesis of Epithermal Gold Deposits. SEG Reviews, 13:221-244.

CORDANI U.G., MILANI E.J., CAMPOS D.A. (edit.) (2000) Tectonic Evolution of South America. 31 st International Congress, Rio de Janeiro, 856p.

COSTA, A.L.L. (1990) Seqüencia Mina Inglesa: caracterização química das rochas granitóides associadas, Crixás-GO. Brasília, Dissertação de Mestrado, Universidade Federal de Brasília.

COSTA, S.A.G. (1980) Correlação da seqüência encaixante das esmeraldas de Santa Terezinha de Goiás com terrenos da tipo Greenstone Belt de Crixás e topologia dos depósitos. In: CONGRESSO BRASILEIRO DE GEOLOGIA, 34, Goiânia, Anais...SBG, 2:597-614.

CRAWFORD, M.L. (1981) Phase equilibria in aqueous inclusions. Mineral. Assoc. Canada. Short Course Handbook, 6:75 100.

DANNI, J.C.M. (1988) Os Greenstone Belts da Província Tocantins no Estado de Goiás, Brasil. Revista Brasileira de Geociências, 18(4):381-390.

DANNI, J.C.M.; RIBEIRO, C.C. (1978) Caracterização Estratigráfica da seqüência Vulcano-sedimentar de Pilar de Goiás e de Guarinos, Goiás. In: CONGRESSO BRASILEIRO GEOLOGIA, 30. Recife, 1978, Anais... Recife, SBG, 2:582-596.

DANNI, J.C.M.; LEONARDOS, O.H.; ANDRADE, G.F. de (1980) Feições vulcânicas das rochas ultramáficas de Hidrolina, Goiás. In: CONGRESSO BRASILEIRO DE GEOLOGLA, 31, Camburiú, 1980. Anais...SBG, 4:1997. 2003.

DANNI, J.C.M.; JOST, H.; WINGE, M.; ANDRADE, G.F. (1986) Aspectos da evolução dos terrenos granitogreenstone: exemplo da região de Hidrolina. In: CONGRESSO BRASILEIRO DE GEOLOGIA, 34, Goiânia, 1986. Anais...SBG, 2:570-584.

DAVIS, D.W., LOWESTEIN, T.K., SPENCER, R.J. (1990) Melting behaviour of fluid inclusions in laboratorygrown halites crystal in the systems $\mathrm{NaCl}-\mathrm{H}_{2} \mathrm{O}, \mathrm{NaCl}-\mathrm{KCl}-\mathrm{H}_{2} \mathrm{O}, \mathrm{NaCl}-\mathrm{MgCl}_{2}-\mathrm{H} 2 \mathrm{O}$ and $\mathrm{NaCl}-\mathrm{CaCl}_{2}-\mathrm{H}_{2} \mathrm{O}$. Geochim. Cosmochim. Acta, 54:591-601.

de WIT, M. J.; ASHWAL, L.D. (1997) Greenstone Belts.Oxford University Press, New York, 810p.

DEER, W.A.; HOWIE, R.A.;ZUSSMAN, J. (1960) Minerais constituintes das rochas -- uma introdução. Lisboa, Fundação Calouste Gulbenkian, Sociadade Gráfica Telles da Silva L.tda, Tradução de L.E.N., Conde, 558 p.

DIAMOND, L.D. (1990) Fluid inclusion evidence for P.V-T-X evolution of hydrotermal solutions in late Alpine gold-quartz veins at Brusson, Val D'Ayas, Northwest Italian Alps. American Journal of Science, 290:912-958.

DICKSON, J.A.D. (1960) A modified staining technique for carbonates in thin section. Nature, $205(1): 587$. 
DICKSON, J.A.D. (1960) Carbonate identification and genesis as revealed by staining. Joumal of Sedimentary Petrology, 32(2):491-505.

DIX, G.R.; THOMSON, M.L., LONGSTAFFE, F.J.; McNUTT, R.H. (1995) Systematic decrease of high $\delta 13 \mathrm{C}$ values with burial in late Archaean $(2.8 \mathrm{Ga})$ diagenetic dolomite: evidence for methanogenesis from the Crixás Greenstone Belt, Brazil. Precambrian Research, 70:253-268.

DUGDALE, A.L.; HAGEMANN, S.G. (2001) The Bronzewing lode-gold deposit, Western Australia: P.T-X evidence for fluid immiscibility caused by cyclic decompression in gold-bearing quartz-veins. Chemical Geology. 173: 59-90.

FIGUEIREDO, M.C.H.; KRONBERG, B.L. (1980) LRE-Emiched komatites from Crixás, Central Brazil. In: GEOCHEMICAL EVOLUTION OF THE CONTINENTAL CRUST, Symposium, Poços de Caldas, Proceedings, p. 209-216

FORTES, P.T.F.O. (1991) Geologia do depósito aurifero Mina Ill, Crixás, Goiás. Brasília, Dissertação de Mestrado, Universidade Federal de Brasília, 194 p.

FORTES, P.T.F.O. (1996) Metalogênia dos depósitos auriferos Mina IIl, Mina Nova e Mina Inglesa, greenstone belt de Crixás, Goiás. Brasília, Dissertação de Doutorado, Universidade Federal de Brasília, 177 p.

FORTES P.T.F.O.; GIULIANI G. (1990) Les phases fluides associés aux corps sulfurés du gisement d'or Mina III, ceinture de roches vertes de Crixás, Etat de Goiás, Brésil. Comples Rondues Académie des Sciences de Paris, T. 320 , serie Iia.p. $1171-1178$.

FORTES P.T.F.O., NLLSON A.A. (1990) Geologia do Depósito Aurifero Mina III, Crixas, Goias. In: SIMPÓSIO DE GEOLOGIA DO CENTRO-OESTE, 3, Cuiabá. Anais... SBG, Núcleo Centro-Oeste e Brasília, p. 1-14.

FORTES, P.T.F.O.; JOST, H. (1990) Mettallogeny of Mina III, Mina Nova and Mina Inglesa gold deposits, Crixás Greenstone Belt, Central Brasil. In: CONGRESSO BRASLLEIRO DE GEOLOGIA, 39, Salvador, 1996. Anais...SBG, Núcleo Bahia Sergipe, 7:234-236.

FORTES, P.T.F.O; RESENDE L. (1990) Nota preliminar do depósito aurífero Mina Inglesa, Crixás, GO. SBG/Núcleo Centro-Oeste, Boletim Informativo, 16:145 156.

FORTES, P.T.F.O.; TAKAKI, T. (1992) Estudo preliminar dde Isótopos de C em Xistos carbonosos e Mármores do Depósito Aurifero Mina III, Crixás, GO. SBG, Núcleo Centro-Oeste, Boletim Informativo 15: 91-98.

FORTES, P.T.F.O.; GIULIANI, G (1992) Estudo preliminar dos fluidos associados aos corpos de sulfeto maciço do Depósito Aurifero Mina III, Crixás, GO. SBG, Núcleo Centro-Oeste, Boletim Informativo, 15: 99-109.

FORTES, P.T.F.O.; TAKAKI, T. (1993) Estudo dos isótopos de carbono e oxigênio em rochas encaixantes do depósito aurífero Mina IIl, Crixás, Goiás. IV CONGRESSO BRASILEIRO DE GEOQUÍMICA, Resumos Expandidos, p. 186-188.

FORTES, P.T.F.O; JOST, H. (1996) Mettallogeny of Mina III, Mina Nova and Mina Inglesa gold deposits, Crixás Greenstone Belt, Central Brasil. In: SYMPOSIUM OF ARCHEAN TERRANES OF THE SOUTH AMERICA PLATFORM, Brasília, Extended Abstracts...SBG, p.18-19.

FORTES, P. T. F. O.; CHEILLETZ, A.; GIULIANI, G. (1990) K/Ar and Ar/Ar geocronology of Mina III gold deposit, Crixás Greenstone Belt, Central Brasil. In: CONGRESSO BRASILEIRO DE GEOLOGIA, 39 , Salvador, 1996. Anais... SBG, Núcleo Bahia e Sergipe, 7:316 318.

FORTES, P.T.F.O.; NLLSON, A.A.; JOST, H. (1992) Evolução do conhecimento sobre a geologia e o potencial aurífero dos "Greenstone Belts" da região de Crixás-Pilar de Goiás, GO. SBG, Núcleo Centro-Oeste, Boletim Informativo, 15:65-89.

FORTES P.T.F.O., GIULIANI G, COELHO R.F. (1994) Estudo de inclusões fluidas associadas ao yeio de quartzo mineralizado do depósito aurífero Mina III, Crixás, GO. SBG/Núcleo Centro-Oeste, Boletim de Geociências do Centro-Oeste, $17(1 / 2): 13-19$.

FORTES P. T. F. O., COELHO R.F., GIULlANI G. (2000) Au/Ag Ratio variations at Mina III, Mina Nova and mina Inglesa Gold Deposits, Crixás Greenstone Belt, Brazil. Revista Brasileira de Geociéncias, 30(2):246-250.

FORTES, P. T. F. O.; CHEILLETZ, A.; GIULIANI, G.; FERAUD, G. (1997) A Brasiliano age (500 t5 5 M) for the Mina III Gold Deposit, Crixás Greenstone Belt, Central Brazil. International Geology Review, 39(5): 449-460.

FORTES, P.T.F.O.; GIULIANI, G.; TAKAKI, T.; PIMENTEL, M. M.; TEIXEIRA, W. (1990) Aspectos geoquimicos do depósito aurifero Mina III, greenstone belt de Crixás, Goiás. Geochimica Brasiliensis, 9(1):1331 . 
FRIEDMAN, G.M. (1950) Identification of carbonate minerals by staining methods. Journal of Sedimentary Petrology, 29(l), 87-97.

FRIEDMAN, G.M.; SANDERS, J.E. (1978) Principles of Sedimentology. - John Wiley \& Sons, USA, 792p.

FROELICH, P.N.; BENDER, M.L, LUEDTKE, N.A., HEATH, G.R., DEVRIES, T. (1982) The marine phosphorus cycle. Am. J. Sci. 282:474-511.

FUCK, R.A. (1994) A Faixa Brasília e a compartimentação tectônica na Província Tocantins. SBG, Simpósio Geologia Centro-Oeste, 4, Brasilia, Resumos Expandidos, p. 184-187.

FUCK, R.A.; JARDIM DE SÁ, E.F.; PIMENTEL, M.M.; DARDENNE, M.A.; PEDROSA SOARES, A.C. (1993) As faixas de dobramentos marginais do Cráton do São Francisco: síntese dos conhecimentos. In: Dominguez, J.M.L. \& Misi, A. (eds.) O Craton do São Francisco. SBG, Núcleos Bahia e Sergipe, p. 161-185.

GOLDSTEIN, R.H. (1986) Reequilibration of fluid inclusions in low temperature calcium-carbonate cement. Geology, 14:792-795.

GOLDSTEIN, R.H.; REYNOLDS, T.J. (1994) Systematics of Fluid Inclusions in Diagenetic Minerals. Society for Sedimentary Geology, Short Course 31. 199p.

GOMES, C.B. (ed.) (1980) Técnicas analiticas instrumentais aplicadas à geologia. São Paulo, Edgard Blücher Ltda., $218 \mathrm{p}$.

HARRAZ, H.Z. (1999) Wall rock alteration, Atud gold mine, Eastern Desert, Egypt: processes and P-T-XCO2 conditions of metassomatism. Journal of African Earth Sciences, 28(3):527-551.

HUTCHISON, C.S. (1974). Laboratory handbook of petrographic techniques. p. 24-26.

JACOBS, G.K.; KERRICK, D.M. (1981) Methane: an equation of state with application to the ternary system $\mathrm{H}_{2} \mathrm{O}$ $\mathrm{CO}_{2}-\mathrm{CH}_{4}$. Geochimica and Cosmochimica Acta. 45:607-614.

JÉBRAK, M. (1997) Hydrotermal breccias in vein-type ore deposits: A review of mechanismus, morphology and size distribution. Ore Geology Reviews, 12:111-134.

JELSMA, H.A.; HUIZENGA, J.M.; TOURET, J.L.R. (1996) Fluids and epigenetic gol mineralization at Shamva Mine, Zimbabwe: a combined structural and fluid inclusion study. Journal of African Earth Sciences, 27(1):5570.

JOST, H.; FERREIRA FILHO, C.F. (1987) Geologia da porção sul do greenstone belt de Guarinos, GO. Instituto de Geociências, Universidade de Brasilia, 37p. (unpublished report).

JOST H.; OSBORNE G.A. (1990) The Guarinos Greenstone Belt: two contrasting stratigraphic domains juxtaposed by the Gold-bearing strike-slip fault of the Maria Lázara trens. (submitted to Revista Brasileira de Geociências).

JOST, H.; DANNI, J.C.M. (1990) Relações tectônicas entre gnaisses e greenstone belts na região de Crixás, Goiás. In: Congresso Brasileiro de Geologia, 34. Natal, 1990. Bol. Resumos... Natal, SBG. p. 258.

JOST, H.; OLIVEIRA, A. M. (1991) Stratigraphy of the greenstone belts, Crixás Region, Goiás, central Brazil. Journal of South American Earth Sciences, 4(3):201-214.

JOST, H.; KUYUMJIAN, R.M. (1998a) Field characteristics and geochemistry of metabasalts of the Crixás region greenstone belts. (in preparation).

JOST, H. OSBORNE, G.A. (1998b) The Guarinos greenstone belt: two contrasting stratigraphic and structural domains juxtaposed by a strike-slip fault. Revista Brasileira de Geociências (submetido)

JOST, H.; FORTES, P. T. F. E. (2001) Gold deposits and occurrences of the Crixás Goldfield, central Brazil. Mineralium Deposita. 36:358-376.

JOST H., FIGUEIREDO A.M.G., FERREIRA A.V. (1990) Elementos em traço e a proveniência clástica na transição de ambiente euxênico para turbidítico em metassedimentos do greenstone belt de Guarinos, goiás. In: SBGq, V Congresso Brasileiro de Geoquímica, Niterói, Anais em CD-ROM....1995, 4p.

JOST H., KUYUMJIAN R.M., SILVA C.A. (1990) Características geoquímicas e a proveniência dos metassedimentos arqueanos do Grupo Guarinos, GO. Soc. Bras. Geoqu., IV Congresso Brasileiro de Geoquímica, Brasília, anais em CD-ROM, p.109-112.

JOST, H.; OLIVEIRA, A.M.; VARGAS, M.C. (1992) Petrography, geochemistry, and structural control of trondhjemitic intrusions in greenstone belts of the Crixás region, Central Brazil. SBG, Congresso Brasileiro de Geologia, 37, São Paulo, Resumos Expandidos, 1:43 44.

JOST H.; CARMELO A.C.; MENEZES P.R. (1994a) Litologias, relações de contato e estrutura do Bloco Caiamar, Crixás, Goiás. Resumos Expandidos, IV Simpósio de Geologia do Centro-Oeste, Brasília, SBG, 18-20. 
JOST H; FIGUEIREDO A.M.G.; FERREIRA A.V. (1996a) Are all detrital metassedimentary rocks of the Crixás greenstone belt Archean and of the same provenance? A discussion based on REE geochemistry. I Symposium on Archaean of the South American Platform, Brasilia, Extended Abstracts, p.44-47.

JOST, H; VARGAS, M.C; GULGELMIN, V.; OLIVEIRA, S.R.M. (1989) Sequiencia Morro Escuro: Uma nova unidade estratigráfica do Arqueano/Proterozóico Inferior na região de Crixás, Estado de Goiás. Revista Brasileira de Geociencias, 19:283-289.

JOST' H.; 'THEODORO S.M.C.H.; FIGUEIREDO A.M.G.; BOAVENTURA G.R. (1996b) Propriedades geoquímicas e proveniência de rochas metassedimentares detríticas arqueanas dos greenstone-belts de Crixás e Guarinos, Goiás. Revista Brasileira de Geociências, 26:151-166.

JOST, H.; PIMENTEL, M.M.; FUCK, R.A.; DANNI, J.C.M.; HEAMAN, L. (1993) Idade U-Pb do Diorito Posselândia, Hidrolina, Goiás. Revista Brasileira de Geociências, 23(4):352-355

JOST, H.; VARGAS, M.C.; FUCK, R.A ., KUYUMJIAN, R.M.; PIRES, A.C.B. (1994b) Relações de contato, litologias, geologia estrutural e geofisica do Bloco Arqueano do Moquém, Crixás, Goiás. SBG, Simpósio de Geologia do Centro-Oeste, IV, Brasília, Resumos Espandidos, p. 15-17.

JOST H; RESENDE: M; KUYUMJIAN, R.M.; QUEIROZ, C.L.; OSBORNE, G.A.; BLUM M.L.B.; PIRES A.C.B.; MORAES R.A.V. (1990) Terrenos Arqueanos de Goiás. In. Geotectônica do brasil, ed. Hasui Y. e Sena Costa R. (in press).

JOST, H.; KUYUMJIAN, R. M. FREITAS, A.L.S.; COSTA, A.L.L.; NASCIMENTO, C.T.C; VASCONCELOS, F.M.; GALOTTI, L.; MARTINS, M.C.A.; CARVALHO, M.N.; CONDÉ, V.C. (1995) Geologia da porção norte do Greenstone Bett de Guarinos, GO. Revista Brasileira de Geociencias, 25:11-20.

KERRICK, D.M. (1974) Review of metamorphic mixed-volatile (H2O-CO2) equilibria. The American Mineralogist, 59(7/8):729-726.

KUYUMJIAN, R.M. (1981) Geologia e mineralizações auríferas do Greenstone Belt da Faixa Crixás - GO. Brasília, Dissertação de Mestrado, Universidade Federal de Brasília, 67p.

KUYUMJIAN, R.M. (1982) Caracterização geoquímica preliminar das rochas graníticas associadas ao greenstone belt da faixa Crixás - GO. Goiânia, SBG. Boletim Informativo. 11:23-29.

KUYUMJIAN, R.M. (1990) Geochemistry of Archaean komatiitic basalts and speculations on the evolution of greenstone terranes, Goiás, Central Brazil. In: International Archaean Symposium, 3, Perth, Australia, Extended Abstrats Volume, pg.: 257-258

KUYUMJIAN, R.M. (1990) Mafic dike swarms of the Goiás Massif, Central Brasil. Revista Brasileira de Geociências, 28:45-50.

KUYUMJIAN,R.M. (1990) Mobilidade de Elementos Terras Raras em metabasaltos de baixo (Crixás) e alto (Chapada) graus metamónficos. Geochimica Brasiliensis, 4:1-8.

KUYUMJIAN, R.M. (1993) Quimismo e significado geotectônico dos metabasaltos pré-cambrianos do Maçico de Goiás. In: SIMPÓSIO SOBRE O CRÁTON DO SÃO FRANCISCO, 2, Salvador, 1993. Anais...SBG, Núcleo Bahia/Sergipe e SGM, p. 101-105.

KUYUMJIAN, R.M.; DARDENNE, M.A. (1981) Geochemical Characteristics of the Crixas Greenstone Belt, Goiás, Brazil. Revista Brasileira de Geociências, 12(1-3):324-330.

KUYUMJIAN, R. M.; TEIXEIRA, N. A. (1982) Um novo tipo de estrutura em lavas ultramáficas: greenstone belt de Crixás, GO. Revista Brasileira de Geociências, 12:572-577

KUYUMJIAN,R.M.; DARDENNE, M.A. (1983) O Controle das mineralizaçôes auríferas no greenstone belt da faixa Crixás - GO. In: Simpósio sobre Mineralizaçōes Auríferas no Estado da Bahia, 1. Salvador, 1983. Anais, Salvador, SBG. p.47-59.

KUYUMJIAN, R.M.; ARAÚJO FILHO, J.O. de (1984) Contribuição à tectônica do Greenstone Belt da Faixa Crixás. Revista Brasileira de Geociências, 14(2):92-96.

KUYUMJIAN, R.M.; DIAS, R.R. (1991a) Variaçôes e implicações geotectônicas de alguns elementos traço incompatíveis nos anfibolitos Proterozóicos do Maciço de Goiás. In: SIMPÓSIO DE GEOLOGIA DO CENTRO-OESTE,3, Cuiabá, 1991. Anais... Cuiabá, SBG, Núcleo Centro Oeste e Brasília, p. 196-199.

KUYUMJIAN, R.M.; DIAS, R.R. (1992) Anfibolitos proterozóicos de Goiás, Brasil: representantes de vuĺcanismo basáltico de arcos magmáticos? Geochimica Brasiliensis, 6(1/2): 35-44. 
KUYUMIIAN, R.M.; JOST, H. (1993) Significado petrogenético de elementos Terras Raras em rochas komatiiticas do greenstone de Guarinos: resultados preliminares - Sociedade Brasileira de Geoquimica, Congresso Brasileiro de Geoquímica, 4, Anais, p.17-19

KUYUMJIAN, R.M.; TEIXEIRA (1993) Um novo tipo de estrutura em lavas ultramáficas: Greenstone Belt Crixás, GO. Revista Brasileira de Geociencias, 12(4): 572-577.

KUYUMJIAN R.M., COSTA A.L.L. (1999) Geologia, geoquímica e mineralizações auríferas da seqüência Mina Inglesa, Greenstone Belt de Crixás, Goiás. Revista Brasileira de Geociências, 29(3):313-318.

LACERDA, H. (1997) Mapa Geológico 1/100.000 do Distrito Mineiro do Greenstone-Belt de Crixás-Guarinos-Pilar de Goiás (GO): versão preliminar. In: SIMPÓSIO DE GEOLOGIA DO CENTRO-OESTE, 6, Cuiabá, 1997. Anais...SBG, Núcleo Centro-Oeste/Brasília, p.65-67.

LACERDA, H.; LIMA JÚNIOR, E.A. (1996) Mapa geológico do greenstone belt de Crixás - faixas Guarinos e Pilar de Goiás. MME/DNPM, $6^{\circ}$ Distrito, Goiânia (inédito)

LEAKE, B.E. (CHAIRMAN) (1997) Nomenclature of amphiboles: Report of the Subcommittee on Amphiboles of the International Mineralogical Association, Commission on New Minerals and Mineral Names. American Mineralogist, 82:1019-1037.

LINDAAS, S.E.; KULIS, J.; CAMPBELL, A.R. (2002) Near-Infrared Observation and Microthermometry of Pyrite-Hosted Fluid Inclusions. Economic Geology, 97: 603 618.

MAGALHÃES, L.F. (1991) Cinturão de cisalhamento de empurrão Córrego Geral-Meia Pataca: geologia, deformação, alteração hidrotermal e mineralizações auríferas associadas (Crixás, Goiás). Brasília, Dissertação de Mestrado, Universidade Federal de Brasília, 233 p.

MAGALHÃES, L.F;; LOBO, R.L. de M. (1986) Greenstone Belt de Crixás - Faixa Crixás - Geologia e Mineralizações Auríferas (Mina Pompex e Mina III). In: CONGRESSO BRASILEIRO DE GEOLOGIA, 34, Goiânia, 1986. Roteiro das Excursões Técnico cientifica...SBG, 2:69-72.

MAGALHÃES, L.F.; NíLSON, A.A. (1992) Geologia do Cinturão de Cisalhamento de Empurrão Córrego GeralMeia Pataca e mineralização aurifera associada, Crixás, Goiás. In: CONGRESSO BRASILEIRO DE GEOLOGIA, 37, São Paulo. Boletim de Resumos Expandidos... SBG, Núcleo de São Paulo, 1:225-226.

MAGALHÃES, L.F.; NLLSON, A.A. (1993) Controle lito-estrutural e características da mineralização aurífera da região do Córrego Geral-Meia Pataca, Crixás (GO). SBG, Núcleo Centro-Oeste, Boletim Informativo, 16: 25-49.

MAGALHÃES, L.F.; NILSON, A.A. (1993) Litoquímica das metagrauvacas do Greenstone Belt de Crixás e sua importância para a evolução dos terrenos arqueanos de Goiás. In: SIMPÓSIO SOBRE O CRÁTON DO SÃO FRANCISCO, 2, Salvador, 1993. Anais...SBG, Núcleo Bahia/Sergipe e SGM, p. 106-108.

MAGALHÃES, L.F.; CASTRO, J.H.G.; BORGES, O.C. (1984) Geologia, prospecção e pesquisa de ouro no greenstone belt de Crixás - Algumas Considerações. In: Encontro Regional do Ouro de Goiás, 1. Goiânia, 1984. Anciis...Goiânia, SBG. p. 26- 51 .

MAGALHÃES, L.F; LOBO, R.L.M.; BOTELHO, L.C.A.; PEREIRA, R.C. (1988) Depósito de ouro de MeiaPataca, Crixás - GO. In: DNPM/CVRD. Principais Depósitos Minerais do Brasil, Vol, IIl, cap. XXXV, Brasília, DF, p. 499-522.

MARINI, O.J.; FUCK, R.A.; DARDENNE, M.A.; DANNI, J.C.M. (1984) Província do Tocantins, Setores Central e Sudeste. IN: Almeida, F.F.M. \& Hasui, Y. coord. O Pré-Cambriano do Brasil. São Paulo, Edgard Blücher, p. 205-264.

MAVROGENES, J.A.; BODNAR, R.J. GRANEY, J.R., MCQUEEN, K.G.; BURLINSON, K. (1995) Comparison of decrepitation, microthermometric and compositional characteristics of fluid inclusions in barren and auriferous mesothermal quartz veins in the Cowra Creek gold district. New South Wales, Australia. Journal of Geochemical Exploration. 54:167-175.

MERNAGH, T. P. (2000) A fluid inclusion study of the Fosterville Mine: a turbidite-hosted gold field in the Western Lachlan Fold Belt, Victoria, Australia. Chemical Geology 173: 91-106.

MIKUCKI, E.J. (1997) Hydrotermal transport and depositional processes in Archean lode-gold systems: A review. Ore Geology Reviews, 13:307-321.

MONTALVÃO, R.M.G. (1985) Evolução geotectônica dos terrenos granitóide-greenstone gelts de Crixás, Guarinos, Pilar de Goiás-Hidrolina (Goiás). São Paulo Disertação de Doutorado, Instituto de Geociências, Universidade de São Pauto, 372p. 
MONTALVÃO, R. M. G. de (1986) Evolução geotectônia dos terrenos granitóides-greenstone belts de Crixás, Guarinos, Pilar de Goiás-Hidrolina. In: CONGRESSO BRASLLEIRO DE GEOLOGLA, 34, Goiânia, 1986. Anais...SBG, 2:585-596.

MONTALVÃO, R.M.G; ARAÚJO, H.T. (1979) Reconhecimento geológico na região de Crixás-AuriverdeGuarinos Pilar de Goiás-Hidrolina-Itapaci. Folha SD.22, Goiás. Projeto RADAMBRASIL (Relatório Interno), Goiânia, $\mathrm{GO}, 24 \mathrm{p}$.

MONTALVÃO, R. M. G.; Lopes, L.M.; PEREIRA, L.G. da M. (1981) Petrografia dos Komatítos de Crixás Goiás. SBG, Núcleo Centro-Oeste, Boletim Informativo 10: 89-127.

MONTALVÃO, R. M. G. de; HLLDED, P.D.; BEZERRA, P.E.1.; PRADO, P.; SILVA, S. de J. (1982) Petrographic and chemical aspects of the mafic-ultramafic rocks of the Crixás, Guarinos, Pilar de GoirsHidrolina and Goiás Greenstone Belt, Central Brazil. Revista Brasileira de Geociencias, 12(1-3):331 - 347.

MORRISON G.W., ROSE W.J., JAIRETH S. (1991) Geological e geochemical controls on the silver content (fineness) of gold in gold-silver deposits. Ore Geology Reviews, 6:333-364.

OAKES, C.S., BODNAR, R.J.,SIMONSON, J.M. (1990) The system NaCl CaCl $2-\mathrm{H}_{2} \mathrm{O}$ The ice liquidus at 1 atm total pressure. Geochim. Cosmochim. Acta, 54:603-6i0.

PASSCHIER, C.W.; TROUW, R.A.J. (1996) Microtectonics. Springer-Verlag. 289p.

PHILLIPS, G.N.; POWELL, R. (1993) Link between gold provinces. Economic Geology, 88: 1084-1098.

PIMENTEL, M.M; FUCK, R.A. (1987) Origem e evolução de rochas meta-vulcânicas da região de Arenópolis. GO. Revista Brasileira de Geociencias, 17(1):2 14.

PIMENTEL, M.M.; FUCK, R.A.; DELL'REY SILVA, J.L.H. (1996) Dados Rb-Sr e Sm-Nd da região de JussaraGoiás-Mossâmedes (GO), e o limite entre terrenos antigos do Maciço de Goiás e o Arco Magmático de Goiás. Revista Brasileira de Geociências, 26:61-70

PIRAJNO (1992) Hydrotermal mineral deposits. Principles and fundamental concepts for the exploration geologist. Berlin, Springer-Verlag, 709p.

PIRES A.C.B. (19950) Identificação geofísica de áreas de alteração hidrotermal, Crixás-Guarinos, Goiás, Revista Brasileira de Geociências, 25(1):61-68.

POKROVSKI, G.S.; KARA, S.; ROUX, J. (2002) Stability and solubility of arsenopyrite, FeAsS, in crustal fluids. Geochimica and Cosmochimica Acta, 66(13):2361-2378.

PULZ, G.M. (1990) Geologia do depósito aurífero tipo Maria Lázara (Guarinos, Goiás). Brasília, Dissertação de Mestrado, Universidade Federal de Brasília, $139 \mathrm{p}$.

PUL.Z, G.M. (1995) Modelos prospectivos para ouro em Greenstone Belts: O exemplo dos depósitos Maria Lázara, Guarinos e Ogó, Pilar de Goiás. Brasilia, Dissertação de Doutorado, Universidade Federal de Brasília, 189p.

QUEIROZ, C.L. (1995) Caracterização dos dominios estruturais e da arquitetura do Greenstone Belt de Crixás (GO). Brasília, Dissertação de Mestrado, Universidade Federal de Brasília, 119 p.

QUEIROZ, C.L. (2000) Evolução tectono-estrutural dos terrenos granito-greenstone belt de Crixás, GO. Brasília, Dissertação de Doutorado, Universidade Federal de Brasilia.

QUEROZ, C.L.; MCNAUGTHON, N.J.; JOST (1999) Formation of a dome-and-keel province: 150 Ma of granitoid magmatism in the Crixás granite-greenstone belt terrane. In: SIMPÓSIO DE GEOLOGIA DO CENTROOESTE, VII, e SIMPÓSIO DE GEOLOGLA DE MINAS GERAIS, X, Boletim de Resumos... SBG, p.71[D17].

QUEIROZ, C.L.; FORTES, P.T.F.O; ALKIMIN, F.F; JOST, H.; KUYUMJIAN, R.M. (1997) Relações entre o controle estrutural da Mina Ill e a evolução estrutual do Greenstone Belt de Crixás, GO: Simpósio Nacional Estudos Tectônicos, 6, Pirenópolis, Resumos Expandidos, p. 343-345.

RADAELLI V.A. (1990) Relatório final da Folha Anápoliss SE-22-Y-B-II. Goiânia. DNPM/CPRM.

RADAELLI V.A. (1992) Archean basement structural features overprinted by Araxá proterozóic orogeny and related gold, tin and emerald deposits in Goiás. SBG, 37 Cong. Bras. Geol., Bol. de Resumos Expandidos, São Paulo. 1:223-224.

RAMBOZ, C.; PICHAVANT, M.; WEISBROD, A. (1982) Fluid immiscibility in natural processes: use and misuse of fluid inclusion data: II. Interpretation of fluid inclusion data in therms of immiscibility. Chemical Geology. 37: $29-48$.

RASMUSSEN, B.; KRAPEZ, B.; GROVES, D.I. (1999) The association between hydrocarbons and mineralization: A case study from Lennard Shelf of Western Australia in: Dunphy, J.M.; Hagemann, S.G. (1999) Seminar on 
Recent Advances in Ore Genesis, Centre for Teaching and Research in Strategic Mineral Deposits, UWA, Western Australia.

RIDLEY, J.; GROVES, D.I; HAGEMANN, S.G. (1995) Exploration and Deposit Models for Gold Deposits in Amphibolit/Granulite Facies Terrains. MERIWA, Rep. 142, 126p.

ROEDDER, E. (1984) Fluid Inclusions. Mineralogical Society of America, Reviews in Mineralogy, 12:644p.

RONDE, C. E. J. de; SPOONER, E.T.C.; WIT, M.J. de; BRAY, C.J. (1992) Shear Zone Related, Au Quartz Vein Deposits in the Barberton Greenstone Belt, South Africa: Field and Petrographic Characteristics, Fluid Properties and Light Stable Isotope Geochemistry. Economic Geology, 87:366-402.

SABOIA, L.A. (1979) Os "Greenstone Belts" de Crixás e Goiás - GO. SBG, Núcleo Centro-Oeste, Boletim Informativo, 9:44-72.

SABOIA, L. A.; TEIXEIRA, N. A. (1980) Lavas ultrabásicas da unidade basal de Greenstone Belt de Crixás (GO): Uma nova classe de rochas ultrabásicas no Estado de Goiás. Revista Brasileilra de Geociências, 10(1): 28-42.

SABOIA, L.A.; TEIXEIRA, N.A. (1983) Ultramafic flows of the Crixás greenstone belt, Goiás, Brazil. Precambrian Research, 22:23-40.

SABOIA, L.A.; TEIXEIRA, N.A.; CASTRO, J.H.G.; TEIXEIRA, A.S. (1981) Geologia do "Greenstone Belt" de Crixás (GO) e suas implicações geotectônicas In: SIMPÓSIO SOBRE O CRÁTON DO SÃO FRANCISCO E SUAS FAIXAS MARGINAIS, 1, Salvador, 1981. Anais... Salvador, SBG, Parte II, Núcleo Bahia, p. 39-50.

SCHOBBENHAUS, C.; CAMPOS, D.A.; DERZI, G.R.; ASMUS, H.E. (1981) Mapa geológico do Brasil e da área oceânica adjacente, incluindo depósitos minerais. DNPM, Brasilia

SCHOBBENHAUS, C; CAMPOS, D. DE A.; DERZE, G.R.; ASMUS, H.E. (Coord.) (1984) Geologia do Brasil, DNPM, Brasília, $501 \mathrm{p}$.

SCHOBBENHIAUS FLLHO, C.; RIBEIRO, C.L.; OLIVA, L.A.; TAKANOHASHI, J.T.; LINDEMAYER, Z.G.; VASCONCELOS, J.B; ORLANDO, V. (1975) Carta Geológica do Brasil ao Milionésimo, Folha de Goiás (SD-22). Brasília, MME/DNPM. 114p.

SIBSON, R.H., ROBERT, F., POULSEN, K.H. (1988) High angle reverse faults, fluid-pressure cycling, and mesothermal gold-quartz deposits. Geology. 16:551-555.

SPANGENBERG, J.E, FRIMMEL, H.E. (2001) Basin-internal derivation of hydrocarbons in the Witwatersrand Basin, South Africa: evidence from bulk and molecular $\delta^{13} \mathrm{C}$ data. Chemical Geology, 173:339-355.

SUGU1O, K. (1998) Dicionário de Geologia Sedimentar e Áreas Afins. Rio de Janeiro, Bertrand Brasil, 1222 p.

TAKENOUCHI, S.; KENNEDY, G.C. (1965) The solubility of carbon dioxide in NaCl solutions at high temperatures and pressures. American Journal of Science, 263:445-454.

TEIXEIRA, A.S. (1981) Geologia da região de Goiás-Faina. SBG, Simpósio Geologia Centro Oeste, Atas, Goiânia, p. 344-360.

TEIXEIRA, N.A.; SABOIA, L.A.; FERREIRA, M.C.B.; TEIXEIRA, A.S.; CASTRO J.H.G. (1981) Estruturas e texturas das lavas ultrabásicas e básicas do greenstone belt de Crixás, Goiás, Brasil. SBG, Núcleo do CentroOeste, Boletim Informativo, 10:33-87.

THEODORO S.M.C.H. (1995) Ambiente de sedimentação da Formação Ribeirão das Antas, Grupo Crixás - Goiás. Brasília, Dissertação de Mestrado, Universidade Federal de Brasília, 88p.

THEODORO S.M.C.H.; Jost, H. (1996) The discovery of primary sedimentary structures in Archean marbles of the Crixás greenstone belt, Central Brazil. In: Symposium Archean Terr. South Amer. Platform, Brasilia, 1996, Extended Abstract, $41-42$

THIERY, R.; VAN DER KERKHOF, A.F.; DUBESSY, F. (1994) vX properties of $\mathrm{CH}_{4}-\mathrm{CO}_{2}$ and $\mathrm{CO}_{2}-\mathrm{N}_{2}$ fluid inclusions: modelling for $\mathrm{T}<31^{\circ} \mathrm{C}$ and $\mathrm{P}<400$ bar. European Journal of Mineralogie. 6:753-771.

THOMSON, M.L. (1986) Petrology of the Crixás gold deposit, Brazil: evidence for gold associated with hydrothermal alteration subsequent to metamorphism. In: A.J. MacDonald editor GOLD'86: An International Symposium on the Geology of Gold, proceedings, p.284 296.

THOMSON, M.L. (1987) The Crixás Gold Deposit, Brazil: Metamorphism, Metasomatism and Gold Mineralization. Ontário, Canadá, Disertação de Doutoramento, Univ. Western Ontário, Canada, 345p.

THOMSON, M.L. (1991) Multiphase deformation and metamorphism of the Crixás Greenstone Belt, Goiás, Brazil: Evidence from poikiloblast inclusion trails and metamorphic mineral assemblages. Joumal of South American Earth Sciences, 4(1/2): 119-130. 
THOMSON, M.L. (1991) Wall-Rock alteration related to Au mineralization in the low amphibolite facies: Crixás Gold Mine, Goiás, Brazil. Canadian Mineralogist, 29:461-480.

THOMSON, M.L.; FYFE, W.S. (1990) The Crixás Gold Deposit, Brazil: Thrust-Related Postpeak Metamorphic Gold Mineralisation of Possible Brasiliano Cycle Age. Economic Geology, 85:928-942.

VARGAS, M.C. (1992) Geologia dos granito-gnaisses dos terrenos granito-greenstone da região de Crixás, Guarino, Pilar de Goiás e Hidrolina, Goiás. Brasília, Dissertação de Mestrado, Universidade Federal de Brasília, 167p.

VILJOEN, M.J., VLLJOEN, M.J. (1969) The geology and geochemistry of the lower ultranafic unit of the Onverwacht group and a proposed new class of igneous rock. Geological Society of South Africa, Special Publication, 2:55-86.

VIVO, B. DE; REZZOTTI, M L. (1994) Fluid Inclusion in Minerals: Methods and Applications. Short Course of the Working Group (IMA) "Inclusions in Minerals" Pontignano - Siena, 376p.

WARNE, S.S.J. (1960) A quick field or laboratory staining carbonate minerals. Journal of Sedimentary Petrology, 32(1):29-38.

WHEAT, C.G.; FEELY, R.A.; MOTTL, M.J. (1996) Phosphate removal by oceanic hydrotermal process: an update of the phosphorous budget in the oceans. Geochim. Cosmochim. Acta, 60:3593-3608.

WILLIAMS, P.J. (1997) A metamorphosed, stratabound-epigenétic origin for a gruneritic Archean gold deposit, Barbetown, South Africa. Ore Geology Reviews, 12:135-151

WORT, M.J.; JONES, M.P. (1980) X-Ray Diffration and Magnetic Studies of Altered Ilmenite and Pseudorutile. Mineralogical Magazine, 43: 659-663.

YAMAOKA, W.N.; ARAÚJO, E. M. (1986) Mineralização de Ouro da Mina III. In: CONGRESSO BRASILEIRO DE GEOLOGIA, 34, Goiânia, 1986. Roteiro das Excursões Técnico-cientifica...SBG, 2:77-78.

YAMAOKA, W. N.; ARAÚJO, E. M. (1988) Depósito de Ouro Mina III, Crixás, Goiás, In: Schobbenhaus, C. \& Coelho, C. E. S. (Eds.) Principais Depósitos Minerais do Brasil, v. III, Capítulo XXXIV. Brasília, DNPM/CVRD, p. 491-498.

YAMAOKA, W.N.; ARAÚJO, E.M.; GARCIA, M.P. (1985) Relatório Final de Pesquisa, Mineração Serra Grande Ltda, Crixás, Goiás (inédito). 
Klaus Juergen Petersen Jr. was born in January $20^{\text {th }}$, 1964 in Santo André, São Paulo state, Brazil. He received his Diploma in Geology Engeneering from the Universidade Federal de Ouro Preto, Minas Gerais, Brazil in 1988, following 3 years as director of the ENGEO Geologia Ltda., working exclusively to DOCEGEO/Vale do Rio Doce Company in gold exploration. The next 5 years he dealt with gems comerce as director of the Minas Gems Com. e Exp. Ltda. (exploration, cutting, enhancement and exporting of gemstones). After enrollement in the Institute of Geocience at the Universidade de São Paulo completed his MSc Project in Petrology and Mineralogy in 1998 (study of a new alexandrite occurence) and completed his $\mathrm{PhD}$ in 2003. He accepted an invitation to work on a one year project with fluid inclusion study at the Centre for Global Metalogeny, University of Western Australia and plans to start a postdoctoral position in gold metalogeny at the same centre in 2005 .

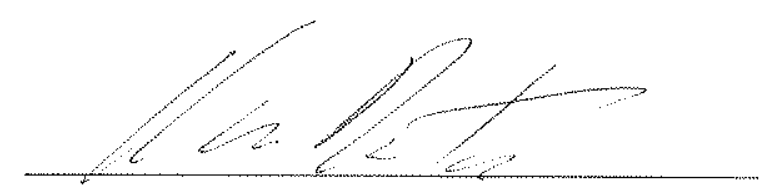

Klaus Juergen Petersen Jr. 
ANEXO 2

TABELAS DE ANÁLISES DE QUÍMICA MINERAL 


\begin{tabular}{|c|c|c|c|c|c|c|c|c|c|c|c|c|c|c|c|c|c|c|c|c|c|c|}
\hline & & & & & & & & & & & & & & & & & & $\mathrm{C}$ & 7 & 717 & $c 3$ & 684 \\
\hline $0=24$ & $\frac{656}{\text { GRT }}$ & $\frac{657}{\text { GRT }}$ & $\begin{array}{l}658 \\
\text { GRT }\end{array}$ & $\begin{array}{l}659 \\
\text { GRT }\end{array}$ & $\begin{array}{c}660 \\
\text { GRT }\end{array}$ & $\frac{661}{\text { GRT }}$ & $\frac{662}{G R T}$ & $\frac{663}{\text { GRT }}$ & $\frac{\mathrm{Cl}}{\mathrm{O}=22}$ & $\frac{681}{B T}$ & $\frac{682}{B T}$ & $\begin{array}{c}\mathrm{Cl} \\
\mathrm{O}=6\end{array}$ & $\frac{711}{C A B}$ & $\frac{712}{\mathrm{CAB}}$ & $\frac{713}{C A B}$ & $\begin{array}{c}\mathrm{C} 2 \\
\mathrm{O}=6\end{array}$ & $\frac{600}{\mathrm{CAB}}$ & $\frac{C 2}{O=31}$ & TUR & TUR & $0=22$ & $\mathrm{BT}$ \\
\hline $\mathrm{SiO}_{2}$ & 36.77 & 37.30 & 36.83 & 36.82 & 36.80 & 36.91 & 36.80 & 37.53 & $\mathrm{SiO}_{2}$ & 34.73 & 34.50 & $\mathrm{SiO}_{2}$ & $0.0 \mathrm{I}$ & 0.02 & 0.03 & $\mathrm{SiO}_{2}$ & 0.05 & $\mathrm{SiO}_{2}$ & 36.78 & 35.16 & $\mathrm{SiO}_{2}$ & 34.80 \\
\hline $\mathrm{Al}_{2} \mathrm{O}_{3}$ & 20.89 & 20.86 & 20.96 & 20.99 & 20.99 & 20.73 & 20.77 & 21.31 & $\mathrm{TO}_{2}$ & 1.53 & 1.66 & FeO & 13.21 & 13.29 & 13.36 & $\mathrm{Al}_{2} \mathrm{O}_{3}$ & 0.01 & $\mathrm{TiO}_{2}$ & 0.65 & 0.64 & $\mathrm{TiO}_{2}$ & 1.76 \\
\hline $\mathrm{TiO}_{2}$ & 0.03 & 0.04 & 0.09 & 0.03 & 0.10 & 0.14 & 0.01 & 0.04 & $\mathrm{Al}_{2} \mathrm{O}_{3}$ & 18.08 & 17.74 & MnO & 1.44 & 1.24 & 1.39 & $\mathrm{riO}_{2}$ & 0.00 & $\mathrm{Al}_{2} \mathrm{O}_{3}$ & 30.32 & 31.81 & $\mathrm{Al}_{2} \mathrm{O}_{3}$ & 17.72 \\
\hline $\mathrm{FeO}$ & 30.80 & 30.49 & 30.34 & 30.50 & 29.79 & 30.05 & 29.21 & 30.78 & $\mathrm{FeO}$ & 20.73 & 20.41 & $\mathrm{MgO}$ & 10.71 & 10.88 & 11.02 & $\mathrm{FeO}$ & 12.85 & $\mathrm{FeO}$ & 8.82 & 7.52 & $\mathrm{FeO}$ & 19.43 \\
\hline $\mathrm{MnO}$ & 4.58 & 4.35 & 4.68 & 4.65 & 4.54 & 4.82 & 4.72 & 4.38 & $\mathrm{MnO}$ & 0.09 & 0.07 & $\mathrm{CaO}$ & 27.35 & 27.13 & 27.62 & $\mathrm{MnO}$ & 1.31 & $\mathrm{MnO}$ & 0.05 & 0.00 & $\mathrm{MnO}$ & 0.07 \\
\hline $\mathrm{MgO}$ & 1.37 & 1.36 & 1.42 & 1.44 & 1.35 & 1.45 & 1.43 & 1.42 & $\mathrm{MgO}$ & 8.28 & 8.63 & - & - & - & - & Migo & 11.13 & $\mathrm{MgO}$ & 6.06 & 6.69 & $\mathrm{MgO}$ & 9.23 \\
\hline $\mathrm{CaO}$ & 4.98 & 5.30 & 4.53 & 4.54 & 4.85 & 4.78 & 4.90 & 4.52 & $\mathrm{CaO}$ & 0.07 & 0.03 & - & - & . & - & $\mathrm{CaO}$ & 26.95 & $\mathrm{CaO}$ & 0.31 & 0.86 & $\mathrm{CaO}$ & 0.09 \\
\hline $\mathrm{Na}_{2} \mathrm{O}$ & 0.05 & 0.00 & 0.00 & 0.02 & 0.04 & 0.03 & 0.04 & 0.00 & $\mathrm{Na}_{2} \mathrm{O}$ & 0.08 & 0.13 & - & - & . & - & $\mathrm{Na}_{2} \mathrm{O}$ & 0.00 & $\mathrm{Na}_{2} \mathrm{O}$ & 1.94 & 1.95 & $\mathrm{Na}_{2} \mathrm{O}$ & 0.13 \\
\hline $\mathrm{Cr}_{2} \mathrm{O}_{3}$ & 0.02 & - & - & - & - & - & - & - & $\mathrm{K}_{2} \mathrm{O}$ & 8.61 & 8.82 & - & - & - & - & $\mathrm{K}_{2} \mathrm{O}$ & 0.00 & $\mathrm{~K}_{2} \mathrm{O}$ & 0.01 & 0.01 & $\mathrm{~K}_{2} \mathrm{O}$ & 8.54 \\
\hline $\mathrm{Y}_{2} \mathrm{O}_{3}$ & 0.21 & - & - & - & - & - & - & - & $\mathrm{Cl}$ & 0.03 & 0.04 & - & - & . & - & - & - & $F$ & 0.00 & 0.24 & $\mathrm{Cl}$ & 0.01 \\
\hline $\mathrm{BaO}$ & 0.00 & - & - & - & - & - & - & - & $\mathrm{F}$ & 0.22 & 0.24 & - & - & - & - & - & - & $\mathrm{Cl}$ & 0.00 & 0.00 & $F$ & 0.41 \\
\hline$\frac{-}{\text { Total }}$ & - & - & - & - & - & - & - & - & $\mathrm{BaO}$ & 0.38 & 0.45 & - & $\cdot$ &. & - & - & - & 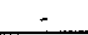 & & & $\mathrm{BaO}$ & 0.35 \\
\hline$\frac{\text { Total }}{\mathrm{Si}}$ & 99.70 & 99.70 & 98.85 & 98.99 & 98.47 & 98.91 & 97.87 & 99.98 & Total & 92.84 & 92.73 & Total & 52.73 & 52.55 & 53.413 & Fotal & $52.30^{\circ}$ & Total & 84.94 & 84.87 & Total & 92.53 \\
\hline $\mathrm{Si}$ & 5.97 & 6.04 & 6.01 & 6.00 & 6.01 & 6.02 & 6.04 & 6.04 & Si & 5.49 & 5.47 & $\mathrm{Si}$ & 0.00 & 0.00 & 0.00 & $\mathrm{Si}$ & 0.00 & $\mathrm{Si}$ & 7.77 & 7.44 & $\mathrm{Si}$ & 5.49 \\
\hline $\begin{array}{l}\mathrm{Al} \\
\mathrm{Ti}\end{array}$ & 4.00 & 3.93 & 4.03 & 4.03 & 4.04 & 3.98 & +02 & 4.04 & Ti & 0.18 & 0.20 & $\mathrm{Fe} 2+$ & 1.15 & 1.16 & 1.15 & AI & 0.00 & Ti & 0.10 & 0.10 & $\mathrm{Ti}$ & 0.21 \\
\hline $\mathrm{Ti}$ & 0.00 & 0.00 & 0.01 & 0.00 & 0.01 & 0.02 & 0.00 & 0.00 & $\mathrm{Al}$ & 3.37 & 3.31 & $\mathrm{Mn}$ & 0.13 & 0.11 & 0.12 & $\mathrm{Ti}$ & 0.00 & $\mathrm{Al}$ & 7.55 & 7.93 & $\mathrm{Al}$ & 3.29 \\
\hline $\mathrm{Fe} 2+$ & 4.18 & 4.59 & 4.14 & 4.16 & 4.07 & 4.10 & 4.01 & 4.14 & $F \in 2 \div$ & 2.74 & 2.70 & $\mathrm{Mg}$ & 1.66 & 1.69 & 1.69 & $\mathrm{Fe} 2 \div$ & 1.12 & $\mathrm{Fe} 2+$ & 1.56 & 1.33 & $1 \div 2$ & 2.56 \\
\hline $\mathrm{Mn}$ & 0.63 & 0.06 & 0.65 & 0.64 & 0.63 & 0.67 & 0.66 & 0.60 & $\mathrm{Mn}$ & 0.01 & 0.01 & $\mathrm{Ca}$ & 3.05 & 3.03 & 3.04 & $\mathrm{Mn}$ & 0.12 & Mn & 0.01 & 0.00 & $\mathrm{Mn}$ & 0.01 \\
\hline $\mathrm{Mg}$ & 0.33 & 0.28 & 0.35 & 0.35 & 0.33 & 0.35 & 0.35 & 0.34 & $\mathrm{Mg}$ & 1.95 & 2.04 & - & - & - & - & $\mathrm{Mg}$ & 1.73 & $\mathrm{Mg}$ & 1.91 & 2.11 & $\mathrm{Mg}$ & 2.17 \\
\hline $\mathrm{Ca}$ & 0.87 & 1.08 & 0.79 & 0.79 & 0.85 & 0.84 & 0.86 & 0.78 & $\mathrm{Ca}$ & 0.01 & 0.00 & - & - & - & - & $\mathrm{Ca}$ & 3.02 & $\mathrm{Ca}$ & 0.07 & 0.19 & $\mathrm{Ca}$ & 0.02 \\
\hline $\mathrm{N} / \mathrm{a}$ & 0.02 & 0.00 & 0.00 & 0.01 & 0.01 & 0.01 & 0.01 & 0.00 & $\mathrm{Na}$ & 0.03 & 0.04 & - & - & . & - & $\mathrm{Na}$ & 0.00 & $\mathrm{Na}$ & 0.80 & 0.80 & $\mathrm{Na}$ & 0.04 \\
\hline $\mathrm{Cr}$ & 0.00 & - & $\cdot$ & - & - & r & - & - & $\mathrm{K}$ & 1.73 & 1.78 & - & . & - & - & $\mathrm{K}$ & 0.00 & $\mathrm{~K}$ & 0.00 & 0.00 & $\mathrm{~K}$ & 1.72 \\
\hline Y & 0.02 & - & - & * & - & - & - & - & $\mathrm{Cl}$ & 0.01 & 0.01 & - & - & - & - & - & - & F & 0.00 & 0.16 & $\mathrm{Cl}$ & 0.00 \\
\hline $\mathrm{Ba}$ & 0.00 & - & - & - & - & - & . & - & $\mathrm{F}$ & 0.11 & 0.12 & - & - & - & - & - & - & $\mathrm{Cl}$ & 0.00 & 0.00 & $F$ & 0.20 \\
\hline- & - & - & - & - & - & - & - & - & $\mathrm{BaO}$ & 0.02 & 0.03 & - & - & $\leftarrow$ & - & - & - & - & & & $\mathrm{BaO}$ & 0.02 \\
\hline al & 16.02 & 15.99 & 15.97 & 15.98 & 15.96 & 15.98 & 15.95 & 15.94 & rotal & 15.65 & 15.72 & Total & 6.00 & 6.00 & 6.00 & Cotal & 5.99 & Total & 19.76 & 20.06 & Total & 15.74 \\
\hline
\end{tabular}

\begin{tabular}{|c|c|c|c|c|c|c|c|c|c|c|c|c|c|c|c|c|c|c|c|c|c|c|c|}
\hline $\mathrm{C3}$ & 719 & 720 & $\mathrm{C} 4$ & 606 & 601 & 602 & 603 & 604 & $\mathrm{C} 4$ & 684 & $\mathrm{C} 5$ & 607 & 608 & 609 & $\mathrm{C5}$ & 664 & 665 & 666 & 667 & 668 & $\mathrm{C5}$ & 686 & 687 \\
\hline $0=31$ & TUR & TUR & $O=32$ & $\overline{P L}$ & PL & PL. & $\overline{\mathrm{PL}}$ & PL & $0=22$ & $\mathrm{BT}$ & $0=32$ & $\mathrm{PL}$ & $\overline{\mathrm{PL}}$ & $\overline{\mathrm{PL}}$ & $O=24$ & $\overline{G R T}$ & GRT & GRT & GRT & GRT & $\mathrm{O}=22$ & BT & BT \\
\hline $\mathrm{SiO}_{3}$ & 36.37 & 35.37 & $\mathrm{SiO}_{2}$ & 63.84 & 61.96 & 61.49 & 60.84 & 64.49 & $\mathrm{SiO}_{2}$ & 35.25 & $\mathrm{SiO}_{2}$ & 60.19 & 62.50 & 60.30 & $\mathrm{SiO}_{2}$ & 37.26 & 37.06 & 36.89 & 36.92 & 36.41 & $\mathrm{SiO}_{2}$ & 34.70 & $\begin{array}{r}34.86 \\
207\end{array}$ \\
\hline $\mathrm{T}: \mathrm{O}_{2}$ & 0.26 & 0.84 & $\mathrm{Al}_{2} \mathrm{O}_{3}$ & 21.86 & 23.21 & 23.18 & 23.38 & 20.83 & $\mathrm{TiO}_{2}$ & 1.82 & $\mathrm{Al}_{2} \mathrm{O}_{3}$ & 22.45 & 22.08 & 23.71 & $\mathrm{Al}_{2} \mathrm{O}_{3}$ & 20.93 & 20.98 & 20.95 & 21.07 & 20.64 & $\mathrm{TiO}_{2}$ & 1.39 & $\begin{array}{r}2.07 \\
18.23\end{array}$ \\
\hline $\mathrm{AH}_{2} \mathrm{O}_{3}$ & 33.02 & 31.21 & $\mathrm{TiO}_{2}$ & 0.00 & 0.05 & 0.00 & 0.00 & 0.06 & $\mathrm{Al}_{2} \mathrm{O}_{3}$ & 17.80 & $\mathrm{TiO}_{2}$ & 0.04 & 0.00 & 0.00 & $\mathrm{THO}_{2}$ & 0.06 & 0.03 & 0.03 & 0.00 & 0.05 & $\mathrm{Al}_{2} \mathrm{O}_{3}$ & 18.07 & $\begin{array}{l}18.23 \\
19.53\end{array}$ \\
\hline $\mathrm{FeO}$ & 8.28 & 8.05 & $\mathrm{Fe}_{2} \mathrm{O}_{3}$ & 0.07 & 0.08 & 0.00 & 0.04 & 0.08 & $\mathrm{FeO}$ & 20.01 & $\mathrm{Fec}_{2} \mathrm{O}_{3}$ & 0.58 & 0.02 & 0.07 & $\mathrm{FeO}$ & 30.15 & 29.77 & 30.14 & 28.71 & 29.56 & $\mathrm{FeO}$ & 19.78 & $\begin{array}{r}19.53 \\
0.07\end{array}$ \\
\hline $\begin{array}{l}\mathrm{MnO} O \\
\mathrm{MpO}\end{array}$ & 0.03 & 0.02 & $\mathrm{MnO}$ & 0.00 & 0.00 & 0.00 & 0.00 & 0.00 & $\mathrm{MnO}$ & 0.09 & $\mathrm{MnO}$ & 0.00 & 0.00 & 0.00 & $\mathrm{MnO}$ & 4.92 & 5.06 & 5.16 & 4.85 & 4.85 & $\mathrm{MnO}$ & 0.19 & $\begin{array}{l}0.07 \\
878\end{array}$ \\
\hline $\mathrm{MgO}$ & 5.49 & 6.32 & $\mathrm{MgO}$ & 0.01 & 0.03 & 0.00 & 0.00 & 0.00 & $\mathrm{MgO}$ & 9.06 & $\mathrm{MgO}$ & 0.13 & 0.00 & 0.00 & $\mathrm{MgO}$ & 1.46 & 1.41 & 1.44 & 1.41 & 1.47 & $\mathrm{MgO}$ & 8.88 & 8.78 \\
\hline $\begin{array}{cc}\mathrm{CaO} \\
\mathrm{NaO}\end{array}$ & 0.11 & 0.37 & $\mathrm{CaO}$ & 2.18 & 4.22 & 4.50 & 5.10 & 2.04 & $\mathrm{CaO}$ & 0.01 & $\mathrm{CaO}$ & 4.37 & 3.74 & 5.67 & $\mathrm{CaO}$ & 4.52 & 5.12 & 4.83 & 5.59 & 4.72 & $\mathrm{CaO}$ & 0.02 & 0.04 \\
\hline $\mathrm{Na}_{2} \mathrm{O}$ & 1.84 & 2.07 & $\mathrm{Na}_{2} \mathrm{O}$ & 9.99 & 8.74 & 8.77 & 8.63 & 10.67 & $\mathrm{~N}_{3} \mathrm{O}_{2} \mathrm{O}$ & 0.11 & $\mathrm{Na}_{2} \mathrm{O}$ & 8.53 & 9.77 & 8.42 & $\mathrm{Na}_{2} \mathrm{O}$ & 0.00 & 0.02 & 0.06 & 0.03 & 0.02 & $\mathrm{Na}_{2} \mathrm{O}$ & 0.08 & 0.09 \\
\hline $\mathrm{K}_{2} \mathrm{O}$ & 0.00 & 0.01 & $\mathrm{~K}_{2} \mathrm{O}$ & 0.40 & 0.38 & 0.09 & 0.08 & 0.07 & $\mathrm{~K}_{2} \mathrm{O}$ & 9.00 & $\mathrm{~K}_{2} \mathrm{O}$ & 0.23 & 0.03 & 0.07 & - & 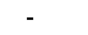 & - & - & - & - & $\mathrm{K}_{2} \mathrm{O}$ & 8.96 & 8.95 \\
\hline $\mathrm{F}$ & 0.11 & 0.16 & - & - & - & - & - & - & $\mathrm{C}$ & 0.02 & - & - & - & - & - & - & - & - & - & - & $\mathrm{Cl}$ & 0.03 & 0.05 \\
\hline $\mathrm{Cl}$ & 0.02 & 0.00 & - & - & - & - & - & - & $F$ & 0.40 & - & - & - & - & - & - & - & - & - & - & $F$ & 0.30 & 0.31 \\
\hline$\frac{-}{\text { Total }}$ & - & - & - & - & - & - & - & - & $\mathrm{BaO}$ & 0.53 & - & - & - & - & $=$ & - &. & 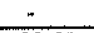 & - & & $\mathrm{BaO}$ & 0.51 & 0.46 \\
\hline$\frac{\text { Total }}{\mathrm{Si}}$ & 85.51 & 84.407 & fotal & 98.36 & 98.68 & 98.04 & 98.07 & 98.221 & otal & 94.18 & Total & 96.52 & 98.14 & 98.24 & total & 99.29 & 99.45 & 99.50 & 98.58 & $97.71 \mathrm{~T}$ & rotal & 92.90 & $\frac{93.44}{5.4}$ \\
\hline $\begin{array}{l}\mathrm{Si} \\
\mathrm{Ti}\end{array}$ & 7.59 & 7.52 & $\mathrm{Si}$ & 11.43 & 11.11 & 11.09 & 11.00 & 11.56 & $\mathrm{Si}$ & 5.49 & $\mathrm{Si}$ & 11.06 & 11.26 & 10.91 & $\mathrm{Si}$ & 6.04 & 6.01 & 5.99 & 6.01 & 6.01 & $\mathrm{Si}$ & 5.48 & 5.46 \\
\hline $\begin{array}{l}\mathrm{Ti} \\
\mathrm{Al}\end{array}$ & 0.04 & 0.13 & AI & 4.61 & 4.91 & 4.93 & 4.98 & 4.40 & Ti & 0.21 & $\mathrm{Al}$ & 4.86 & 4.69 & 5.06 & Al & 4.00 & 4.01 & 4,01 & 4.05 & 4.01 & $\mathrm{Ti}$ & 0.17 & 0.24 \\
\hline $\begin{array}{c}\mathrm{Al} \\
\mathrm{Fe} 2 \div\end{array}$ & 8.12 & 7.82 & $\Upsilon \mathrm{Ti}$ & 0.00 & 0.01 & 0.00 & 0.00 & 0.01 & AI & 3.27 & $T_{i}$ & 0.01 & 0.00 & 0.00 & $\pi$ & 0.01 & 0.00 & 0.00 & 0.00 & 0.01 & $A^{3}$ & 3.36 & 3.36 \\
\hline $\mathrm{Fe} 2+$ & 1.45 & 1.43 & $\mathrm{Fe} 3$ & 0.01 & 0.01 & 0.00 & 0.01 & 0.01 & $\mathrm{Fe} 2$ & 2.61 & Fe3- & 0.08 & 0.00 & 0.01 & $\mathrm{Fe} 2+$ & 4.09 & 4.04 & 4.09 & 3.91 & 4.08 & $F \in 2+$ & 2.61 & 2.56 \\
\hline$M_{n}$ & 0.00 & 0.00 & Mn & 0.00 & 0.00 & 0.00 & 0.00 & 0.00 & $\mathrm{Mn}$ & 0.08 & $\mathrm{Mn}$ & 0.00 & 0.00 & 0.00 & $\mathrm{Mrr}$ & 0.68 & 0.70 & $0.7 \mathrm{I}$ & 0.67 & 0.68 & Mn & 0.03 & 0.01 \\
\hline $\mathrm{Mg}$ & 1.71 & 2.00 & $\mathrm{Mg}$ & 0.00 & 0.01 & 0.00 & 0.00 & 0.00 & $\mathrm{Mg}$ & 2.11 & $\mathrm{Mg}$ & 0.04 & 0.00 & 0.00 & $\mathrm{Mg}$ & 0.35 & 0.34 & 0.35 & 0.34 & 0.35 & $\mathrm{Mg}$ & 2.09 & 2.05 \\
\hline $\mathrm{Ca}$ & 0.02 & 0.08 & $\mathrm{Ca}$ & 0.42 & 0.81 & 0.87 & 0.99 & 0.39 & $\mathrm{Ca}$ & 0.00 & $\mathrm{Ca}$ & 0.86 & 0.72 & 1.10 & $\mathrm{Ca}$ & 0.79 & 0.89 & 0.84 & 0.98 & 0.83 & $\mathrm{Ca}$ & 0.00 & 0.01 \\
\hline $\mathrm{Na}$ & 0.74 & 0.85 & $\aleph_{3}$ & 3.47 & 3.04 & 3.07 & 3.03 & 3.71 & $\mathrm{Na}$ & 0.03 & $\mathrm{Na}$ & 3.04 & 3.41 & 2.95 & $\mathrm{Na}$ & 0.00 & 0.01 & 0.02 & 0.01 & 0.01 & $\mathrm{Na}$ & 0.00 & 0.03 \\
\hline $\mathrm{K}$ & 0.00 & 0.00 & $\mathrm{~K}$ & 0.09 & 0.09 & 0.02 & 0.02 & 0.02 & $\bar{K}$ & 1.81 & $\mathrm{~K}$ & 0.05 & 0.01 & 0.02 & - & - & - & - & - & - & $\mathrm{K}$ & 1.80 & 1.79 \\
\hline I: & 0.07 & 0.11 & - & - & - & - & - & - & $\mathrm{Cl}$ & 0.01 & - & - & - & . & - & - & - & - & - & - & $\mathrm{Cl}$ & 0.01 & 0.01 \\
\hline $\mathrm{Cl}$ & 0.01 & 0.04 & - & - & - & - & - & - & F & 0.20 & - & - & - & - & - & - & - & - & - & - & $\mathrm{F}$ & 0.15 & 0.15 \\
\hline- & 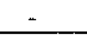 & - & - & - & - & . & - & - & $\mathrm{BaO}$ & 0.03 & & & & - & - & . & - & - & . & - & $\mathrm{BaO}$ & 0.03 & 0.03 \\
\hline
\end{tabular}




\begin{tabular}{|c|c|c|c|c|c|c|c|c|c|c|}
\hline \multicolumn{11}{|c|}{ V.22-16303 } \\
\hline $\mathrm{CS}$ & 688 & 689 & $\mathrm{Cs}$ & 714 & 715 & $\mathrm{C} 6$ & 669 & 670 & 671 & 672 \\
\hline $0=22$ & $B T$ & BT & $O=6$ & $\mathrm{CAB}$ & $\mathrm{CAB}$ & $0=24$ & GRT & GRT & GRT & GRT \\
\hline $\mathrm{SiO}_{2}$ & 35.03 & 35.01 & $\mathrm{SiO}_{2}$ & 0.01 & 0.01 & $\mathrm{SiO}_{2}$ & 36.53 & 36.58 & 36.58 & 36.84 \\
\hline $\mathrm{THO}_{2}$ & 1.64 & 1.76 & $\mathrm{FeO}$ & 13.88 & 13.84 & $\mathrm{Al}_{2} \mathrm{O}_{3}$ & 20.75 & 207.76 & 20.81 & 21.04 \\
\hline $\mathrm{Al}_{2} \mathrm{O}_{3}$ & 18.08 & 18.44 & $\mathrm{Mn}(\mathrm{B}$ & 1.22 & 1.26 & $\mathrm{TO}_{2}$ & 0.08 & 0.02 & 0.13 & 0.00 \\
\hline $\mathrm{FeO}$ & 19.20 & 19.24 & $\mathrm{MgO}$ & 10.38 & 10.42 & Feo & 30.34 & 29.46 & 29.83 & 30.13 \\
\hline $\mathrm{MnO}$ & 0.08 & 0.09 & $\mathrm{CaO}$ & 27.11 & 27.83 & MnO & 4.93 & 4.76 & 4.84 & 4.91 \\
\hline $\mathrm{MgO}$ & 8.98 & 8.96 & - & - & - & $\mathrm{MgO}$ & 1.54 & 1.53 & 1.52 & 1.36 \\
\hline $\mathrm{CaO}$ & 0.00 & 0.00 & - & - & - & $\mathrm{CaO}$ & 4.17 & $\$ .42$ & 4.18 & 4.18 \\
\hline $\mathrm{Na}_{2} \mathrm{O}$ & 0.12 & 0.10 & . & - & - & $\mathrm{Na}_{2} \mathrm{O}$ & 0.03 & 0.01 & 0.04 & 0.00 \\
\hline $\mathrm{K}_{\mathrm{n}} \mathrm{O}$ & 8.94 & 8.74 & - & . & - & . & - & - & - & - \\
\hline $\mathrm{Cl}$ & 0.03 & 0.01 & - & - & - & - & - & - & - & - \\
\hline$F$ & 0.39 & 0.32 & - & - & - & - & - & - & - & - \\
\hline $\mathrm{BaO}$ & 0.53 & 0.50 & . & - & - & - & - & - & - & - \\
\hline Total & 93.00 & 93.18 & cotal & 52.59 & 53.35 & Iotal & 98.38 & 97.53 & 97.93 & 98.461 \\
\hline $\mathrm{Si}$ & 5.50 & 5.48 & $\mathrm{Si}$ & 0.00 & 0.00 & $\mathrm{Si}$ & 6.00 & 6.03 & 6.01 & 6.03 \\
\hline $\mathrm{Ti}$ & 0.19 & 0.21 & $F \in 2 \div$ & 1.22 & 1.20 & Al & $\frac{f}{4.11}$ & 4.03 & 4.03 & 4.06 \\
\hline $\mathrm{A} 1$ & 3.35 & 3.40 & $\mathrm{Mn}$ & 0.11 & 0.11 & $\mathrm{Ti}$ & 0.01 & 0.00 & 0.02 & 0,00 \\
\hline $\mathrm{Fe} 2 \div$ & 2.52 & 2.52 & $\mathrm{Mg}$ & 1.62 & 1.61 & $\mathrm{~F}=2+$ & 4.17 & 4.06 & 4.10 & 4.12 \\
\hline $\mathrm{Mn}$ & 0.01 & 0.01 & $\mathrm{Ca}$ & 3.05 & 3.08 & $\mathrm{Mn}$ & 0.69 & 0.66 & 0.67 & 0.68 \\
\hline $\mathrm{Mg}$ & 2.10 & 2.09 & - & - & - & $\mathrm{Mg}$ & 0.38 & 0.38 & 0.37 & 0.33 \\
\hline $\mathrm{Ca}$ & 0.00 & 0.00 & - & - & - & $\mathrm{Ca}$ & 0.73 & 0.78 & 0.74 & 0.73 \\
\hline $\mathrm{Na}$ & 0.04 & 0.03 & - & - & - & $\mathrm{Na}$ & 0.01 & 0.00 & 0.01 & 0.00 \\
\hline $\mathrm{k}$ & 1.79 & 1.74 & - & - & - & - & - & - & - & - \\
\hline $\mathrm{Cl}$ & 0.01 & 0.00 & - & - & - & - & - & - & - & - \\
\hline$F$ & 0.19 & 0.16 & - & - & - & - & - & - & - & - \\
\hline $\mathrm{BaO}$ & 0.03 & 0.03 & - & - &. & & - & - & - & - \\
\hline Total & 15.74 & 15.67 & otal & 6.00 & 6.00 & rotal & 15.99 & 15.95 & 15.96 & 15.95 \\
\hline \multicolumn{11}{|c|}{ IV-22-16303 } \\
\hline $\mathrm{C} 7$ & 692 & 693 & 694 & $\mathrm{C} 8$ & 612 & 613 & 614 & 615 & $\mathrm{C} 8$ & 697 \\
\hline $0=22$ & BT & $\mathrm{BT}$ & $\mathrm{CHL}$ & $0=32$ & $\mathrm{PL}$ & $\mathrm{PL}$ & $\mathrm{PL}$ & $\mathrm{PL}$ & $O=22$ & $\mathrm{BT}$ \\
\hline $\mathrm{SiO}_{2}$ & 34.61 & 34.71 & 23.83 & $\mathrm{SiO}_{2}$ & 59.66 & 60.59 & 60.99 & 61.99 & $\mathrm{SiO}_{2}$ & 34.92 \\
\hline $\mathrm{TiO}_{2}$ & 1.94 & 1.68 & 0.10 & $\mathrm{Al}_{2} \mathrm{O}_{3}$ & 23.66 & 23.40 & 23.22 & 22.86 & $\mathrm{TiO}_{2}$ & 1.48 \\
\hline $\mathrm{Al}_{2} \mathrm{O}_{3}$ & 18.33 & 17.62 & 21.77 & $\mathrm{TiO}_{2}$ & 0.00 & 0.02 & 0.00 & 0.00 & $\mathrm{Al}_{2} \mathrm{O}_{3}$ & 17.60 \\
\hline FeO & 19.67 & 19.41 & 26.07 & $\mathrm{Fe}_{2} \mathrm{O}_{3}$ & 0.04 & 0.12 & 0.04 & 0.09 & $\mathrm{FeO}$ & 20.02 \\
\hline $\mathrm{MnO}$ & 0.08 & 0.09 & 0.17 & $\mathrm{MnO}$ & 0.00 & 0.00 & 0.0 & 0.00 & $\mathrm{MnO}$ & 0.03 \\
\hline $\mathrm{MgO}$ & 8.77 & 9.16 & 13.30 & $\mathrm{MgO}$ & 0.00 & 0.0 & 0.0 & 0.00 & $\mathrm{MgO}$ & 9.12 \\
\hline $\mathrm{CaO}$ & 0.03 & 0.03 & & $\mathrm{CaO}$ & 5.59 & 4.7 & & 4.44 & $\mathrm{CaO}$ & 0.05 \\
\hline $\mathrm{N}_{2} \mathrm{O}$ & 0.14 & 0.08 & 0.02 & $\mathrm{Na}_{2} \mathrm{O}$ & 8.39 & 8.68 & 8.67 & 9.27 & $\mathrm{Na}_{2} \mathrm{O}$ & 0.06 \\
\hline $\mathrm{K}_{2} \mathrm{O}$ & 8.81 & 8.94 & 0.03 & $\mathrm{~K}_{2} \mathrm{O}$ & 0.05 & 0.28 & 0.07 & 0.04 & $\mathrm{~K}_{2} \mathrm{O}$ & 8.89 \\
\hline a & 0.04 & 0.02 & 0.03 & - & - & - & - & r & $\mathrm{Cl}$ & 0.03 \\
\hline$F$ & 0.43 & 0.19 & 0.01 & - & - & - & - & - & $F$ & 0.50 \\
\hline $\mathrm{BaC}$ & 0.55 & & 0.00 & - & - & - & & - & 1330 & 0.34 \\
\hline Total & 93.38 & 92.26 & 85.38 & Total & 97.38 & 97.82 & 97.99 & 98.69 & Total & 93.03 \\
\hline $\mathrm{Si}$ & 5.43 & 5.49 & & $\mathrm{Si}$ & 10.89 & 10.99 & 11.03 & 11.13 & $\mathrm{Si}$ & 5.51 \\
\hline $\mathrm{Ti}$ & 0.23 & 0.20 & & $\mathrm{Al}$ & 5.09 & 5.00 & 4.95 & 4.84 & $\Pi$ & 0.18 \\
\hline Al & & 3.29 & & $\mathfrak{t i}$ & 0.00 & 0.0 & 0.00 & 0.00 & $\mathrm{Al}$ & 3.27 \\
\hline $\mathrm{Fe} 2 \div$ & 2.58 & 2.57 & & $F \in 3 \div$ & 0.01 & 0.02 & 0.01 & 0.01 & $\mathrm{~F}<2 \div$ & 2.64 \\
\hline $\mathrm{Mn}$ & 0.01 & 0.01 & & $\mathrm{Mn}$ & 0.00 & 0.0 & 0.00 & 0.00 & $\mathrm{Mn}$ & 0.00 \\
\hline $\mathrm{Mg}$ & 2.05 & 2.16 & & $\mathrm{Mg}$ & 0.00 & 0.00 & 0.00 & 0.00 & $\mathrm{Mg}$ & 2.14 \\
\hline $\mathrm{Ca}$ & 0.00 & 0.00 & & $\mathrm{Ca}$ & 1.09 & 0.92 & 0.96 & 0.85 & $\mathrm{Ca}$ & 0.01 \\
\hline $\mathrm{Na}$ & 0.04 & 0.02 & & $\mathrm{Na}$ & 2.97 & 3.05 & 3.04 & 3.23 & $\mathrm{Na}$ & 0.02 \\
\hline K & 1.77 & 1.81 & & $\mathrm{~K}$ & 0.01 & 0.06 & 0.02 & 0.01 & $\mathrm{~K}$ & 1.79 \\
\hline $\mathrm{Cl}$ & 0.01 & 0.00 & & - & - & - & - & . & $\mathrm{Cl}$ & 0.01 \\
\hline $\mathrm{F}$ & 0.21 & 0.10 & & - & - & - & - & - & $F$ & 0.25 \\
\hline $\mathrm{BaO}$ & 0.03 & 0.02 & & - & - & - & $=$ & $=$ & $\mathrm{BaO}$ & 0.02 \\
\hline Total & 15.77 & 15.68 & 0.00 & Total & 20.06 & 20.05 & 20.02 & 20.07 & Total & 15.84 \\
\hline
\end{tabular}

\begin{tabular}{|c|c|c|c|c|c|c|c|c|c|c|c|}
\hline 690 & $\mathrm{C6}$ & 721 & 722 & C7 & 673 & 674 & 675 & 676 & 677 & 678 & 679 \\
\hline $\mathrm{BT}$ & $0=31$ & TUR & TUR & $0=24$ & GR? & GRT & GRT & GRT & GRT & GRT & GRT \\
\hline 34.56 & $\mathrm{SiO}_{2}$ & 36.16 & 35.79 & $\mathrm{SiO}_{2}$ & 36.49 & 36.59 & 36.56 & 36.86 & 36.86 & 36.85 & 36.55 \\
\hline 1.50 & $\mathrm{TH} \mathrm{O}_{2}$ & 0.28 & 0.62 & $\mathrm{Al}_{2} \mathrm{O}_{3}$ & 20.67 & 20.57 & 20.77 & 20.69 & 20.83 & 20.70 & 20,93 \\
\hline 18.14 & $\mathrm{Al}_{2} \mathrm{O}_{3}$ & 33.17 & 31.53 & $\mathrm{TiO}_{2}$ & 0.06 & 0.06 & 0.00 & 0.04 & 0.01 & 0.07 & 0.00 \\
\hline 20.16 & $\mathrm{FeO}$ & 8.16 & 7.97 & $\mathrm{FeO}$ & 30.16 & 29.18 & 28.94 & 29.13 & 29.19 & 29.04 & 30.18 \\
\hline 0.14 & MnO & 0.00 & 0.00 & $\mathrm{MnO}$ & 4.70 & 5.06 & 5.10 & 5.03 & 5.02 & 5.24 & 5.12 \\
\hline 9.64 & $\mathrm{MgO}$ & 5.58 & 6.66 & $\mathrm{MgO}$ & 1.42 & 1.42 & 1.41 & 1.46 & 1.44 & 1.53 & 1.44 \\
\hline 0.03 & $\mathrm{CaO}$ & 0.07 & 0.84 & $\mathrm{CaO}$ & 4.16 & 4.67 & 4.84 & 4.92 & 5.27 & 4.92 & 4.13 \\
\hline 0.06 & $\mathrm{Na}_{2} \mathrm{O}$ & 1.81 & 1.99 & $\mathrm{Na}_{2} \mathrm{O}$ & 0.04 & 0.03 & 0.05 & 0.03 & 0.00 & 0.00 & 0.03 \\
\hline 8.44 & $\mathrm{~K}_{\mathrm{z}} \mathrm{O}$ & 0.00 & 0.03 & - & . & - & - & - & - & - & - \\
\hline 0.03 & F & 0.26 & 0.29 & - & - & - & - & - & - & - & - \\
\hline 0.45 & $\mathrm{Cl}$ & 0.01 & 0.00 & - & - & - & - & - & - & - & - \\
\hline 0.60 & - & 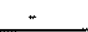 & - & - & - & - & - & $\therefore$ & 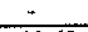 & & \\
\hline 93.74 & otal & 85.50 & 85.72 & Total & 97.68 & 97.58 & 97.66 & 98.15 & 98.62 & 98.35 & 98.39 \\
\hline 5.41 & $\overline{\mathrm{Si}}$ & 7.56 & 7.51 & $\mathrm{Si}$ & 6.02 & 6.04 & 6.02 & 6.04 & 6.02 & 6.03 & 6.00 \\
\hline 0.18 & Ti & 0.04 & 0.10 & Al & 4.02 & 4.00 & 4.03 & 4.00 & 4.01 & 3.99 & 4.05 \\
\hline 3.35 & Al & 8.17 & 7.80 & $\mathrm{Ti}$ & 0.01 & 0.01 & 0.00 & 0.00 & 0.00 & 0.01 & 0.00 \\
\hline 2.64 & $F \in 2 \div$ & 1.43 & 1.40 & $\mathrm{Fe} 2 \div$ & 4.16 & 4.03 & 3.99 & 3.99 & 3.99 & 3.97 & 4.14 \\
\hline 0.02 & $\mathrm{Mn}$ & 0.00 & 0.00 & Mn & & 0.71 & 0.71 & 0.70 & 0.69 & 0.73 & 0. 71 \\
\hline 2.25 & $\mathrm{Mg}$ & 1.74 & 2.09 & $\mathrm{Mg}$ & 0.35 & 0.35 & 0.35 & 0.36 & 0.35 & 0.37 & 0).35 \\
\hline 0.01 & $\mathrm{Ca}$ & 0.02 & 0.19 & $\mathrm{Ca}$ & 0.73 & 0.83 & 0.85 & 0.86 & 0.92 & 0.86 & 0.73 \\
\hline 0.02 & $\mathrm{Na}$ & 0.73 & 0.81 & $\mathrm{Na}$ & 0.01 & 0.01 & 0.02 & 0.01 & 0.00 & 0.00 & 0.01 \\
\hline 1.69 & $\mathrm{~K}$ & 0.00 & 0.01 & - & - & - & - & - & - & - & - \\
\hline 0.01 & $F$ & 0.17 & 0.19 & - & - & - & - & - & - & - & - \\
\hline 0.22 & $\mathrm{Cl}$ & 0.00 & 0.00 & - & - & - & - & - & - & - & - \\
\hline
\end{tabular}

15.82 Tota

\begin{tabular}{|c|c|c|c|c|c|c|c|c|c|}
\hline \multicolumn{10}{|c|}{695} \\
\hline $\mathrm{Cl}$ & 620 & 621 & $\mathrm{Cl}$ & 637 & $638^{\circ}$ & $\mathrm{Cl}$ & 812 & 813 & 814 \\
\hline$O=32$ & $\mathrm{PL}$ & PL & $\mathrm{O}=22$ & BT & $\mathrm{BT}$ & Atom $\%$ & PO & $\mathrm{PO}$ & $\mathrm{PO}$ \\
\hline $\mathrm{SiO}_{z}$ & 66.79 & 67.90 & $\mathrm{SiO}_{2}$ & 37.41 & 37.38 & $\mathrm{Fe}$ & 47.08 & 70.36 & 47.16 \\
\hline $\mathrm{Al}_{2} \mathrm{O}_{3}$ & 19.98 & 20.05 & $\mathrm{MO}_{2}$ & 1.50 & 1.72 & As & 0.02 & 1.84 & 0.01 \\
\hline $\mathrm{TiO}_{2}$ & 0.02 & 0.00 & $\mathrm{Al}_{2} \mathrm{O}_{3}$ & 16.76 & 17.14 & s & 52.82 & 27.60 & 52.75 \\
\hline $\mathrm{Fe}_{2} \mathrm{O}_{3}$ & 0.04 & 0.00 & $\mathrm{FeO}$ & 12.38 & 11.99 & $\mathrm{Co}$ & 0.00 & 0.00 & 0.00 \\
\hline $\mathrm{MnO}$ & 0.01 & 0.00 & MnO & 0.10 & 0.01 & $\mathrm{Cu}$ & 0.00 & 0.00 & 0.00 \\
\hline $\mathrm{MgO}$ & 0.00 & 0.00 & $\mathrm{MgO}$ & 16.43 & 15.78 & $\mathrm{Ni}$ & 0.08 & 0.20 & 0.08 \\
\hline $\mathrm{CaO}$ & 0.35 & 0.54 & $\mathrm{CaO}$ & 0.02 & 0.08 & $\mathrm{Au}$ & 0.00 & 0.00 & 0.00 \\
\hline $\mathrm{Na}_{2} \mathrm{O}$ & 11.33 & 11.41 & $\mathrm{Na}_{2} \mathrm{O}$ & 0.14 & 0.15 & - & - & - & - \\
\hline $\mathrm{K}_{2} \mathrm{O}$ & 0.04 & 0.03 & $\mathrm{~K}_{2} \mathrm{O}$ & 8.74 & 8.76 & - & - & - & - \\
\hline - & & . & $\mathrm{Cl}$ & 0.01 & 0.00 & - & - & - & - \\
\hline \multirow[t]{2}{*}{-} & - & - & $\mathrm{E}$ & 1.27 & 1.01 & - & . & - & - \\
\hline & & & $\mathrm{BaO}$ & 0.09 & 0.12 & - &. & - & - \\
\hline Toul & 98.55 & 99.93 & Total & 94.85 & 94.14 & Total & 100,00 & 100.00 & 100.00 \\
\hline $\mathrm{Si}$ & 18.85 & 11.88 & $\mathrm{Si}$ & 5.58 & 5.59 & $\mathrm{Wt} \%$ & & & \\
\hline Al & 4.18 & 4.13 & $\mathrm{Ti}$ & 0.17 & 0.19 & $\mathrm{Fe}$ & 60.54 & 1.15 & 60.43 \\
\hline$\Upsilon_{i}$ & 0.00 & 0.00 & Al & 2.95 & 3.02 & As & 0.04 & 0.04 & 0.01 \\
\hline $\mathrm{Fe} 3+$ & 0.01 & 0.00 & Fe2 & 1.55 & 1.50 & $\mathrm{~s}$ & 39.00 & 0.26 & 38.81 \\
\hline $\mathrm{Mn}$ & 0.00 & 0.00 & $\mathrm{Mn}$ & 0.01 & 0.00 & $\mathrm{Co}$ & 0.00 & 0.00 & 0.00 \\
\hline $\mathrm{Mg}$ & 0.00 & 0.00 & $\mathrm{Mg}$ & 3.66 & 3.52 & $\mathrm{Cu}$ & 0.00 & 0.00 & 0.00 \\
\hline $\mathrm{Ca}$ & 0.07 & 0.10 & $\mathrm{Ca}$ & 0.00 & 0.01 & $\mathrm{NI}$ & 0.11 & 0.00 & 0.11 \\
\hline $\mathrm{Na}$ & 3.90 & 3.87 & $\mathrm{Na}$ & 0.04 & 0.04 & Au & 0.00 & 0.00 & 0.00 \\
\hline K & 0.01 & $0.0 \mathrm{I}$ & $\mathrm{K}$ & 1.66 & 1.67 & - & - & - & - \\
\hline - & - & . & $\mathrm{Cl}$ & 0.00 & 0.00 & - & - & - & - \\
\hline - & - & - & F & 0.60 & 0.48 & - & - & - & - \\
\hline- & - & & $\mathrm{Ba}$ & 0.01 & 0.01 & & - & - & - \\
\hline Total & 20.01 & 19.99 & Total & 16.23 & 16.04 & Total & 99.68 & 1.45 & 99.36 \\
\hline
\end{tabular}




\begin{tabular}{|c|c|c|c|c|c|c|c|c|c|c|c|c|c|c|c|c|c|c|c|c|c|c|c|}
\hline $\begin{array}{ll}\mathrm{C} 2 \\
\end{array}$ & 639 & 640 & $\mathrm{C} 2$ & 723 & 724 & $\mathrm{C} 3$ & 622 & 623 & 624 & 625 & 626 & 627 & $\mathrm{C3}$ & 641 & 642 & 643 & 645 & 646 & $\mathrm{C4}$ & 629 & 630 & 631 & 632 \\
\hline $0=22$ & $\overline{\mathrm{BT}}$ & $\mathrm{BT}$ & $\mathrm{O}=3 \mathrm{I}$ & TUR & TURR & $\mathrm{O}=32$ & PL & $\mathrm{PL}$ & PL & PI & $\overline{\mathrm{PL}}$ & $\mathrm{PL}$ & $\mathrm{O}=22$ & BT & $\overline{\mathrm{BT}}$ & SE & BT & BT & $\mathrm{O}=32$ & $\mathrm{PL}$ & PI & PL & PI \\
\hline $\mathrm{SiO}_{2}$ & 38.40 & 37.70 & $\mathrm{SiO}_{2}$ & 35.92 & 35.83 & $\mathrm{SiO}_{2}$ & 66.44 & 66.25 & 65.66 & 66.92 & 67.02 & 67.66 & $\mathrm{SiO}_{2}$ & 37.55 & 38.12 & 44.56 & 38.13 & 39.27 & $\mathrm{SiO}_{2}$ & 59.02 & 66.38 & 68.53 & 68.61 \\
\hline $\mathrm{TiO}_{2}$ & 1.16 & 1.09 & $\mathrm{TiO}_{3}$ & 0.53 & 0.68 & $\mathrm{Al}_{2} \mathrm{O}_{3}$ & 19.92 & 20.66 & 20.42 & 19.75 & 19.58 & 19.68 & $\mathrm{TiO}_{2}^{-}$ & 1.29 & 1.21 & 0.51 & 1.47 & 1.22 & $\mathrm{Al}_{2} \mathrm{O}_{3}$ & 17.47 & 19.35 & 19.52 & 19.57 \\
\hline $\mathrm{AH}_{2} \mathrm{O}_{3}$ & 16.72 & 16.63 & $\mathrm{Al}_{2} \mathrm{O}_{3}$ & 31.70 & 32.32 & $\mathrm{TiO}_{2}$ & 0.01 & 0.00 & 0.00 & 0.00 & 0.11 & 0.00 & $\mathrm{Al}_{2} \mathrm{O}_{3}$ & 17.50 & 17.14 & 29.67 & 17.43 & 20.21 & $\mathrm{TiO}_{2}$ & 0.00 & 0.00 & 0.00 & 0.00 \\
\hline $\mathrm{FeO}$ & 12.51 & 12.82 & $\mathrm{FeO}$ & 8.23 & 7.56 & $\mathrm{Fe}_{2} \mathrm{O}_{3}$ & 0.02 & 0.02 & 0.05 & 0.05 & 0.02 & 0.00 & $\mathrm{FeO}$ & 11.35 & 12.27 & 4.27 & 11.17 & 10.99 & $\mathrm{Fe}_{2} \mathrm{O}_{3}$ & 1.15 & 0.01 & 0.06 & 0.02 \\
\hline $\mathrm{Mn}(\mathrm{l}$ & 0.03 & 0.08 & Mno & 0.04 & 0.00 & $\operatorname{Mn} O$ & 0.00 & 0.01 & 0.00 & 0.00 & 0.00 & 0.01 & $\mathrm{MnO}$ & 0.04 & 0.05 & 0.02 & 0.08 & 0.07 & Mno & 0.18 & 0.00 & 0.00 & 0.03 \\
\hline $\mathrm{MgO}$ & 15.91 & 16.00 & $\mathrm{MgC})$ & 6.13 & 6.09 & $\mathrm{MgO}$ & 0.01 & 0.00 & 0.00 & 0.04 & 0.00 & 0.00 & $\mathrm{MgO}$ & 15.45 & 15.73 & 4.20 & 15.96 & 12.86 & $\mathrm{MgO}$ & 1.60 & 0.01 & 0.00 & 0.00 \\
\hline $\mathrm{Sa}(\mathrm{O}$ & 0,00 & 0,00 & $(\mathrm{a})$ & 0.21 & 0.35 & $\mathrm{CaO}$ & 1.05 & 1.56 & 1.29 & 0.29 & 0.48 & 0.65 & $\mathrm{CaO}$ & 0.10 & 0.01 & 0.03 & 0.08 & 0.05 & $\mathrm{CaO}$ & 3.93 & 0.55 & 0.48 & 0.33 \\
\hline $\mathrm{Na}, \mathrm{b})$ & 0.14 & 0.11 & $\mathrm{Na}, \mathrm{C}$ & $2.2 i)$ & 2.19 & $\mathrm{~N}_{\mathrm{I}_{2}(\mathrm{O}}$ & 11.07 & 10.96 & 10.93 & 11.33 & 11.44 & 11.36 & $\mathrm{Na}_{2} \mathrm{O}$ & 0.13 & 0.14 & 0.38 & 0.13 & 0.16 & $\mathrm{Na}_{2} \mathrm{O}$ & 10.28 & 11.46 & 11.38 & 11.63 \\
\hline $\mathrm{K}_{2} \mathrm{O}$ & 9.11 & 8.98 & $\mathrm{~K}_{2} \mathrm{O}$ & 0.02 & 0.02 & $\mathrm{~K}_{2} \mathrm{O}$ & 0.05 & 0.07 & 0.08 & 0.33 & 0.07 & 0.02 & $\mathrm{~K}_{2} \mathrm{O}$ & 8.88 & 9.08 & 9.11 & 9.03 & 8.57 & $\mathrm{~K}_{2} \mathrm{O}$ & 0.02 & 0.04 & 0.05 & 0.04 \\
\hline $\mathrm{Cl}$ & 0.02 & 0.01 & $\mathrm{~F}$ & 0.30 & 0.38 & - & - & - & - & - & - & - & $\mathrm{Cl}$ & 0.01 & 0.01 & 0.01 & 0.01 & 0.01 & - & - & - & - & - \\
\hline $\begin{array}{c}F \\
\mathrm{BaO}\end{array}$ & 1.30 & 0.93 & $\mathrm{Cl}$ & 0.00 & 0.01 & - & - & - & - & - & - & - & $\mathrm{F}$ & 1.12 & 1.38 & 0.43 & 0.86 & 0.95 & - & - & - & . & - \\
\hline$\frac{\mathrm{BaO}}{\text { Total }}$ & 0.14 & 0.10 & & - & - & - & - & - & 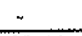 & & 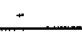 & & $\mathrm{BaO}$ & 0.08 & 0.22 & 0.48 & 0.23 & 0.22 & - & - & - & - & + \\
\hline$\frac{\text { Total }}{\mathrm{Si}}$ & 95.43 & 94.347 & otal & 85.27 & 85.22 & otal & 98.56 & 99.52 & 98.44 & 98.71 & 98.72 & $99.38 \mathrm{~T}$ & otai & 93.50 & 95.14 & 93.66 & 94.36 & 94.371 & Cotal & 93.65 & 97.79 & 100.02 & 100.23 \\
\hline $\begin{array}{l}\mathrm{Si} \\
\mathrm{Ti}\end{array}$ & 5.70 & 5.64 & $\mathrm{Si}$ & 7.57 & 7.53 & $\mathrm{Si}$ & 11.81 & 11.69 & 11.71 & 11.87 & 11.88 & 11.91 & $\mathrm{Si}$ & 5.64 & 5.66 & 6.18 & 5.65 & 5.75 & $\mathrm{Si}$ & 11.31 & 11.89 & 13.97 & 11.96 \\
\hline $\begin{array}{l}\mathrm{Ti} \\
\mathrm{Al}\end{array}$ & 0.13 & 0.12 & $\mathrm{Ti}$ & 0.08 & 0.11 & Al & 4.17 & 4.29 & 4.29 & 4.13 & 4.09 & 4.08 & $\mathrm{Ti}$ & 0.15 & 0.13 & 0.05 & 0.16 & 0.13 & $\mathrm{Al}$ & 3.95 & 4.08 & 4.02 & 4.02 \\
\hline $\begin{array}{c}\mathrm{Al} \\
\mathrm{F} e 2+\end{array}$ & 2.92 & 2.93 & $\mathrm{Al}$ & 7.87 & 8.01 & $\mathrm{Ti}_{\mathrm{i}}$ & 0.00 & 0.00 & 0.00 & 0.00 & 0.01 & 0.00 & $\mathrm{Al}$ & 3.10 & 3.00 & 4.85 & 3.04 & 3.49 & $\mathrm{Ti}$ & 0.00 & 0.00 & 0.00 & 0.00 \\
\hline $\begin{array}{c}\mathrm{Fe} 2+ \\
\mathrm{Mnn}\end{array}$ & 1.55 & 1.60 & $\mathrm{Fe} 2 \div$ & 1.45 & 1.33 & Fe3+ & 0.00 & 0.00 & 0.01 & 0.01 & 0.00 & 0.00 & $\mathrm{Fe} 2+$ & 1.43 & 1.52 & 0.49 & 1.38 & 1.35 & $\mathrm{Fe} 3+$ & 0.17 & 0.00 & 0.01 & 0.00 \\
\hline $\begin{array}{l}\mathrm{Mn} \\
\mathrm{Mg}\end{array}$ & 0.00 & 0.01 & $\mathrm{Mn}$ & 0.01 & 0.00 & Mn & 0.00 & 0.00 & 0.00 & 0.00 & 0.00 & 0.00 & $\mathrm{Mn}$ & 0.00 & 0.01 & 0.00 & 0.01 & 0.01 & $\mathrm{Mn}$ & 0.03 & 0.00 & 0.00 & 0.00 \\
\hline $\begin{array}{l}\mathrm{Mg} \\
\mathrm{Ca}\end{array}$ & 3.52 & 3.57 & $\mathrm{Mg}$ & 1.93 & 1.91 & Mg & 0.00 & 0.00 & 0.00 & 0.01 & 0.00 & 0.00 & $\mathrm{Mg}$ & 3.46 & 3.48 & 0.87 & 3.52 & 2.81 & $\mathrm{Mg}$ & 0.46 & 0.00 & 0.00 & 0.00 \\
\hline $\begin{array}{l}\mathrm{Ca} \\
\mathrm{Na}\end{array}$ & 0.00 & 0.00 & $\mathrm{Ca}$ & 0.05 & 0.03 & $\mathrm{Ca}$ & 0.20 & 0.29 & 0.25 & 0.06 & 0.09 & 0.12 & $\mathrm{Ca}$ & 0.02 & 0.00 & 0.00 & 0.01 & 0.01 & $\mathrm{Ca}$ & 0.81 & 0.10 & 0.09 & 0.06 \\
\hline $\begin{array}{l}\mathrm{Na} \\
\mathrm{K}\end{array}$ & 0.04 & 0.03 & $\mathrm{Na}$ & 0.90 & 0.89 & $\mathrm{Na}$ & 3.81 & 3.75 & 3.78 & 3.90 & 3.93 & 3.88 & $\mathrm{Na}$ & 0.04 & 0.04 & 0.10 & 0.04 & 0.05 & $\mathrm{Na}$ & 3.82 & 3.98 & 3.85 & 3.93 \\
\hline $\begin{array}{l}\mathrm{K} \\
\mathrm{Cl}\end{array}$ & 1.72 & 1.72 & $\mathrm{~K}$ & 0.00 & 0.00 & K & 0.01 & 0.02 & 0.02 & 0.08 & 0.02 & 0.00 & $\mathrm{~K}$ & 1.70 & 1.72 & 1.61 & 1.71 & 1.60 & $\mathrm{~K}$ & 0.00 & 0.01 & 0.01 & 0.01 \\
\hline $\begin{array}{l}\mathrm{Cl} \\
\mathrm{F}\end{array}$ & 0.00 & 0.00 & $E$ & 0.20 & 0.25 & - & - & - & - & - & - & - & $\mathrm{Cl}$ & 0.00 & 0.00 & 0.00 & 0.00 & 0.00 & $\sim$ & r & $\sim$ & - & - \\
\hline $\begin{array}{c}F \\
B_{3} \\
\end{array}$ & 0.61 & 0.44 & $\mathrm{Cl}$ & 0.00 & 0.00 & - & - & - & - & - & - & - & F & 0.53 & 0.65 & 0.19 & 0.40 & 0.44 & - & - & - & - & - \\
\hline $\mathrm{Ba}$ & $\frac{0.01}{162 t}$ & $\frac{0.01}{1608}$ & 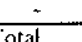 & $\overline{20.06}$ & 20.06 & fotal & $\frac{\overline{2}}{20.01}$ & $\overline{2005}$ & $\overline{20.05}$ & $\frac{\overline{2}}{20.04}$ & $\frac{-}{20.03}$ & & $\frac{\mathrm{Ba}}{\text { rotal }}$ & $\frac{0.00}{1607}$ & 0.01 & 0.03 & $\frac{0.01}{1505}$ & $\frac{0.01}{15.64}$ & Total & $\frac{*}{20.54}$ & $\frac{-}{20.06}$ & $\overline{19.95}$ & $\overline{19.99}$ \\
\hline
\end{tabular}

\begin{tabular}{|c|c|c|c|c|c|c|c|c|c|c|c|c|c|c|c|c|c|c|c|c|c|c|c|}
\hline $\mathrm{C} 4$ & 633 & 634 & 635 & 636 & $\mathrm{C4}$ & 647 & 648 & 649 & 650 & $\mathrm{C} 4$ & 706 & 707 & 708 & 709 & 710 & $\mathrm{C5}$ & 651 & 652 & $\mathrm{C6}$ & 653 & 654 & 655 & 656 \\
\hline $0=32$ & PL & $\mathrm{PL}$ & PL & $\mathrm{PL}$ & $\bar{O}=22$ & $\mathrm{BT}$ & BT & $\mathrm{BT}$ & BT & $0=6$ & $\overline{\mathrm{CAB}}$ & $\mathrm{CAB}$ & $\mathrm{CAB}$ & $\mathrm{CAB}$ & $\overline{\mathrm{CAB}}$ & $\mathrm{O}=22$ & SE & $\mathrm{SE}$ & $0=22$ & $\mathrm{BT}$ & $\mathrm{BT}$ & $\overline{B T}$ & $\overline{B T}$ \\
\hline $\mathrm{SiO}_{2}$ & 66.84 & 68.22 & 68.29 & 68.99 & $\mathrm{SiO}_{2}$ & 37.92 & 37.94 & 37.63 & 37.79 & $\mathrm{SiO}_{2}$ & 0.04 & 0.05 & 0.08 & 0.00 & 0.02 & $\mathrm{SiO}_{2}$ & 46.74 & 46.87 & $\mathrm{SiO}_{2}$ & 37.32 & 37.43 & 37.85 & 36.48 \\
\hline $\mathrm{Al}_{2} \mathrm{O}_{3}$ & 19.89 & 19.35 & 19.32 & 20.02 & $\mathrm{TiO}_{2}$ & 1.32 & 1.56 & 0.93 & 1.45 & $\mathrm{FeO}$ & 14.37 & 9.88 & 8.17 & 7.32 & 7.66 & $\mathrm{TiO}_{2}$ & 0.57 & 0.34 & $\mathrm{TiO}_{2}$ & 1.13 & 1.24 & 1.16 & 1.16 \\
\hline $\mathrm{TO}_{2}$ & 0.00 & 0.00 & 0.01 & 0.00 & $\mathrm{At}_{2} \mathrm{O}_{3}$ & 16.76 & 17.56 & 16.22 & 17.29 & $\mathrm{MnO}$ & 0.14 & 0.52 & 0.87 & 0.83 & 0.84 & $\mathrm{Al}_{2} \mathrm{O}_{3}$ & 32.35 & 32.29 & $\mathrm{Al}_{2} \mathrm{O}_{3}$ & 17.34 & 17.04 & 16.94 & 17.05 \\
\hline $\mathrm{Fe}_{2} \mathrm{O}_{3}$ & 0.02 & 0.00 & 0.03 & 0.11 & FeO & 12.52 & 12.05 & 11.78 & 11.82 & $\mathrm{MgO}$ & 11.87 & 15.00 & 16.06 & 16.25 & 15.95 & $\mathrm{FeO}$ & 1.08 & 1.32 & $\mathrm{FeO}$ & 12.81 & 12.67 & 12.45 & 12.39 \\
\hline Mno & 0.00 & 0.02 & 0.01 & 0.00 & $\mathrm{MnO}$ & 0.10 & 0.05 & 0.08 & 0.08 & $\mathrm{CaO}$ & 26.62 & 26.81 & 28.27 & 28.39 & 28.12 & $\mathrm{MnO}$ & 0.00 & 0.02 & $\mathrm{MnO}$ & 0.05 & 0.01 & 0.05 & 0.03 \\
\hline $\mathrm{MgO}$ & 0.00 & 0.01 & 0.02 & 0.00 & $\mathrm{MgO}$ & 15.73 & 15.61 & 17.12 & 16.14 & - & - & - & - & - & - & $\mathrm{MgO}$ & 1.76 & 1.75 & $\mathrm{MgO}$ & 15.34 & 16.06 & 16.18 & 15.95 \\
\hline $\mathrm{CaO}$ & 0.97 & 3.41 & 0.21 & 0.60 & $\mathrm{CaO}$ & 0.00 & 0.01 & 0.06 & 0.00 & - & - & - & - & - & - & $\mathrm{CaO}$ & 0.01 & 0.00 & $\mathrm{CaO}$ & 0.21 & 0.07 & 0.00 & 0.01 \\
\hline $\mathrm{Na}_{2} \mathrm{O}$ & 11.09 & 8.16 & 11.38 & 11.01 & $\mathrm{Na}_{2} \mathrm{O}$ & 0.10 & 0.14 & 0.13 & 0.16 & . & - & - & - & - & - & $\mathrm{Na}_{2} \mathrm{O}$ & 0.46 & 0.38 & $\mathrm{Na}_{2} \mathrm{O}$ & 0.10 & 0.13 & 0.12 & 0.10 \\
\hline $\mathrm{K}_{2} \mathrm{O}$ & 0.05 & 0.05 & 0.03 & 0.07 & $\mathrm{~K}_{2} \mathrm{O}$ & 9.36 & 9.24 & 8.98 & 9.07 & . & - & - & - & - & - & $\mathrm{K}_{2} \mathrm{O}$ & 9.87 & 9.75 & $\mathrm{~K}_{2} \mathrm{O}$ & 8.50 & 8.77 & 9.13 & 8.57 \\
\hline - & - & - & - & - & $\mathrm{Cl}$ & $0.0 \mathrm{I}$ & 0.03 & 0.02 & 0.03 & - & - & - & - & . & - & $\mathrm{Cl}$ & 0.00 & 0.02 & $\mathrm{Cl}$ & 0.01 & 0.01 & 0.02 & 0.01 \\
\hline - & - & - & - & - & $\mathrm{F}$ & 1.27 & 0.95 & 1.35 & 1.18 & - & - & - & - & - & - & $F$ & 0.24 & $0.2 \mathrm{I}$ & $F$ & 1.07 & 1.21 & 1.03 & 1.00 \\
\hline & & & & & $\mathrm{BaO}$ & 0.14 & 0.20 & 0.01 & 0.15 & + & + & - & - & - & & $\mathrm{BaO}$ & 0.30 & 0.45 & $\mathrm{BaO}$ & 0.23 & 0.02 & 0.19 & 0.02 \\
\hline Tot3l & 98.85 & 99.21 & 99.30 & 100.82 & Total & 95.21 & 95.13 & 94.29 & 95.00 & Cotal & 53.03 & 52.25 & 53.45 & 52.79 & \multicolumn{2}{|c|}{52.59 Total } & 93.37 & \multicolumn{2}{|c|}{92.94 Total } & 94.09 & 94.62 & 95.12 & 92.74 \\
\hline $\mathrm{Si}$ & 11.84 & 11.98 & 12.00 & 11.94 & $\mathrm{Si}$ & 5.65 & 5.61 & 5.64 & 5.61 & $\mathrm{Si}$ & 0.00 & 0.00 & 0.01 & 0.00 & 0.00 & $\mathrm{Si}$ & 6.35 & 6.37 & $\mathrm{Si}$ & 5.61 & 5.59 & 5.63 & 5.55 \\
\hline Al & 4.15 & 4.00 & 4.00 & 4.08 & $\mathrm{Ti}$ & 0.15 & 0.17 & 0.10 & 0.16 & $F e 2+$ & 1.23 & 0.83 & 0.66 & 0.60 & 0.63 & $\mathrm{Ti}$ & 0.06 & 0.03 & $\mathrm{ni}$ & 0.13 & 0.14 & 0.13 & 0.13 \\
\hline $\mathrm{Ti}$ & 0.00 & 0.00 & 0.00 & 0.00 & $A$ & 2.94 & 3.06 & 2.87 & 3.02 & Mn & 0.01 & 0.04 & 0.07 & 0.07 & 0.07 & Al & 5.18 & 5.17 & A! & 3.07 & 3.00 & 2.97 & 3.06 \\
\hline $\mathrm{Fe} 3+$ & 0.00 & 0.00 & $0.0 \%)$ & 0,01 & $\operatorname{lic} 2+$ & 1.56 & 1.49 & 1.78 & 1.47 & $\mathrm{Mg}$ & 1.82 & 2.24 & 2.32 & 2.37 & 2.34 & $F=2+$ & 0.12 & 0.15 & $\mathrm{Fe} 2$ & 1.61 & 1.58 & 1.55 & 1.58 \\
\hline Mn & 0.00 & 0.60 & 0.00 & 0.00 & $\mathrm{Mn}$ & 0.01 & 0.01 & 0.01 & 0.01 & $\mathrm{Ca}$ & 2.93 & 2.88 & 2.93 & 2.97 & 2.96 & $\mathrm{Mn}$ & 0.00 & 0.00 & $M n$ & 0.01 & 0.00 & 0.01 & 0.00 \\
\hline Mg & 0.00 & 0.00 & 0.00 & 0.00 & $\mathrm{Mg}$ & 3.50 & 3.44 & 3.83 & 3.57 & - & - & - & - & - & - & $\mathrm{Mg}$ & 0.36 & 0.35 & $\mathrm{Mg}$ & 3.44 & 3.58 & 3.59 & 3.62 \\
\hline $\mathrm{Ca}$ & 0.18 & 0.64 & 0.04 & 0.11 & $\mathrm{Ca}$ & 0.00 & 0.00 & 0.01 & 0.00 & - & - & - & - & - & - & $\mathrm{Ca}$ & 0.00 & 0.00 & $\mathrm{Ca}$ & 0.03 & 0.01 & 0.00 & 0.00 \\
\hline $\mathrm{Na}$ & 3.81 & 2.78 & 3.88 & 3.70 & $\mathrm{Na}$ & 0.03 & 0.04 & 0.04 & 0.05 & - & . & - & - & - & - & $\mathrm{Na}$ & 0.12 & 0.10 & Na & 0.03 & 0.04 & 0.03 & 0.03 \\
\hline $\mathrm{k}$ & 0.01 & 0.01 & 0.01 & 0.02 & $\mathrm{k}$ & 1.78 & 1.74 & 1.72 & 1.72 & - & - & - & - & - & - & $K$ & 1.71 & 1.69 & $\mathrm{~K}$ & 1.63 & 1.67 & 1.73 & 1.66 \\
\hline- & - & - & - & - & $\mathrm{Cl}$ & 0.00 & 0.01 & 0.00 & 0.01 & - & - & - & - & - & - & $\mathrm{Cl}$ & 0.00 & 0.00 & $\mathrm{Cl}$ & 0.00 & 0.00 & 0.00 & 0.00 \\
\hline - & . & - & - & - & $F$ & 0.60 & 0.44 & 0.64 & 0.55 & . & - & - & - & - & . & $F$ & 0.10 & 0.09 & $F$ & 0.51 & 0.57 & 0.48 & 0.48 \\
\hline$\therefore$ & - & - & - & - & $\mathrm{Ba}$ & 0.01 & 0.01 & 0.00 & 0.01 &. & - & - & - & - & 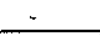 & $\mathrm{Ba}$ & 0.02 & 0.02 & $\mathrm{Ba}$ & 0.01 & 0.00 & 0.01 & 0.00 \\
\hline & 19.99 & 19.42 & 19.94 & 19.86 & rotal & 16.23 & 16.03 & 16.34 & 16.16 & Cotal & 6.00 & 6.00 & 5.99 & 6.00 & 6.001 & rotal & 14.02 & 14,001 & Total & 16.07 & 16.19 & 16.13 & 16.12 \\
\hline
\end{tabular}




\begin{tabular}{|c|c|c|c|c|c|c|c|c|c|c|c|c|c|c|c|c|c|c|c|c|c|c|c|}
\hline \multicolumn{3}{|c|}{ IV.22.17695 } & \multicolumn{20}{|c|}{05} & \\
\hline $\mathrm{C6}$ & 657 & & $\mathrm{C} 1$ & 605 & 616 & 617 & 618 & 619 & $\mathrm{Cl}$ & 698 & $\mathrm{C} 2$ & 699 & 670 & 671 & $\mathrm{C} 2$ & 808 & 809 & $\mathrm{C} 2$ & 704 & $\mathrm{C}_{3}$ & 702 & 703 & \\
\hline$O=24$ & $\mathrm{BT}$ & & $0=32$ & $\mathrm{PL}$ & $\mathrm{PL}$ & $\mathrm{PL}$ & $\mathrm{PL}$ & P! & $0=22$ & SE & $0=22$ & SE & SE & SE & Atom\% & PO & $\mathrm{PO}$ & $0=6$ & $C A B$ & $0=22$ & SE & $\overline{B T}$ & \\
\hline $\mathrm{SiO}_{2}$ & 0.04 & & $\mathrm{SiO}_{2}$ & 67.97 & 67.60 & 67.53 & 67.15 & 61.26 & $\mathrm{SiO}_{2}$ & 45.97 & $\mathrm{SiO}_{2}$ & 45.13 & 45.94 & 46.49 & Fe & 47.14 & 46.85 & $\mathrm{SiO}_{z}$ & 0.00 & $\mathrm{SiO}_{2}$ & 46.36 & 38.64 & \\
\hline $\mathrm{Al}_{2} \mathrm{O}_{3}$ & 0.00 & & $\mathrm{Al}_{2} \mathrm{O}_{3}$ & 19.50 & 19.52 & 19.29 & 19.28 & 22.47 & $\mathrm{THO}_{2}$ & 0.58 & $\mathrm{TiO}_{2}^{-}$ & 0.58 & 0.32 & 0.47 & As & 0.01 & 0.01 & FeO & 3.63 & $\mathrm{TO}_{2}$ & 0.36 & 1.29 & \\
\hline $\mathrm{TiO}_{2}$ & 0.00 & & $\mathrm{TiO}_{2}$ & 0.04 & 0.00 & 0.02 & 0.00 & 0.00 & $\mathrm{AH}_{2} \mathrm{O}_{3}$ & 32.13 & $\mathrm{Al}_{2} \mathrm{O}_{3}$ & 32.16 & 32.51 & 32.39 & $\mathrm{~s}$ & 52.77 & 53.07 & Mro & 0.55 & $\mathrm{~A}_{2} \mathrm{O}_{3}$ & 32.63 & 16.87 & \\
\hline FeO & 0.08 & & $\mathrm{Fe}_{2} \mathrm{O}_{3}$ & 0.01 & 0.01 & 0.00 & 0.00 & 0.66 & Feo & 0.87 & $\mathrm{FeO}$ & 2.78 & 1.62 & 0.91 & $\mathrm{Co}_{0}$ & 0.00 & 0.00 & $\mathrm{MgO}$ & 18.91 & $\mathrm{FeO}$ & 0.94 & 8.95 & \\
\hline Mno & 0.02 & & $\mathrm{MnO}$ & 0.00 & 0.01 & 0.01 & 0.04 & 0.01 & MnO & 0.01 & $\mathrm{MnO}$ & 0.00 & 0.01 & 0.00 & $\mathrm{Cu}$ & 0.00 & 0.00 & $\mathrm{CaO}$ & 29.54 & Mno & 0.00 & 0.05 & \\
\hline $\mathrm{MgO}$ & 0.00 & & $\mathrm{MgO}$ & $0.0 \mathrm{I}$ & 0.01 & 0.00 & 0.00 & 0.39 & $\mathrm{MgO}$ & 1.78 & $\mathrm{MgO}$ & 1.71 & 1.72 & 1.74 & $\mathrm{Ni}$ & 0.09 & 0.07 & - & - & $\mathrm{MgO}$ & 1.70 & 18.11 & \\
\hline $\mathrm{CaO}$ & 51.23 & & $\mathrm{CaO}$ & 0.20 & 0.20 & 0.17 & 0.22 & 3.81 & $\mathrm{CaO}$ & 0.00 & $\mathrm{CaO}$ & 0.01 & 0.00 & 0.00 & $\mathrm{Au}$ & 0.00 & 0.00 & - & - & $\mathrm{CaO}$ & 0.00 & 0.00 & \\
\hline $\mathrm{Na}_{2} \mathrm{O}$ & 0.05 & & $\mathrm{Na}_{2} \mathrm{O}$ & 11.60 & 11.68 & 11.46 & 11.58 & 8.88 & $\mathrm{Na}_{2} \mathrm{O}$ & 0.49 & $\mathrm{Na}_{2} \mathrm{O}$ & 0.52 & 0.57 & 0.47 & - & - & - & - & - & $\mathrm{Ni}_{2} \mathrm{O}$ & 0.51 & 0.15 & \\
\hline $\mathrm{Cr}_{2} \mathrm{O}_{3}$ & 0.00 & & $\mathrm{~K}_{2} \mathrm{O}$ & 0.07 & 0.04 & 0.05 & 0.05 & 0.07 & $\mathrm{~K}_{2} \mathrm{O}$ & 9.97 & $\mathrm{~K}_{2} \mathrm{O}$ & 9.51 & 9.68 & 10.11 & - & - & - & - & - & $\mathrm{K}_{2} \mathrm{O}$ & 10.16 & 9.33 & \\
\hline $\mathrm{Y}_{2} \mathrm{O}_{3}$ & 0.13 & & - & - & - & - & - & - & $\mathrm{Cl}$ & 0.00 & $\mathrm{Cl}$ & 0.01 & 0.00 & 0.00 & - & - & . & - & - & $\mathrm{Cl}$ & 0.00 & 0.00 & \\
\hline $\mathrm{BaO}$ & 0.09 & & - & - & - & - & . & - & $\mathrm{F}$ & 0.09 & $F$ & 0.22 & 0.19 & 0.21 & - & - & - & - & - & $F$ & 0.20 & 1.63 & \\
\hline- & & & & & & & & & (BaC) & 0.68 & $3 \mathrm{aO}$ & 0.60 & 0.69 & 0.29 & - & - & & - & - & $\mathrm{BaO}$ & 0.60 & 0.22 & \\
\hline Total & 51.63 & & Total & 99.40 & 99.07 & 98.52 & 98.31 & 97.55 & Total & 92.58 & Total & 93.21 & 92.56 & 93.08 & Total & 100.00 & $100.00 \mathrm{I}$ & Total & 52.63 & Tota! & 93.46 & 95.03 & \\
\hline $\mathrm{Si}$ & 0.02 & & $\mathrm{Si}$ & 11.95 & 11.93 & 11.97 & 11.94 & 11.12 & $\mathrm{Si}$ & 6.32 & Si & 6.22 & 6.29 & 6.34 & $\mathrm{~W} \% \%$ & & & $\mathrm{Si}$ & 0.00 & $\mathrm{Si}$ & 6.32 & 5.68 & \\
\hline Al & 0.00 & & Al & 4.04 & 4.06 & 4.03 & 4.04 & 4.81 & $\mathrm{Ti}$ & 0.06 & $\mathrm{Ti}_{\mathrm{i}}$ & 0.06 & 0.03 & 0.05 & $\mathrm{Fe}$ & 60.14 & 59.96 & $\mathrm{Fe} 2+$ & 0.29 & $\mathrm{Ti}$ & 0.04 & 0.14 & \\
\hline $\mathrm{Ti}$ & 0.00 & & $\Upsilon_{i}$ & 0.01 & 0.00 & 0.00 & 0.00 & 0.00 & All & 5.20 & Al & 5.22 & 5.24 & 5.21 & As & 0.02 & 0.02 & $\mathrm{Mn}$ & 0.04 & $\mathrm{~A}$ & 5.24 & 2.92 & \\
\hline $\mathrm{Fe} 2+$ & 0.03 & & $\mathrm{Fe} 3+$ & 0.00 & 0.00 & 0.00 & 0.00 & 0.09 & $\mathrm{~F} \in 27$ & 0.10 & $F \in 2 \tau$ & 0.32 & 0.19 & 0.10 & $\mathrm{~s}$ & 38.65 & 39.00 & $\mathrm{Mg}$ & 2.67 & $\mathrm{Fe} 2$ & 0.11 & 1.10 & \\
\hline $\mathrm{Mn}$ & 0.01 & & $\mathrm{Mn}$ & 0.00 & 0.00 & 0.00 & 0.01 & 0.00 & $\mathrm{Mn}$ & 0.00 & $\mathrm{Mn}$ & 0.00 & 0.00 & 0.00 & $\mathrm{Co}$ & 0.00 & 0.00 & $\mathrm{Ca}$ & 3.00 & $\mathrm{Mn}$ & 0.00 & 0.01 & \\
\hline $\mathrm{Mg}$ & 0.00 & & $\mathrm{Mg}$ & 0.00 & 0.00 & 0.00 & 0.00 & 0.10 & $\mathrm{Mg}$ & 0.37 & $\mathrm{Mg}$ & 0.35 & 0.35 & 0.35 & $\mathrm{Cu}$ & 0.00 & 0.00 & - & - & $\mathrm{Mg}$ & 0.35 & 3.97 & \\
\hline $\mathrm{Ca}$ & 23.85 & & $\mathrm{Ca}$ & 0.04 & 0.04 & 0.03 & 0.04 & 0.74 & $\mathrm{Ca}$ & 0.00 & $\mathrm{Ca}$ & 0.00 & 0.00 & 0.00 & $\mathrm{Ni}$ & 0.12 & 0.10 & - & - & $\mathrm{Ca}$ & 0.00 & 0.00 & \\
\hline $\mathrm{Na}$ & 0.04 & & $\mathrm{Na}$ & 3.95 & 4.00 & 3.94 & 3.99 & 3.13 & $\mathrm{Na}$ & 0.13 & $\mathrm{Na}$ & 0.14 & 0.15 & 0.12 & Au & 0.00 & 0.00 & - & - & $\mathrm{Na}$ & 0.14 & 0.04 & \\
\hline $\mathrm{Cr}$ & 0.00 & & $\mathrm{~K}$ & 0.02 & 0.01 & 0.01 & 0.01 & 0.02 & $\mathrm{k}$ & 1.75 & $\mathrm{~K}$ & 1.67 & 1.69 & 1.76 & - & $\sim$ & - & . & - & k & 1.77 & 1.75 & \\
\hline$Y$ & 0.03 & & - & - & - & - & - & - & $\mathrm{Cl}$ & 0.00 & $\mathrm{Cl}$ & 0.00 & 0.00 & 0.00 & - & - & - & - & - & $\mathrm{Cl}$ & 0.00 & 0.00 & \\
\hline $\mathrm{Ba}$ & 0.02 & & - & - & - & - & . & - & $\mathrm{F}$ & 0.04 & $\xi$ & 0.09 & 0.08 & 0.09 & - & - & - & - & - & $F$ & 0.08 & 0.76 & \\
\hline & & & - & - & - & - &. & - & $\mathrm{Ba}$ & 0.04 & $\mathrm{Ba}$ & 0.03 & 0.04 & 0.02 & - & & & - & - & $B a$ & 0.03 & 0.01 & \\
\hline Total & 23.99 & & Total & 20.01 & 20.04 & 19.99 & 20.04 & 20.00 & Total & $44.00 ?$ & Total & 14.11 & 14.06 & 14.04 & Total & 98.92 & 99.071 & Total & 6.00 & Total & 14.06 & 16.38 & \\
\hline WV-22-19 & & & & & & & & ORPOI & $V-G a k$ & & & & & & & & & & & & & & \\
\hline $\mathrm{C3}$ & 705 & $\mathrm{C} 3$ & 725 & C3 & 810 & 811 & & $\mathrm{Cl}$ & 333 & 334 & 335 & 336 & 337 & 338 & $\mathrm{C} 2$ & 342 & 340 & 341 & $\mathrm{C} 2$ & 372 & $\mathrm{C} 3$ & 343 & 350 \\
\hline $0=6$ & $\mathrm{CAB}$ & $O=22$ & $\mathrm{SE}$ & Atom $\%$ & 90 & MAG? & & $0=22$ & BT & $\mathrm{BT}$ & $\overline{B T}$ & BT & $\mathrm{BT}$ & BT & $\mathrm{O}=22$ & BT & SE & $\mathrm{SE}$ & $\mathrm{O}=31$ & TUR & $0=\underline{22}$ & SE & $\mathrm{SE}$ \\
\hline $\mathrm{SiO}_{2}$ & 0.00 & $\mathrm{SiO}_{2}$ & 45.30 & $F_{v}$ & 46.82 & 90.06 & & $\mathrm{SiO}_{2}$ & 37.50 & 37.73 & 36.90 & 36.73 & 36.81 & 34.47 & $\mathrm{SiO}_{2}$ & 36.71 & 45.56 & 46.39 & $\mathrm{SiO}_{2}$ & 40.59 & $\mathrm{SiO}_{2}$ & 46.64 & 47.62 \\
\hline $\mathrm{FeO}$ & 6.57 & $\mathrm{TiO} \mathrm{O}_{2}$ & 0.37 & As & 0.01 & 3.09 & & $\mathrm{TO}_{2}$ & 1.65 & $1.6 \mathrm{l}$ & 1.55 & 1.73 & 1.58 & 3.65 & $\mathrm{TiO}_{2}$ & 1.55 & 0.81 & 0.51 & $\mathrm{TiO}_{2}$ & 0.05 & $\mathrm{TiO}_{2}$ & 0.35 & 0.25 \\
\hline $\mathrm{MnO}$ & 0.85 & $\mathrm{Al}_{2} \mathrm{O}_{3}$ & 32.78 & $S$ & 53.13 & 5.16 & & $\mathrm{Al}_{2} \mathrm{O}_{3}$ & 17.58 & 17.31 & 17.15 & 18.04 & 17.86 & 17.39 & $\mathrm{Al}_{2} \mathrm{O}_{3}$ & 17.99 & 34.95 & 34.91 & $\mathrm{Al}_{2} \mathrm{O}_{3}$ & 32.44 & $\mathrm{~A}_{2} \mathrm{O}_{3}$ & 35.98 & 35.47 \\
\hline $\mathrm{MgO}$ & 16.85 & $\mathrm{EOO}$ & 0.96 & Co & 0.00 & 0.00 & & FeO & 15.03 & 14.39 & 15.12 & 15.49 & 15.11 & 17.33 & FeO & 14.96 & 1.51 & 1.39 & $\mathrm{FeO}$ & 5.85 & FeO & 1.21 & 1.20 \\
\hline $\mathrm{CaO}$ & 27.79 & $\mathrm{MnO}$ & 0.00 & $\mathrm{Cu}$ & 0.00 & 0.32 & & Mno & 0.08 & 0.13 & 0.13 & 0.13 & 0.09 & 0.11 & $\mathrm{MnO}$ & 0.06 & 0.00 & 0.01 & $\mathrm{MnO}$ & 0.04 & Mno & 0.03 & 0.00 \\
\hline - & - & $\mathrm{MgO}$ & 1.72 & $\mathrm{Ni}$ & 0.04 & 0.00 & & $\mathrm{MgO}$ & 13.80 & 14.19 & 14.52 & 14.15 & 14.22 & 14.56 & $\mathrm{MgO}$ & 13.74 & 1.50 & 1.66 & $\mathrm{MgO}$ & 6.36 & $\mathrm{MgO}$ & 1.35 & 1.56 \\
\hline - & - & $\mathrm{CaO}$ & 0.00 & All & 0.00 & 1.37 & & $\mathrm{CaO}$ & 0.00 & 0.00 & 0.01 & 0.00 & 0.00 & 0.02 & $\mathrm{CaO}$ & 0.00 & 0.00 & 0.00 & $\mathrm{CaO}$ & 0.07 & $\mathrm{CaO}$ & 0.00 & 0.00 \\
\hline . & - & $\mathrm{Na}_{2} \mathrm{O}$ & 0.43 & - & - & - & & $\mathrm{Na}_{2} \mathrm{O}$ & 0.06 & 0.07 & 0.05 & 0.06 & 0.06 & 0.05 & $\mathrm{Na}_{2} \mathrm{O}$ & 0.07 & 0.20 & 0.27 & $\mathrm{Na}_{2} \mathrm{O}$ & 1.79 & $\mathrm{Na}_{2} \mathrm{O}$ & 0.17 & 0.22 \\
\hline - & - & $\mathrm{K}_{2} \mathrm{O}$ & 10.38 & . & - & - & & $\mathrm{K}_{2} \mathrm{O}$ & 9.08 & 8.88 & 8.91 & 8.47 & 8.31 & 6.90 & $\mathrm{~K}_{2} \mathrm{O}$ & 8.86 & 9.16 & 8.73 & $\mathrm{~K}_{2} \mathrm{O}$ & 0.04 & $\mathrm{~K}_{2} \mathrm{O}$ & 8.78 & 9.07 \\
\hline - & - & $\mathrm{F}$ & 0.30 & - & - & - & & $\mathrm{Cl}$ & 0.03 & 0.03 & 0.03 & 0.01 & 0.00 & 0.02 & $\mathrm{Cl}$ & 0.01 & 0.02 & 0.00 & $\vec{F}$ & 0.40 & $\mathrm{Cl}$ & 0.00 & 0.00 \\
\hline - & - & $\mathrm{Cl}$ & 0.01 & - & - & - & & $\mathrm{F}$ & 0.72 & 0.86 & 0.95 & 0.92 & 0.94 & 0.73 & $F$ & 1.13 & 0.15 & 0.00 & - & - & $\mathrm{F}$ & 0.21 & 0.36 \\
\hline - & - & - & - & - & - & - & & $\mathrm{BaO}$ & 0.52 & 0.38 & 0.41 & 0.61 & 0.45 & 0.26 & $\mathrm{BaO}$ & 0.64 & 1.76 & 1.45 & . & - & $\mathrm{BaO}$ & 0.99 & 0.80 \\
\hline Total & 52.067 & Total & 92.24 & Total & 100.00 & 100.00 & & rotal & 96.03 & 95.97 & 95.71 & 96.33 & 95.43 & 93.51 & Total & 95.71 & 95.62 & 95.32 & Total & 87.63 & Total & 95.72 & 96.54 \\
\hline $\mathrm{Si}$ & 0.00 & $\mathrm{Si}$ & & $\overline{W t} \%$ & & & & $\mathrm{Si}$ & 5.58 & 5.59 & 5.53 & 5.47 & 5.51 & 5.30 & $\mathrm{Si}$ & 5.51 & 6.10 & 6.17 & $\mathrm{Si}$ & 8.13 & $\mathrm{Si}$ & 6.16 & 6.24 \\
\hline $\mathrm{Fe} 2 \div$ & 0.54 & $\mathrm{Ti}$ & & Fe & 59.74 & 0.58 & & $\mathrm{Ti}$ & 0.18 & 0.18 & 0.17 & 0.19 & 0.18 & 0.19 & $\mathrm{Ti}$ & 0.18 & 0.08 & 0.05 & Ti & 0.01 & $\mathrm{Ti}$ & 0.04 & 0.02 \\
\hline $\mathrm{Mn}$ & 0.07 & $\mathrm{Al}$ & & As & 0.02 & 0.03 & & $\mathrm{Al}$ & 3.08 & 3.09 & 3.03 & 3.17 & 3.15 & 3.15 & Al & 3.18 & 5.51 & 5.48 & $\mathrm{Al}$ & 7.65 & Al & 5.60 & 5.48 \\
\hline $\mathrm{Mg}$ & 2.47 & $\mathrm{Fe} 2 \div$ & & $\mathrm{s}$ & 38.92 & 0.02 & & $\mathrm{~F} \in 2$ & 1.87 & 1.78 & 1.90 & 1.93 & 1.89 & 2.23 & $\mathrm{~F}: 2+$ & 1.88 & 0.17 & 0.16 & $\mathrm{Fe} 2+$ & 0.98 & $\mathrm{~F} \in 2$ & 0.13 & 0.13 \\
\hline $\mathrm{Ca}$ & 2.92 & $\mathrm{Mn}$ & & Co & 0.00 & 0.00 & & $\mathrm{Mn}$ & 0.01 & 0.02 & 0.02 & 0.02 & 0.01 & 0.01 & Mn & 0.01 & 0.00 & 0.00 & $\mathrm{Mn}$ & 0.01 & $\mathrm{Mn}$ & 0.00 & 0.00 \\
\hline - & $\cdot$ & $\mathrm{Mg}$ & & $\mathrm{Cu}$ & 0.00 & 0.00 & & $\mathrm{Mg}$ & 3.06 & 3.14 & 3.25 & 3.14 & 3.17 & 3.34 & $\mathrm{Mg}$ & 3.07 & 0.30 & 0.33 & $\mathrm{Mg}$ & 1.90 & $\mathrm{Mg}$ & 0.27 & 0.30 \\
\hline - & - & $\mathrm{Ca}$ & & $\mathrm{Ni}$ & 0.06 & 0.00 & & $\mathrm{Ca}$ & 0.00 & 0.00 & 0.00 & 0.00 & 0.00 & 0.00 & $\mathrm{Ca}$ & 0.00 & 0.00 & 0.00 & $\mathrm{Ca}$ & 0.02 & $\mathrm{Ca}$ & 0.00 & 0.00 \\
\hline - & - & $\mathrm{Na}$ & & $\mathrm{Au}$ & 0.00 & 0.03 & & $\mathrm{Na}$ & 0.02 & 0.02 & 0.01 & 0.02 & 0.02 & 0.02 & $\mathrm{Na}$ & 0.02 & 0.05 & 0.07 & $\mathrm{Na}$ & 0.70 & $\mathrm{Na}$ & 0.04 & 0.06 \\
\hline - & - & $\kappa$ & & - & $\cdot$ & . & & $\mathbb{N}$ & 1.72 & 3.68 & 1.70 & 1.61 & 1.59 & 1.35 & $\dddot{\mathrm{K}}$ & 1.70 & 1.56 & 1.48 & $\mathrm{~K}$ & 0.01 & $\mathrm{~K}$ & 1.48 & 1.51 \\
\hline - & - & : & & - & . & . & & 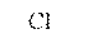 & (0.01 & 0.01 & 0.01 & 0.00 & 0.000 & $0.0 \mathrm{I}$ & $c$ & 0.00 & 0.00 & 0.00 & $\mathrm{~F}$ & 0.25 & $\mathrm{Cl}$ & 0.00 & 0.00 \\
\hline - & . & $\mathrm{Cl}$ & & - & - & - & & $n$ & 6.34 & 0.40 & 0.45 & 0.43 & 0.44 & 0.36 & $E$ & 0.54 & 0.07 & 0.00 & - & - & $F$ & 0.09 & 0.15 \\
\hline- & - & - & & - & - & - & & $\mathrm{Ba}$ & 0.03 & 0.02 & 0.02 & 0.04 & 0.03 & 0.02 & $\mathrm{~B} 3 \mathrm{3}$ & 0.04 & 0.09 & 0.08 & - & - & $\mathrm{Ba}$ & 0.05 & 0.04 \\
\hline Total & 6.6007 & Total & 0.60 & Total & 98.74 & 0.65 & & Cotal & 15.91 & 15.94 & 16.10 & 16.00 & 15.98 & 15.98 & Total & 16.12 & 13.94 & 13.81 & Total & 19.64 & Total & 13.86 & 13.93 \\
\hline
\end{tabular}


CORPON N - Galeria

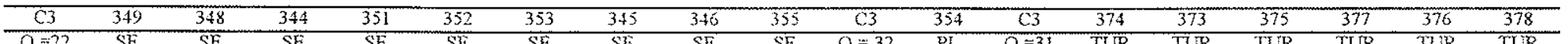

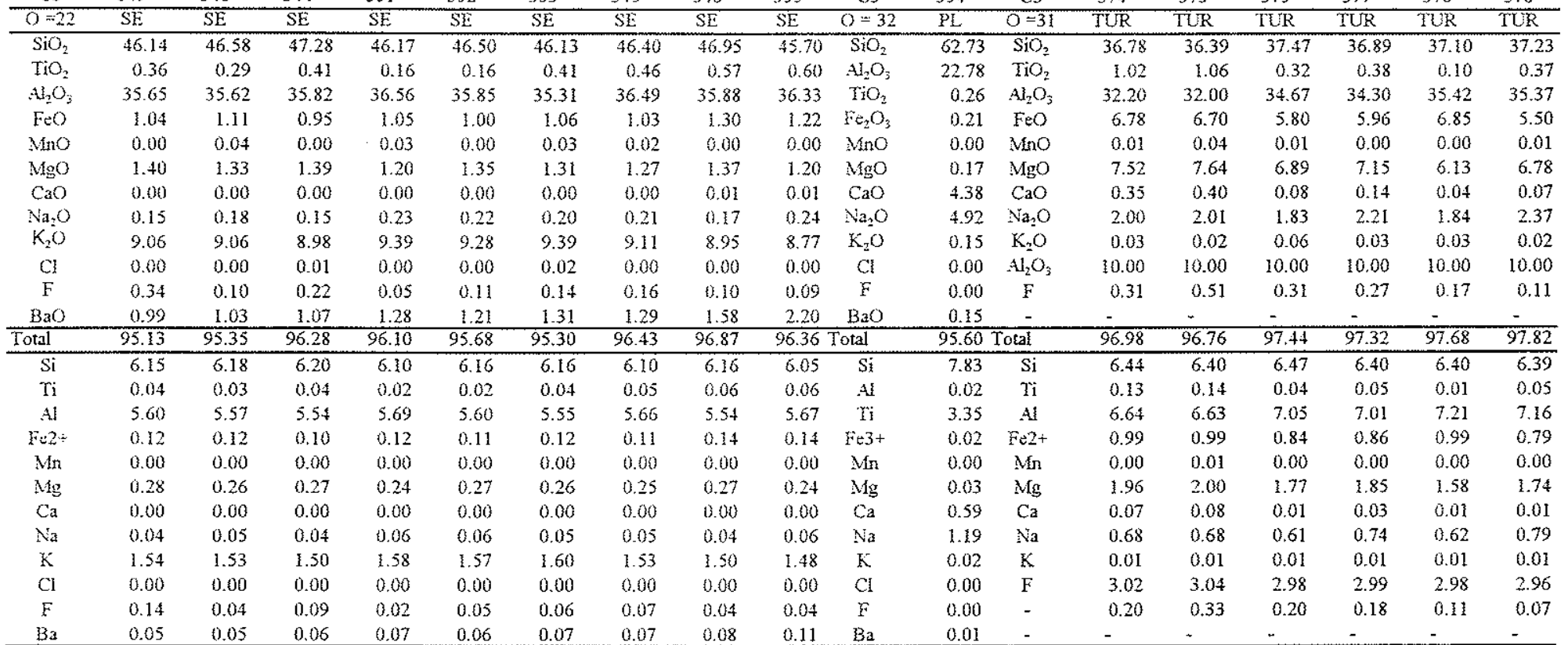

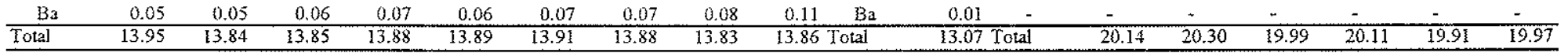

K59 19420

\begin{tabular}{crcc}
\hline $\mathrm{Cl}$ & \multicolumn{1}{c}{495} & $\mathrm{Cl}$ & \multicolumn{1}{c}{540} \\
\hline $\mathrm{O}=28$ & \multicolumn{1}{c}{$\mathrm{CHL}$} & $\mathrm{O}=6$ & \multicolumn{1}{c}{$\mathrm{CAL}$} \\
\hline $\mathrm{SiO}_{2}$ & 37.22 & $\mathrm{SiO}_{2}$ & 0.00 \\
$\mathrm{TiO}_{2}$ & 0.14 & $\mathrm{SrO}$ & 0.04 \\
$\mathrm{Al}_{2} \mathrm{O}_{3}$ & 29.00 & $\mathrm{FeO}$ & 1.91 \\
$\mathrm{FeO}$ & 9.17 & $\mathrm{MnO}$ & 0.38 \\
$\mathrm{MnO}$ & 0.03 & $\mathrm{MgO}$ & 1.30 \\
$\mathrm{MgO}$ & 7.14 & $\mathrm{CaO}$ & 51.24 \\
$\mathrm{CaO}$ & 0.05 & $\mathrm{ZnO}$ & 0.00 \\
$\mathrm{Na} \mathrm{a}_{2} \mathrm{O}$ & 0.59 & $\mathrm{BaO}$ & 0.00 \\
$\mathrm{~K}_{2} \mathrm{O}$ & 5.65 & - & - \\
$\mathrm{Cl}$ & 0.05 & - & - \\
$\mathrm{F}$ & 0.31 & - & - \\
- & - & - & - \\
\hline $\mathrm{Ootal}$ & 89.34 & & 54.86 \\
\hline $\mathrm{Si}$ & 7.02 & $\mathrm{Si}$ & 0.00 \\
$\mathrm{Ti}$ & 0.02 & $\mathrm{Sr}$ & 0.00 \\
$\mathrm{Al}$ & 6.45 & $\mathrm{Fe} 2+$ & 0.16 \\
$\mathrm{Fe} 2+$ & 1.45 & $\mathrm{Mn}$ & 0.03 \\
$\mathrm{Mn}$ & 0.00 & $\mathrm{Mg}$ & 0.20 \\
$\mathrm{Mg}$ & 2.01 & $\mathrm{Ca}$ & 5.60 \\
$\mathrm{Ca}$ & 0.01 & $\mathrm{Zn}$ & 0.00 \\
$\mathrm{Na}$ & 0.22 & $\mathrm{Ba}$ & 0.00 \\
$\mathrm{~K}$ & 1.36 & - & - \\
$\mathrm{Cl}$ & 0.01 & - & - \\
$\mathrm{F}$ & 0.15 & - & - \\
- & - & - & - \\
\hline $\mathrm{Ob}$ & 18.53 & & 6.00 \\
\hline & & &
\end{tabular}

K59-19420

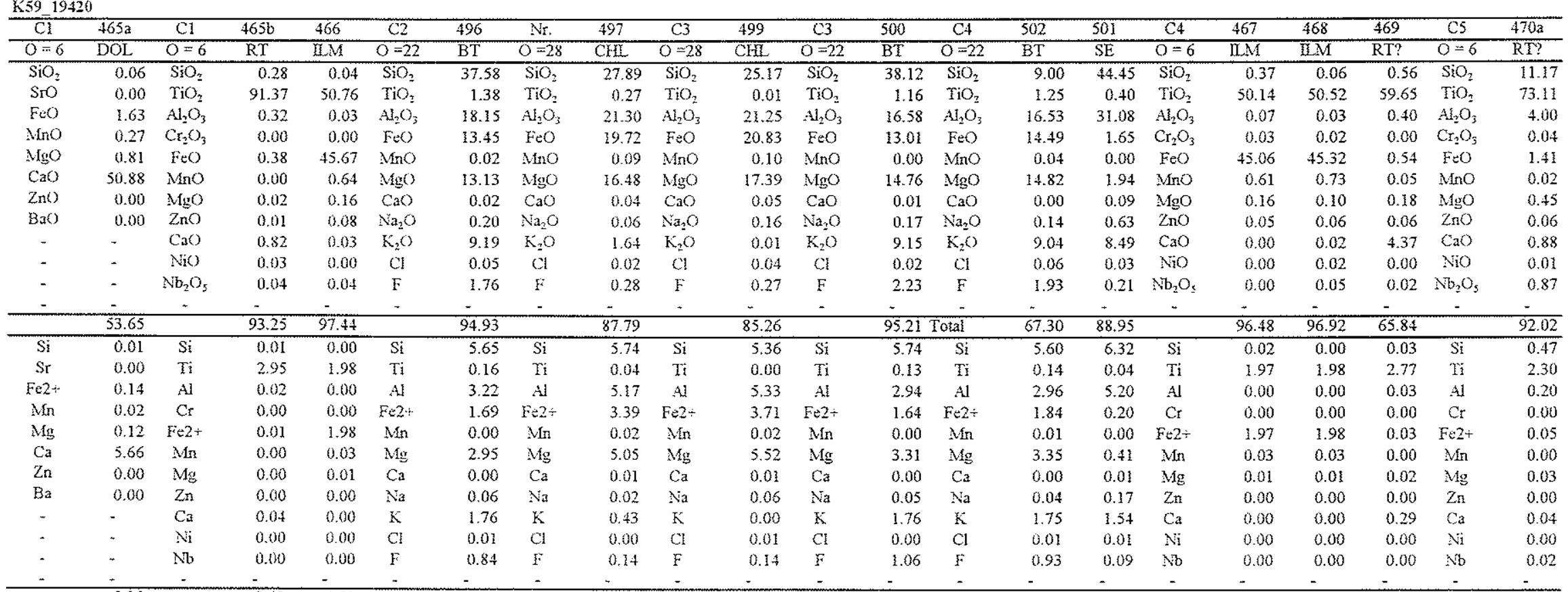




\begin{tabular}{|c|c|c|c|c|c|c|c|c|c|c|c|c|c|c|c|c|c|c|c|c|c|c|c|}
\hline $\mathrm{C} 2$ & 486 & 488 & $\mathrm{C} 2$ & 487 & $\mathrm{C3}$ & 489 & 490 & $C 3$ & 461 & 462 & 463 & $\mathrm{C3}$ & $464 a$ & $464 \mathrm{~b}$ & $\mathrm{C} 4$ & 491 & 493 & 492 & $\mathrm{C} 4$ & 494 & $\mathrm{CA}_{4}$ & 536 & 537 \\
\hline $0=28$ & $\mathrm{CHI}$. & $\mathrm{CHL}$ & $O=22$ & OLG & $O=28$ & CFIL & CHL & $0=6$ & $\overline{\mathrm{IM}}$ & $\overline{\mathrm{L} M}$ & IIM & $0=6$ & RT? & III? & $\mathrm{O}=22$ & $\mathrm{BT}$ & $B T$ & $\overline{B T}$ & $0=28$ & $\mathrm{CHL}$ & $0=6$ & CAL & $\mathrm{CAB}$ \\
\hline $\mathrm{SiO}_{2}$ & 26.13 & 25.10 & $\mathrm{SiO}_{2}$ & 62.78 & $\mathrm{SiO}_{2}$ & 25.80 & 26.25 & $\mathrm{SiO}_{2}$ & 1.42 & 0.04 & 0.03 & $\mathrm{SiO}_{2}$ & 18.10 & 20.34 & $\mathrm{SiO}_{2}$ & 36.43 & 30.91 & 36.51 & $\mathrm{SiO}_{2}$ & 26.24 & $\mathrm{SiO}_{2}$ & 0.01 & 0.00 \\
\hline $\mathrm{TiO}_{2}$ & 0.01 & 0.20 & $\mathrm{THO}_{2}$ & 0.00 & $\mathrm{TiO}_{2}$ & 0.01 & 0.09 & $\mathrm{TiO}_{2}$ & 44.70 & 26.82 & 49.18 & $\mathrm{TiO}_{2}$ & 76.41 & 36.44 & $\mathrm{THO}_{2}$ & 1.67 & 0.93 & 1.75 & $\mathrm{TiO}_{2}$ & 0.05 & $\mathrm{SrO}$ & 0.02 & $0.0 \mathrm{r}$ \\
\hline. $\mathrm{Al}_{2} \mathrm{O}_{3}$ & 21.77 & 20.52 & $\mathrm{Al}_{2} \mathrm{O}_{3}$ & 23.33 & $\mathrm{Al}_{2} \mathrm{O}_{3}$ & 21.73 & 21.91 & $\mathrm{Al}_{2} \mathrm{O}_{3}$ & 0.98 & 0.03 & 0.00 & $\mathrm{Al}_{2} \mathrm{O}_{3}$ & 1.70 & 8.26 & $\mathrm{Al}_{2} \mathrm{O}_{3}$ & 15.68 & 18.84 & 15.93 & $\mathrm{Al}_{2} \mathrm{O}_{3}$ & 21.28 & FeO & 8.00 & 8.05 \\
\hline $\mathrm{FeO}$ & 19.39 & 19.28 & $\mathrm{Fe}_{2} \mathrm{O}_{3}$ & 0.41 & $\mathrm{FeO}$ & 20.34 & 19.30 & $\mathrm{Cr}_{2} \mathrm{O}_{3}$ & 0.04 & 0.00 & 0.04 & $\mathrm{Cr}_{2} \mathrm{O}_{3}$ & 0.00 & 0.02 & FEO & 18.08 & 19.21 & 18.02 & FeO & 19.33 & Mno & 0.83 & 0.58 \\
\hline $\mathrm{MnC}$ & 0.06 & 0.08 & $\mathrm{MnO}$ & 0.00 & $\mathrm{MnO}$ & 0.07 & 0.10 & FeO & 48.27 & 23.67 & $\{7.63$ & $\mathrm{FeO}$ & 1.10 & 29.82 & $\mathrm{MnO}$ & 0.04 & 0.11 & 0.08 & MnO & 0.11 & $\mathrm{MgO}$ & 15.22 & 14.92 \\
\hline $\mathrm{MgO}$ & 19.38 & 18.62 & $\operatorname{Mg}()$ & 0.00 & $\mathrm{MgO}$ & 18.26 & 18.79 & Mno & 0.83 & 0.77 & 0.84 & Mno & 0.03 & 0.96 & $\mathrm{MgO}$ & 13.14 & 16.08 & 12.74 & $\mathrm{MgO}$ & 18.92 & $\mathrm{CaO}$ & 28.30 & 28.35 \\
\hline $\mathrm{Ca}(\mathrm{C})$ & 0.03 & 0.07 & $\mathrm{Ca}()$ & 4.74 & $\mathrm{Ca}(\mathrm{x})$ & 0.05 & 0.07 & $\mathrm{Mg}(\mathrm{l})$ & 0.14 & 7.87 & 0.23 & $\mathrm{MgO}$ & 0.01 & 0.10 & $\mathrm{CaC}$ & 0.01 & 0.02 & 0.00 & $\mathrm{CaO}$ & 0.09 & $\mathrm{ZnO}$ & 0.11 & 0.04 \\
\hline $\mathrm{Na}_{z} \mathrm{O}$ & 0.04 & 0.08 & $\mathrm{Na}_{2} \mathrm{O}$ & 8.78 & $\mathrm{~N}: \mathrm{a}_{2}, \mathrm{l}$ & 0.05 & 0.06 & $(\sin ()$ & 0.044 & 0.00 & 0.05 & $2 \mathrm{n}()$ & 0.01 & 0.00 & $\mathrm{Na}_{2} \mathrm{O}$ & 0.18 & 0.09 & 0.20 & $\mathrm{Na}_{2} \mathrm{O}$ & 0.11 & $\mathrm{BaO}$ & 0,09 & 0.04 \\
\hline $\mathrm{K}_{2} \mathrm{O}$ & 0.01 & 0.24 & $\mathrm{~K}_{2} \mathrm{O}$ & 0.04 & $\mathrm{~K}_{2} \mathrm{O}$ & 0.02 & 0.03 & $\mathrm{CaO}$ & 0.95 & 13.70 & 0.26 & $\mathrm{CaO}$ & 0.22 & 1.02 & $\mathrm{~K}_{2} \mathrm{O}$ & 8.84 & 4.18 & 8.97 & $\mathrm{~K}_{2} \mathrm{O}$ & 0.13 & - & - & - \\
\hline $\mathrm{Cl}$ & 0.00 & 0.00 & $\mathrm{Cl}$ & 0.01 & $\mathrm{Cl}$ & 0.00 & 0.02 & $\mathrm{NiO}$ & 0.02 & 0.01 & 0.00 & $\mathrm{NiO}$ & 0.04 & 0.00 & $\mathrm{Cl}$ & 0.01 & 0.01 & 0.01 & $\mathrm{Cl}$ & 0.00 & - & - & - \\
\hline$\xi$ & 0.00 & 0.09 & F & 0.01 & F & 0.00 & 0.00 & $\mathrm{Nb}_{2} \mathrm{O}_{5}$ & 0.03 & 0.00 & 0.01 & $\mathrm{Nb}_{2} \mathrm{O}_{3}$ & 0.03 & 0.01 & $F$ & 0.34 & 0.28 & 0.55 & $\mathrm{~F}$ & 0.00 & . & - & . \\
\hline- & - & - & - & - & - & - & & - & - & - & & - & - & & - & & - & - & - & & - & - & - \\
\hline Total & 86.82 & 84.29 & Iotal & 100.09 & Cotal & 86.33 & 86.60 & Total & 97.40 & 72.89 & 98.27 & Total & 97.64 & 96.96 & Total & 94.42 & 90.66 & 94.75 & Total & 86.251 & Cotal & 52.58 & 51.98 \\
\hline $\mathrm{Si}$ & 5.38 & 5.36 & $\mathrm{Si}$ & 7.64 & $\mathrm{Si}$ & 5.37 & 5.41 & $\mathrm{Si}$ & 0.07 & 0.00 & 0.00 & Si & 0.70 & 0.89 & $\mathrm{Si}$ & 5.58 & 4.88 & 5.58 & $\mathrm{Si}$ & 5.45 & $\mathrm{Si}$ & 0.00 & 0.00 \\
\hline $\mathrm{Ti}$ & 0.00 & 0.03 & $T i$ & 0.00 & $\mathrm{Ti}$ & 0.00 & 0.01 & $\mathrm{Ti}$ & 1.77 & 1.39 & 1.92 & $\mathrm{Ti}$ & 2.22 & 1.20 & $\mathrm{Ti}$ & 0.19 & 0.11 & 0.20 & $\mathrm{Ti}_{\mathrm{i}}$ & 0.01 & Sr & 0.00 & 0.00 \\
\hline $\mathrm{Al}$ & 5.28 & 5.17 & Al & 3.35 & Al & 5.34 & 5.33 & Al & 0.06 & 0.00 & 0.00 & Al & 0.08 & 0.43 & Al & 2.83 & 3.50 & 2.87 & $\mathrm{Al}$ & 5.21 & $\mathrm{~F} * 2+$ & 0.66 & 0.67 \\
\hline$K e 2+$ & 3.34 & 3.45 & $\mathrm{Fe} 3+$ & 0.04 & $F * 2 \div$ & 3.54 & 3.33 & $\mathrm{Cr}$ & 0.00 & 0.00 & 0.00 & $\mathrm{Cr}$ & 0.00 & 0.00 & $\mathrm{Fe}_{2} 2+$ & 2.32 & 2.54 & 2.30 & $\mathrm{Fe} 2 \tau$ & 3.35 & $\mathrm{Mn}$ & 0.07 & 0.05 \\
\hline $\mathrm{Mn}$ & 0.01 & 0.01 & $M_{n}$ & 0.00 & $\mathrm{Mn}$ & 0.01 & 0.02 & $F \in 2+$ & 2.12 & 1.36 & 2.07 & $\mathrm{Fe} 2+$ & 0.04 & 1.09 & Mn & 0.00 & 0.01 & 0.01 & $\mathrm{Mn}$ & 0.02 & $\mathrm{Mg}$ & 2.25 & 2.23 \\
\hline $\mathrm{Mg}$ & 5.95 & 5.93 & $\mathrm{Mg}$ & 0.00 & $\mathrm{Mg}$ & 5.67 & 5.78 & $\mathrm{Mr}$ & 0.04 & 0.04 & 0.04 & $M n$ & 0.00 & 0.04 & $\mathrm{Mg}$ & 3.00 & 3.78 & 2.90 & $\mathrm{Mg}$ & 5.85 & $\mathrm{Ca}$ & 3.00 & 3.04 \\
\hline $\mathrm{Ca}$ & 0.01 & 0.02 & $\mathrm{C} 3$ & 0.62 & $\mathrm{Ca}$ & 0.01 & 0.02 & $\mathrm{Mg}$ & 0.01 & 0.81 & 0.02 & $\mathrm{Mg}$ & 0.00 & 0.01 & $\mathrm{Ca}$ & 0.00 & 0.00 & 0.00 & $\mathrm{Ca}$ & 0.02 & $\mathrm{Zn}$ & 0.01 & 0.00 \\
\hline $\mathrm{Na}$ & 0.02 & 0.03 & $\mathrm{Na}$ & 2.07 & $\mathrm{Na}$ & 0.02 & 0.03 & $\mathrm{Zn}$ & 0.00 & 0.00 & 0.00 & $\mathrm{Zn}$ & 0.00 & 0.00 & $\mathrm{Na}$ & 0.05 & 0.03 & 0.06 & $\mathrm{Na}$ & 0.04 & $\mathrm{Ba}$ & 0.00 & 0.00 \\
\hline $\mathrm{K}$ & 0.00 & 0.07 & $\mathrm{~K}$ & 0.01 & $\mathrm{~K}$ & $0.0 \mathrm{I}$ & 0.01 & $\mathrm{Ca}$ & 0.05 & 1.01 & 0.01 & $\mathrm{Ca}$ & 0.01 & 0.05 & $\mathrm{~K}$ & 1.73 & 0.84 & 1.75 & $\mathrm{~K}$ & 0.03 & - & . & - \\
\hline Cl & 0.00 & 0.00 & $\mathrm{Cl}$ & 0.00 & $\mathrm{Cl}$ & 0.00 & 0.00 & $\mathrm{Ni}$ & 0.00 & 0.00 & 0.00 & $\mathrm{Ni}$ & 0.00 & 0.00 & $\mathrm{Cl}$ & 0.00 & 0.00 & 0.00 & $\mathrm{Cl}$ & 0.00 & - & - & - \\
\hline$F$ & 0.00 & 0.05 & $\mathrm{~F}$ & 0.00 & $\mathrm{~F}$ & 0.00 & 0.00 & $\mathrm{Nb}$ & 0.00 & 0.00 & 0.00 & $\mathrm{Nb}$ & 0.00 & 0.00 & $F$ & 0.16 & 0.14 & 0.27 & $\mathrm{~F}$ & 0.00 & - & - & - \\
\hline & & - & & - & - & - & & - & 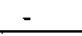 & & & & & - & - & & & & - & & $\approx$ & - & - \\
\hline
\end{tabular}

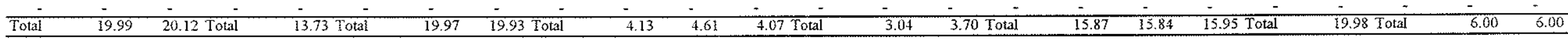

\begin{tabular}{|c|c|c|c|c|}
\hline \multicolumn{5}{|c|}{ K59_29280 } \\
\hline $\mathrm{C5}$ & 538 & 539 & $\mathrm{C} 5$ & 541 \\
\hline $0=6$ & $\mathrm{CAB}$ & $\mathrm{CAB}$ & $0=6$ & MAG \\
\hline $\mathrm{SiO}_{2}$ & 0.01 & 0.00 & $\mathrm{SiO}_{2}$ & 0.02 \\
\hline $\mathrm{SrO}^{\circ}$ & 0.01 & 0.00 & $\mathrm{TiO}_{2}^{-}$ & 0.10 \\
\hline $\mathrm{FeO}$ & 2.31 & 2.57 & $\mathrm{Al}_{2} \mathrm{O}_{3}$ & 0.28 \\
\hline $\mathrm{MnO}$ & 0.56 & 0.52 & $\mathrm{Cr}_{2} \mathrm{O}_{3}$ & 0.01 \\
\hline $\mathrm{MgO}$ & 1.87 & 1.97 & $\mathrm{FeO}$ & 91.66 \\
\hline $\mathrm{CaO}$ & 53.71 & 55.06 & MnO & 0.01 \\
\hline 200 & 0.07 & 0.03 & $\mathrm{MgO}$ & 0.00 \\
\hline $\mathrm{BaO}$ & 0.05 & 0.00 & $\mathrm{ZnO}$ & 0.10 \\
\hline - & - & - & $\mathrm{CaO}$ & 0.01 \\
\hline . & - & - & $\mathrm{NiO}$ & 0.00 \\
\hline - & - & - & $\mathrm{Nb}_{2} \mathrm{O}_{3}$ & 0.01 \\
\hline- & - & - & - & \\
\hline Total & 58.59 & 60.15 & Total & 92.19 \\
\hline $\mathrm{Si}$ & 0.00 & 0.00 & Si & 0.00 \\
\hline Sr & 0.00 & 0.00 & Ti & 0.01 \\
\hline $\mathrm{re} 2+$ & 0.18 & 0.20 & Al & 0.03 \\
\hline $\mathrm{M}_{n}$ & 0.04 & 0.04 & $\mathrm{Cr}$ & 0.00 \\
\hline $\mathrm{Mg}$ & 0.27 & 0.27 & $1+2+$ & 5.94 \\
\hline $\mathrm{Ca}$ & 5.50 & 5.48 & $\mathrm{Mn}$ & 0.00 \\
\hline $\mathrm{zn}$ & 0.01 & 0.00 & $\mathrm{Mg}$ & 0.00 \\
\hline $\mathrm{Ba}$ & 0.00 & 0.00 & $2 \mathrm{n}$ & 0.01 \\
\hline - & - & - & $\mathrm{Ca}$ & 0,00 \\
\hline - & - & - & $\mathrm{Ni}$ & 0.00 \\
\hline - & - & - & $\mathrm{N}_{b}$ & 0.00 \\
\hline
\end{tabular}

\begin{tabular}{lll}
\hline Total & 6.00 & 6.00 Total \\
\hline
\end{tabular}

\begin{tabular}{|c|c|c|c|c|c|c|c|c|c|c|c|c|c|c|c|c|}
\hline $\mathrm{Cl}$ & 726 & 727 & 728 & 729 & 730 & 730 & $\mathrm{Cl}$ & 780 & 781 & $\mathrm{C} 2$ & 776 & 777 & $\mathrm{C} 2$ & 797 & 798 & 799 \\
\hline$O=31$ & TUR & TUR & TUR & TUR & TUR & TUR & $\mathrm{O}=32$ & $\overline{\mathrm{PL}}$ & $\overline{\mathrm{PL}}$ & $\mathrm{O}=6$ & $\mathrm{CAB}$ & $\overline{C A B}$ & Atom $\%$ & po & $\mathrm{PO}$ & PO \\
\hline $\mathrm{SiO}_{2}$ & 36.12 & 35.72 & 36.17 & 36.05 & 36.58 & 35.83 & $\mathrm{SiO}_{2}$ & 69.14 & 69.34 & $\mathrm{SiO}_{2}$ & 0.01 & 0.00 & $\mathrm{Fe}$ & 47.38 & 77.70 & 47.27 \\
\hline $\mathrm{TiO}_{2}$ & 0.09 & 0.60 & 0.46 & 0.29 & 0.17 & 0.71 & $\mathrm{Al}_{2} \mathrm{O}_{3}$ & 19.42 & 19.41 & $\mathrm{FeO}$ & 1.89 & 1.75 & As & 0.01 & 0.03 & 0.03 \\
\hline $\mathrm{Al}_{2} \mathrm{O}_{3}$ & 31.96 & 31.51 & 32.51 & 31.93 & 32.93 & 31.97 & $\mathrm{TiO}_{2}$ & 0.00 & 0.00 & $\mathrm{MnO}$ & 0.29 & 0.32 & s & 52.48 & 22.16 & 52.56 \\
\hline $\mathrm{FeO}$ & 8.77 & 8.08 & 6.67 & 6.11 & 6.31 & 6.02 & $\mathrm{Fe}_{2} \mathrm{O}_{3}$ & 0.50 & 0.00 & $\mathrm{MgO}$ & 0.74 & 0.75 & $\mathrm{Zn}$ & 0.00 & 0.02 & 0.00 \\
\hline $\mathrm{MnO}$ & 0.00 & 0.03 & 0.06 & 0.00 & 0.01 & 0.03 & $\mathrm{MnO}$ & 0.01 & 0.02 & $\mathrm{CaO}$ & 52.94 & 54.56 & $\mathrm{Cu}$ & 0.00 & 0.00 & 0.00 \\
\hline $\mathrm{MgO}$ & 6.16 & 6.78 & 7.22 & 7.68 & 7.28 & 7.56 & $\mathrm{MgO}$ & 0.03 & 0.00 & - & - & - & Co & 0.00 & 0.00 & 0.00 \\
\hline $\mathrm{CaO}$ & 0.12 & 0.32 & 0.49 & 0.69 & 0.30 & 0.77 & $\mathrm{CaO}$ & 0.16 & 0.14 & - & - & - & $\mathrm{Ni}$ & 0.13 & 0.09 & 0.13 \\
\hline $\mathrm{Na}_{2} \mathrm{O}$ & 2.01 & 2.39 & 2.19 & 2.06 & 1.98 & 1.95 & $\mathrm{Na}_{2} \mathrm{O}$ & 11.35 & 11.67 & - & - & - & $\mathrm{Au}$ & 0.00 & 0.00 & 0.00 \\
\hline $\mathrm{K}_{2} \mathrm{O}$ & 0.01 & 0.00 & 0.01 & 0.02 & 0.01 & 0.01 & $\mathrm{~K}_{2} \mathrm{O}$ & 0.06 & 0.04 & - & - & - & - & - & - & $\cdot$ \\
\hline$F$ & 0.20 & 0.22 & 0.17 & 0.63 & 0.01 & 0.67 & - & - & - & - & - & - & - & - & - & - \\
\hline $\mathrm{Cl}$ & 0.01 & 0.00 & 0.00 & 0.00 & 0.01 & 0.00 & - & - & - & - & - & - & - & - & - & - \\
\hline - & & - & - & - & - & & - & - & 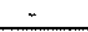 & - & - & - & - & & - & \\
\hline Total & 85.45 & 85.64 & 85.94 & 85.47 & 85.59 & \multicolumn{2}{|c|}{85.51 Total } & 100.67 & 100.63 & Fotal & 55.87 & \multicolumn{2}{|c|}{57.37 Total } & 300.00 & 100.00 & 100.00 \\
\hline $\mathrm{Si}$ & 7.59 & 7.50 & 7.50 & 7.54 & 7.56 & 7.49 & $\mathrm{Si}$ & 12.00 & 12.03 & $\mathrm{Si}$ & 0.00 & \multicolumn{2}{|c|}{$0.00 \mathrm{Wt} \%$} & & & \\
\hline$\Upsilon_{i}$ & 0.01 & 0.09 & 0.07 & 0.05 & 0.03 & 0.11 & A] & 3.97 & 3.97 & $\mathrm{Fe} 2+$ & 0.16 & 0.14 & $\mathrm{Fe}$ & 60.93 & 51.45 & 60.31 \\
\hline $\mathrm{Al}$ & 7.92 & 7.80 & 7.94 & 7.87 & 8.02 & 7.88 & $\mathrm{Ti}$ & 0.00 & 0.00 & $\mathrm{Mn}$ & 0.02 & 0.03 & As & 0.02 & 0.03 & 0.06 \\
\hline $\mathrm{Fe} 2+$ & 1.54 & 1.42 & 1.16 & 1.07 & 1.09 & 1.05 & $\mathrm{Fe} 3+$ & 0.06 & 0.00 & $\mathrm{Mg}$ & 0.11 & 0.11 & s & 38.74 & 8.42 & 38.49 \\
\hline Mn & 0.00 & 0.01 & 0.01 & 0.00 & 0.00 & 0.01 & $\mathrm{Mn}$ & 0.00 & 0.00 & $\mathrm{Ca}$ & 5.70 & 5.72 & $Z n$ & 0.00 & 0.02 & 0.00 \\
\hline $\mathrm{Mg}$ & 1.93 & 2.12 & 2.23 & 2.39 & 2.24 & 2.36 & $\mathrm{Mg}$ & 0.01 & 0.00 & - & - & - & $\mathrm{Cu}$ & 0.00 & 0.00 & 0.00 \\
\hline $\mathrm{Ca}$ & 0.03 & 0.07 & 0.11 & 0.16 & 0.07 & 0.17 & $\mathrm{Ca}$ & 0.03 & 0.03 & - & - & - & Co & 0.00 & 0.00 & 0.00 \\
\hline $\mathrm{Na}$ & 0.82 & 0.97 & 0.88 & 0.83 & 0.79 & 0.79 & $N_{3}$ & 3.82 & 3.93 & - & - & - & $\mathrm{Ni}$ & 0.17 & 0.07 & 0.18 \\
\hline $\mathrm{k}$ & 0.00 & 0.00 & 0.00 & 0.01 & 0.00 & 0.00 & $\mathrm{~K}$ & 0.01 & 0.01 & - & - & - & $\mathrm{Au}$ & 0.00 & 0.00 & 0.02 \\
\hline $\mathrm{F}$ & 0.13 & 0.15 & 0.11 & 0.42 & 0.01 & 0.44 & - & - & . & - & . & - & - & - & - & - \\
\hline $\mathrm{cl}$ & 0.00 & 0.00 & 0.00 & 0.00 & 0,00 & 000 & - & - & - & - & - & - & - & & - & \\
\hline
\end{tabular}

\begin{tabular}{lllllllllllllll}
\hline Total & 19.98 & 20.14 & 20.01 & 20.32 & 19.81 & 20.30 Total & 19.90 & 19.96 Total & 6.00 & 6.00 Total & 99.87 & 59.98 & 99.06 \\
\hline
\end{tabular} 


\begin{tabular}{|c|c|c|c|c|c|c|c|c|c|c|c|c|c|c|c|c|c|c|c|}
\hline $\mathrm{C} 3$ & 767 & 768 & 769 & 770 & $\mathrm{C} 3$ & 782 & 783 & 784 & $\mathrm{C} 4$ & 771 & 772 & $\mathrm{C} 4$ & 779 & 780 & $\mathrm{C} 4$ & 785 & 786 & $\mathrm{CH}$ & $\frac{807 ?}{80}$ \\
\hline$O=22$ & $\mathrm{CHL}$ & BT & $\mathrm{CFI}$ & CHI & $0=32$ & PL & PL & $P L$ & $\mathrm{O}=22$ & BT & BT & $0=6$ & CAB & $\mathrm{CAB}$ & $0=32$ & PI. & PL & Atom\% & $\mathrm{PO}$ \\
\hline $\mathrm{SiO}_{2}$ & 30.48 & 32.08 & 22.70 & 23.15 & $\mathrm{SiO}_{2}$ & 69.57 & 69.72 & 69.57 & $\mathrm{SiO}_{2}$ & 35.14 & 34.98 & $\mathrm{SiO}_{2}$ & 0.05 & 0.00 & $\mathrm{SiO}_{2}$ & 69.17 & 69.26 & $\mathrm{Fe}$ & 99.86 \\
\hline $\mathrm{rO}_{2}$ & 3.97 & 1.92 & 0.61 & 0.13 & $\mathrm{Al}_{2} \mathrm{O}_{3}$ & 19.56 & 19.28 & 19.50 & $\mathrm{YHO}_{2}$ & 1.56 & 1.75 & $\mathrm{FeO}$ & 11.26 & 11.46 & $\mathrm{Al}_{2} \mathrm{O}_{3}$ & 19.72 & 19.41 & As & 0.12 \\
\hline $\mathrm{Al}_{2} \mathrm{O}_{3}$ & 19.77 & 15.45 & 18.97 & 20.55 & $\mathrm{TiO}_{2}$ & 0.01 & 0.01 & 0.02 & $\mathrm{AH}_{2} \mathrm{O}_{3}$ & 16.95 & 16.90 & $\mathrm{MnO}$ & 0.69 & 0.49 & $\mathrm{TiO}_{z}$ & 0.00 & 0.01 & $s$ & 0.02 \\
\hline $\mathrm{FeO}$ & 27.19 & 28.62 & 33.26 & 33.37 & $\mathrm{Fe}_{2} \mathrm{O}_{3}$ & 0.05 & 0.01 & 0.02 & $\mathrm{FeO}$ & 18.20 & 18.67 & $\mathrm{MgO}$ & 13.19 & 12.99 & $\mathrm{Fe}_{2} \mathrm{O}_{3}$ & 0.01 & 0.07 & $\mathrm{Cu}$ & 0.00 \\
\hline $\mathrm{MnO}$ & 0.00 & 0.04 & 0.02 & 0.02 & $\mathrm{MnO}$ & 0.02 & 0.02 & 0.00 & MnO & 0.01 & 0.04 & $\mathrm{CaO}$ & 27.36 & 28.01 & $\mathrm{MnO}$ & 0.03 & 0.05 & $\mathrm{Ni}$ & 0.00 \\
\hline MgO & 1.22 & 5.59 & 8.45 & 9.31 & $\mathrm{MgO}$ & 0.00 & 0.00 & 0.00 & $\mathrm{MgO}$ & 10.39 & 10.12 & • & - & - & $\mathrm{MgO}$ & 0.00 & 0.01 & Aux & 0.00 \\
\hline $\mathrm{CaO}$ & 0.16 & 0.29 & 0.08 & 0.03 & $\mathrm{CaO}$ & 0.34 & 0.10 & 0.18 & $\mathrm{CaO}$ & 0.05 & 0.00 & - & - & . & $\mathrm{CaO}$ & 0.41 & 0.19 & - & - \\
\hline $\mathrm{Na}_{2} \mathrm{O}$ & 0.19 & 0.03 & 0.27 & 0.13 & $\mathrm{Na}_{2} \mathrm{O}$ & 11.34 & 11.59 & 11.72 & $\mathrm{Na}_{2} \mathrm{O}$ & 0.63 & 0.21 & - & - & - & $\mathrm{Na}_{2} \mathrm{O}$ & 11.44 & 11.65 & - & " \\
\hline $\mathrm{K}_{2} \mathrm{O}$ & 3.79 & 6.09 & 0.08 & 0.01 & $\mathrm{~K}_{2} \mathrm{O}$ & 0.03 & 0.03 & 0.04 & $\mathrm{~K}_{2} \mathrm{O}$ & 8.49 & 9.05 & - & - & - & $\mathrm{K}_{2} \mathrm{O}$ & 0.06 & 0.04 & - & - \\
\hline $\mathrm{Cl}$ & 0.04 & 0.06 & 0.04 & 0.03 & - & - & - & - & $\mathrm{Cl}$ & 0.08 & 0.02 & - & - & - & " & - & - & - & - \\
\hline$F$ & 0.16 & 0.19 & 0.04 & 0.03 & - & - & - & - & $\xi$ & 0.17 & 0.22 & - & - & - & - & - & - & - & - \\
\hline $\mathrm{BaO}$ & 0.00 & 0.40 & 0.04 & 0.00 & - & - & - & - & 1330 & 0.50 & 0.63 & - & - & & -1 & - & - & - & $\therefore$ \\
\hline Total & 86.97 & 90.36 & 84.56 & 86.75 & Iotal & 100.92 & 100.76 & 101.04 & Total & 92.15 & 92.61 & Total & 52.55 & 52.95 & Total & 100.83 & 100.67 & Total & 100.00 \\
\hline $\mathrm{Si}$ & & 5.39 & & & $\mathrm{Si}$ & 12.02 & 12.06 & 12.02 & $\mathrm{Si}$ & 5.54 & 5.52 & $\mathrm{Si}$ & 0.00 & 0.00 & $\mathrm{Si}$ & 11.98 & 12.01 & $w+\%$ & \\
\hline $\mathrm{Ti}$ & & 0.24 & & & Al & 3.98 & 3.93 & 3.97 & $\mathrm{Ti}$ & 0.18 & 0.21 & $\mathrm{Fe} 2+$ & 0.96 & 0.97 & Al & 4.02 & 3.97 & $\mathrm{Fet}$ & 32.42 \\
\hline $\mathrm{Al}$ & & 3.06 & & & $\mathrm{Ti}$ & 0.00 & 0.00 & 0.00 & Al & 3.15 & 3.14 & $\mathrm{Mn}$ & 0.06 & 0.04 & $\mathrm{Ti}_{\mathrm{s}}$ & 0.00 & 0.00 & As & 0.05 \\
\hline$F \in 2 \div$ & & 4.02 & & & Fe3- & 0.01 & 0.00 & 0.00 & $\mathrm{Fe} 2+$ & 2.40 & 2.46 & $\mathrm{Mg}$ & 2.00 & 1.96 & $F \in 3+$ & 0.00 & 0.01 & $\mathrm{~S}$ & 0.00 \\
\hline $\mathrm{Mr} r$ & & 0.01 & & & $\mathrm{Mn}$ & 0.00 & 0.00 & 0.00 & $\mathrm{Mn}$ & 0.00 & 0.01 & $\mathrm{Ca}$ & 2.98 & 3.03 & $\mathrm{Mn}$ & 0.00 & 0.01 & $\mathrm{Ca}$ & 0.00 \\
\hline $\mathrm{Mg}$ & & 1.40 & & & Mg & 0.00 & 0.00 & 0.00 & $\mathrm{Mg}$ & 2.44 & 2.38 & - & - & $\cdot$ & $\mathrm{Mg}$ & 0.00 & 0.00 & $\mathrm{Ni}$ & 0.00 \\
\hline $\mathrm{Ca}$ & & 0.05 & & & $\mathrm{Ca}$ & 0.06 & 0.02 & 0.03 & $\mathrm{Ca}$ & 0.01 & 0.00 & - & - & - & $\mathrm{Ca}$ & 0.08 & 0.03 & $\mathrm{Au}$ & 0.00 \\
\hline $\mathrm{Na}$ & & 0.01 & & & $\mathrm{Na}$ & 3.80 & 3.89 & 3.93 & $\mathrm{Na}$ & 0.19 & 0.07 & - & - & - & $\mathrm{Na}$ & 3.84 & 3.92 & - & - \\
\hline $\mathrm{K}$ & & 1.31 & & & $\mathrm{~K}$ & 0.01 & 0.01 & 0.01 & 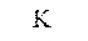 & 1.71 & 1.82 & - & - & - & $\mathrm{K}$ & 0.01 & 0.01 & - & - \\
\hline $\mathrm{Cl}$ & & 0.02 & & & . & - & - & - & $\mathrm{Cl}$ & 0.02 & 0.01 & - & . & - & - & - & - & - & - \\
\hline $\mathrm{F}$ & & 0.10 & & & - & . & - & - & $\mathrm{F}$ & 0.08 & 0.11 & . & - & . & - & - & - & • & - \\
\hline $\mathrm{Ba}$ & & 0.03 & & & - & - & - & - & $8 \mathrm{a}$ & 0.03 & 0.04 & - & - & - &. & - & $\approx$ & - & - \\
\hline Total & 0.00 & 15.62 & 0.00 & 0.00 & Total & 19.88 & 19.92 & 19.96 & Total & 15.76 & 15.76 & Total & 6.00 & 6.00 & Total & 19.94 & 19.96 & Total & 32.47 \\
\hline
\end{tabular}

\begin{tabular}{|c|c|c|c|c|c|c|c|c|c|c|c|c|c|c|c|c|c|c|c|c|c|c|c|}
\hline & & & & & & & & & & & & & & & & & & & 206 & 204 & 205 & $\mathrm{Cl}$ & 235 \\
\hline $0=6$ & $\begin{array}{c}67 \\
\mathrm{CAB}\end{array}$ & $\frac{194}{\mathrm{CAB}}$ & $\frac{198}{C A B}$ & $\begin{array}{c}195 \\
\text { CAB }\end{array}$ & $\begin{array}{c}197 \\
\mathrm{CAB} \\
\end{array}$ & $\frac{196}{\mathrm{CAB}}$ & $\frac{199}{\mathrm{CAB}}$ & $\begin{array}{l}200 \\
C A B\end{array}$ & $\frac{201}{\mathrm{CAB}}$ & $\frac{202}{\mathrm{CAB}}$ & $\frac{207}{\mathrm{CAB}}$ & $\frac{\mathrm{Cl}}{\mathrm{O}=22}$ & $\frac{63}{\mathrm{SE}}$ & $\begin{array}{l}64 \\
\mathrm{SE}\end{array}$ & $\begin{array}{l}65 \\
S E \\
E\end{array}$ & $\frac{66}{\mathrm{CHL}}$ & $\frac{68}{\mathrm{CHI}}$ & $\frac{203}{\mathrm{CHIL}}$ & $\frac{206}{\text { CFII }}$ & $\frac{204}{\mathrm{CHCL}}$ & $\mathrm{CH}$ & $\frac{1}{0=14}$ & $\mathrm{CLD}$ \\
\hline $\mathrm{SiO}_{2}$ & 0.00 & 0.02 & 0.00 & 0.03 & 0.01 & 0.05 & 0.05 & 0.02 & 0.06 & 0.04 & 0.09 & $\mathrm{SiO}_{t}$ & 45.81 & 45.41 & 45.67 & 22.19 & 22.38 & 22.06 & 22.12 & 23.00 & 23.05 & $\mathrm{SiO}_{2}$ & 24.06 \\
\hline $\mathrm{FeO}$ & 0.30 & 0.34 & 0.85 & 5.16 & 1.00 & 2.90 & 2.75 & 3.29 & 0.70 & 3.63 & 1.87 & $\mathrm{TiO}_{2}$ & 0.10 & 0.00 & 0.17 & 0.00 & 0.08 & 0.02 & 0.00 & 0.02 & 0.03 & $\mathrm{TiO}_{2}$ & 0.00 \\
\hline MnO & 0.32 & 0.34 & 0.21 & 0.16 & 0.15 & 0.09 & 0.09 & 0.18 & 0.24 & 0.14 & 0.22 & $\mathrm{Al}_{2} \mathrm{O}_{3}$ & 35.04 & 37.59 & 36.23 & 23.00 & 22.34 & 22.68 & 22.72 & 23.36 & 22.81 & $\mathrm{Al}_{2} \mathrm{O}_{3}$ & 42.36 \\
\hline $\mathrm{MgO}$ & 0.09 & 0.07 & 0.10 & 0.68 & 0.07 & 0.54 & 0.39 & 0.42 & 0.04 & 0.67 & 0.77 & $\mathrm{FeO}$ & 1.28 & 0.59 & 1.39 & 32.26 & 35.03 & 35.06 & 34.09 & 32.89 & 32.70 & FeO & 25.13 \\
\hline $\mathrm{CaO}$ & 57.90 & 62.20 & 54.56 & 47.87 & 56.43 & 49.65 & 51.71 & 51.58 & 54.02 & 50.76 & 49.01 & $\mathrm{MnO}$ & 0.00 & 0.00 & 0.01 & 0.00 & 0.04 & 0.00 & 0.00 & 0.03 & 0.03 & $\mathrm{MnO}$ & 0.04 \\
\hline - & - & - & - & - & - & . & - & - & - & . & - & $\mathrm{MgO}$ & 0.54 & 0.19 & 0.37 & 8.30 & 7.14 & 6.15 & 7.62 & 8.35 & 8.89 & $\mathrm{MgO}$ & 1.78 \\
\hline - & - & - & - & - & - & . & - & - & - & - & - & $\mathrm{CaO}$ & 0.00 & 0.27 & 0.05 & 0.12 & 0.04 & 0.32 & 0.20 & 0.07 & 0.04 & $\mathrm{CaO}$ & 0.00 \\
\hline - & . & - & - & - & - & - & - & - & - & - & . & $\mathrm{Na}_{2} \mathrm{O}$ & 1.40 & 3.37 & 1.61 & 0.01 & 0.00 & 0.01 & 0.01 & 0.00 & 0.03 & $\mathrm{~N}_{z_{2}} \mathrm{O}$ & 0.01 \\
\hline - & - & - & - & - & - & . & - & - & - & - & - & $\mathrm{K}_{2} \mathrm{O}$ & 8.83 & 5.42 & 8.40 & 0.00 & 0.01 & 0,00 & 0.01 & 0.01 & 0.00 & $\mathrm{~K}_{2} \mathrm{O}$ & 0.00 \\
\hline - & - & - & - & - & - & - & - & - & - & - & - & $\mathrm{Cl}$ & 0.00 & 0.00 & 0.01 & 0.04 & 0.04 & 0.03 & 0.03 & 0.01 & 0.02 & - & - \\
\hline - & - & - & - & - & - & - & - & - & - & - & - & $\mathrm{F}$ & 0.36 & 0.10 & 0.14 & 0.00 & 0.06 & 0.04 & 0.01 & 0.00 & 0.09 & - & - \\
\hline Total & $\frac{-}{58.60}$ & $\frac{-}{62,96}$ & $\frac{-}{55.72}$ & $\frac{-}{53.90}$ & $\frac{-}{57.66}$ & $\frac{-}{53.22}$ & $\frac{-}{54.99}$ & $\frac{-}{55.49}$ & $\frac{\pi}{5506}$ & 55.24 & $\frac{-}{51.96}$ & Total & 93.36 & $\overline{-}$ & $\overline{94.06}$ & $\frac{-}{85.91}$ & $\frac{-}{87.14}$ & & - & 877 & $\therefore$ & $\frac{-}{\text { Total }}$ & 93.38 \\
\hline $\mathrm{Si}$ & 0.00 & 0.00 & 0.00 & 0.00 & 0.00 & 0.01 & 0.01 & 0.00 & 0.01 & 0.00 & 0.01 & $\mathrm{Si}$ & 6.20 & 6.05 & 6.11 & 3.92 & 3.96 & $\frac{86.38}{3.94}$ & $\frac{80.81}{3.91}$ & 3.97 & 3.99 & $\mathrm{Si}$ & 2.30 \\
\hline$F \times 2$ & 0.09 & 0.03 & 0.07 & 0.45 & 0.08 & 0.25 & 0.23 & 0.28 & 0.06 & 0.31 & 0.17 & $\mathrm{~T}_{\mathbf{i}}^{\prime}$ & 0.01 & 0.00 & 0.02 & 0.00 & 0.01 & 0.00 & 0.00 & 0.00 & 0.00 & $T i$ & 0.00 \\
\hline $\mathrm{Mn}$ & 0.09 & 0.03 & 0.02 & 0.01 & 0.01 & 0.01 & 0.01 & 0.02 & 0.02 & 0.01 & 0.02 & $\mathrm{Al}$ & 5.59 & 5.90 & 5.72 & 4.79 & 4.66 & 4.78 & 4.73 & 4.76 & 4.65 & $\mathrm{Al}$ & 4.76 \\
\hline $\mathrm{Mg}$ & 0.04 & 0.01 & $0.0 \mathrm{I}$ & 0.11 & 0.01 & 0.08 & 0.06 & 0.06 & 0.01 & 0.10 & 0.12 & $\mathrm{Fe} 2+$ & 0.15 & 0.07 & 0.16 & 4.77 & 5.18 & 5.24 & 5.04 & 4.75 & 4.73 & $562 \div$ & 2.01 \\
\hline $\mathrm{Ca}$ & 21.75 & 5.92 & 5.87 & 5.39 & 5.89 & 5.59 & 5.65 & 5.61 & 5.88 & 5.49 & 5.61 & $\mathrm{Mn}$ & 0.00 & 0.00 & 0,00 & 0.00 & 0.01 & 0.00 & 0.00 & 0.00 & 0.00 & $\mathrm{Mn}$ & 0.00 \\
\hline 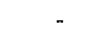 & r & - & - & - & - & - & - & - & - & - & - & $\mathrm{Mg}$ & 0.11 & 0.04 & 0.07 & 2.18 & 1.88 & 1.64 & 2.01 & 2.15 & 2.29 & $\mathrm{Mg}$ & 0.25 \\
\hline - & - & - & - & - & - & - & - & - & - & - & - & $\mathrm{Ca}$ & 0.00 & 0.04 & 0.01 & 0.02 & 0.01 & 0.06 & 0.04 & 0.01 & 0.01 & $\mathrm{Ca}$ & 0.00 \\
\hline- & - & - & - & - & - & - & - & - & - & . & - & $\mathrm{Na}$ & 0.37 & 0.87 & 0.42 & 0.00 & 0.00 & 0.00 & 0.00 & 0.00 & 0.01 & $\mathrm{Na}$ & 0.00 \\
\hline - & - & - & - & - & - & - & - & - & - & - & - & $\mathrm{k}$ & 1.52 & 0.92 & 1.43 & 0.00 & 0.00 & 0.00 & 0.00 & 0.00 & 0.00 & $\mathrm{k}$ & 0.00 \\
\hline- & - & - & - & - & - & - & - & - & - & - & - & $\mathrm{Cl}$ & 0.00 & 0.00 & 0,00 & 0.01 & 0.01 & 0.01 & 0.01 & 0.00 & 0.00 & - & - \\
\hline - & - & - & - & - & - & - & - & - & - & - & - & $\mathrm{F}$ & 0.15 & 0.04 & 0.06 & 0.00 & 0.03 & 0.02 & 0.01 & 0.00 & 0.05 & - & - \\
\hline
\end{tabular}




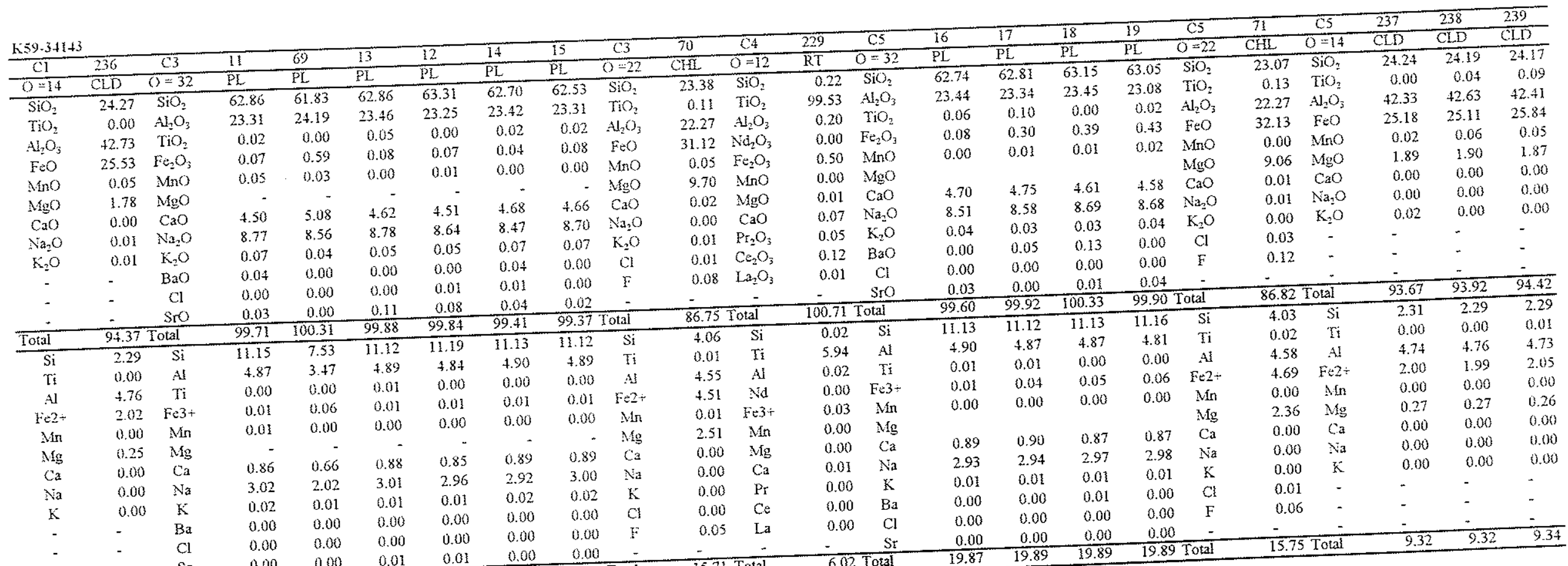
Total

\begin{tabular}{cc}
\multicolumn{3}{l}{$\mathrm{K5y-34143}$} \\
\hline $\mathrm{C5}$ & 240 \\
\hline $\mathrm{O}=14$ & $\mathrm{CLD}$ \\
\hline $\mathrm{SiO}_{2}$ & 24.08 \\
$\mathrm{TiO}_{2}$ & 0.02 \\
$\mathrm{~A}_{2} \mathrm{O}_{3}$ & 42.46 \\
$\mathrm{FO}$ & 25.66 \\
$\mathrm{MnO}$ & 0.06 \\
$\mathrm{MgO}$ & 1.92 \\
$\mathrm{CaO}$ & 0.01 \\
$\mathrm{Na}_{2} \mathrm{O}$ & 0.01 \\
$\mathrm{~K}_{2} \mathrm{O}$ & 0.00 \\
- & - \\
- & - \\
- & - \\
\hline $\mathrm{Total}$ & 94.22 \\
\hline $\mathrm{Si}$ & 2.28 \\
$\mathrm{Ti}$ & 0.00 \\
$\mathrm{Al}$ & 4.75 \\
$\mathrm{Fe} 2 \div$ & 2.04 \\
$\mathrm{Mn}$ & 0.00 \\
$\mathrm{Mg}$ & 0.27 \\
$\mathrm{Ca}$ & 0.00 \\
$\mathrm{Na}$ & 0.00 \\
$\mathrm{~K}$ & 0.00 \\
- & - \\
- & - \\
- & - \\
\hline $\mathrm{Total}$ & 9.34 \\
\hline &
\end{tabular}




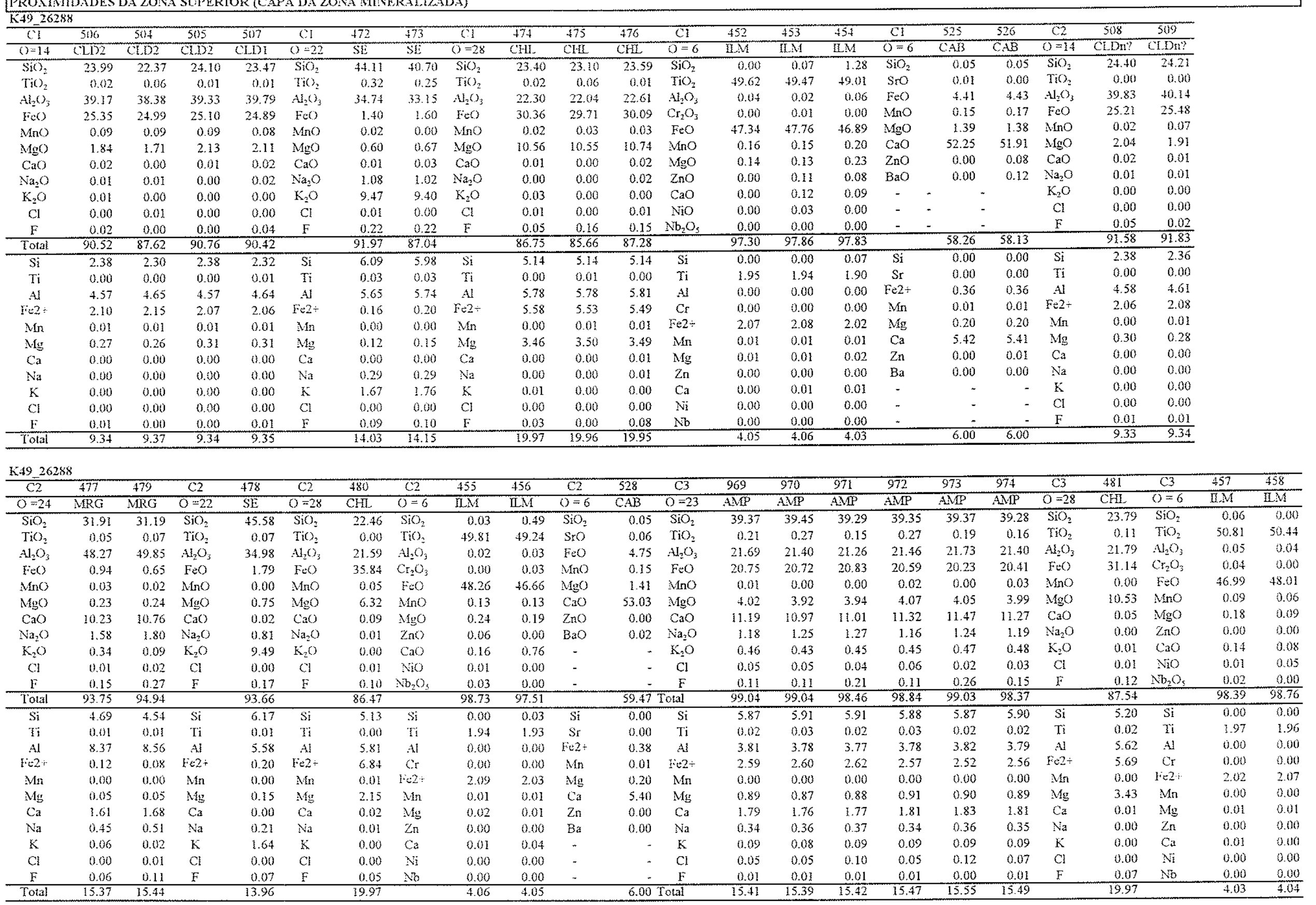


K49 26288

\begin{tabular}{|c|c|c|c|c|c|c|c|c|c|c|c|c|c|c|c|c|c|c|c|c|c|c|c|}
\hline $\mathrm{C} 3$ & 510 & $\mathrm{C3}$ & 529 & $\mathrm{CH}$ & 975 & 976 & 977 & $\mathrm{CH}$ & 483 & $\mathrm{C4}$ & 530 & $53 !$ & $\mathrm{C5}$ & 484 & 485 & $\mathrm{CS}$ & 532 & 534 & $\mathrm{C5}$ & 511 & 512 & 513 & 514 \\
\hline $0=24$ & $\mathrm{ALM}$ & $0=6$ & $\overline{\mathrm{CAB}}$ & $0=23$ & AMP & $\mathrm{AMP}$ & AMP & $0=28$ & CrII & $0=6$ & $\mathrm{CAB}$ & $\mathrm{CAB}$ & $O=28$ & $\mathrm{CHI}$ & $\mathrm{CHL}$ & $\mathrm{O}=6$ & $\mathrm{CAB}$ & $\mathrm{CAB}$ & $\mathrm{O}=24$ & GRT & GRT & GRT & GRT \\
\hline $\mathrm{SiO}_{3}$ & 34,91 & $\mathrm{SiO}_{2}$ & 0.02 & $\mathrm{SiO}_{2}$ & 39.36 & 39.39 & 39.62 & $\mathrm{SiO}_{2}$ & 23.03 & $\mathrm{SiO}_{2}$ & 0.01 & 0.02 & $\mathrm{SiO}_{2}$ & 22.88 & 22.40 & $\mathrm{SiO}_{2}$ & 0.03 & 0.03 & $\mathrm{SiO}_{2}$ & 32.30 & 31.78 & 36.67 & 36.84 \\
\hline $\mathrm{Al}_{2} \mathrm{O}_{3}$ & 20.40 & $\mathrm{SrO}^{\circ}$ & 0.00 & $\mathrm{TiO}_{7}$ & 0.27 & 0.32 & 0.28 & $\mathrm{TiO}_{2}$ & 0.06 & $\mathrm{SrO}^{\circ}$ & 0.00 & 0.04 & $\mathrm{THO}_{2}$ & 0.09 & 0.05 & $\mathrm{SrO}$ & 0.01 & 0.02 & $\mathrm{Al}_{2} \mathrm{O}_{3}$ & 19.54 & 19.34 & 20.95 & 20.81 \\
\hline $\mathrm{TO}_{3}$ & 0.09 & $\mathrm{FeO}$ & 2.86 & $\mathrm{~A}_{2} \mathrm{O}_{3}$ & 21.23 & 21.15 & 21.34 & $\mathrm{Al}_{2} \mathrm{O}_{3}$ & 21.74 & $\mathrm{FeO}$ & 3.26 & 3.36 & $\mathrm{Al}_{2} \mathrm{O}_{3}$ & 22.16 & 21.43 & $\mathrm{FeO}$ & 3.20 & 2.47 & $\mathrm{TiO}_{2}$ & 0.00 & 0.06 & 0.10 & 0.08 \\
\hline $\mathrm{FoO}$ & 33.50 & $\mathrm{Mnc}$ & 0.13 & $\mathrm{FeO}$ & 20.64 & 20.41 & 20.73 & $\mathrm{FeO}$ & 30.79 & $\mathrm{MnO}$ & 0.10 & 0.09 & $\mathrm{FeO}$ & 34.64 & 32.96 & $\mathrm{MnO}$ & 0.10 & 0.12 & $\mathrm{~F} \in \mathrm{O}$ & 31.68 & 31.58 & 33.71 & 34,05 \\
\hline $\ln (\mathrm{n})$ & 0.37 & $\mathrm{Mg}(\mathrm{g}$ & 0.87 & $\mathrm{MnO}$ & a.t: $A$ & 0.00 & $\{0,31$ & $\operatorname{Mn}(3)$ & 0.10 & $\operatorname{Mg}($ & 0.98 & 1.09 & $\mathrm{AnO}$ & 0.08 & 0.09 & $\mathrm{MgO}$ & 0.07 & 0.34 & $\mathrm{MnC}$ & 0.36 & 0.28 & 0.38 & 0.53 \\
\hline $\operatorname{Mg} 0$ & 1.26 & (a) & 54.66 & $\mathrm{M}_{\mathrm{g}(\mathrm{l})}$ & 4.25 & 4.15 & +.17 & $\mathrm{M}(\mathrm{s})$ & 1006 & (a) & 50.46 & 51.67 & $\mathrm{M}(\mathrm{g}()$ & 7.24 & 7.86 & $\mathrm{CaO}$ & 51.15 & 52.25 & Myst & 1.37 & 1.39 & 1.28 & 1.17 \\
\hline (a') & 6.02 & $\operatorname{ZnO}($ & 0.01 & (a) & 11.26 & 11.18 & 11.11 & $\mathrm{CaO}$ & 0.04 & $2 \mathrm{nO}$ & 0.00 & 0.00 & $\mathrm{CaO}$ & 0.01 & 0.05 & $\mathrm{ZnO}$ & 0.03 & 0.02 & $\mathrm{Ca}()$ & 6.76 & 6.04 & 6.40 & 6.18 \\
\hline $\mathrm{Niz}_{2} \mathrm{O}$ & 0.05 & $\mathrm{BaO}$ & 0.09 & $\mathrm{Na}_{2} \mathrm{O}$ & 1.35 & 1.23 & 1.25 & $\mathrm{Na}_{2} \mathrm{O}$ & 0.05 & $\mathrm{BaO}$ & 0.00 & 0.12 & $\mathrm{Na}_{2} \mathrm{O}$ & 0.04 & 0.01 & $\mathrm{BaO}$ & 0.00 & 0.05 & $\mathrm{Na}_{2} \mathrm{O}$ & 0.00 & 0.00 & 0.03 & 0.00 \\
\hline $\mathrm{Cr}_{2} \mathrm{O}_{3}$ & 0.06 & - & - & $\mathrm{K}_{2} \mathrm{O}$ & 0.51 & 0.52 & 0.48 & $\mathrm{~K}_{2} \mathrm{O}$ & 0.01 & - & - & . & $\mathrm{K}_{2} \mathrm{O}$ & 0.01 & 0.03 & - & - & - & $\mathrm{Cr}_{2} \mathrm{O}_{3}$ & 0.09 & 0.07 & 0.04 & 0.05 \\
\hline- & . & . & . & $c$ & 0.04 & 0.06 & 0.04 & $\mathrm{Cl}$ & 0.01 & - & - & - & $\mathrm{Cl}$ & 0.00 & 0.00 & - & - & - & - & - & - & - & - \\
\hline . & & - & & $F$ & 0.15 & 0.35 & 0.16 & $F$ & 0.21 & - & . & - & F & 0.22 & 0.15 & - & - & 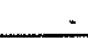 & - & - & 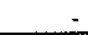 & - & \\
\hline \multicolumn{3}{|c|}{96.67} & \multicolumn{2}{|c|}{58.63 Total } & 99.06 & 98.76 & 99.18 & Total & 86.08 & & 54.82 & 56.40 & & 87.34 & 85.02 & & 54.59 & 55.29 & & 92.09 & 90.54 & 99.55 & 99.70 \\
\hline Si & 5.87 & $\mathrm{Si}$ & 0.00 & $\mathrm{Si}$ & 5.88 & 5.91 & 5.90 & $\mathrm{Si}$ & 5.14 & $\mathrm{Si}$ & 0.00 & 0.00 & Si & 5.13 & 5.13 & $\mathrm{Si}$ & 0.00 & 0.00 & Si & 5.73 & 5.73 & 5.95 & 5.98 \\
\hline $\mathrm{Al}$ & 4.04 & $\mathrm{Sr}$ & 0.00 & Ti & 0.03 & 0.04 & 0.03 & $\mathrm{Ti}$ & 0.01 & $\mathrm{Sr}$ & 0.00 & 0.00 & $\mathrm{Ti}$ & 0.02 & 0.01 & $\mathrm{Sr}$ & 0.00 & 0.00 & A! & 4.08 & 4.11 & 4,01 & 3.98 \\
\hline $\mathrm{Ti}_{\mathrm{i}}$ & 0.01 & $\mathrm{Fe} 2 \div$ & 0.23 & Al & 3.74 & 3.74 & 3.75 & $\mathrm{Al}$ & 5.72 & $F e 2+$ & 0.23 & 0.28 & $\mathrm{Al}$ & 5.85 & 5.79 & Ee $2+$ & 0.27 & 0.21 & $\mathrm{Ti}$ & 0.00 & 0.01 & 0.01 & 0.01 \\
\hline $\mathrm{Fe} 2 \div$ & 4.71 & $M n$ & 0.01 & $\mathrm{~F} 22$ & 2.58 & 2.56 & 2.58 & $\mathrm{Fe} 2 \div$ & 5.74 & $\mathrm{Mn}$ & 0.01 & 0.01 & $F \in 2+$ & 6.49 & 6.32 & $\mathrm{Mn}$ & 0.01 & 0.01 & $\mathrm{Fe} 2+$ & 4.70 & 4.76 & 4.58 & 4.62 \\
\hline $\mathrm{Mn}$ & 0.05 & $\mathrm{Mg}$ & 0.12 & $\mathrm{Mn}$ & 0.00 & 0.00 & 0.00 & $\mathrm{Mn}$ & 0.02 & $\mathrm{Mg}$ & 0.12 & 0.16 & $\mathrm{Mn}$ & 0.01 & 0.02 & $\mathrm{Mg}$ & 0.11 & 0.05 & $\mathrm{Mn}$ & 0.05 & 0.04 & 0.05 & 0.07 \\
\hline Mg & 0.32 & $\mathrm{Ca}$ & 5.63 & $\mathrm{Mg}$ & 0.95 & 0.93 & 0.93 & $\mathrm{Mg}$ & 3.35 & $\mathrm{Ca}$ & 5.63 & 5.54 & $\mathrm{Mg}$ & 2.42 & 2.68 & $\mathrm{Ca}$ & 5.60 & 5.72 & $\mathrm{Mg}$ & 0.36 & 0.37 & 0.31 & 0.28 \\
\hline $\mathrm{Ca}$ & 1.08 & $2 n$ & 0.00 & $\mathrm{Ca}$ & 1.80 & 1.80 & 1.77 & $\mathrm{Ca}$ & 0.01 & $\mathrm{Zn}$ & 0.00 & 0.00 & $\mathrm{Ca}$ & 0.00 & 0.01 & $\mathrm{Zn}$ & 0.00 & 0.00 & $\mathrm{Ca}$ & 1.28 & 1.17 & 1.11 & 1.07 \\
\hline $\mathrm{Na}$ & 0.02 & $\mathrm{Ba}$ & 0.00 & $\mathrm{Na}$ & 0.39 & 0.36 & 0.36 & $\mathrm{Na}$ & 0.02 & $\mathrm{Ba}$ & 0.00 & 0.00 & $\mathrm{Na}$ & 0.02 & 0.01 & $\mathrm{Ba}$ & 0.00 & 0.00 & $\mathrm{Na}$ & 0.00 & 0.00 & 0.01 & 0.100 \\
\hline $\mathrm{Cr}$ & 0.01 & - & - & $\mathrm{K}$ & 0.10 & 0.10 & 0.09 & $\mathrm{~K}$ & 0.00 & $\because$ & - & - & $\mathrm{K}$ & 0.00 & 0.01 & - & - & 0 & $C_{r}$ & 0.01 & 0.01 & 0.00 & 0.01 \\
\hline - & - & - & - & $\mathrm{Cl}$ & 0.07 & 0.17 & 0.07 & $\mathrm{Cl}$ & 0.00 & - & - & - & $\mathrm{Cl}$ & 0.00 & 0.00 & - & - & - & - & - & - & - & \\
\hline- & - & - & - & $\mathrm{F}$ & 0.01 & 0.01 & 0.01 & I: & 0.11 & . & - & & F & 0.12 & 0.09 & - & - & - & . & & - & & \\
\hline & 16.11 & & 6.00 & otal & 15.54 & 15.60 & 15.50 & Total & 20.01 & & 6.00 & 6.00 & & 19.94 & 19.97 & & 6.00 & 6.00 & & 16.22 & 16.20 & 16.03 & 16.02 \\
\hline
\end{tabular}

K49 26288

\begin{tabular}{|c|c|c|c|c|c|c|c|c|c|c|c|c|c|}
\hline $\mathrm{CS}$ & 515 & 516 & 517 & 518 & 519 & 520 & $\mathrm{CS}$ & 522 & 523 & 524 & $\mathrm{ClO}$ & 988 & 989 \\
\hline $0=24$ & GRT & GRT & GRT & GRT & GRT & GRT & $O=24$ & GRT & GRT & GRT & $\mathrm{O}=22$ & $\mathrm{SE}$ & SE \\
\hline $\mathrm{SiO}_{3}$ & 36.68 & 33.68 & 36.50 & 36.67 & 37.02 & 37.24 & $\mathrm{SiO}_{2}$ & 36.88 & 36.84 & 36.70 & $\mathrm{SiO}_{2}$ & 44.73 & 45.66 \\
\hline $\mathrm{Al}_{2} \mathrm{O}_{3}$ & 20.78 & 19.89 & 20.83 & 20.85 & 20.84 & 21.07 & $\mathrm{Al}_{2} \mathrm{O}_{3}$ & 20.78 & 20.77 & 21.10 & $\mathrm{TiO}_{2}$ & 0.22 & 0.14 \\
\hline $\mathrm{TiO}_{2}$ & 0.05 & 0.03 & 0,00 & 0.02 & 0.00 & 0.00 & $\mathrm{TiO}_{z}$ & 0.00 & 0.00 & 0.02 & $\mathrm{Al}_{2} \mathrm{O}_{3}$ & 33.54 & 34.24 \\
\hline FeO & 33.17 & 31.82 & 34.20 & 34.03 & 34.11 & 34.10 & $\mathrm{FeO}$ & 33.97 & 33.32 & 33.92 & $\mathrm{FeO}$ & 2.51 & 1.81 \\
\hline $\mathrm{MnO}$ & 0.78 & 0.99 & 0.38 & 0.40 & 0.50 & 0.40 & Mno & 1.33 & 0.69 & 0.43 & $\mathrm{MnO}$ & 0.01 & 0.02 \\
\hline $\mathrm{MgO}$ & 0.98 & 0.94 & 1.23 & 1.25 & 1.13 & 1.33 & $\mathrm{MgO}$ & 0.91 & 1.00 & 1.40 & $\mathrm{MgO}$ & 0.58 & 0.82 \\
\hline $\mathrm{CaO}$ & 7.20 & 6.81 & 6.05 & 6.39 & 6.41 & 6.00 & $\mathrm{CaO}$ & 6.27 & 6.79 & 6.17 & $\mathrm{CaC}$ & 0.02 & 0.01 \\
\hline $\mathrm{Na}_{2} \mathrm{O}$ & 0.05 & 0.01 & 0.01 & 0.00 & 0.02 & 0.01 & $\mathrm{Na}_{2} \mathrm{O}$ & 0.02 & 0.00 & 0.00 & $\mathrm{Na}_{2} \mathrm{O}$ & 0.76 & 0.88 \\
\hline $\mathrm{Cr}_{2} \mathrm{O}_{3}$ & 0.00 & 0.05 & 0.03 & 0.04 & 0.07 & 0.07 & $\mathrm{Cr}_{2} \mathrm{O}_{3}$ & 0.08 & 0.06 & 0.03 & $\mathrm{~K}_{2} \mathrm{O}$ & 9.42 & 9.44 \\
\hline - & - & - & - & - & & & - & & & & $\mathrm{Cl}$ & 0.01 & 0.00 \\
\hline- & - & - & - & - & & & & & & & $F$ & 0.12 & 0.24 \\
\hline & 99.67 & 94.21 & 99.22 & 99.66 & 100.09 & \multicolumn{2}{|c|}{100.22 Total } & 100.24 & 99.46 & \multicolumn{2}{|c|}{ 99.76 Total } & 91.93 & 93.24 \\
\hline Si & 5.96 & 5.82 & 5.96 & 5.95 & 5.98 & 5.99 & $\mathrm{Si}$ & 5.97 & 5.99 & 5.94 & Si & 6.18 & 6.20 \\
\hline Ad & 3.98 & 4.05 & 4.00 & 3.99 & 3.97 & 4.00 & $\mathrm{Al}^{\prime}$ & 3.97 & 3.98 & 4.03 & Ti & 0.0 & 0.01 \\
\hline $\mathrm{Ti}$ & 0.01 & 0.00 & 0.00 & 0.00 & 0.00 & 0,00 & $\mathrm{Ti}$ & 0.00 & 0.00 & 0.00 & AI & 5.46 & 5.48 \\
\hline Fez 2 & 4.51 & 4.60 & 4.67 & 4.62 & 4.61 & 4.59 & $\mathrm{Fe} 2+$ & 4.60 & 4.53 & 4.59 & $F<2 \div$ & 0.29 & 0.21 \\
\hline $\mathrm{Mn}$ & 0.11 & 0.15 & 0.05 & 0.06 & 0.07 & 0.05 & $\mathrm{Mn}$ & 0.18 & 0.09 & 0.06 & $\mathrm{Mn}$ & 0.00 & 0.00 \\
\hline $\mathrm{Mg}$ & 0.24 & 0.24 & 0.30 & 0.30 & 0.27 & 0.32 & $\mathrm{Mg}$ & 0.22 & 0.24 & 0.34 & $\mathrm{Mg}$ & 0.1 & 0.17 \\
\hline $\mathrm{Ca}$ & 1.25 & 1.26 & 1.06 & 1.11 & 1.11 & 1.04 & $\mathrm{Ca}$ & 1.09 & 1.18 & 1.07 & $\mathrm{Ca}$ & 0.00 & 0.00 \\
\hline $\mathrm{N3}$ & 0.01 & 0.00 & 0.00 & 0.00 & 0.01 & 0.00 & $\mathrm{Na}$ & 0.01 & 0.00 & 0.00 & $\mathrm{Na}$ & 0.2 & 0.23 \\
\hline $\mathrm{Cr}$ & 0.00 & 0.01 & 0.00 & 0.00 & 0.01 & 0.01 & $\mathrm{Cr}$ & 0.01 & 0.01 & 0.00 & $\kappa$ & 1.66 & 1.63 \\
\hline - & - & 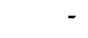 & - & & & & - & & & - & $\mathrm{Cl}$ & 0.00 & 0.00 \\
\hline- & - & - &. & 3 & - & - & - & & & & $F$ & 0.05 & 0.10 \\
\hline & 16.06 & 16.14 & 16.04 & 16.04 & 16.03 & 16.00 & Total & 16.04 & 16.02 & 16.041 & rotal & 13.95 & 13.93 \\
\hline
\end{tabular}




\begin{tabular}{|c|c|c|c|c|c|c|c|c|c|c|c|c|c|c|c|c|c|c|c|c|c|c|c|}
\hline $0=24$ & GRT & GRT & GRT & GRT & GRT & GRT & GRT & GRT & $0=22$ & SE & $B \mathrm{~B}$ & BT & $\mathrm{BTT}$ & BT & $\Delta R$ & SE & CFIL & $0-32$ & & & & & \\
\hline $\mathrm{SiO}_{2}$ & 37.23 & 37.45 & 37.64 & 37.43 & 37.79 & 37.58 & 37.44 & 37.69 & $\mathrm{SiO}_{z}$ & 42.81 & 34.41 & 34.82 & 44.01 & 44.26 & 44.01 & 44.26 & 21.49 & $\mathrm{SiO}_{2}$ & 67.59 & 66.22 & 66.08 & 69.63 & 69.68 \\
\hline $\mathrm{Al}_{2} \mathrm{O}_{3}$ & 19.83 & 21.35 & 21.15 & 21.11 & 21.23 & 21.15 & 21.12 & 21.21 & $\mathrm{THO}_{2}$ & 0.19 & 2.27 & 2.31 & 0.23 & 0.29 & 0.23 & 0.29 & 0.02 & $\mathrm{Al}_{2} \mathrm{O}_{3}$ & 20.41 & 21.19 & 21.09 & 19.32 & 20.13 \\
\hline $\mathrm{THO}_{2}$ & 0.09 & 0.01 & 0.07 & 0.03 & 0.13 & 0.05 & 0.00 & 0.09 & $\mathrm{Al}_{2} \mathrm{O}_{3}$ & 34.13 & 19.49 & 19.92 & 34.63 & 34.36 & 34.63 & 34.36 & 22.63 & $\mathrm{TiO}_{2}$ & 0.04 & 0.06 & 0.00 & 0.08 & 0.00 \\
\hline $\mathrm{FeO}$ & 32.58 & 34.91 & 34.25 & 33.34 & 32.92 & 34.34 & 34.83 & 35.31 & FEO & 3.11 & 26.21 & 24.93 & 3.66 & 2.84 & 3.66 & 2.84 & 35.52 & $\mathrm{Fe}_{2} \mathrm{O}_{3}$ & 0.11 & 0.15 & 0.55 & 0.07 & 0.04 \\
\hline $\mathrm{MnO}$ & 0.71 & 0.08 & 0.06 & 0.26 & 0.85 & 0.08 & 0.10 & 0.09 & $\mathrm{MnO}$ & 0.01 & 0.00 & 0.00 & 0.02 & 0.00 & 0.02 & 0.00 & 0.00 & $\mathrm{MnO}$ & 0.01 & 0.00 & 0.03 & 0.01 & 0.00 \\
\hline $\mathrm{MgO}$ & 0.50 & 1.32 & 0.80 & 0.54 & 0.50 & 0.66 & 1.05 & 1.44 & $\mathrm{MgO}$ & 0.58 & 3.97 & 0.54 & 0.58 & 0.54 & 0.58 & 0.54 & 5.43 & $\mathrm{MgO}$ & - & - & - & 0.00 & 0.00 \\
\hline $\mathrm{CaO}$ & 7.24 & 5.17 & 6.61 & 6.73 & 7.57 & 6.54 & 5.41 & 5.06 & $\mathrm{CaO}$ & 0.02 & 0.05 & 0.00 & 0.00 & 0.00 & 0.00 & 0.00 & 0.02 & $\mathrm{CaO}$ & 1.13 & 2.11 & 2.09 & 0.14 & 0.63 \\
\hline $\mathrm{Na}_{2} \mathrm{O}$ & 0.00 & 0.06 & 0.06 & 0.04 & 0.08 & 0.06 & 0.04 & 0.06 & $\mathrm{Na}_{2} \mathrm{O}$ & 0.53 & 0.25 & 0.51 & 0.52 & $0.5 \mathrm{I}$ & 0.52 & 0.51 & 0.43 & $\mathrm{Na}_{2} \mathrm{O}$ & 10.59 & 10.26 & 10.25 & 11.49 & 11.22 \\
\hline $\mathrm{Cr}_{2} \mathrm{O}_{3}$ & - & 0.05 & 0.00 & 0.01 & 0.03 & 0.04 & 0.05 & 0.02 & $\mathrm{~K}_{2} \mathrm{O}$ & 9.24 & 8.56 & 9.61 & 9.40 & 9.61 & 9.40 & 9.61 & 0.05 & $\mathrm{~K}_{2} \mathrm{O}$ & 0.11 & 0.05 & 0.03 & 0.05 & 0.05 \\
\hline- & 0.02 & - & - & - & - & . & - & . & $\mathrm{Cl}$ & 0.01 & 0.14 & 0.01 & 0.01 & 0.01 & 0.01 & 0.01 & 0.03 & $\mathrm{BaO}$ & 0.00 & 0.15 & 0.04 & - & - \\
\hline - & - & - & - & - & - & - & - & - & $F$ & 0.13 & 0.37 & 0.28 & 0.21 & 0.28 & 0.21 & 0.28 & 0.00 & $\mathrm{Cl}$ & 0.01 & 0.00 & 0.00 & - & - \\
\hline & - & - & - & - & 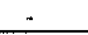 & - & - & - & . & & 0.52 & 1.79 & 1.66 & 1.79 & 1.66 & 1.79 & 0.00 & $\mathrm{SrO}$ & 0.03 & 0.03 & 0.06 & - &. \\
\hline$\frac{T_{\text {Total }}}{\mathrm{Si}}$ & 98.20 & 100.39 & 100.63 & 99.49 & 101.10 & 100.51 & 100.04 & 100.96 & rotal & 90.76 & 96.24 & 94.71 & 94.92 & 94.48 & 94.92 & 94.48 & 85.61 & Total & 100.03 & 100.03 & 100.12 & 100.79 & 101.76 \\
\hline $\begin{array}{l}\mathrm{Si} \\
\mathrm{AI}\end{array}$ & 6.12 & 6.01 & 6.03 & 6.05 & 6.03 & 6.03 & 6.04 & 6.02 & $\mathrm{Si}$ & 6.03 & 5.39 & 6.08 & 6.03 & 6.08 & 6.03 & 6.08 & 3.90 & $\mathrm{Si}$ & 11.82 & 11.61 & 11.60 & 12.05 & 11.95 \\
\hline $\begin{array}{l}\text { Al } \\
\text { TI }\end{array}$ & 3.84 & 4.04 & 3.99 & 4.02 & 3.99 & 4.00 & 4.01 & 3.99 & Ti & 0.02 & 0.27 & 0.03 & 0.02 & 0.03 & 0.02 & 0.03 & 0.00 & Al & 4.21 & 4.38 & 4.36 & 3.94 & 4.07 \\
\hline $\begin{array}{c}\mathrm{Ti} \\
\mathrm{F} 2 \mathrm{2}\end{array}$ & 0.01 & 0.00 & 0.01 & 0.00 & 0.02 & $0.0 \mathrm{D}$ & 0.00 & 0.01 & Al & 5.67 & 3.60 & 5.56 & 5.59 & 5.56 & 5.59 & 5.56 & 4.84 & $\mathrm{Ti}$ & 0.00 & 0.01 & 0.00 & 0.01 & 0.00 \\
\hline $\begin{array}{l}F_{22} \\
\mathrm{Mnn}\end{array}$ & 4.48 & 4.69 & 4.59 & 4.51 & 4.39 & 4.61 & 4.70 & 4.72 & $\mathrm{Fe} 2 \div$ & 0.37 & 3.43 & 0.33 & 0.42 & 0.33 & 0.42 & 0.33 & 5.39 & $\mathrm{Fe} 3+$ & 0.01 & 0.02 & 0.07 & 0.01 & 0.01 \\
\hline $\begin{array}{l}\mathrm{Mrn} \\
\mathrm{Mg}\end{array}$ & 0.10 & 0.01 & 0.01 & 0.03 & 0.12 & 0.01 & 0.01 & 0.01 & $\mathrm{Mn}$ & 0.00 & 0.00 & 0.00 & 0.00 & 0.00 & 0.00 & 0.00 & 0.00 & $\mathrm{Mn}$ & 0.00 & 0.00 & 0.00 & 0.00 & 0.00 \\
\hline $\begin{array}{l}\mathrm{Mg} \\
\mathrm{Ca}\end{array}$ & 0.12 & 0.31 & 0.19 & 0.13 & 0.12 & 0.16 & 0.25 & 0.34 & $\mathrm{Mg}$ & 0.12 & 0.93 & 0.11 & 0.12 & 0.11 & 0.12 & 0.11 & 1.47 & $\mathrm{Mg}$ & - & - & - & 0.00 & 0.00 \\
\hline $\begin{array}{l}\mathrm{Ca} \\
\mathrm{Na}\end{array}$ & 1.27 & 0.89 & 1.14 & 1.17 & 1.29 & 1.12 & 0.93 & 0.87 & $\mathrm{Ca}$ & 0.003 & 0.01 & 0.00 & 0.00 & 0.00 & 0.00 & 0.00 & 0.00 & $\mathrm{Ca}$ & 0.21 & 0.40 & 0.39 & 0.03 & 0.12 \\
\hline $\begin{array}{l}\mathrm{Na} \\
\mathrm{Cr}\end{array}$ & 0.00 & 0.02 & 0.02 & 0.01 & 0.03 & 0.02 & 0.01 & 0.02 & $\mathrm{Na}$ & 0.15 & 0.08 & 0.13 & 0.14 & 0.13 & 0.14 & 0.13 & 0.15 & $\mathrm{Na}$ & 3.59 & 3.49 & 3.49 & 3.55 & 3.73 \\
\hline $\mathrm{Cr}$ & - & 0.01 & 0.00 & 0.00 & 0.00 & 0.01 & 0.01 & 0.00 & $\mathrm{k}$ & 1.66 & 1.71 & 1.68 & 1.64 & 1.68 & 1.64 & 1.68 & 0.01 & $\mathrm{~K}$ & 0.03 & 0.01 & 0.01 & 0.01 & 0.01 \\
\hline$\therefore$ & 0.00 & - & - & - & - & - & - & - & $\mathrm{Cl}$ & 0.00 & 0.04 & 0.00 & 0.00 & 0.00 & 0.00 & 0.00 & 0.01 & $\mathrm{Ba}$ & 0.00 & 0.01 & 0.00 & - & - \\
\hline- & - & - & - & - & - & - & . & - & $F$ & 0.06 & 0.18 & 0.12 & 0.09 & 0.12 & 0.09 & 0.12 & 0.00 & $\mathrm{Cl}$ & 0.00 & 0.00 & 0.00 & . & - \\
\hline- & - & - & + & - & - & $\cdot$ & - & - & - &. & 0.03 & 0.10 & 0.09 & 0.10 & 0.09 & 0.10 & 0.00 & $\mathrm{Sr}$ & 0.00 & 0.00 & 0.01 & & \\
\hline & 15.95 & 15.98 & 15.97 & 15.94 & 15.98 & 15.97 & 15.96 & $15.98 \mathrm{I}$ & otal & 14.08 & 15.66 & 14.14 & 14.14 & 14.14 & 14.14 & 14.14 & 15.77 & Total & 19.87 & 19.92 & 19.93 & 19.60 & 19.88 \\
\hline
\end{tabular}

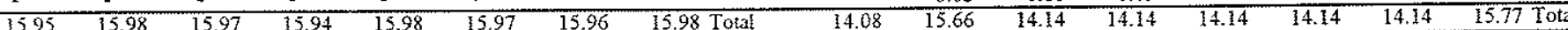

\begin{tabular}{|c|c|c|c|c|c|c|c|c|c|c|c|c|c|c|c|c|c|c|c|c|c|c|c|}
\hline $\mathrm{C} 3$ & 993 & 994 & $\overline{\mathrm{C} 3}$ & 190 & 191 & 192 & 193 & $\mathrm{C3}$ & 82 & 83 & $\mathrm{C} 3$ & 84 & 85 & 81 & 80 & C4 & 211 & 210 & 212 & 213 & 214 & 215 & 216 \\
\hline $\mathrm{O}=32$ & YL & $\overline{\mathrm{PL}}$ & $\mathrm{O}=24$ & $\overline{G R T}$ & GRT & GRT & $\overline{G R T}$ & $\mathrm{O}=22$ & BT & BT & $\mathrm{O}=28$ & $\mathrm{CHL}$ & CHI & CHIL & $\mathrm{CH}$ & $0=6$ & SID & $\mathrm{Sm}$ & $\mathrm{SDD}$ & $\mathrm{CAL}$ & CAL & $\mathrm{CAL}$ & $\overline{\mathrm{CAI}}$ \\
\hline $\mathrm{SiO}_{2}$ & 78.69 & 69.77 & $\mathrm{SiO}_{2}$ & 36.92 & 36.39 & 37.10 & 37.26 & $\mathrm{SiO}_{2}$ & 34.08 & 33.20 & $\mathrm{SiO}_{2}$ & 21.22 & 26.36 & 23.01 & 21.82 & $\mathrm{SiO}_{2}$ & 0.02 & 0.01 & 0.02 & 0.00 & 0.04 & 0.00 & 0.01 \\
\hline $\mathrm{Al}_{2} \mathrm{O}_{3}$ & 14.33 & 19.38 & $\mathrm{Al}_{2} \mathrm{O}_{3}$ & 20.42 & 19.84 & 20.49 & 20.54 & $\mathrm{THO}_{2}$ & 2.01 & 2.24 & $\mathrm{WO}_{2}$ & 0.00 & 0.87 & 0.11 & 0.16 & $\mathrm{TiO}_{2}^{-}$ & 0.01 & 0.00 & 0.00 & 0.02 & 0.04 & 0.00 & 0.07 \\
\hline $\mathrm{TiO}_{2}$ & 0.00 & 0.00 & $\mathrm{TiO}_{2}$ & 0.05 & 0.01 & 0.02 & 0.05 & $\mathrm{Al}_{2} \mathrm{O}_{3}$ & 17.31 & 17.01 & $\mathrm{Al}_{2} \mathrm{O}_{3}$ & 22.01 & 20.73 & 21.97 & 21.54 & $\mathrm{Al}_{2} \mathrm{O}_{3}$ & 0.02 & 0.02 & 0.01 & 0.02 & 0.03 & 0.06 & 0.05 \\
\hline $\mathrm{Fe}_{2} \mathrm{O}_{3}$ & 0.01 & 0.06 & $\mathrm{FeO}$ & 35.77 & 35.60 & 35.88 & 34.82 & $\mathrm{FeO}$ & 28.85 & 28.38 & $\mathrm{FeO}$ & 36.17 & 34.91 & 35.25 & 35.88 & $\mathrm{FeO}$ & 51.52 & 53.35 & 53.27 & 1.40 & 0.96 & 0.78 & 0.70 \\
\hline Mno & 0.00 & 0.00 & $\mathrm{MnO}$ & 0.08 & 0.08 & 0.10 & 0.05 & $\mathrm{MnO}$ & 0.00 & 0.00 & $\mathrm{MnO}$ & 0.03 & 0.01 & 0.03 & 0.02 & $\mathrm{MnO}$ & 0.10 & 0.11 & 0.10 & 0.16 & 0.12 & 0.20 & 0.14 \\
\hline $\mathrm{MgO}$ & 0.00 & 0.01 & $\mathrm{MgO}$ & 1.28 & 1.14 & 0.97 & 0.68 & $\mathrm{MgO}$ & 4.03 & 4.17 & $\mathrm{MgO}$ & 5.33 & 4.05 & 5.66 & 6.03 & $\mathrm{MgO}$ & 5.89 & 4.52 & 4.63 & 0.06 & 0.04 & 0.04 & 0.03 \\
\hline $\mathrm{CaO}$ & 0.13 & 0.09 & $\mathrm{CaO}$ & 5.17 & 5.30 & 5.43 & 6.48 & $\mathrm{CaO}$ & 0.01 & 0.06 & $\mathrm{CaO}$ & 0.01 & 0.04 & 0.07 & 0.04 & $\mathrm{CaO}$ & 0.32 & 0.37 & 0.32 & 55.63 & 55.58 & 55.50 & 56.02 \\
\hline $\mathrm{Na}_{2} \mathrm{O}$ & 8.69 & 11.31 & $\mathrm{Na}_{2} \mathrm{O}$ & 0.02 & 0.00 & 0.00 & 0.00 & $\mathrm{Na}_{2} \mathrm{O}$ & 0.06 & 0.05 & $\mathrm{Na}_{2} \mathrm{O}$ & 0.03 & 0.05 & 0.03 & 0.03 & SrO & 0.03 & 0.02 & 0.00 & 0.06 & 0.05 & 0.04 & 0.03 \\
\hline $\mathrm{K}_{2} \mathrm{O}$ & 0,07 & 0.03 & $\mathrm{Cr}_{2} \mathrm{O}_{3}$ & - & - & - & - & $\mathrm{K}_{2} \mathrm{O}$ & 8.46 & 7.86 & $\mathrm{~K}_{2} \mathrm{O}$ & 0.03 & 2.53 & 0.48 & 0.01 & $\mathrm{BaO}$ & 0.00 & 0.00 & 0.00 & 0.08 & 0.00 & 0.00 & 0.03 \\
\hline $\mathrm{BaC}$ & - & - & $\mathrm{X}_{2} \mathrm{O}_{3}$ & 0.01 & 0.02 & 0.03 & 0.00 & Cl & 0.11 & 0.14 & $\mathrm{Cl}$ & 0.04 & 0.04 & 0.04 & 0.03 & - & - & - & - & - & - & - & - \\
\hline $\mathrm{Cl}$ & - & - & $\mathrm{BaO}$ & - & - & - & . & F & 0.48 & 0.50 & $\mathrm{~F}$ & 0.08 & 0.07 & 0.05 & 0.15 & - & - & - & - & - & - & - & - \\
\hline$\frac{\operatorname{sic} O}{\text { Total }}$ & - & - & + & - & - & - & + & - & & - & - & & - & & & 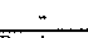 & - & & - & $\therefore$ & - & 5663 & $\frac{-}{5708}$ \\
\hline$\frac{\text { Total }}{\mathrm{Si}}$ & 101.92 & 100.63 & otal & 99.70 & 98.38 & 100.00 & 99.87 & Total & 95.40 & 93.59 & Total & 84.95 & 89.67 & 86.70 & 85.70 & Total & 57.92 & 58.42 & 58.35 & 57.42 & 56.86 & 56.62 & $\frac{57.08}{0.00}$ \\
\hline $\mathrm{Si}$ & 13.16 & 12.07 & $\mathrm{Si}$ & 6.01 & 6.02 & 6.02 & 6.04 & $\mathrm{Si}$ & 5.46 & 5.41 & $\mathrm{Si}$ & 4.97 & 5.78 & 5.22 & 5.05 & $\mathrm{Si}$ & 0.00 & 0.00 & 0.00 & 0.00 & 0.00 & 0.00 & 0.00 \\
\hline Al & 2.82 & 3.95 & $\mathrm{Al}$ & 3.92 & 3.87 & 3.92 & 3.93 & $\mathrm{Ti}$ & 0.24 & 0.27 & $\mathrm{Ti}$ & 0.00 & 0.14 & 0.02 & 0.03 & Tì & 0.00 & 0.00 & 0.00 & 0.00 & 0.00 & 0.00 & 0.01 \\
\hline $\mathrm{Ti}_{\mathrm{i}}$ & 0.00 & 0.00 & $\pi$ & 0.01 & 0.00 & 0.00 & 0.01 & Al & 3.27 & 3.27 & Al & 6.07 & 5.36 & 5.88 & 5.87 & A & 0.00 & 0.00 & 0.00 & 0.00 & 0.00 & $0.0 \mathrm{I}$ & 0.01 \\
\hline Fe3\% & 0.00 & 0.01 & $\mathrm{Fe} 2+$ & 4.87 & 4.92 & 4.87 & 4.72 & $\mathrm{Fe} 2 \dot{\mathrm{T}}$ & 3.86 & 3.87 & $\mathrm{Fe} 2+$ & 7.08 & 6.40 & 6.69 & 6.94 & $\mathrm{Fe} 2+$ & 4.93 & 5.15 & 5.15 & 0.11 & 0.08 & 0.06 & 0.06 \\
\hline Min & 0.00 & 0.00 & $\mathrm{Mn}$ & 0.01 & 0.01 & 0.01 & 0.01 & $\mathrm{Mn}$ & 0.00 & 0.00 & $\mathrm{Mn}$ & 0.01 & 0.00 & 0.01 & 0.00 & $\mathrm{Mn}$ & 0.01 & 0.01 & 0.01 & 0.01 & 0.01 & 0.02 & 0.01 \\
\hline $\mathrm{Mg}$ & 0.01 & 0.00 & $\mathrm{Mg}$ & $0.3 !$ & 0.28 & 0.23 & 0.16 & $\mathrm{Mg}$ & 0.96 & 1.01 & $M g$ & 1.86 & 1.32 & 1.91 & 2.08 & $\mathrm{Mg}$ & \pm .01 & 0.78 & 0.80 & 0.01 & 0.01 & 0.01 & 0.00 \\
\hline $\mathrm{Ca}$ & 0.02 & 0.02 & $\mathrm{Ca}$ & 0.90 & 0.94 & 0.94 & 1.13 & $\mathrm{Ca}$ & 0.00 & 0.01 & $\mathrm{Ca}$ & 0.00 & 0.01 & 0.02 & 0.01 & $\mathrm{Ca}$ & 0.04 & 0.05 & 0.04 & 5.85 & 5.88 & 5.90 & 5.90 \\
\hline $\mathrm{Na}$ & 2.82 & 3.79 & $\mathrm{Na}$ & 0.01 & 0.00 & 0.00 & 0.00 & $\mathrm{Na}$ & 0.02 & 0.01 & $\mathrm{Na}$ & 0.01 & 0.02 & 0.01 & 0.01 & $S r$ & 0.00 & 0.00 & 0.00 & 0.00 & 0.00 & 0.00 & 0.00 \\
\hline$K$ & 0.01 & 0.01 & $\mathrm{Cr}$ & - & - & - & - & $\mathrm{K}$ & 1.73 & 1.63 & $\mathrm{~K}$ & 0.01 & 0.71 & 0.14 & 0.00 & $\mathrm{Ba}$ & 0.00 & 0.00 & 0.00 & 0.00 & 0.00 & 0.00 & 0.00 \\
\hline $\mathrm{Ba}$ & - & - & $Y$ & 9.00 & 0.00 & 0.00 & 0.00 & $\mathrm{cl}$ & 0.03 & 0.04 & $\mathrm{Cl}$ & 0.01 & $0.0 \mathrm{I}$ & 0.01 & 0.01 & - & - & - & - & - & - & - & - \\
\hline $\mathrm{Cl}$ & . & - & $\mathrm{Ba}$ & - & - & - & 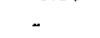 & $F$ & 0.24 & 0.26 & F & 0.05 & 0.04 & 0.03 & 0.09 & - & - & - & - & - & - & - & - \\
\hline
\end{tabular}


K59-38571

\begin{tabular}{|c|c|c|c|c|c|c|c|c|c|c|c|c|c|c|c|c|c|c|c|c|c|c|}
\hline $\mathrm{CH}$ & 217 & $\mathrm{C} 4$ & 88 & 86 & 87 & 89 & 90 & 91 & 92 & $\mathrm{C} 5$ & 218 & 219 & 220 & 221 & 222 & 223 & $\mathrm{C5}$ & 93 & 94 & 95 & 96 & 98 \\
\hline $0=6$ & CAL & $0=22$ & $\mathrm{SE}$ & SE & SE & SE & $\mathrm{SE}$ & $\mathrm{SE}$ & SE & $0=6$ & SID & $\mathrm{SID}$ & SH & Si & SD & $\mathrm{CAL}$ & $0=22$ & $S E$ & $S E$ & SE & BT & $S E$ \\
\hline $\mathrm{SiO}_{2}$ & 0.00 & $\mathrm{SiO}_{2}$ & 43.40 & $4+.24$ & 43.58 & 43.13 & 43.86 & 44.18 & 44.04 & $\mathrm{SiO}_{2}$ & 0.00 & 0.04 & 0.01 & 0.01 & 0.03 & 0.00 & $\mathrm{SiO}_{2}$ & 45.02 & 44.66 & 42.82 & 39.96 & 47.07 \\
\hline $\mathrm{TiO}_{2}$ & 0.00 & $\mathrm{TO}_{2}$ & 0.09 & 0.20 & 0.24 & 0.15 & 0.25 & 0.19 & 0.08 & $\mathrm{YiO}_{2}$ & 0.00 & 0.00 & 0.00 & 0.00 & 0.00 & 0.00 & $\mathrm{THO}_{2}$ & 0.18 & 0.10 & 0.04 & 0.11 & 0.04 \\
\hline $\begin{array}{l}\mathrm{AL}_{2}\left(\mathrm{O}_{3}\right. \\
\mathrm{FEO}\end{array}$ & 0.11 & $\mathrm{Al}_{2} \mathrm{O}_{3}$ & 33.42 & $3+.07$ & 34.71 & 33.12 & 33.94 & 33.77 & 33.82 & $\mathrm{Al}_{2} \mathrm{O}_{3}$ & 0.00 & 0.03 & 0.08 & 0.00 & 0.01 & 0.02 & $\mathrm{Al}_{2} \mathrm{O}_{3}$ & 34.69 & 34.21 & 32.30 & 29.85 & 34.19 \\
\hline $\begin{array}{l}\mathrm{FeO} \\
\mathrm{MnO}\end{array}$ & 0.89 & $\mathrm{FeO}$ & 2.78 & 2.87 & 3.01 & 3.36 & 3.47 & 2.76 & 3.01 & $\mathrm{FeO}$ & 51.34 & 51.20 & 51.63 & 55.34 & 54.96 & 1.08 & $\mathrm{FeO}$ & 2.40 & 2.46 & 2.09 & 13.43 & 2.04 \\
\hline $\begin{array}{l}\mathrm{MnO} \\
\mathrm{MgO})\end{array}$ & 0.13 & $\mathrm{MrO}$ & 0.00 & 0.02 & 0.00 & 0.00 & 0.01 & 0.00 & 0.02 & $\mathrm{MnO}$ & 0.13 & 0.09 & 0.06 & 0.07 & 0.05 & 0.02 & AnO & 0.00 & 0.00 & 0.02 & 0.06 & 0.00 \\
\hline $\begin{array}{l}\mathrm{Mg}() \\
\mathrm{Ca}()\end{array}$ & 0.04 & $\mathrm{Mg}()$ & 0.52 & 0.50 & 0.45 & 0.67 & 0.65 & 0.53 & 0.57 & $\mathrm{MgO}$ & 6.26 & 5.97 & 6.21 & 2.52 & 3.17 & 0.08 & $\mathrm{MgO}$ & 0.53 & 0.51 & 0.44 & 0.90 & 0.61 \\
\hline $\begin{array}{l}\mathrm{CaO}) \\
\mathrm{SrO}\end{array}$ & 55.39 & $\mathrm{CaO}$ & 0.01 & 0.01 & 0.00 & 0.00 & 0.00 & 0.00 & 0.00 & $\mathrm{CaO}$ & 0.59 & 0.59 & 0.15 & 0.18 & 0.48 & 53.64 & $\mathrm{CaO}$ & 0.01 & 0.00 & 0.00 & 0.02 & 0.00 \\
\hline $\begin{array}{l}\mathrm{SrO} \\
\mathrm{BaO}\end{array}$ & 0.06 & $\mathrm{Na}_{2} \mathrm{O}$ & 0.61 & 0.35 & 0.30 & 0.52 & 0.42 & 0.39 & 0.40 & $\mathrm{SrO}$ & 0.00 & 0.01 & 0.00 & 0.00 & 0.00 & 0.03 & $\mathrm{~N}_{3_{2}} \mathrm{O}$ & 0.23 & 0.40 & 0.16 & 0.10 & 0.09 \\
\hline $\begin{array}{c}\mathrm{BaO} \\
-\end{array}$ & 0.06 & $\mathrm{~K}_{2} \mathrm{O}$ & 9.66 & 9.95 & 10.17 & 9.35 & 9.53 & 9.89 & 10.19 & $\mathrm{BaO}$ & 0.03 & 0.00 & 0.01 & 0.03 & 0.00 & 0.00 & $\mathrm{~K}_{2} \mathrm{O}$ & 10.24 & 10.04 & 9.13 & 6.94 & 9.89 \\
\hline - & - & $\mathrm{Cl}$ & 0.03 & 0.01 & 0.03 & 0.03 & 0.00 & 0.00 & 0.01 & - & - & - & - & - & - & - & $\mathrm{Cl}$ & 0.00 & 0.01 & 0.07 & 0.03 & 0.02 \\
\hline- & - & $F$ & 0.20 & 0.11 & 0.04 & 0.18 & 0.15 & 0.17 & 0.24 & - & - & - & - & - & - & - & $F$ & 0.10 & 0.12 & 0.19 & 0.19 & 0.32 \\
\hline$\frac{-}{\text { Total }}$ & - & $\mathrm{BaO}$ & - & - & $\therefore$ & - & 1.51 & 1.33 & 1.23 & - &. &. & - & & & - & $\mathrm{BaO}$ & 0.72 & 1.08 & 0.35 & 0.39 & 0.49 \\
\hline$\frac{\text { Tota! }}{\mathrm{Si}}$ & 56.68 & Total & 90.72 & 92.32 & 92.54 & 90.51 & 93.79 & 93.21 & 93.61 & Total & 58.35 & 57.92 & 58.15 & 58.16 & 58.69 & 54.87 & Total & 94.10 & 93.60 & 87.60 & 91.98 & 94.76 \\
\hline $\begin{array}{l}\mathrm{Si} \\
\mathrm{Ti}\end{array}$ & 0.00 & $\mathrm{Si}$ & 6.13 & 6.13 & 6.04 & 6.11 & 6.07 & 6.13 & 6.10 & $\mathrm{Si}$ & 0.00 & 0.00 & 0.00 & 0.00 & 0.00 & 0.00 & $\mathrm{Si}$ & 6.13 & 6.14 & 6.23 & 5.85 & 6.32 \\
\hline $\begin{array}{l}\mathrm{Ti} \\
\mathrm{A}\end{array}$ & 0.00 & $\mathrm{Ti}$ & 0.01 & 0.02 & 0.03 & 0.02 & 0.03 & 0.02 & 0.01 & $\mathrm{Ti}$ & 0.00 & 0.00 & 0.00 & 0.00 & 0.00 & 0.00 & $\mathrm{Ti}$ & 0.02 & 0.01 & 0.00 & 0.01 & 0.00 \\
\hline $\begin{array}{c}\text { Ai } \\
F \bullet 2 \div\end{array}$ & 0.01 & Al & 5.56 & 5.56 & 5.67 & 5.53 & 5.53 & 5.52 & 5.52 & $\mathrm{Al}$ & 0.00 & 0.00 & 0.01 & 0.00 & 0.00 & 0.00 & $\mathrm{Al}$ & 5.57 & 5.54 & 5.53 & 5.15 & 5.41 \\
\hline $\begin{array}{l}\mathrm{F} \in 2 \div \\
\mathrm{Mn}\end{array}$ & 0.07 & $\mathrm{Fe} 2+$ & 0.33 & 0.33 & 0.35 & 0.40 & 0.40 & 0.32 & 0.35 & $\mathrm{Fe} 2+$ & 4.86 & 4.89 & 4.90 & 5.52 & 5.38 & 0.09 & $F=2 \%$ & 0.27 & 0.28 & 0.25 & 1.65 & 0.23 \\
\hline $\begin{array}{l}\mathrm{Mn} \\
\mathrm{Mg}\end{array}$ & 0.01 & $\mathrm{Mn}$ & 0.00 & 0.00 & 0.00 & 0.00 & 0.00 & 0.00 & 0.00 & $\mathrm{Mn}$ & 0.01 & 0.01 & 0.01 & 0.01 & 0.00 & 0.00 & $\mathrm{Mn}$ & 0.00 & 0.00 & 0.00 & 0.01 & 0.00 \\
\hline $\begin{array}{c}\mathrm{Mg} \\
\mathrm{Ca}\end{array}$ & 0.01 & $\mathrm{Mg}$ & 0.11 & 0.10 & 0.09 & 0.14 & 0.13 & 0.11 & 0.12 & $\mathrm{Mg}$ & 1.06 & 1.02 & 1.05 & 0.45 & 0.55 & 0.01 & $\mathrm{Mg}$ & 0.11 & 0.11 & 0.10 & 0.20 & 0.12 \\
\hline $\begin{array}{l}\mathrm{Ca} \\
\mathrm{St}\end{array}$ & 5.88 & $\mathrm{Ca}$ & 0.00 & 0.00 & 0,00 & 0.00 & 0.60 & 0.00 & 0.00 & $\mathrm{Ca}$ & 0.07 & 0.07 & 0.02 & 0.02 & 0.06 & 5.89 & $\mathrm{C}_{3}$ & 0.00 & 0.00 & 0.00 & 0.00 & 0.00 \\
\hline $\begin{array}{l}\mathrm{Sr} \\
\mathrm{Ba}\end{array}$ & 0.00 & $\mathrm{Na}$ & 0.17 & 0.09 & 0.08 & 0.14 & 0.11 & 0.11 & 0.11 & $S_{r}$ & 0.00 & 0.00 & 0.00 & 0.00 & 0.00 & 0.00 & $\mathrm{Na}$ & 0.06 & 0.11 & 0.04 & 0.03 & 0.02 \\
\hline $\mathrm{Ba}$ & 0.00 & $\mathrm{~K}$ & 1.74 & 1.76 & 1.80 & 1.69 & 1.68 & 1.75 & 1.80 & $\mathrm{Ba}$ & 0.00 & 0.00 & 0.00 & 0.00 & 0.00 & 0.00 & $\mathrm{~K}$ & 1.78 & 1.76 & 1.69 & 1.30 & 1.69 \\
\hline 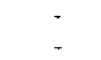 & - & $\mathrm{Cl}$ & 0.01 & 0.00 & 0.01 & 0.01 & 0.00 & 0.00 & 0.00 & - & - & + & - & - & - & - & $\mathrm{Cl}$ & 0.00 & 0.00 & 0.02 & 0.01 & 0.01 \\
\hline - & . & $F$ & 0.09 & 0.05 & 0.02 & 0.08 & 0.07 & 0.07 & 0.11 & * & - & - & - & - & - & - & $F$ & 0.0 & 0.05 & 0.09 & 0.09 & 0.14 \\
\hline & - & $B x$ & & - & & - & 0.08 & 0.07 & 0.07 & - & - & - & & + & - & 5 & $\mathrm{Ba}$ & 0.04 & 0.06 & 0.02 & 0.02 & 0.03 \\
\hline & & & 14.14 & 14.05 & 14.07 & 14.12 & 84.11 & 14.10 & 14.19 & Total & 6.00 & 5.99 & 5.99 & 6.00 & 6.00 & 6.00 & Total & 14.03 & 14.07 & 13.98 & 14.32 & 13.97 \\
\hline
\end{tabular}

$\begin{array}{lllllllll}5.99 & \text { Total } & 14.14 & 14.05 & 14.07 & 14.12 & 14.11 & 14.10 & 14.19 \text { Total }\end{array}$

\begin{tabular}{|c|c|c|c|c|c|c|c|c|c|c|c|c|c|c|c|c|c|c|c|c|c|c|c|}
\hline $\mathrm{CS}$ & 97 & 99 & C6 & 224 & 225 & 226 & 227 & 228 & $\mathrm{C} 6$ & 35 & 36 & $\mathrm{C} 6$ & 103 & 102 & C6 & 100 & 103 & 104 & 105 & 106 & 107 & 109 & 108 \\
\hline$O=28$ & $\mathrm{CHL}$ & $\mathrm{CHL}$ & $\mathrm{O}=6$ & CAI. & ANK & SID & SD & SD & $\mathrm{O}=32$ & PL & $\overline{\mathrm{PL}}$ & $\mathrm{O}=22$ & SE & $\mathrm{SE}$ & $0=28$ & $\mathrm{CHL}$ & $\mathrm{CHL}$ & $\mathrm{CHL}$ & $\overline{\mathrm{CHI}}$ & CHL & $\mathrm{CHL}$ & $\mathrm{CHL}$ & CIIL \\
\hline $\mathrm{SiO}_{2}$ & 22.71 & 22.68 & $\mathrm{SiO}_{2}$ & 0.01 & 0.04 & 0.01 & 0.02 & 0.00 & $\mathrm{SiO}_{2}$ & 69.10 & 66.68 & $\mathrm{SiO}_{2}$ & 44.01 & 44.26 & $\mathrm{SiO}_{2}$ & 22.55 & 30.55 & 22.24 & 21.86 & 22.98 & 22.58 & 22.78 & 22.53 \\
\hline $\mathrm{TiO}_{2}$ & 0.09 & 0.15 & $\mathrm{TiO}_{2}$ & 0.00 & 0.05 & 0.00 & 0.08 & 0.02 & $\mathrm{Al}_{2} \mathrm{O}_{3}$ & 19.38 & 20.74 & $\mathrm{THO}_{2}$ & 0.23 & 0.29 & $\mathrm{FiO}_{2}$ & 0.11 & 0.06 & 0.12 & 0.03 & 0.15 & 0.01 & 0.06 & 0.05 \\
\hline $\mathrm{Al}_{2} \mathrm{O}_{3}$ & 21.74 & 21.80 & $\mathrm{Al}_{2} \mathrm{O}_{3}$ & 0.04 & 0.07 & 0.07 & 0.03 & 0.00 & $\mathrm{TiO}_{2}$ & 0.04 & 0.00 & $\mathrm{Al}_{2} \mathrm{O}_{3}$ & 34.63 & 34.36 & $\mathrm{Al}_{2} \mathrm{O}_{3}$ & 21.58 & 24.69 & 21.85 & 21.67 & 21.68 & 21.61 & 21.53 & 21.34 \\
\hline $\mathrm{FeO}$ & 32.39 & 32.59 & $\mathrm{FeO}$ & 0.55 & 23.35 & 54.05 & 51.29 & 51.34 & $\mathrm{Fe}_{2} \mathrm{O}_{3}$ & 0.15 & 0.13 & FeO & 3.66 & 2.84 & $\mathrm{FeO}$ & 34.35 & 28.27 & 34.73 & 34.33 & 34.02 & 35.60 & 34.95 & 35.19 \\
\hline $\mathrm{MnO}$ & 0.02 & 0.02 & $\mathrm{MnO}$ & 0.04 & 0.12 & 0.07 & 0.16 & 0.19 & $\mathrm{MnO}$ & 0.04 & 0.04 & $\mathrm{MnO}$ & 0.02 & 0.00 & Mno & 0.02 & 0.00 & 0.03 & 0.07 & 0.06 & 0.05 & 0.02 & 0.00 \\
\hline $\mathrm{MgO}$ & 8.37 & 8.45 & $\mathrm{MgO}$ & 0.04 & 6.18 & 4.31 & 6.56 & 6.57 & $\mathrm{MgO}$ & - & - & $\mathrm{MgO}$ & 0.58 & 0.54 & $\mathrm{MgO}$ & 7.51 & 1.59 & 7.14 & 7.42 & 8.26 & 6.68 & 7.83 & 7.01 \\
\hline $\mathrm{CaO}$ & 0.00 & 0.02 & $\mathrm{CaO}$ & 53.95 & 26.17 & 0.35 & 0.50 & 0.64 & $\mathrm{CaO}$ & 0.23 & 1.84 & $\mathrm{CaO}$ & 0.00 & 0.00 & $\mathrm{CaO}$ & 0.02 & 0.02 & 0.02 & 0.03 & 0.01 & 0.02 & 0.01 & 0.03 \\
\hline $\mathrm{Na}_{2} \mathrm{O}$ & 0.00 & 0.01 & $\mathrm{SrO}$ & 0.00 & 0.00 & 0.00 & 0.00 & 0.02 & $\mathrm{Na}_{2} \mathrm{O}$ & 11.37 & 10.58 & $\mathrm{Na}_{2} \mathrm{O}$ & 0.52 & 0.51 & $\mathrm{Na}_{2} \mathrm{O}$ & 0.03 & 0.08 & 0.02 & 0.01 & 0.00 & 0.00 & 0.00 & 0.01 \\
\hline $\mathrm{K}_{2} \mathrm{O}$ & 0.01 & 0.01 & $\mathrm{BaO}$ & 0.00 & 0.00 & 0.00 & 0.02 & 0.00 & $\mathrm{~K}_{z} \mathrm{O}$ & 0.02 & 0.07 & $\mathrm{~K}_{2} \mathrm{O}$ & 9.40 & 9.61 & $\mathrm{~K}_{2} \mathrm{O}$ & 0.02 & 3.07 & 0.02 & 0.01 & 0.00 & 0.00 & 0.01 & 0.02 \\
\hline $\mathrm{Cl}$ & 0.02 & 0.00 & - & - & - & - & . & - & $\mathrm{BaO}$ & 0.03 & 0.02 & $\mathrm{Cl}$ & 0.01 & 0.01 & $\mathrm{Cl}$ & 0.02 & 0.02 & 0.03 & 0.03 & 0.03 & 0.02 & 0.01 & 0.01 \\
\hline F & 0.09 & 0.04 & - & - & - & - & - & - & $\mathrm{Ol}$ & 0.00 & 0.01 & $\mathrm{~F}$ & 0.21 & 0.28 & $F$ & 0.02 & 0.00 & 0.07 & 0.07 & 0.12 & 0.10 & 0.04 & 0.00 \\
\hline $\mathrm{Ba}(3)$ & 0.00 & 0.11 & . & - & . & . & - & & $\mathrm{SrO}$ & 0.05 & 0.30 & $\mathrm{BaO}$ & 1.66 & 1.79 & $\mathrm{BaO}$ & 0.00 & 0.06 & 0.00 & 0.01 & 0.00 & 0.00 & 0.00 & 0.00 \\
\hline Total & 85.45 & 85.88 & Total & 54.63 & 55.99 & 58.85 & 58.65 & 58.77 & Total & 100.41 & 100.09 & Total & 94.92 & 94.487 & Total & 86.22 & 88.39 & 86.26 & 85.53 & 87.30 & 86.67 & 87.24 & 86.18 \\
\hline $\mathrm{Si}$ & 5.15 & 5.12 & Si & 0.00 & 0.00 & 0.00 & 0.00 & 0.00 & $\mathrm{Si}$ & 12.02 & 11.69 & $\mathrm{Si}$ & 6.03 & 6.08 & $\mathrm{Si}$ & 5.12 & 6.44 & 5.06 & 5.02 & 5.13 & 5.13 & 5.12 & 5.14 \\
\hline$T i$ & 0.01 & 0.03 & Ti & 0,00 & 0.00 & 0.00 & 0.01 & 0.00 & At & 3.97 & 4.29 & $\mathrm{Ti}$ & 0.02 & 0.03 & $\mathrm{Ti}$ & 0.02 & 0.01 & 0.02 & 0.01 & 0.02 & 0.00 & 0.01 & 0.01 \\
\hline $\mathrm{A} 1$ & 5.81 & 5.80 & $\mathrm{~A}$ & 0.00 & 0.01 & 0.01 & 0.00 & 0.00 & $\mathrm{Ti}$ & 0.01 & 0.00 & A1 & 5.59 & 5.56 & $\mathrm{Al}$ & 5.77 & 6.13 & 5.86 & 5.87 & 5.71 & 5.79 & 5.70 & 5.74 \\
\hline$F \subset 2:$ & 6.14 & 6.15 & Fe?t & 0.05 & 205 & 5.20 & 4.81 & 4.80 & $\mathrm{~F} \approx 3+$ & 0.62 & 0.02 & $\mathrm{Fe} 2+$ & 0.42 & 0.33 & $\mathrm{~F} \in 2+$ & 6.52 & 4.98 & 6.61 & 6.59 & 6.36 & 6.77 & 6.56 & 6.71 \\
\hline $\mathrm{Mn}$ & 0.00 & 0,00 & $\mathrm{Mn}$ & 0.60 & 0.01 & $0.0 \mathrm{i}$ & 0,02 & 0.02 & $\mathrm{Mr}$ & 0.01 & 0.01 & $\mathrm{Mn}$ & 0.00 & 0.00 & $\mathrm{Mn}$ & 0.00 & 0.00 & 0.01 & 0.01 & 0.01 & 0.01 & 0.00 & 0.00 \\
\hline $\mathrm{Mg}$ & 2.83 & 2.84 & $\mathrm{Mg}$ & 0.01 & 0.97 & 0.74 & 1.10 & $\therefore .10$ & $\mathrm{Mg}$ & - & - & $\mathrm{Mg}$ & 0.12 & 0.11 & $\mathrm{Mg}$ & 2.54 & 0.50 & 2.42 & 2.54 & 2.75 & 2.26 & 2.62 & 2.38 \\
\hline $\mathrm{Ca}$ & 0.00 & 0.01 & $\mathrm{Ca}$ & 5.93 & 2.94 & 0.04 & 0.06 & 0.08 & $\mathrm{Ca}$ & 0.04 & 0.35 & $\mathrm{Ca}$ & 0.00 & 0.00 & $\mathrm{Ca}$ & 0.00 & 0.00 & 0.01 & 0.01 & 0.00 & 0.00 & 0.00 & 0.01 \\
\hline $\mathrm{Na}$ & 0.00 & 0.00 & $\mathrm{Sr}$ & 0.00 & 0.00 & 0.00 & 0.00 & 0.00 & $\mathrm{Na}$ & 3.83 & 3.60 & $\mathrm{Na}$ & 0.14 & 0.13 & $\mathrm{Na}$ & 0.01 & 0.03 & 0.01 & 0.00 & 0.00 & 0.00 & 0.00 & 0.00 \\
\hline K & 0.00 & 0.00 & $\mathrm{Ba}$ & 0.00 & 0.00 & 0.00 & 0.00 & 0.00 & $\kappa$ & 0.01 & 0.02 & $\mathrm{~K}$ & 1.64 & 1.68 & $\mathrm{~K}$ & 0.00 & 0.82 & 0.00 & 0.00 & 0.00 & 0.00 & 0.00 & 0.00 \\
\hline $\mathrm{Cl}$ & 0.01 & 0.00 & - &. & - & - & . & - & $\mathrm{Ba}$ & 0.00 & 0.00 & $\mathrm{Cl}$ & 0.00 & 0.00 & $\mathrm{Cl}$ & 0.01 & 0.00 & 0.01 & 0.01 & 0.01 & 0.01 & 0.00 & 0.00 \\
\hline$F$ & 0.05 & 0.02 & - & . & - & - & - & - & $\mathrm{Cl}$ & 0.00 & 0.00 & $F$ & 0.09 & 0.12 & F & 0.01 & 0.00 & 0.04 & 0.04 & 0.07 & 0.06 & 0.02 & 0.007 \\
\hline $\mathrm{Ba}$ & 0.00 & 0.01 & - & - & - & - & - & - & $\mathrm{Sr}$ & 0.00 & 0.00 & $\mathrm{Ba}$ & 0.09 & 0.10 & $\mathrm{Ba}$ & 0.00 & 0.00 & 0.00 & 0.00 & 0.00 & 0.00 & 0.00 & 0.00 \\
\hline tal & 20.00 & 19.99 & Total & 6.00 & 5.99 & 5.99 & 5.99 & 6.00 & Total & 19.90 & 19.96 & Total & 14.14 & 14.14 & Total & 20.01 & 18.93 & 20.04 & 20.10 & 20.06 & 20.04 & 20.05 & 20.00 \\
\hline
\end{tabular}


K59-38571

\begin{tabular}{|c|c|c|c|c|c|c|c|c|c|c|c|c|c|c|c|c|c|c|c|c|c|c|c|}
\hline $\mathrm{C} 6$ & 110 & C7 & 907 & 908 & 909 & 910 & 911 & $\mathrm{C7}$ & 960 & 961 & 962 & C7 & 995 & 996 & 997 & 998 & 299 & $\mathrm{C} 8$ & 913 & 914 & 915 & 916 & 917 \\
\hline $0=28$ & CHL & $0=22$ & $\mathrm{BT}$ & BT & BT & BT & BT & $\mathrm{O}=24$ & GRT & GRT & GRT & $0=32$ & $\mathrm{PL}$ & PL & PI & $P L$ & PL & $0=22$ & BT & $\mathrm{BT}$ & BT & BT & $\frac{\mathrm{BT}}{3 \mathrm{~T}}$ \\
\hline $\mathrm{SiO}_{2}$ & 22.94 & $\mathrm{SiO}_{2}$ & 32.12 & 32.00 & 34.23 & 29.88 & 30.80 & $\mathrm{SiO}_{2}$ & 37.48 & 37.56 & 37.66 & $\mathrm{SiO}_{2}$ & 67.00 & 67.18 & 68.60 & 68.79 & 79.07 & $\mathrm{SiO}_{2}$ & 34.24 & 33.74 & 33.40 & 30.91 & 31.54 \\
\hline $\mathrm{THO}_{2}$ & 0.04 & $\mathrm{THO}_{2}$ & 1.34 & 1.81 & 1.76 & 1.41 & 1.25 & $\mathrm{Al}_{2} \mathrm{O}_{3}$ & 21.02 & 21.23 & 21.22 & $\mathrm{Al}_{2} \mathrm{O}_{3}$ & 20.29 & 20.84 & 20.04 & 19.32 & 13.80 & $\mathrm{TiO}_{2}$ & 1.73 & 1.64 & 1.57 & 1.09 & 0.81 \\
\hline $\mathrm{Al}_{2} \mathrm{O}_{3}$ & 21.47 & $\mathrm{Al}_{2} \mathrm{O}_{3}$ & 19.88 & 18.21 & 18.27 & 18.59 & 18.54 & $\mathrm{TH}_{2}$ & 0.00 & 0.10 & 0.08 & $\mathrm{TiO}_{2}$ & 0.00 & 0.00 & 0.05 & 0.00 & 0.00 & $\mathrm{Al}_{2} \mathrm{O}_{3}$ & 18.90 & 18.72 & 18.78 & 18.47 & 19.43 \\
\hline $\mathrm{FeO}_{\mathrm{eO}}$ & 34.90 & $\mathrm{FeO}$ & $27 . \$ 3$ & 28.07 & 25.66 & 31.92 & 30.46 & $\mathrm{FeO}$ & 33.81 & 35.04 & 32.96 & $\mathrm{Fe}_{2} \mathrm{O}_{3}$ & 0.37 & 0.10 & 0.22 & 0.10 & 0.19 & $\mathrm{FeO}$ & 24.25 & 24.57 & 25.71 & 28.41 & 27.85 \\
\hline $\mathrm{MnO}$ & 0.01 & $\mathrm{MnO}$ & 0.04 & 0.00 & 0.01 & 0.00 & 0.00 & Mino & 0.11 & 0.08 & 0.56 & $\mathrm{MnO}$ & 0.00 & 0.02 & 0.00 & 0.00 & 0.00 & $\mathrm{MnO}$ & 0.03 & 0.00 & 0.00 & 0.03 & 0.00 \\
\hline $\mathrm{MgO}$ & 7.58 & $\mathrm{MgO}$ & 4.43 & 5.10 & 4.91 & 4.3 & 4.54 & $\mathrm{MgO}$ & 1.26 & 1.00 & 0.59 & $\mathrm{MgO}$ & 0.01 & 0.02 & 0.01 & 0.00 & 0.01 & $\mathrm{MgO}$ & 5.63 & 6.12 & 5.83 & 5.66 & 5.93 \\
\hline $\begin{array}{l}(\mathrm{CO}) \\
\mathrm{Na}_{2}(\mathrm{C})\end{array}$ & 0.01 & ( $(a)$ & 0.05 & 0.05 & 0,02 & 0.05 & 0.01 & $(x)$ & 5.58 & 5.42 & 7.08 & $\mathrm{CaO}$ & 1.26 & 1.90 & 0.68 & 0.43 & 0.31 & $\mathrm{CaO}$ & 0.01 & 0.00 & 0.05 & 0.04 & 0.08 \\
\hline $\begin{array}{l}\mathrm{Na}_{2}(>) \\
\mathrm{K}_{2} \mathrm{O}\end{array}$ & 0.03 & $\mathrm{Nat}_{2}(3)$ & $0.34)$ & 0.31 & (3.21 & 0.15 & 0.18 & ${\mathrm{~N}: \mathrm{z}_{2}}_{\mathrm{O}} \mathrm{)}$ & 0.05 & a.6.3 & 0.013 & $\mathrm{Na}_{2} \mathrm{O}$ & 10.78 & 10.61 & 11.17 & 11.16 & 8.36 & $\mathrm{Nat}(\mathrm{C})$ & 0.15 & 0.16 & 0.20 & 0.20 & 0.22 \\
\hline $\begin{array}{c}\mathrm{K}_{2} \mathrm{O} \\
\mathrm{Cl}\end{array}$ & 0.01 & $\mathrm{~K}_{2} \mathrm{O}$ & 6.19 & 6.72 & 8.62 & 4.51 & 5.32 & $\mathrm{Cr}_{2} \mathrm{O}_{3}$ & 0.02 & 0.08 & 0.03 & $\mathrm{~K}_{2} \mathrm{O}$ & 0.06 & 0.04 & 0.04 & 0.05 & 0.02 & $\mathrm{~K}_{2} \mathrm{O}$ & 7.57 & 8.17 & 7.22 & 5.72 & 5.75 \\
\hline $\begin{array}{l}\mathrm{Cl} \\
\mathrm{F}\end{array}$ & 0.02 & $\mathrm{Cl}$ & 0.09 & 0.12 & 0.02 & 0.03 & 0.03 & & - & - & - & - & - & - & - & - & - & $\mathrm{cl}$ & 0.11 & 0.10 & 0.08 & 0.12 & 0.15 \\
\hline $\begin{array}{c}\mathrm{F} \\
\mathrm{BaO}\end{array}$ & 0.10 & F & 0.24 & 0.48 & 0.56 & 0.28 & 0.01 & - & - & - & - & - & - & - & - & - & - & $F$ & 0.48 & 0.53 & 0.44 & 0.37 & 0.35 \\
\hline$\frac{\mathrm{BaO}}{\text { Total }}$ & 0.00 & $\mathrm{BaO}$ & 0.34 & 0.45 & 0.44 & 0.20 & 0.24 & . & - & - & - & - & - & - & & & & $\mathrm{BaO}$ & 0.57 & 0.62 & 0.57 & 0.27 & 0.36 \\
\hline$\frac{\text { Total }}{\mathrm{Si}}$ & 87.127 & Total & 92.54 & 93.31 & 94.71 & 91.36 & 91.38 & Cotal & 99.34 & 100.54 & 100.21 & Tozal & 99.76 & 100.71 & 100.81 & 99.85 & $101.75 \mathrm{~T}$ & Cotal & 93.66 & 94.36 & 93.83 & 91.29 & 92.45 \\
\hline $\begin{array}{c}\mathrm{Si} \\
\mathrm{Ti}\end{array}$ & 5.16 & $\mathrm{Si}$ & 5.22 & 5.22 & 5.45 & 5.01 & 5.13 & $\mathrm{Si}$ & 6.06 & 6.03 & 6.05 & $\mathrm{Si}$ & 11.77 & 11.70 & 11.89 & 12.02 & 13.23 & $\mathrm{Si}$ & 5.44 & 5.37 & 5.34 & 5.14 & 5.14 \\
\hline $\begin{array}{l}\mathrm{Ti} \\
\mathrm{Al}\end{array}$ & 0.01 & $\mathrm{Ti}$ & 0.16 & 0.22 & 0.21 & 0.18 & 0.16 & A) & 4.01 & & 4.01 & AI & 4.20 & 4.28 & 4.10 & 3.98 & 2.72 & $\mathrm{Ti}$ & 0.21 & 0.20 & 0.19 & 0.14 & 0.10 \\
\hline $\begin{array}{c}\text { Al } \\
F \in 2+\end{array}$ & 5.69 & Al & 3.80 & 3.50 & 3.43 & 3.68 & 3.64 & $\mathrm{Ti}$ & 0.00 & 0.01 & 0.01 & $\mathrm{Ti}$ & 0.00 & 0.00 & 0.01 & 0.00 & 0.00 & AI & 3.54 & 3.51 & 3.54 & 3.62 & 3.73 \\
\hline $\begin{array}{l}\text { Fe2 } \\
\mathrm{Mnz}\end{array}$ & 6.57 & $F=2+$ & 3.72 & 3.83 & 3.42 & 4.48 & 4.24 & $\mathrm{Fe} 2+$ & 4.57 & 4.70 & 4.42 & Fe3- & 0.05 & 0.01 & 0.03 & 0.01 & 0.02 & $\mathrm{Fe} 2+$ & 3.22 & 3.27 & 3.44 & 3.95 & 3.80 \\
\hline $\begin{array}{l}\mathrm{Mnz} \\
\mathrm{Mg}\end{array}$ & 0,00 & $\mathrm{Mn}$ & 0.01 & 0.00 & 0.00 & 0.00 & 0.00 & $\mathrm{Mn}$ & 0.02 & 0.01 & 0.08 & Mn & 0.00 & 0.00 & 0.00 & 0.00 & 0.00 & $\mathrm{Mn}$ & 0.00 & 0.00 & 0.00 & 0.00 & 0.00 \\
\hline $\begin{array}{l}\mathrm{Mg} \\
\mathrm{Ca}\end{array}$ & 2.54 & $\mathrm{Mg}$ & 1.07 & 1.24 & 1.17 & 1.09 & 1.13 & $\mathrm{Mg}$ & 0.30 & 0.24 & 0.14 & $\mathrm{Mg}$ & 0.00 & 0.01 & 0.00 & 0.00 & 0.00 & $\mathrm{Mg}$ & 1.33 & 1.45 & 1.39 & 1.40 & 1.44 \\
\hline $\begin{array}{l}\mathrm{Ca} \\
\mathrm{Na}\end{array}$ & 0.00 & $\mathrm{Ca}$ & 0.01 & 0.01 & 0.00 & 0.01 & 0.00 & $\mathrm{Ca}$ & 0.97 & 0.93 & 1.22 & $\mathrm{Ca}$ & 0.24 & 0.35 & 0.13 & 0.08 & 0.06 & $\mathrm{Ca}$ & 0.00 & 0.00 & 0.01 & 0.01 & 0.01 \\
\hline $\begin{array}{l}\mathrm{Na} \\
\mathrm{X}\end{array}$ & 0.01 & $\mathrm{Na}$ & & & 0.06 & 0.05 & 0.06 & $\mathrm{Na}$ & $0.0 \mathrm{1}$ & 0.01 & 0.01 & $\mathrm{Na}$ & 3.67 & 3.58 & 3.76 & 3.78 & 2.71 & $\mathrm{Na}$ & 0.05 & 0.05 & 0.06 & $\begin{array}{l}0.06 \\
1.21\end{array}$ & $\begin{array}{l}0.07 \\
1.20\end{array}$ \\
\hline $\mathrm{Cl}$ & $\begin{array}{l}0.00 \\
0.01\end{array}$ & $\begin{array}{l}\mathrm{K} \\
\mathrm{Cl}\end{array}$ & 1.28 & 1.40 & 1.75 & 0.97 & 1.13 & $\mathrm{Cr}$ & 0.00 & 0.01 & 0.00 & $\mathrm{~K}$ & 0.01 & 0.01 & 0.01 & 0.01 & 0.00 & $\begin{array}{l}K \\
\mathrm{Cl}\end{array}$ & $\begin{array}{l}1.53 \\
0.03\end{array}$ & $\begin{array}{l}1.66 \\
0.03\end{array}$ & $\begin{array}{l}1.47 \\
0.02\end{array}$ & $\begin{array}{l}1.21 \\
0.03\end{array}$ & $\begin{array}{l}.210 \\
0.04\end{array}$ \\
\hline$E$ & 0.06 & $\mathrm{~F}$ & $\begin{array}{l}0.03 \\
0.12\end{array}$ & $\begin{array}{l}0.03 \\
0.25\end{array}$ & $\begin{array}{l}0.01 \\
0.28\end{array}$ & $\begin{array}{l}0.01 \\
0.15\end{array}$ & $\begin{array}{l}0.01 \\
0.01\end{array}$ & - & $=$ & - & - & 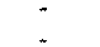 & - & . & - & - & - & $\begin{array}{l}C l \\
F\end{array}$ & 0.24 & 0.27 & 0.22 & 0.20 & 0.18 \\
\hline $\mathrm{Ba}$ & 0.00 & $\mathrm{Ba}$ & 0.012 & 0.03 & 0.03 & 0.01 & 0.02 & - & - & - & 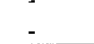 & - & - & 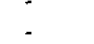 & - & - & - & $\mathrm{Ba}$ & 0.04 & 0.04 & 0.04 & 0.02 & 0.02 \\
\hline & 006 & & & & 1582 & 1563 & 155 & a) & 1594 & 1595 & 159 & otal & $\overline{19.95}$ & 19.95 & 19.92 & 19.88 & & Cotal & 15.64 & 15.83 & 15.71 & 15.79 & 15.74 \\
\hline
\end{tabular}

\begin{tabular}{|c|c|c|c|c|c|c|c|c|}
\hline \multicolumn{6}{|c|}{$\frac{K 59-38571}{C 8} 918$} & & & \\
\hline $0=28$ & $\mathrm{CHI}$ & $0=24$ & GRT & GRT & GRT & GRT & GRT & GRT \\
\hline $\mathrm{SiO}_{2}$ & 22.85 & $\mathrm{SiO}_{2}$ & 37.40 & $37 . \hat{3} 3$ & 37.55 & 37.71 & 37.62 & 37.25 \\
\hline $\mathrm{TiO}_{2}$ & 0.00 & $\mathrm{Al}_{2} \mathrm{O}_{3}$ & 21.23 & 21.16 & 21.21 & 21.23 & 21.14 & 21.15 \\
\hline $\mathrm{Al}_{2} \mathrm{O}_{3}^{+}$ & 22.08 & $\mathrm{TiO}_{2}$ & 0.36 & 0.06 & 0.12 & 0.07 & 0.05 & 0.04 \\
\hline $\mathrm{FeO}$ & 34.32 & $\mathrm{FeO}$ & 35.03 & 34.40 & 33.23 & 33.39 & 34.74 & 34.69 \\
\hline Mno & 0.03 & $\mathrm{MnO}$ & 0.12 & 0.11 & 0.12 & 0.49 & 0.08 & 0.09 \\
\hline $\mathrm{MgO}$ & 7.47 & $\mathrm{MgO}$ & 1.38 & 1.10 & 0.68 & 0.54 & 1.33 & 1.00 \\
\hline $\mathrm{CaO}$ & 0.03 & Cal & 4.60 & 5.65 & 7.25 & 7.40 & 4.79 & 5.44 \\
\hline $\mathrm{Na}_{2} \mathrm{O}$ & 0.13 & $\mathrm{Ni}_{2} \mathrm{O}$ & 0.04 & 0.04 & 0.03 & 0.00 & 0.01 & 0.03 \\
\hline $\mathrm{K}_{2} \mathrm{O}$ & 0.02 & $\mathrm{Cr}_{2} \mathrm{O}_{3}$ & 0.02 & 0,06 & 0.04 & 0.01 & 0.06 & 0.02 \\
\hline $\mathrm{Cl}$ & 0.01 & - & - & - & - & - & - & - \\
\hline$F$ & 0.00 & . & - & - & - & - & - & - \\
\hline $\mathrm{BaO}$ & 0.02 & - & - & - & - & - & - & 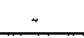 \\
\hline Total & 86.96 & Total & 99.96 & 99.91 & 100.22 & 100.84 & 99.83 & 99.70 \\
\hline$\overline{\mathrm{Si}}$ & 4.03 & $\mathrm{Si}$ & 6.02 & 6.02 & 6.03 & 6.03 & 6.06 & 6.02 \\
\hline Ti & 0.00 & Al & 4.03 & 4.02 & 4.01 & 4.00 & 4.01 & 4.03 \\
\hline Al & 4.59 & $T i$ & 0.02 & 0.01 & 0.01 & 0.01 & 0.01 & 0.00 \\
\hline$F=2+$ & 5.06 & $\mathrm{~F} \in 2+$ & 4.72 & 4.64 & 4.46 & 4.46 & 4.68 & 4.69 \\
\hline $\mathrm{Mn}$ & 0.01 & $\mathrm{Mn}$ & 0.02 & 0.01 & 0.02 & 0.07 & 0.01 & 0.01 \\
\hline $\mathrm{Mg}$ & 1.96 & $\mathrm{Mg}$ & 0.33 & 0.26 & 0.16 & 0.13 & 0.32 & 0.24 \\
\hline $\mathrm{Ca}$ & 0.01 & $\mathrm{ca}$ & 0.79 & 0.98 & 1.25 & 1.27 & 0.83 & 0.94 \\
\hline $\mathrm{Na}$ & 0.04 & $\mathrm{Na}$ & 0.01 & 0.01 & 0.01 & 0.00 & 0.00 & 0.01 \\
\hline$k$ & 0.00 & $\mathrm{Cr}$ & 0.00 & 0.01 & 0,01 & 0.00 & 0.01 & 0.00 \\
\hline Cl & 0.00 & - & - & - & - & - & - & - \\
\hline $\mathrm{F}$ & 0.00 & - & - & - & - & - & - & - \\
\hline $\mathrm{Ba}$ & 0.00 & - & 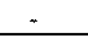 & - & - & - & - & - \\
\hline
\end{tabular}

\begin{tabular}{|c|c|c|c|c|c|c|c|c|c|c|c|c|c|}
\hline $\mathrm{Cl}$ & 39 & 38 & $\mathrm{Cl}$ & 112 & 111 & 113 & 118 & 115 & $11 \frac{f}{2}$ & 116 & 114 & $\mathrm{Cl}$ & 232 \\
\hline$O=24$ & $\mathrm{CHL}$ & CHII & $\mathrm{O}=24$ & GRT & GRT & GRT & GRT & $\overline{\mathrm{GR}}$ & GRT & GRT & GRT & $0=6$ & $\mathrm{OP}$ \\
\hline $\mathrm{SiO}_{2}$ & 22.71 & 22.71 & $\mathrm{SiO}_{2}$ & 37.16 & 37.04 & 37.04 & 36.77 & 36.85 & 36.40 & 36.84 & 36.65 & $\mathrm{SiO}_{2}$ & 37.31 \\
\hline $\mathrm{TiO}_{2}$ & 0.00 & 0.00 & $\mathrm{Al}_{2} \mathrm{O}_{3}$ & 20.24 & 20.22 & 20.44 & 20.22 & 20.18 & 19.98 & 20.25 & 19.98 & $\mathrm{TOO}_{2}$ & 0.23 \\
\hline $\mathrm{AH}_{2} \mathrm{O}_{3}$ & 21.10 & 21.10 & $\mathrm{TiO}_{2}$ & 0.10 & 0.15 & 0.12 & 0.02 & 0.06 & 0.07 & 0.05 & 0.11 & $\mathrm{Al}_{2} \mathrm{O}_{3}$ & 20.98 \\
\hline FeO & 36.36 & 36.36 & $\mathrm{FeO}$ & 35.01 & 34.93 & 35.14 & 34.44 & 34.38 & 34.34 & 34.35 & 33.65 & $\mathrm{Cr}_{2} \mathrm{O}_{3}$ & 0.05 \\
\hline $\mathrm{MrO}$ & 0.03 & 0.03 & $\mathrm{Mno}$ & 0.16 & 0.11 & 0.37 & 0.63 & 0.50 & 0.36 & 0.53 & 0.72 & $\mathrm{FOO}$ & 35.87 \\
\hline $\mathrm{MgO}$ & 6.45 & 6.45 & $\mathrm{MgO}$ & 0.61 & 0.63 & 0.47 & 0.38 & 0.41 & 0.47 & 0.53 & 0.51 & Mno & 0.07 \\
\hline $\mathrm{CaO}$ & 0.01 & 0.01 & $\mathrm{CaO}$ & 6.16 & 6.36 & 5.92 & 6.53 & 6.56 & 6.42 & 6.66 & 6.81 & $\mathrm{MgO}$ & 0.94 \\
\hline $\mathrm{Na}_{2} \mathrm{O}$ & 0.01 & 0.01 & $\mathrm{Na}_{2} \mathrm{O}$ & 0.00 & 0.00 & 0.02 & 0.01 & 0.01 & 0.01 & 0.02 & 0.01 & $\mathrm{ZnO}$ & 0.02 \\
\hline $\mathrm{K}_{2} \mathrm{O}$ & 0.02 & 0.02 & $\mathrm{Y}_{2} \mathrm{O}_{3}$ & 0.01 & 0.00 & 0.03 & 0.00 & 0.00 & 0.00 & 0.00 & 0.01 & $\mathrm{CaO}$ & 6.57 \\
\hline $\mathrm{Cl}$ & 0.01 & 0.01 & - & - & . & - & - & " & - & - & - & $\mathrm{NiO}$ & 0.00 \\
\hline$F$ & 0.07 & 0.07 & - & . & - & - & - & - & - & - & - & - & - \\
\hline- & - & - & - & - & - & - & - & - & - & - & & $=$ & \\
\hline Total & 86.77 & 86.77 & Total & 99.46 & 99.44 & 99.54 & 99.00 & 98.93 & 98.04 & 99.23 & 98.43 & Fotal & 102.05 \\
\hline $\mathrm{Si}$ & 4.44 & 4.07 & $\mathrm{Si}$ & 6.06 & 6.04 & 6.04 & 6.04 & 6.05 & 6.03 & 6.03 & 6.04 & $\mathrm{Si}$ & 1.49 \\
\hline Ti & 0.00 & 0.00 & Al & 3.89 & 3.89 & 3.93 & 3.91 & 3.90 & 3.90 & 3.90 & 3.88 & $\mathrm{Ti}$ & 0.01 \\
\hline$A$ & 4.86 & 4.46 & $\mathrm{ri}$ & 0.01 & 0.02 & 0.01 & 0.00 & 0.01 & 0.01 & 0.01 & 0.01 & Al & 0.99 \\
\hline $\mathrm{F} \in 2+$ & 5.94 & 5.45 & $\mathrm{Fe} 2+$ & 4.77 & 4.77 & 4.79 & 4.73 & 4.72 & 4.76 & 4.70 & 4.64 & $\mathrm{Cr}$ & 0.00 \\
\hline $\mathrm{Mn}$ & 0.01 & 0.01 & $\mathrm{Mn}$ & 0.02 & 0.02 & 0.05 & 0.09 & 0.07 & 0.05 & 0.07 & 0.10 & $\mathrm{Fe} 2:$ & 1.19 \\
\hline $\mathrm{Mg}$ & 1.88 & 1.72 & $\mathrm{Mg}$ & 0.15 & 0.15 & 0.11 & 0.09 & 0.10 & 0.12 & 0.13 & 0.12 & $\mathrm{Mn}$ & 0.00 \\
\hline $\mathrm{Ca}$ & 0.00 & 0.00 & $\mathrm{Ca}$ & 10.77 & 1.11 & 10.34 & 1.15 & 1.15 & 1.14 & 1.17 & 1.20 & $\mathrm{Mg}$ & 0.06 \\
\hline $\mathrm{Na}$ & 0.00 & 0.00 & $\mathrm{Na}$ & 0.00 & 0.00 & 0.01 & 0.00 & 0.00 & 0.00 & 0.01 & 0.00 & $\mathrm{Zn}$ & 0.00 \\
\hline$\kappa$ & 0.00 & 0.00 & $\mathrm{Y}$ & 0.00 & 0.00 & 0.00 & 0.00 & 0.00 & 0.00 & 0.00 & 0.00 & $\mathrm{Ca}$ & 0.28 \\
\hline $\mathrm{Cl}$ & 0.00 & 0.00 & - & - & - & - & - & $\cdot$ & - & - & - & $\mathrm{Ni}$ & 0.00 \\
\hline $\mathrm{F}$ & 0.04 & 0.04 & . & - & - & - & + & - & - & - & - & - & $\cdot$ \\
\hline- & - & - & . & - & - & - & - & - & - & $\therefore$ & - & - & - \\
\hline Total & 17.18 & 15.75 & Total & 25.67 & 16.00 & 25.29 & 16.01 & 16.00 & 16.01 & 16.02 & 16.01 & otal & 4.01 \\
\hline
\end{tabular}




\begin{tabular}{|c|c|c|c|c|c|c|c|c|c|c|c|c|c|c|c|c|c|c|c|c|c|c|}
\hline $\mathrm{Cl}$ & 233 & $\mathrm{C} 2$ & 40 & 41 & $\mathrm{C} 2$ & 119 & 120 & $\mathrm{C} 2$ & $i$ & 2 & 4 & 3 & 5 & 6 & $C 2$ & 151 & 152 & 153 & 154 & 155 & 156 & 157 \\
\hline $0=6$ & $\overline{O P}$ & $\mathrm{O}=24$ & CHI & $\mathrm{CHL}$ & $0=24$ & GRT & GRT & $0=32$ & PL & PL & $\mathrm{PL}$ & $P L$ & $\mathrm{PL}$ & PL & $0=6$ & $\overline{\mathrm{CAL}}$ & CAL & $\mathrm{CAL}$ & $\mathrm{CAl}$ & $\mathrm{CAL}$ & $\mathrm{CAL}$ & CAL \\
\hline $\mathrm{SiO}_{2}$ & 36.98 & $\mathrm{SiO}_{2}$ & 22.80 & 22.14 & $\mathrm{SiO}_{2}$ & 36.92 & 37.17 & $\mathrm{SiO}_{2}$ & 62.66 & 63.30 & 63.26 & 62.84 & 62.83 & 62.59 & $\mathrm{SiO}_{2}$ & 0.05 & 0.06 & 0.02 & 0.02 & 0.02 & 0.02 & 0.05 \\
\hline $\mathrm{THO}_{2}$ & 0.16 & $\mathrm{THO}_{2}$ & 0.17 & 0.15 & $\mathrm{Al}_{2} \mathrm{O}_{3}$ & 20.28 & 20.37 & $\mathrm{Al}_{2} \mathrm{O}_{3}$ & 23.24 & 22.59 & 22.77 & 23.00 & 22.94 & 22.66 & $\mathrm{TiO}_{2}$ & 0.03 & 0.00 & 0.07 & 0.00 & 0.00 & 0.00 & 0.00 \\
\hline $\mathrm{Al}_{2} \mathrm{O}_{3}$ & 20.81 & $\mathrm{Al}_{2} \mathrm{O}_{3}$ & 21.24 & 21.08 & $\mathrm{TiO}_{2}$ & 0.07 & 0.03 & $\mathrm{TH}_{2}$ & 0.00 & 0.00 & 0.00 & 0.00 & 0.02 & 0.06 & $\mathrm{Al}_{2} \mathrm{O}_{3}$ & 0.14 & 0.22 & 0.07 & 0.62 & 0.18 & 0.29 & 0.39 \\
\hline $\mathrm{Cr}_{2} \mathrm{O}_{3}$ & 0.06 & $\mathrm{FeO}$ & 34.02 & 33.54 & $5 \in O$ & 34.68 & 34.01 & $\mathrm{Fe}_{2} \mathrm{O}_{3}$ & 0.03 & 0.03 & 0.04 & 0.00 & 0.00 & 0.05 & $\mathrm{FeO}$ & 23.70 & 2.52 & 2.20 & 1.67 & 1.74 & 2.24 & 2.75 \\
\hline $\mathrm{FeO}$ & 36.45 & $\mathrm{MnO}$ & 0.03 & 0.01 & $\mathrm{MnO}$ & 0.32 & 0.34 & $\mathrm{MnO}$ & 0.01 & 0.00 & 0.02 & 0.01 & 0.00 & 0.00 & $\mathrm{MnO}$ & 0.12 & 0.14 & 0.14 & 0.18 & 0.13 & 0.12 & 0.14 \\
\hline $\begin{array}{l}\mathrm{MnO} \\
\mathrm{M}(\mathrm{s})\end{array}$ & 0.09 & $\mathrm{MgO}$ & 6.44 & 6.95 & $\mathrm{MgO}$ & 0.55 & 0.59 & $\mathrm{MgO}$ & 0.00 & 0.00 & 0.00 & 0.00 & 0.00 & 0.00 & $\mathrm{MgO}$ & 0.07 & 0.13 & 0.05 & 0.06 & 0.25 & 0.11 & 0.08 \\
\hline $\begin{array}{l}\mathrm{MgO} \\
\mathrm{ZnO}\end{array}$ & 0,66 & $\mathrm{Ca}()$ & 0.1 & 0.07 & $\mathrm{CaO}$ & 6.20 & 6.55 & $\mathrm{CaO}$ & 4.56 & 4.02 & 4.11 & 4.32 & 4.52 & 4.10 & $\mathrm{CaO}$ & 50.69 & 50.49 & 51.43 & 51.30 & 51.81 & 50.73 & 50.21 \\
\hline $\begin{array}{l}\mathrm{ZnO} \\
\mathrm{CaO}\end{array}$ & 0.02 & $\mathrm{Na}_{2} \mathrm{O}$ & 0.04 & 0.00 & $\mathrm{Na}_{2} \mathrm{O}$ & 0.02 & 0.00 & $\mathrm{~N}_{3_{2}} \mathrm{O}$ & 8.62 & 8.79 & 8.90 & 8.72 & 8.60 & 8.90 & $\mathrm{SrO}$ & 0.19 & 0.12 & 0.19 & 0.19 & 0.06 & 0.32 & 0.18 \\
\hline $\begin{array}{l}\mathrm{CaO} \\
\mathrm{NO}\end{array}$ & 6.11 & $\mathrm{~K}_{2} \mathrm{O}$ & 0.08 & 0.00 & $\mathrm{Y}_{2} \mathrm{O}_{3}$ & 0.00 & 0.00 & $\mathrm{~K}_{2} \mathrm{O}$ & 0.08 & 0.06 & 0.07 & 0.09 & 0.06 & 0.07 & $\mathrm{BaO}$ & 0.09 & 0.03 & 0.12 & 0.00 & 0.00 & 0.00 & 0.11 \\
\hline $\begin{array}{c}\mathrm{NO} \\
-\end{array}$ & 0.00 & $\mathrm{Cl}$ & 0.03 & 0.02 & - & . & - & $\mathrm{BaO}$ & 0.12 & 0.00 & 0.00 & 0.00 & 0.03 & 0.00 & - & - & - & - & - & - & - & - \\
\hline - & - & F & 0.08 & 0.01 & - & . & - & $\mathrm{Cl}$ & 0.00 & 0.00 & 0.00 & 0.01 & $0.0 \mathrm{I}$ & 0.00 & - & - & - & . & - & - & - & - \\
\hline Total & 101.33 & Tołal & $\overline{85.05}$ & $\frac{-}{83.96}$ & Total & 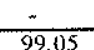 & $\frac{.}{9906}$ & $\frac{\text { Sro }}{\text { Total }}$ & $\frac{0.03}{99.36}$ & 0.00 & 0.00 & 0.06 & 0.05 & 0.03 & - & - & $\frac{-}{5369}$ & $\ddot{54.28}$ & $\frac{-}{54,04}$ & $\frac{-}{54.18}$ & $\overline{53.82}$ & $\frac{-}{53.89}$ \\
\hline $\mathrm{Si}$ & 1.49 & Si & 4.12 & 4.05 & $\frac{\mathrm{Si}}{\mathrm{Si}}$ & 6.05 & 6.07 & $\frac{1 \text { total }}{\mathrm{Si}}$ & 99.36 & 98.80 & 99.18 & 98.98 & $\frac{98.98}{11.20}$ & $\frac{98.431}{11.22}$ & $\frac{\text { Cota! }}{\mathrm{Si}}$ & $\frac{75.08}{0.00}$ & $\frac{53.69}{0.01}$ & $\frac{54.28}{0.00}$ & $\frac{34.07}{0.00}$ & 0.00 & $\frac{33.82}{0.00}$ & $\frac{53.89}{0.00}$ \\
\hline $\mathrm{Ti}$ & 0.00 & $T i$ & 0.02 & 0.02 & A & 3.91 & 3.92 & A] & $\begin{array}{r}11.15 \\
4.87\end{array}$ & $\begin{array}{r}11.29 \\
4.75\end{array}$ & $\begin{array}{r}11.25 \\
4.77\end{array}$ & 4.83 & $\begin{array}{r}1.20 \\
4.82\end{array}$ & 4.79 & Ti & 0.00 & 0.00 & 0.01 & 0.00 & 0.00 & $\begin{array}{l}0.00 \\
0.00\end{array}$ & 0.00 \\
\hline Al & 0.99 & Al & 4.52 & 4.55 & $\mathrm{ri}$ & 0.01 & 0.00 & $\mathrm{Ti}$ & 0.00 & 0.00 & 0.00 & 0.00 & 0.00 & 0.01 & AI & 0.02 & 0.03 & 0.01 & 0.08 & 0.02 & 0.04 & 0.05 \\
\hline $\mathrm{Cr}$ & 0.00 & $\mathrm{Fe} 2 \div$ & 5.14 & 5.13 & $\mathrm{Fe} 2+$ & 4.75 & 4.64 & $\mathrm{Fe} 3+$ & 0.00 & 0.00 & 0.01 & 0.00 & 0.00 & 0.01 & $\mathrm{Fe} 2$ & 0.21 & 0.22 & 0.19 & 0.15 & 0.15 & 0.20 & 0.24 \\
\hline $\begin{array}{c}\mathrm{Fe} 2+ \\
\mathrm{Mn}\end{array}$ & 1.23 & $\mathrm{Mn}$ & 0.00 & 0.00 & $\mathrm{Mn}$ & 0.05 & 0.05 & $\mathrm{Mn}$ & 0.00 & 0.00 & 0.00 & 0.00 & 0.00 & 0.00 & $\mathrm{Mn}$ & 0.01 & 0.01 & 0.01 & 0.02 & 0.01 & 0.01 & 0.01 \\
\hline $\mathrm{Mn}$ & 0.00 & $\mathrm{Mg}$ & 1.74 & 1.90 & $\mathrm{Mg}$ & 0.13 & 0.14 & $\mathrm{Mg}$ & 0.00 & 0.00 & 0.00 & 0.00 & 0.00 & 0.00 & $\mathrm{Mg}$ & 0.01 & 0.02 & 0.01 & 0.01 & 0.04 & 0.02 & 0.01 \\
\hline$\frac{\mathrm{Mg}}{\mathrm{Zn}}$ & 0.04 & $\mathrm{Ca}$ & 0.03 & 0.01 & $\mathrm{Ca}$ & 1.09 & 1.15 & $\mathrm{Ca}$ & 0.87 & 0.77 & 0.78 & 0.82 & 0.86 & 0.79 & $\mathrm{Ca}$ & 5.71 & 5.69 & 5.74 & 5.70 & 5.76 & 5.70 & 5.64 \\
\hline $\begin{array}{l}\mathrm{Zn} \\
\mathrm{Ca}\end{array}$ & 0.00 & $\mathrm{Na}$ & 0. & 0.00 & $\mathrm{Na}$ & 0.01 & 0.00 & $\mathrm{Na}$ & 2.98 & 3.04 & 3.07 & 3.01 & 2.97 & 3.10 & $\mathrm{Sr}$ & 0.01 & 0.01 & 0.01 & 0.01 & 0.00 & 0.02 & 0.01 \\
\hline $\begin{array}{l}\mathrm{Ca} \\
\mathrm{Ni}\end{array}$ & 0.26 & $\mathrm{~K}$ & 0.02 & 0.00 & $\mathrm{Y}$ & 0.00 & 0.00 & $\mathrm{~K}$ & 0.02 & 0.01 & 0.02 & 0.02 & 0.01 & 0.02 & $\mathrm{Ba}$ & 0.00 & 0.00 & 0.00 & 0.00 & 0.00 & 0.00 & 0.00 \\
\hline $\mathrm{Ni}$ & 0.00 & $\mathrm{Cl}$ & 0.01 & 0.01 & - & - & - & $\mathrm{Ba}$ & 0.01 & 0.00 & 0.00 & 0.00 & 0.00 & 0.00 & - & - & - & - & - & - & - & - \\
\hline$"$ & - & $\mathrm{F}$ & 0.04 & 0.00 & - & - & - & $\mathrm{Cl}$ & 0.00 & 0.00 & 0.00 & 0.00 & 0.00 & 0.00 & - & - & - & . & - & - & - & - \\
\hline Total & 4.01 & Total & $\overline{-}$ & $\dot{i 567}$ & Total & $\frac{-}{15.99}$ & 15.97 & $\frac{\mathrm{Sr}}{\text { Total }}$ & $\frac{0.00}{19.89}$ & 0.00 & 0.00 & 0.01 & 0.01 & 0.00 & - & $\frac{-}{598}$ & - & $\frac{-}{5.99}$ & - & 5 & - & - \\
\hline
\end{tabular}

\begin{tabular}{|c|c|c|c|c|c|c|c|c|c|c|c|c|c|c|c|c|c|c|c|c|c|c|}
\hline C3 & 42 & 43 & 44 & 45 & $\mathrm{C} 3$ & 121 & 122 & 123 & 124 & 125 & 126 & 127 & 128 & 130 & 131 & 132 & 133 & 134 & $\mathrm{C} 4$ & 47 & 48 & 49 \\
\hline $0=24$ & BT & BT & CHL & BT & $O=24$ & GRT & GRT & GRT & GRT & $\overline{G R T}$ & GRT & GRT & GRT & GRT & GRT & GRT & GRT & GRT & $\mathrm{O}=24$ & $\mathrm{SE}$ & SE & $\overline{S E}$ \\
\hline $\mathrm{SiO}_{2}$ & 33.82 & 34.12 & 22.46 & 33.86 & $\mathrm{SiO}_{2}$ & 37.01 & 36.75 & 37.07 & 36.87 & 36.53 & 36.80 & 36.95 & 36.71 & 36.25 & 36.93 & 36.94 & 36.90 & 37.20 & $\overline{\mathrm{SiO}_{2}}$ & 45.30 & 45.50 & 43.62 \\
\hline $\mathrm{TiO}_{z}$ & 2.00 & 1.75 & 0.09 & 1.98 & $\mathrm{Al}_{2} \mathrm{O}_{3}$ & 20.20 & 20.23 & 20.15 & 20.15 & 20.05 & 20.41 & 20.10 & 20.19 & 20.01 & 20.07 & 20.32 & 20.05 & 20.12 & $\mathrm{TiO}_{2}^{-}$ & 0.15 & 0.10 & 0.26 \\
\hline $\begin{array}{c}\mathrm{Al}_{2} \mathrm{O}_{3} \\
\mathrm{FeO}\end{array}$ & 18.07 & 17.78 & 22.22 & 18.16 & $\mathrm{TrO}_{2}$ & 0.00 & 0.11 & 0.09 & 0.01 & 0.03 & 0.00 & 0.06 & 0.00 & 0.04 & 0.04 & 0.00 & 0.03 & 0.04 & $\mathrm{Al}_{2} \mathrm{O}_{3}$ & 33.44 & 33.80 & 33.63 \\
\hline $\begin{array}{l}\mathrm{FeO} \\
\mathrm{MnO}\end{array}$ & 24.69 & 25.47 & 33.75 & 25.55 & $\mathrm{FeO}$ & 35.16 & 34.96 & 35.34 & 35.30 & 35.19 & 35.68 & 35.20 & 34.59 & 34.06 & 34.62 & 35.15 & 35.27 & 35.30 & $\mathrm{FeO}$ & 2.71 & 2.77 & 2.95 \\
\hline $\begin{array}{l}\mathrm{MnO} \\
\mathrm{MgO}\end{array}$ & 0.02 & 0.05 & 0.00 & 0.02 & Mnt) & 0.12 & 0.06 & 0,06 & 0.10 & 0.09 & 0.06 & 0.12 & 0.11 & 0.46 & 0.21 & 0.10 & 0.05 & 0.15 & $\mathrm{MnO}$ & 0.00 & 0.03 & 0.03 \\
\hline $\begin{array}{l}\mathrm{MgO} \\
\mathrm{CaO}\end{array}$ & 5.37 & 5.33 & 7.17 & 5.08 & $\mathrm{MgO}$ & 0.85 & 0.78 & 0.82 & 1.08 & 1.26 & 1.28 & 0.89 & 0.67 & 0.55 & 0.59 & 0.79 & 101 & 1.28 & $\mathrm{MgO}$ & 0.47 & 0.43 & 0.49 \\
\hline $\begin{array}{l}\mathrm{CaO} \\
\mathrm{Na}_{2} \mathrm{O}\end{array}$ & 0.05 & 0.00 & 0.01 & 0.02 & $\mathrm{CaO}$ & 5.72 & 5.85 & 5.87 & 5.55 & 5.15 & 4.88 & 5.32 & 6.18 & 6.59 & 6.33 & 5.54 & 5.52 & 4.85 & $\mathrm{CaO}$ & 0.00 & 0.07 & 0.00 \\
\hline $\begin{array}{c}\mathrm{N}_{2} \mathrm{O} \\
\mathrm{K}_{2} \mathrm{O}\end{array}$ & 0.13 & 0.10 & 0.00 & 0.10 & $\mathrm{Na}_{2} \mathrm{O}$ & 0.01 & 0.00 & 0.02 & 0.03 & 0.01 & 0.01 & 0.00 & 0.02 & 0.01 & 0.00 & 0.03 & 0.02 & 0.01 & $\mathrm{Na}_{2} \mathrm{O}$ & 0.47 & 0.52 & 0.61 \\
\hline $\begin{array}{c}\mathrm{K}_{2} \mathrm{O} \\
\mathrm{Cl}\end{array}$ & 8.36 & 8.54 & 0.03 & 8.48 & $\mathrm{Y}_{2} \mathrm{O}_{3}$ & 0.00 & 0.02 & 0.00 & 0.02 & 0.03 & 0.01 & 0.01 & 0.01 & 0.03 & 0.02 & 0.00 & 0.01 & 0.00 & $\mathrm{~K}_{2} \mathrm{O}$ & 10.09 & 9.90 & 9.55 \\
\hline $\mathrm{Cl}$ & 0.09 & 0.08 & 0.01 & 0.12 & - & - & - &. & - & - & - & - & - & - & - & & 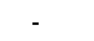 & & CI & 0.00 & 0.00 & 0.01 \\
\hline$F$ & 0.30 & 0.54 & 0.05 & 0.31 & - & - & - & - & - & - & - & - & - & - & - & - & - & - & $F$ & 0.14 & 0.17 & 0.21 \\
\hline$\frac{\sim}{\text { Total }}$ & - & - & &. & & - & - & - & - & - & - & - & - & - & - & - & $\therefore$ & 0804 & $\frac{-}{T}$ & 0778 & 0328 & $\frac{-}{9135}$ \\
\hline $\mathrm{Si}$ & $\frac{92.90}{5.44}$ & $\frac{93.76}{5.47}$ & $\frac{85.78}{4.01}$ & $\frac{93.69}{5.43}$ & $\frac{\text { lozal }}{\mathrm{Si}}$ & $\frac{99.07}{6.06}$ & 98.77 & 99.41 & 99.10 & 98.34 & $\frac{99.12}{6.02}$ & $\frac{98.65}{6.07}$ & $\frac{98.48}{6.04}$ & $\frac{97.99}{6.01}$ & $\frac{98.81}{6.06}$ & $\begin{array}{r}98.87 \\
6.06\end{array}$ & $\frac{98.83}{6.06}$ & $\frac{98.94}{6.08}$ & $\frac{\text { Total }}{\mathrm{Si}}$ & $\frac{92.78}{6.24}$ & $\frac{93.28}{6.23}$ & $\frac{91.35}{6.11}$ \\
\hline $\mathrm{Ti}$ & 0.24 & 0.21 & 0.01 & 0.24 & Af & $\begin{array}{l}6.06 \\
3.90\end{array}$ & $\begin{array}{l}6.03 \\
3.91\end{array}$ & $\begin{array}{l}6.05 \\
3.88\end{array}$ & $\begin{array}{l}6.04 \\
3.89\end{array}$ & $\begin{array}{l}6.03 \\
3.90\end{array}$ & $\begin{array}{l}0.02 \\
3.94\end{array}$ & 3.89 & $\begin{array}{l}.07 \\
3.92\end{array}$ & 3.91 & 3.88 & 3.93 & 3.88 & 3.88 & $\mathrm{Ti}$ & 0.02 & 0.01 & 0.03 \\
\hline $\mathrm{Al}$ & 3.43 & 3.36 & 4.67 & 3.43 & $T_{i}$ & 0.00 & 0.01 & 0.01 & 0.00 & 0.00 & 0.00 & 0.01 & 0.00 & 0.00 & 0.00 & 0.00 & 0.00 & 0.00 & $\mathrm{Al}$ & 5.43 & 5.45 & 5.56 \\
\hline $\mathrm{Fe} 2 \div$ & 3.32 & 3.42 & 5.04 & 3.42 & $F \in 2$ & 4.81 & 4.80 & 4.82 & 4.83 & 4.86 & 4.88 & 4.84 & 4.76 & 4.72 & 4.75 & 4.82 & 4.84 & 4.83 & $\mathrm{~F} \geq 2+$ & 0.31 & 0.32 & 0.35 \\
\hline $\mathrm{Mn}$ & 0.00 & 0.01 & 0.00 & 0.00 & $\mathrm{Mn}$ & 0.02 & 0.01 & 0.01 & 0.01 & 0.01 & 0.01 & 0.02 & 0.01 & 0.06 & 0.03 & 0.01 & 0.01 & 0.02 & $\mathrm{Mn}$ & 0.00 & 0.00 & 0.00 \\
\hline $\mathrm{Mg}$ & 1.29 & 1.28 & 1.91 & 1.21 & $\mathrm{Mg}$ & 0.21 & 0.19 & 6.20 & 0.26 & 0.31 & 0.31 & 0.22 & 0.16 & 0.14 & 0.14 & 0.19 & 0.25 & 0.31 & $\mathrm{Mg}$ & 0.10 & 0.09 & 0.10 \\
\hline $\mathrm{Ca}$ & 0.01 & 0.00 & 0.00 & 0.00 & $\mathrm{Ca}$ & 1.00 & 1.03 & 1.03 & 0.97 & 0.91 & 0.86 & 0.94 & 1.09 & 1.17 & 1.11 & 0.97 & 0.97 & 0.85 & $\mathrm{Ca}$ & 0.00 & 0.01 & 0.00 \\
\hline $\mathrm{Na}$ & 0.04 & 0.03 & 0.00 & 0.03 & $\mathrm{Na}$ & 0.00 & 0.00 & 0.00 & 0.01 & 0.00 & 0.00 & 0.00 & 0.01 & 0.00 & 0.00 & 0.01 & 0.00 & 0.00 & $\mathrm{Na}$ & 0.13 & 0.14 & 0.17 \\
\hline$x$ & 1.72 & 1.75 & $0.0 \mathrm{I}$ & 1.73 & $Y^{\prime}$ & 0.00 & 0,00 & 0.00 & 0.00 & 0.00 & 0.00 & 0.00 & 0.00 & 0.00 & 0.00 & 0.00 & 0.00 & 0.00 & $\mathrm{~K}$ & 1.77 & 1.73 & 1.71 \\
\hline c & 0.122 & 0.02 & (0.0) & 0.03 & - & - & - & - & 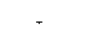 & - & - & - & - & - & - & 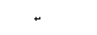 & - & - & $\mathrm{Cl}$ & 0.00 & 0.00 & 0.00 \\
\hline F & 0.15 & 0.27 & 0.03 & 0.16 & - & . & - & - & - & - & - & - & - & - & . & & - & - & $\mathrm{I}:$ & 0.06 & 0.07 & $0.0 \%$ \\
\hline
\end{tabular}

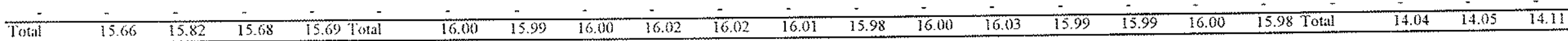




\begin{tabular}{|c|c|c|c|c|c|c|c|c|c|c|c|c|c|c|c|c|c|c|c|c|c|c|c|}
\hline $0=24$ & GRT & GRT & GRT & $\overline{\mathrm{GRT}}$ & GRT & GRT & GRT & $O=6$ & CAL & $\mathrm{CAL}$ & CAL & CAL & $\mathrm{CAL}$ & $O=24$ & $\mathrm{BT}$ & $\mathrm{BT}$ & $\mathrm{BT}$ & CHL & $0=24$ & GRT & GRT & GRT & GR1 \\
\hline $\mathrm{SiO}_{2}$ & 37.29 & 37.15 & 38.40 & 37,00 & 36.57 & 36.71 & 37.15 & $\mathrm{SiO}_{2}$ & 0.01 & 0.04 & 0.04 & 0.09 & 0.03 & $\mathrm{SiO}_{2}$ & 33.18 & 33.70 & 33.91 & 22.19 & $\mathrm{SiO}_{2}$ & 37.32 & 37.32 & 37.09 & 37.07 \\
\hline $\mathrm{Al}_{2} \mathrm{O}_{3}$ & 20.19 & 20.26 & 20.17 & 20.20 & 19.95 & 20.21 & 20).16 & $\mathrm{TiO}_{2}$ & 0.00 & 0.00 & 0.00 & 0.04 & 0.00 & $\mathrm{TiO}_{2}$ & 1.78 & 1.77 & 1.97 & 0.03 & $\mathrm{Al}_{2} \mathrm{O}_{3}$ & 20.36 & 20.32 & 20.17 & 20.34 \\
\hline $\mathrm{TiO}_{2}$ & 0.08 & 0.04 & 0.09 & 0.04 & 0.01 & 0.03 & 0.01 & $\mathrm{Al}_{2} \mathrm{O}_{3}$ & 0.02 & 0.05 & 0.03 & 0.34 & 0.04 & $\mathrm{Al}_{2} \mathrm{O}_{3}$ & 16.51 & 17,02 & 17.64 & 21.76 & $\mathrm{TiO}_{z}$ & 0.00 & 0.00 & 0.06 & 0.07 \\
\hline $\mathrm{FeO}$ & 34.23 & 35.44 & 33.15 & 34.23 & 34.61 & 35.45 & 35.27 & FuO & 25.46 & 25.20 & 25.52 & 25.40 & 25.30 & 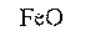 & 28.40 & 28.10 & 27.03 & 35.91 & $\mathrm{FeO}$ & 35.36 & 35.05 & 35.08 & 35.90 \\
\hline Mno & 0.06 & 0.11 & 0.40 & 0.18 & 0.13 & 0.07 & 0.10 & $\mathrm{MnO}$ & 0.29 & 0.25 & 0.26 & 0.25 & 0.28 & $\mathrm{MnO}$ & 0.00 & 0.03 & 0.02 & 0.08 & $\mathrm{MnO}$ & 0.15 & 0.10 & 0.08 & 0.10 \\
\hline $\mathrm{MgO}$ & 0.75 & 0.76 & 0.90 & 0.82 & 0.76 & 0.92 & 1.25 & MgO & 3.76 & 3.65 & 3.69 & 3.79 & 3.27 & $\mathrm{MgO}$ & 4.35 & 4.45 & 4.50 & 5.89 & $\mathrm{MgO}$ & 1.27 & 1.17 & 0.93 & 0.57 \\
\hline $\mathrm{CaO}$ & 7.04 & 6.15 & 6.75 & 6.62 & 6.30 & 5.60 & 5.06 & $\mathrm{CaO}$ & 26.22 & 26.50 & 26.33 & 26.20 & 26.88 & $\mathrm{CaO}$ & 0.02 & 0.01 & 0.01 & 0.02 & $\mathrm{CaO}$ & 4.63 & 5.28 & 5.52 & 5.20 \\
\hline $\mathrm{Na}_{2} \mathrm{O}$ & 0.00 & 0.01 & 0.01 & 0.03 & 0.00 & 0.01 & 0.01 & $\mathrm{SNO}$ & 0.02 & 0.00 & 0.02 & 0.00 & 0.00 & $\mathrm{Na}_{2} \mathrm{O}$ & 0.09 & 0.08 & 0.11 & 0.03 & $\mathrm{Na}_{2} \mathrm{O}$ & 0.05 & 0.02 & 0.00 & 0.03 \\
\hline $\mathrm{Y}_{2} \mathrm{O}_{3}$ & 0.01 & 0.02 & 0.00 & 0.02 & 0.01 & 0.01 & 0.00 & $\mathrm{BaO}$ & 0.00 & 0.00 & 0.00 & 0.00 & 0.07 & $\mathrm{~K}_{2} \mathrm{O}$ & 7.97 & 8.29 & 8.52 & 0.01 & $\mathrm{Y}_{2} \mathrm{O}_{3}$ & 0.00 & 0.02 & 0.03 & 0.00 \\
\hline - & + & - & - & - & + & - & - & • & 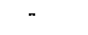 & - & - & $\begin{array}{ll}- \\
-\end{array}$ & - & $\mathrm{Cl}$ & 0.09 & 0.10 & 0.07 & 0.03 & - & - & - & - & $\sim$ \\
\hline $\begin{array}{l}- \\
-\end{array}$ & - & - & - & - & - & $\begin{array}{ll}- & -1 \\
-1\end{array}$ & - & - & - & - & - & - & - & $\mathrm{F}$ & 0.32 & 0.31 & 0.37 & 0.00 & - & 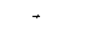 & - & - & - \\
\hline Total & 99.64 & $\overline{99.91}$ & - & $\therefore$ & - & $\dot{\pi}$ & - & - & 858 & & $\% 0$ & & & - & & & - & & - & & & 9895 & 5078 \\
\hline $\mathrm{Si}$ & $\frac{99.64}{6.06}$ & $\frac{99.91}{6.04}$ & $\frac{99.80}{6.18}$ & $\frac{99.14}{6.04}$ & $\frac{98.34}{6.04}$ & $\frac{99.00}{6.02}$ & $99.00^{\circ}$ & Iotal & 55.78 & 55.68 & 55.89 & 56.11 & 55.87 & Total & 92.71 & $\frac{93.84}{6.17}$ & $\frac{94.15}{5.15}$ & $\frac{85.95}{401}$ & $\frac{\text { rotal }}{\mathrm{Si}}$ & $\frac{99.14}{6.08}$ & $\frac{99.28}{6.08}$ & $\frac{98.95}{6.07}$ & $\frac{99.28}{6.06}$ \\
\hline A & 3.87 & $\begin{array}{l}0.04 \\
3.88\end{array}$ & $\begin{array}{l}6.18 \\
3.82\end{array}$ & $\begin{array}{l}6.04 \\
3.89\end{array}$ & $\begin{array}{l}6.04 \\
3.88\end{array}$ & 6.02 & 6.07 & $\mathrm{Si}$ & 0.00 & 0.00 & 0.00 & 0.01 & $\begin{array}{l}0.00 \\
0.00\end{array}$ & $\begin{array}{c}\mathrm{Si} \\
\mathrm{Ti}\end{array}$ & $\begin{array}{l}5.46 \\
0.22\end{array}$ & $\begin{array}{l}5.47 \\
0.22\end{array}$ & $\begin{array}{l}5.45 \\
0.24\end{array}$ & $\begin{array}{l}4.01 \\
0.00\end{array}$ & $\begin{array}{l}\text { Si } \\
\text { Al }\end{array}$ & $\begin{array}{l}0.08 \\
3.91\end{array}$ & $\begin{array}{l}0.08 \\
3.90\end{array}$ & $\begin{array}{l}6.07 \\
3.89\end{array}$ & $\begin{array}{l}0.00 \\
3.92\end{array}$ \\
\hline $\mathrm{Ti}$ & 0.01 & 0.00 & $\begin{array}{l}3.82 \\
0.01\end{array}$ & 0.01 & $\begin{array}{l}3.88 \\
0.00\end{array}$ & $\begin{array}{l}3.91 \\
0.00\end{array}$ & $\begin{array}{l}3.88 \\
0.00\end{array}$ & $\begin{array}{l}n \\
\text { Al }\end{array}$ & $\begin{array}{l}0.60 \\
0.00\end{array}$ & $\begin{array}{l}0.00 \\
0.01\end{array}$ & $\begin{array}{l}0.00 \\
0.00\end{array}$ & $\begin{array}{l}0.00 \\
0.04\end{array}$ & $\begin{array}{l}0.00 \\
0.00\end{array}$ & $A$ & 3.20 & 3.25 & 3.34 & 4.63 & $\mathrm{Ti}$ & 0.00 & 0.00 & 0.01 & 0.01 \\
\hline $\mathrm{F} 02 \div$ & 4.65 & 4.82 & 4.46 & 4.68 & 4.78 & 4.86 & 4.82 & $F<2 \div$ & 2.31 & 2.29 & 2.31 & 2.28 & 2.30 & $\mathrm{~F} \in 2+$ & 3.91 & 3.81 & 3.63 & 5.42 & $\mathrm{Fe} 2$ & 4.82 & 4.77 & 4.80 & 4.91 \\
\hline Mn & 0.01 & 0.02 & 0.05 & 0.02 & 0.02 & 0.01 & 0.01 & $\mathrm{Mn}$ & 0.03 & 0.02 & 0.02 & 0.02 & 0.03 & $\mathrm{Mn}$ & 0.00 & 0.00 & 0.00 & 0.01 & $\mathrm{Mn}$ & 0.02 & 0.01 & 0.01 & 0.01 \\
\hline $\mathrm{Mg}$ & 0.18 & 0.18 & 0.21 & 0.20 & 0.19 & 0.22 & 0.30 & $\mathrm{Mg}$ & 0.6 & 0.59 & 0.59 & 0.60 & 0.53 & $\mathrm{Mg}$ & 1.07 & 1.07 & 1.08 & 1.59 & $\mathrm{Mg}$ & 0.31 & 0.28 & 0.23 & 0.14 \\
\hline $\mathrm{Ca}$ & 1.23 & 1.07 & 1.16 & 1.16 & 1.12 & 0.98 & 0.89 & $\mathrm{Ca}$ & 3.05 & 3.08 & 3.05 & 3.01 & 3.13 & $\mathrm{Ca}$ & 0.00 & 0.00 & 0.00 & 0.00 & $\mathrm{Ca}$ & 0.81 & 0.92 & 0.97 & 0.91 \\
\hline $\mathrm{Na}$ & 0.00 & 0.00 & 0.00 & 0.01 & 0.00 & 0.00 & 0.00 & $\mathrm{Sr}$ & 0.00 & 0.00 & 0.00 & 0.00 & 0.00 & $\mathrm{Na}$ & 0.03 & 0.03 & 0.04 & 0.01 & $\mathrm{Na}$ & 0.01 & 0.01 & 0.00 & $0.0 \mathrm{I}$ \\
\hline$Y$ & 0.00 & 0.00 & 0.00 & 0.00 & 0.00 & 0.00 & 0.00 & $\mathrm{Ba}$ & 0.00 & 0.00 & 0.00 & 0.00 & 0.00 & K & 1.67 & 1.71 & 1.75 & 0.00 & $\mathrm{Y}$ & 0.00 & 0.00 & 0.00 & 0.00 \\
\hline- & & - & . & - & - & - & - & - & & 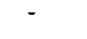 & & & - & $\mathrm{Cl}$ & 0.03 & 0.03 & 0.02 & 0.01 & - & - & - & - & - \\
\hline
\end{tabular}

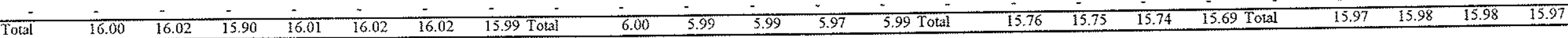

\begin{tabular}{|c|c|c|c|c|c|c|c|c|c|c|c|c|c|c|c|c|c|c|c|c|c|c|c|}
\hline $\mathrm{C} 5$ & 162 & 163 & 164 & 165 & 166 & 167 & 168 & 169 & 170 & $\mathrm{C6}$ & 54 & 55 & 56 & 58 & 59 & 60 & 61 & 62 & $\mathrm{C} 6$ & 171 & 172 & $\mathrm{C} 6$ & 9 \\
\hline$O=24$ & GRT & GRT & GRT & GRT & GRT & GRT & $\mathrm{GR}_{\mathrm{T}}^{\mathrm{T}}$ & GRT & GRT & $O=24$ & BT & $\overline{\mathrm{BT}}$ & $\overline{B T}$ & $\overline{B T}$ & $\mathrm{CHI}$ & $\mathrm{CHI}$ & $\mathrm{CHL}$ & $\mathrm{CHI}$ & $O=24$ & GRT & GRT & $\mathrm{O}=32$ & \\
\hline $\mathrm{SiO}_{2}$ & 37.22 & 36.53 & 37.02 & 36.87 & 36.88 & 36.07 & 36.24 & 36.44 & 36.48 & $\mathrm{SiO}_{2}$ & 33.66 & 32.68 & 33.64 & 34.03 & 23.03 & 23.16 & 27.05 & 24.07 & $\mathrm{SiO}_{2}$ & 36.84 & 37.39 & $\mathrm{SiO}_{2}$ & 65.71 \\
\hline $\mathrm{Al}_{2} \mathrm{O}_{3}$ & 20.14 & 20.04 & 20.09 & 20.34 & 20.24 & 19.87 & 19.94 & 20.13 & 20.03 & $\mathrm{TOO}_{2}$ & 1.93 & 1.90 & 1.80 & 1.74 & 0.16 & 0.17 & 0.07 & 0.11 & $\mathrm{Al}_{2} \mathrm{O}_{3}$ & 20.24 & 20.28 & $\mathrm{Al}_{2} \mathrm{O}_{3}$ & 21.38 \\
\hline $\mathrm{TiO}_{2}$ & 0.09 & 0.52 & 0.08 & 0.03 & 0.07 & 0.02 & 0.03 & 0.01 & 0.00 & $\mathrm{Al}_{2} \mathrm{O}_{3}$ & 16.92 & 17.14 & 17.41 & 17.58 & 21.27 & 22.36 & 24.22 & 22.43 & $\mathrm{TiO}_{2}$ & 0.20 & 0.06 & $\mathrm{TiO}_{2}$ & 0.04 \\
\hline $\mathrm{FeO}$ & 35.80 & 35.46 & 34.95 & 35.19 & 35.54 & 35.79 & 35.74 & 35.60 & 36.66 & $\mathrm{~F} e \mathrm{O}$ & 25.49 & 26.17 & 24.52 & 24.34 & 32.52 & 31.52 & 24.43 & 31.02 & $\mathrm{FeO}$ & 35.36 & 35.29 & $\mathrm{Fe}_{2} \mathrm{O}_{3}$ & 0.31 \\
\hline $\mathrm{MnO}$ & 0.19 & 0.15 & 0.38 & 0.19 & 0.07 & 0.09 & 0.06 & 0.11 & 0.13 & $\mathrm{MnO}$ & 0.02 & 0.00 & 0.00 & 0.05 & 0.02 & 0.03 & 0.01 & 0.02 & $\mathrm{MnO}$ & 0.10 & 0.08 & $\mathrm{MnO}$ & 0.00 \\
\hline $\begin{array}{l}\mathrm{MgO} \\
\mathrm{CaO}\end{array}$ & 0.48 & 0.47 & 0.42 & 0.47 & 0.55 & 0.77 & 0.99 & 1.23 & 1.53 & MgO & 6.96 & 6.95 & 6.26 & 6.59 & 8.83 & 8.74 & 9.96 & 9.18 & $\mathrm{MgO}$ & 1.37 & 1.16 & $\mathrm{MgO}$ & 0.00 \\
\hline $\begin{array}{l}\mathrm{CaO} \\
\mathrm{Ni}_{2} \mathrm{O}\end{array}$ & 5.12 & 5.63 & 5.71 & 5.69 & 5.44 & 5.32 & 5.00 & 5.21 & 3.70 & $\mathrm{CaO}$ & 0.00 & 0.11 & 0.08 & 0.00 & 0.00 & 0.03 & 0.04 & 0.01 & $\mathrm{CaO}$ & 5.06 & 5.26 & $\mathrm{Ca}$ & 2.42 \\
\hline $\begin{array}{l}\mathrm{Ni}_{2} \mathrm{O} \\
\mathrm{Y}_{2} \mathrm{O}_{3}\end{array}$ & 0.01 & 0.00 & 0.03 & 0.04 & 0.04 & 0.03 & 0.04 & 0.00 & 0.00 & $\mathrm{Na}_{2} \mathrm{O}$ & 0.06 & 0.06 & 0.08 & 0.08 & 0.01 & 0.00 & 0.22 & 0.09 & $\mathrm{Na}_{2} \mathrm{O}$ & 0.00 & 0.04 & $\mathrm{Na}_{2} \mathrm{O}$ & 9.85 \\
\hline $\mathrm{Y}_{2} \mathrm{O}_{3}$ & 0.01 & 0.04 & 0.01 & 0.01 & 0.04 & 0.00 & 0.02 & 0.00 & 0.00 & $\mathrm{~K}_{2} \mathrm{O}$ & 8.34 & 7.18 & 8.45 & 8.53 & 0.02 & 0.22 & 2.39 & 0.32 & $\mathrm{Y}_{2} \mathrm{O}_{3}$ & 0.00 & 0.00 & $\mathrm{~K}_{2} \mathrm{O}$ & 0.06 \\
\hline - & - & - & - & - & - & . & - & - & & $\mathrm{Cl}$ & 0.06 & 0.07 & 0.06 & 0.11 & 0.00 & 0.01 & 0.02 & 0.00 & - & - & 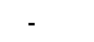 & $\mathrm{BaO}$ & 0.00 \\
\hline - & - & - & - & - & - & . & - & + & & $F$ & 0.46 & 0.47 & 0.43 & 0.27 & 0.06 & 0.02 & 0.20 & 0.00 & - & - & - & $\mathrm{Cl}$ & 0.00 \\
\hline$\frac{-}{\text { Total }}$ & + & - & - & - & - & - & - & . & & - & - & - & & - & . & - & - & & - & - & & Sro & 0.01 \\
\hline$\frac{\text { Total }}{\mathrm{Si}}$ & 99.05 & 98.82 & 98.70 & 98.82 & 98.87 & 97.97 & 98.05 & 98.72 & 98.52 & Total & 93.91 & 92.73 & 92.71 & 93.32 & 85.91 & 86.26 & 88.59 & 87.241 & Cotal & 99.16 & 99.58 & Total & 99.79 \\
\hline $\begin{array}{l}\mathrm{Si} \\
\mathrm{Al}\end{array}$ & 6.10 & 6.01 & 6.08 & 6.05 & 6.06 & 6.00 & 6.02 & 6.00 & 6.02 & $\mathrm{Si}$ & 5.40 & 5.30 & 5.44 & 5.45 & 4.08 & 4.05 & 4.44 & 4.14 & $\mathrm{Si}$ & 6.02 & 6.07 & $\mathrm{Si}$ & 11.56 \\
\hline $\mathrm{Al}$ & 3.89 & 3.89 & 3.89 & 3.94 & 3.92 & 3.90 & 3.90 & 3.91 & 3.90 & $\mathrm{II}$ & 0.23 & 0.23 & 0.22 & 0.21 & 0.02 & 0.02 & 0.01 & 0.01 & Al & 3.90 & 3.88 & AI & 4.44 \\
\hline $\mathrm{Ti}$ & 0.01 & 0.06 & 0.01 & 0.00 & 0.01 & 0.00 & 0.00 & 0.00 & 0.00 & Al & 3.20 & 3.28 & 3.32 & 3.32 & 4.44 & 4.61 & 4.68 & 4.55 & $\mathrm{Ti}$ & 0.02 & 0.01 & $\mathrm{~T}_{\mathrm{i}}$ & 0.01 \\
\hline $\mathrm{Fe} 2 \div$ & 4.90 & 4.88 & 4.80 & 4.83 & 4.88 & 4.98 & 4.96 & 4.90 & 5.06 & $\mathrm{Fe} 2+$ & 3.42 & 3.55 & 3.31 & 3.26 & 4.81 & $4.6\}$ & 3.35 & 4.46 & $\mathrm{Fe} 2 \div$ & 4.83 & 4.80 & $\mathrm{Fe} 3 \div$ & 0.04 \\
\hline $\mathrm{Mn}$ & 0.03 & 0.02 & 0.05 & 0.03 & 0.01 & 0.01 & 0.01 & 0.02 & 0.02 & $\mathrm{Mn}$ & 0.00 & 0.00 & 0.00 & 0.01 & 0.00 & 0.00 & 0.00 & 0.00 & $\mathrm{Mn}$ & 0.01 & 0.01 & $\mathrm{Mn}$ & 0.00 \\
\hline $\mathrm{Mg}$ & 0.12 & 0.12 & 0.10 & 0.11 & 0.13 & 0.19 & 0.25 & 0.30 & 0.38 & $\mathrm{Mg}$ & 1.66 & 1.68 & 1.51 & 1.57 & 2.33 & 2.28 & 2.44 & 2.35 & $M g$ & 0.33 & 0.28 & $\mathrm{Mg}$ & 0.00 \\
\hline $\mathrm{Ca}$ & 0.90 & 0.99 & 1.01 & 1.00 & 0.96 & 0.95 & 0.89 & 0.92 & 0.65 & $\mathrm{Ca}$ & 0.00 & 0.02 & 0.01 & 0.00 & 0.00 & 0.00 & 0.01 & 0.00 & Ca & 0.89 & 0.92 & $\mathrm{Ca}$ & 0.46 \\
\hline $\mathrm{Na}$ & 0.00 & 0.00 & 0.01 & 0.01 & 0.01 & 0.01 & 0.01 & 0,00 & 0.00 & $\mathrm{Na}$ & 0.02 & 0.02 & 0.02 & 0.02 & 0.00 & 0.00 & 0.07 & 0.03 & $\mathrm{Na}$ & 0.00 & 0.01 & $\mathrm{Na}$ & 3.36 \\
\hline$Y$ & 0.00 & 0.00 & 0.00 & 0.00 & 0.00 & 0.00 & 0.00 & 0,00 & 0.00 & $\mathrm{~K}$ & 1.71 & 1.49 & 1.74 & 1.74 & 0.01 & 0.05 & 0.50 & 0.07 & $\mathrm{Y}$ & 0.00 & 0.00 & K & 0.01 \\
\hline- & - & - & $\cdot$ & - & - & - & - & - & - & $\mathrm{Cl}$ & 0.02 & 0.02 & 0.02 & 0.03 & 0.00 & 0.00 & 0.01 & 0.00 & . & - & - & $\mathrm{Ba}$ & 0.00 \\
\hline - & . & - & - & - & - & - & & - & - & $F$ & 0.24 & 0.24 & 0.22 & 0.14 & 0.03 & 0.01 & 0.10 & 0.00 & - & - & - & $\mathrm{Cl}$ & $\begin{array}{l}0.00 \\
0.00\end{array}$ \\
\hline
\end{tabular}




\begin{tabular}{|c|c|c|}
\hline \multicolumn{3}{|c|}{ K59.38587 } \\
\hline & 8 & 10 \\
\hline $0=32$ & PL & PL \\
\hline $\mathrm{SiO}_{2}$ & 66.601 & 65.34 \\
\hline $\mathrm{Al}_{2} \mathrm{O}_{j}$ & 21.24 & 21.84 \\
\hline $\mathrm{TiC}_{2}$ & 0.00 & $0 .(w)$ \\
\hline $\mathrm{Fe}_{7} \mathrm{O}_{3}$ & 0.35 & 0.32 \\
\hline Mno & 0.02 & 0.00 \\
\hline $\mathrm{MgO}$ & 0.00 & 0.00 \\
\hline $\mathrm{CaO}$ & 2.32 & 2.84 \\
\hline $\mathrm{Na}, \mathrm{O}$ & 9.94 & 9.63 \\
\hline $\mathrm{K}_{2} \mathrm{O}$ & 0.05 & 0.05 \\
\hline $\mathrm{BaO}$ & 0.07 & 0.02 \\
\hline $\mathrm{Cl}$ & 0.00 & 0.01 \\
\hline $\mathrm{SrO}$ & 0.05 & 0.00 \\
\hline Tota! & 99.93 & 100.01 \\
\hline $\mathrm{Si}$ & 11.59 & 11.48 \\
\hline $\mathrm{AI}$ & 4.40 & 4.52 \\
\hline $\mathrm{Ti}$ & 0.00 & 0.00 \\
\hline $\mathrm{Fe} 3 \div$ & 0.05 & 0.04 \\
\hline $\mathrm{Mn}$ & 0.00 & 0.00 \\
\hline $\mathrm{Mg}$ & 0.00 & 0.00 \\
\hline $\mathrm{Ca}$ & 0.44 & 0.53 \\
\hline $\mathrm{Na}$ & 3.39 & 3.28 \\
\hline $\mathrm{K}$ & 0.01 & 0.03 \\
\hline $\mathrm{Ba}$ & 0.01 & 0.00 \\
\hline $\mathrm{Cl}$ & 0.00 & 0.00 \\
\hline$S_{T}$ & 0.01 & 0.00 \\
\hline & 19.87 & 19.88 \\
\hline
\end{tabular}

\begin{tabular}{|c|c|c|c|c|c|c|c|c|c|c|c|c|c|c|c|c|c|c|c|}
\hline & & & & & & & & & & & & & & & & & $C 2$ & 804 & 805 \\
\hline$\frac{C 1}{O=24}$ & $\frac{789}{G R T}$ & $\begin{array}{l}790 \\
\mathrm{GRT}\end{array}$ & $\frac{791}{G R T}$ & $\begin{array}{l}792 \\
\text { GRT }\end{array}$ & $\mathrm{Cl}^{\prime}$ & $\begin{array}{l}800 \\
00\end{array}$ & 801 & $\frac{802}{\mathrm{PO}}$ & 803 & $\begin{array}{c}\mathrm{C} 2 \\
\mathrm{O}=22\end{array}$ & $\frac{774}{\mathrm{CHC}}$ & $\frac{C 2}{O=24}$ & $\begin{array}{l}793 \\
\text { GRT }\end{array}$ & $\frac{794}{\text { GRT }}$ & $\frac{795}{G R T}$ & $\frac{796}{G R T}$ & $\frac{\mathrm{C} 2}{\text { Atom }^{\circ} \%}$ & $\overline{M M}$ & $\frac{805}{P 0}$ \\
\hline $\mathrm{SiO}_{2}$ & 35.89 & 36.09 & 36.61 & 36.21 & $\mathrm{Fe}$ & 47.76 & 99.80 & 47.35 & 99.87 & $\mathrm{SiO}_{2}$ & 22.92 & $\mathrm{SiO}_{2}$ & 36.13 & 36.48 & 36.42 & 36.64 & $\mathrm{Fe}$ & 99.83 & $47.6 !$ \\
\hline $\mathrm{Al}_{2} \mathrm{O}_{3}$ & 20.06 & 20.03 & 20.15 & 20.21 & As & 0.03 & 0.14 & 0.02 & 0.00 & $\mathrm{TO}_{2}$ & 0.12 & $\mathrm{Al}_{2} \mathrm{O}_{3}$ & 20.23 & 20.44 & 20.38 & 20.37 & As & 0.09 & 0.01 \\
\hline $\mathrm{TiO}_{2}$ & 0.04 & 0.01 & 0.02 & 0.07 & s & 52.15 & 0.03 & 52.50 & 0.00 & $\mathrm{Al}_{2} \mathrm{O}_{3}$ & 21.16 & $\mathrm{TiO}_{2}$ & 0.00 & 0.04 & 0.02 & 0.04 & $\mathrm{~s}$ & $n \in 00$ & 52.31 \\
\hline FeO & 34.38 & 34.68 & 34.07 & 33.85 & $\angle n$ & 0.00 & 0.02 & 0.00 & 0.05 & Fo & 32.66 & FeO & 34.67 & 35.12 & 34.94 & 34.40 & $Z \mathrm{n}$ & 0.05 & 0.00 \\
\hline $\mathrm{MnO}$ & 1.35 & 1.28 & 1.20 & 1.29 & $\mathrm{Cu}$ & 0.03 & 0.00 & 0.01 & 0.01 & $\mathrm{MnO}$ & 0.03 & Mnó & 1.11 & 1.19 & 1.11 & 1.21 & $\mathrm{Cu}$ & 0.00 & 0.00 \\
\hline $\mathrm{MgO}$ & 0.99 & 1.04 & 0.98 & 1.04 & $\mathrm{Co}_{0}$ & 0.00 & 0.00 & 0.00 & 0.00 & $\mathrm{MgO}$ & 8.46 & $\mathrm{MgO}$ & 1.07 & 1.04 & 1.08 & 1.05 & Co & 0.000 & 0.00 \\
\hline $\mathrm{CaO}$ & 4.34 & 4.48 & 4.26 & 4.10 & $\mathrm{Ni}$ & 0.07 & 0.02 & 0.10 & 0.00 & $\mathrm{CaO}$ & 0.01 & $\mathrm{CaO}$ & 3.83 & 3.51 & 3.87 & 3.77 & $\mathrm{NI}$ & 0.01 & 0.08 \\
\hline $\mathrm{Na}_{2} \mathrm{O}$ & 0.03 & 0.01 & 0.03 & 0.03 & $\mathrm{Au}$ & 0.00 & 0.00 & 0.02 & 0.07 & $\mathrm{Na}_{2} \mathrm{O}$ & 0.02 & $\mathrm{Na}_{2} \mathrm{O}$ & 0.03 & 0.01 & 0.06 & 0.03 & $\mathrm{Au}$ & 0.02 & 0.00 \\
\hline $\mathrm{Cr}_{2} \mathrm{O}_{3}$ & 0.13 & 0.04 & 0.12 & 0.15 & $\because$ & - & - & - & - & $\mathrm{K}_{2} \mathrm{O}$ & 0.00 & $\mathrm{Cr}_{2} \mathrm{O}_{3}$ & 0.06 & 0.15 & 0.05 & 0.14 & - & - & - \\
\hline $\mathrm{Y}_{2} \mathrm{O}_{3}$ & 0.10 & 0.05 & 0.05 & 0.10 & - & - & . & . & - & $\mathrm{Cl}$ & 0.02 & $\mathrm{Y}_{2} \mathrm{O}_{3}$ & 0.14 & 0.12 & 0.13 & 0.16 & - & - & - \\
\hline $\mathrm{BaO}$ & 0.00 & 0.11 & 0.06 & 0.05 & - & - & - & - & . & $\mathrm{F}$ & 0.01 & $\mathrm{BaO}$ & 0.20 & 0.03 & 0.00 & 0.03 & - & - & - \\
\hline- & - & - & - & & . & - & - & - & 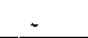 & $\mathrm{BaO}$ & 0.03 & &. &. & & $\sim$ & - & - & \\
\hline Total & 97.30 & 97.81 & 97.54 & \multicolumn{2}{|c|}{97.09 Total } & 100.00 & 100.00 & 100.00 & 100.00 & Total & \multicolumn{2}{|c|}{85.42 Total } & 97.45 & 98.13 & 98.06 & \multirow{2}{*}{\multicolumn{2}{|c|}{97.83 Total }} & 100.00 & 100.00 \\
\hline Si & 5.9997 & 6.01 & 6.08 & 6.0393 & $\bar{W} \%$ & & & & & $\mathrm{Si}$ & 4.09 & $\mathrm{Si}$ & 6.02 & 6.03 & 6.03 & 6.06 & & & \\
\hline Al & 3.9527 & 3.93 & 3.94 & 3.9736 & Fe & 60.95 & 32.69 & 60.04 & 24.49 & $\mathrm{Ti}$ & 0.02 & Al & 3.98 & 3.98 & 3.97 & 3.97 & Fe & 32.31 & 60.06 \\
\hline $\mathrm{Ti}$ & 0.0046 & 0.00 & 0.00 & 0.0087 & As & 0.05 & 0.06 & 0.03 & 0.00 & Al & 4.45 & $\mathrm{Ti}$ & 0.00 & 0.01 & 0.00 & 0.01 & As & 0.04 & 0.01 \\
\hline$F=2 \div$ & 4.8055 & 4.83 & 4.73 & 4.7208 & $\mathrm{~s}$ & $38.2 !$ & 0.01 & 38.21 & 0.00 & $\mathrm{~F}=2 \div$ & 4.87 & $\mathrm{Fe} 2 \tau$ & 4.83 & 4.86 & 4.84 & 4.76 & $s$ & 0.00 & 37.89 \\
\hline $\mathrm{Mrn}$ & 0.1913 & 0.18 & 0.17 & 0.182 & $\mathrm{zn}$ & 0.00 & 0.01 & 0.00 & 0.01 & $\mathrm{Mn}$ & 0.00 & $\mathrm{Mn}$ & 0.16 & 0.17 & 0.16 & 0.17 & $\mathrm{Zn}$ & 0.02 & 0.00 \\
\hline $\mathrm{Mg}$ & 0.2454 & 0.26 & 0.24 & 0.2572 & $\mathrm{Cu}$ & 0.00 & 0.00 & 0.02 & 0.00 & $\mathrm{Mg}$ & 2.25 & $\mathrm{Mg}$ & 0.27 & 0.26 & 0.27 & 0.26 & $\mathrm{Cu}$ & 0.60 & 0.00 \\
\hline $\mathrm{Ca}$ & 0.7765 & 0.80 & 0.76 & 0.7322 & $\mathrm{Co}$ & 0.00 & 0.00 & 0.00 & 0.00 & $\mathrm{Ca}$ & 0.00 & $\mathrm{Ca}$ & 0.68 & 0.62 & 0.69 & 0.67 & Co & 0.00 & 0.000 \\
\hline $\mathrm{Na}$ & 0.0092 & 0.00 & 0.01 & 0.0111 & $\mathrm{Ni}$ & 0.10 & 0.01 & 0.13 & 0.00 & $\mathrm{Na}$ & 0.01 & $\mathrm{Na}$ & 0.01 & 0.00 & 0.02 & $0.0 \mathrm{t}$ & $\mathrm{Ni}$ & 0.00 & 0.11 \\
\hline $\mathrm{Cr}$ & 0.0169 & 0.01 & 0.02 & 0.0199 & An & 0.00 & 0.00 & 0.08 & 0.06 & $\mathrm{~K}$ & 0.00 & $\mathrm{Cr}$ & 0.01 & 0.02 & 0.01 & 0.02 & Aus & 0.03 & 0.00 \\
\hline $\mathrm{Y}$ & 0.009 & 0.00 & 0.00 & 0.0084 & - & . & - & - & $\sim$ & $\mathrm{Cl}$ & 0.01 & $\mathrm{Y}$ & 0.01 & 0.01 & 0.01 & 0.01 & - & - & - \\
\hline $\mathrm{Ba}$ & 0 & 0.01 & 0.00 & 0.0032 & - & - & - & - & . & $F$ & 0.01 & $\mathrm{Ba}$ & 0.01 & 0.00 & 0.00 & 0.00 & - & - & - \\
\hline. & & & - & & . & - & . & - & & $\mathrm{Ba}$ & 0.00 & - & & & & & - & - & - \\
\hline Total & 16.01 & 16.02 & 15.95 & 15.96 & Total & 99.30 & 32.77 & 98.51 & 24.57 & rotal & 15.69 & Total & 15.98 & 15.96 & 15.98 & 15.94 & Total & 32.39 & 98.07 \\
\hline
\end{tabular}

\begin{tabular}{|c|c|c|c|c|c|c|}
\hline \multicolumn{7}{|c|}{ K $03-22755$} \\
\hline C3 & 773 & $\mathrm{C} 3$ & 775 & $\mathrm{C} 2$ & 805 & 806 \\
\hline $\mathrm{O}=22$ & $\mathrm{CHL}$ & $\mathrm{O}=6$ & $\mathrm{CAB}$ & Atom\% & $\mathrm{PO}$ & $\mathrm{PO}$ \\
\hline $\mathrm{SiO}_{2}$ & 22.85 & $\mathrm{SiO}_{2}$ & 0.00 & $\mathrm{Fe}$ & 47.44 & 47.55 \\
\hline $\mathrm{TiO}_{2}$ & 0.08 & FeO & 18.75 & As & 0.01 & 0.01 \\
\hline $\mathrm{Ad}_{2} \mathrm{O}_{3}$ & 20.55 & $\mathrm{MnO}$ & 0.64 & $s$ & 52.48 & 52.36 \\
\hline $\mathrm{FeO}$ & 32.17 & $\mathrm{MgO}$ & 7.66 & $\mathrm{Cu}$ & 0.00 & 0.00 \\
\hline Mo & 0.02 & $\mathrm{CaO}$ & 26.07 & $\mathrm{Ni}$ & 0.07 & 0.08 \\
\hline $\mathrm{MgO}$ & 8.89 & - & - & $\mathrm{Au}$ & 0.00 & 0.00 \\
\hline $\mathrm{CaO}$ & 0.09 & - & - & - & - & - \\
\hline $\mathrm{Na}_{2} \mathrm{O}$ & 0.01 & - & - & - & - & - \\
\hline $\mathrm{K}_{2} \mathrm{O}$ & 0.00 & - & - & - & - & - \\
\hline $\mathrm{Cl}$ & 0.00 & - & - & . & - & - \\
\hline $\mathrm{F}$ & 0.08 & - & - & - & - & - \\
\hline $\mathrm{BaO})$ & 0.02 & . & - & - & - & \\
\hline Total & 84.75 & Total & 53.12 & Total & 100.00 & 100.00 \\
\hline $\mathrm{Si}$ & 4.11 & $\mathrm{Si}$ & 0.00 & $\bar{W} \%$ & & \\
\hline Ti & 0.01 & $\mathrm{~F} e 2+$ & 1.69 & $F_{c}$ & 60.14 & 60.22 \\
\hline Al & 4.35 & $\mathrm{Mn}$ & 0.06 & As & 0.01 & 0.02 \\
\hline$F \in 2 \div$ & 4.83 & $\mathrm{Mg}$ & 1.23 & $\mathrm{~s}$ & 38.19 & 38.07 \\
\hline $\mathrm{Mn}$ & 0.00 & $\mathrm{Ca}$ & 3.02 & $\mathrm{Cu}$ & 0.00 & 0.00 \\
\hline $\mathrm{Mg}$ & 2.38 & - & - & $\mathrm{Ni}$ & 0.10 & 0.11 \\
\hline $\mathrm{Ca}$ & 0.02 & - & . & $\mathrm{Au}$ & 0.00 & 0.00 \\
\hline $\mathrm{Na}$ & 0.00 & - & - & - &. & \\
\hline$\kappa$ & 0.00 & - & - & - & - & - \\
\hline $\mathrm{Cl}$ & 0.00 & - & - & - & - & - \\
\hline $\mathrm{F}$ & 0.04 & - & - & - & - & - \\
\hline $\mathrm{Ba}$ & 0.00 & - & - & - & - & \\
\hline Total & 15.75 & Total & 6.00 & Total & 98.43 & 98.42 \\
\hline
\end{tabular}

\begin{tabular}{|c|c|c|c|c|c|c|c|c|c|c|c|c|c|c|c|}
\hline $\mathrm{Cl}$ & 829 & 830 & 831 & 832 & $\mathrm{Cl}$ & 838 & 839 & 840 & $\mathrm{Cl}$ & 815 & 816 & 817 & 818 & $\mathrm{Cl}$ & 852 \\
\hline $0=22$ & $\mathrm{SE}$ & $\overline{\mathrm{SE}}$ & $\mathrm{SE}$ & $\mathrm{BT}$ & $\mathrm{O}=32$ & PL & $\mathrm{PL}$ & PL & Acom $\%$ & $\mathrm{ASP}$ & $\mathrm{ASP}$ & $\overline{\mathrm{ASP}}$ & ASP & $0=6$ & $\overline{C A B}$ \\
\hline $\mathrm{SiO}_{2}$ & 46.50 & 46.89 & 46.46 & 34.64 & $\mathrm{SiO}_{2}$ & 63.93 & 62.22 & 63.28 & $\mathrm{Fe}$ & 33.45 & 33.44 & 33.56 & 33.55 & $\mathrm{SiO}_{2}$ & 0.00 \\
\hline $\mathrm{TiO}_{2}$ & 0.25 & 0.17 & 0.12 & 1.86 & $\mathrm{Al}_{2} \mathrm{O}_{3}$ & 23.45 & 24.23 & 23.38 & As & 31.04 & 30.00 & 33.09 & 31.54 & FeO & 2.52 \\
\hline $\mathrm{Al}_{2} \mathrm{O}_{3}$ & 33.23 & 33.10 & 33.75 & 17.31 & $\mathrm{TO}_{2}$ & 0.00 & 0.00 & 0.00 & $s$ & 35.40 & 36.43 & 33.22 & 34.82 & $\mathrm{MnO}$ & 0.30 \\
\hline $\mathrm{FeO}$ & 1.57 & 1.49 & 1.38 & 19.46 & $\mathrm{Fe}_{2} \mathrm{O}_{3}$ & 0.04 & 0.05 & 0.05 & $\mathrm{Ca}$ & 0.00 & 0.00 & 0.00 & 0.00 & $\mathrm{MgO}$ & 1.08 \\
\hline $\mathrm{Mno}$ & 0.00 & 0.03 & 0.04 & 0.02 & $\mathrm{MnO}$ & 0.00 & 0.02 & 0.00 & $\mathrm{Cu}$ & 0.01 & 0.01 & 0.00 & 0.00 & $\mathrm{CaO}$ & 49.32 \\
\hline $\mathrm{MgO}$ & 1.08 & 1.16 & 1.00 & 8.74 & $\mathrm{MgO}$ & 0.00 & 0.00 & 0.00 & $\mathrm{Ni}$ & 0.10 & 0.13 & 0.14 & 0.08 & - & - \\
\hline $\mathrm{CaO}$ & 0.00 & 0.00 & 0.01 & 0.04 & $\mathrm{CaO}$ & 4.74 & 5.76 & 4.81 & $\mathrm{Al}$ & 0.00 & 0.00 & 0.60 & 0.01 & - & - \\
\hline $\mathrm{Na}_{2} \mathrm{O}$ & 0.45 & 0.58 & 0.58 & 0.14 & $\mathrm{Na}_{2} \mathrm{O}$ & 8.92 & 8.16 & 8.73 & - & - & - & - & - & - & - \\
\hline $\mathrm{K}_{2} \mathrm{O}$ & 9.85 & 9.68 & 9.75 & 9.06 & $\mathrm{~K}_{2} \mathrm{O}$ & 0.07 & 0.12 & 0.08 & - & - & - & - & - & - & - \\
\hline $\mathrm{Cl}$ & 0.00 & 0.00 & 0.00 & 0.03 & - & - & - & - & - & - & - & - & - & - & - \\
\hline$F$ & 0.03 & 0.07 & 0.06 & 0.52 & - & - & - & - & - & . & - & - & - & - & - \\
\hline $\mathrm{BaO}$ & 0.33 & 0.43 & 0.28 & 0.72 & - & - & - & - & - & - & - & - & & - & \\
\hline Totat & 93.28 & 93.58 & 93.43 & 92.54 & Total & 101.15 & 100.55 & 100.33 & Sotal & 100.00 & 100.00 & 100.00 & 100.00 & rotal & 53.23 \\
\hline $\mathrm{Si}$ & 6.32 & 6.35 & 6.30 & 5.51 & $\mathrm{Si}$ & 11.17 & 10.97 & 11.15 & $W t \%$ & & & & & $\mathrm{Si}$ & 0.00 \\
\hline $\mathrm{Ti}$ & 0.03 & 0.02 & 0.01 & 0.22 & Al & 4.83 & 5.03 & 4.85 & $F_{i}$ & 35.40 & 35.55 & 34.71 & 35.09 & Fe? & 0.22 \\
\hline $\mathrm{Al}$ & 5.32 & 5.28 & 5.39 & 3.25 & $\mathrm{Ti}^{3}$ & 0.00 & 0.00 & 0.00 & As & 44.06 & 42.78 & 45.91 & 44.26 & $\mathrm{Mn}$ & 0.03 \\
\hline $\mathrm{Fe} 2+$ & 0.18 & 0.17 & 0.16 & 2.59 & $\mathrm{Fe} 3+$ & 0.01 & 0.01 & 0.01 & $\$$ & 21.50 & 22.23 & 19.72 & 20.90 & $\mathrm{Mg}$ & 0.17 \\
\hline $\mathrm{Mn}$ & 0.00 & 0.00 & 0.00 & 0.00 & $\mathrm{Mn}$ & 0.00 & 0.00 & 0.00 & $C_{0}$ & 0.00 & 0.00 & 0.00 & 0.00 & $\mathrm{Ca}$ & 5.58 \\
\hline $\mathrm{Mg}$ & 0.22 & 0.23 & 0.20 & 2.07 & $\mathrm{Mg}$ & 0.00 & 0.00 & 0.00 & $\mathrm{Ca}$ & 0.01 & 0.01 & 0.00 & 0.00 & . & $r$ \\
\hline $\mathrm{Ca}$ & 0.00 & 0.00 & 0.00 & $0.0 \mathrm{I}$ & $\mathrm{Ca}$ & 0.89 & 1.09 & 0.91 & $\mathrm{Ni}$ & 0.11 & 0.15 & 0.15 & 0.09 & - & - \\
\hline $\mathrm{Na}$ & 0.12 & 0.15 & 0.15 & 0.04 & $\mathrm{Na}$ & 3.02 & 2.79 & 2.98 & $\mathrm{Au}$ & 0.00 & 0.00 & 0.00 & 0.04 & - & - \\
\hline$\kappa$ & 1.71 & 1.67 & 1.69 & 1.84 & $\mathrm{~K}$ & 0.02 & 0.03 & 0.02 & - & - & - & - & - & - & - \\
\hline $\mathrm{Cl}$ & 0.00 & 0.00 & 0.00 & 0.01 & - & - & - & - & - & - & - & - & - & - & - \\
\hline $\mathrm{F}$ & 0.01 & 0.03 & 0.03 & 0.26 & - & . & - & - & - & - & - & - & " & - & - \\
\hline $\mathrm{Ba}$ & 0.02 & 0.02 & 0.01 & 0.04 & - & - & - & $\therefore$ & - & - & - & - & $\therefore$ & T- & 5 \\
\hline Total & 13.92 & 13.93 & 13.94 & 15.85 & Cotal & 19.93 & 19.92 & 19.92 & robal & 02.08 & 100.70 & 100.49 & 100.38 & Total & 6.00 \\
\hline
\end{tabular}




\begin{tabular}{|c|c|c|c|c|c|c|c|c|c|c|c|c|c|c|c|c|c|c|c|c|c|c|c|}
\hline $\mathrm{C2}$ & 833 & $\mathrm{C} 2$ & 841 & 842 & 843 & 844 & 845 & 846 & 847 & $\mathrm{C2}$ & 853 & $\mathrm{C3}$ & 819 & 820 & 821 & 822 & 823 & 824 & $\mathrm{C} 3$ & 834 & 835 & $\mathrm{CA}$ & 825 \\
\hline$O=22$ & BT & $O=32$ & PL & PL & PL & $\mathrm{PL}$ & PL. & $\mathrm{PL}$ & PL & $O=6$ & $\mathrm{CAB}$ & Atom\% & ASP & ASP & ASP & IM? & ASP & ASP & $\mathrm{O}=22$ & $\overline{B T}$ & $\mathrm{BT}$ & Atom $\%$ & ASP \\
\hline $\mathrm{SiO}_{2}$ & 35.45 & $\mathrm{SiO}_{2}$ & 63.28 & 63.93 & 63.50 & 65.85 & 64.49 & 64.80 & 63.29 & $\mathrm{SiO}_{2}$ & 0.00 & $\mathrm{Fe}$ & 33.60 & 33.55 & 33.69 & 99.78 & 33.52 & 34.36 & $\mathrm{SiO}_{2}$ & 35.25 & 35.00 & $\mathrm{Fe}$ & 33.47 \\
\hline $\mathrm{THO}_{2}$ & 1.38 & $\mathrm{Al}_{2} \mathrm{O}_{3}$ & 23.58 & 23.10 & 23.12 & 22.02 & 23.28 & 22.58 & 23.49 & $\mathrm{FeO}$ & 3.14 & As & 30.10 & 32.68 & 30.78 & 0.16 & 31.63 & 29.44 & $\mathrm{TiO}_{2}$ & 1.88 & 1.62 & As & 30.89 \\
\hline $\mathrm{Al}_{2} \mathrm{O}_{3}$ & 17.40 & $\mathrm{TiO}_{2}$ & 0.12 & 0.00 & 0.00 & 0.00 & 0.00 & 0.08 & 0.00 & Mro & 0.43 & $s$ & 36.20 & 33.58 & 35.46 & 0.06 & 34.69 & 36.12 & $\mathrm{Al}_{2} \mathrm{O}_{3}$ & 18.15 & 18.08 & $S$ & 35.56 \\
\hline $\mathrm{FeO}$ & 21.68 & $\mathrm{Fe}_{2} \mathrm{O}_{3}$ & 0.00 & 0.01 & 0.06 & 0.30 & 0.23 & 0.03 & 0.12 & $\mathrm{MgO}$ & 0.99 & Co & 0.00 & 0.00 & - & - & - & - & $\mathrm{FeO}$ & 19.69 & 19.62 & $\mathrm{Ni}$ & 0.09 \\
\hline $\mathrm{MnO}$ & 0.02 & $\mathrm{MnO}$ & 0.00 & 0.04 & 0.00 & 0.00 & 0.02 & 0.00 & 0.02 & $\mathrm{CaO}$ & 51.67 & $\mathrm{Cu}$ & 0.00 & 0.00 & - & - & - & - & $\mathrm{MnO}$ & 0.01 & 0.00 & - & - \\
\hline$\frac{\operatorname{Mg}(0)}{(a)}$ & 7.43 & $\mathrm{MgO})$ & 0.00 & 0.00 & 0.00 & 0.00 & 0.00 & 0.00 & 0.01 & - & - & $\mathrm{Ni}$ & 0.11 & 0.19 & 0.08 & 0.00 & 0.07 & 0.08 & Mgo & 8.21 & 8.62 & - & - \\
\hline$(x)$ & 0.10 & (a) & 4.89 & 4.34 & 4.43 & 3.02 & 4.25 & 3.88 & 4.99 & . & - & Au & 0,00 & 0,00 & - & - & - & - & $\mathrm{CaO}$ & 0.02 & 0.03 & - & - \\
\hline $\begin{array}{l}\mathrm{N}_{3,3}, \\
\mathrm{~K}_{2} \mathrm{O}\end{array}$ & 0.11 & $\mathrm{Na}_{2}(3)$ & 8.92 & 1.0.08 & 9.01 & 9.81 & 9.34 & 9.3 .3 & 892 & - & - & - & - & - & - & - & - & - & $\mathrm{Na}_{2} \mathrm{O}$ & 0.11 & 0.14 & - & - \\
\hline $\mathrm{K}_{2} \mathrm{C}$ & 9.29 & $\mathrm{~K}_{2} \mathrm{C}$ & 0.09 & 0.09 & 0.10 & 0.0 .4 & 0.03 & 0.03 & 0.05 & - & - & . & - & - & - & - & - & - & $\mathrm{K}_{2} \mathrm{O}$ & 9.25 & 9.26 & - & - \\
\hline $\begin{array}{l}\mathrm{Cl} \\
\mathrm{F}\end{array}$ & 0.04 & - & - & - & - & - & - & - & - & - & - & - & - & - & - & - & - & - & $\mathrm{Cl}$ & 0.04 & 0.02 & - & - \\
\hline$F$ & 0.43 & - & - & - & - & $\begin{array}{l}- \\
-\end{array}$ & - & - & - & - & - & - & - & - & - & - & - & - & $F$ & 0.46 & 0.32 & - & - \\
\hline$\frac{\mathrm{BaO}}{\text { Tota! }}$ & 0.44 & - & - & - & - & - & - & - & - & - & - & - & - & - & - & - & - & . & $\mathrm{BaO}$ & 0.57 & 0.58 & - & - \\
\hline$\frac{\text { Tota! }}{\mathrm{Si}}$ & 23.77 & rotal & 100.88 & 100.60 & 100.23 & 101.04 & 101.64 & 100.74 & 100.89 & Total & 56.231 & Total & 100.00 & 100.00 & 100.00 & 100.00 & 100.00 & 100.00 & Total & 93.62 & 93.30 & Total & 100.00 \\
\hline $\mathrm{Si}$ & 5.60 & $\mathrm{Si}$ & 11.10 & 11.22 & 11.20 & 11.47 & 11.21 & 11.34 & 11.11 & $\mathrm{Si}$ & $0.00 \mathrm{~V}$ & Wr\% & & & & & & & $\mathrm{Si}$ & 5.52 & 5.50 & $\mathrm{~W} \% \%$ & \\
\hline $\begin{array}{l}\text { Ti } \\
\text { Al }\end{array}$ & 0.16 & Al & 4.88 & 4.78 & 4.81 & 4.52 & 4.77 & 4.66 & 4.86 & $\mathrm{Fe}_{2+}$ & 0.27 & Fe & 35.72 & 34.85 & 35.39 & 31.91 & 35.38 & 36.39 & $\mathrm{Ti}$ & 0.22 & 0.19 & $\mathrm{Fe}$ & 35.13 \\
\hline Al & 3.24 & $\mathrm{Ti}$ & 0.02 & 0.00 & 0.60 & 0.00 & 0.00 & 0.01 & 0.00 & $\mathrm{Mn}$ & 0.04 & As & 42.93 & 45.54 & 43.38 & 0.07 & 44.66 & 41.82 & As & 3.35 & 3.35 & As & 43.49 \\
\hline Fe $2+$ & 2.86 & $\mathrm{Fe} 3 \div$ & 0.00 & 0.00 & 0.01 & 0.04 & 0.03 & 0.00 & 0.02 & $\mathrm{Mg}$ & 0.15 & $\mathrm{~s}$ & 22.09 & 20.03 & 21.39 & 0.01 & 20.96 & 21.96 & $\mathrm{Fe} 2+$ & 2.58 & 2.58 & $S$ & 23.43 \\
\hline $\mathrm{Mn}$ & 0.00 & $\mathrm{Mn}$ & 0.00 & 0.01 & 0.00 & 0.00 & 0.00 & 0.00 & 0.00 & $\mathrm{Ca}$ & 5.55 & Co & 0.00 & 0.00 & - & $\sim$ & - & - & $\mathrm{Mn}_{\mathrm{n}}$ & 0.00 & 0.00 & $\mathrm{Ni}$ & 0.10 \\
\hline $\begin{array}{c}\mathrm{Ng} \\
\mathrm{Ca}\end{array}$ & 1.75 & $\mathrm{Mg}$ & 0.00 & 0.00 & 0.00 & 0.00 & 0.00 & 0.00 & 0.00 & - & - & $\mathrm{Cu}$ & 0.00 & 0.00 & - & - & - & - & $\mathrm{Mg}$ & 1.92 & 2.02 & - & - \\
\hline $\mathrm{Ca}$ & 0.02 & $\mathrm{Ca}$ & 0.92 & 0.82 & 0.84 & 0.56 & 0.79 & 0.73 & 0.94 & - & - & $\mathrm{Ni}$ & 0.12 & 0.21 & 0.09 & 0.00 & 0.08 & 0.09 & $\mathrm{Ca}$ & 0.00 & 0.01 & - & - \\
\hline $\begin{array}{c}\mathrm{Na} \\
\mathrm{K}\end{array}$ & 0.03 & $\mathrm{Na}$ & 3.03 & 3.09 & 3.08 & 3.31 & 3.15 & 3.17 & 3.04 & . & - & $\mathrm{Au}$ & 0.00 & 0.00 & - & - & . & - & $\mathrm{Na}$ & 0.03 & 0.04 & - & - \\
\hline K & 1.87 & $\mathrm{~K}$ & 0.02 & 0.02 & 0.02 & 0.01 & 0.01 & 0.01 & 0.01 & - & - & - & + & - & - & - & - & . & $\mathrm{K}$ & 1.85 & 1.86 & - & - \\
\hline Cl & 0.01 & $\sim$ & - & - & - & - & - & - & - & - & - & - & - & - & - & . & 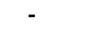 & - & $\mathrm{Cl}$ & 0.01 & 0.01 & - & - \\
\hline $\begin{array}{l}\mathrm{F} \\
\mathrm{Ba}\end{array}$ & 0.21 & - & - & - & - & - & - & - & - & - & - & - & - & - & - & - & - & - & $\mathrm{F}$ & 0.23 & 0.16 & - & - \\
\hline $\mathrm{Ba}$ & 0.03 & - & - & - & - & - & - & - & - & - & - & . & 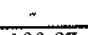 & & - & - & - & 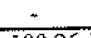 & $\mathrm{Ba}$ & 0.04 & 0.04 & - & 3 \\
\hline & 15.79 & Total & 19.97 & 19.94 & 19.95 & 19.91 & 19.96 & 19.91 & 19.98 & Total & 6.007 & Total & 100.87 & 100.63 & 100.25 & 31.99 & 101.08 & 100.26 & Total & 15.76 & 15.75 & Total & 100.14 \\
\hline
\end{tabular}

\begin{tabular}{|c|c|c|c|c|c|c|c|c|c|c|c|c|}
\hline \multicolumn{13}{|c|}{ K03-23040 } \\
\hline$C 4$ & 826 & 827 & $\mathrm{C} 4$ & 855 & $\mathrm{C5}$ & 849 & 850 & $\mathrm{C5}$ & 828 & $\mathrm{CS}$ & 836 & 837 \\
\hline Atom $\%$ & ASP & ASP & $O=6$ & $\overline{\mathrm{CAB}}$ & $O=32$ & PL & $\mathrm{PL}$ & Atom $\%$ & IIM? & $0=22$ & SE & \\
\hline $\mathrm{Fe}$ & 33.55 & 33.62 & $\mathrm{SiO}_{2}$ & 0.06 & $\mathrm{SiO}_{2}$ & 62.74 & 63.26 & $\mathrm{Fe}$ & 99.91 & $\mathrm{SiO}_{2}$ & 46.09 & 34.80 \\
\hline As & 30.86 & 30.36 & $\mathrm{FeO}$ & 12.96 & $\mathrm{Al}_{2} \mathrm{O}_{3}$ & 23.51 & 23.35 & As & 0.09 & $\mathrm{TiO}_{2}$ & 0.16 & 2.89 \\
\hline$s$ & 35.49 & 35.92 & Mno & 0.42 & $\mathrm{HO}_{2}$ & 0.100 & 0.00 & $\mathrm{~s}$ & 0.00 & $\mathrm{Al}_{2} \mathrm{O}_{3}$ & 33.07 & 17.48 \\
\hline $\mathrm{Ni}$ & 0.10 & 0.10 & $\mathrm{MgO}$ & 11.91 & $\mathrm{Fe}_{2} \mathrm{O}_{3}$ & 0.19 & 0.01 & $\mathrm{Ni}$ & 0.00 & FeO & 1.56 & 20.52 \\
\hline - & - & - & $\mathrm{CaO}$ & 27.76 & MnO & 0.00 & 0.01 & - & - & $\mathrm{MnO}$ & 0.00 & 0.00 \\
\hline . & - & - & - & 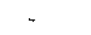 & $\mathrm{MgO}$ & 0.02 & 0.00 & - & - & $\mathrm{AgO}$ & 1.08 & 8.78 \\
\hline - & - & - & - & . & $\mathrm{CaO}$ & 5.08 & 5.01 & - & - & $\mathrm{CaO}$ & 0.00 & 0.03 \\
\hline . & - & - & - & - & $\mathrm{Na}_{2} \mathrm{O}$ & 8.66 & 8.97 & - & - & $\mathrm{Na}_{2} \mathrm{O}$ & 0.56 & 0.11 \\
\hline - & - & - & - & - & $\mathrm{K}_{2} \mathrm{O}$ & 0.07 & 0.08 & - & - & $\mathrm{K}_{2} \mathrm{O}$ & 10.29 & 9.09 \\
\hline - & - & - & - & - & - & - & - & - & - & $\mathrm{Cl}$ & 0.00 & 0.01 \\
\hline - & - & - & . & - & - & - & - & - & - & $F$ & 0.18 & 0.65 \\
\hline - & - & . & - & . & - & - & - & . & - & $\mathrm{BaO}$ & 0.41 & 0.83 \\
\hline Total & 100.00 & 100.00 & otal & 53.05 & rotal & 100.27 & 100.69 & Total & 100.00 & Tota! & 93.40 & 94.19 \\
\hline $\bar{W} \%$ & & & $\mathrm{Si}$ & 0.00 & $\mathrm{Si}$ & 11.08 & 11.13 & $\mathrm{Wt} \%$ & & $\mathrm{Si}$ & 6.29 & 5.47 \\
\hline $\mathrm{Ft}$ & 35.47 & 35.63 & $F_{22}:$ & 1.11 & Al & 4.89 & 4.84 & Fo & 31.71 & $\mathrm{Ti}$ & 0.02 & 0.22 \\
\hline As & 43.77 & 43.17 & $\mathrm{Mn}$ & 0.04 & $\mathrm{Ti}$ & 0.00 & 0.00 & As & 0.04 & Al & 5.32 & 3.24 \\
\hline$s$ & 21.54 & 21.86 & $\mathrm{Mg}$ & 1.82 & Fe3: & 0.03 & 0.00 & s & 0.00 & $F=2+$ & 0.18 & 2.70 \\
\hline $\mathrm{Ni}$ & 0.11 & 0.11 & $\mathrm{Ca}$ & 3.04 & $\mathrm{Mn}$ & 0.00 & 0.00 & $\mathrm{Ni}$ & 0.00 & $\mathrm{Mn}$ & 0.00 & 0.00 \\
\hline . & - & 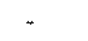 & - & - & $\mathrm{Mg}$ & 0.00 & 0.00 & - & - & $\mathrm{Mg}$ & 0.22 & 2.06 \\
\hline - & - & - & - & - & $\mathrm{Ca}$ & 0.96 & 0.94 & - & - & $\mathrm{Ca}$ & 0.00 & 0.01 \\
\hline - & - & - & - & - & $\mathrm{Na}$ & 2.97 & 3.06 & - & - & $\mathrm{Na}$ & 0.15 & 0.03 \\
\hline - & - & - & - & - & $\mathrm{K}$ & 0.02 & 0.02 & - & - & $\mathrm{x}$ & 1.79 & 1.82 \\
\hline - & - & - & - & - & - & - & - & - & - & $\mathrm{Cl}$ & 0.00 & 0.00 \\
\hline - & . & - & - & - & - & - & . & - & - & $F$ & 0.08 & 0.32 \\
\hline . & - & . & . & - & - & - & - & - & . & $\mathrm{Ba}$ & 0.02 & $\frac{0.05}{5504}$ \\
\hline
\end{tabular}




\begin{tabular}{|c|c|c|c|c|c|c|c|c|c|c|c|c|c|c|c|c|c|c|c|c|c|c|c|}
\hline $\mathrm{C3}$ & $+1 / 2$ & 399 & 401 & 400 & $\mathrm{C} 4$ & 331 & 332 & $\mathrm{C4}$ & 926 & $\$ 28$ & 427 & $\mathrm{CS}$ & 260 & 261 & 263 & 264 & 265 & 266 & 267 & 268 & $\mathrm{C5}$ & 420 & 421 \\
\hline $0=23$ & AMP & $\mathrm{AMP}$ & $\mathrm{AMP}$ & $\mathrm{AMP}$ & $0=22$ & $\mathrm{SE}$ & SE & $0=25$ & EP & $E P$ & EP & $0=32$ & FSP & FSP & FSP & FSP & FSP & FSP & FSP & ESP & $0=24$ & GRT & GRT \\
\hline $\mathrm{SiO}_{2}$ & 39.48 & 39.24 & 39.34 & 39.28 & $\mathrm{SiO}_{2}$ & 45.68 & 47.23 & $\mathrm{SiO}_{2}$ & 36.13 & 36.74 & 37.94 & $\mathrm{SiO}_{2}$ & 62.56 & 62.21 & 61.46 & 60.67 & 60.68 & 60.34 & 60.75 & 60.24 & $\mathrm{SiO}_{2}$ & 37.21 & 37.10 \\
\hline $\mathrm{TiO}_{2}$ & 0.33 & 0.31 & 0.16 & 0.30 & $\mathrm{TO}_{3}$ & 0.16 & 0.19 & $\mathrm{THO}_{2}$ & 0.00 & 0.03 & 0.08 & $\mathrm{Al}_{2} \mathrm{O}_{3}$ & 23.20 & 23.19 & 23.65 & 24.07 & 24.25 & 24.48 & 24.24 & 24.46 & $\mathrm{Al}_{2} \mathrm{O}_{3}$ & 20.53 & 20,22 \\
\hline $\mathrm{AL}_{2} \mathrm{O}_{3}$ & 21.04 & 20.98 & 21.26 & 21.12 & $\mathrm{Al}_{2} \mathrm{O}_{3}$ & 35.26 & 36.53 & $\mathrm{Al}_{2} \mathrm{O}_{3}$ & 24.04 & 24.62 & 26.37 & $\mathrm{TiO}_{2}$ & 0.00 & 0.00 & 0.01 & 0.00 & 0.00 & 0.00 & 0.02 & 0.00 & $\mathrm{TiO}_{2}$ & 0.03 & 0.14 \\
\hline FeO & 20.88 & 20.52 & 20.19 & 20.05 & $\mathrm{FeO}$ & 2.03 & 2.28 & $\mathrm{Nd}_{2} \mathrm{O}_{3}$ & 0.19 & 0.39 & 0.05 & $\mathrm{Fe}_{2} \mathrm{O}_{3}$ & 0.03 & 0.06 & 0.03 & 0.07 & 0.17 & 0.17 & 0.06 & 0.08 & $\mathrm{~F}=\mathrm{O}$ & 33.85 & 33.87 \\
\hline MnO & 0.01 & 0.02 & 0.03 & 0.06 & $\mathrm{MnO}$ & 0.00 & 0.00 & $\mathrm{Fe}_{2} \mathrm{O}_{3}$ & 9.57 & 9.02 & 7.84 & $\mathrm{MnO}$ & 0.00 & 0.01 & 0.00 & 0.02 & 0.02 & 0.01 & 0.01 & 0.01 & $\mathrm{MnO}$ & 0.45 & 0.46 \\
\hline $\mathrm{MgO}$ & 3.66 & 3.82 & 3.97 & 4.04 & $\mathrm{MgO}$ & 0.57 & 0.87 & $\mathrm{MnO}$ & 0.16 & 0.12 & 0.08 & $\mathrm{MgO}$ & 0.00 & 0.00 & 0.00 & 0.00 & 0.00 & 0.01 & 0.00 & 0.01 & $\mathrm{MgO}$ & 1.17 & 1.04 \\
\hline $\mathrm{CaO}$ & 11.29 & 11.38 & 11.37 & 11.39 & $\mathrm{CrO}$ & 0.04 & 0.05 & $\mathrm{MgO}$ & 0.04 & 0.03 & 0.02 & $\mathrm{CaO}$ & 4.67 & 4.84 & 5.40 & 5.86 & 6.01 & 6.26 & 5.89 & 5.76 & $\mathrm{CaO}$ & 6.18 & 6.68 \\
\hline $\mathrm{Na}_{2} \mathrm{O}$ & 1.12 & 1.08 & 1.10 & 1.08 & $\mathrm{Na}_{a_{2}} \mathrm{O}$ & 0.76 & 0.26 & $\mathrm{CaO}$ & 17.87 & 19.70 & 23.50 & $\mathrm{~N}_{2}{ }_{2} \mathrm{O}$ & 9.10 & 9.05 & 8.62 & 8.40 & 8.27 & 7.87 & 8.13 & 7.80 & $\mathrm{Na}_{2} \mathrm{O}$ & 0.00 & 0.01 \\
\hline $\mathrm{K}_{2} \mathrm{O}$ & 0.49 & 0.49 & 0.51 & 0.47 & $\mathrm{~K}_{2} \mathrm{O}$ & 9.68 & 9.05 & $\mathrm{Pr}_{2} \mathrm{O}_{3}$ & 0.00 & 0.00 & 0.00 & $\mathrm{~K}_{2} \mathrm{O}$ & 0.13 & 0.13 & 0.11 & 0.11 & 0.06 & 0.07 & 0.12 & 0.43 & $\mathrm{Y}_{2} \mathrm{O}_{3}$ & 0.03 & 0.00 \\
\hline $\begin{array}{l}\mathrm{F} \\
-\end{array}$ & 0.14 & 0.00 & 0.07 & 0.06 & $\mathrm{Cl}$ & 0.31 & 0.14 & $\mathrm{Ce}_{2} \mathrm{O}_{3}$ & 0.26 & 0.39 & 0.00 & $\mathrm{BaO}$ & 0.00 & 0.00 & 0.00 & 0.07 & 0.01 & 0.02 & 0.00 & 0.06 & $\mathrm{BaO}$ & 0.00 & 0.05 \\
\hline- & 98.43 & $\overline{97.83}$ & $\frac{-}{97.98}$ & $\frac{-}{97.84}$ & $\mathrm{~F}$ & $\frac{0.00}{94.51}$ & $\frac{0.15}{96.76}$ & $\mathrm{~L}_{2} \mathrm{O}_{3}$ & $\begin{array}{r}0.07 \\
88.32\end{array}$ & $\frac{0.08}{91.12}$ & $\frac{0.00}{95.86}$ & - & $-\overline{99.68}$ & $\overline{99.48}$ & $\overline{99.28}$ & $\frac{-}{99.27}$ & $\overline{99.46}$ & 99.23 & $\frac{-}{99.21}$ & $\overline{98.84}$ & & $\overline{99.46}$ & 99.57 \\
\hline $\mathrm{si}$ & 5.93 & 5.92 & 5.92 & 5.91 & Si & 6.14 & 6.16 & Si & 6.22 & 6.17 & 6.05 & Si & 11.12 & 11.09 & 10.99 & 10.88 & 10.85 & 10.81 & 10.88 & 10.84 & $\mathrm{Si}$ & 6.04 & 6.03 \\
\hline $\mathrm{Ti}$ & 0.04 & 0.04 & 0.02 & 0.03 & Ti & 0.02 & 0.02 & $\mathrm{Ti}$ & 0.00 & 0.00 & 0.01 & Al & 4.86 & 4.87 & 4.98 & 5.08 & 5.11 & 5.17 & 5.11 & 5.19 & A] & 3.93 & 3.87 \\
\hline $\mathrm{Al}$ & 3.73 & 3.73 & 3.77 & 3.75 & Al & 5.59 & 5.62 & Al & 4.88 & 4.87 & 4.96 & $\mathrm{Ti}_{\mathrm{i}}$ & 0.00 & 0.00 & 0.00 & 0.00 & 0.00 & 0.00 & 0.00 & 0.00 & $\mathrm{Ti}$ & 0.00 & 0.02 \\
\hline$F \in 2$ & 2.62 & 2.59 & 2.54 & 2.53 & $\mathrm{~F} \in 2+$ & 0.23 & 0.25 & $\mathrm{Nd}$ & 0.01 & 0.02 & 0.00 & Fe3+ & 0.00 & 0.01 & 0.00 & 0.01 & 0.02 & 0.02 & 0.01 & 0.01 & $\mathrm{Fe} 2$ & 4.59 & 4.61 \\
\hline $\mathrm{Mn}$ & 0.00 & 0.00 & 0.00 & 0.01 & $\mathrm{Mn}$ & 0.00 & 0.00 & $\mathrm{Fe} 3+$ & 1.24 & 1.14 & 0.94 & $\mathrm{Mn}$ & 0.00 & 0.00 & 0.00 & 0.00 & 0.00 & 0.00 & 0.00 & 0.00 & $\mathrm{Mn}$ & 0.06 & 0.06 \\
\hline $\mathrm{Mg}$ & 0.82 & 0.86 & 0.89 & 0.91 & $\mathrm{Mg}$ & 0.12 & 0.17 & $\mathrm{Mn}$ & 0.02 & 0.02 & 0.01 & $\mathrm{Mg}$ & 0.00 & 0.00 & 0.00 & 0.00 & 0.00 & 0.00 & 0.00 & 0.00 & $\mathrm{Mg}$ & 0.28 & 0.25 \\
\hline $\mathrm{Ca}$ & 1.82 & 1.84 & 1.83 & 1.84 & $\mathrm{Ca}$ & 0.01 & 0.01 & $\mathrm{Mg}$ & $0.0 \mathrm{t}$ & 0.01 & 0.00 & $\mathrm{Ca}$ & 0.89 & 0.92 & 1.03 & 1.13 & 1.15 & 1.20 & 1.13 & 1.11 & $\mathrm{Ca}$ & 1.08 & 1.16 \\
\hline $\mathrm{Na}$ & 0.33 & 0.32 & 0.32 & 0.31 & $\mathrm{Na}$ & 0.20 & 0.06 & $\mathrm{Ca}$ & 3.30 & 3.54 & 4.02 & $\mathrm{Na}$ & 3.13 & 3.13 & 2.99 & 2.92 & 2.87 & 2.73 & 2.82 & 2.72 & $\mathrm{Nia}$ & 0.00 & 0.00 \\
\hline $\mathrm{K}$ & 0.09 & 0.09 & 0.10 & 0.09 & $\mathrm{~K}$ & 1.66 & 1.51 & $\mathrm{Pr}$ & 0.00 & 0.00 & 0.00 & K & 0.03 & 0.03 & 0.03 & 0.03 & 0.01 & 0.02 & 0.03 & 0.10 & $Y$ & 0.00 & 0.00 \\
\hline $\mathrm{F}$ & 0.07 & 0.00 & 0.03 & 0.03 & $\mathrm{Cl}$ & 0.02 & 0.01 & $\mathrm{Ce}$ & 0.02 & 0.02 & 0.00 & $\mathrm{Ba}$ & 0.00 & 0.00 & 0.00 & 0.01 & 0.00 & 0.00 & 0.00 & 0.00 & $\mathrm{Ba}$ & 0.00 & 0.00 \\
\hline- & $\div$ & & - & - & $F$ & 0.00 & 0.06 & $\underline{L a}$ & 0.00 & $\frac{0,00}{150}$ & $\frac{0.00}{15.99}$ & & $\overline{20.03}$ & $-\overline{20.05}$ & $\div$ & $\therefore$ & 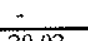 & 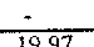 & $\frac{-}{19.99}$ & $\overline{1997}$ & & 15.99 & $\frac{-}{16,02}$ \\
\hline
\end{tabular}

\begin{tabular}{|c|c|c|c|c|c|c|c|c|c|c|c|c|c|c|c|c|c|c|c|c|c|c|}
\hline $\mathrm{C5}$ & 422 & 423 & 424 & 425 & C6 & 370 & $\mathrm{C} 6$ & 269 & 271 & 272 & 273 & 274 & 276 & 277 & 278 & 279 & 280 & 281 & 282 & 283 & 284 & 285 \\
\hline $0=24$ & GRT & GRT & GRT & GRT & $O=6$ & $\mathrm{CAB}$ & $\mathrm{O}=32$ & FSP & FSP & FSP & FSP & FSP & FSP & $\overline{F S P}$ & $\mathrm{ESP}$ & FSP & $\mathrm{FSP}$ & $\overline{F S P}$ & FSP & FSP & $\overline{F S P}$ & FSP \\
\hline $\mathrm{SiO}_{2}$ & 37.55 & 37.40 & 37.24 & 37.20 & $\mathrm{SiO}_{2}$ & 0.05 & $\mathrm{SiO}_{2}$ & 57.84 & 59.51 & 58.17 & 58.83 & 60.37 & 58.27 & 54.05 & 56.30 & 56.38 & 54.64 & 58.19 & 58.89 & 57.54 & 58.05 & 55.63 \\
\hline $\mathrm{Al}_{2} \mathrm{O}_{3}$ & 20.29 & 20.33 & 20.38 & 20.45 & $\mathrm{THO}_{2}$ & 0.00 & $\mathrm{Al}_{2} \mathrm{O}_{3}$ & 23.49 & 25.43 & 26.45 & 25.69 & 25.16 & 25.95 & 27.15 & 27.90 & 27.75 & 28.68 & 26.48 & 25.98 & 26.26 & 26.59 & 28.35 \\
\hline $\mathrm{TiO}_{2}$ & 0.13 & 0.19 & 0.07 & 0.05 & $\mathrm{Al}_{2} \mathrm{O}_{3}$ & 0.04 & $\mathrm{TiO}_{2}$ & 0.00 & 0.03 & 0.05 & 0.02 & 0.01 & 0.06 & 0.01 & 0.00 & 0.10 & 0.01 & 0.01 & 0.07 & 0.00 & 0.00 & 0.00 \\
\hline FeO & 33.30 & 33.76 & 33.84 & 33.58 & $\mathrm{FeO}$ & 2.05 & $\mathrm{Fe}_{2} \mathrm{O}_{3}$ & 2.76 & 0.24 & 0.01 & 0.13 & 0.07 & 0.03 & 0.00 & 0.03 & 0.09 & 0.06 & 0.13 & 0.08 & 0.14 & 0.12 & 0.17 \\
\hline $\mathrm{MnO}$ & 0.36 & 0.43 & 0.37 & 0.34 & $\mathrm{MnO}$ & 0.11 & $\mathrm{MnO}$ & 0.01 & 0.00 & 0.00 & 0.00 & 0.00 & 0.00 & 0.00 & 0.00 & 0.01 & 0.01 & 0.00 & 0.00 & 0.00 & 0.01 & 0.00 \\
\hline $\mathrm{MgO}$ & 1.08 & 1.10 & 1.19 & 1.42 & $\mathrm{MgO}$ & 0.43 & $\mathrm{MgO}$ & 0.56 & 0.0 & 0.01 & 0.01 & 0.00 & 0.00 & 0.00 & 0.00 & 0.01 & 0.00 & 0.01 & 0.01 & 0.00 & 0.00 & 0.01 \\
\hline $\mathrm{CaO}$ & 7.02 & 6.52 & 6.81 & 6.1 & $\mathrm{CaO}$ & 56.26 & $\mathrm{CaC}$ & 3. & & 8.05 & 7.54 & 6.74 & 8.20 & 9.83 & 9.81 & 9.86 & 11.03 & 8.00 & 7.76 & 8.40 & 8.37 & 10.36 \\
\hline $\mathrm{Na}_{2} \mathrm{O}$ & 0.00 & 0.03 & 0.00 & 0.02 & $\mathrm{SrO}$ & 0.01 & $\mathrm{Na}_{2} \mathrm{O}$ & 8.28 & 7.81 & 6.76 & 7.27 & 7.82 & 6.96 & 5.5 & 6.11 & 6.07 & 5.31 & 6.85 & 7.36 & 6.76 & 6.97 & 5.76 \\
\hline $\mathrm{Y}_{2} \mathrm{O}_{3}$ & 0.00 & 0.00 & 0.00 & 0.00 & $\mathrm{BaO}$ & 0.07 & $\mathrm{~K}_{2} \mathrm{O}$ & 0.2 & 0.61 & 0.20 & 0.20 & 0.09 & 0.07 & 0.09 & 0.06 & 0.06 & 0.04 & 0.13 & 0.09 & 0.07 & 0.08 & 0.06 \\
\hline $\mathrm{BaCO}$ & 0.09 & 0.10 & 0.00 & 0.01 & - & - & $\mathrm{BaO}$ & 0.07 & 0.00 & 0.00 & 0.00 & 0.00 & 0.05 & 0.02 & 0.00 & 0.09 & 0.13 & 0.02 & 0.00 & 0.00 & 0.00 & 0.00 \\
\hline & & - & $\therefore$ & - & - & - & - & - & & & & - & & & & & & & & & & \\
\hline & 99.82 & 99.84 & 99.90 & 99.19 & & 59.00 & & 97.16 & $\$ 8.89$ & 99.73 & 99.69 & 100.27 & 99.58 & 96.71 & 100.21 & 100.41 & 99.90 & 99.81 & 100.24 & 99.16 & 100.18 & 100.35 \\
\hline $\begin{array}{l}\mathrm{Si} \\
\mathrm{Al}\end{array}$ & 6.07 & 6.05 & 6.03 & 6.05 & $\mathrm{Si}$ & 0.00 & $\mathrm{Si}$ & 10.66 & 10.70 & 10.43 & 10.55 & 10.72 & 10.47 & 10.05 & 10.10 & 10.10 & 9.87 & 10.42 & 10.50 & 10.39 & 10.38 & 9.98 \\
\hline $\begin{array}{l}\mathrm{A} \\
\mathrm{Ti}\end{array}$ & 3.87 & 3.88 & 3.89 & 3.92 & Ti & & Al & & & 5.5 & 5.4 & 5.2 & 5.49 & 5.9 & 5.90 & 5.8 & 6.1 & 5.59 & 5.46 & 5.59 & 5.60 & 6.00 \\
\hline $\begin{array}{c}\mathrm{Ti} \\
\mathrm{F}=2 \div\end{array}$ & 0.02 & 0.02 & 0.01 & 0.01 & Al & 0.00 & $\mathrm{Ti}$ & 0.0 & 0.0 & 0.0 & 0.0 & 0.00 & 0.01 & 0.0 & 0.00 & 0.0 & 0.0 & 0.00 & 0.01 & 0.00 & 0.00 & 0.00 \\
\hline $\begin{array}{l}F=2 \div \\
M n\end{array}$ & 4.50 & 4.57 & 4.58 & 4.56 & Fe $2 \div$ & 0.16 & nie $3 \div$ & 6. & & 0. & 0.0 & 0.01 & 0.00 & 0.0 & 0.00 & 0.01 & 0.01 & 0.02 & 0.01 & 0.02 & 0.02 & 0.02 \\
\hline $\begin{array}{l}\mathrm{Mn} \\
\mathrm{Mg}\end{array}$ & 0.05 & & 0.05 & 0.05 & $\mathrm{Mn}$ & 0.01 & $\mathrm{Mnz}$ & 0.00 & 0.0 & 0.00 & 0.0 & 0.00 & 0.00 & 0.0 & 0.00 & 0.0 & 0.0 & 0.00 & 0.00 & 0.00 & 0.00 & 0.00 \\
\hline $\begin{array}{l}\mathrm{Mg} \\
\mathrm{Ca}\end{array}$ & 0.26 & 0.27 & 0.29 & 0.34 & $\mathrm{Mg}$ & 0.06 & $\mathrm{Mg}$ & 0.1 & 0.6 & 0. & 0.0 & 0.0 & 0. & 0.0 & 0.0 & 0.1 & 0.0 & 0.00 & 0.00 & 0.00 & 0.00 & 0.00 \\
\hline $\begin{array}{l}\mathrm{Ca} \\
\mathrm{Na}\end{array}$ & 1.22 & 1.13 & 1.18 & & $\mathrm{Ca}$ & 5.75 & $\mathrm{Ca}$ & 0.77 & 1.01 & 1.5 & 3.4 & 1.2 & 1.5 & 1.9 & 1.88 & 1.85 & 2.14 & 1.54 & 1.48 & 1.63 & 1.60 & 1.99 \\
\hline $\begin{array}{l}\mathrm{Na} \\
\mathrm{Y}\end{array}$ & 0.00 & 0.01 & 0.00 & 0.01 & $\mathrm{Sr}$ & 0.00 & $\mathrm{Na}$ & 2.96 & 2.72 & 2.35 & 2.5 & 2.6 & 2. & 2.0 & 2.13 & 2. & 1.8 & 2.38 & 2.55 & 2.36 & 2.42 & 2.01 \\
\hline $\begin{array}{l}\mathrm{Y} \\
\mathrm{Ba}\end{array}$ & $\begin{array}{l}0.00 \\
0.01\end{array}$ & & 0.00 & 0.00 & $\mathrm{Ba}$ & 0.00 & $\mathrm{~K}$ & 0.06 & & 0.05 & 0. & 0.02 & $0 . t$ & 0.02 & 0.01 & 0.0 & 0.01 & 0.03 & 0.02 & 0.02 & 0.02 & 0.01 \\
\hline+ & 0.01 & 0.01 & 0.00 & 0.00 & - & - & $\mathrm{Ba}$ & 0.01 & 0.00 & 0.00 & 0.00 & 0.00 & 0.00 & 0.00 & 0.00 & 0.01 & 0.01 & 0.00 & 0.00 & 0.00 & 0.00 & 0.00 \\
\hline & & & 3600 & & & 599 & & 20.10 & 20.01 & 19.97 & 20.02 & 20.00 & 19.99 & 19.99 & 20.02 & 20.01 & 20.00 & 19.98 & 20.04 & 20.00 & 20.03 & 20.02 \\
\hline
\end{tabular}


$\mathrm{K}+4939664$

(20.04

\begin{tabular}{|c|c|c|c|c|c|c|c|c|c|c|c|c|c|c|c|c|c|c|c|c|c|c|c|}
\hline $\mathrm{C}_{2}$ & & & & & $C_{2}$ & 361 & 362 & 364 & $\mathrm{C} 3$ & 286 & C3 & 386 & 385 & 388 & 387 & C3 & 240 & 241 & 242 & 243 & 244 & 243 & $2+0$ \\
\hline $0=23$ & $\mathrm{AMP}$ & AMP & AMP & AMP & $\mathrm{O}=6$ & $\mathrm{CAB}$ & $\mathrm{CAB}$ & $\mathrm{CAB}$ & $O=32$ & GRT & $\mathrm{O}=23$ & AMP & AMP & $\mathrm{AMP}$ & $\mathrm{AMP}$ & $\mathrm{O}=32$ & FSP & FSP & FSP & ESP & FSP & FSP & FSP \\
\hline $\mathrm{SiO}_{2}$ & 39.22 & 39.06 & 39.38 & 39.03 & $\mathrm{SiO}_{2}$ & 0.06 & 0.04 & 0.04 & $\mathrm{SiO}_{2}$ & 36.70 & $\mathrm{SiO}_{2}$ & 39.72 & 39.31 & 39.03 & 39.37 & $\mathrm{SiO}_{2}$ & 59.28 & 58.27 & 55.96 & 55.97 & 54.02 & 57.64 & 57.38 \\
\hline $\mathrm{TiO}_{2}$ & 0.12 & 0.21 & 0.24 & 0.22 & $\mathrm{HO}_{2}$ & 0.02 & 0.00 & 0.04 & $\mathrm{Al}_{2} \mathrm{O}_{3}$ & 20.63 & $\mathrm{TiO}_{2}$ & 0.21 & 0.25 & 0.32 & 0.25 & $\mathrm{Al}_{2} \mathrm{O}_{3}$ & 25.82 & 26.15 & 25.60 & 26.82 & 28.55 & 26.17 & 25.37 \\
\hline $\mathrm{Al}_{2} \mathrm{O}_{3}$ & 21.13 & 21.25 & 21.16 & 21.42 & $\mathrm{Al}_{2} \mathrm{O}_{3}$ & 0.12 & 0.12 & 0.03 & $\mathrm{THO}_{2}$ & 0.05 & $\mathrm{Al}_{2} \mathrm{O}_{3}$ & 21.18 & 20.90 & 20.69 & 21.12 & $\mathrm{TiO}_{2}$ & 0.00 & 0.00 & 0.00 & 0.02 & 0.01 & 0.03 & 0.00 \\
\hline $\mathrm{FeO}$ & 20.22 & 19.74 & 19.76 & 19.43 & $\mathrm{FuO}$ & 3.66 & 3.57 & 4.53 & $\mathrm{Fe}_{2} \mathrm{O}_{3}$ & 36.16 & FEO & 19.03 & 20.67 & 20.27 & 19.31 & $\mathrm{Fe}_{2} \mathrm{O}_{3}$ & 0.06 & 0.04 & 0.28 & 0.07 & 0.01 & 0.02 & 0.03 \\
\hline Mno & 0.02 & 0.08 & 0.05 & 0.07 & $\mathrm{MnO}$ & 0.21 & 0.21 & 0.27 & $\mathrm{MnO}$ & 0.84 & $\mathrm{MnO}$ & 0.04 & 0.05 & 0.04 & 0.02 & $\mathrm{MnO}$ & 0.00 & 0.01 & 0.00 & 0.00 & 0.00 & 0.00 & 0.00 \\
\hline $\mathrm{MgO}$ & 3.68 & 3.89 & 4.06 & 4.17 & $\mathrm{MgO}$ & 1.06 & 0.93 & 0.88 & $\mathrm{MgO}$ & 1.16 & $\mathrm{MgO}$ & 4.02 & 3.86 & 3.82 & 4.28 & $\mathrm{MgO}$ & 0.00 & 0.00 & 0.00 & 0.00 & 0.00 & 0.00 & 0.00 \\
\hline $\mathrm{CaO}$ & 11.57 & 11.56 & 11.57 & 10.40 & $\mathrm{CaO}$ & 52.08 & 52.30 & 54.69 & $\mathrm{CaO}$ & 6.77 & $\mathrm{CaO}$ & 10.52 & 11.11 & 11.43 & 11.39 & $\mathrm{CaO}$ & 7.37 & 7.74 & 7.47 & 9.02 & 11.08 & 8.32 & 7.51 \\
\hline $\mathrm{Na}_{2} \mathrm{O}$ & 1.08 & 1.02 & 1.02 & 0.81 & $\mathrm{SrO}$ & 0.06 & 0.01 & 0.05 & $\mathrm{Na}_{2} \mathrm{O}$ & 0.02 & $\mathrm{Na}_{2} \mathrm{O}$ & 0.98 & 1.07 & 1.02 & 1.10 & $\mathrm{Na}_{2} \mathrm{O}$ & 7.11 & 6.93 & 6.70 & 6.06 & 5.06 & 6.65 & 7.15 \\
\hline $\mathrm{K}_{2} \mathrm{O}$ & 0.50 & 0.45 & 0.48 & 0.70 & $\mathrm{BaO}$ & 0.00 & 0.00 & 0.00 & $\mathrm{~K}_{2} \mathrm{O}$ & 0.00 & $\mathrm{~K}_{2} \mathrm{O}$ & 0.69 & 0.45 & 0.46 & 0.53 & $\mathrm{~K}_{2} \mathrm{O}$ & 0.07 & 0.06 & 0.28 & 0.05 & 0.07 & 0.07 & 0.06 \\
\hline $\mathrm{F}$ & 0.05 & 0.07 & 0.04 & 0.10 & - & 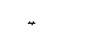 & - & - & $\mathrm{BaO}$ & 0.06 & $\mathrm{~F}$ & 0.06 & 0.09 & 0.18 & 0.00 & - & - & - & - & - & - & - & - \\
\hline- & - & - & - & - & - & - & - & - & - & - & - & & - & - & - & - & - & - & - & - & - & - & - \\
\hline- & 9760 & - & - & - & - & - & - & - & $=$ & - & - & & & - & & - & & & & 9800 & 9870 & 9890 & $\overline{9750}$ \\
\hline $\mathrm{Si}$ & $\frac{97.60}{5.93}$ & $\frac{97.32}{5.91}$ & 97.76 & $\frac{96.33}{5.94}$ & & 57.26 & 57.16 & 60.53 & & $\frac{102.39}{732}$ & & $\frac{96.45}{602}$ & $\frac{97.76}{5.94}$ & $\frac{97.24}{5.93}$ & $\frac{97.37}{5.93}$ & Si & $\frac{99.71}{10.59}$ & $\frac{99.20}{10.48}$ & $\frac{96.28}{10.40}$ & $\frac{98.00}{10.23}$ & $\frac{98.19}{9.86}$ & $\frac{88.90}{10.42}$ & $\frac{97.50}{10.51}$ \\
\hline$\Upsilon_{i}$ & 0.01 & $\begin{array}{l}3.91 \\
0.02\end{array}$ & $\begin{array}{l}3.93 \\
0.03\end{array}$ & $\begin{array}{l}3.94 \\
0.02\end{array}$ & $\begin{array}{l}\text { Si } \\
T i\end{array}$ & $\begin{array}{l}0.01 \\
0.00\end{array}$ & $\begin{array}{l}0.00 \\
0.00\end{array}$ & $\begin{array}{l}0.00 \\
0.00\end{array}$ & $\frac{\mathrm{Si}}{\mathrm{Al}}$ & $\begin{array}{l}7.32 \\
4.85\end{array}$ & $\begin{array}{l}\mathrm{Si} \\
\mathrm{Ti}\end{array}$ & $\begin{array}{l}0.01 \\
0.02\end{array}$ & 0.03 & $\begin{array}{l}5.93 \\
0.04\end{array}$ & $\begin{array}{l}3.93 \\
0.03\end{array}$ & $\begin{array}{l}\text { SI } \\
\text { Al }\end{array}$ & 5.44 & $\begin{array}{r}10 .+8 \\
5.54\end{array}$ & $\begin{array}{r}0 .+0 \\
5.61\end{array}$ & 5.78 & 6.14 & 5.58 & 5.48 \\
\hline Al & 3.76 & 3.79 & 3.75 & 3.84 & AH & 0.01 & 0.01 & 0.00 & $\mathrm{Ti}$ & $0.0 \mathrm{i}$ & $\mathrm{Al}$ & 3.78 & 3.72 & 3.71 & 3.75 & $\mathrm{Ti}$ & 0.00 & 0.00 & 0.00 & 0.00 & 0.00 & 0.00 & 0.00 \\
\hline$I \bullet 2$ & 2.56 & 2.50 & 2.49 & 2.47 & $\mathrm{Fe} 2$ & 0.30 & 0.29 & 0.35 & $\mathrm{Fe} 3-$ & 5.43 & $F \in 2 \div$ & 2.41 & 2.61 & 2.58 & 2.43 & $\mathrm{Fe} \div$ & 0.01 & 0.01 & 0.04 & 0.01 & 0.00 & 0.00 & 0.00 \\
\hline $\mathrm{Mn}$ & 0.00 & 0.01 & 0.01 & 0.01 & $\mathrm{Mn}$ & 0.02 & 0.02 & 0.02 & $\mathrm{Mm}$ & 0.14 & $\mathrm{Mn}$ & 0.01 & 0.01 & 0.01 & 0.00 & $\mathrm{Mn}$ & 0.00 & 0.00 & 0.00 & 0.00 & 0,00 & 0.00 & 0.00 \\
\hline $\mathrm{Mg}$ & 0.83 & 0.88 & 0.91 & 0.95 & $\mathrm{Mg}$ & 0.15 & 0.14 & 0.12 & $\mathrm{Mg}$ & 0.35 & $\mathrm{Mg}$ & 0.91 & 0.87 & 0.87 & 0.96 & $\mathrm{Mg}$ & 0.00 & 0.00 & 0.00 & 0.00 & 0.00 & 0.00 & 0.00 \\
\hline $\mathrm{Ca}$ & 1.87 & 1.87 & 1.86 & 1.70 & $\mathrm{Ca}$ & 5.49 & 5.52 & 5.48 & $\mathrm{Ca}$ & 1.45 & $\mathrm{Ca}$ & 1.71 & 1.80 & 1.86 & 1.84 & $\mathrm{Ca}$ & 1.4 & 1.49 & 1.49 & 1.77 & 2.17 & 1.61 & 1.47 \\
\hline $\mathrm{Na}$ & 0.32 & 0.30 & 0.30 & 0.24 & $\mathrm{Sr}$ & 0.00 & 0.00 & 0.00 & $\mathrm{Na}$ & 0.01 & $\mathrm{Na}$ & 0.29 & 0.31 & 0.30 & 0.32 & $\mathrm{Na}$ & 2.4 & 2.42 & 2.41 & 2.15 & 1.79 & 2.33 & 2.54 \\
\hline K & 0.10 & 0.09 & 0.09 & 0.14 & $\mathrm{Ba}$ & 0.00 & 0.00 & 0.00 & $\mathrm{~K}$ & 0.00 & $\mathrm{~K}$ & 0.13 & 0.09 & 0.09 & 0.10 & $\mathrm{~K}$ & 0.02 & 0.01 & 0.07 & 0.01 & 0.02 & 0.02 & 0.01 \\
\hline$F$ & 0.02 & 0.03 & 0.02 & 0.05 & - & - & - & . & $\mathrm{B} z$ & 0.00 & $\vec{F}$ & 0.03 & 0.04 & 0.08 & 0.00 & - & - & - & - & - & - & - & - \\
\hline & - & - & - & & & - & - & - & - & & - & & - & & - & - & & - & - & - & - & - & - \\
\hline
\end{tabular}




\begin{tabular}{|c|c|c|c|c|c|c|c|c|c|c|c|c|c|c|c|c|c|c|c|c|c|c|}
\hline $\mathrm{C3}$ & 249 & 255 & 257 & 250 & 251 & 253 & 254 & $\mathrm{CA}$ & 324 & 323 & $\mathrm{C} 4$ & 325 & 326 & 327 & 328 & 329 & 330 & $\mathrm{C} 4$ & 389 & 390 & $\mathrm{C4}$ & 287 \\
\hline $0=32$ & FSP & FSP & FSP & FSP & FSP & FSP & FSP & $O=28$ & $\mathrm{CHL}$ & $\mathrm{CHL}$ & $0=22$ & $\mathrm{SE}$ & SE & $\mathrm{BT}$ & BT & BT & BT & $\mathrm{O}=23$ & ANP & AMP & $O=32$ & $\frac{\text { GRT }}{380}$ \\
\hline $\mathrm{SiO}_{2}$ & 59.25 & 58.36 & 56.28 & 58.11 & 58.65 & 56.96 & 57.89 & $\mathrm{SiO}_{2}$ & 27.40 & 26.71 & $\mathrm{SiO}_{2}$ & 45.58 & 45.49 & 38.17 & 33.88 & 34.79 & 33.98 & $\mathrm{SiO}_{2}$ & 39.57 & 39.70 & $\mathrm{SiO}_{2}$ & 38.06 \\
\hline $\mathrm{Al}_{2} \mathrm{O}_{3}$ & 24.72 & 24.75 & 26.17 & 24.13 & 25.03 & 24.87 & 25.91 & $\mathrm{TiO}_{2}$ & 0.11 & 0.19 & $\mathrm{TiO}_{2}$ & 0.28 & 0.22 & 0.21 & 1.90 & 1.62 & 1.77 & $\mathrm{TiO}_{2}$ & 0.18 & 0.17 & $\mathrm{Al}_{2} \mathrm{O}_{3}$ & 27.64 \\
\hline $\mathrm{TO}_{2}$ & 0.03 & 0.000 & 0.02 & 0.02 & 0.00 & 0.04 & 0.00 & $\mathrm{AJ}_{2} \mathrm{O}_{3}$ & 20.08 & 20.86 & $\mathrm{Al}_{2} \mathrm{O}_{3}$ & 33.78 & 34.29 & 31.18 & 19.12 & 18.93 & 18.42 & $\mathrm{Al}_{2} \mathrm{O}_{3}$ & 21.10 & 21.02 & $\mathrm{THO}_{2}$ & 0.07 \\
\hline $\mathrm{Fe}_{2} \mathrm{O}_{3}$ & 0.01 & 1).12 & 0.07 & 0.06 & 0.15 & 0.13 & 0.16 & $\mathrm{FeO}$ & 27.30 & 26.95 & $\mathrm{FeO}$ & 2.31 & 1.62 & 10.15 & 20.01 & 21.30 & 21.32 & $\mathrm{FeO}$ & 19.60 & 19.67 & $\mathrm{Fe}_{2} \mathrm{O}_{3}$ & 7.19 \\
\hline $\mathrm{MnO}$ & 0.00 & 0.00 & 0.01 & 0.00 & 0.03 & 0.00 & 0.00 & $\mathrm{MnO}$ & 0.03 & 0.02 & $\mathrm{MOO}$ & 0.00 & 0.00 & 0.00 & 0.04 & 0.01 & 0.04 & $\mathrm{MnO}$ & 0.06 & 0.07 & $\mathrm{MnO}$ & 0.09 \\
\hline $\mathrm{MgO}$ & 0.00 & 0.00 & 0.00 & 0.00 & 0.00 & 0.00 & $0.00)$ & Mg) & 10.23 & 9.97 & $\mathrm{MgO}$ & 1.12 & 0.90 & 4.17 & 8.11 & 8.43 & 8.71 & $\mathrm{MgO}$ & 4.16 & 4.23 & $\mathrm{Mg}_{\mathrm{g}}()$ & 0.05 \\
\hline $\mathrm{CaO}$ & 6.76 & 5.75 & 8.57 & 6.01 & 6.86 & 6.68 & 7.65 & (3) & 0.04 & 0.03 & $\mathrm{Ca}(\mathrm{)}$ & 0.02 & 0.06 & 0.06 & 0.07 & 0.01 & 0.02 & $\mathrm{CaO}$ & 11.41 & 11.56 & (a) & 22.71 \\
\hline $\left.\mathrm{Na}_{2} \mathrm{O}\right)$ & 7.48 & 7.06 & 6.15 & 7.74 & 7.44 & 6.86 & 6.82 & $\mathrm{Na}_{2} \mathrm{O}$ & 0.01 & 0.05 & $\mathrm{Na}_{2} \mathrm{O}$ & 0.41 & 0.46 & 0.34 & 0.14 & 0.14 & 0,12 & $\mathrm{Na}_{2} \mathrm{O}$ & 1.05 & 1.05 & $\left.\mathrm{~N}_{3_{2}} \mathrm{O}\right)$ & 0.01 \\
\hline $\mathrm{K}_{2} \mathrm{O}$ & 0.06 & 0.73 & 0.22 & 0.06 & 0.09 & 0.35 & 0.10 & $\mathrm{~K}_{2} \mathrm{O}$ & 2.84 & 2.52 & $\mathrm{~K}_{2} \mathrm{O}$ & 9.79 & 9.85 & 6.35 & 8.69 & 8.81 & 8.49 & $\mathrm{~K}_{2} \mathrm{O}$ & 0.51 & 0.50 & $\mathrm{~K}_{2} \mathrm{O}$ & 0.03 \\
\hline - & - & - & - & - & - & - & - & $\mathrm{cl}$ & 0.02 & 0.02 & $\mathrm{Cl}$ & 0.00 & 0.00 & 0.00 & 0.03 & 0.03 & 0.03 & $F$ & 0.00 & 0.08 & $\mathrm{BaO}$ & 0.04 \\
\hline 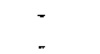 & - & - & - & - & - & - & - & $\mathrm{F}$ & 0.07 & 0.06 & $F$ & 0.17 & 0.00 & 0.03 & 0.28 & 0.37 & 0.23 & - & - & - & - & - \\
\hline- & - & - & $\therefore$ & - & - & 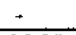 & - & $\mathrm{BaO}$ & 0.06 & 0.00 & $\mathrm{BaO}$ & 0.31 & 0.34 & 0.26 & 0.06 & 0.06 & 0.14 & $=$ & - & & $=$ & \\
\hline & 98.31 & 96.77 & 97.49 & 96.12 & 98.25 & 95.88 & 98.54 & & 88.20 & 87.36 & & 93.75 & 93.23 & 90.91 & 92.33 & 94.49 & 93.26 & & 97.64 & 98.05 & & 95.87 \\
\hline $\begin{array}{l}\mathrm{Si} \\
\mathrm{A} 1\end{array}$ & 10.72 & 10.72 & 10.33 & 10.75 & 10.64 & 10.59 & 10.49 & $\mathrm{Si}$ & 5.88 & 5.77 & $\mathrm{Si}$ & 6.20 & 6.19 & 5.56 & 5.36 & 5.40 & 5.35 & Si & 5.95 & 5.95 & $\mathrm{Si}$ & 7.72 \\
\hline $\begin{array}{c}\text { Al } \\
\text { Ti }\end{array}$ & 5.27 & 5.36 & 5.66 & 5.26 & 5.35 & 5.45 & 5.53 & $\mathrm{Ti}$ & 0.02 & 0.03 & Ti & 0.03 & 0.02 & 0.02 & 0.23 & 0.19 & 0.21 & $\mathrm{Ti}$ & 0.02 & 0.02 & $\mathrm{Ad}$ & 6.61 \\
\hline $\begin{array}{c}\mathrm{Ti} \\
\mathrm{Fe} 3\end{array}$ & 0.00 & 0.00 & 0.00 & 0.00 & 0.00 & 0.00 & 0.00 & Al & 5.08 & 5.31 & $\mathrm{Al}$ & 5.42 & 5.50 & 5.35 & 3.57 & 3.47 & 3.42 & $\mathrm{Al}$ & 3.74 & 3.72 & $\mathrm{Ti}$ & 0.01 \\
\hline $\begin{array}{l}\text { Fe3 } \\
\text { Mn }\end{array}$ & $\begin{array}{l}0.00 \\
0.00\end{array}$ & 0.02 & 0.01 & 0.01 & 0.02 & 0.02 & 0.02 & $\mathrm{~F}=2 \div$ & 4.90 & 4.87 & $\mathrm{Fe} 2+$ & 0.26 & 0.18 & 1.24 & 2.65 & 2.77 & 2.81 & $\mathrm{Fe} 2+$ & 2.47 & 2.47 & $503 \div$ & 1.10 \\
\hline $\mathrm{Mg}$ & 0.00 & 0.00 & 0.00 & 0.00 & 0.00 & 0.00 & 0.00 & $\mathrm{Mn}$ & 0.01 & 0.00 & $\mathrm{Mn}$ & 0.00 & 0.00 & 0.00 & 0.00 & 0.00 & 0.01 & $\mathrm{Mn}$ & 0.01 & 0.01 & $\mathrm{Mn}$ & 0.01 \\
\hline $\mathrm{Ca}$ & $\begin{array}{l}0.00 \\
1.31\end{array}$ & 0.00 & 0.00 & 0.00 & 0.00 & 0.00 & 0.00 & $\mathrm{Mg}$ & 3.27 & 3.21 & $\mathrm{Mg}_{\mathrm{g}}$ & 0.23 & 0.18 & 0.91 & 1.91 & 1.95 & $\begin{array}{l}2.05 \\
0.00\end{array}$ & $\mathrm{Mg}$ & $\begin{array}{l}0.93 \\
1.84\end{array}$ & $\begin{array}{l}0.95 \\
1.86\end{array}$ & $\mathrm{Mg}$ & $\begin{array}{l}0.01 \\
4.94\end{array}$ \\
\hline $\mathrm{Na}$ & 2.62 & $\begin{array}{l}.13 \\
2.51\end{array}$ & $\begin{array}{l}1.68 \\
2.19\end{array}$ & 1.19 & 1.33 & 1.33 & 1.49 & $\mathrm{Ca}$ & 0.01 & $\begin{array}{l}0.01 \\
0.02\end{array}$ & $\mathrm{Ca}$ & $\begin{array}{l}0.00 \\
0.11\end{array}$ & $\begin{array}{l}0.01 \\
0.12\end{array}$ & $\begin{array}{l}0.01 \\
0.09\end{array}$ & $\begin{array}{l}0.01 \\
0.04\end{array}$ & $\begin{array}{l}0.00 \\
0.04\end{array}$ & $\begin{array}{l}0.00 \\
0.04\end{array}$ & $\begin{array}{l}\mathrm{Ca} \\
\mathrm{Na}\end{array}$ & $\begin{array}{l}1.84 \\
0.31\end{array}$ & $\begin{array}{l}1.86 \\
0.30\end{array}$ & $\begin{array}{l}\mathrm{Ca} \\
\mathrm{Na}\end{array}$ & $\begin{array}{l}1.94 \\
0.00\end{array}$ \\
\hline $\mathrm{K}$ & 0.01 & $\begin{array}{l}2.31 \\
0.17\end{array}$ & $\begin{array}{l}2.19 \\
0.05\end{array}$ & $\begin{array}{l}2.78 \\
0.02\end{array}$ & $\begin{array}{l}2.62 \\
0.02\end{array}$ & $\begin{array}{l}2.47 \\
0.08\end{array}$ & $\begin{array}{l}2.40 \\
0.02\end{array}$ & $\begin{array}{c}\mathrm{Na} \\
\mathrm{K}\end{array}$ & $\begin{array}{l}0.00 \\
0.78\end{array}$ & $\begin{array}{l}0.02 \\
0.69\end{array}$ & $\begin{array}{l}\mathrm{Na} \\
\mathrm{K}\end{array}$ & 1.70 & 1.71 & 1.18 & 1.75 & 1.75 & 1.71 & $\mathrm{~K}$ & 0.10 & 0.10 & $x$ & 0.01 \\
\hline - & - & - & - & - & - & - & - & $\mathrm{Ba}$ & 0.00 & 0.00 & $\mathrm{Ba}$ & 0.02 & 0.02 & 0.01 & 0.00 & 0.00 & 0.01 & $F$ & 0.00 & 0.04 & $\mathrm{Ba}$ & 0.00 \\
\hline - & - & . & - & - & - & 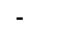 & - & $\mathrm{Cl}$ & 0.01 & 0.01 & $\mathrm{Cl}$ & 0.00 & 0.00 & 0.00 & 0.01 & 0.01 & 0.01 & - & - & 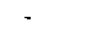 & - & - \\
\hline- & - & - & - & - & - & & - & $\mathrm{F}$ & 0.04 & 0.03 & $F$ & 0.07 & 0.00 & 0.01 & 0.14 & $\begin{array}{r}0.18 \\
3=57\end{array}$ & $\frac{0.11}{1560}$ & - & - & $\overline{-}$ & - & 20.42 \\
\hline
\end{tabular}

\begin{tabular}{|c|c|c|c|c|c|c|c|c|}
\hline \multicolumn{9}{|c|}{ K49 39664} \\
\hline $\mathrm{C5}$ & 392 & 393 & 394 & $\mathrm{C5}$ & 366 & 367 & 368 & 369 \\
\hline $\mathrm{O}=23$ & AMPP & $\mathrm{AMP}$ & AMPP & $0=6$ & $\mathrm{CAB}$ & $\mathrm{CAB}$ & $C A B$ & $\mathrm{CAB}$ \\
\hline $\mathrm{SiO}_{2}$ & 38.12 & 38.82 & 38.68 & $\mathrm{SiO}_{2}$ & 0.01 & 0.03 & 0.02 & 0.03 \\
\hline $\mathrm{THO}_{2}$ & 0.27 & 0.16 & 0.12 & $\mathrm{TiO}_{2}$ & 0.03 & 0.05 & 0.01 & 0.00 \\
\hline $\mathrm{Al}_{2} \mathrm{O}_{3}$ & 20.51 & 20.72 & 20.67 & $\mathrm{Al}_{2} \mathrm{O}_{3}$ & 0.01 & 0.02 & 0.12 & 0.16 \\
\hline $\mathrm{F} 0 \mathrm{O}$ & 19.71 & 19.71 & 19.62 & FeO & 1.36 & 2.10 & 2.00 & 4.04 \\
\hline $\mathrm{MnO}$ & 0.11 & 0.09 & 0.06 & $\mathrm{MnO}$ & 0.12 & 0.30 & 0.30 & 0.31 \\
\hline $\mathrm{MgO}$ & 3.96 & 4.01 & 4.04 & MgO & 0.09 & 0.32 & 0.31 & 1.14 \\
\hline $\mathrm{CaO}$ & 11.31 & 11.51 & 11.52 & $\mathrm{CaO}$ & 57.12 & 58.05 & 57.76 & 54.25 \\
\hline $\mathrm{Na}_{2} \mathrm{O}$ & 0.97 & 1.06 & 0.97 & sro & 0.00 & 0.02 & 0.04 & 0.02 \\
\hline $\mathrm{K}_{2} \mathrm{O}$ & 0.60 & 0.50 & 0.49 & $\mathrm{BaO}$ & 0.00 & 0.00 & 0.00 & 0.00 \\
\hline$F$ & 0.04 & 0.00 & 0.05 & - & - & - & - & - \\
\hline - & - & - & - & - & - & - & - & - \\
\hline- & - & - & - & - & - & - & - & \\
\hline & 95.58 & 96.58 & 96.22 & Total & 58.76 & 60.88 & 60.55 & 59.96 \\
\hline Si & 5.89 & 5.92 & 5.92 & $\mathrm{Si}$ & 0.00 & 0.00 & 0.00 & 0.00 \\
\hline $\mathrm{Ti}$ & 0.03 & 0.02 & 0.01 & Ti & 0.00 & 0.00 & 0.00 & 0.00 \\
\hline Al & 3.74 & 3.73 & 3.73 & Al & 0.00 & 0.00 & 0.01 & 0.02 \\
\hline $\mathrm{re} 2+$ & 2.55 & 2.51 & 2.51 & $\mathrm{Fe} 2+$ & 0.11 & 0.16 & 0.16 & 0.32 \\
\hline$M n$ & 0.01 & 0.01 & 0.01 & $\mathrm{Mn}$ & 0.01 & 0.02 & 0.02 & 0.03 \\
\hline $\mathrm{Mg}$ & 0.91 & 0.91 & 0.92 & $\mathrm{My}$ & 0.01 & 0.04 & 0.04 & 0.16 \\
\hline $\mathrm{Ca}$ & 1.87 & 1.88 & 1.89 & $\mathrm{Ca}$ & 5.86 & 5.75 & 5.75 & 5.46 \\
\hline $\mathrm{Na}$ & 0.29 & 0.31 & 0.29 & $\mathrm{Sr}$ & 0.00 & 0.00 & 0.00 & 0.00 \\
\hline$k$ & 0.12 & 0). 10 & 0.10 & Ba & 0.060 & 0.00 & 0.00 & 0.00 \\
\hline I: & 0.02 & 0.000 & 0.02 & - & - & - & - & $\cdot$ \\
\hline - & - & - & - & - & - & - & - & - \\
\hline- & - & - & - & - & - & - & & \\
\hline & 15.41 & 15.40 & 15.39 & Total & 6.00 & 5.99 & 5.99 & 5.99 \\
\hline
\end{tabular}


ANEXO 3

TABELAS DE MICROTERMOMETRIA 
ANEXO 4 - DADOS MICROTERMOMÉTRICOS

VEIO DE QUARTZO DA PRIMEIRA GERAÇÃO (Q-IV1)

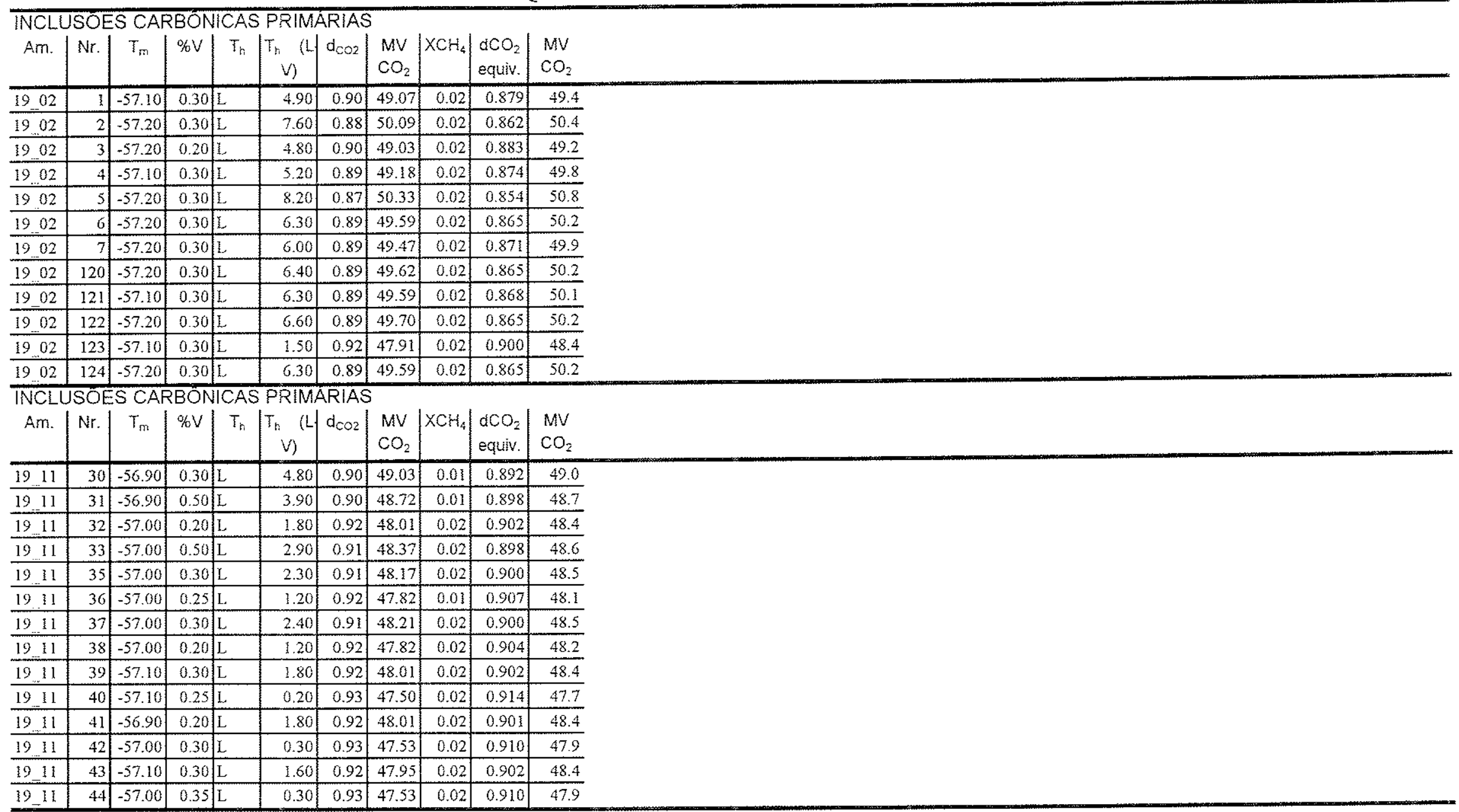




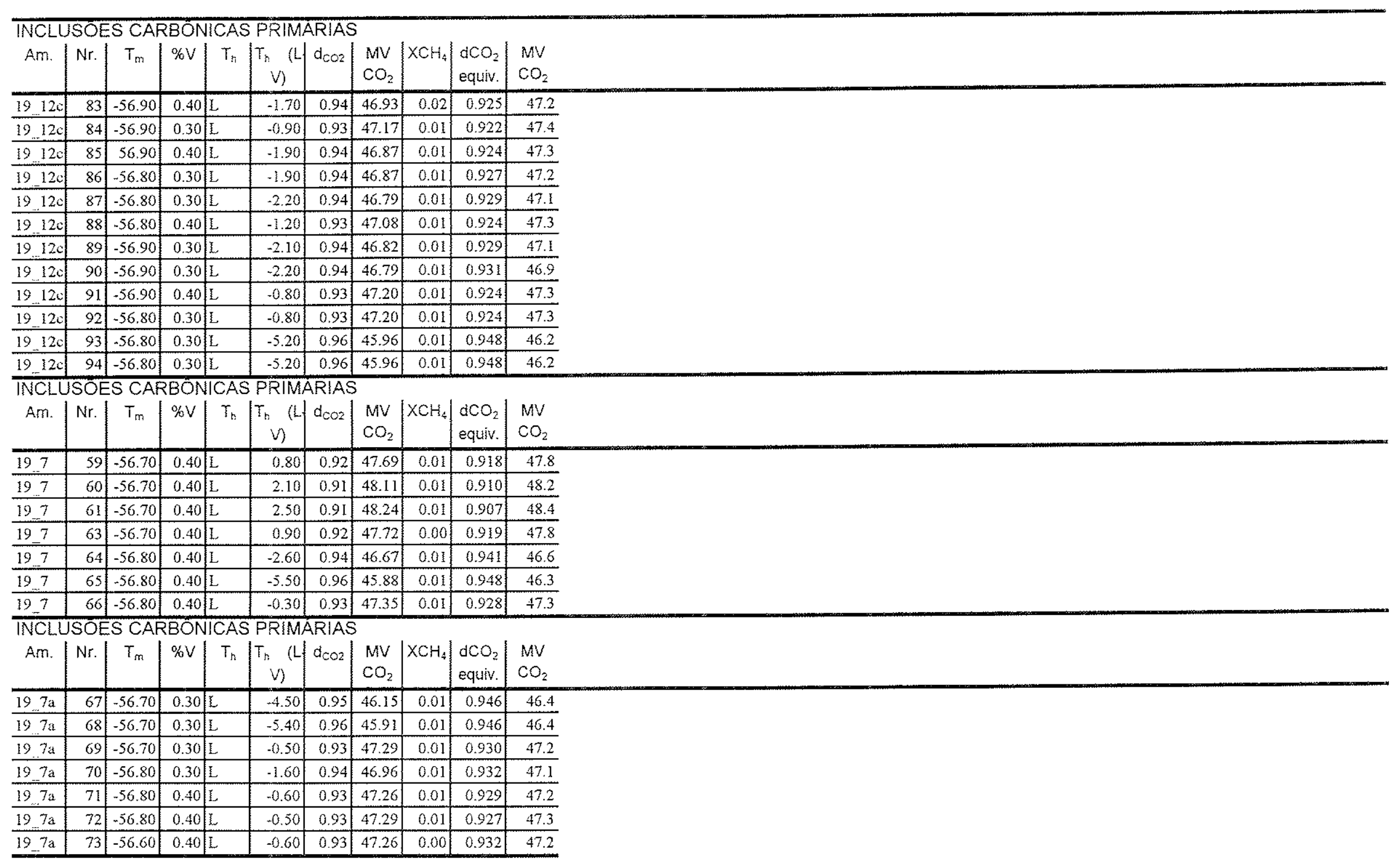




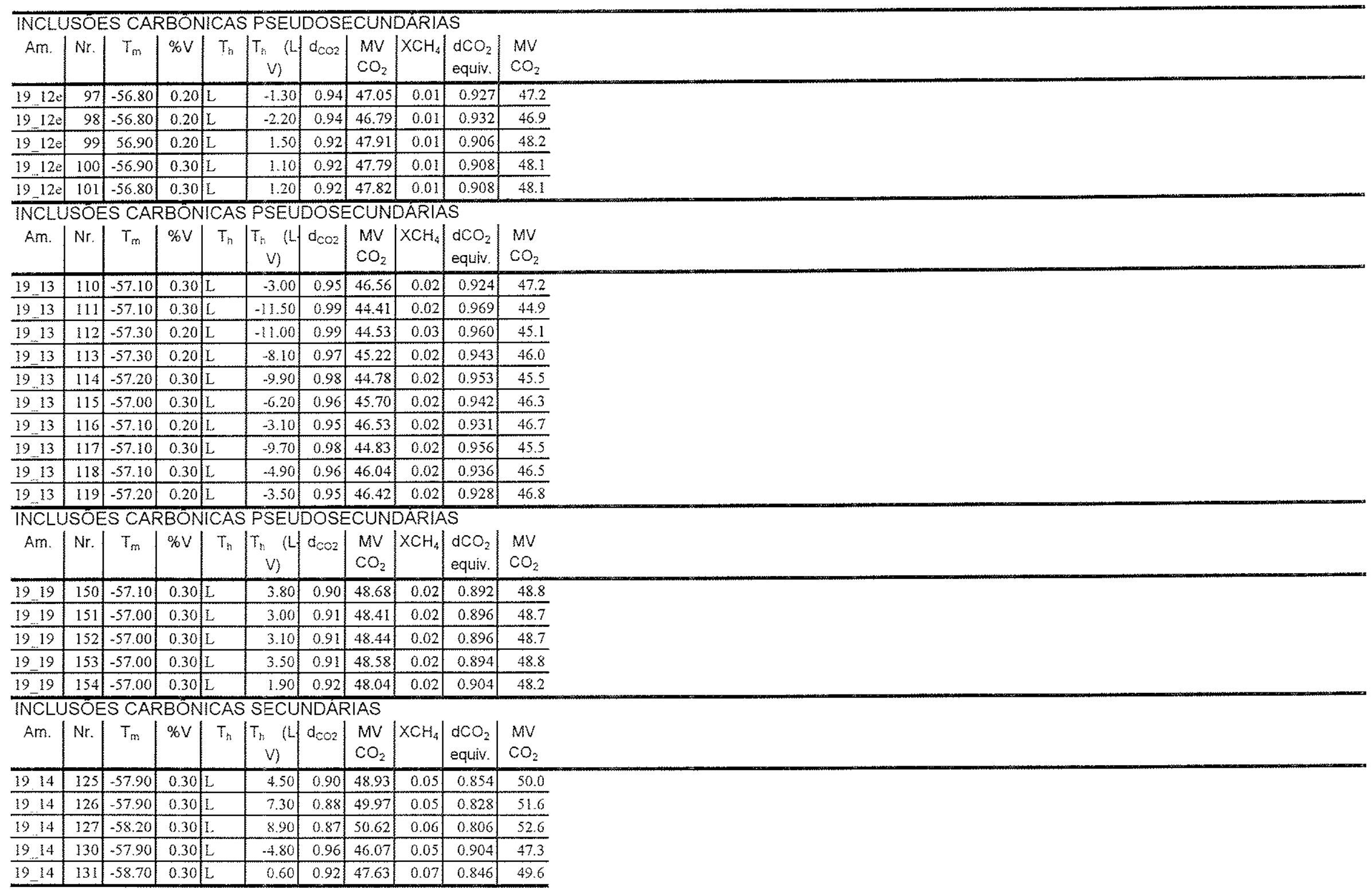




\begin{tabular}{|c|c|c|c|c|c|c|c|c|c|c|c|c|c|c|c|c|c|c|c|c|c|c|c|c|c|c|}
\hline \multicolumn{27}{|c|}{ INCLUSŌES CARBŌNICAS SECUNDÁRIAS } \\
\hline Am. & Nr. & $\left|T_{m}\right|$ & $\% \mathrm{~V}$ & $\mid T_{n}$ & $\left|\begin{array}{cc}r_{0} & (4) \\
v & 1\end{array}\right|$ & $d_{c 02}$ & $\left|\begin{array}{c|}\mathrm{MV} \\
\mathrm{CO}_{2}\end{array}\right|$ & $\left|\mathrm{XCH}_{4}\right|$ & $\left|\begin{array}{l}\mathrm{d} \mathrm{CO}_{2} \\
\text { equiv. }\end{array}\right|$ & $\begin{array}{l}\mathrm{MV} \\
\mathrm{CO}_{2}\end{array}$ & & & & & & & & & & & & & & & & \\
\hline $1912 \mathrm{t}$ & 102 & -57.00 & 0.30 & L. & 5.00 & 0.90 & 49.11 & 0.02 & 0.884 & 49.3 & & & & & & & & & & & & & & & & \\
\hline $19 \quad 124$ & 103 & -57.00 & 0.30 & $\mathrm{~L}$ & 6.60 & 0.89 & 49.70 & 0.02 & 0.871 & $\overline{50.1}$ & & & & & & & & & & & & & & & & \\
\hline 19.121 & 104 & -57.00 & 0.30 & $\mathrm{~L}$ & 5.50 & 0.89 & 49.29 & 0.02 & 0.876 & 49.8 & & & & & & & & & & & & & & & & \\
\hline $19.12 \mathrm{f}$ & 105 & -57.00 & 0.30 & $\mathrm{~L}$ & 1.00 & 0.92 & 47.75 & 0.02 & 0.906 & 48.1 & & & & & & & & & & & & & & & & \\
\hline $1912 \mathrm{f}$ & 106 & -57.00 & 0.30 & L & 8.00 & 0.88 & 50.25 & 0.02 & 0.865 & 50.4 & & & & & & & & & & & & & & & & \\
\hline $19.12 \mathrm{f}$ & 107 & -57.00 & 0.30 & $\mathrm{~L}$ & 9.80 & 0.86 & 51.01 & 0.02 & 0.858 & 50.8 & & & & & & & & & & & & & & & & \\
\hline $19.12 \mathrm{t}$ & 108 & -56.90 & 0.30 & $L$ & 4.50 & 0.90 & 48.93 & 0.01 & 0.891 & 49.0 & & & & & & & & & & & & & & & & \\
\hline $1912 \mathrm{t}$ & 109 & $\mid-56.90$ & 0.30 & L & 4.30 & 0.90 & \begin{tabular}{|l|}
48.86 \\
\end{tabular} & 0.01 & 0.894 & 48.9 & & & & & & & & & & & & & & & & \\
\hline \multicolumn{27}{|c|}{ INCLUSOES CARBONICAS SECUNDARIAS } \\
\hline Am. & Nr. & $T_{n}$ & $\% \mathrm{~V}$ & $T_{n}$ & $\left|\begin{array}{ll}T_{1} & (\mathrm{~L} \\
v & v\end{array}\right|$ & $d_{\mathrm{CO} 2}$ & $\left|\begin{array}{c}\mathrm{MV} \\
\mathrm{CO}_{2}\end{array}\right|$ & $\mathrm{XCH}_{4} \mid$ & $\left|\begin{array}{l}\mathrm{d} \mathrm{CO}_{2} \\
\text { equiv. }\end{array}\right|$ & $\begin{array}{l}\mathrm{MV} \\
\mathrm{CO}_{2}\end{array}$ & & & & & & & & & & & & & & & & \\
\hline 194 & 138 & $\mid-57.10$ & 0.40 & L & 21.50 & 0.76 & 58.16 & 0.02 & 0.753 & 57.7 & & & & & & & & & & & & & & & & \\
\hline 194 & 139 & \begin{tabular}{|l|l|}
-57.10 \\
\end{tabular} & 0.30 & L & 21.50 & 0.76 & 58.16 & 0.02 & \begin{tabular}{|l|l|} 
& 0.753 \\
\end{tabular} & 57.7 & & & & & & & & & & & & & & & & \\
\hline 19.4 & 140 & \begin{tabular}{|l|}
-57.10 \\
\end{tabular} & 0.30 & $L$ & 21.60 & \begin{tabular}{|l|}
0.76 \\
\end{tabular} & \begin{tabular}{|l|l|}
58.25 \\
\end{tabular} & 0.02 & 0.751 & 57.9 & & & & & & & & & & & & & & & & \\
\hline 194 & 141 & \begin{tabular}{|l|}
-57.20 \\
\end{tabular} & 0.30 & L & 21.60 & \begin{tabular}{l|l|}
0.76 \\
\end{tabular} & \begin{tabular}{|l|}
58.25 \\
\end{tabular} & 0.02 & 0.748 & 58.0 & & & & & & & & & & & & & & & & \\
\hline 19.4 & 142 & \begin{tabular}{|l|}
-57.00 \\
\end{tabular} & 0.40 & $L$ & 21.50 & 0.76 & 58.16 & 0.02 & 0.747 & 58.3 & & & & & & & & & & & & & & & & \\
\hline 19.4 & 143 & $\mid-57.10$ & 0.30 & $L$ & 21.40 & 0.76 & \begin{tabular}{|l|}
58.07 \\
\end{tabular} & 0.02 & 0.746 & 58.3 & & & & & & & & & & & & & & & & \\
\hline 194 & 144 & \begin{tabular}{|l|l|}
-57.10 \\
\end{tabular} & 0.30 & $\mathrm{~L}$ & 21.40 & 0.76 & \begin{tabular}{|l|l|}
58.07 \\
\end{tabular} & 0.02 & 0.746 & 58.3 & & & & & & & & & & & & & & & & \\
\hline 194 & 145 & \begin{tabular}{|l|}
-57.00 \\
\end{tabular} & 0.30 & L & 21.50 & 0.76 & 58.16 & 0.02 & 0.750 & 58.1 & & & & & & & & & & & & & & & & \\
\hline 194 & 146 & \begin{tabular}{|c|}
-57.00 \\
\end{tabular} & 0.30 & $\mathrm{~L}$ & 21.50 & $\begin{array}{ll}0.76 \\
\end{array}$ & 58.16 & 0.02 & 0.750 & 58.1 & & & & & & & & & & & & & & & & \\
\hline 194 & 147 & $\mid-57.10$ & 0.30 & $\mathrm{~L}$ & 17.50 & $\begin{array}{ll}0.80 \\
\end{array}$ & 55.10 & 0.02 & 0.772 & 56.3 & & & & & & & & & & & & & & & & \\
\hline 194 & 148 & \begin{tabular}{|l|}
57.10 \\
\end{tabular} & 0.30 & L & 21.40 & 0.76 & \begin{tabular}{|l|}
58.07 \\
\end{tabular} & 0.02 & 0.750 & 58.0 & & & & & & & & & & & & & & & & \\
\hline \multirow{2}{*}{\multicolumn{27}{|c|}{ 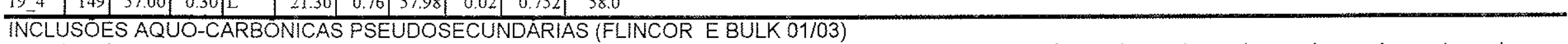 }} \\
\hline & & & & & & & & & & & & & & & & & & & & & & & & & & \\
\hline Am. & Nr. & $T_{m}$ & $\% \vee$ & $T_{\text {mg }} \mid$ & $\begin{array}{l}\mathrm{Tm} \\
\text { clat }\end{array} \mid$ & Th & $\left|\begin{array}{c}T_{h} \\
\mathrm{CO} 2\end{array}\right|$ & $\left|\begin{array}{c}\% \vee \\
\mathrm{CO} 2\end{array}\right|$ & F estim & $T_{\text {rnaci }} T$ & $T_{\text {hiot }} \mid \mathrm{L}$ & $L-V / d$ & $d_{H 20} \mid \begin{array}{l}N \\
m\end{array}$ & $\begin{array}{c}\mathrm{NaCl} \\
\mathrm{mola}\end{array}$ & $\left|\begin{array}{l}\mathrm{NaCl} \\
\%_{\text {pess }}\end{array}\right|$ & $\begin{array}{c}\mathrm{X} \\
\mathrm{NaCl}\end{array} \mid$ & $d_{\text {Carb }}$ & $\begin{array}{c}\text { MV } \\
\text { Carb }\end{array}$ & $\left|\begin{array}{l}\mathrm{XCO}_{2} \\
\mathrm{Carb}\end{array}\right|$ & $\left|\begin{array}{l}\mathrm{XCH}_{4} \\
\mathrm{Carb}\end{array}\right|>$ & $\left|\begin{array}{c}\mathrm{XH}_{2} \mathrm{O} \\
\text { tot }\end{array}\right|$ & $\left|\begin{array}{c}\mathrm{XCO}_{2} \\
\text { tot }\end{array}\right|$ & $\left|\begin{array}{ll}X \mathrm{NaC} \\
1 & \text { tot }\end{array}\right|$ & $\left|\begin{array}{c}\mathrm{x} \mathrm{CH} 4 \\
\text { tot }\end{array}\right|$ & $d_{\mathrm{sot}}$ & $v m_{\text {tot }}$ \\
\hline 1921 & 161 & \begin{tabular}{|l|}
-56.70 \\
\end{tabular} & 0.50 & -11.6 & 10.001 & $\mathrm{~L}$ & 30.90 & \begin{tabular}{ll|l}
0.103 \\
\end{tabular} & 30.900 & \begin{tabular}{|l|}
254.5 \\
\end{tabular} & \begin{tabular}{|c|}
$258.1 \mathrm{~g}$ \\
\end{tabular} & & \begin{tabular}{l|l}
1.29 \\
\end{tabular} & 9.19 & \begin{tabular}{|l|}
34.96 \\
\end{tabular} & 0.25 & 0.52 & \begin{tabular}{|l|}
84.35 \\
\end{tabular} & 1.00 & \begin{tabular}{|l|}
0.00 \\
\end{tabular} & \begin{tabular}{|l|}
0.62 \\
\end{tabular} & \begin{tabular}{|l|}
0.17 \\
\end{tabular} & \begin{tabular}{|l|}
0.21 \\
\end{tabular} & \begin{tabular}{|l|}
0.00 \\
\end{tabular} & \begin{tabular}{|l|l|}
0.906 \\
\end{tabular} & 27.338 \\
\hline 1921 & 162 & \begin{tabular}{|l|}
-56.70 \\
\end{tabular} & 0.30 & \begin{tabular}{|l|}
-11.5 \\
\end{tabular} & -1.90 & L & 25.10 & $0 . 2 0 \longdiv { 2 }$ & 25.100 & \begin{tabular}{l|}
216.2 \\
\end{tabular} & $2589.9 \mathrm{~g}$ & & 1.29 & 8.31 & \begin{tabular}{|l|}
32.71 \\
\end{tabular} & 0.23 & 0.71 & 62.07 & 1.00 & 0.00 & 0.68 & 0.11 & 0.21 & 0.00 & \begin{tabular}{|l|}
1.101 \\
\end{tabular} & 21.092 \\
\hline 19.21 & 181 & $|-56.60|$ & 0.50 & \begin{tabular}{|l|}
-7.9 \\
\end{tabular} & 6.701 & L & 10.00 & \begin{tabular}{l|l}
0.50 & 1 \\
\end{tabular} & 10.000 & 228.6 & \begin{tabular}{|l|l|}
236.8 & $\mathrm{~g}$ \\
\end{tabular} & & 1.28 & \begin{tabular}{l|l}
9.19 &
\end{tabular} & \begin{tabular}{|l|}
34.96 \\
\end{tabular} & \begin{tabular}{l|l|}
0.23 \\
\end{tabular} & 0.86 & 51.11 & 1.00 & 0.00 & 0.57 & 0.25 & 0.18 & 0.00 & \begin{tabular}{|l|} 
\\
\end{tabular} & 24.804 \\
\hline 1921 & 182 & -56.50 & 0.40 & \begin{tabular}{|l|}
-11.1 \\
\end{tabular} & $10.00 \mathrm{I}$ & $\mathrm{L}$ & 8.50 & 0.30 & \begin{tabular}{|l|}
8.500 \\
\end{tabular} & \begin{tabular}{|l|}
245.3 \\
\end{tabular} & \begin{tabular}{|l|l|l|}
276.4 \\
\end{tabular} & & 1.29 & \begin{tabular}{l|l|l}
8.97 & \\
\end{tabular} & \begin{tabular}{|l|}
34.39 \\
\end{tabular} & \begin{tabular}{l|l|l|l|l|}
0.24 & \\
\end{tabular} & \begin{tabular}{|l|}
0.87 \\
\end{tabular} & 50.47 & 1.00 & 0.00 & 0.61 & 0.19 & 0.20 & 0.00 & \begin{tabular}{|l|l|} 
\\
\end{tabular} & 22.369 \\
\hline 19.21 & 183 & $\mid-56.50$ & 0.50 & \begin{tabular}{|l|} 
\\
\end{tabular} & $7.80 \sqrt{\mathrm{L}}$ & $\mathrm{L}$ & 0.60 & 0.60 & 0.600 & 259.8 & $265.6 \mathrm{~g}$ & & 1.01 & \begin{tabular}{ll|l}
9.34 & \\
\end{tabular} & \begin{tabular}{|l|l}
35.31 \\
\end{tabular} & 0.25 & 0.92 & 47.64 & 1.00 & 0.00 & 0.55 & 0.26 & 0.19 & 0.00 & \begin{tabular}{|l|l|}
1.112 \\
\end{tabular} & 24.204 \\
\hline 19.21 & 184 & \begin{tabular}{|l|}
-56.60 \\
\end{tabular} & \begin{tabular}{l|l|}
0.40 \\
\end{tabular} & -10.3 & & $\mathrm{~L}$ & 0.20 & 0.90 & 0.200 & & & $\mathrm{~L}$ & 1.11 & 2.85 & 14.26 & 0.05 & \begin{tabular}{|l|}
0.93 \\
\end{tabular} & 47.48 & 1.00 & 0.00 & 0.22 & 0.77 & 0.01 & 0.00 & \begin{tabular}{|l|l|}
0.945 \\
\end{tabular} & 40.789 \\
\hline 1921 & 185 & \begin{tabular}{|c|}
-56.60 \\
\end{tabular} & 0.30 & \begin{tabular}{|l|}
-11 \\
\end{tabular} & & $\mathrm{~L}$ & -1.00 & \begin{tabular}{|c|}
0.90 \\
\end{tabular} & -1.000 & & I & L & \begin{tabular}{l|l|}
1.12 \\
\end{tabular} & 3.01 & \begin{tabular}{|l|}
14.98 \\
\end{tabular} & 0.05 & \begin{tabular}{|c|}
0.93 \\
\end{tabular} & 47.12 & 1.00 & 0.00 & 0.21 & 0.78 & 0.01 & 0.00 & \begin{tabular}{|l|}
0.952 \\
\end{tabular} & 40.549 \\
\hline \multirow{2}{*}{$\begin{array}{l}\text { INCLUS } \\
\text { Am. }\end{array}$} & SOE & $=S A Q U$ & $\frac{\mathrm{JO-CA}}{\mathrm{O}}$ & ARBOI & $\overline{\text { NICAS }}$ & $S$ SECU & UTAAR & RIAS $(\%$ & $\% \mathrm{EMF}$ & PESO & EQUIV & V.DE & $\overline{E N A C}$ & $\overline{C L \gg ?}$ & $26 \%-$ & - $\overrightarrow{A O}$ & FOIP & pOSSIV & VEL OE & BTERT & $\mathrm{IfNaCl}$ & E Thtot) & & & & \\
\hline & Nr. & $T_{n:} \quad 10$ & $\% \vee$ & $T_{m s}$ & $\begin{array}{c}T_{m} \\
\text { clat }\end{array} \mid$ & In & $\begin{array}{c}T_{n} \\
\mathrm{CO} 2\end{array} \mid$ & $\begin{array}{c}\% \mathrm{~V} \\
\mathrm{co} 2\end{array}$ & T estim / & $T_{\text {mNac }} T^{T}$ & $T_{\text {thor }} \mid L$ & $L-V \mid d_{f}$ & $\left.d_{H 2 O}\right|_{m} ^{N}$ & $\mathrm{NaCl} / \mathrm{N}$ & $\begin{array}{l}\mathrm{NaCl} \\
\%_{\text {peso }}\end{array}$ & $\begin{array}{c}x \\
\mathrm{NaCl}\end{array}$ & $d_{\text {Carb }}$ & $\begin{array}{c}\text { MV } \\
\text { Carb }\end{array}$ & $\left|\begin{array}{l}\mathrm{XCO}_{2} \\
\mathrm{Carb}\end{array}\right|$ & $\left|\begin{array}{l}\mathrm{XCH}_{4} \\
\mathrm{Carb}\end{array}\right|>$ & $\left|\begin{array}{c}\mathrm{X}_{2} \mathrm{O} \\
\text { tot }\end{array}\right|$ & $\left|\begin{array}{c}x \mathrm{CO}_{2} \\
\text { tot }\end{array}\right|$ & \begin{tabular}{ll|}
$X N a C$ \\
1 & tot
\end{tabular} & $\left|\begin{array}{c}\mathrm{x} \mathrm{CH} 4 \\
\text { tot }\end{array}\right|$ & $d_{t o t}$ & $V m_{\text {tot }}$ \\
\hline $19.12 \mathrm{a}$ & 74 & -56.50 & 0.05 & -15 & 2.101 & E & 25.20 & $0.10] 2$ & 25.200 & & & L & \begin{tabular}{l|l}
1.14 \\
\end{tabular} & 3.91 & 18.62 & 0.07 & 0.71 & \begin{tabular}{|l|}
62.12 \\
\end{tabular} & 1.00 & 0.00 & \begin{tabular}{|l|l|}
0.91 \\
\end{tabular} & \begin{tabular}{|l|}
0.03 \\
\end{tabular} & 0.06 & $\begin{array}{ll}0.00 \\
\end{array}$ & 1.092 & 19.604 \\
\hline 19 12a & 781. & -56.90 & 0.10 & -15 & & $\mathrm{~L}$ & 4.20 & 0.30 & 4.200 & & I & $\mathrm{L}$ & 1.14 & 3.91 & 18.62 & 0.07 & \begin{tabular}{|l|l|}
0.89 \\
\end{tabular} & 48.99 & 0.99 & 0.01 & 0.81 & 0.14 & 0.06 & 0.00 & \begin{tabular}{|l|}
1.070 \\
\end{tabular} & 22.310 \\
\hline
\end{tabular}


INCLUSÖES AQUOWCARBONNICAS SECUNDARIAS

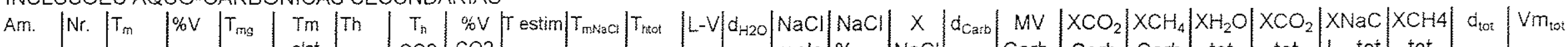

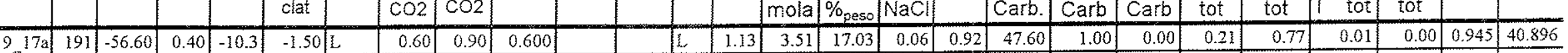

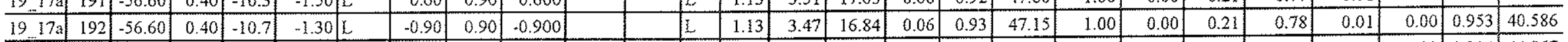

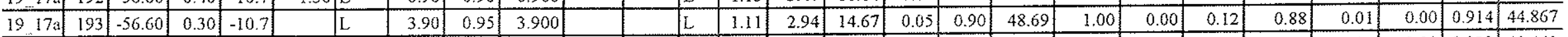

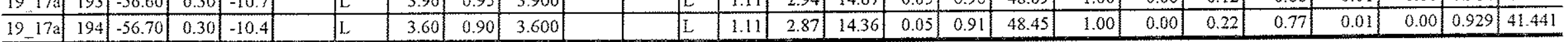
INCLUSOES AQUO-CARBONICAS SECUNDARIAS

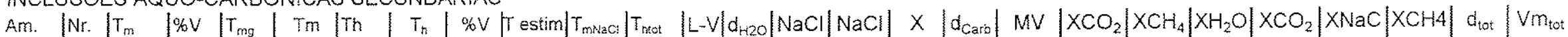

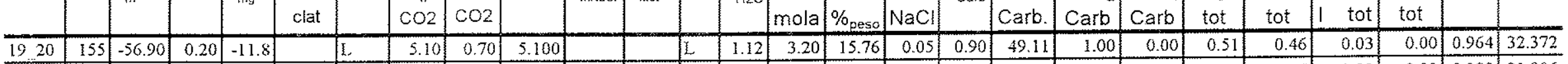

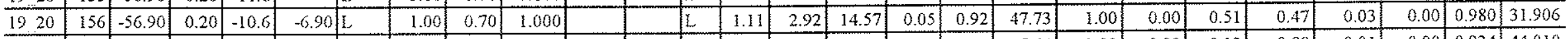

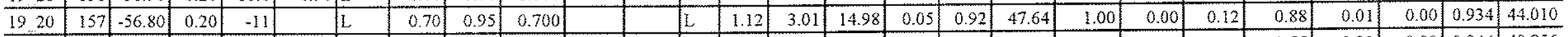

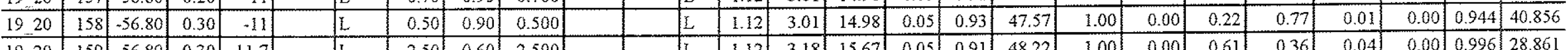

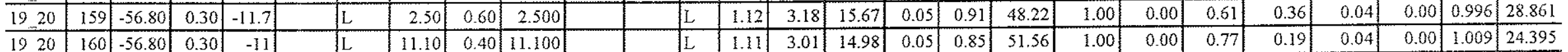

\section{VEIO DE QUARTZO DA SEGUNDA GERAÇÃO (Q-IV2)}

INCLUSŐES AQUO-CARBÓNICAS PRIMARIAS (\% EM PESO EQUIV. DE NACL $\gg 26 \%$ - NÁO FOI POSSIVEL OBTER Tf $f_{\text {NaCl }}$ E Thtot)

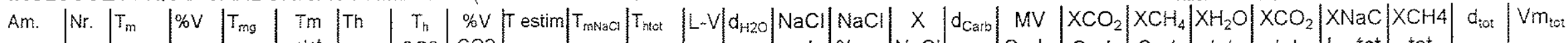

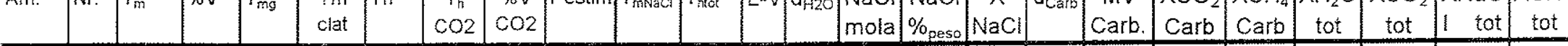

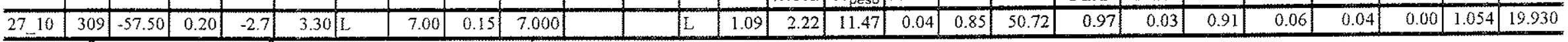
INCLUSOEES AQUO-CARBONICAS PSEUDOSECUNDARIAS

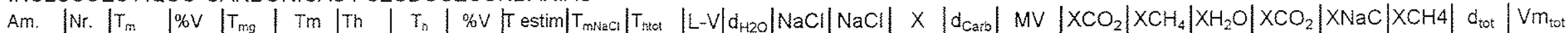

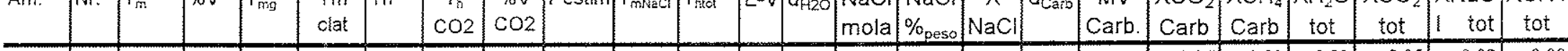

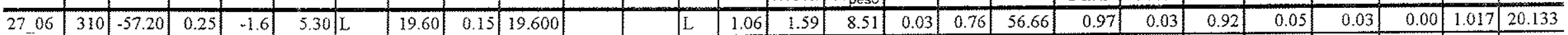

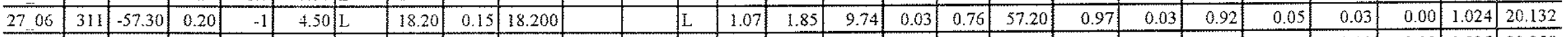

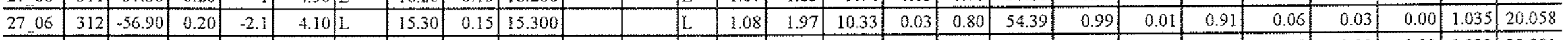

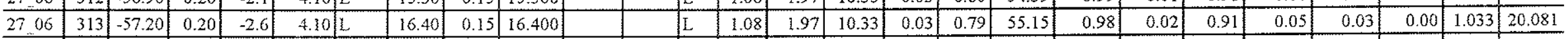

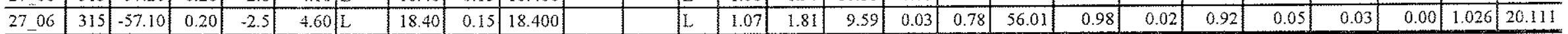
INCLUSOES AQUO-CARBONICAS PSEUDOSECUNDARIAS

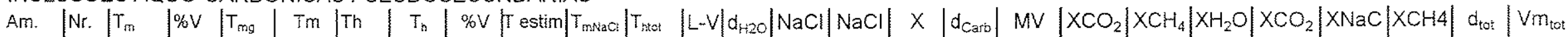

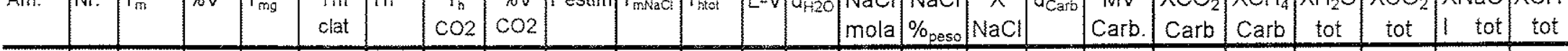

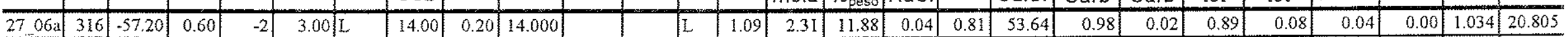

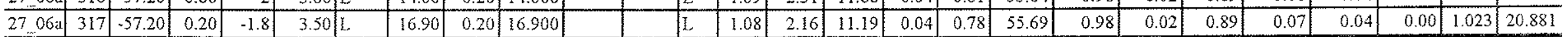
INCLUSÓES AQUO-CARBONICAS PSEUDOSECUNDARIAS

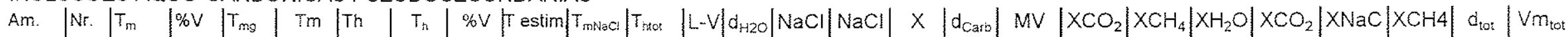

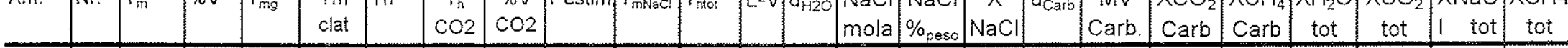

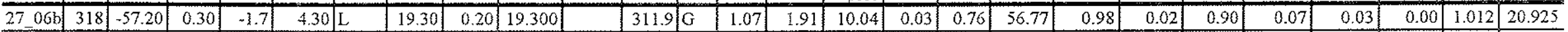

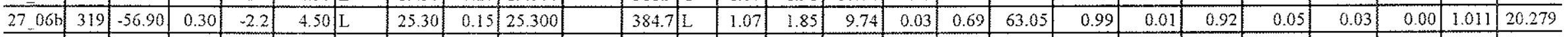

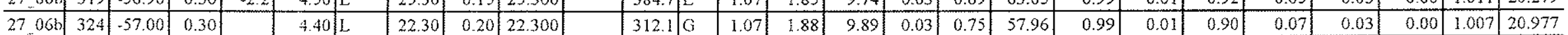

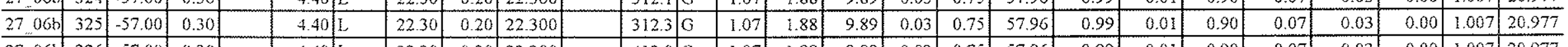

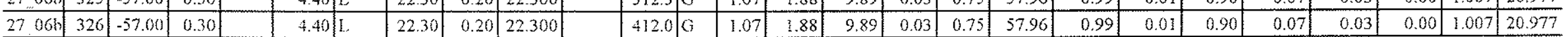


INCLUSOES AQUO-CARBONICAS SECUNDARIAS

\begin{tabular}{|c|c|c|c|c|c|c|c|c|c|c|c|c|c|c|c|c|c|c|c|c|c|c|c|c|c|c|}
\hline $\mathrm{Am}$ & Nr. & $T_{m i}$ & $\% \mathrm{~V}$ & $T_{m g}$ & $\begin{array}{l}\text { Tm } \\
\text { clat }\end{array}$ & Th & $\begin{array}{c}T_{h} \\
\mathrm{CO} 2\end{array}$ & $\begin{array}{l}\% \mathrm{~V} \\
\mathrm{CO} 2\end{array}$ & T estim & $T_{\text {mNaCl }}$ & $T_{\text {htot }}$ & $L-V$ & $d_{H 2 O}$ & $\left|\begin{array}{c}\mathrm{NaCl} \\
\mathrm{mola}\end{array}\right|$ & $\left|\begin{array}{l}\mathrm{NaCl} \\
\%_{\text {peso }}\end{array}\right|$ & $\left|\begin{array}{c}x \\
\mathrm{NaCl}\end{array}\right|$ & $d_{C a r b}$ & $\begin{array}{c}\text { MV } \\
\text { Carb. }\end{array}$ & $\begin{array}{l}\mathrm{XCO}_{2} \\
\mathrm{Carb}\end{array}$ & $\begin{array}{l}\mathrm{XCH}_{4} \\
\text { Carb }\end{array}$ & $\begin{array}{c}\mathrm{XH}_{2} \mathrm{O} \\
\text { tot }\end{array}$ & $\begin{array}{c}\mathrm{XCO}_{2} \\
\text { tot }\end{array}$ & $\begin{array}{l}X \mathrm{NaC} \\
1 \text { tot }\end{array}$ & {$\left[\begin{array}{c}\times \mathrm{CH} 4 \\
\text { tot }\end{array}\right.$} & $d_{t o t}$ & $V m_{\text {tot }}$ \\
\hline 27060 & 320 & -57.00 & 0.20 & & 4.50 & $L$ & 22.10 & 0.10 & 22.100 & & & L & 1.07 & 1.85 & 9.74 & 0.03 & 0.75 & 58.17 & 0.98 & 0.02 & 0.94 & 0.03 & 0.03 & 0.00 & 1.037 & 19.429 \\
\hline 27060 & 321 & -57.40 & 0.30 & -1.4 & 4.60 & I & 14.60 & 0.30 & 14.600 & & & L & 1.07 & 1.81 & 9.59 & 0.03 & 0.79 & 54.18 & 0.97 & 0.03 & 0.85 & 0.12 & 0.03 & 0.00 & 0.992 & 22.558 \\
\hline $27 \quad 060$ & 322 & -57.40 & 0.30 & -0.6 & 3.10 & $\mathrm{~L}$ & 13.60 & 0.30 & 13.600 & & 245.1 & G & 1.09 & 2.28 & 11.75 & 0.04 & 0.80 & 53.64 & 0.97 & 0.03 & 0.84 & 0.12 & 0.03 & 0.00 & 1.007 & 22.525 \\
\hline 27060 & 323 & -57.40 & 0.30 & -1.6 & 4.10 & $\mathrm{~L}$ & 14.90 & 0.30 & 14.900 & & 233.5 & G & 1.08 & 1.97 & 10.33 & 0.03 & 0.79 & 54.39 & 0.97 & 0.03 & 0.85 & 0.12 & 0.03 & 0.00 & 0.995 & 22.570 \\
\hline
\end{tabular}

\section{VEIO DE QUARTZO DA QUARTA GERAÇÁO (Q-IV4)}

INCLUSOES CARBONICAS PRIMARIAS

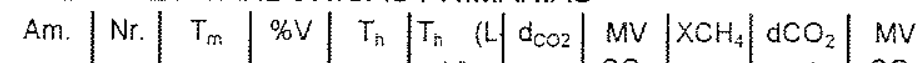

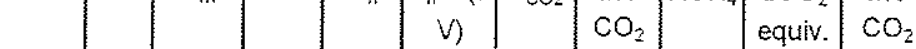

\begin{tabular}{l|l|l|l|l|l|l|l|l|l|l}
\hline 73 a! & 266 & -57.70 & 0.40 & $\mathrm{~L}$ & 23.30 & 0.73 & 59.93 & 0.04 & 0.643 & 66.6 \\
\hline
\end{tabular}

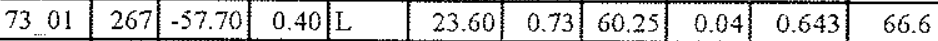

\begin{tabular}{l|l|l|l|l|l|l|l|l|l|l}
\hline 73.01 & 268 & -57.70 & 0.50 & $\mathrm{~L}$ & 23.00 & 0.74 & 59.61 & 0.04 & 0.646 & 66.2 \\
\hline
\end{tabular}

\begin{tabular}{l|l|l|l|l|l|l|l|l|l|l}
\hline 7301 & 269 & -57.70 & 0.50 & $\mathrm{~L}$ & 22.90 & 0.74 & 59.50 & 0.04 & 0.650 & 65.8 \\
\hline
\end{tabular}

\begin{tabular}{|l|l|l|l|l|l|l|l|l|l|l}
\hline 73.01 & 270 & -57.70 & 0.40 & $\mathrm{~L}$ & 23.70 & 0.73 & 60.37 & 0.05 & 0.631 & 67.7 \\
\hline
\end{tabular}

\begin{tabular}{l|l|l|l|l|l|l|l|l|l|l}
\hline 7301 & 271 & -57.70 & 0.40 & $\mathrm{~L}$ & 23.00 & 0.74 & 59.61 & 0.05 & 0.640 & 66.8 \\
\hline
\end{tabular}

\begin{tabular}{l|l|l|l|l|l|l|l|l|l|l}
\hline 73.01 & 272 & -57.70 & 0.50 & $L$ & 21.90 & 0.75 & 58.52 & 0.05 & 0.682 & 62.7 \\
\hline
\end{tabular}

\begin{tabular}{l|l|l|l|l|l|l|l|l|l|l|l}
\hline $73 \quad 01$ & 273 & -57.70 & 0.40 & $\mathrm{~L}$ & 23.20 & 0.74 & 59.82 & 0.05 & 0.645 & 66.2 \\
\hline 73
\end{tabular}

\begin{tabular}{l|l|l|l|l|l|l|l|l|l|l}
\hline 7301 & 274 & -57.60 & 0.50 & $\mathrm{~L}$ & 22.30 & 0.75 & 58.90 & 0.04 & 0.657 & 65.1 \\
\hline
\end{tabular}

\begin{tabular}{l|l|l|l|l|l|l|l|l|l|l}
\hline 73.01 & 275 & -57.60 & 0.40 & $\mathrm{~L}$ & 23.10 & 0.74 & 59.71 & 0.04 & 0.654 & 65.5 \\
\hline
\end{tabular}

\begin{tabular}{l|l|l|l|l|l|l|l|l|l|l|l}
\hline 73.01 & 276 & -57.60 & 0.40 & $\mathrm{~L}$ & 23.60 & 0.73 & 60.25 & 0.04 & 0.648 & 66.0 \\
\hline 73
\end{tabular}

\begin{tabular}{l|l|l|l|l|l|l|l|l|l|l}
\hline $73 \_01$ & 277 & -57.60 & 0.50 & $\mathrm{~L}$ & 23.60 & 0.73 & 60.25 & 0.04 & 0.648 & 66.0 \\
\hline
\end{tabular}

INCLUSÓES AQUO-CARBONICAS PRIMARIAS

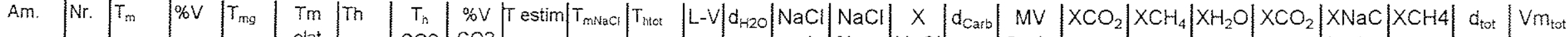

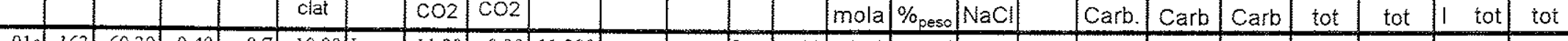

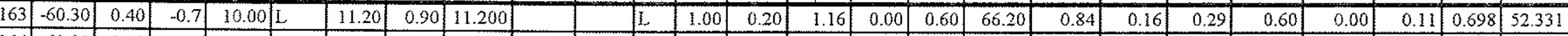

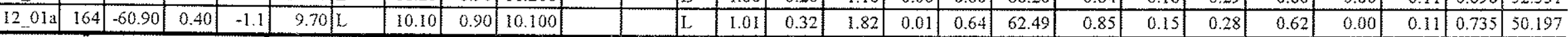
INCLUSOES AQUO-CARBONICAS PSEUDO-SECUNDARIAS (ZONA DE IMISCIBILIDADE)

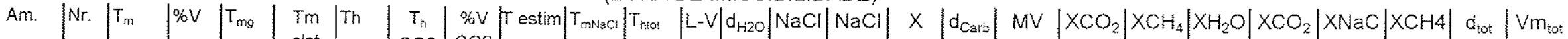
mola \% $\%_{\text {peso }} \mathrm{NaCl}$ Carb. Carb Carb tot tot 1 tot tot

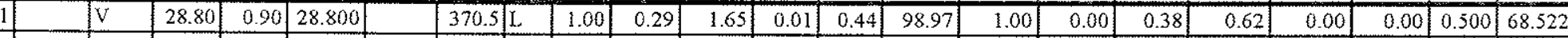

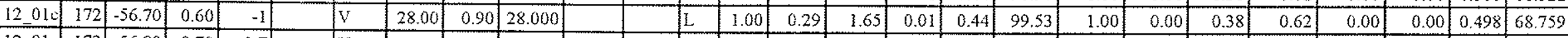

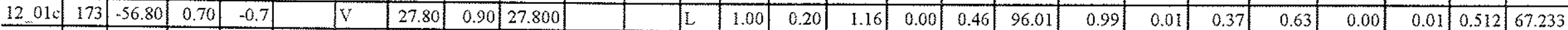

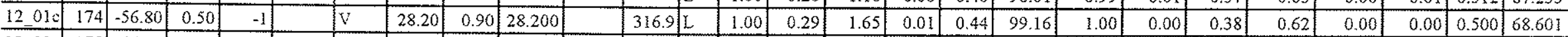

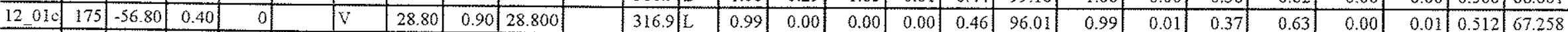

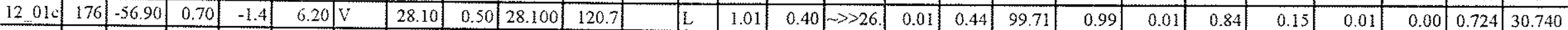

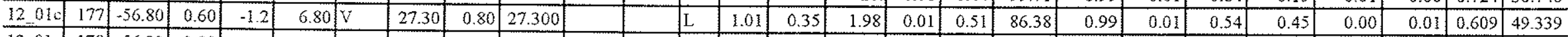

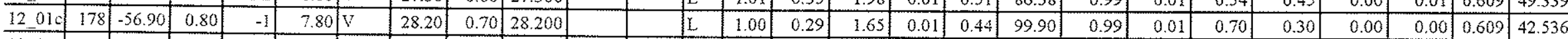

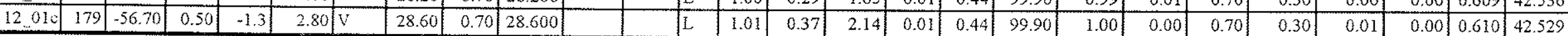


INCLUSOES AQUO-CARBONICAS PSEUDO-SECUNDARIAS (\% EM PESO EQUIV. DE NACL $\gg 26 \%$ - NAO FOI POSSIVEL OBTER TFNaCIEThtot)

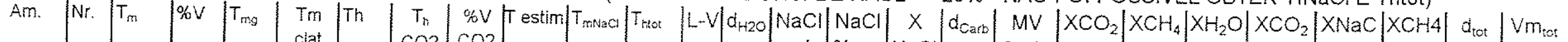

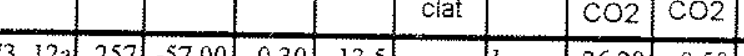

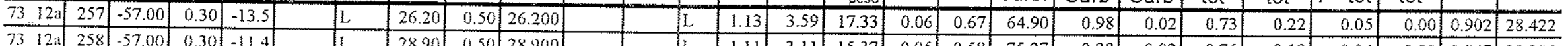

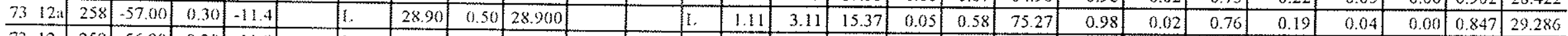

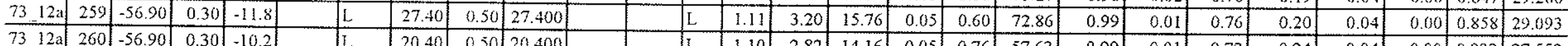

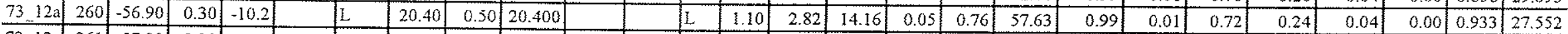

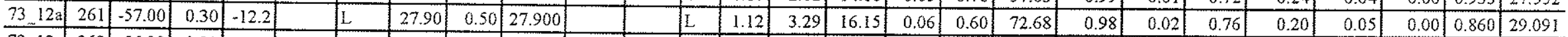

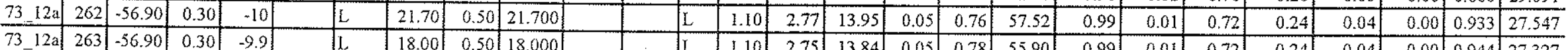

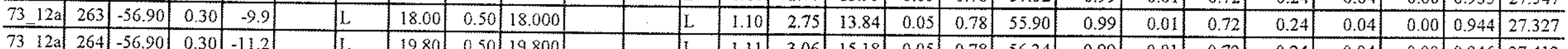

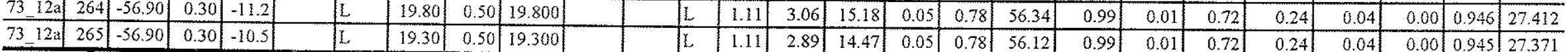
INCLUSOEES AQUO-CARBONICAS SECUNDARIAS

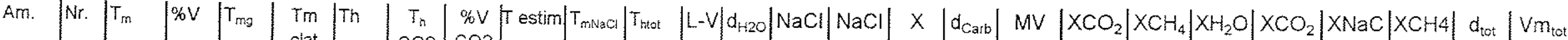

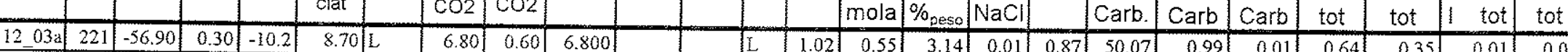

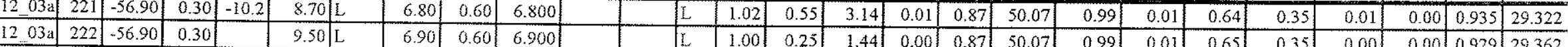

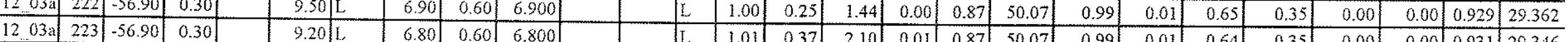

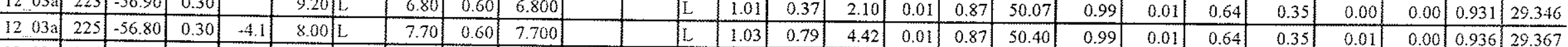

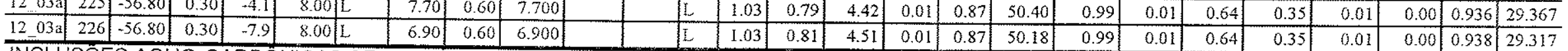
INCLUSOES AQUO-CARBONICAS SECUNDARIAS

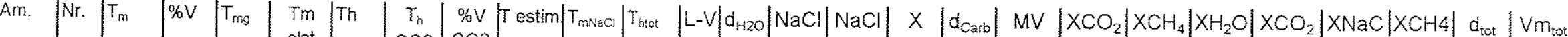

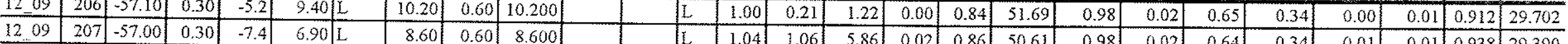

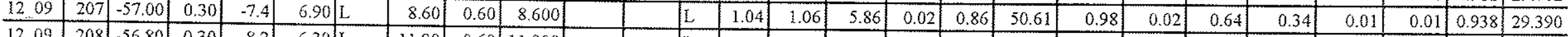

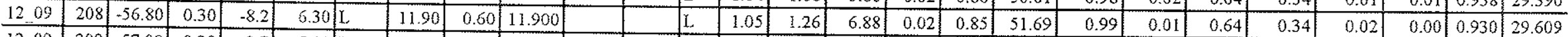

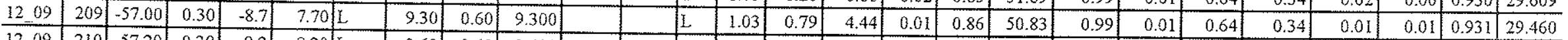

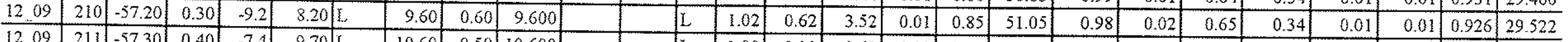

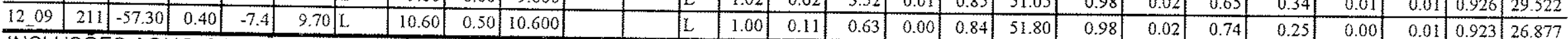
INCLUSOES AQUO-CARBONICAS PRIMARIAS (NO QUARTZO RELACIONADO A SIDERITA)

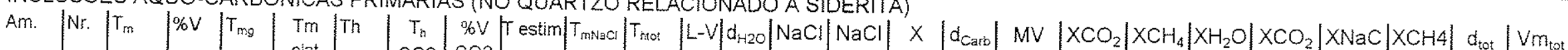

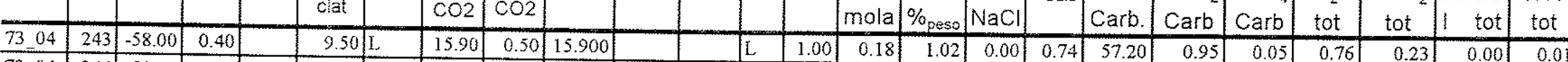

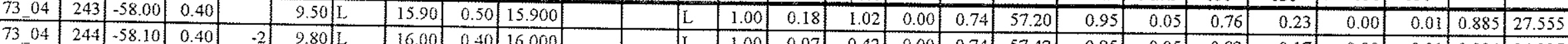

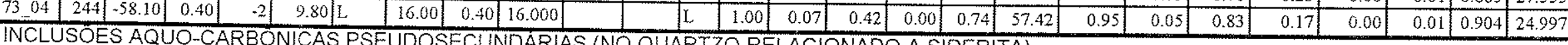

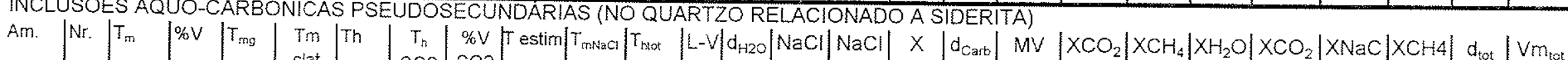

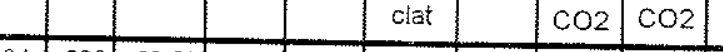

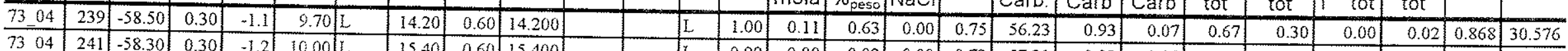

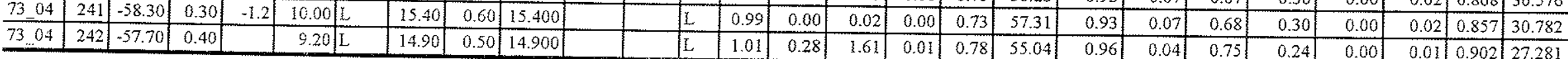


INCLUSOES AQUO-CARBONNICAS PRIMARIAS EM SIDERITA

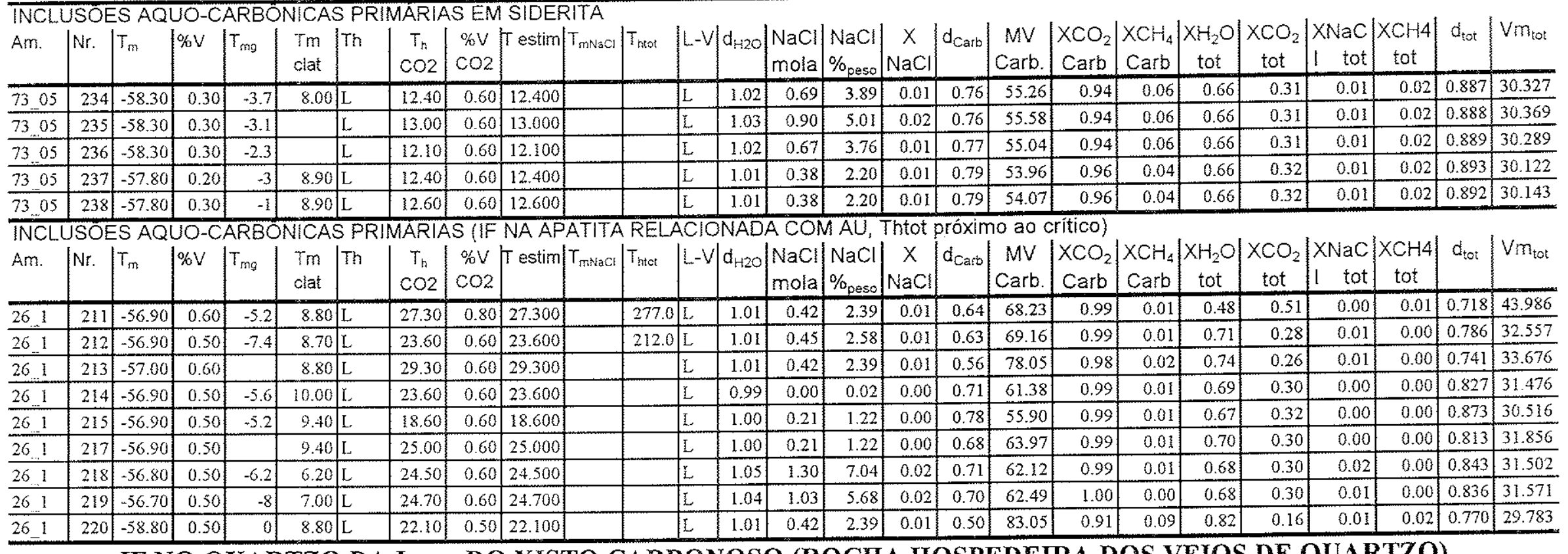

\section{IF NO QUARTZO DA L $\mathrm{M}_{\mathrm{E} 3}$ DO XISTO CARBONOSO (ROCHA HOSPEDEIRA DOS VEIOS DE QUARTZO)}

INCLUSOES AQUO-CARBONICAS PRIMARIAS

\begin{tabular}{|c|c|c|c|c|c|c|c|c|c|c|c|c|c|c|c|c|c|c|c|c|c|c|c|c|c|c|}
\hline Am. & $\mathrm{Nr}$. & $T_{m}$ & $\% \mathrm{~V}$ & $T_{m g}$ & $\begin{array}{l}\mathrm{Tm} \\
\text { clat }\end{array}$ & Th & $\begin{array}{c}T_{h} \\
\mathrm{CO} 2\end{array}$ & $\begin{array}{c}\% \mathrm{~V} \\
\mathrm{CO} 2\end{array}$ & T estim & $T_{\text {manacl }}$ & {$\left[T_{\text {fitot }}\right.$} & $|L-V|$ & $\mathrm{d}_{\mathrm{H} 2 \mathrm{O}}$ & $\begin{array}{l}\mathrm{NaCl} \\
\text { mola }\end{array}$ & $\begin{array}{l}\mathrm{NaCl} \\
\%_{\text {peso }} \\
\end{array}$ & $\begin{array}{c}\mathrm{X} \\
\mathrm{NaCl} \\
\end{array}$ & $d_{C a r b}$ & $\begin{array}{c}\text { MV } \\
\text { Carb. }\end{array}$ & $\begin{array}{c}\mathrm{XCO}_{2} \\
\text { Carb } \\
\end{array}$ & $\begin{array}{l}\mathrm{XCH}_{4} \\
\text { Carb }\end{array}$ & $\begin{array}{c}\mathrm{XH}_{2} \mathrm{O} \\
\text { tot }\end{array}$ & $\begin{array}{c}\mathrm{XCO}_{2} \\
\text { tot } \\
\end{array}$ & $\left|\begin{array}{rr}\mathrm{XNaC} \\
1 & \text { tot }\end{array}\right|$ & $\begin{array}{c}\mathrm{xCH} 4 \\
\text { tot }\end{array}$ & $d_{\text {tot }}$ & $V m_{i s t}$ \\
\hline$\sqrt{22}$ & 450 & -57.80 & & -0.7 & 8.30 & $\mathrm{~L}$ & 21.90 & 0.10 & 21.900 & & 300.0 & L & 1.02 & 0.59 & 3.33 & 0.011 & 0.67 & 63.60 & 0.96 & 0.04 & 0.96 & 0.03 & 0.01 & 0.00 & 0.985 & 19.528 \\
\hline$\sqrt{22}$ & 451 & -57.80 & & -1.6 & 7.90 & $\mathrm{~L}$ & 24.40 & 0.10 & 24.400 & & 299.2 & L & 1.02 & 0.73 & 4.07 & 0.01 & 0.62 & 69.16 & 0.95 & 0.05 & 0.96 & 0.03 & 0.01 & 0.00 & 0.984 & 19.579 \\
\hline & 5 & & & -0.8 & 7 & & & 0.15 & 22.300 & & 305.9 & & 1.01 & 0.45 & 2.58 & 0.01 & 0.64 & 66.01 & 0.94 & 0.06 & 0.95 & 0.04 & 0.01 & 0.00 & 0.959 & 20.358 \\
\hline
\end{tabular}




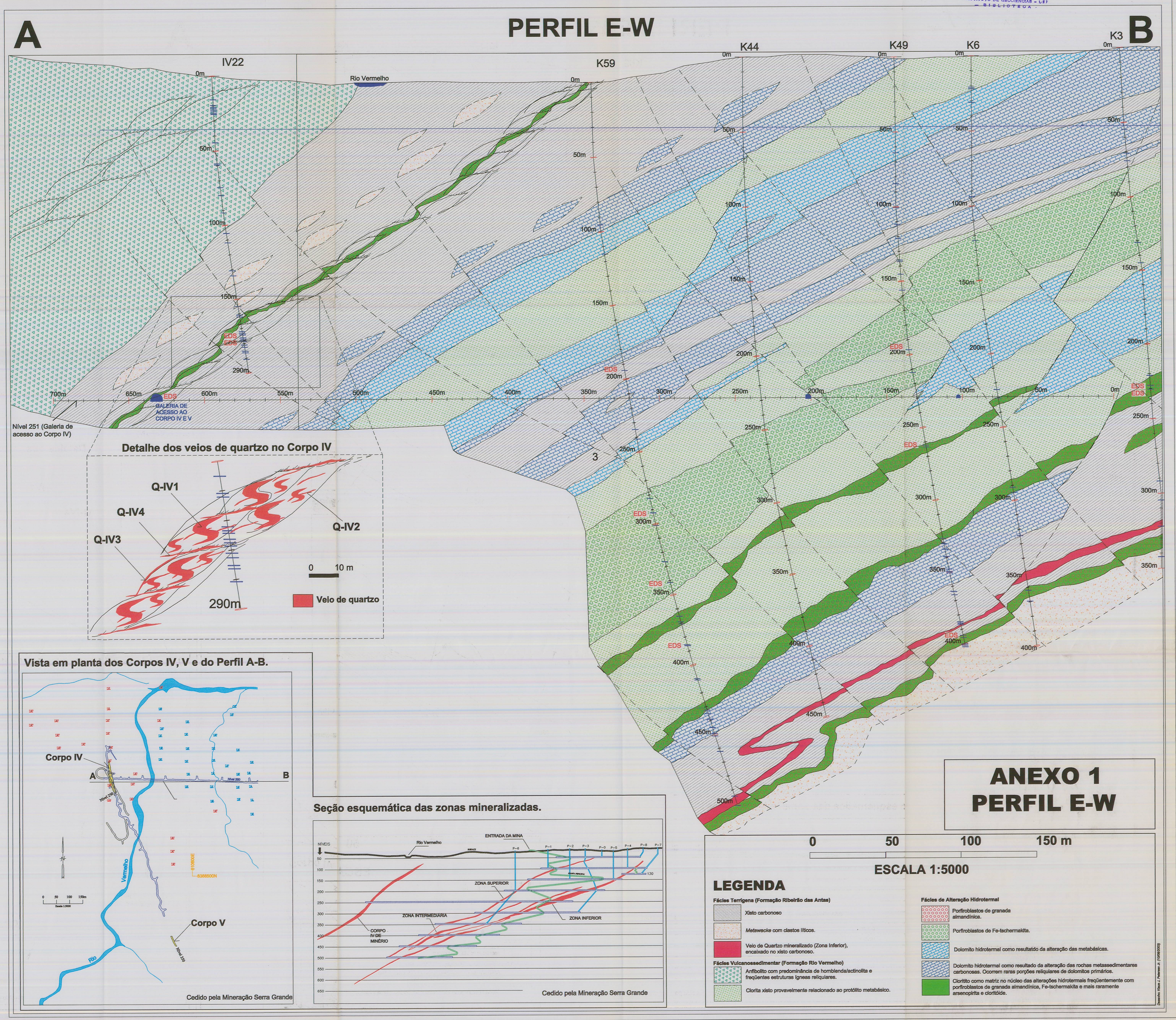

